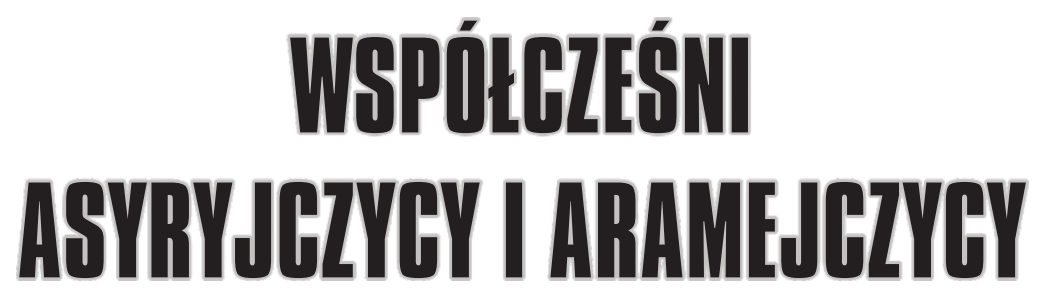


盗 


\title{
MARTA WOŹNIAK
}

\section{WSPÓtCZEŚNII \\ ASYRYJGZYGY I ARAMEJGZYYY}

\author{
Bliskowschodni chrześcijanie \\ w poszukiwaniu tożsamości narodowej
}

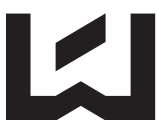

WYDAWNICTWO

UNIWERSYTETU

KÓDZKIEGO

kóDź 2014 
Marta Woźniak - Uniwersytet Łódzki, Wydział Studiów Międzynarodowych i Politologicznych Katedra Bliskiego Wschodu i Północnej Afryki

90-131 Łódź, ul. Narutowicza 59a

\title{
RECENZENCI
}

Marek M. Dziekan, Stanisław Obirek

\author{
EDYCJA TEKSTU, SKŁAD, ŁAMANIE \\ Ibidem s.c. \\ B. Walicka, A. Łopatka
}

\section{PROJEKT OKŁADKI \\ Barbara Grzejszczak}

Na okładce wykorzystano grafikę autorstwa Pawła Piekarskiego

Wydrukowano z gotowych materiałów dostarczonych do Wydawnictwa UŁ przez Katedrę Bliskiego Wschodu i Północnej Afryki UŁ

C Copyright by Uniwersytet Łódzki, Łódź 2014

Wydane przez Wydawnictwo Uniwersytetu Łódzkiego

Wydanie I. W.06653.14.0.D

ISBN (wersja drukowana) 978-83-7969-264-4

ISBN (ebook) 978-83-7969-742-7
Wydawnictwo Uniwersytetu Łódzkiego
90-131 Łódź, ul. Lindleya 8
www.wydawnictwo.uni.lodz.pl
e-mail: ksiegarnia@uni.lodz.pl

tel. (42) 66558 63, faks (42) 6655862 
Rodzicom i Bratu 



\section{Spis treści}

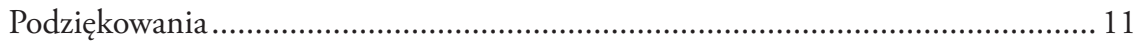

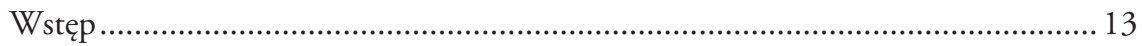

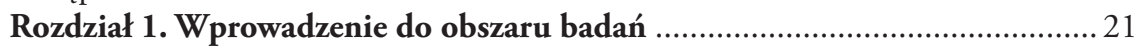

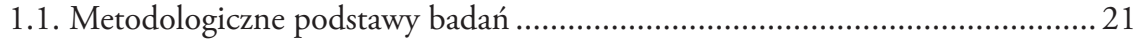

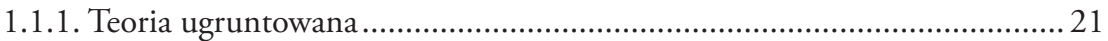

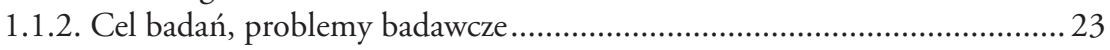

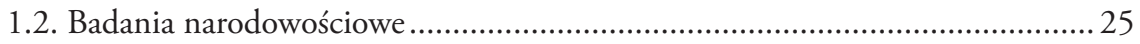

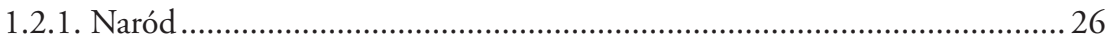

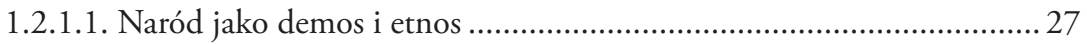

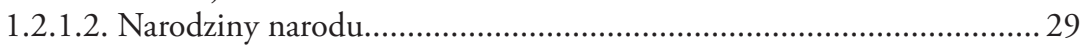

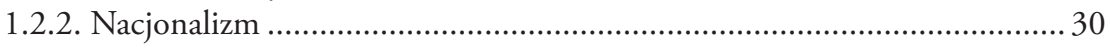

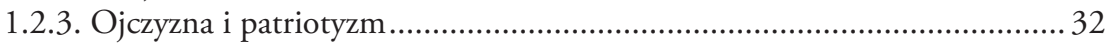

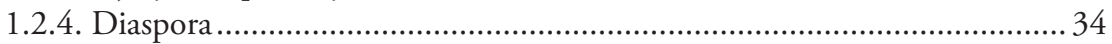

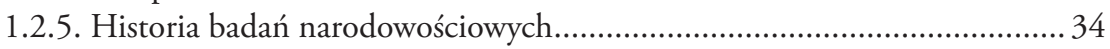

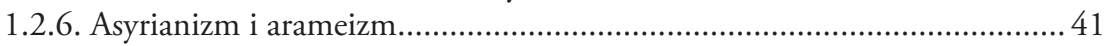

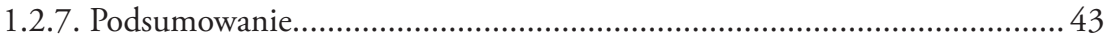

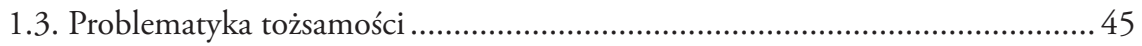

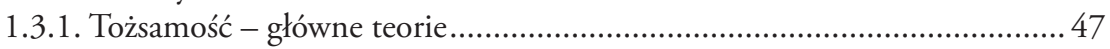

1.3.2. Rozróżnienia tożsamości .............................................................. 51

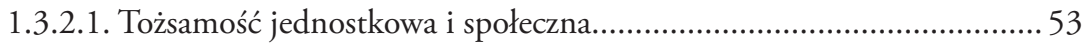

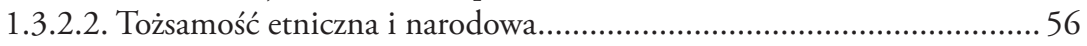

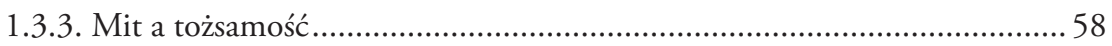

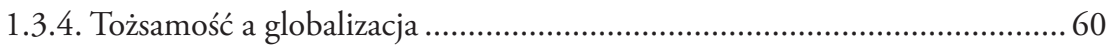

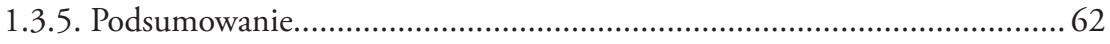

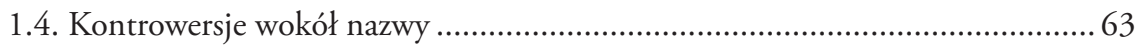

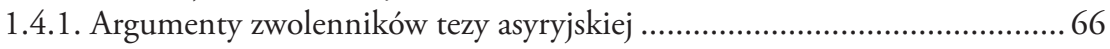

1.4.2. Argumenty przeciwników tezy asyryjskiej ...............................................69

1.4.3. Spory w łonie samej wspólnoty oraz nazewnictwo w krajach imigracji ..... 73

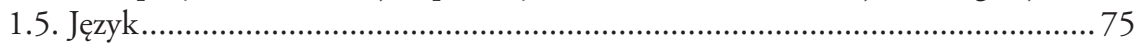

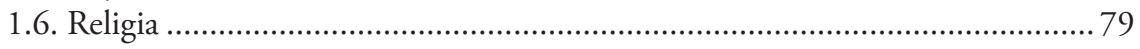

Rozdział 2. Asyryjczycy/Aramejczycy na Bliskim Wschodzie.

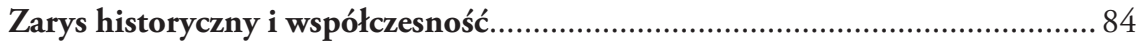

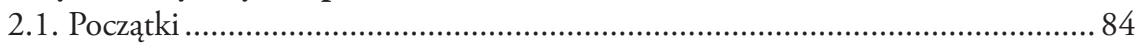

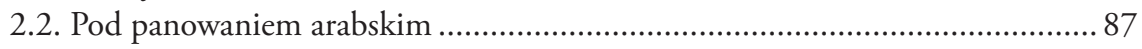


2.3. Wiek XIX

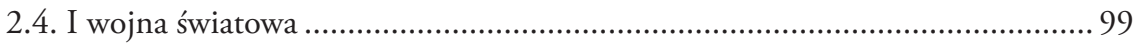

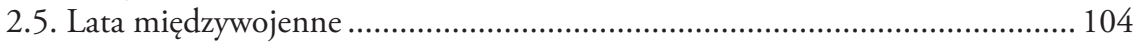

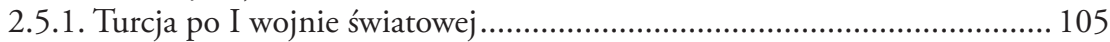

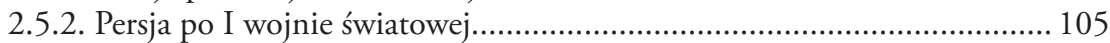

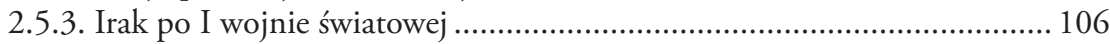

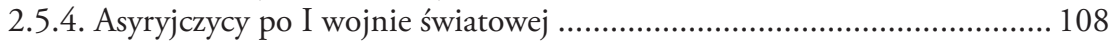

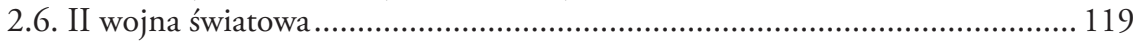

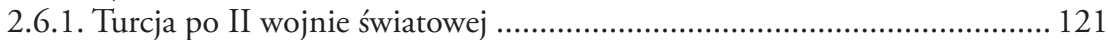

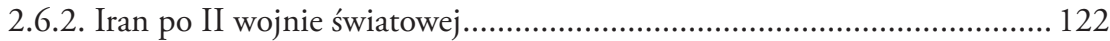

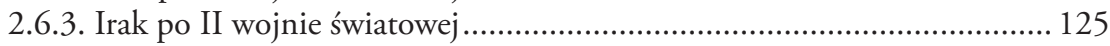

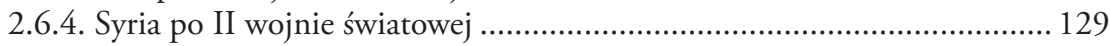

Rozdział 3. Współcześni Asyryjczycy/Aramejczycy w diasporze …………...... 130

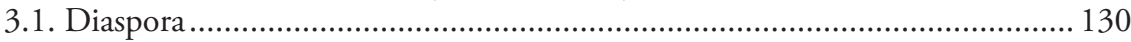

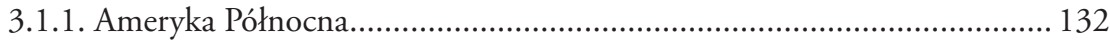

3.1.1.1. Stany Zjednoczone ......................................................................... 132

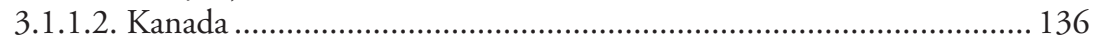

3.1.2. Europa i Azja ……………………………………………………1 136

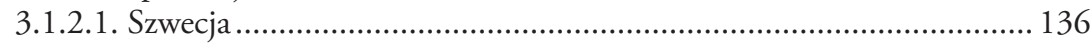

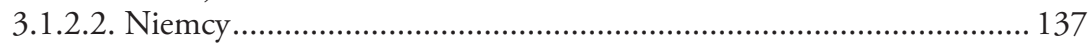

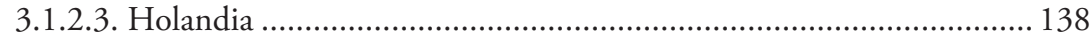

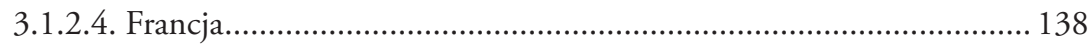

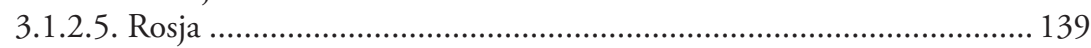

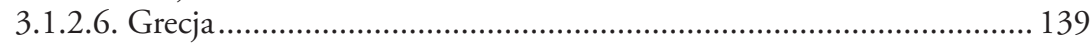

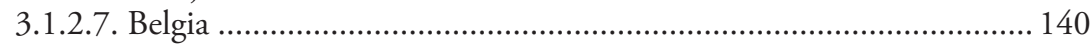

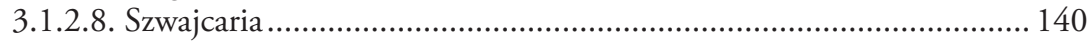

3.1.2.9. Wielka Brytania ............................................................................ 140

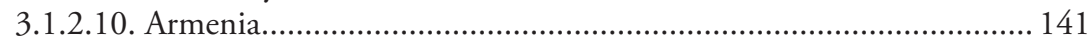

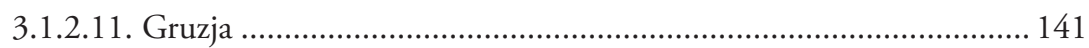

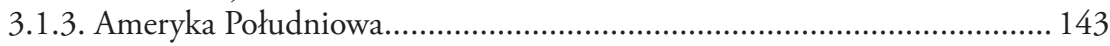

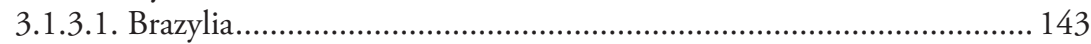

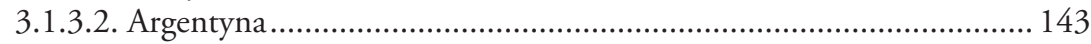

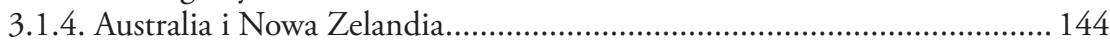

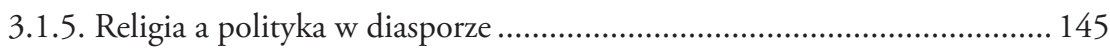

3.1.6. Organizacje asyryjskie oraz aramejskie ......................................................... 149

3.1.7. Problem asymilacji............................................................................... 153

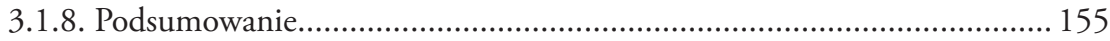

3.2. Internet jako narzędzie kształtowania tożsamości ........................................... 156

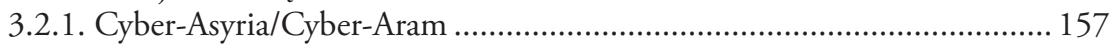

Rozdział 4. Tożsamość $\mathrm{i}$ historia w świadomości współczesnych

Asyryjczyków/Aramejczyków w świetle badań ankietowych .............................. 161

4.1. Metoda, techniki badań i procedura opracowywania wyników....................... 161

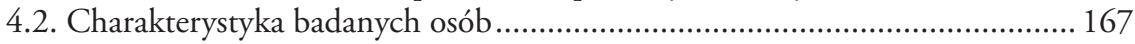

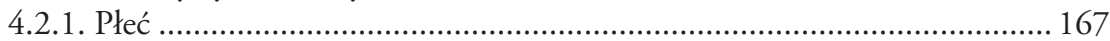

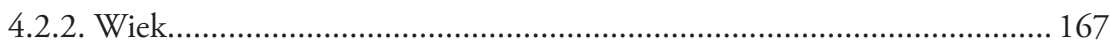

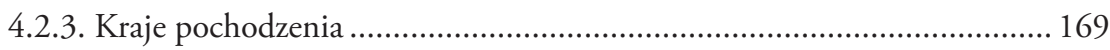




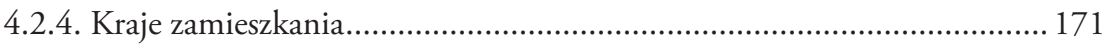

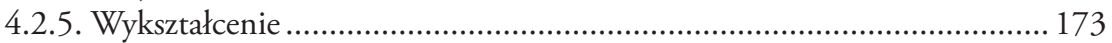

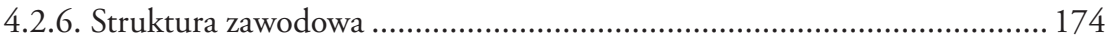

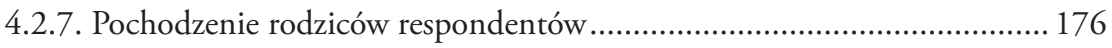

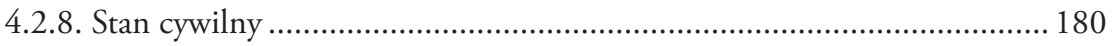

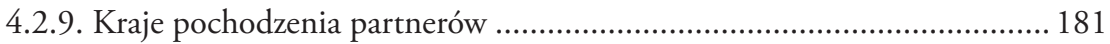

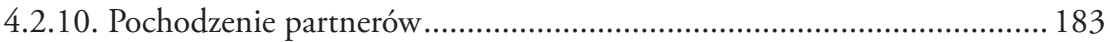

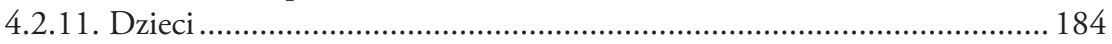

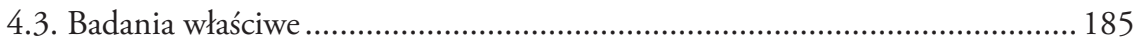

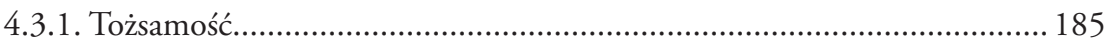

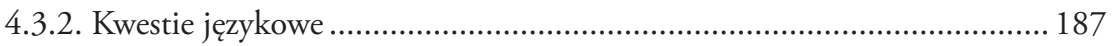

4.3.2.1. Znajomość syryjskiego języka klasycznego ........................................ 187

4.3.2.1.1. Stopień opanowania klasycznego języka syryjskiego ..................... 188

4.3.2.2. Znajomość języka aramejskiego ………………………………..... 188

4.3.2.2.1. Stopień opanowania języka aramejskiego ................................ 189

4.3.2.2.2. Znajomość dialektów aramejskiego .......................................... 190

4.3.2.2.3. Sposoby uczenia się aramejskiego …………………………....... 191

4.3.2.3. Znajomość języków używanych w konkretnych interakcjach ......... 191

4.3.2.3.1. Język komunikacji z rodzicami................................................. 191

4.3.2.3.2. Język komunikacji z dziadkami ............................................ 192

4.3.2.3.3. Język komunikacji z rodzeństwem........................................... 194

4.3.2.3.4. Język komunikacji w szkole/pracy ………………………….... 196

4.3.2.3.5. Język komunikacji w innych sytuacjach ................................... 197

4.3.2.4. Rodzaje znajomości języków ....................................................... 199

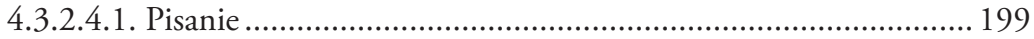

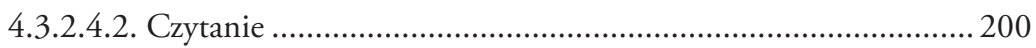

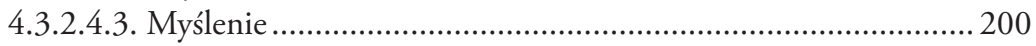

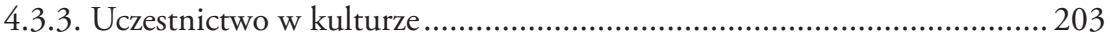

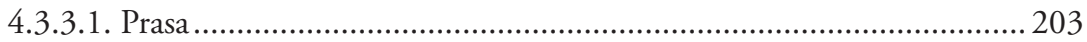

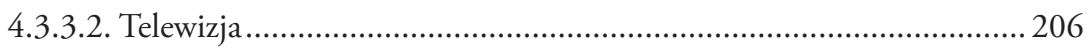

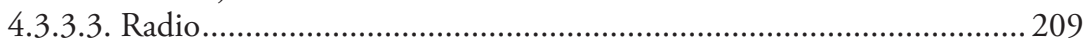

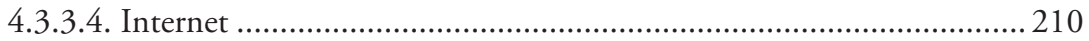

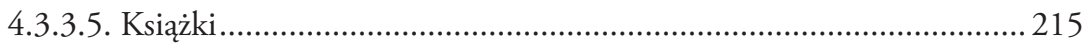

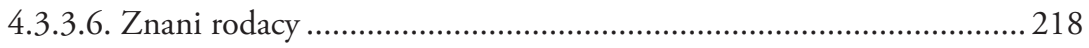

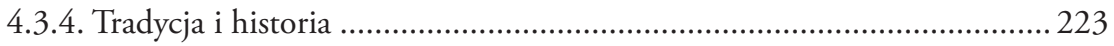

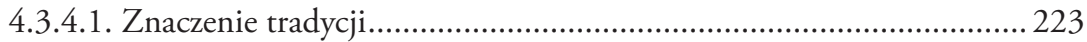

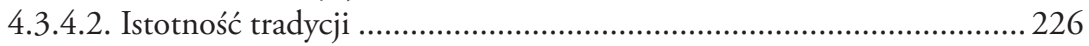

4.3.4.3. Elementy tradycji........................................................................ 227

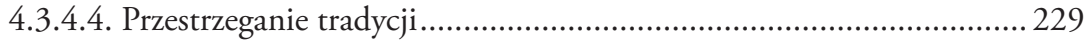

4.3.4.5. Sposoby pielęgnowania tradycji.................................................... 230

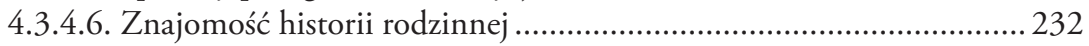

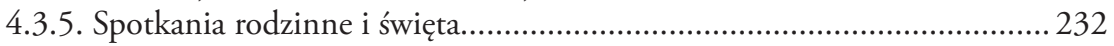

4.3.5.1. Okazje do spotkań rodzinnych..................................................... 233

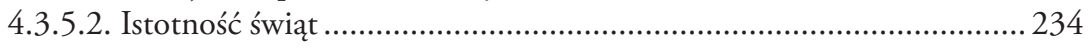




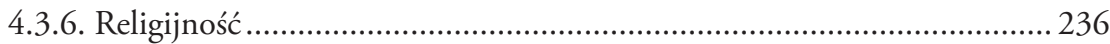

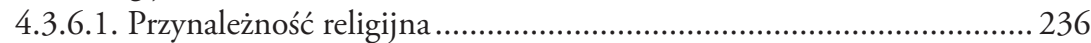

4.3.6.2. Praktyki religijne........................................................................ 238

4.3.6.3. Nasilenie praktyk religijnych...........................................................239

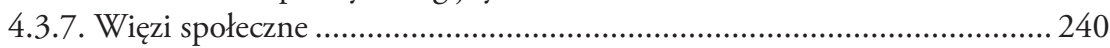

4.3.7.1. Zainteresowanie życiem rodaków...................................................... 240

4.3.7.1.1. Geograficzne rozłożenie zainteresowania .................................... 241

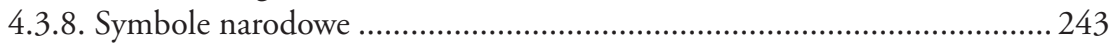

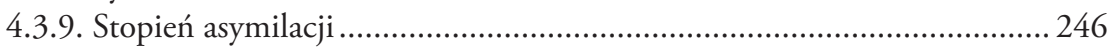

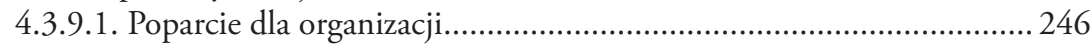

4.3.9.2. Poparcie dla klubów sportowych...................................................... 247

4.3.9.3. Integracja w krajach zamieszkania ..................................................... 249

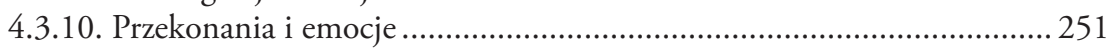

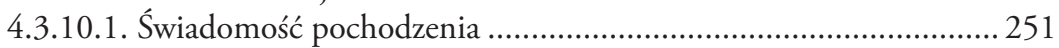

4.3.10.2. Poczucie szczęścia z przynależności do wspólnoty...........................252

4.3.10.3. Pochodzenie od starożytnych imienników.....................................252

4.3.10.4. Poczucie przynależności do rdzennych ziem ................................. 253

4.3.10.5. Indywidualne dociekania historii przodków................................ 254

4.3.10.6. Preferencja tradycyjnej kuchni, muzyki, zwyczajów....................... 254

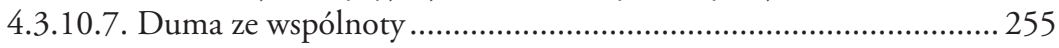

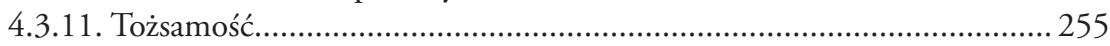

4.3.11.1. Najważniejsze zagrożenia dla tożsamości .........................................25

4.3.11.2. Istotność zachowania tożsamości...................................................258

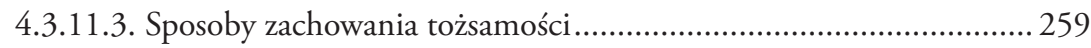

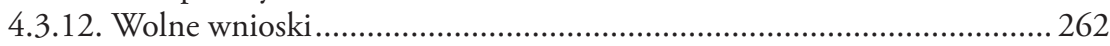

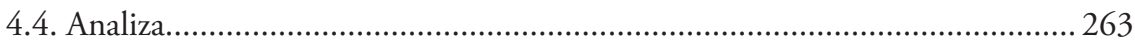

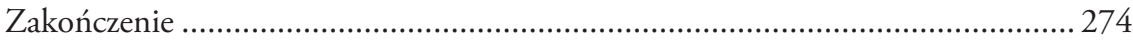

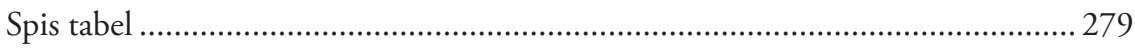

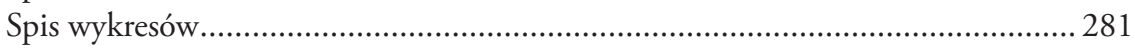

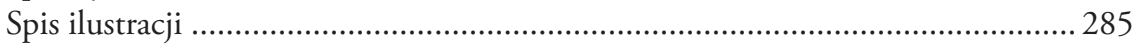

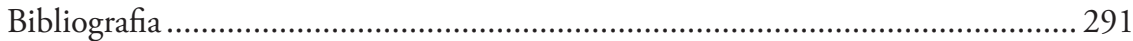

Aneks 1. Ankieta „Tożsamość asyryjska” ............................................................. 310

Aneks 2. Ankieta „Tożsamość aramejska” .............................................................319

Aneks 3. Ankieta „Assyrian Identity” ...................................................................... 328

Aneks 4. Ankieta „Aramean (Suryoyo) Identity” ......................................................337

Aneks 5. Ankieta „Assyrische Identität” ................................................................... 346 


\section{Podziękowania}

Moja przygoda z tymi, którzy samych siebie zwą Asyryjczykami lub Aramejczykami, zaczęła się w 2001 roku w Södertälje w Szwecji - ich nieoficjalnej stolicy w Europie. To wtedy po raz pierwszy doświadczyłam gościnności i uprzejmości chrześcijańskiej mniejszości, dumnie wywodzącej swój rodowód od starożytnych imienników z Bliskiego Wschodu. Zaintrygowana obrazami, na których patriarchowie w turbanach dzierżyli pastorały oplecione złotymi wężami, postanowiłam znaleźć odpowiedź na pytanie: „Kim są owi wygnańcy z kolebki cywilizacji znad Tygrysu i Eufratu?”

Przez kolejne lata jeszcze wiele razy byłam gościem w asyryjskich/aramejskich domach i kościołach, rozrzuconych po całym świecie - wsłuchiwałam się w głosy, które kreśliły różne wizje przeszłości i przyszłości. Niezastąpionym źródłem informacji były też asyryjskie i aramejskie strony internetowe, których rozwój i dywersyfikację w ciągu ponad dekady obserwowałam z wielką ciekawością, zastanawiając się, czy i w jakim stopniu rodzące się w przestrzeni wirtualnej „Cyber-Asyria” oraz „Cyber-Aram” mogą zastąpić opisywanemu przeze mnie ludowi ojczyznę. Swoje przemyślenia zawarłam w kilku artykułach, a wreszcie w pracy doktorskiej. Książka niniejsza jest nieco zmodyfikowaną, mam nadzieję, że lepszą, wersją tej ostatniej.

Nie powstałaby ona, gdyby nie pomoc i wsparcie wielu osób - przede wszystkim mojego promotora i Mistrza, prof. Marka M. Dziekana, któremu pragnę podziękować jako pierwszemu - pisanie pracy pod jego kierunkiem było zaszczytem, a jednocześnie przyjemnością. Następnie podziękowania należą się mojemu recenzentowi, prof. Michaelowi Abdalli, oddanemu propagatorowi sprawy asyryjskiej, który ułatwił mi kontakt ze swoimi rodakami i krewnymi w Szwecji, Niemczech oraz na Ukrainie, a także wraz z małżonką gościł mnie u siebie w Poznaniu. Profesor Witold Witakowski z Uniwersytetu w Uppsali dwukrotnie zaprosił mnie do Szwecji na słynne wśród młodych orientalistów „stypendium Witakowskiego”; oboje wraz 
z żoną, dr Ewą Balicką-Witakowską, udostępnili mi swoje materiały oraz służyli bezcennymi radami.

$\mathrm{Na}$ gruncie polskim moje zainteresowanie losami chrześcijan bliskowschodnich podzielali życzliwi mi arabiści - doktorzy Michał Moch, Bartłomiej Grysa oraz Sebastian Bednarowicz. Pod względem socjologicznym pracę tę na wczesnym etapie konsultował prof. Andrzej Flis z Uniwersytetu Jagiellońskiego, zaś na późniejszym prof. Ryszard Machnikowski z Uniwersytetu Łódzkiego. Pracy dr Bożeny Walickiej oraz dr. Jacka Walickiego książka zawdzięcza swój ostateczny kształt. Koleżanki i koledzy z Katedry Bliskiego Wschodu i Północnej Afryki Uniwersytetu Łódzkiego motywowali mnie i inspirowali - za co im bardzo dziękuję. Z zagranicznych naukowców wymienić muszę poznanych w Grenadzie na X Symposium Syriacum dr. George’a A. Kiraza, współzałożyciela Gorgias Press, prof. Edwarda Y. Odisho z Northeastern Illinois University, dr Naures Atto z Uniwersytetu w Lejdzie oraz Sonera Öndera z Uniwersytetu w Sztokholmie, którzy zechcieli mi udostępnić swoje teksty. Johny Messo, przewodniczący Syriac Universal Alliance (obecnie World Council of Arameans), oraz jego współpracownik, Emanuel Barhaido, pomogli mi dotrzeć do aramejskich respondentów. Żałuję, że nie było mi dane poznać osobiście dr. Fuata Deniza z Uniwersytetu w Örebro, na którego publikacjach częściowo się opierałam, a który został tragicznie zamordowany w Szwecji w 2007 roku.

Osobne podziękowania składam Eliasowi Mardiniemu za napisanie listu, od którego wszystko się zaczęło, oraz jego rodzinie w Södertälje za życzliwość okazaną nieznanej polskiej studentce.

Nigdy nie napisałabym tej książki, gdyby nie wsparcie mojej rodziny. W skonstruowaniu elektronicznej wersji kilkujęzycznego kwestionariusza pomógł mi Brat, Tata był pierwszym recenzentem, Mama i Babcie zawsze we mnie wierzyły.

Na końcu pragnę podziękować wszystkim respondentom asyryjskim i aramejskim, z którymi rozmawiałam bezpośrednio oraz tym, którzy zechcieli poświęcić swój czas na wypełnienie długiej ankiety - bez ich odpowiedzi moja praca byłaby wyłącznie kompilacją tego, co napisano wcześniej. 


\section{Wstęp}

Niniejsza książka stanowi studium współczesnego doświadczenia aramejskojęzycznych chrześcijan wywodzących się z Bliskiego Wschodu. Ta jedna z najdawniejszych chrześcijańskich mniejszości na świecie, będąca historycznie ważną, a zarazem tragiczną ofiarą regionalnych konfliktów i nacjonalizmów, której liczebność według różnych źródeł waha się od $1 \mathrm{mln}$ do $4 \mathrm{mln}^{1}$, jest obecnie podzielona na kilka odłamów, zamieszkujących zarówno swoje rdzenne tereny (Irak, Iran, Syrię, Turcję), jak i diasporę. Spośród nich najistotniejsze są rywalizujące ze sobą frakcje asyryjska oraz aramejska ${ }^{2}$, które - co staram się wykazać na bazie przeprowadzonych przez mnie badań komparatystycznych - łączy bardzo wiele, lecz i dzieli niemało - podgrupy różni przede wszystkim percepcja pochodzenia i wizja przyszłości.

Jeszcze ponad stulecie temu opisywaną wspólnotę charakteryzowała silna świadomość etniczno-religijna, którą na ojczystych terenach umacniały: autorytet Kościoła, rolnicza struktura społeczna, życie blisko siebie, endogamia, brak integracji ze społeczeństwem regionu, dodatkowo prześladowania lub wspomnienia o nich. Pojawienie się chrześcijańskich misjonarzy z Zachodu zaowocowało wykształceniem nowej grupy społecznej - nacjonalistycznie nastawionych działaczy, którzy założyli pierwsze organizacje o profilu narodowościowym.

Transformacja tradycyjnej tożsamości w kierunku etniczno-narodowym rozpoczęla się pod wpływem zmian strukturalnych zachodzących w spo-

${ }^{1}$ Realistycznie są to $2 \mathrm{mln}$ osób.

${ }^{2} \mathrm{Z}$ tego względu piszę o „Asyryjczykach” i „Aramejczykach”; nie rozstrzygam, czy należą oni do jednej i tej samej grupy etnicznej czy też do dwóch grup bardzo blisko ze sobą spokrewnionych. W fragmentach dotyczących całej wspólnoty stosuję zapis z ukośnikiem (Asyryjczycy/Aramejczycy) bądź z myślnikiem (np. mniejszość asyryjsko-aramejska). Zdaję sobie przy tym sprawę, że jest to rozwiązanie arbitralne, a jednocześnie kompromisowe - pomiędzy ekonomią języka (preferującą jak najkrótsze nazwy, stąd decyzja o pominięciu jeszcze jednej nazwy - „Chaldejczycy”), a chęcią objęcia jak najszerszego spektrum postaw i identyfikacji. Na temat nazwy zob. więcej w podrozdziale 1.4 . 
łecznościach na Bliskim Wschodzie, a nasiliła się w diasporze. W XX wieku nastąpiła masowa emigracja Asyryjczyków/Aramejczyków z rdzennych terenów, która rzuciła ich w wir modernizacji. Mimo że pierwsze pokolenie imigrantów było niemal zupełnie nieprzygotowane na wyzwania współczesności, szybko wypracowało pewne mechanizmy utrzymania dawnej tożsamości, rozwijane następnie przez kolejne pokolenia. Do tych mechanizmów należały: odwiedziny ojczystych ziem, moralne i finansowe wspieranie rodaków, którzy zostali na Bliskim Wschodzie, częste spotkania w rodzinnym gronie, aktywna partycypacja w inicjatywach asyryjskich/aramejskich klubów, promowanie endogamii, wreszcie kontrola społeczna (wpisująca się w kolektywistyczną „kulturę wstydu” poprzez stanie na straży honoru poszczególnych członków mniejszości $\left.{ }^{3}\right)$. Z drugiej strony nasiliły się, szczególnie wśród elit intelektualnych, tendencje do budowania asyryjskiego, a potem także aramejskiego narodu.

$\mathrm{Na}$ przeszkodzie wykrystalizowaniu się nowej, jednolitej tożsamości narodowej - oprócz czynników zewnętrznych - stoi multietniczność badanej grupy, przejawiająca się w używaniu przez jej członków wielu języków (tureckiego, perskiego, arabskiego, rozmaitych dialektów aramejskiego, ostatnio również języków zachodnich) oraz przynależność do kilku Kościołów orientalnych. Wymienione różnice przekładają się na odmienne postrzeganie własnego pochodzenia oraz tożsamości grupowej, sprawiając, że szczególnie w Europie pogłębia się podział na Asyryjczyków i Aramejczyków.

Wielu Asyryjczyków kultywuje bowiem etniczną mitologię odwołującą się do tradycji imperium asyryjskiego (zniszczonego przez Babilończyków, Medów i Scytów w VII wieku p.n.e. $\left.{ }^{4}\right)$, która przekształca ich pierwotną religijną i językową tożsamość w etniczny nacjonalizm5 ${ }^{5}$ tzw. asyrianizm. Ideę pochodzenia od Asyryjczyków z epoki żelaza odrzuca grupa identyfikująca się jako Aramejczycy (arameizm), wywodząca swoje pochodzenie od lewantyńskich imienników.

${ }^{3} \mathrm{O}$ społecznym odczuwaniu wstydu przez członków opisywanej wspólnoty w Europie zob. N. Atto, „»We have come here and left all the shame and sin behind there«: Changes in the understanding of Shame and Sin among Suryoye in Europe", Presentation Symposium Syriacum, Malta 2012.

${ }^{4}$ Co prawda, jeszcze przez trzy lata wojska asyryjskie, wspierane przez Egipcjan, stawiały gdzieniegdzie opór, ale zburzenie Niniwy w 612 roku p.n.e. stało się symbolem upadku Asyrii.

${ }^{5}$ Por. K. L. Ross, Note on the Modern Assyrians, „The Proceedings of the Friesian School”, http://web.archive.org/web/20000816221217/http://www.friesian.com/notes/note-n.htm, data wejścia 14.08.2009. 
W rzeczywistości mieszanie ras - starożytnych Asyryjczyków z napływowymi Aramejczykami oraz wieloma innymi semickimi ludami - które dokonywało się przez stulecia, nie pozwala na jasne stwierdzenie, która grupa „ma rację”. Nie jest to zresztą celem mojej pracy. Pragnę jedynie spróbować prześledzić, w jaki sposób kształtuje się współczesna tożsamość asyryjska i/lub aramejska, w jaki sposób linie z przeszłości przebiegają, transformują się, jakie nowe elementy są dodawane w postrzeganiu własnej tożsamości przez Asyryjczyków i Aramejczyków ${ }^{6}$. Stoję na stanowisku, że wszystkie tożsamości są konstruowane, tym samym ich "prawdziwość” bądź „fałszywość” uznaję za określenia irrelewantne.

Zresztą, jak stwierdził Zygmunt Bauman, epoka, w której żyjemy, to „czasy ponowoczesne”, charakteryzujące się m.in. kryzysem, wręcz dekonstrukcją wielkich pojęć, takich jak: naród, narodowość, nacjonalizm czy właśnie tożsamość. W epoce nowożytnej nauki społeczne nie poświęciły powyższym zagadnieniom pogłębionej refleksji, dopiero globalizacja wymogła próbę osadzenia ich w nowym, krytycznym kontekście ${ }^{7}$. Współczesne debaty o tożsamościach zbiorowych i kulturze dobitnie zaświadczają, jak istotne są nadal w skali społecznej problemy identyfikacji narodowej i etnicznej. Nacjonalizm to bodajże jedyna dzisiaj globalna ideologia, która, wbrew prognozom sprzed lat, wcale nie traci na popularności, a wręcz przeciwnie - jej atrakcyjność wzrasta. Niesie to ze sobą zarówno szanse, jak i potencjalne zagrożenia. Troska o zachowanie różnorodności kulturowej narodów świata, a zarazem lęk przed konfliktogennymi separatyzmami, to tylko niektóre przykłady wskazujące na aktualność i wagę problemu.

Jednym z obszarów wstrząsanych od wieków konfliktami na tle etnicznym i narodowym jest Bliski Wschód, którego dzieje długo opowiadane były niemal wyłącznie z punktu widzenia muzułmanów. Argument stanowienia przez nich większości w regionie nie usprawiedliwia pomijania perspektywy mniejszości religijnych. Islam bowiem nie istniał nigdy w kontekście wolnym od wpływów innych religii. Tak jak jego wyznawcy mieli olbrzymi i niepodważalny wpływ na niemuzułmanów, tak ci ostatni stanowili - dzięki samemu swemu istnieniu - jeden z powodów ciągłego rozwoju

${ }^{6}$ N. Atto, „Perception of Identity Among Suroye in European Diaspora”, Presentation Symposium Syriacum, Sayyidat al-Bir 2004.

${ }^{7}$ M. Dudziak, rec. pracy Naród - tożsamość - kultura. Między koniecznościa a wyborem, W. J. Burszta, K. Jaskułowski, J. Nowak (red.), Warszawa 2005, „Studia z Filologii Polskiej i Słowiańskiej" 41/2006, s. 253.

${ }^{8}$ Por. Dylematy tożsamości, „Horyzonty Wychowania”, 4/2005 (7), s. 237-257. 
muzułmańskich społeczeństw i reżimów, a nawet całej cywilizacji islamu. Prezentowane w książce ujęcie rozwoju tożsamości i nacjonalizmu wśród wspólnoty asyryjsko-aramejskiej ilustruje wielowymiarową dynamikę historii i podważa pogląd o jednokierunkowości relacji większości-mniejszości czy silniejszego-słabszego ${ }^{9}$. Co więcej, wpisuje się w nader aktualne badania nad rolą jednostek i grup tworzących narodowy margines (mniejszości narodowych, imigrantów, pracowników-obcokrajowców).

Celem moich badań było zidentyfikowanie i opisanie tożsamości Asyryjczyków i Aramejczyków w krajach ich pochodzenia oraz w diasporze, jak również zrozumienie i wyjaśnienie, w jaki sposób owa tożsamość jest przekształcana przez wspólnotę, zwłaszcza przez elity używające jako budulca historii etnicznych stosunków z innymi grupami oraz polityki tożsamościowej.

U podstaw pracy legło założenie, że transformacja tożsamości etnicznej/narodowej zachodzi w określonych historycznych, społeczno-ekonomicznych, politycznych i kulturowych okolicznościach, zaś ludzie sami się definiują, szukają znaczenia i sensu, mają własne koncepcje tożsamości. Innymi słowy, tożsamość narodowa ma charakter relacyjny i dialogowy - jest aktywnie utrzymywana i przekształcana przez jednostki w konkretnych historycznych i społecznych warunkach.

Takie założenie przekłada się na wybór metodologii - zarówno historycznej, jak i socjologicznej, gdyż zastosowanie tylko jednej z nich uniemożliwiłoby holistyczne zrozumienie zagadnienia. Komparatystyczna perspektywa historyczna jest konieczna, by pojąć ciągły i zmieniający się charakter tożsamości, ukazać, w jaki sposób identyfikacja asyryjsko-aramejska kształtowała się w różnych okresach i krajach. Bez perspektywy socjologicznej z kolei niemożliwe byłoby uzyskanie nowego materiału badawczego i zweryfikowanie tezy o transformacji tożsamości omawianej grupy w kierunku bardziej narodowej. Zastosowanie dwóch komplementarnych perspektyw wymogło podział pracy na część teoretyczno-historyczną oraz socjologiczną.

Książka składa się z czterech rozdziałów. W rozdziale pierwszym, który ma charakter wprowadzający do zagadnienia, zostaną omówione cele i problemy badawcze, jak również badania narodowościowe, z kluczowymi

${ }^{9}$ Por. A. I. Laing-Marshall, „Modern Assyrian Identity and the Church of the East: An Exploration of Their Relationship and the Rise of the Assyrian Nationalism, From the World Wars to 1980", niepublikowana praca magisterska, Department of History, University of Saint Michael's College, Toronto School of Theology, Toronto 2001, s. 131-132. 
dla pracy pojęciami narodu, nacjonalizmu, ojczyzny ideologicznej, diaspory, asyrianizmu oraz arameizmu. Zawiera on również historię badań narodowościowych. Podrozdział poświęcony tożsamości przedstawia różnorakie podejścia do tożsamości narodowej, albowiem książka pod względem metodologicznym nie czerpie z jednej teorii tożsamości, a z kilku uzupełniających się koncepcji. Mit oraz globalizacja to zagadnienia, które zasłużyły na odrębne omówienia ze względu na ich istotność dla badanej wspólnoty - wokół mitu powrotu koncentruje się bowiem wiele asyryjsko-aramejskich narracji, zaś globalizacja przyśpiesza proces transformacji tożsamości.

Niezwykle ważną kwestię stanowi sprawa nazwy, gdyż jest ona jedną z najbardziej antagonizujących wspólnotę. W tej części książki zaprezentowane zostały argumenty zarówno zwolenników, jak i przeciwników obu nazw - „asyryjskiej” oraz „,aramejskiej”. Grupę na tle innych mniejszości bliskowschodnich wyróżnia unikatowy język i przynależność do syryjskich Kościołów orientalnych - tym dwóm zagadnieniom poświęcone są ostatnie podpunkty omawianego rozdziału.

Rozdział drugi szkicuje historię wspólnoty od przyjęcia chrześcijaństwa w pierwszych wiekach naszej ery do czasów współczesnych, przy czym najwięcej uwagi poświęcono kluczowym dla Asyryjczyków/Aramejczyków momentom minionego wieku, takim jak rozpad imperium osmańskiego i stworzenie narodowego państwa tureckiego, które były związane z wymuszonymi migracjami i masową eksterminacją omawianej populacji. Odrębne punkty opisują sytuację Asyryjczyków/Aramejczyków w Iraku, Iranie i Syrii, czyli we wszystkich państwach, których tereny tradycyjnie zamieszkiwali. Ramy chronologiczne wyznaczają dwie wojny światowe.

Dociekania historyczne kontynuowane są w rozdziale trzecim, który bada asyryjsko-aramejską diasporę żyjącą w Ameryce Północnej (w Stanach Zjednoczonych i Kanadzie), Europie i Azji (w Szwecji, Niemczech, Holandii, Francji, Rosji, Grecji, Belgii, Szwajcarii, Wielkiej Brytanii, Armenii i Gruzji), Ameryce Południowej (w Brazylii i Argentynie) oraz w Australii i Nowej Zelandii. Kwestie dotyczące diaspory jako całości zostaną omówione w odrębnych podpunktach, mianowicie: powiązania między religią a polityką ze szczególnym uwzględnieniem roli patriarchów pełniących funkcję tradycyjnych przywódców, następnie przykładowe organizacje asyryjskie i aramejskie, wreszcie problem asymilacji, który stanowi największe zagrożenie dla tożsamości asyryjsko-aramejskich emigrantów i ich potomków. Rozdział zamykają rozważania nad Internetem jako na- 
rzędziem kształtowania dwóch wirtualnych rzeczywistości: Cyber-Asyrii i Cyber-Aramu, wraz z opisem najważniejszych stron internetowych, które odwiedzają członkowie obu podgrup. Te rozważania, mimo że niezbyt obszerne ilościowo, uznaję za nader istotne dla zrozumienia procesów tożsamościowych, jakim podlegają Asyryjczycy i Aramejczycy.

Najobszerniejszy rozdział, czwarty, napisany z perspektywy socjologicznej, zaczyna się od części teoretycznej - przedstawiającej model triangulacyjny, techniki badań i procedurę opracowania danych. Te ostatnie pozyskane zostały za pomocą elektronicznych ankiet poświęconych asyryjskiej oraz aramejskiej tożsamości, wywiadów, obserwacji uczestniczących i analizy tekstów pisanych; różne źródła i metody zostały użyte świadomie, aby zwiększyć wiarygodność badań własnych. Wybór wątków poruszanych podczas wywiadów i ankiet został teoretycznie umocowany w cytowanej w rozdziale pierwszym literaturze o kształtowaniu się narodów i tożsamości.

W tej części książki, oprócz charakterystyki badanych (m.in. państw ich pochodzenia i zamieszkania, struktury zawodowej, endogamii), przedstawione i przeanalizowane zostaną następujące zagadnienia: czynniki decydujące o przynależności do wspólnoty, używanie unikatowego języka a wielojęzyczność grupy, organizacja społeczna, uczestnictwo w kulturze, znajomość historii, pielęgnowanie tradycji, formalna przynależność religijna i deklarowana religijność, więzi społeczne, internalizacja symboli narodowych, stopień asymilacji (selektywny wybór elementów z innych kultur), poparcie dla organizacji i klubów sportowych, poglądy i emocje, w końcu zagrożenia dla tożsamości zbiorowej i sposoby jej chronienia. Odpowiedzi na pytania otwarte oraz wpisy w rubryce „wolne wnioski” ujawniają dodatkowo społeczne podziały, które w pytaniach zamkniętych rozmyślnie nie zostały zasugerowane. W aneksie znajdują się ankiety w trzech wersjach językowych - angielskiej i niemieckiej (które zostały użyte w badaniach) oraz ich tłumaczenia na język polski.

Jeśli chodzi o literaturę, to tematowi ewolucji asyryjsko-aramejskiej tożsamości poświęcono wyjątkowo niewiele analiz, poza studiami dotyczącymi konkretnych diaspor. Zdecydowanie więcej materiałów publikuje strona asyryjska (przede wszystkim na łamach JAAS - „Journal of Assyrian Academic Studies"), starałam się jednak pokazać poglądy obu opisywanych frakcji; cytuję więc zarówno proaramejskiego Jeana M. Fiey’a, jak i proasyryjskiego Simo Parpolę. Część historyczną pracy oparłam głównie na dwóch książkach Johna Josepha: The Nestorians and Their Muslim Neighbors. A Study of Western 
Influence on Their Relations z 1961 roku oraz The Modern Assyrians of the Middle East. Encounters with Western Christian Missions, Archeologists, and Colonial Powers z 2000 roku, jak również na klasycznym dziele Aziza S. Atiyi A History of Eastern Christianity z 1968 roku (polskie tłumaczenie: Historia Kościołów Wschodnich, Warszawa 1978). Natomiast rozdział poświęcony diasporze w dużej mierze powstał na bazie książki Madawi Al-Rasheed Iraqi Assyrian Christians in London: The Construction of Ethnicity z 1998 roku, pracy magisterskiej Andrei I. Laing-Marshall ,Modern Assyrian Identity and the Church of the East: An Exploration of Their Relationship and the Rise of the Assyrian Nationalism, From the World Wars to 1980" z 2001 roku oraz niepublikowanego tekstu referatu Naures Atto „Perception of Identity Among Suroye in European Diaspora”, wygłoszonego na Symposium Syriacum w 2004 roku $^{10}$.

Należy również wspomnieć o polskiej literaturze przedmiotu - na rodzimym gruncie tematyką asyryjską od lat zajmuje się Michael Abdalla, którego publikacje, choć dotyczą głównie kwestii związanych z kulturą żywienia na Bliskim Wschodzie, dotykają również problemów tożsamości Asyryjczyków ${ }^{11}$.

${ }^{10}$ Już po zakończeniu przeze mnie badań i zbierania materiałów do książki wyszedł drukiem doktorat N. Atto, Hostages in the Homeland, Orphans in the Diaspora: Identity Discourses Among the Assyrian/Syriac Elites in the European Diaspora, Leiden 2011. W tym samym roku została obroniona praca magisterska A. Burçaka, „Assyrian Transnational Politics: Activism From Europe Towards Homeland”, Middle East Technical University, Cypr Północny 2011.

${ }^{11}$ M. Abdalla: W kręgu asyryjskiej tradycji, „Poznaj świat”, nr 1, 1985, s. 8-10; Z kręgu folkloru chrześcijańskich Asyryjczyków, „Literatura Ludowa”, nr 4-6, 1986, s. 63-76; Losy Asyryjczyków, „Sprawy Narodowościowe. Seria nowa” 2/1 (2), 1993, s. 67-82; Asyryjska diaspora, „Sprawy Narodowościowe. Seria nowa” 3/1 (4), 1994, s. 55-75; Problemy kultury ludności asyryjskiej na pograniczu syryjsko-turecko-irackim [w:] T. Smolińska (red.), Pogranicze jako problem kultury, Opole 1994, s. 131-139; Asyryjczycy w Tur Abdinie między kurdyjskim młotem a tureckim mieczem [w:] I. Kabzińska-Stawarz, S. Szynkiewicz (red.), Konflikty etniczne. Źródta - typy - sposoby rozstrzygania, Warszawa 1996, s. 271-282; Asyryjscy imigranci w Szwecji między tradycja a wspótczesnościa [w:] J. Mucha, W. Olszewski (red.), Dylematy tożsamości europejskich pod koniec drugiego tysiąclecia, Toruń 1997, s. 197-218; O Kościele asyryjskim i męczeństwie chrześcijan Kościołów Wschodnich, „Mozaika Obrzańska” nr 40/1, 1999, s. 10-15; Kultura żywienia dawnych i wspótczesnych Asyryjczyków. Uwarunkowania społeczno-kulturowe, Warszawa 2001, O chrześsijaństwie asyryjskim wśród Arabów przed islamem. Zarys problematyki [w:] S. Wojciechowski (red.), Irak wczoraj i dziś, Poznań 2005, s. 31-45. Tematyką asyryjską zajmuje się ponadto uczeń M. Abdalli - B. Grysa: Asyryjski klasztor Mār Mãtāy (św. Mateusza) w pótnocnym Iraku [w:] M. Abdalla (red.), Niemuzutmańskie mniejszości Iraku. Historia - kultura - problemy przetrwania, Poznań 2008, s. 167-175; Sytuacja Asyryjczyków w pótnocnym Iraku po obaleniu Saddama Husajna [w:] A. Kapiszewski (red.), Swiat arabski w procesie przemian, Kraków 2008, s. 205-217. 
Co się tyczy części teoretycznej opracowania, to spośród licznych źródeł dotyczących tożsamości na uwagę zasługują dwie prace zbiorowe: Kłopoty z tożsamościa pod redakcją Mariana Golki z 2006 roku oraz wydane rok później Wokót tożsamości: teorie, wymiary, ekspresje, zredagowane przez Irenę Borowik i Katarzynę Leszczyńską, ponadto publikacje Zygmunta Baumana i Zbigniewa Bokszańskiego. Z kolei prace Ernesta Gellnera i Benedicta Andersona wnoszą najwięcej do rozdziału o badaniach narodowościowych - jeśli nie pod względem ilościowym, to jakościowym. Artykuły Krzysztofa T. Koneckiego i Lecha M. Nijakowskiego stanowią zaś punkt wyjścia dla omówienia metodologii badań.

Refleksje prezentowane w toku pracy nie pretendują do całościowego opisu złożonego zjawiska rodzącej się tożsamości narodowej Asyryjczyków i Aramejczyków; mają jedynie zarysować niektóre wybrane, emblematyczne przejawy tejże, jej blaski, ale również cienie, będące znakiem pewnego kryzysu obecnego w społeczności asyryjsko-aramejskiej. 


\section{ROZDZIAŁ 1 Wprowadzenie do obszaru badań}

\subsection{Metodologiczne podstawy badań}

\subsubsection{Teoria ugruntowana}

Według Karla Poppera celem nauki nie jest zdobywanie wiedzy prawdziwej, lecz nieustanne przybliżanie się do niej. To samo przybliżanie, gdyż gwarancji odkrycia nie ma żadnej, stanowi motor napędowy nauki. Ten, kto twierdzi, że prawdę odnalazł, przyznaje się w istocie do rezygnacji z jej poszukiwań. Sama prawda istnieje jednak obiektywnie, bo idea błędu lub obalalności zakłada ideę prawdy obiektywnej, wzorca, który nie został osiągnięty.

Jak zostanie wykazane w rozdziale pierwszym, literatura poświęcona tożsamości narodowej oraz nacjonalizmowi jest konceptualnym labiryntem. W tym miejscu należy zaznaczyć, że jest to literatura o brakujących danych empirycznych i słabej mocy wyjaśniającej ${ }^{1}$. Idea „nacjonalizmu” może być bowiem rozważana na wielu poziomach analizy: jako ideologia, ruch, orientacja polityczna jednostki. Często nacjonalizm mylony jest z innymi narodowymi orientacjami, jak „duma narodowa” ${ }^{2}$. W pracy niniejszej nacjonalizm postrzegany jest jako immanentny element procesu budowana narodu. Nie istnieją całkowicie adekwatne narzędzia do jego badania. $\mathrm{Z}$ jednej strony, „sposób, w jaki naród postrzegany jest z dołu (...) przez

${ }^{1}$ H. Dekker, Nationalism, Its Conceptualization and Operationalization [w:] K. Phalet \& A. Örkény (red.), Ethnic Minorities and Inter-Ethnic Relations, Farnham, Surrey 2001; H. Dekker, D. Malová, The Concept of Nationalism [w:] M. Cross (red.), Nationalism, Ethnic Conflict and Conceptions of Citizenship and Democracy in Western and Eastern Europe, Vol. 1: Theories and Concepts, Utrecht 1995.

${ }^{2}$ H. Dekker, D. Malová, S. Hoogendoorn, Nationalism and Its Explanations, „Political Psychology”, Vol. 24, No. 2, Special Issue: National Identity in Europe, June 2003, s. 345. 
zwykłych ludzi (...) jest niezwykle trudny do odkrycia”’3, z drugiej zaś rzeczywistość społeczną najlepiej rozumieją zaangażowani w nią aktorzy. $\mathrm{Z}$ tego założenia wyrasta metodologia niniejszej książki, mianowicie metodologia teorii ugruntowanej.

Według niej na początku badań odrzuca się tradycyjne funkcjonalistyczne podejście, w którym badacz analizuje zbiorowość przy użyciu wcześniej opracowanego modelu teoretycznego, ponieważ ścisłe trzymanie się modelu powoduje jedynie samopotwierdzanie się danej teorii (badacz utwierdza się we własnym zamyśle, bo znajduje to, co chce znaleźć). Koncepcja badawcza, jej główne kategorie i/lub hipotezy oraz cały konstrukt teoretyczny, na który składają się połączone ze sobą hipotezy i ich opis, powinny wyłonić się w trakcie badań empirycznych i towarzyszących im permanentnych analiz. W miarę, jak w kolejnych iteracjach zbierany jest materiał badawczy (w wywiadach, obserwacjach, analizie tekstu itp.), teoria wyłania się z samych badań, "gruntując się" w terenie. Jest to zatem teoria dotycząca jedynie wybranej, konkretnej społeczności, ale za to znacznie lepiej do niej pasująca $^{4}$.

Niezwykłą trudność stanowi badanie bez prekonceptualizacji. Jak wiadomo, każde działanie ma swój początek, zaś w przypadku każdego badania powinniśmy wiedzieć, kto lub co będzie podlegać obserwacji i opisowi. Pierwszy wybór dotyczy zatem obiektu obserwacji i/lub zjawiska, a nie przyjmowania określonych pojęć i założeń czy też hipotez 5 . Bardzo istotna jest tutaj kategoria opisująca zjawisko tzw. kontekstu odkrycia (serendipity) ${ }^{6}$. „Kontekst odkrycia” pojawia się już u wspomnianego wcześniej Karla Poppera i oznacza przypadkowe wytworzenie pomysłu; jego uzupełnieniem jest „kontekst uzasadnienia”, czyli etap sprawdzania tego, czy pomysł jest dobry $^{7}$.

Zaletą metodologii teorii ugruntowanej jest to, że postulując ograniczenie prekonceptualizacji badań i założeń odnośnie do przebiegu badanych zjawisk, pomaga ona odkryć ich nowe wymiary i uwarunkowania.

${ }^{3}$ E. Hobsbawm, Nations and Nationalism since 1780, Cambridge 1990, s. 11.

${ }^{4}$ K. T. Konecki, Teoria ugruntowana a kontekst odkrycia. Naturalna historia pewnego badania, qsr.webd.pl/KKonecki/publikacje/publikacja27.doc, data wejścia 14.11.2009.

${ }^{5}$ Ibidem.

${ }^{6} \mathrm{Idem}$, Studia z metodologii badań jakościowych. Teoria ugruntowana, Warszawa 2000, s. 27, 101-102 i nast.; zob. także G. Fine, J. Deegan, Three Principles of Serendip: Insight, Chance, and Discovery, "Qualitative Research Studies Education”, No. 9, 1996, s. 434447; R. Merton, E. Barber, The Travels and Adventures of Serendipity, Princeton 2004.

${ }^{7}$ Cyt. za: T. Laskowski, Karl Rajmund Popper i jego filozofia nauki, http://vharijjen.w.interia.pl/content/Popper.html, data wejścia 10.10.2009. 
Co więcej, często pozwala dotrzeć do zjawisk jeszcze nieprzebadanych i nieprzeanalizowanych, które pojawiają się przy okazji badania wybranego wcześniej zjawiska. Innymi słowy, wybór opisywanej metodologii nierzadko umożliwia znalezienie, w sensie przedmiotowym, ale i teoretycznym, czegoś, czego badacz nie szukał na początku swoich badań ${ }^{8}$.

\subsubsection{Cel badań, problemy badawcze}

„Kontekst odkrycia” obecny był także w moich badaniach. Początkowo zamierzałam skupić się jedynie na grupie identyfikującej się jako „Asyryjczycy”. Po zagłębieniu się w temat doszłam jednak do wniosku, że grupa aramejska jest na tyle silna, iż nie można traktować jej wyłącznie jako podgrupy asyryjskiej. Tym samym pierwotnie zamierzony opis mniej lub bardziej homogenicznej grupy został zarzucony na rzecz komparatystyki dwóch podgrup etnicznych. Jednocześnie podjęłam decyzję o nieuwzględnianiu jako oddzielnego podmiotu badań podgrupy chaldejskiej, lecz traktowaniu jej łącznie z asyryjską?

Tym samym został wyraźnie wyznaczony cel badań, mianowicie analiza procesu kształtowania się tożsamości współczesnych Asyryjczyków i Aramejczyków. Chcąc jak najlepiej zrozumieć specyfikę zjawisk towarzyszących temu procesowi, zdecydowałam się na zgromadzenie przynajmniej części materiału w trakcie badań terenowych. Tego typu badania umożliwiają poznawanie zjawisk $\mathrm{w}$ ich naturalnym kontekście, a więc tym samym wpływają na lepsze zrozumienie ich złożoności. Uważa się, że „najlepiej dla rzetelności badań jest, gdy używa się do zbadania danego problemu wielu technik. Kontrolują się one niejako nawzajem, pozwalając spojrzeć na dane zjawisko z wielu punktów widzenia" ${ }^{10}$.

Wybierając taką perspektywę, zastosowałam zróżnicowane techniki zbierania danych; ich wybór został podyktowany bogactwem i dywersyfikacją

\footnotetext{
8 „Serendipity” oznacza dokonanie odkrycia przez przypadek lub zdolność dokonywania szczęśliwych i nieoczekiwanych odkryć przez przypadek. Twórcą tego terminu jest angielski pisarz Horace Walpole (1754).

${ }^{9}$ Czynię to jednak ze świadomością, że tożsamość współczesnych Chaldejczyków wymaga oddzielnego opisania, co jednak przekracza ramy tej pracy. Ich polityce poświęcona została dysertacja doktorska Y. S. Hanoosh, „The Politics of the Minority. Chaldeans between Iraq and America”, obroniona na University of Michigan, Michigan (USA) 2008, oraz praca magisterska R. H. Georgesa, „The Chaldeans between Religion and Politics: The Struggle of Iraq's Minority and US National Security”, San Diego State University, San Diego (USA) 2010.

${ }^{10}$ K. T. Konecki, Studia z metodologii badań jakościowych. Teoria ugruntowana, PWN, Warszawa 2000, s. 144.
} 
badanego obszaru, a także logiką i dynamiką przebiegu projektu badawczego $^{11}$. Analizie poddane zostały wywiady pogłębione, przeprowadzone z Asyryjczykami i/lub Aramejczykami, zapisy z obserwacji, materiały dotyczące spraw asyryjsko-aramejskich, które ukazały się w magazynach wydawanych przez wspólnotę oraz na stronach internetowych. Wymienione techniki zbierania danych były stosowane równolegle, przez cały czas trwania badania (od sierpnia 2006 roku do sierpnia 2009 roku). Konsekwencją takiego rozwiązania było wzajemne uzupełnianie się technik w procesie permanentnego porównywania ${ }^{12}$.

Zgodnie z teorią ugruntowaną na początku nie postawiono żadnych hipotez. W trakcie wstępnych wywiadów i obserwacji zaczęła wyłaniać się mapa zagadnień istotnych z punktu widzenia Asyryjczyków i Aramejczyków, natomiast podczas konstruowania kwestionariusza i przeprowadzania badań właściwych zrodziły się następujące problemy badawcze: Kto konstruuje naród asyryjski/aramejski? W jaki sposób to czyni?

Tym samym przedmiotem analizy stały się podmioty uczestniczące w procesach tworzenia i transmisji reprezentacji tożsamości narodowej ${ }^{13}$. Możemy mieć tu do czynienia z wielką rozmaitością podmiotów - od przedstawicieli elit politycznych, przez intelektualistów, naukowców, artystów, duchownych, biznesmenów, do ludzi mediów. Na drugim biegunie znajdują się odbiorcy, którzy nigdy nie są do końca bierni, choć ich wpływ jest bardzo zróżnicowany ${ }^{14}$. Granica pomiędzy odbiorcami i nadawcami jest o tyle nieostra, że jednostki w zależności od kontekstu pełnią różne role ${ }^{15}$.

Równie ważną kwestią była identyfikacja podstawowych kategorii, tematów ${ }^{16}$, zworników ${ }^{17}$, czy też głównych wątków dyskursu ${ }^{18}$, wokół których

${ }^{11}$ M. Hammersley, P. Atkinson, Ethnography: Practices and Principles, New York 1995, polskie tłumaczenie: Metody badań terenowych, Poznań 2000.

${ }^{12}$ B. Glaser, A. L. Strauss, The Discovery of Grounded Theory: Strategies for Qualitative Research, Chicago 1967; M. B. Miles, M. A. Huberman, Qualitive Data Analysis: An Expanded Source Book, Sage, Thousand Oaks 1994, polskie tłumaczenie: Analiza danych jakościowych, Białystok 2000.

${ }^{13}$ Por. A. Raciniewska, Tożsamość narodowa i „cultural studies” [w:] M. Golka (red.), Kłopoty z tożsamościa, „Człowiek i Społeczeństwo”, t. XXVI, Poznań 2006, s. 136.

${ }_{14}$ J. Kilias, Wspólnota abstrakcyjna - zarys socjologii narodu, Warszawa 2004, s. 10 i nast., cyt. za: A. Raciniewska, op. cit., s. 137.

${ }^{15}$ L. M. Nijakowski, Znaczenie analizy dyskursu dla socjologii narodowości, „Kultura i Społeczeństwo" nr 1, 2004, s. 74.

${ }^{16}$ J. van Dijk, K. L. Hacker (red.), Digital Democracy: Issues of Theory and Practice, London 2001, s. 19.

${ }^{17}$ L. M. Nijakowski, Analiza dyskursu na temat mniejszości narodowych $i$ etnicznych w polskich mediach, http://www.racjonalista.pl/kk.php/s,4820, data wejścia 20.08.2009.

${ }^{18}$ A. Raciniewska, op. cit., s. 137. 
koncentruje się uwaga jego uczestników. Nie istnieją one bowiem w próżni, łączą się ze sobą w sieci wiązek tematycznych, schematów fabularnych czy też „kompleksów dyskursywnych”" ${ }^{19}$. Analiza ma tu na celu zidentyfikowanie znaczenia przypisywanego poszczególnym zdarzeniom, obiektom i postaciom przez uczestników dyskursu. Równie ciekawe może być zauważenie tematów przemilczanych lub pojawiających się na marginesie debat ${ }^{20}$.

Poza analizą treści dyskursu konieczne jest zbadanie sposobu konstrukcji komunikatów - na poziomie lingwistycznym chodzi tu o style wypowiedzi oraz figury retoryczne. Dodatkowo zidentyfikować można elementy $\mathrm{z}$ innego poziomu, całe schematy argumentacyjne, konwencjonalne zasoby interpretacyjne, ideologie, a w szczególności stereotypy i uprzedzenia etniczne ${ }^{21}$. Wreszcie należy $\mathrm{w}$ analizie dyskursu uwzględnić kontekst, czyli zjawiska i procesy społeczne, kulturowe i polityczne, w obrębie których zachodzi reprodukcja reprezentacji tożsamości narodowej. Do lokalnych uwarunkowań należą np. miejsce, czas i okoliczności, w jakich dochodzi do formułowania i przekazywania kulturowych reprezentacji narodu ${ }^{22}$. Interesującym pomysłem analitycznym jest uwzględnienie na omawianym tutaj poziomie kategorii „trajektorii” Fritza Schützego, czyli bezładnych procesów społecznych naznaczonych cierpieniem, prowadzących do odkrywania własnej odmienności, nieprzystawalności, upośledzenia czy zmarginalizowania ze względu na przynależność narodową lub etniczną ${ }^{23}$.

\subsection{Badania narodowościowe}

Jak trafnie zauważył Ernest Gellner, „idea nienależenia do żadnego narodu wymaga od dzisiejszej wyobraźni nie lada akrobacji”. W powszechnym przekonaniu bowiem każdy człowiek „musi mieć jakąśs narodowość, podobnie jak musimy mieć nos i dwoje uszu; brak którejś z tych rzeczy nie jest czymś niepojętym, może się zdarzyć, ale tylko w wyniku jakiegoś nieszczęścia; brak tego rodzaju jest zresztą sam nieszczęściem"24.

Zagadnienia oscylujące wokół tematyki narodu i narodowości od wielu lat stanowią jeden z głównych problemów badawczych analizowanych

${ }^{19}$ L. M. Nijakowski, Znaczenie analizy..., s. 79.

${ }^{20}$ A. Raciniewska, op. cit., s. 138.

${ }^{21}$ Ibidem.

${ }^{22}$ J. Kilias, op. cit., za: A. Raciniewska, op. cit., s. 139.

${ }^{23}$ F. Schütze, Trajektorie cierpienia jako przedmiot badań socjologii interptetatywnej, „Studia Socjologiczne” 1/1997, za: A. Raciniewska, op. cit., s. 139.

${ }^{24}$ E. Gellner, Narody i nacjonalizm, Warszawa 1991, s. 15. 
przez przedstawicieli nauk humanistycznych i społecznych. We współczesnym świecie widoczne są dwie tendencje - do globalizacji, objawiającej się m.in. poprzez tworzenie wspólnot ponadnarodowych z jednej strony, z drugiej zaś do coraz powszechniejszego rodzenia się tzw. kwestii narodowych, związanych z rozbieżnością między historycznie ukształtowaną strukturą państwową a strukturą etniczną 25. Według Antoniny Kłoskowskiej następuje „odradzanie się starych i rodzenie się nowych tendencji narodowego wyodrębnienia i politycznego samopotwierdzenia"26. Napięcia i konflikty związane z budzeniem się tożsamości narodowych pojawiają się nie tylko w państwach Trzeciego Świata, ale też w pozornie stabilnych demokracjach Zachodu. Nie sposób uniknąć wrażenia, że myślenie narodowe jest ciągle silniejsze niż kosmopolityczne marzenia o wspólnocie i solidarności ogólnoludzkiej.

\subsubsection{Naród}

Jak pisze Benedykt Zientara: „Wszystkie próby zdefiniowania narodu są zgodne w stwierdzaniu, że jest to wspólnota ludzka. Ale na tym zgodność się kończy" ${ }^{27}$. Kategoria narodu jest pojęciem niezwykle szerokim i złożonym, obejmującym zarówno potoczne przekonania wynikające z codziennych obserwacji, jak i naukowe próby uchwycenia zjawiska. Narodowy i ojczyźniany porządek świata tkwi w większości kultur w sposób, który nie dopuszcza zbyt wielu pytań o jego istotę. Trudno wyzwolić się od swoistej reifikacji narodu, czyli postrzegania go jako zjawiska spoza sfery wytworów ludzkich działań, jako bytu odrębnego i samoistnego ${ }^{28}$. Potoczne podejście bazuje na emocjach, na wierze, a objawia się częstokroć w samej nazwie - etymologia słowa „naród” w wielu językach wywodzi się od łacińskiej formy natio (od nascere 'rodzić się)') lub od analogicznych rodzimych odpowiedników ${ }^{29}$. Naród jest więc kategorią dyskursywną, która początek bierze w nazwie, jaką wspólnota sobie nadaje, a następnie istnieje w wyobrażeniach tej wspólnoty i wyobrażeniach o niej, podsuwanych jednostkom jako „budulec” ich tożsamości ${ }^{30}$.

${ }^{25}$ R. Zenderowski, Stosunki międzynarodowe. Vademecum, Wrocław 2006, s. 325.

${ }^{26}$ A. Kłoskowska, Kultury narodowe u korzeni, Warszawa 1996, s. 7.

${ }^{27}$ B. Zientara, Świt narodów europejskich, Warszawa 1996, s. 11.

${ }^{28}$ M. Starnawski, Naród, ojczyzna, tożsamość. O iluzjach urzeczywistnionych, „Recykling Idei”, $\mathrm{nr}$ 7, 20.04.2006.

${ }^{29}$ A. Kłoskowska, op. cit., s. 15.

${ }^{30}$ Por. P. Sériot, Ethnos i demos: dyskursywne konstruowanie zbiorowej tożsamości, „Teksty Drugie", nr 1/1994. 
Nie istnieje jedna powszechnie akceptowana przez badaczy definicja narodu. W literaturze zachodniej można się spotkać z częstym utożsamianiem tego ostatniego z państwem. Jest to uzasadnione, o ile przyjmie się jedną z dwóch zasadniczych koncepcji narodu - mianowicie wspólnoty politycznie zorganizowanej, w której proces narodowotwórczy wspierany był przez państwo; pojęcia „naród” i „państwo” są tożsame dla większości mieszkańców Zachodu z przyczyn historycznych. Z drugiej strony obecne są głosy różnicujące te dwa podejścia - szczególnie tam, gdzie koncepcje narodu rozwijały się niezależnie od państwa (np. w Europie Środkowej i Wschodniej w XIX wieku). Możemy zatem mówić o dwóch zasadniczych koncepcjach narodu - zachodnioeuropejskiej (postrzegającej naród jako demos) oraz środkowo- i wschodnioeuropejskiej (utożsamiającej naród $\mathrm{z}$ etosem ${ }^{31}$ ). $\mathrm{Na}$ gruncie nauk społecznych obserwuje się w związku z tym spór o to, jakiemu zjawisku przysługuje nazwa „naród” - czy wspólnocie zorganizowanej politycznie, czy określonej grupie etniczno-kulturowej. Nie jest to spór wyłącznie o nazwę, lecz przede wszystkim o realność tego, co ona oznacza $^{32}$.

\subsubsection{Naród jako demos i etnos}

Anthony Smith wyróżnił kluczowe różnice między podejściem esencjalistycznym oraz modernistycznym: naród jest tworem współczesnym (v. istniał odwiecznie), jego stworzenie nastąpiło na skutek współczesnych procesów (v. powstał naturalnie), szczególną rolę w jego konstrukcji odgrywają elity (v. buduje go etniczno-kulturowa wspólnota), przynależność narodowa przybiera charakter obywatelstwa (v. wyrasta z więzi kulturowych i etnicznych) ${ }^{33}$.

Oba ujęcia - narodu jako demosu i narodu jako etnosu - są oczywiście modelowe, gdyż każdy proces narodowotwórczy jest zarówno celowy,

${ }^{31} \mathrm{Na}$ pojęcie etnosu składają się następujące elementy: epos (świadomość ciągłości narodu, jego wzlotów i upadków, legendy itp. - historia zinterpretowana w specyficzny sposób); etos (sakralizacja całokształtu norm i instytucji regulujących życie społeczne narodu, uznanie za własne i święte różnych tradycji); logos (wspólny język, powszechnie akceptowany sposób komunikacji wewnątrz wspólnoty, symbole werbalne i niewerbalne); genos (przekonanie o posiadaniu wspólnych przodków, często uznawanych za założycieli narodu i wielkich bohaterów); topos (przeżywanie ziemi ojczystej w kategoriach szczególnej wartości) - R. Zenderowski, op. cit., s. 313-314.

${ }^{32}$ Ibidem, s. 312.

${ }^{33}$ A. D. Smith, Nationalism and Modernism: A Critical Survey of Recent Theories of Nations and Nationalism, London-New York 1998, s. 22-23. 
jak i żywiołowy. Narody ani nie są w całości stwarzane, ani nie budzą się; w czystej formie nie występuje zasadniczo żaden naród. Można natomiast postawić tezę, że istnieją narody bardziej polityczne i bardziej kulturowe (bardziej i mniej „znacjonalizowane” czy zintegrowane). Niezależnie od przyjętej koncepcji, na model narodu powinny składać się:

- dziedzictwo kulturowe (historia), z którym znaczna część zbiorowości identyfikuje się jako z własnym;

- wspólna bogata symbolika; katalog „punktów odniesienia”, wspólny zasób uczuć i myśli „tu i teraz”;

- wspólny język i system komunikacji wewnątrz wspólnoty narodowej;

- przeświadczenie o wspólnym pochodzeniu etnicznym znacznej większości;

- istnienie terytorium państwowego, które znajduje się bądź w posiadaniu narodu, bądź pod czyjąś okupacją;

- znaczne poczucie wspólnoty między ludźmi różnych klas i warstw społecznych (identyfikacja wewnętrzna);

- poczucie odrębności narodowej, bycia narodem wśród innych (identyfikacja zewnętrzna);

- istnienie w przeszłości lub obecnie państwa traktowanego jako swoje, zaś w przypadku braku państwowości - wola stworzenia jej lub przynajmniej uzyskania pewniej autonomii w ramach istniejącego państwa (państw) ${ }^{34}$.

Nie należy przy tym utożsamiać narodu z narodowością. Terminu „narodowość” używa się w dwóch znaczeniach: jako przynależność do danego narodu oraz jako „niepełność narodową” - pośrednie stadium między plemieniem czy grupą etniczną a narodem. Oczywiście niełatwo jest rozróżnić narody i grupy etniczne - właśnie ze względu na ową płynność kryteriów. Thomas Eriksen nazwał protonarodami grupy etniczne, które same uważają się za prawdziwe narody (np. Sikhowie, Palestyńczycy, Kurdowie), ale na arenie międzynarodowej często nie ma pewności co do uznania ich jako odrębnych narodów, zasługujących na polityczną autonomię. Czasami określić je można jako zalążki narodu. Uważam, że pojęcie „protonarodu” bardzo dobrze opisuje Asyryjczyków/Aramejczyków, którzy często sami za naród się uważają, jednak na forum międzynarodowym postrzegani są wyłącz-

${ }^{34}$ R. Zenderowski, op. cit., s. 317. 
nie jako mniejszość etniczna czy religijna wywodząca się z Bliskiego Wschodu.

Taki stan rzeczy związany jest z problemem, jaki stwarza prawo narodów do samostanowienia. Choć głosi ono, że każdy naród (w odróżnieniu od grupy etnicznej lub mniejszości) ma prawo do samostanowienia, to jednak wydzielanie się nowych państw jest obecnie rzadkością. Stoi bowiem w sprzeczności z wolą utrzymania ładu na świecie, z interesami mocarstw oraz tendencją do integracji ponadnarodowej. Dlatego też dążenia do suwerenności wielu zależnych narodów, czy też protonarodów, takich jak Asyryjczycy/Aramejczycy, bojkotowane są w przede wszystkim poprzez odmówienie im prawa do określenia się jako „naród”.

\subsubsection{Narodziny narodu}

Narodziny narodu oznaczają narodziny nowego ładu społecznego. Przywódcy narodowi spoglądają do wewnątrz i na zewnątrz narodowych granic, stopniowo budują wizerunek narodowego „się” o dwoistej naturze - opartej na samoświadomości, wyrosłej ze szczególnych cech wspólnoty, oraz percepcji „znaczących innych” należących do społeczności międzynarodowej. Konstrukcja tożsamości narodu rozpoczyna się więc od odróżnienia się od otoczenia, „wyjścia z tła” - rodzący się naród zaczyna postrzegać siebie jako gracza zdolnego kształtować rzeczywistość, ale i będącego przedmiotem działań innych graczy. W celu podkreślenia swojego wyjątkowego charakteru naród przyjmuje różnorodne symbole, m.in. konstytucje i deklaracje niepodległości oraz święta narodowe. Granice narodowe wyznaczają z kolei znaczniki takie, jak paszporty, waluty czy języki. Wszystkie one służą izolacji, koniecznej do rozwinięcia unikatowych $\operatorname{cech}^{35}$.

Następną fazą jest integracja - naród rozpoznaje, jaka jest jego pozycja w społeczności międzynarodowej, która staje się „zgeneralizowanym innym”, jednocześnie pomagając mu stać się „sobą”. Na tym etapie następuje internalizacja zewnętrznych wartości; symbole służą integracji - dyplomaci są żyjącymi symbolami, wysyłanymi, by reprezentować naród (ich rozmieszczenie i działania stanowią ważne punkty odniesienia), zaś flagi często kopiują kolory i wzory oznaczeń innych państw, by wskazać na łączące je więzi ${ }^{36}$.

${ }^{35}$ K. A. Cerulo, Identity Designs: The Sights and Sounds of a Nation, New BrunswickNew Jersey 1995, s. 55-56.

${ }^{36}$ Ibidem, s. 57-59. 


\subsubsection{Nacjonalizm}

Z terminem „naród” ściśle łączy się termin „nacjonalizm”, którego pozytywne konotacje, zwłaszcza w wyniku dramatycznych doświadczeń II wojny światowej, w naszym kręgu kulturowym dziś prawie całkowicie zniknę$\mathrm{yy}^{37}$. O ile łatwo jest zaakceptować istnienie narodów jako realnej, ważnej w ludzkim życiu rzeczywistości, o tyle pozytywna ewaluacja idei narodowej jest już sprawą trudniejszą. Duża część współczesnych publicystów i historyków idei dostrzega w nacjonalizmie największe zagrożenie dla współczesnego, popperowskiego „społeczeństwa otwartego”38.

Ciekawe są spostrzeżenia dotyczące różnic pomiędzy nacjonalizmem wschodu i zachodu Europy, związanych z dualizmem w rozwoju gospodarczym naszego kontynentu. Zdaniem Ryszarda Radzika, Europa podzieliła się narodowo na dwie części, a linią podziału stała się w przybliżeniu Łaba i północne Włochy. Na zachodzie rozwinął się kapitalizm i powstał typ narodu państwowo-politycznego, podczas gdy na wschodzie ukształtował się naród etniczno-językowy. W konsekwencji istniejące na wschodzie narody są znacznie silniejsze niż analogiczne wspólnoty na zachodzie, choć jednocześnie znacznie bardziej konfliktogenne ${ }^{39}$.

Podobnie jak w przypadku narodu, istnieje spore zróżnicowanie stanowisk co do istoty i zakresu przedmiotowego nacjonalizmu. Generalnie można przyjąć, że nacjonalizm jest to światopogląd, który zawiera wątki polityczne, kulturowe, ekonomiczne, religijne itp. i który w centrum ludzkich wysiłków umieszcza dobro narodu jako wspólnoty gwarantującej optymalny byt jednostce. Współcześnie jest to światopogląd demokratyczny (adresowany i przyjmowany przez wszystkie warstwy społeczne), choć kiedyś zarezerwowany był dla warstw wyższych.

Nacjonalizm stanowi świecką ideologię integracyjną - rekompensuje utracone więzi rodzinne i klanowe. Jego źródłem jest psychologiczna potrzeba definiowania własnej tożsamości za pośrednictwem członkostwa w szerszej społeczności ${ }^{40}$. Ponadto nacjonalizm to program polityczny, który postrzega naród jako dany i ma za zadanie promować interesy tegoż,

\footnotetext{
${ }^{37}$ M. Hroch, Mate narody Europy, Wrocław 2003, s. 97.

${ }^{38}$ Por. K. Popper, The Open Society and Its Enemies, London 1945, polskie tłumaczenie: Społeczeństwo otwarte i jego wrogowie, Warszawa 2006.

${ }^{39}$ Ł. Moczydłowski, Powrót idei. Czym jest a czym nie jest nacjonalizm?, „Magazyn Kulturalny Phalanx", nr 3/2002.

${ }^{40}$ R. Zenderowski, op. cit., s. 318.
} 
przede wszystkim przez stworzenie terytorialnego państwa ${ }^{41}$. Często żywi się on „historyczną mitologią”, mieszaniną faktów i fantazji, uproszczoną wersją historii narodowej ${ }^{42}$.

Zasadniczy spór dotyczący relacji nacjonalizm-naród przebiega pomiędzy tymi, którzy uważają, że narody generują nacjonalizmy będące emanacją ich tożsamości (naturalizm), a tymi, według których to nacjonalizmy (ideologie narodowe) tworzą narody (konstruktywizm). Pierwsze podejście związane jest z przekonaniem, że nacjonalizm jest immanentną cechą dojrzałych narodów, sposobem zbiorowej wypowiedzi. Natomiast w drugim przypadku bazuje się na przeświadczeniu, że narody nie istniałyby bez przemyślanych zabiegów socjotechnicznych i ideologicznych ${ }^{43}$. Według konstruktywistów to „nacjonalizm stwarza narody, a nie na odwrót” ${ }^{44}$, a człowiek, ulegając uwiedzeniu przez „przynależność” bądź „tożsamość”, staje się nieodzownym elementem tworzenia narodowej rzeczywistości, będącej de facto iluzją ${ }^{45}$.

Oba te podejścia są skrajne - w rzeczywistości nacjonalizm jednocześnie tworzy narody i jest przez nie generowany. $Z$ jednej strony może być traktowany jako przejaw żywotności narodu (wyraz zintegrowania), z drugiej jako odpowiedź na kryzys sensu i autorytetu (poszukiwanie integracji). W obu przypadkach niebagatelną rolę odgrywają państwowe i niepaństwowe elity polityczne różnego szczebla ${ }^{46}$.

Inny podział istnieje pomiędzy nacjonalizmem jako umacnianiem państwa i narodu państwowego a nacjonalizmem jako umacnianiem narodu bezpaństwowego. Pierwszy typ - nacjonalizm państwa narodowego - inicjowany jest odgórnie, przez elity państwowe, które pragną wzmocnienia istniejących struktur lub wprowadzania określonych reform. Drugi typ inspirowany jest oddolnie - przez elity niepaństwowe (duchowieństwo i inteligencję).

Według Normana Davisa etnonacjonalizm (który za wartość uznaje jedność między ludźmi „tej samej krwi”) rozkwita najlepiej w okresie prześladowań i kryzysu ${ }^{47}$. Podlegający zewnętrznemu uciskowi, np. kolonial-

${ }^{41}$ E. J. Hobsbawm, Ethnicity and Nationalism in Europe Today, „Anthropology Today”, Vol. 8, No. 1, February 1992, s. 4.

${ }^{42}$ H. Seton-Watson, Nations and States, London 1977, s. 87.

${ }^{43}$ R. Zenderowski, op. cit., s. 319.

${ }^{44}$ E. Gellner, op. cit., s. 72.

${ }^{45}$ M. Starnawski, op. cit.

${ }^{46}$ R. Zenderowski, op. cit., s. 320.

${ }^{47}$ Ibidem, s. 321. 
nemu, posługuje się retoryką narodowowyzwoleńczą w celu emancypacji; służy mobilizacji mas przeciwko najeźdźcom, okupantom czy zaborcom i uzyskaniu autonomii politycznej, najczęściej w formie własnego państwa narodowego ${ }^{48}$. Z kolei nacjonalizm ziemski (terytorialny), który był charakterystyczny dla epoki średniowiecza, a obecnie przybiera formę tzw. regionalizmu (lokalizmu), jest „ślepy etnicznie” - z jego punktu widzenia liczy się wyłącznie zamieszkiwanie na jednym terytorium, umiłowanie wspólnej ziemi ${ }^{49}$.

Konkurencją dla nacjonalizmu są zarówno wspólnoty szersze od narodu (religijne, klasowe, regionalno-kontynentalne), jak i wspólnoty mniejsze od niego (rodzinne, klanowe, plemienne, lokalne, regionalne itp.). Można więc powiedzieć, że identyfikacja narodowa znajduje się w swoistym polu napięcia między tym, co lokalne, a tym, co uniwersalne $e^{50}$.

\subsubsection{Ojczyzna i patriotyzm}

W polskiej rzeczywistości ciągle żywa jest klasyczna teoria Stanisława Ossowskiego, według którego naród powstał w momencie pojawienia się świadomości ojczyzny ideologicznej ${ }^{51}$; badacz rozróżniał bowiem „ojczyznę ideologiczną” oraz „ojczyznę prywatną”52. W przeciwieństwie do ojczyzny prywatnej, która bazuje na więziach emocjonalnych pomiędzy jednostką bądź wspólnotą a terytorium wraz z jego topografią fizyczną i symboliczną, ojczyzna ideologiczna „nie opiera się na bezpośrednich przeżyciach jednostki względem ojczystego terytorium i na wytworzonych przez te przeżycia nawykach, ale na pewnych przekonaniach: na przekonaniu jednostki o jej uczestnictwie w pewnej zbiorowości i na przekonaniu, że jest to zbiorowość terytorialna związana z tym właśnie obszarem. Moja ojczyzna w tym ideologicznym znaczeniu - to ziemia mojego narodu" 53 .

Ojczyzna ideologiczna jest więc pewną „umowną konstrukcją imaginacyjną" (określenie Zygmunta Baumana), projektem wynikającym z historii oraz ram ideologicznych narodu i państwa. Nawet jeśli od wieków nie jest centrum życia narodowego, stanowi ważny symbol i inspiruje „mit powrotu” społeczności żyjących w rozproszeniu. Związek z ojczyzną ideologiczną

\footnotetext{
${ }^{48}$ M. Starnawski, op. cit.

${ }^{49}$ R. Zenderowski, op. cit., s. 322.

${ }^{50}$ Ibidem, s. 324.

${ }^{51}$ Ł. Moczydłowski, op. cit.

${ }^{52}$ Por. S. Ossowski, Analiza socjologiczna pojęcia ojczyzny, t. 4, Łódź 1946.

${ }^{53}$ Ibidem, s. 16.
} 
miewa też realne konsekwencje polityczne - retoryka narodowej „własności” ziemi staje się narzędziem mobilizacji i ekspansji ${ }^{54}$.

Jak zwrócił uwagę Andrzej Walicki, słowo „patriotyzm” nie pozostaje w koniecznym związku z ideą narodu. Uważa on, że „patriotyzm jest pojęciem terytorialnym, mogącym abstrahować od narodowości”. Tak pojmowany patriotyzm jest lojalnością w stosunku do określonego terytorium, podczas gdy nacjonalizm jest lojalnością w stosunku do grupy ludzi - wspólnoty narodowej. Pojęcia te zazwyczaj jednak występują obok siebie, wzajemnie się uzupełniając i najczęściej nie stanowią względem siebie żadnej opozycji5s.

Patriotyzm, jako strategia tworzenia więzi z ojczyzną ideologiczną, opiera się na pewnego rodzaju mitologizacji, czy też reifikacji. Według Rolanda Barthesa główną zasadą mitu jest przekształcanie historii w naturę, odebranie rzeczom historyczności i pamięci ich kreacji. Zadaniem mitu jest nadanie politycznej, socjologicznie złożonej i historycznie wytwarzanej rzeczywistości statusu naturalnego porządku rzeczy, niepodlegającego dyskusji, oczywistego. Mity początku, autochtoniczności (związku z ziemia), ojczyźnianych praprzodków oraz kolejnych pokoleń obrońców granic i narodowej tożsamości, wsparte moralnymi kodeksami patriotycznych zobowiązań i ojczyźnianej dumy, służą uprawomocnieniu więzi ideologicznej. Wraz z kierunkiem patriotyzmu określa się też to, czym on nie jest, lub co stanowi względem niego zagrożenie. Nader często zagrożeniem są wewnętrzni lub zewnętrzni „obcy”. Czynnik zagrożenia, niezbędny dla zaszczepienia troski o ojczyznę i gotowości poświęcenia się dla niej, jest stałym, choć w różnym natężeniu, składnikiem patriotycznego mitu ${ }^{56}$.

Patriotyzm, ze swym arsenałem estetycznie i moralnie uwodzicielskich obrazów i zasad kształtujących świadomościowe oraz behawioralne struktury działania, można więc określić jako formę przemocy symbolicznej57. Bez tej symbolicznej przemocy - narzucania prawomocnej kultury i identyfikacji - nie byłoby „wychowanków” narodu i ojczyzny, reprodukowanych i definiowanych z pokolenia na pokolenie jako „rodacy”. Nie byłoby też problemu „innych”, wewnątrz i na zewnątrz ojczyźniano-narodowego ideału $^{58}$.

${ }^{54}$ M. Starnawski, op. cit.

${ }^{55}$ Ł. Moczydłowski, op. cit.

${ }^{56}$ M. Starnawski, op. cit.

${ }^{57}$ Por. P. Bourdieu, J.-C. Passeron, Reproduction: In Education, Society and Culture, London 1977, polskie tłumaczenie: Reprodukcja. Elementy teorii systemu nauczania, Warszawa 1990.

${ }^{58}$ M. Starnawski, op. cit. 


\subsubsection{Diaspora}

W społecznościach rozproszonych (diasporach), zwłaszcza w pokoleniach uchodźców bądź wysiedleńców, doświadczających tożsamościowych wstrząsów związanych z przemieszczeniami geograficznymi i kulturowymi, fakt uznawania dwóch lub więcej ojczyzn nie należy do rzadkości. Ojczyźniane czy patriotyczne dyskursy uprawiane w ideologicznym centrum i w diasporze mogą się znacznie od siebie różnić, inaczej prezentować wizję „domu”, „przynależności” czy „korzeni”. W przestrzeni diasporycznej ojczyzna ideologiczna oraz „ci, którzy tam zostali”, są często tylko jednym z punktów odniesienia, obok kultury dominującej kraju osiedlenia oraz transnarodowego przenikania się diaspory z mniejszościami etnicznymi zamieszkującymi ten $\mathrm{kraj}^{59}$.

Z drugiej strony, niejedna wspólnota żyjąca w diasporze wkłada wiele wysiłku i angażuje znaczny kapitał, aby w kraju przyjmującym utrzymać kulturową odrębność oraz komunikację z żyjącymi w innych miejscach globu rodakami. Czasami ustanawia nawet polityczne przywództwo na emigracji. Tym samym zdarza się, że wspólnoty diasporyczne odgrywają niezwykle ważną rolę w podtrzymaniu tożsamości całego narodu ${ }^{60}$.

Brytyjski badacz kultury, Paul Gilroy, zwraca uwagę na fakt, że pojęcie diaspory umożliwia krytykę wizji zdyscyplinowanej tożsamości państwowo-narodowej poprzez „dowartościowanie relacji o zasięgu węższym lub szerszym niż więzi propagowane przez państwo/naród i poprzez umożliwienie bardziej wieloznacznego stosunku względem nacjonalizmu”. Termin „diaspora” ujawnia istnienie „rozłamu pomiędzy miejscem zamieszkania i tym, do którego się przynależy. (...) Świadomość przynależności do diaspory stoi w opozycji do nowoczesnych struktur i form władzy koordynowanych przez instytucjonalną złożoność państw narodowych" ${ }^{61}$.

\subsubsection{Historia badań narodowościowych}

Przez wiele lat historiografia zajmowała się kwestią nacjonalizmu, postrzegając centralność pojęcia „narodu” jako sposobu organizowania tożsamości w nowoczesnym świecie. Jednak ostatnio, mimo nieprzerwanego strumienia publikacji na ten temat, dynamizm badań zdaje się słabnąć

\footnotetext{
${ }^{59}$ Por. A. Brah, Cartographies of Diaspora. Contesting Identities, London 1996, s. 208-209.

${ }^{60}$ Por. A. I. Laing-Marshall, op. cit., s. 17.

${ }^{61}$ P. Gilroy, Diaspora and the Detours of Identity [w:] K. Woodward (red.), Identity and Difference, London 1997, s. 328-329.
} 
w porównaniu do intelektualnej stymulacji, która panowała w latach 90 . XX wieku. Prawdopodobnie dzieje się tak dlatego, że badania narodowościowe osiągnęły taki poziom rozwoju, w którym rzuciły wyzwanie własnym założeniom badawczym. Jednocześnie, nawet jeśli tożsamość narodowa miałaby kiedyś ulec erozji i fragmentacji - co jednak nie wydaje się realistyczne w świetle faktu, jak wielu ludzi deklaruje lojalność wobec narodu i gotowa jest nawet oddać życie za „wspólnotę krwi” - historycy wciąż będą mieć prawo do badania tego zjawiska jako jednego z podstawowych problemów XIX i XX wieku ${ }^{62}$.

Już sama liczba monografii szczegółowo omawiających rozmaite rodzaje nacjonalizmu ukazuje jasno jego złożoność i zróżnicowanie, a tym samym płonność idei poszukiwania jednej „teorii nacjonalizmu”. Niemniej warto przybliżyć pokrótce poglądy najważniejszych badaczy na kwestie związane z narodem, począwszy od XIX stulecia aż po współczesność.

Jednym z pierwszych, którzy stworzyli naukową koncepcję narodu ściśle związaną z kulturą, był Ernest Renan (1823-1892). Choć jego główne dzieła dotyczyły religijnych zagadnień starożytności, to pośmiertnie popularność zdobyły jego prace polityczne, przede wszystkim zwięzły artykuł, będący pierwotnie wykładem akademickim, Co to jest naród? („Qu'est-ce qu'une nation?”) ${ }^{63}$. Francuski pisarz krytykuje w nim utożsamianie narodu $\mathrm{z}$ rasą (choć pojęcie to w XIX wieku miało bardzo szeroki zakres znaczeniowy, podobny do dzisiejszego rozumienia kultury), wyjątkowo ważna jest dla niego wspólna przeszłość i związana z nią duma. Fundamentem narodu jest pamięć historyczna - pamięć o zbiorowych osiąnnięciach, pielęgnowanie bohaterskiego dziedzictwa. Badacz zauważa jednak coś jeszcze - aby naród przetrwał, musi nie tylko pamiętać, ale także zapominać o określonych wydarzeniach historycznych, niszczących jedność i przywołujących krwawe wspomnienia. Bardzo prawdziwy jest ten błyskotliwy paradoks - wiele narodów spycha w nieświadomość niewygodne dla siebie fakty, deprecjonuje zasługi innych nacji czy ich wpływ na własną kulturę, a czasem wręcz zakłamuje rzeczywistość, po to tylko (lub aż), by możliwa była afirmacja wspólnoty ${ }^{64}$.

${ }^{62}$ B. Porter, Podzwonne dla badań nad nacjonalizmem [w:] W. Burszta, K. Jaskułowski, J. Nowak (red.), Naród - tożsamość-kultura. Między koniecznością a wyborem, Warszawa 2005.

${ }^{63}$ E. Renan, Co to jest naród?, „Res Publica Nowa”, R. XVIII, nr 1 (183), Warszawa 2005, s. 143.

${ }^{64}$ M. Moch, „Kształtowanie się i rozwój palestyńskiego nacjonalizmu i tożsamości narodowej”, Instytut Orientalistyczny, Uniwersytet Warszawski, Warszawa 2005, s. 16, niepublikowana praca magisterska w posiadaniu autorki. 
Omawiając chronologicznie badania nad nacjonalizmem, należy wspomnieć dwóch wybitnych autorów anglojęzycznych z połowy XX wieku: Carltona Hayesa i Hansa Kohna, których idee obowiązywały przez dziesiątki lat ${ }^{65}$. Obaj uczeni odróżnili dobry nacjonalizm (charakteryzujący się otwartością obywatelską i łagodną miłością do własnego kraju) oraz zły nacjonalizm (cechujący się agresywnością, szowinizmem i rasizmem). Tę dychotomię powielano wielokrotnie w ciągu lat, wpadając w pułapkę ferowania osądów moralnych.

Kolejnym wkładem obu autorów było opisanie rozwoju nacjonalizmu na przestrzeni historii. Kohn prześledził ewolucję „idei nacjonalizmu” od czasów starożytnej Grecji do okresu oświecenia, charakteryzując ją jako preludium do narodzin „nowoczesnego nacjonalizmu” w czasie rewolucji francuskiej. Hayes natomiast przedstawił nieco inną narrację, jednak w obu przypadkach wyłonienie się tożsamości narodowej i państwa narodowego pozostaje integralną częścią nowoczesności. Stąd dla licznych historyków nacjonalizmu naród stanowi główny sposób kształtowania zbiorowej tożsamości w nowoczesnym świecie ${ }^{66}$.

Historycy nacjonalizmu postrzegali przedmiot swoich badań w obrębie gatunku historii intelektualnej, natomiast reprezentanci nauk społecznych wyjaśniali go przez powiązania z ewolucją społeczną. W latach 60. i 70. XX wieku nastąpiło podkreślenie dominującej roli industrializacji, urbanizacji i odpowiadających im przemian świadomości politycznej ${ }^{67}$. Badacze, choć nie porzucili zupełnie esencjalizmu ${ }^{68}$, skłaniali się teraz ku interpretacjom modernistycznym. Jak słusznie odnotował Karl Deutsch, „studia nad nacjonalizmem $\mathrm{w}$ tym okresie cechował pozytywistyczny optymizm

${ }^{65}$ Do najważniejszych książek C. Hayesa należą: Essays on Nationalism, New York 1954; The Historical Evolution of Modern Nationalism, New York 1931; Nationalism: A Religion, New York 1960. Wśród kluczowych tekstów H. Kohna wymienić można: The Age of Nationalism: The First Era of Global History, New York 1962; The Idea of Nationalism: A Study in Its Origins and Background, New York 1944; Nationalism. Its Meaning and History, Princeton 1955; Prelude to Nation-States. The French and German Experience, 1789-1815, Princeton 1967; Prophets and Peoples: Studies in Nineteenth Century Nationalism, New York 1946, za B. Porter, op. cit.

${ }^{66}$ B. Porter, op. cit.

${ }^{67}$ Wiele opracowań z lat 70. i początku lat 80 . XX wieku objaśniało historiozoficzną wizję narodzin nacjonalizmu w nowoczesności i poprzez nią. Do najważniejszych przykładów w języku angielskim zaliczają się prace: J. A. Armstrong, Nations before Nationalism, North Carolina 1982; J. Breuilly, Nationalism and the State, New York 1982; G. Mosse, The Nationalization of the Masses: Political Symbolism and Mass Movements in Germany from the Napoleonic Wars through the Third Reich, New York 1975.

${ }^{68}$ Por. A. D. Smith, op. cit., s. 11. 
i poszukiwanie modelu pojęciowego procesów nacjonalizmu i narodowości, który pasowałby do znanych faktów i ułatwiałby przewidywanie i kontrolowanie zdarzeń" ${ }^{69}$.

Następnie próbowano zdefiniować naród za pomocą kategorii wspólnej kultury oraz woli. Obie koncepcje, zarówno kulturowa, jak i woluntarystyczna, nie są wolne od wad. Kultura ma często rozmyte granice (możliwe są państwa o pluralistycznych kulturach), a wola jest obecna również w innych grupach, niekoniecznie o narodowym charakterze. Poza tym wola często łączy się z różnego rodzaju kalkulacją korzyści, strachem, przymusem i zniewoleniem, dlatego też nie wystarczy jako jedyny wyznacznik narodu.

Według Gellnera tym, co stwarza narody, jest nacjonalizm, który w sposób selektywny czyni użytek z historycznie odziedziczonych zasobów kulturowych, bardzo często ożywiając martwe języki, wymyślając tradycję, a nawet historię $e^{70}$. Co do samego nacjonalizmu, to niemal wszyscy badacze są skłonni się zgodzić, że zrodziła go modernizacja. Najcelniej podsumowuje owo przekonanie cytat z Hayesa: „,[Nacjonalizm] był odpowiedzią na industrializm i materializm epoki, a także na pseudonaukową propagandę, która szerzyła się na narody poprzez nowe ruchy masowe, nową powszechną edukację i nowe powszechne dziennikarstwo. Uczestniczył on - i inspirował - nacjonalistyczny imperializm i nietolerancję (...) A w obecnym stuleciu doprowadził (...) do wojen światowych"71.

Przełom w badaniach nad nacjonalizmem dokonał się w roku 1983, ukazały się wtedy bowiem: Wspólnoty wyobrażone Benedicta Andersona ${ }^{72}$, Narody $i$ nacjonalizmy Ernesta Gellnera ${ }^{73}$ oraz Tradycja wynaleziona Erica Hobsbawma i Trence'a Rangera ${ }^{74}$. Przekład na język angielski Miroslava Hrocha

${ }^{69}$ K. W. Deutsch, Nationalism and Social Communication, Cambridge 1966, s. 86.

${ }^{70}$ Przez nacjonalizm Gellner rozumie „globalną dyfuzję zapośredniczonego przez szkolnictwo i nadzorowanego przez wyższe uczelnie idiomu, który skodyfikowano zgodnie z wymogami biurokratycznej i technologicznej precyzji komunikowania się. Nacjonalizm to ustanowienie anonimowej, bezosobowej zbiorowości, na którą składają się wymienialne wzajem jednostki, związane wspólną kulturą; to likwidacja niegdysiejszego złożonego systemu grup lokalnych, opartego na kulturach ludowych, odtwarzających się na własną rękę z pokolenia na pokolenie", cyt. za E. Gellner, op. cit., s. 73.

${ }^{71}$ C. Hayes, Nationalism..., s. 93.

${ }^{72}$ B. Anderson, Imagined Communities: Reflections of the Origin and Spread of Nationalism, London 1983, polskie tłumaczenie: Wspólnoty wyobrażone. Rozważania o źródtach i rozprzestrzenianiu się nacjonalizmu, Kraków 1997.

${ }^{73}$ E. Gellner, Nations and Nationalism, Oxford 1983.

${ }^{74}$ Autorzy analizują przykłady wymyślania tradycji na przykładzie walijskiej i szkockiej „kultury narodowej”, brytyjskich obrzędów królewskich w XIX i XX wieku, początków imperialnych rytuałów w Indiach i Afryce oraz prób zbudowania przez radykalne ruchy 
Social Preconditions of National Revival in Europe („Społeczne uwarunkowania narodowego odrodzenia w Europie") ukazał się dwa lata później ${ }^{75}$. Te cztery książki stworzyły fundament pod nową, ożywioną dyskusję naukową nad nacjonalizmem. Nie sposób nie odwołać się do tych kanonicznych prac, których znaczenie leży nie tyle w nowatorstwie, co w sposobie ujęcia i podsumowania wcześniejszych dociekań. Dyskusję wywołały już same określenia narodów - jako „wyobrażonych” czy „wynalezionych”.

Czołowym współczesnym myślicielem tego nurtu jest amerykański historyk i politolog Benedict Anderson. Jego definicja narodu jest dziś jedną z najbardziej rozpowszechnionych i najczęściej dyskutowanych. Anderson pisze: „Proponuję następującą antropologiczną definicję narodu: jest to wyobrażona wspólnota polityczna, wyobrażona jako nieuchronnie ograniczona i suwerenna"76. Andersonowska narodowa wspólnota polityczna ma więc trzy podstawowe cechy: jest wyobrażona, ograniczona i suwerenna. Jest wyobrażona, ponieważ członkowie nawet najmniej licznego narodu nie znają większości swoich rodaków, nic o nich nie wiedzą, lecz mimo to noszą w umyśle obraz wspólnoty ${ }^{77}$. Ograniczona, ponieważ naród zawsze zajmuje określony, skończony obszar i nie ma możliwości, by wyobrażał sobie siebie w kategoriach całej ludzkości. Suwerenna, gdyż mimo dostrzegalnych przypadków nierówności i wyzysku panuje w niej poziomy układ solidarności i pragnienie wolności politycznej ${ }^{78}$.

Anderson polemizuje z pozornie podobnymi poglądami Gellnera: „Gellner (...) stwierdza: »Nacjonalizm to nie przebudzenie narodów ku samoświadomości: wynajduje on narody tam, gdzie one nie istnieją". Wadą tego sformułowania jest jednak to, że Gellner tak bardzo stara się ujawnić nacjonalistyczną maskaradę, że utożsamia "wynalezienie« $\mathrm{z}$ "fabrykowaniem» i "fałszowaniem«, a nie z "wyobrażaniem sobie« i »tworzeniem». Wynikać by z tego miało, że istnieją rzeczywiste wspólnoty, które zasadnie można przeciwstawić narodom"79.

społeczne własnych kontrtradycji. Zob. E. Hobsbawm, T. Ranger (red.), The Invention of Tradition, Cambridge 1983, polskie tłumaczenie: Tradycja wynaleziona, Kraków 2008.

${ }^{75}$ Dla M. Hrocha naród jest wielką grupą społeczną, złączoną przemienną kombinacją kilku rodzajów historycznie ugruntowanych stosunków, które mogą się wzajemnie zastępować. Według czeskiego teoretyka polityki niezbędnym i niezastąpionym stosunkiem jest równość obywatelska wszystkich członków grupy oraz ich świadomość wspólnej przeszłości.

${ }^{76}$ B. Anderson, op. cit., s. 19.

${ }^{77}$ M. Moch, op. cit., s. 18.

${ }^{78}$ B. Anderson, op. cit., s. 24.

${ }^{79}$ Ibidem, s. 20. 
Spostrzeżenie to jest istotne, gdyż pozwala na wyrwanie się z zachodniocentrycznej perspektywy. Według podejścia Andersona wspólnotami wyobrażonymi mogą więc być zarówno nowoczesne państwa Zachodu o jednolitej strukturze etnicznej, zbudowane wokół nacjonalistycznych ideologii, jak i przedindustrialne społeczności Wschodu czy Południa, opierające się na zasadach pokrewieństwa i klientelizmu. Różnice między wspólnotami nie polegają bowiem na prawdziwości lub fałszywości niektórych z nich, lecz na sposobie ich konstruowania i wyobrażania ${ }^{80}$.

Pojawienie się współczesnego nacjonalizmu Anderson wyjaśnia w zestawieniu z wcześniejszymi szerszymi systemami kulturowymi, np. wspólnotą religijną i monarchią dynastyczną ${ }^{81}$. Niegdyś systemy te stanowiły takie same punkty odniesienia jak we współczesnym świecie narody.

Amerykański badacz nawiązuje do teorii Renana, analizując i reinterpretując przytaczany wcześniej wywód tegoż o dialektyce pamięci/zapominania w kształtowaniu wspólnoty narodowej. Zwraca uwagę na dziwną składnię zwrotu doit avoir oublièr - „powinien był już zapomnieć” i przekonywająco uzasadnia, że słowa te dowodzą wręcz przeciwnego stanu rzeczy: obywatele powinni już zapomnieć o wydarzeniach, które jednak doskonale pamiętają. Pisze: „Możemy być pewni, że pozostawiona sama sobie większość rodaków Renana nigdy by się nie dowiedziała o Nocy św. Bartłomieja czy o masakrach na Południu, zdajemy sobie sprawę z systematycznej kampanii historiograficznej prowadzonej przez państwo za pośrednictwem szkolnictwa, mającej przypominać każdemu młodemu Francuzowi czy Francuzce o dawnych rzeziach, które wpisały się w historię "rodzinną" "82.

Narodową genealogię tworzy się więc za pomocą wygodnego narzędzia, jakim jest przypominanie/zapominanie o historycznych tragediach. Takie założenie prowadzi do reinterpretacji historii w duchu współczesnego nacjonalizmu i nowoczesnych podziałów etnicznych.

Niemniej żaden z tych badaczy nie twierdził, że narody są tak efemeryczne, jak sugerują to nazwy „wynaleziony” czy „wyobrażony”. De facto postrzegali oni narody jako tak samo „realne” jak wszystkie inne formacje społeczne, zakorzenione w zmiennej narracji historycznej, a nie w niezmiennym porządku naturalnym. Zastrzeżenie modernistów brzmiało: choć narody istnieją faktycznie, to jednak ich pochodzenie nie jest odwieczne

\footnotetext{
${ }^{80}$ Por. M. Moch, op. cit., s. 18.

${ }^{81}$ B. Anderson, op. cit., s. 25.

${ }^{82}$ Ibidem, s. 194.
} 
- narody stanowią pochodną przemian społeczno-gospodarczych ${ }^{83}$. Gellner przywoływał wręcz historyczną konieczność tego procesu ${ }^{84}$. Dzisiaj mało kto z poważnych badaczy utrzymywałby, że tożsamość narodowa jest wbudowana w ludzką psychikę.

Jeśli nawet nowatorstwo opisywanej grupy badaczy zostało nieco wyolbrzymione, to zmiany, jakie nastąpiły w latach 90. XX wieku, pozostają niedocenione. Tymczasem nastąpił wówczas tzw. zwrot kulturowy ${ }^{85}$. Przede wszystkim zaczęto dostrzegać pomijane wcześniej aspekty przeszłości. W szczególności badania nad kulturą popularną poszerzyły dotychczasowe rozumienia tożsamości narodowej ${ }^{86}$. Właśnie to skupienie na „kulturze” (sama próba zdefiniowania tego ulotnego terminu) pomogło przezwyciężyć napięcie między historią intelektualną a społeczną. Ponadto „zwrot kulturowy” ukazał badaczom, w jaki sposób narracje historyczne są angażowane do konstruowania i utrzymywania tożsamości narodowej. Tradycja historiograficzna niejednokrotnie sama służyła agendzie nacjonalizmu przez naturalizowanie tożsamości narodowej oraz zaciemnianie całej gamy alternatywnych form podmiotowości ${ }^{87}$.

Najbardziej doniosłą innowacją w badaniach nad nacjonalizmem w ostatnim dziesięcioleciu jest skupienie uwagi na dialogowym charakterze polityki tożsamościowej. Najnowsze badania zmierzają do syntezy poglądów tych, którzy w latach 60. i 70. XX wieku koncentrowali swoją uwagę na elitach inteligenckich, z tymi, którzy badali ruch sił społecznych „od dołu”. Nie powinno się wyobrażać sobie wyraźnej dychotomii między „ideologiami” intelektualistów a „praktykami” mas. Partha Chatterjee mówi wręcz o „schodzeniu się dwóch domen polityki” (elitarnej i popularnej) ${ }^{88}$, a Michael Billig poświęcił procesowi reprodukcji nacjonalizmu w toku codziennych, „oddol-

${ }^{83}$ R. Zenderowski, op. cit., s. 314.

${ }^{84}$ E. Gellner, op. cit., s. 35.

${ }^{85}$ Ogólny przegląd reakcji historyków na „zwrot kulturowy” zob. zbiór esejów: V. E. Bonnell, L. Hunt (red.), Beyond the Cultural Turn: New Directions in the Study of Society and Culture, Berkeley 1999.

${ }^{86}$ Zob. na przykład: T. Edensor, National Identity, Popular Culture, and Everyday Life, New York 2002, polskie tłumaczenie: Tożsamość narodowa, kultura popularna $i$ życie codzienne, Kraków 2004.

${ }^{87}$ Por. H. K. Bhabha (red.), Nation and Narration, New York 1990; G. Eley, R. G. Suny (red.), Becoming National: A Reader, New York 1996. O tym, jak nowa fala badań naukowych zmieniła rozumienie nacjonalizmu w szerokim spektrum, zob. P. Chatterjee, The Nation and Its Fragments: Colonial and Postcolonial Histories, Princeton 1993; idem, Nationalist Thought and the Colonial World: A Derivative Discourse, Minneapolis 1986.

${ }^{88}$ P. Chatterjee, The Nation and Its Fragments..., s. 159-160. 
nych” praktyk obszerne studium. Według niego proces „flagowania” narodu może odbywać się za pomocą dwóch rodzajów praktyk - odświętnych, widowiskowych, typowych dla momentów podniosłych, czy kryzysowych (na ich określenie autor używa nazwy „flagi powiewającej”, waved), oraz rutynowych, banalnych, niezauważalnych przez swoje wtopienie w tło (pojęcie tzw. flagi zwisającej, „niepowiewającej”, unwaved ${ }^{89}$.

Drugim badaczem koncentrującym się na „banalnym nacjonalizmie” jest Tim Edensor, który uważając, że „naród pozostaje główną przestrzenią, w której lokuje się tożsamość" "90, analizuje proces jego udomowiania $\mathrm{w}$ obrębie różnych przestrzeni ${ }^{91}$. Interesuje go problematyka narodowości z perspektywy świadomości praktycznej, to jest odgrywania rytuałów narodowych na co dzień i od święta, poprzez sport, karnawał, mitologizację krajobrazu itp. Zdaniem Edensora, wspólnota wyobrażona, jaką jest naród, jest podtrzymywana i wytwarzana za pomocą kultury materialnej. Odzież, przedmioty użytku codziennego, samochody itp. mogą być nasycone treściami narodowymi i stanowić kolejny aspekt procesu przejścia od rytuału politycznego do rytuału komercyjnego. Edensor zdaje sobie przy tym sprawę ze złożoności tego procesu i nie przecenia „wszechogarniającej mocy rynku"92.

Wreszcie, w czasach najnowszych termin „nacjonalizm” jest przesuwany z pozycji podmiotu do pozycji dopełnienia naukowych dociekań - nacjonalizm traci użyteczność jako sposób nadania sensu heterogeniczności życia społecznego i politycznego; badaczy interesuje raczej, co konkretni historyczni aktorzy mają nadzieję osiągnąć, wykorzystując elementy retoryczne słownika nacjonalizmu ${ }^{93}$.

\subsubsection{Asyrianizm i arameizm}

Asyrianizm - asyryjski nacjonalizm - narodził się u schyłku XIX wieku jako bezpośrednia reakcja na panarabizm. Należy go odróżnić od sporadycznego używania egzonimu „Asyryjczycy” w XIX i XX wieku. Asyrianizm jest ideologią jednoczącą Asyryjczyków, odwołującą się do starożytnych asyryj-

${ }^{89}$ M. Billig, Banal Nationalism, London 1995, polskie tłumaczenie: Banalny nacjonalizm, Kraków 2008, s. 34-35, 85-92. Szerzej o codziennym flagowaniu ojczyzny ibidem, s. $175-232$.

${ }^{90}$ T. Edensor, op. cit., s. 89.

${ }^{91}$ Ibidem, s. $80-88$.

${ }^{92}$ Ibidem, s. 147 i nast.

${ }^{93}$ B. Porter, op. cit. 
skich korzeni, od zakończenia I wojny światowej nawołującą do asyryjskiej niepodległości. Jego zwolennicy pragną stworzenia państwa; wskazują przy tym często na Równinę Niniwy w tzw. asyryjskim trójkącie w okolicach Mosulu w północnym Iraku, tj. na ziemiach wchodzących niegdyś w skład imperium asyryjskiego, a do dziś zamieszkanych przez znaczną populację asyryjską.

W Iraku pobasistowskim Asyryjski Ruch Demokratyczny (ARD) pojawił się w społecznym chaosie okupacji jako jedna $\mathrm{z}$ mniejszych partii politycznych. Jego oficjalne stanowisko brzmiało: mimo że członkowie ARD brali udział w wyzwalaniu tak kluczowych miast, jak Kirkuk i Mosul, Asyryjczycy nie zostali uwzględnieni w komitecie, który miał zadecydować o przyszłości Iraku. ARD żądał uznania praw Asyryjczyków, podobnie jak Asyryjskie Przymierze Powszechne oraz Szuraja (szerzej o partiach zob. w rozdziale 3.: Współcześni Asyryjczycy/Aramejczycy - diaspora; Organizacje asyryjskie oraz aramejskie).

Raif Toma uważa, że asyrianizm jest czymś więcej niż syryjskim patriotyzmem, dąży bowiem do zjednoczenia wszystkich „Mezopotamczyków”, można go więc określić jako ruch „panmezopotamski”. Ten wariant asyrianizmu pozostaje niezależny od wyznania chrześcijańskiego, jest etnicznym nacjonalizmem w takim sensie, iż definiuje Asyryjczyków jako dziedziców imperium asyryjskiego i rdzennej ludności Mezopotamii, postrzegając arabizm jako element wrogi i napływowy ze względu na podbój muzułmański w VII wieku. Przekonanie to znajduje wyraz we wprowadzonym w latach 50. XX wieku kalendarzu asyryjskim ${ }^{94}$.

David B. Perley, jeden z twórców asyrianizmu, pisze o nim w ten sposób:

Człowiek, w którego żyłach płynie asyryjska krew, z urodzenia posiada prawo do poczucia własnej godności, do spuścizny przodków. Z tego względu może być nazywany jakobitą-Asyryjczykiem, nestorianinemAsyryjczykiem, Asyryjczykiem-prezbiterianinem albo chaldejskim chrześcijaninem. Nazywanie kogoś jakobitą-Asyryjczykiem nie powinno dziwić bardziej niż określanie kogoś innego jako irlandzkiego katolika. To jedynie

${ }^{94}$ Współczesny kalendarz asyryjski luźno bazuje na księżycowo-słonecznym kalendarzu babilońskim. Rok zaczyna się wraz z pierwszymi oznakami wiosny. Początek datowania ustalono na rok 4750 p.n.e., tj. szacowanej daty wzniesienia pierwszej - prehistorycznej i presemickiej - świątyni w mieście Aszur. Datę tę uznano za początek cywilizacji w Mezopotamii. Inspirację stanowiły artykuły ukazujące się w asyryjskim magazynie „Gilgamesz”, wydawanym przez braci Addiego i Jeana Alkhasów oraz Nemroda Simono, cyt. za: W. Alkhas, Assyrian Calender, Niniveh On Line, http://www.nineveh.com/Assyrian\%20 Calendar.html, data wejścia 8.09.2009. 


\begin{abstract}
kwestia użycia dywizu w nazwie, nie zaś wprowadzania podziału. Dywiz nie dzieli, przeciwnie - jednoczy. Użycie terminu nestorianin-Asyryjczyk to najprostszy sposób na określenie nestorianina pochodzenia asyryjskiego. Termin „Asyryjczyk” wskazuje na jedność. Ta jedność wszystkich Asyryjczyków manifestuje się, bez względu na przynależność religijną, poprzez wspólnotę krwi i bogactwo wspólnych wspomnień. Religia to wiara, która może być nabyta i zmieniona. Narodowość tkwi w ciele i krwi jednostki, w jej całej naturze. Nawet śmierć nie może jej wymazaćn
\end{abstract}

Asyrianizm spotyka się z oporem ze strony części frakcji aramejskiej, która odrzuca przekonanie o pochodzeniu współczesnych Asyryjczyków od starożytnych ${ }^{96}$, upatrując swych przodków pośród starożytnych Aramejczyków. Ci ostatni zamieszkiwali Lewant od późnej epoki brązu, tworząc liczne małe królestwa, zanim w IX i VIII wieku p.n.e. nie zostali wchłonięci przez imperium asyryjskie. Zwolennicy arameizmu to głównie chrześcijanie syryjscy w Libanie, Turcji, Syrii, jak również w niemieckiej i szwedzkiej diasporze. Ważnym momentem jest dla nich I wiek n.e. i nadejście chrześcijaństwa.

Opozycję pomiędzy zwolennikami asyrianizmu i arameizmu wzmacniają różnice wyznaniowe, przede wszystkim podział na Syryjski Kościół Ortodoksyjny (zachodniosyryjski) ${ }^{97}$ oraz Asyryjski Kościół Wschodu ${ }^{98}$ i Chaldejski Kościół Katolicki ${ }^{99}$ (wschodniosyryjskie). Wymienionych Kościołów nie dzieli formalnie ogłoszona schizma, jednak wzajemne oskarżenia o herezję odsuwają ich wyznawców od siebie.

\title{
1.2.7. Podsumowanie
}

Podsumowując zaprezentowane powyżej opinie, pragnę zaznaczyć, że sam przedmiot moich badań, jakim są Asyryjczycy/Aramejczycy, narzuca niejako preferencje pewnych teorii i wybór aparatu pojęciowego.

Ważna jest dla mnie perspektywa historyczna, która pozwala dostrzegać złożoność procesu narodowotwórczego i tym samym abstrahować od pojmowania narodu jako tworu wyraźnie skrystalizowanego. Bezkrytyczne przenoszenie realiów historycznych i kulturowych, związanych z uformowaniem się nowoczesnych państw na Zachodzie, na analogiczne wydarzenia w innych częściach

${ }^{95}$ F. Aprim, Assyrians. The Continuous Saga, Philadelphia 2004, cytat z okładki.

${ }^{96}$ S. Parpola, Assyrian Identity in Ancient Times and Today, http://www.aina.org/articles/assyrianidentity.pdf, data wejścia 28.06.2009.

${ }^{97}$ Więcej o tym Kościele zob. Ch. Chaillot, The Syrian Orthodox Church of Antioch and All the East: A Brief Introduction to Its Life and Spirituality, Geneva 1998.

${ }^{98}$ Więcej zob. Ch. Baumer, The Church of the East: An Illustrated History of Assyrian Christianity, London-New York 2006.

${ }^{99}$ Zob. A. Kaim, Kościót Chaldejski, Dziedzic Objawienia i źródło charyzmatu, Poznań 2001. 
świata, np. na Bliski Wschód, może prowadzić do fałszywych i uproszczonych wniosków. Odrzucam stwierdzenie A. Smitha, jakoby „naród bezpaństwowy był sprzecznością samą w sobie" ${ }^{100}$, gdyż uważam, że choć Asyryjczycy/Aramejczycy - jak wiele innych mniejszości - nie posiadają własnej siedziby narodowej, to mają szansę na stworzenie narodu - przynajmniej w sferze mentalnej.

Zdaję sobie sprawę z ograniczeń, jakie niesie przyjęcie bądź to realistycznego, bądź konstruktywistycznego myślenia o narodzie ${ }^{101}$, toteż nie postrzegam narodów ani jako bytów koniecznych i naturalnych, ani z gruntu przygodnych, sztucznych, świadomie tworzonych przez różnego rodzaju elity. Zdaniem Antoniny Kłoskowskiej, koncepcje radykalnych konstruktywistów nie są konsekwentne, albowiem ich analiza wykazuje, że zakładają oddziaływanie narodu, którego jeszcze nie ma. $Z$ drugiej strony bezkrytyczne przyjęcie podejścia realistycznego w kulturalistycznym wydaniu, bazującego na esencjalistycznym rozumieniu samej kultury (czyli przypisującego jej „obiektywne” i względnie trwałe cechy), niesie ze sobą zagrożenie uniwersalizmu - zepchnięcia dyskursu grup niedominujących do statusu subkultur mniejszościowych.

Biorąc pod uwagę powyższe, za punkt wyjścia przyjmuję umiarkowany społeczny konstruktywizm. W tej optyce historia jest „budulcem” niezbędnym do „wytwarzania” narodu, który istnieje jako rodzaj dyskursu i wspólnota pewnych praktyk społecznych. Przewaga tej perspektywy badawczej polega na tym, że chroni ona przed popadnięciem w przekonanie o naturalności porządku świata, jakoby trwale podzielonego na narody. Zastrzec wszelako należy, że jednostka nie tworzy rzeczywistości „na sposób woluntarystyczny", niezależny od kontekstu - zakładając totalnie wyobrażony charakter rzeczywistości podważałabym sens własnych badań ${ }^{102}$.

Rozmyślnie używam niektórych określeń zaproponowanych przez konstruktywistów. Szczególnie zdefiniowanie narodu w kategoriach „wspólnoty wyobrażonej” przez B. Andersona jest wyjątkowo istotne z punktu widzenia aparatu pojęciowego moich badań ${ }^{103}$. Naród w tym ujęciu jest „budowany” przez nacjonalistów, którzy dokonują „wynalezienia tradycji” poprzez reinterpretację elementów symbolicznych, wcześniej wiązanych już z daną wspólnotą. Ponadto kluczowe znaczenie ma dla mnie zasada wyra-

${ }^{100}$ A. D. Smith, Myths and Memories of the Nation, New York 1999, s. 149.

${ }^{101}$ T. Stryjek, Jakiej przeszłości potrzebuje przyszłość? Interpretacje dziejów narodowych w historiografii i debacie publicznej na Ukrainie 1991-2004, Warszawa 2007, s. 17.

102 Ibidem, s. 15-16.

${ }^{103}$ Nie w sensie wspólnoty „sztucznie sfabrykowanej”, lecz takiej, w której jednostki nie będąc ze sobą w osobistym kontakcie, tworzą większe struktury społeczne - członkowie narodu nie znają przecież większości swoich rodaków, a jednak w ich umysłach tkwi wyobrażenie wspólnoty. 
żona przez Williama I. Thomasa, że „sytuacje uważane przez ludzi za rzeczywiste, mają rzeczywiste konsekwencje" ${ }^{104}$. Jednocześnie szukając prawdy w przekazie kultur narodowych, staram się zachować krytycyzm wobec fikcji i mitów obecnych w narodowotwórczych przekazach.

Czym jest więc naród? Próbując odpowiedzieć na pytanie, na które istnieje tak wiele odpowiedzi, skłaniam się ku opinii sformułowanej przez Johna Stuarta Milla, że „naród jest grupą, która raczej definiuje sama siebie, niż jest definiowana przez innych" (chociaż uznanie zewnętrzne jest ostatecznie decydujące ${ }^{105}$ ). Aby można było mówić o narodzie, musi istnieć wspólnota posiadająca świadomość narodową lub akceptująca polityczne przywództwo elit, które taką świadomość posiadają.

Nie istnieją prawdopodobnie narody bez ideologii i przywódców, choć zawsze powstają z realnie istniejących substratów, na kanwie realnie istniejącej historii, od której nie sposób się oderwać. Jerzy Szacki zauważył, iż narody nie powstają, ale są tworzone, a „w myśleniu potocznym jest zawarta trafna intuicja, że nie ma narodu bez jakiegoś historycznego dziedzictwa, które w ideologiach narodowych ulega wprawdzie z reguły zniekształceniu i monstrualnemu nierzadko wyolbrzymieniu, ale na ogół nie jest czystym wymysłem"106.

Jeśli chodzi o stosunek do nacjonalizmu w kontekście asyryjsko-aramejskim, to bliski jest mi pogląd Szackiego, który pisze, że nacjonalizm odgrywał i nadal odgrywa „pozytywną rolę, służąc budzeniu ludzkiej godności i zaspokajając potrzebę wspólnoty, której nie jest w stanie zaspokoić ani wzrost gospodarczy, ani demokracja, ani żadne inne - skądinąd wielkie - osiągnięcie nowoczesnego społeczeństwa”.

Idea miłości do własnego narodu, praca nad jego rozwojem są godne pochwały i pielęgnowania, jednak należy uważać, by nie zbudzić demonów przeszłości. W przypadku Asyryjczyków/Aramejczyków, którzy są na etapie protonarodu, szczególnie aktualne pozostaje pytanie, czy możliwe jest odrodzenie idealistycznego, uniwersalnego, nowoczesnego nacjonalizmu bez pogłębiania starych i generowania nowych konfliktów.

\subsection{Problematyka tożsamości}

Ujęcie problematyki narodu w kategoriach „tożsamości narodowej” jest obiecującym rozwiązaniem, gdyż zakorzenia problematykę narodu w teorii tożsamości społecznej, nie zawężając się bynajmniej tylko do kwestii

${ }^{104}$ Ł. Moczydłowski, op. cit.

${ }^{105}$ Por. A. D. Smith, National Identity, London 1991, s. 14.

${ }^{106}$ Ł. Moczydłowski, op. cit. 
politycznych. Problem stanowi natomiast brak przejrzystości dyskursu tożsamościowego. Sam termin „tożsamość”107 jest wyjątkowo wieloznaczny; jako taki dzieli los wielu interdyscyplinarnych pojęć - zajmują się nim przedstawiciele bardzo różnych nauk społecznych: filozofowie, psycholodzy, socjolodzy, politolodzy itp. Elementem wspólnym ich poszukiwań jest powiązanie kwestii tożsamości z pytaniami o istotę człowieczeństwa, kondycję człowieka, świadomość i samoświadomość jednostki ${ }^{108}$. Oczywiście na pytania te trudno znaleźć konkluzywne odpowiedzi ${ }^{109}$.

Powodów rosnącej popularności dyskursu tożsamościowego należy szukać w procesach rozpadu dwubiegunowego świata po 1989 roku oraz następujących w jego wyniku procesach globalizacyjnych: upadku „wielkich narracji”, przyspieszonej indywidualizacji, wzrostu mobilności społecznej, wzrostu znaczenia mediów, wielokulturowości, wreszcie renesansu etniczności i nacjonalizmu ${ }^{110}$.

Wymienione zmiany spowodowały, że nienowy termin zmienił swój status - tożsamość przestała być „busolą i kotwicą" ${ }^{111}$, a zaczęła być dobrem poszukiwanym bardziej intensywnie niż kiedykolwiek przedtem ${ }^{112}$. Wielu badaczy podkreśla, że jednostka znajduje się dziś na rynku tożsamości, gdzie nie tylko ma możliwość wybrać dowolne elementy konstrukcyjne według zasady „zrób to sam”, „wykreuj sam siebie”, ale wręcz ma obowiązek stworzyć czy uformować własną tożsamość ${ }^{113}$. Problem tożsamości pojawia się więc de facto dopiero w rzeczywistości ponowoczesnej, gdy świat nie jest już oczywisty, a biografia staje się sekwencją wyborów. Przestrzeń niepewności rośnie, jednostka nie mając gotowych odpowiedzi, zagląda w głąb siebie, w subiektywności poszukując tożsamości ${ }^{114}$.

${ }^{107}$ P. Cichocki, Tożsamość narodowa a post-narodowa konstelacja [w:] M. Golka, op. cit., s. 146.

${ }^{108}$ Wstęp [w:] I. Borowik, K. Leszczyńska (red.), Wokót tożsamości: teorie, wymiary, ekspresje, Kraków 2007, s. 7.

${ }^{109}$ B. Skarga, Tożsamość i różnica: eseje metafizyczne, Kraków 1997, s. 168.

${ }^{110}$ Por. Ch. Delsol, Éloge de la singularité, essai sur la modernité tardive, Paris 2000, polskie tłumaczenie: Esej o człowieku późnej nowoczesności, Kraków 2003; J. Szacki, O tożsamości (zwłaszcza narodowej), „Kultura i Społeczeństwo”, nr 3, 2004.

${ }^{111}$ B. Misztal, Teoria socjologiczna i praktyka społeczna, Kraków 2000, s. 146-147.

${ }^{112}$ D. Kellner, Media Culture. Cultural Studies, Identity and Politics between the Modern and Postmodern, London 1995; Z. Bauman, Tożsamość. Wtedy, teraz, po co? [w:] E. Nowicka, M. Chałubiński (red.), Idee a urządzanie świata społecznego. Ksiega jubileuszowa dla Jerzego Szackiego, Warszawa 1999; W. Burszta, Posłowie [w:] K. Bondyra, S. Lisiecki (red.), Odmiany polskich tożsamości, Poznań 2002, cyt. za: A. Raciniewska, op. cit., s. 122.

${ }^{113}$ A. Raciniewska, op. cit., s. 123.

${ }^{114}$ Wstęp [w:] I. Borowik, K. Leszczyńska, op. cit., s. 8. 
Podobnie jak zdecydowana większość analityków współczesnej kultury, stoję na stanowisku konstruktywistycznym, zakładającym, że tożsamość jednostki, podobnie jak wspólnoty, jest nieustannie konstruowana w toku twórczej interpretacji i reinterpretacji, które mogą prowadzić do napięcia między dziedziczeniem a wyborem ${ }^{115}$. Według najbardziej rozpowszechnionych koncepcji tożsamość ma elastyczną, zmienną naturę i powstaje w toku dynamicznego procesu autonarracji i identyfikacji ${ }^{116}$.

\subsubsection{Tożsamość - główne teorie}

Gordon Mathews pisze, że „tożsamością jest to, jak jednostka siebie pojmuje, klasyfikuje, nazywa"117. Innymi słowy, tożsamość to odpowiedź na pytanie „kim jestem?”. Jednostka funkcjonująca w wielu kontekstach interakcyjnych najczęściej ma zestaw gotowych odpowiedzi, czasem jednak przygotowuje je ad hoc, stąd tożsamość może mieć różny charakter - od niewielkiego stopnia refleksyjności do tożsamości niemal obsesyjnie rozważanej ${ }^{118}$. To jednak tylko część problemu. Pytanie o to, kim jestem „ja”, ewokuje bowiem pytanie o to, kim jestem ,ja” w relacji z „my”, jak również „ja” i „my” w relacji do „ty”, „on/ona”, „wy”, „oni” ${ }^{119}$.

W społecznościach tradycyjnych pytanie o tożsamość indywidualną pojawiało się rzadko, gdyż nie istniała praktycznie możliwość wyboru. Człowiek przednowożytny posiadał tożsamość daną przez określone miejsce i czas narodzenia, przez wychowanie w określonej tradycji i warstwie społecznej. Wyznawał takie same zasady jak jego rodzice czy opiekunowie, kontynuował ich praktyki ${ }^{120}$. W tego rodzaju społeczeństwie człowiek był, jak to ujmowała Margaret Mead, „tym, czym był - jednym ze swego ludu (...) niepodlegającą wyobcowaniu jednostką, bezpiecznie ukrytą i podtrzymywaną przy życiu w kokonie zwyczajów od chwili urodzenia aż do śmierci”.

${ }^{115}$ Por. M. Ziółkowski, Dziedziczenie i wybór. Zwiększenie możliwości wyboru, nierówności społeczne i problemy społecznej tożsamości, „Studia Socjologiczne”, nr 3, 2002, cyt. za: A. Raciniewska, op. cit., s. 123.

${ }^{116}$ A. Raciniewska, op. cit., s. 124.

${ }^{117}$ G. Mathews, Global Culture/Individual Identity: Searching for Home in the Cultural Supermarket, London 2000, polskie tłumaczenie: Supermarket kultury. Kultura globalna a tożsamość jednostki, Warszawa 2005, s. 36.

${ }^{118}$ Ibidem, s. 14.

${ }^{119}$ Wstęp [w:] I. Borowik, K. Leszczyńska, op. cit., s. 7.

${ }^{120}$ A. Karczmarek, Tęsknota za tożsamością [w:] M. Golka, op. cit., s. 37. 
Pojęcie tożsamości było nieobecne w klasycznej teorii socjologii oraz psychologii ze względu na ignorowanie procesów makrospołecznych w opisie doznań jednostki. Ortodoksyjna socjologia uznała tożsamość za iluzję bądź mit $^{121}$. Dopiero pod koniec XIX wieku zaczęto pojmować tożsamość jako związaną z samoświadomością i egzystencją ludzką - głównie dzięki amerykańskiemu psychologowi i filozofowi Williamowi Jamesowi ${ }^{122}$. W latach 20. i 30. XX wieku badania nad tożsamością prowadzone były w ramach psychoanalizy i symbolicznego interakcjonizmu. W połowie XX stulecia termin ten zaczął robić błyskotliwą karierę wraz z przemianą nowoczesności w ponowoczesnośćc ${ }^{123}$. Początek owej kariery, określany jako „zwrot tożsamościowy”, wiąże się z pierwszą publikacją Erika Eriksona o tożsamości ${ }^{124}$ oraz pracami interakcjonistów symbolicznych ${ }^{125}$, a jej współczesność należy do teoretyków ponowoczesności.

Zmiany koncepcji tożsamości zachodzą pod wpływem obiektywnych przemian w świecie społecznym, ale również pod wpływem antropologicznych przesłanek - współcześnie tożsamość ujmuje się jako proces i dialog. Sposób rozumienia samego siebie i rzeczywistości fizycznej oraz społecznej jest zmienny w czasie, tym samym tożsamość nie jest zamknięta i ostateczna, lecz otwarta i nieokreślona. W poszukiwaniu odpowiedzi o tożsamość człowieka współczesnego przydatna zdaje się kategoria narracji ${ }^{126}$.

Martin Heidegger jako pierwszy sformułował explicite założenia ontologiczne, na których wyrosła narracyjna koncepcja tożsamości. Z punktu widzenia tego filozofa każdemu bytowi jako takiemu przypisana jest tożsamość w znaczeniu „jedność z samym sobą”. W przypadku ludzi sprawa jest jednak bardziej skomplikowana, tożsamość jest czymś więcej niż tylko problemem metafizycznym - jest kategorią świadomości. Ludzka tożsamość dotyczy przede wszystkim postrzegania samego siebie, pewnych swoich cech, mających znaczenie na tle wszystkich innych właściwości ${ }^{127}$.

${ }^{121}$ J. Kociuba, Narracyjna koncepcja tożsamości [w:] I. Borowik, K. Leszczyńska, op. cit., s. 53-54.

${ }^{122}$ Por. W. James, The Principles of Psychology, New York 1890.

${ }^{123}$ Por. Z. Bokszański, Tożsamości zbiorowe, Warszawa 2005, s. 52, cyt. za: M. Golka, op. cit., s. 10.

${ }^{124}$ E. Erikson, Identity and the Life Cycle. Selected Papers, New York 1959; idem, Identity: Youth and Crisis, New York 1968.

${ }^{125}$ Interakcjonizm symboliczny posługiwał się pojęciem tożsamości podmiotu indywidualnego. Zob. A. L. Strauss, Mirrors and Masks, San Francisco 1959.

${ }^{126}$ J. Kociuba, op. cit., s. 56.

${ }^{127}$ M. Golka, op. cit., s. 12. 
Charles Taylor uważa z kolei, że fundamentem współczesnej koncepcji tożsamości stał się ekspresywizm, to jest założenie, iż każda jednostka może wyrażać się w sposób dowolny i oryginalny. Zakłada on ścisły związek między tożsamością jednostki a jej horyzontem moralnym - jeśli jednostka jest moralna, rozróżnia dobro i zło, to wie także, kim jest; samowystarczalność jest niebezpieczną iluzją ${ }^{128}$. Taylor podkreśla różnicę między tożsamością tradycyjną, daną, moralną a współczesną, kreowaną i negocjowaną ${ }^{129}$. Pisze, że w nowoczesnym świecie tożsamość nie jest już dana - jest zadana ${ }^{130}$ oraz o tym, iż „czasem pragniemy, aby przyszłość zbawiła przeszłość, aby uczyniła ją częścią opowieści życia, częścią obdarzoną sensem i celem”"131.

Dla Giddensa najważniejszy jest związek pomiędzy tożsamością a kulturą. $\mathrm{Na}$ indywidualne poczucie tożsamości ma według niego wpływ refleksyjność kultury, a na tę z kolei składają się formy kultury współczesnej, takie jak opracowania socjologiczne i psychologiczne, poradniki, książki popularnonaukowe oraz terapi $\mathrm{e}^{132}$. Giddens twierdzi, że refleksyjny projekt „ja”, który polega na utrzymywaniu spójnych, chociaż wciąż na bieżąco weryfikowanych narracji biograficznych, rozgrywa się w kontekście wielokrotnego wyboru zapośredniczonego przez systemy abstrakcyjne ${ }^{133}$ : „Tożsamość jednostki nie jest po prostu czymś danym jako wynik ciągłości jej działania, ale czymś, co musi być (...) wytwarzane i podtrzymywane przez refleksyjnie działającą jednostkę"134. W ujęciu badacza własna tożsamość jest czymś ustawicznie zdobywanym, tworzonym i utrzymywanym dzięki refleksji i świadomym działaniom podmiotu.

Podobnego zdania jest Zygmunt Bauman, który posługuje się poniższą metaforą - w nowoczesności budowanie tożsamości jest dla jednostki wyzwaniem - poszukiwaniem miejsca, gdzie można się zakotwiczyć, jednak w ponowoczesności tożsamość jest już tylko dryfowaniem ${ }^{135}$. Wtóruje mu

${ }^{128}$ A. Karczmarek, op. cit., s. 36.

${ }^{129}$ J. Kociuba, op. cit., s. 58.

${ }^{130}$ A. Karczmarek, op. cit., s. 42.

${ }^{131}$ Ch. Taylor, Sources of the Self: The Making of the Modern Identity, Cambridge 1989, polskie tłumaczenie: Źródta podmiotowości. Narodziny tożsamości nowoczesnej, Warszawa 2001, s. 101.

${ }^{132}$ J. Kociuba, op. cit., s. 59.

${ }^{133}$ A. Giddens, Modernity and Self-Identity: Self and Society in the Late Modern Age, Stanford 1991, polskie tłumaczenie: Nowoczesność i tożsamość. "Ja" i społeczeństwo w epoce późnej nowoczesności, Warszawa 2001, s. 8-9.

${ }^{134}$ Ibidem, s. 74.

${ }^{135}$ Wstęp [w:] I. Borowik, K. Leszczyńska, op. cit., s. 9. 
Amin Maalouf: „Tożsamość nie jest nam dana raz na zawsze, ona się tworzy i przeobraża w ciągu naszego życia" ${ }^{136}$. Niemniej jednak, tożsamość nie będąc ani jasno określoną, ani daną na zawsze, nie jest też tak krucha, jak twierdzą postmoderniści ${ }^{137}$.

David Carr również postrzega tożsamość jednostki jako ciągle konstruowaną, jej struktura odwołuje się do przeszłości i uzgadnia ją z teraźniejszością i projektowaną przyszłością (ujęcie prospektywno-retrospektywne). Według Carra niemożliwa jest narracja bez narratora, który organizuje sekwencję zdarzeń w strukturę znaczenia. Jednak narrator to nie autor, zdaniem filozofa jednostki są najwyżej współautorami swoich narracji, a nie - jak chciał Heidegger - ich konstruktorami ${ }^{138}$.

Nieco odmienne podejście prezentuje Paul Ricoeur, który podkreśla wtórność narracji - doświadczenie uzyskuje formę narracji dopiero po odniesieniu do kodu kulturowego, który jest niezbędny. W takim ujęciu narracja nie jest strukturą ludzkiego myślenia, ale kodem tekstowym wypracowanym przez kulturę. Różnica pomiędzy życiem a opowiadaniem jest nieprzekraczalna, ludzkie rozumienie zaś zawsze zapośredniczone poprzez interpretację cudzych tekstów, które stanowiąc część dziedzictwa kulturowego, dostarczają czytelnikom struktur znaczących ${ }^{139}$. Ricoeur zwraca też uwagę na fakt, że czasem dochodzi do zerwania narracji, szczególnie w traumie, kiedy jednostka wybiera istnienie raczej niż mówienie, nie uświadamiając sobie własnej opowieści życia ${ }^{140}$.

Bazując na tej myśli, stoję na stanowisku, że tożsamość to coś więcej niż tylko narracja, poczucie tożsamości nie jest bowiem zjawiskiem wyłącznie poznawczym, lecz emocjonalno-doświadczeniowym. Każdy człowiek ma tożsamość nieuświadomioną, przedpojęciową, opartą na doświadczeniu niewerbalnym i nieobrazowym. Nie każda jednostka natomiast ma tożsamość refleksyjną, wyrosłą z doświadczenia własnego „ja”. Również nie wszyscy spośród tych, którzy posiadają ową pogłębioną tożsamość, budują ją poprzez fabularyzację faktów z własnego życia ${ }^{141}$.

${ }^{136}$ A. Maalouf, Les Identités Meurtrières, Paris 1998, polskie tłumaczenie: Zabójcze tożsamości, Warszawa 2002, s. 31.

${ }^{137}$ G. Mathews, op. cit., s. 35.

${ }^{138}$ J. Kociuba, op. cit., s. 60.

${ }^{139}$ Ibidem, s. 61.

${ }^{140} \mathrm{P}$. Ricoeur, Soi-même comme un autre, Paris 1990, polskie tłumaczenie: O sobie samym jako innym, Warszawa 2005, s. 8, 202-203.

${ }^{141}$ Por. J. Kociuba, op. cit., s. 64-65. 
Ponad pięćdziesiąt lat dorobku w dziedzinie rozumienia pojęcia tożsamości przekłada się na jego pluralizm i niejednoznaczność, czyniąc materię trudną do uporządkowania. Nie sposób mówić o jednej, wspólnej koncepcji tożsamości. Jednak niemal wszystkie ujęcia akcentują jej procesualny charakter, tym bardziej że każda zmiana, niezależnie od tego, w jakim wymiarze zachodzi, może stać się czynnikiem kształtującym świadomośćc ${ }^{142}$.

$\mathrm{Na}$ użytek tej pracy przyjęta zostanie definicja Manuela Castellsa, który przez tożsamość rozumie „proces konstruowania sensu na podstawie pewnego atrybutu kulturowego lub powiązanego zbioru atrybutów kulturowych, któremu/którym przyznaje się pierwszeństwo przed innymi źródłami sensu"143. Internalizacja tych atrybutów kulturowych jest niezbędna dla konstruowania znaczenia, a wraz z nim dla konstruowania tożsamości.

\subsubsection{Rozróżnienia tożsamości}

Istnieje wiele typologii i rozróżnień tożsamości. Zbigniew Bokszański podkreśla rozróżnienie na ujęcie deskryptywne (stosowane przede wszystkim w badaniach empirycznych) oraz normatywne (mające charakter światopoglądowy, np. jako odnalezienie siebie $)^{144}$. Pierwsze ujęcie zakłada pytanie o to, „jaka jest” tożsamość, drugie o to, ,jaka powinna być”. Pokusa określenia tego, jaka powinna być rzeczywistość, jest dla badacza niezwykle silna. Bokszański przypomina również o rozróżnieniu Castellsa na tożsamości legitymizujące (wprowadzane przez dominujące grupy i narzucane grupom pozostałym) oraz tożsamości oporu (wytwarzane przez grupy marginalizowane $)^{145}$.

Inni badacze mówią o tożsamości otwartej (nacechowanej aktywnością i liberalizmem) oraz tożsamości zamkniętej (pasywnej i separatystycznej) ${ }^{146}$. Wyróżniana jest tożsamość płynna i trwała ${ }^{147}$, czy inkluzywna i ekskluzyw$\mathrm{na}^{148}$. Podobne treści, tj. rozproszenie versus trwałość, można znaleźć w po-

${ }^{142}$ Wstęp [w:] I. Borowik, K. Leszczyńska, op. cit., s. 10.

${ }^{143}$ M. Castells, The Power of Identity, Malden-Oxford-Carlton 2004, polskie thumaczenie: Siła tożsamości, Warszawa 2008, s. 22.

${ }^{144}$ Z. Bokszański, Tożsamości..., s. 30 i nast.

${ }^{145}$ Ibidem, s. 39.

${ }^{146}$ Por. Z. Chlewiński, Tożsamość a tolerancja [w:] J. Kłoczkowski, S. Łukasiewicz (red.), Tożsamość, odmienność, tolerancja a kultura pokoju, Lublin 1998, s. 61; J. Nikitorowicz, Kreowanie tożsamości dziecka. Wyzwania edukacji międzykulturowej, Gdańsk 2005, s. 57.

${ }^{147}$ Por. M. O’Brien, Esej o plynnej tożsamości [w:] A. Jawłowska (red.), Wokót problemów tożsamości, Warszawa 2001.

${ }^{148}$ Zob. T. Edensor, op. cit., s. 40 i nast. 
dziale na tożsamość silną i słabą ${ }^{149}$, czy na tożsamość rozlaną i zwartą ${ }^{150}$. Maria Jarymowicz proponuje inny podział - na tożsamość pozytywną (wiąże się ona z przeświadczeniem o własnych możliwościach i umiejętnościach wpływania na innych) i na tożsamość negatywną (wyrosłą z przekonania o własnej bezsilności, upokorzenia) ${ }^{151}$.

Wszystkie te rozróżnienia, jedne bardziej, inne mniej trafne, od dawna funkcjonują w literaturze światowej. Ewokują wiele pytań, chociażby o korzyści płynące z posiadania „stałej”, niejako absolutnej tożsamości. Nawet gdyby wykrystalizowanie takowej było możliwe, to stworzenie jej wcale nie byłoby korzystne - absolutna pewność uniemożliwia rozwój i dialog ${ }^{152}$.

Określając tożsamość, człowiek najczęściej stara się oddzielić to, co własne, od tego, co obce. Problem polega na tym, że tożsamość składa się zawsze z elementów własnych i obcych - te ostatnie przestają być obcymi, gdy tylko „trafiają” do osobowości jednostki. Staje się tak dzięki procesowi identyfikacji. Granice i zakres konstrukcji tożsamości, dopuszczalności zmienności są dyskusyjne. Nie ma odgórnie ustalonych norm, według których można daną jednostkę czy grupę uznawać za tożsamą z sobą samą mimo zachodzących w niej zmian ${ }^{153}$. Robert Spaemann uważa, że „proces zmian nie przynosi tożsamości uszczerbku, a nawet ją wzmacnia, o ile doznawana zmiana jawi się jako sensowna, a stany późniejsze jako lepsze od wcześniejszych" ${ }^{154}$. W zdecydowanej większości przypadków zmiany nie niszczą tożsamości, lecz ją wzmacniają. Rozważając kwestie związane z tożsamością, trudno uniknąć pytania o jej „prawdziwość” bądź też „fałszywość”. Jednak, co było już sygnalizowane we Wstępie, niemożliwe jest określenie kryteriów prawdziwej tożsamości. To, co jest możliwe, to zdolność odróżnienia dzięki „prawdziwej” tożsamości, co jest dla jednostki istotne, a co obojętne ${ }^{155}$.

Kolejne zagadnienie dotyczy złożoności tożsamości. Badaczom zależy najczęściej bardziej na jednoprzymiotnikowym (jednowymiarowym) określeniu typu: „jestem Polakiem (Anglikiem, Niemcem)” czy „jestem

${ }^{149}$ A. Jawłowska, Tożsamość na sprzedaż [w:] A. Jawłowska, Wokót problemów..., s. 56.

${ }^{150}$ P. Boski, M. Jarymowicz, H. Malewska-Peyre, Tożsamość a odmienność kulturowa, Warszawa 1992, s. 229.

${ }^{151}$ Ibidem, s. 45.

${ }^{152}$ M. Golka, op. cit., s. 26.

${ }^{153}$ Ibidem, s. 27.

${ }^{154}$ R. Spaemann, Tożsamość religijna [w:] K. Michalski (red.), Tożsamość w czasach zmiany. Rozmowy w Castel Gandolfo, Kraków-Warszawa 1995, s. 59.

${ }^{155}$ Por. Ch. Taylor, Źródta wspótczesnej tożsamości [w:] K. Michalski (red.), op. cit., s. 10. 
chrześcijaninem (muzułmaninem, buddysta)" niż o rzeczywisty i skomplikowany obraz. Jednowymiarowe tożsamości często prowadzą do fanatyzmu, konfliktu; tworzone są w sytuacjach zagrożenia, wojny. Odrzucenie jednowymiarowych tożsamości postuluje m.in. Amin Maalouf ${ }^{156}$ czy Jerzy Nikitorowicz ${ }^{157}$. Badacze ci wychodzą z założenia, że części mogą się dookreślać. Nie ma dwóch identycznych kombinacji składników tożsamości, każda stanowi charakterystyczny układ ${ }^{158}$.

\subsubsection{Tożsamość jednostkowa i społeczna}

Tożsamość jest kategorią znajdującą się na przecięciu podmiotów i struktur społecznych, subiektywności i obiektywności, wyborów i narzucania, własnej refleksji i doświadczeń społecznych. Dlatego też przyjęto dzielić ją na tożsamość jednostkową (osobową, osobista) i społeczną (zbiorową, kolektywną, grupowa) ${ }^{159}$.

Tożsamość jednostkowa oscyluje wokół pytania - czym jest „ja”. Składać się na nią mogą: samowiedza jednostki w sensie opisowym, samoocena, wiedza o własnych cechach osobowości, system wartości, poglądy na temat sposobów komunikowania się, wiedza o własnych potrzebach itp. ${ }^{160}$ Może się zdarzyć, że jeden z aspektów osobowości zdominuje całe poczucie tożsamości, wypierając pozostałe składniki tejże.

Według klasyków (Eriksona czy Ricouera) tożsamość konstytuują trzy elementy: poczucie odrębności od innych (indywidualność), spójność (integralność) i ciągłość (stałość) ${ }^{161}$. To ostatnie poczucie opiera się na przeszłości i jej pamięci. Rolą pamięci jest zaś odtwarzanie przeszłych sytuacji społecznych, pełnionych ról, doświadczeń, wszystkich tych elementów, które kształtują tożsamość. Z drugiej strony tożsamość może w pewnym stopniu determinować zapamiętywane, a w jeszcze większym stopniu odtwarzane,

${ }^{156}$ A. Maalouf, op. cit.

${ }^{157}$ J. Nikitorowicz, Pogranicze. Tożsamość. Edukacja międzykulturowa, Białystok 1995.

${ }^{158}$ M. Golka, op. cit., s. 29.

${ }^{159}$ Ibidem, s. 15. To dychotomiczne rozróżnienie, choć mocno zakorzenione w literaturze przedmiotu, nie jest jednak - jak dowodzi T. Edensor - „heurystycznie zbyt pomocne, powinno się więc rozumieć te dwa pojęcia jako raczej wielorako powiązane niż odrębne, gdyż tożsamość indywidualna opiera się na myśleniu za pomocą kategorii społecznych oraz na społecznym działaniu, obojętnie czy w sposób refleksyjny, czy pozbawiony refleksji”, cyt. za: T. Edensor, op. cit., s. 40. Innymi słowy, istnieje raczej jeden mechanizm tożsamości, tyle że sama zawartość tożsamości różni się w zależności od kategorii, do której się odnosi, cyt. za: P. Cichocki, op. cit., s. 148.

${ }^{160}$ M. Golka, op. cit., s. 15-16.

${ }^{161}$ Ibidem, s. 16. 
treści z przeszłości. Do jednych bowiem wraca się chętnie, inne natomiast omija, spycha w podświadomość lub w ogóle wymazuje ${ }^{162}$.

Tożsamość społeczna/zbiorowa nie jest zwykłą ekstrapolacją pojęcia tożsamości jednostkowej, bo żadna zbiorowość społeczna, do której można byłoby odnieść pojęcie tożsamości, nie ma psychicznego organu samowiedzy wytwarzającego ścisły odpowiednik samoświadomości osobniczej, innymi słowy, nie istnieje żadne sensorium zbiorowe (dusza zbiorowa). Większość badaczy uważa, że tożsamość powiązana jest ze świadomością, ta zaś jest cechą osoby ${ }^{163}$. Dla Cezarego J. Olbromskiego tożsamość zbiorowa jest zastępczą fikcją lub próbą rezygnacji z tożsamości jednostkowej ${ }^{164}$. Według Bokszańskiego, który bazuje m.in. na poglądach Petera L. Bergera i Thomasa Luckmanna ${ }^{165}$, istnieje wyłącznie tożsamość jednostkowa ${ }^{166}$.

Większość badaczy zgadza się, że zarówno tożsamość jednostkowa, jak i społeczna, lokalizuje się w świadomości jednostki. Jednak przyjmując, że świadomość mogą mieć tylko jednostki, należy przyznać, że pewne grupy społeczne istnieją, komunikują się, posiadają społeczną pamięć, która w jakimś stopniu kształtuje ich świadomość oraz tożsamość według pewnego wzorca, w końcu, że funkcjonują pewne wspólne stany świadomości i wytwory kultury, jak chociażby mity czy stereotypy ${ }^{167}$. Zresztą przywoływany już Bokszański definiuje tożsamość zbiorową jako „takie ukształtowanie podmiotu, w którym podstawową rolę odgrywają więzi grupy z wartościami »istotnymi« czy »nieprzemijającymi«. (...) powstawanie tożsamości zbiorowej jest odkrywaniem »istoty« zbiorowości bądź "prawdziwego« sensu jej istnienia"168.

Pomiędzy tożsamością jednostkową a społeczną zachodzi związek „samozwrotności” (określenie Giddensa). Przede wszystkim jednostka postrzega siebie w kategoriach przynależności do określonej grupy społecznej ${ }^{169}$, co więcej, uważa, że inni postrzegają ją przez ten sam pryzmat ${ }^{170}$.

${ }^{162}$ Ibidem, s. 17.

${ }^{163}$ M. Golka, op. cit., s. 21.

${ }^{164}$ C. J. Olbromski, Tożsamość spoleczna: typowość czy wspólność, bezbarwność czy przejrzystość? [w:] J. Mizińska (red.), Tożsamość podmiotu zbiorowego, Torun 2002, s. 15.

${ }^{165}$ P. L. Berger, T. Luckmann, The Social Construction of Reality: A Treatise in the Sociology of Knowledge, Garden City, New York 1967, polskie tłumaczenie: Społeczne tworzenie rzeczywistości, Warszawa 1983.

${ }^{166}$ Z. Bokszański, Tożsamość [w:] Encyklopedia socjologii, t. 4, Warszawa 2002, s. 254.

${ }^{167}$ M. Golka, op. cit., s. 22

${ }^{168}$ Z. Bokszański, Tożsamości..., s. 63.

${ }^{169}$ Por. B. Synak, Kaszubska tożsamość, ciagtość i zmiana, Gdańsk 1998, s. 74.

${ }^{170}$ M. Golka, op. cit., s. 19. 
$\mathrm{Na}$ tożsamość społeczną składają się te cechy, które jednostce przypisują inni ludzie. Ową konstrukcję inni tworzą, przekształcają i narzucają w trakcie interakcji ${ }^{171}$. Tożsamość społeczna jest silnie uzależniona od struktury społecznej, zarówno obiektywnej, jak i subiektywnej - istniejącej jedynie w świadomości jej uczestników. W toku zmian historycznych zmienia się sama struktura oraz tożsamość społeczna, przy czym zmiana jednej pociąga za sobą przekształcenia drugiej i vice versa ${ }^{172}$.

W tożsamościach zbiorowych odbija się poczucie kolektywnego „my”, a składają się na nie: wiara w pochodzenie od wspólnych przodków, wspólne mity i wierzenia religijne, przejawy wspólnego kultu, tradycja, ideologia, hymn, godło, język, dzieła literatury, wspólne zwyczaje, a ponadto wspólna przestrzeń, wspólna pamięć, wspólny system wartości, wspólne relacje $\mathrm{z}$ innymi zbiorowościami itp. Im silniejsze to poczucie, tym sprawniej zbiorowości funkcjonują, radzą sobie z przeciwnościami. W zakres tożsamości zbiorowych wchodzą bowiem, oprócz wyżej wymienionych aspektów świadomościowych, wzorce zachowań i same zachowania ${ }^{173}$.

Charles Taylor utrzymuje, że tożsamość społeczna jest dopełnieniem, legitymizacją tożsamości jednostkowej. Obecnie jednostce zdarza się nie zgadzać na tę tożsamość narzuconą niejako odgórnie. To, czy ostatecznie zostanie przyznane jej prawo do zadecydowania o własnej tożsamości, zależy od układu sił pomiędzy jednostką a grupą ${ }^{174}$. W obliczu konfliktu pomiędzy tożsamością jednostkową a społeczną jednostki wewnątrzsterowne (określenie Davida Riesmana ${ }^{175}$ ) wybiorą tę pierwszą, natomiast jednostki zewnątrzsterowne - tę drugą ${ }^{176}$, gdyż percepcja indywidualna traci na istotności w obliczu silnej tożsamości społecznej - jednostka przestaje postrzegać siebie jako byt autonomiczny, a zaczyna jako członka danej grupy.

Tkwiące w tożsamościach zbiorowych obrazy lub wyobrażenia na swój temat - bez względu na to, czy są „prawdziwe”, czy nie - pomagają zrekonstruować życie społeczne, świadczą o istnieniu pewnych grup. Ewa Banaszak-Karpińska twierdzi, że tożsamość zbiorowa pełni funkcję stabilizacji danej grupy i uważa, że można ją uchwycić poprzez określenie typów wie-

${ }^{171}$ Ibidem, s. 18.

${ }^{172}$ Ibidem, s. 19.

${ }^{173}$ Ibidem, s. 22 oraz B. Synak, op. cit., s. 43.

${ }^{174}$ M. Golka, op. cit., s. 20.

175 Por. D. Riesman, The Lonely Crowd, New Haven 1950, polskie tłumaczenie: Samotny thum, Warszawa 1971.

${ }^{176}$ M. Golka, op. cit., s. 21. 
dzy, obyczajów, wzorów zachowań, norm i stereotypów, czyli elementów kulturowych ${ }^{177}$. Może zachodzić rozdźwięk między zbiorową tożsamością, jaką przypisuje sobie dana grupa, a tym, jak postrzegają ją inne grupy - a to za sprawą stereotypów oraz autostereotypów, czy nawet uprzedzeńn ${ }^{178}$.

Według Leszka Kołakowskiego potwierdzenie własnej tożsamości, czy to jednostkowej, czy zbiorowej, niesie jednak ze sobą niebezpieczeństwo agresji, chęci panowania nad innymi ${ }^{179}$. Na szczęście nie jest to regułą, nie zdarza się zawsze i wszędzie. Zagrożenie pojawia się wtedy, gdy jakaś grupa chce wykreować swoją tożsamość kosztem innych (np. przez podkreślanie własnych roszczeń czy dyskryminowanie), co może prowadzić do błędnego koła nienawiści ${ }^{180}$.

\subsubsection{Tożsamość etniczna i narodowa}

Tożsamość narodowa jest szczególną formą tożsamości zbiorowej. Na jej pojmowanie wpływają zainteresowania antropologów kultury grupami etnicznymi i etnicznością. Anya Peterson-Royce, po dokonaniu przeglądu współczesnej literatury przedmiotu, pisze: „Grupa etniczna jest grupą odniesienia przywoływaną przez ludzi, którzy podzielają wspólny styl historyczny (może być on jedynie zakładany), oparty na jawnych cechach i właściwościach oraz wartościach, i którzy poprzez procesy interakcji z innymi identyfikują się sami jako zbiorowość podzielająca ten styl. Natomiast tożsamość etniczna jest całością uczuć i doznań ze strony członków skoncentrowanych na tych wartościach, symbolach i poczuciu wspólnoty zakorzenionej historycznie, która identyfikuje ich jako odrębną grupę"181. Oznacza to, że postrzeganie własnej kultury (stylu historycznego) jest warunkiem utrzymania odrębności tożsamości etnicznej ${ }^{182}$.

W badaniach etniczności można wyróżnić dwa konkurencyjne podejścia - tzw. obiektywne, traktujące grupy etniczne jako trwałe, wyraźnie wyodrębnione zbiorowości, oraz subiektywne. To pierwsze podejście postuluje konstruowanie definicji grup etnicznych na bazie kryteriów „obiek-

${ }^{177}$ E. Banaszak-Karpińska, Kategoria tożsamości zbiorowej w socjologii [w:] I. Szlachcicowa (red.), Biografia a tożsamość, Wrocław 2003, s. 159, cyt. za: M. Golka, op. cit., s. 22.

${ }^{178}$ M. Golka, op. cit., s. 23.

${ }^{179}$ L. Kołakowski, O tożsamości zbiorowej [w:] K. Michalski (red.), op. cit., s. 55.

${ }^{180}$ M. Golka, op. cit., s. 23.

${ }^{181}$ A. Peterson-Royce, Ethnic Identity, Bloomington 1982, s. 18.

${ }^{182}$ Z. Bokszański, Tożsamość narodowa: pojęcie i problematyka badawcza [w:] M. Czyżewski, A. Piotrkowski, A. Rokuszwska-Pawłek (red.), Biografia a tożsamość narodowa, Łódź 1997, s. 27. 
tywnych”, wśród których najczęściej pojawiają się: przekonanie o wspólnym pochodzeniu, wspólna kultura (zwyczaje), religia, podobieństwo cech fizycznych lub „rasy” oraz język ${ }^{183}$. Problem jest jednak znacznie bardziej złożony, istnieją bowiem trzy zasadnicze powody odrzucenia powyższych kryteriów. Po pierwsze - łatwo znaleźć wyjątek od definicji (grupa etniczna może istnieć bez terytorium bądź języka czy religii), po drugie - jawne cechy kulturowe zmieniają swoją formę (a mimo to grupa zachowuje autoidentyfikację), po trzecie - jawne cechy kulturowe nie odróżniają wyraźnie grup etnicznych od innych grup, np. zawodowych czy lokalnych, posiadających własną subkulturę ${ }^{184}$.

W świetle powyższych argumentów poszukiwanie obiektywnych kryteriów kulturowej odrębności zdaje się zadaniem niewykonalnym. Tym bardziej rośnie znaczenie czynników świadomościowych, których rdzeń stanowią przekonania składające się na „koncepcję siebie”. Koncepcja siebie jest konstruowana przede wszystkim dzięki kontrastowi między „nami” i „nimi”, co podkreśla szczególnie mocno Frederik Barth ${ }^{185}$, postulujący ideę etnicznej granicy (boundry), jako linię demarkacyjną pomiędzy tymi, którzy są „wewnątrz”, a tymi, którzy są „na zewnątrz”. Tożsamość etniczna nie jest bowiem - jak pisze George DeVos - „jedynie kwestią, kim ktoś jest subiektywnie dla siebie, ale także, jak jest postrzegany z zewnątrz" ${ }^{186}$.

Z kolei tożsamość narodowa często postrzegana jest jako poczucie odrębności wobec innych narodów kształtowane przez czynniki narodowotwórcze. Anthony Smith wymienia wśród nich: terytorium historyczne, wspólne mity i historyczne wspomnienia, kulturę publiczną, wspólną gospodarkę i wspólne dla całej społeczności prawa i obowiązki, ufundowane w prawie ${ }^{187}$. Podkreśla przy tym znaczenie symboli i wartości narodowych, gdyż poprzez symbolikę flag, ceremonii, monet, pomników, nazw ulic itp. „członkowie [narodu] przypominają sobie swój wspólny dorobek oraz czują się wzmocnieni w poczuciu swojej tożsamości i przynależności” ${ }^{188}$.

Na potrzeby niniejszej pracy wprowadzona zostanie definicja tożsamości narodowej jako „poczucia członków jakiejś grupy kulturowej pewnej od-

${ }^{183}$ V. Isajiw, Definitions of Ethnicity, „Ethnicity”, No. 1, 1974.

${ }^{184}$ L. Holy, Kulturowe tworzenie tożsamości etnicznej [w:] Z. Mach, A. K. Paluch (red.), Sytuacja mniejszościowa a tożsamość, Kraków 1992, s. 106.

${ }^{185}$ F. Barth (red.), Ethnic Groups and Boundaries, Boston 1996.

${ }^{186}$ G. DeVos, Ethnic Identity: Creation, Conflict, and Accommodation, Chicago 1975, s. 374.

${ }^{187}$ A. D. Smith, National..., s. 14.

${ }^{188}$ Ibidem, s. 17. 
rębności od obcych i związku z grupą swoich oraz świadomości ciągłości, historycznego trwania tej grupy i jej zbiorowej filiacji”' ${ }^{189}$. Taka definicja nie wiąże tożsamości narodowej z polityczną organizacją państwa narodowego. Tożsamość narodowa jest bowiem tożsamością polityczną i ideologiczną, niewynikającą z bezpośredniej relacji do zajmowanego terytorium ${ }^{190}$, niemniej zakładającą związek - faktyczny lub postulowany - zbiorowości narodowej z określonym terytorium ${ }^{191}$.

\subsubsection{Mit a tożsamość}

Mit jest czynnikiem stwarzającym punkt identyfikacji i jednocześnie remedium na utraconą tożsamość. Zarówno archaiczny mit symboliczny, jak i mit socjo-polityczny stanowi środek, dzięki któremu możliwe jest zbudowanie więzi z rzeczywistością ${ }^{192}$. Jako taki tworzy on poczucie przynależności do określonego miejsca na świecie, do określonej grupy oraz ułatwia orientację w stosunku do tej grupy. Wiąże jednostkę z kategorią „my” i pozwala na tym gruncie odnaleźć własną tożsamość, jest łącznikiem między jednostką a światem społecznym: opowiada o wspólnym pochodzeniu i wspólnej przeszłości ${ }^{193}$, o istocie tradycji i rytuałów, sankcjonuje istniejący porządek społeczny, określa przynależność do wyznaczonej grupy i sposób życia ${ }^{194}$.

Mity dzielą się na „zbiorowe” oraz „indywidualne” - pierwsze pomagają utożsamić się z grupą, drugie dostarczają "matryc” zachowania poprzez ukazanie indywidualnych bohaterów. Ci ostatni są najczęściej czymś więcej niż ludźmi, często mają boskie pochodzenie i dysponują niezwykłymi mocami, a mimo to stają się punktem odniesienia dla zwykłych śmiertelników ${ }^{195}$. Człowiek bowiem pragnie przekraczać samego siebie, nie godzi się z naturą - to nienasycenie i chęć transgresji zostało przez Józefa Kozieleckiego

${ }^{189}$ Por. A. Kłoskowska, Tożsamość i identyfikacja narodowa w perspektywie historycznej i psychologicznej, „Kultura i Społeczeństwo”, nr 1, 1992, s. 134.

${ }^{190}$ M. Dudziak, op. cit., s. 255.

${ }^{191}$ S. Ossowski, O ojczyźnie i narodzie, Warszawa 1984, s. 35, cyt. za: M. Starnawski, op. cit.

${ }^{192}$ A. M. Kłonkowska, Mit jako czynnik nadająy tożsamość [w:] I. Borowik, K. Leszczyńska, op. cit., s. 298.

${ }^{193}$ Y. Zerubavel określa publiczne upamiętnianie przeszłości jako „niewidzialne więzi pomiędzy wspólnotami żywych i umarłych”, innymi słowy, przeszłość znów żyje bądź odżywa w teraźniejszości, cyt. za: Y. Zerubavel, Recovered Roots: Collective Memory and the Making of the Israeli National Tradition, Chicago 1995, s. xvii, za: A. I. Laing-Marshall, op. cit., s. 16.

${ }^{194}$ B. Malinowski, Mit, magia, religia, Dzieła, t. VII, Warszawa 1990, s. 319, 349, 358, cyt. za: A. M. Kłonkowska, op. cit., s. 299.

${ }^{195}$ A. M. Kłonkowska, op. cit., s. 300. 
określone jako „zjawisko polegające na tym, że człowiek wychodzi poza to, co posiada i czym jest" ${ }^{\prime 196}$. U podstaw potrzeby transgresji leży motywacja hubrystyczna, czyli nieustanne dążenie człowieka do potwierdzania i powiększania własnej wartości i ważności ${ }^{197}$. Mity przepojone pragnieniem wykraczania poza samych siebie i rozszerzania swoich wpływów na świat, nie tylko pomagają marzyć, ale również popychają do działania, motywują, katalizują wolę życia ${ }^{198}$.

Arnold J. Toynbee dostrzega w mitach relację wyzwanie-odpowiedź. Wyzwania pomagają jednostkom, ale też całym cywilizacjom, rozwijać się. Te grupy ludzi, które podjęły wyzwanie (jakie stanowiło np. nieprzyjazne środowisko życia) i dostosowały się do nowej sytuacji, przekształcając rzeczywistość tak, by lepiej służyła ich potrzebom, osiagnnęły wyższy poziom rozwoju. W mitach zostaje zaburzona homeostaza, pojawia się wyzwanie, najczęściej spotykają się dwie siły - dobra i zła, które wyrywają ludzi z uśpienia i każą im buntować się przeciwko narzuconym warunkom i postrzegać własne życie jako zadanie ${ }^{199}$.

Jak pisze Rollo May: „Mit jest sposobem na to, by do bezsensownego świata wprowadzić ład. Mity są narracyjnymi wzorami, nadającymi ludzkiej egzystencji znaczenie" ${ }^{200}$. Nawet gdy mit sakralny traci swą symboliczną moc i przestaje być „świętą opowieścią”, nie sposób nie dostrzec „drzemiącej w nas wszystkich potrzeby mitu, wyrastającej z istoty naszego człowieczeństwa" ${ }^{201}$. W sytuacji braku mitu symbolicznego jego miejsce zajmuje często mit socjo-polityczny, który również próbuje podtrzymać poczucie sensu i celowości świata, stworzyć więź pomiędzy jednostką i określoną grupą. Claude Lévi-Strauss uważa, że „nic nie przypomina bardziej myśli mitycznej niż ideologia polityczna. Być może w naszych współczesnych społeczeństwach druga z nich zastępuje tylko pierwszą"202.

${ }^{196}$ J. Kozielecki, Koncepcja transgresyjna człowieka. Analiza psychologiczna, Warszawa 1987.

${ }^{197}$ A. M. Kłonkowska, op. cit., s. 301.

${ }^{198}$ Ibidem, s. 302-303.

${ }^{199}$ Ibidem, s. 303-304.

${ }^{200}$ R. May, The Cry for Myth, Norton, New York 1991, polskie tłumaczenie: Btaganie o mit, Poznań 1997, s. 13.

${ }^{201}$ Ibidem, s. 17. Por. C. G. Jung, Archetypy i symbole. Pisma wybrane, Warszawa 1981; E. Fromm, The Forgotten Language: An Introduction to the Understanding of Dreams, Fairy Tales, and Myths, New York 1957, polskie tłumaczenie: Zapomniany język. Wstęp do rozumienia snów, baśni i mitów, Warszawa 1977, cyt. za: A. M. Kłonkowska, op. cit., s. 306.

${ }^{202}$ C. Lévi-Strauss, Anthropologie structurale, Paris 1958, polskie tłumaczenie: Antropologia strukturalna, Warszawa 2000, s. 188, za: A. M. Kłonkowska, op. cit., s. 307. 


\subsubsection{Tożsamość a globalizacja}

Ricoeur określił dwie składowe tożsamości - l’ipséité (różnicę względem innych) i la mêmeté (tożsamość względem siebie w czasie). Załamanie się tej pierwszej powoduje, że współczesne tożsamości zdają się niestabilne. Procesy globalizacji ${ }^{203}$ i wielowymiarowość współczesnego świata ${ }^{204}$ wiążą się z tworzeniem nowej perspektywy tożsamościowej - przejściem z poziomu tożsamości narodowej na poziom tożsamości zglobalizowanej. Nie oznacza to zaniknięcia niższych poziomów identyfikacyjnych. Warstwy tożsamości, często opozycyjne, nakładają się bowiem na siebie, co rodzi konieczność ich „nieschizofrenicznego” połączenia, a to jest psychologicznie trudne ${ }^{205}$.

Wielu współczesnych humanistów ustosunkowało się do tego tematu. Giddens podkreśla pozbawienie lokalnych przestrzeni waloru wyłączności oraz upowszechnienie w świadomości ogólnej istnienia innych punktów odniesienia i rozmaitych możliwości wyboru ${ }^{206}$. Według niego dawniej niemobilne lub mało mobilne grupy znalazły się w zupełnie nowej sytuacji ${ }^{207}$, która, z jednej strony, wymusza przedefiniowanie własnych tożsamości w celu dostosowania się do wielokulturowego świata, z drugiej zaś - daje możliwość ich ukształtowania według całego spektrum niegdyś niedostępnych wzorców. Powstawanie nowych tożsamości, które jest efektem, celem, a niekiedy skutkiem ubocznym procesów adaptacyjnych, może rodzić konflikty i napięcia ${ }^{208}$. Sytuację komplikuje fakt, że procesy globalizacyjne zachodzą w różnym tempie w różnych obszarach świata, rozbijając homogeniczne wcześniej grupy lub potęgując rozdrobnienie grup heterogenicznych. Równolegle do wykształcania się kosmopolitycznej świadomości narasta świadomość różnicy i przywiązania do lokalnej, tradycyjnej tożsamości. Konieczność zredefiniowania swojej tożsamości staje zarówno przed jednostkami, jak i całymi społecznościami ${ }^{209}$.

${ }^{203}$ Globalizacja będzie tu rozumiana jako „intensyfikacja stosunków społecznych o światowym zasięgu, która łączy różne lokalności w ten sposób, że lokalne wydarzenia kształtowane są przez zdarzenia zachodzące $\mathrm{w}$ odległości wielu tysięcy mil i vice versa" (tłum. J. Isański), cyt. za: A. Giddens, The Consequences of Modernity, Cambridge 1990, s. 40 .

${ }^{204}$ W. Morawski, Globalizacja: wyzwania i problemy [w:] M. Marody (red.), Wymiary życia spotecznego. Polska na przełomie XX i XXI wieku, Warszawa 2002, s. 441-464.

${ }^{205}$ E. Wysocka, Podstawowe wyznaczniki ksztattowania się tożsamości w percepcji mtodzieży studenckiej [w:] I. Borowik, K. Leszczyńska, op. cit., s. 309.

${ }^{206}$ A. Giddens, The Consequences..., s. 19, cyt. za: J. Isański, Tożsamość w czasach globalizacji [w:] M. Golka (red.), op. cit., s. 161.

${ }^{207}$ A. Giddens, op. cit., s. 103, cyt. za: J. Isański, op. cit., s. 162.

${ }^{208}$ J. Isański, op. cit., s. 162.

${ }^{209}$ Ibidem, s. 163. 
Hanna Mamzer zastanawia się, czy globalizacja może mieć pozytywny wpływ na kształtowanie się tożsamości: „Wydaje się, że tak może być. Dostarczając możliwości konfrontowania różnych systemów wartości ze sobą, znosząc granice i podziały, ułatwiając komunikację i przepływ informacji, procesy globalizacji automatycznie umożliwiają bliższe kontakty przedstawicielom różnych kultur"210.

Słuszna wydaje się refleksja Edmunda Wnuka-Lipińskiego nad skutkami globalizacji dla tożsamości lokalnych, że ,globalna wioska zastępowana jest przez globalne miasto, z charakterystycznymi dla wspólnot miejskich stosunkami społecznymi: anonimowość, niska kontrola społeczna, interakcje przez sfragmentaryzowane role społeczne raczej niż przez integralne osobowości”211. Podobnie uważa Mamzer: „W epoce nowoczesności granice tożsamości były jasno zdefiniowane, spójne i stabilne (...) Współczesne dyscyplinowanie tożsamości polega na obowiązku bycia sfragmentaryzowanym - przekaz „musisz być taki a taki” zastąpiony został przekazem „możesz być każdy (jednocześnie)”212. Tożsamość konstruuje się więc poprzez akcentowanie wolności wyboru. Globalność objawia się większymi możliwościami budowania przez jednostkę jej własnej tożsamości.

Miejsce w nowej hierarchii określają m.in.: mobilność, znajomość języków, kompetencje cywilizacyjne, możliwości konsumpcyjne oraz rzeczywiście posiadane przez jednostkę dobra. Posiadanie znacznej własności gwarantuje prestiż nawet w oczach społeczności, która wcześniej nie przywiązywała wagi do aspektów materialnych ${ }^{213}$.

Zmiana w obszarze tożsamości związana jest z szeroko pojętymi skutkami globalizacji. Formą reakcji może być podział spójnej dotychczas kultury oraz jej ewolucja. Nie ma jednej możliwej drogi - istnieje wiele możliwości. Tracąc lokalność, jednostki zyskują możliwość wyboru. Jednak, jak słuszne zauważa Bauman, globalizacja poszerza możliwości jednych panowania nad własną tożsamością, a odbiera je drugim. Doświadczenie tych, których nie dotyczą ograniczenia poruszania i przemieszczania się jest pozytywne, wręcz radosne, natomiast doświadczenie przykutych do miejsca jest trudne, a nawet przerażające ${ }^{214}$. Najczęściej

${ }^{210}$ H. Mamzer, Tożsamość w podróży, Poznań 2002, s. 130.

${ }^{211}$ E. Wnuk-Lipiński, Świat międzyepoki. Globalizacja, demokracja, państwo narodowe, Kraków 2004, s. 32, cyt. za: J. Isański, op. cit., s. 170.

${ }^{212}$ H. Mamzer, op. cit., s. 58, za: J. Isański, op. cit., s. 172-173.

${ }^{213}$ J. Isański, op. cit., s. 172-173.

${ }^{214}$ Z. Bauman, Tożsamość-jaka była, jest i po co? [w:] A. Jawłowska, Wokót problemów..., s. 11. 
rzekomo samodzielna droga autoidentyfikacji sprowadza się do wyboru spośród szlaków już wytyczonych - wolność wyboru jest pozorna i ograniczona $^{215}$. Kierunek zmian jest raczej pochodną czynników zewnętrznych $^{216}$.

\subsubsection{Podsumowanie}

Tożsamość, czy to jednostkowa, czy zbiorowa, zakłada poczucie ciaggłości podmiotu, jest swoistą zasadą „porządku świata”, naszej kultury i naszego istnienia. Jest wartością nader istotną, gdyż gwarantującą ład i źródło poznania. Jak pisze Barbara Skarga, „jej brak postawiłby nas wobec świata chaosu, pojawiających się bezsensownych rzeczy i wydarzeń, zmienności absolutnej, w której my sami rozpłynęlibyśmy się od wewnątrz w potoku nieuporządkowanych wrażeń, bez punktu oparcia, niby nurt zmieniający nieustannie swe koryto i swój kierunek, rozlany, coraz płytszy, wsysany w piasek otaczającej nas rzeczywistości”217.

Współcześnie socjologowie zwracają uwagę, że jednostka oderwana od narodu czy rodziny, a więc pozbawiona jakiegoś aspektu tożsamości kolektywnej, może utracić tożsamość indywidualną. Procesy modernizacyjne, globalizacja stanowią zagrożenie dla „starych” tożsamości - narodowych czy kulturalnych, kształtują za to nową tożsamość globalną lub masową. Homogenizacja kultury wytwarza tożsamość hybrydalną. Zagrożeniem dla tożsamości jest utrata bądź to poczucia odrębności od innych, bądź to podobieństwa do innych. Bauman uważa, że obecnie w pytaniu o tożsamość zanika wymiar uniwersalny na rzecz indywidualizmu, specyficznych potrzeb i preferencji ${ }^{218}$.

Rysujący się kryzys tożsamości stwarza jednak szansę na tożsamość ponowoczesną. Rośnie bowiem zapotrzebowanie na nową tożsamość, a nawet na „politykę tożsamościową ${ }^{219}$, której rdzeniem ma być wspólna kultura. Globalizacja kultury, mnożąc tożsamości, wzmacnia pragnienie zachowania własnego oblicza ${ }^{220}$. Ponadto globalizacja „wyłuskuje tożsa-

${ }^{215}$ Z. Bauman, op. cit., s. 14.

${ }^{216}$ J. Isański, op. cit., s. 176.

${ }^{217}$ B. Skarga, op. cit., s. 12.

${ }^{218}$ J. Kociuba, op. cit., s. 55.

${ }^{219}$ Zob. S. Huntington, The Clash of Civilizations and the Remaking of World Order, New York 1996, polskie tłumaczenie: Zderzenie cywilizacji i nowy kształt tadu światowego, Warszawa 1997.

${ }^{220}$ K. Krzysztofek, Tendencje globalnej dyfuzji u progu XXI wieku [w:] A. Tyszka (red.), Róża wiatrów Europy, Warszawa 1999. 
mość” z jej wcześniejszego lokalnego kontekstu ${ }^{221}$, umożliwiając przeformułowanie tożsamości indywidualnej $\mathrm{w}$ ramach tożsamości zbiorowych $^{222}$.

Współcześni Asyryjczycy i Aramejczycy, szczególnie ci zamieszkujący diasporę, stoją w punkcie, w którym ich tradycyjna tożsamość zostaje przeformułowana. Bardzo często wytwarzają tożsamości hybrydalne, wielowymiarowe.

\subsection{Kontrowersje wokół nazwy}

Wybór adekwatnej nazwy dla omawianej wspólnoty jest kwestią wysoce problematyczną. Różne wspólnoty chrześcijan syryjskich oraz użytkowników dialektów nowoaramejskich postulują bowiem odmienne określenia swojej przynależności. W literaturze przedmiotu można napotkać następujące terminy:

- Asyryjczycy - od nazwy starożytnego imperium asyryjskiego, forsowany przez Asyryjski Kościół Wschodu oraz Starożytny Kościół Wschodu, ponadto przez innych chrześcijan Kościołów syryjskich, np. asyryjskich nacjonalistów z Syryjskiego Kościoła Ortodoksyjnego i Chaldejskiego Kościoła Katolickiego;

- Aramejczycy (wariantywnie Syryjczycy ${ }^{223}$, Syriacy ${ }^{224}, S_{\text {urjoje }}{ }^{225}$ ) - od nazwy starożytnych Aramejczyków, postulowany przez niektórych wyznawców Syryjskiego Kościoła Ortodoksyjnego, jak też innych chrześcijan Kościołów syryjskich, np. Syryjskiego Kościoła Katolickiego oraz Kościoła Maronickiego;

${ }^{221} \mathrm{~B}$. Misztal, Tożsamość jako pojęcie i zjawisko społeczne $w$ zderzeniu z procesami globalizacji [w:] E. Budakowska (red.), Tożsamość bez granic, Warszawa 2000.

${ }^{222}$ J. Kociuba, op. cit., s. 55.

${ }^{223}$ Niewielu samych zainteresowanych określa się obecnie wyłącznie tym mianem częstsze są połączenia: Syryjczycy/Aramejczycy czy Aramejczycy/Syryjczycy.

${ }^{224}$ Syriacy (ang. Syriacs), w piśmiennictwie anglojęzycznym termin używany wyłącznie w sensie „autorów piszących w języku syryjskim” pojawił się jeszcze przed I wojną światową. Dziś bywa używany w znaczeniu rozszerzonym - na określenie całej wspólnoty. Świat akademicki pozostaje jednak przy wersji „Syryjczycy” (ang. Syrians), uważając, że „Syriakom" brak mocnych historycznych fundamentów, cyt. za: J. Messo, The Aramean Identity of Tur Abdin and its Native Population, http://www.midyatcity.com/articles/turabdin_aramean.pdf, s. 6, data wejścia 16.07.2009.

${ }^{225}$ Surjoje (ang. Suryoye), nazywa własna w języku aramejskim, tłumaczona przeważnie jako „Syryjczycy”. Niektórzy współcześni Asyryjczycy również godzą się na bycie określanymi tą nazwą. 
- Chaldejczycy - od nazwy starożytnej Chaldei, preferowany przez część wyznawców Chaldejskiego Kościoła Katolickiego, szczególnie w diasporze;

- Asyro-chaldejczycy - nazwa obejmująca oba wschodnie odłamy chrześcijaństwa syryjskiego: ortodoksyjny oraz unicki;

- Nestorianie - dawna, błędna nazwa wyznawców Asyryjskiego Kościoła Wschodu;

- Jakobici - dawna, błędna nazwa wyznawców Syryjskiego Kościoła Ortodoksyjnego.

Uznane historycznie przez większość naukowców określenie dla grupy to „Syryjczycy”. Współcześnie termin ten jest rzadziej używany, ponieważ po uzyskaniu niepodległości przez Syrię, przez „Syryjczyka” rozumie się przede wszystkim obywatela Syryjskiej Republiki Arabskiej ${ }^{226}$. Warto zauważyć, że przymiotnik „syryjski” (ang. Syrian/Syriac), odnoszący się do chrześcijan syryjskich, został tymczasem zastąpiony „aramejskim” (ang. Aramean/Aramaic) ${ }^{227}$, stąd współcześni Syryjczycy często nazywają samych siebie „Aramejczykami”. Jednak częściej spotykane, szczególnie poza dyskursem stricte naukowym, jest określenie „Asyryjczycy”, które pojawiło się na większą skalę w zachodnim piśmiennictwie obok tradycyjnych „Syryjczyków” mniej więcej na przełomie XIX i XX wieku (początkowo na określenie wyznawców Kościoła Wschodu ${ }^{228}$, potem zaś wszystkich chrześcijan syryjskich) i zostało zaadaptowane przez samych zainteresowanych, którzy w owym okresie byli „etnicznie bezimienni” ${ }^{229}$.

Kontrowersja nie ogranicza się do egzonimów w językach zachodnich, jak „Asyryjczyk” v. „Aramejczyk”, ale dotyczy również określeń w nowo-

${ }^{226}$ Sami zainteresowani unikają używania tego terminu, gdyż nie chcą być myleni z Arabami (muzułmanami) z Syrii, co m.in. tłumaczy rosnącą popularność opcji „asyryjskiej”, cyt. za: J. Messo, The Identity of the People Described in the Writings of Gabriele Yonan, http://www.midyatcity.com/articles/gyonan_messo.pdf, s. 4, data wejścia 3.08.2009.

${ }^{227} \mathrm{~J}$. Joseph, The Nestorians and Their Muslim Neighbors. A Study of Western Influence on Their Relations, Princeton, New Jersey 1961, s. 12. Właściwie był to powrót do pierwotnej nazwy, gdyż „Syryjczykami” nazywali Aramejczyków w III/IV wieku p.n.e. Grecy, bez względu na to, czy ci pierwsi żyli we właściwej Syrii czy Babilonii, cyt. za: J. Messo, The Identity of the People..., s. 5 oraz Th. Nöldeke, Assyrios Syrios Syros, „Hermes”, 5, 1871, s. 461 i 468; idem, Die Namen der aramäischen Nation und Sprache, "Zeitschrift der Deutschen Morgenländischen Gesellschaft”, 25, 1871, s. 113 i 115.

${ }^{228}$ W XIX wieku część badaczy uważała zachodnich Syryjczyków za Aramejczyków, cyt. za: J. Messo, Identity of the People..., s. 6.

${ }^{229}$ R. Macuch, Assyrians in Iran [w:] E. Yarshater (red.), Encyclopedia Iranica, Vol. IV, London-New York 1987, s. 818. 
aramejskim: odłam aramejski uznaje zarówno nazwę „Surjaje” i „Aramaje”, podczas gdy odłam asyryjski nalega na „Aturaje”, akceptując jednak „Surjaje”, ewentualnie „Suraje”. Współczesny słownik języka aramejskiego z 2007 roku ${ }^{230}$ traktuje te określenia jako synonimy; według niego Asyryjczycy nazywają samych siebie w odmianie wschodniej (suret): Suraje, Surjaje, Aturaje, w odmianie zachodniej (turojo): Suroje, Sorjoje, Otoroje $e^{231}$.

Bardzo ograniczona dostępność materiału historycznego dotyczącego losów Asyryjczyków od upadku Niniwy w 612 roku p.n.e. do nadejścia chrześcijaństwa utrudnia rozwianie kontrowersji. Źródła są skąpe, sprowadzają się głównie do kilku notatek autorów klasycznych, takich jak Strabon, Pliniusz, Polibiusz i Ptolemeusz, podczas gdy tabliczki zapisane pismem klinowym zawierają przeważnie inkantacje, opisy obrzędów religijnych i kopie starożytnych tekstów religijnych ${ }^{232}$. Zresztą już starożytni pisarze mieli problemy terminologiczne - dyskutowali problem synonimiczności słów „Syria” i „Asyria” (używali obu terminów), czując, że onomastycznie muszą być one jakoś powiązane ${ }^{233}$.

Punkt zwrotny nastąpił w V wieku p.n.e., gdy Herodot w swych Dziejach wyróżnił dwie odrębne nazwy, pisząc o tych, których „Hellenowie nazywali Syryjczykami, barbarzyńcy zaś Asyryjczykami”234, zaś toponimy „Syria” oraz „Asyria” ściśle rozgraniczył, odróżniając lewantyńskich i kapadockich „Syryjczyków” od mezopotamskich „Asyryjczyków”235. To oznaczałoby, że po V wieku p.n.e. terminy „Syria” i „Asyria” przestały być używane wymiennie. W II wieku p.n.e. Posejdoniusz pisał, że ci, których Grecy nazywają Syryjczykami, sami siebie nazywają Aramejczykami.

Średniowieczni autorzy syryjscy mieli świadomość pochodzenia swojego języka od starożytnych Aramejczyków, nie używali jednak terminu „Ara-

${ }^{230}$ N. Awde, N. Lamassu, N. Al-Jeloo, Modern Aramaic (Assyrian/Syriac) Dictionary \& Phrasebook, New York 2007, s. 4.

${ }^{231} \mathrm{O}$ tych samookreśleniach pisali m.in.: W. Heinrichs, The Modern Assyrians - Name and Nation [w:] R. Contini i in. (red.), Semitica: Serta Philologica Constantino Tsereteli dicata, Torino 1993, s. 102; S. Parpola, National and Ethnic Identity in the Neo-Assyrian Empire and Assyrian Identity in Post Empire Times, JAAS, Vol. 18, No. 2, 2004, s. 18; R. Rollinger, Assyrios, Syrios, Syros und Leukosyros, „Die Welt des Orients”, 36, 2006, s. 285, cyt. za: J. Messo; „The Origin of the Terms 'Syria(n)' \& Süryoyo once again”, Presentation Symposium Syriacum 2008, s. 3, niepublikowany tekst w posiadaniu autorki.

${ }^{232}$ Encyclopedia Britannica, CD 2002, zob. Mesopotamia, 320 BC to 620 AD.

${ }^{233}$ P. R. Helm, „'Greeks' in the Neo-Assyrian Levant and 'Assyria' in Early Greek Writers", niepublikowana praca doktorska obroniona na University of Pennsylvania, Pennsylvania (USA) 1980, s. 31, cyt. za: J. Messo, The Origin..., s. 1.

${ }^{234}$ Herodot, Dzieje, Warszawa 1954, s. 479.

${ }^{235}$ Por. P. R. Helm, op. cit., s. 288 i 294, cyt. za: J. Messo, op. cit., s. 2. 
mejczyk" na określenie własnej przynależności etnicznej. Michał Wielki, jakobicki patriarcha Antiochii w XII wieku, pisał: „Królestwa wzniesione przez naszą rasę w starożytności, (te należące do) Aramejczyków, mianowicie potomków Aramu, którzy nazywani byli Syryjczykami”" ${ }^{36}$. Gdzie indziej zanotował zaś: „Asyryjczycy, to jest Syryjczycy”237. Z drugiej strony ten sam autor wspominał również wcześniejszą, IX-wieczną dysputę między jakobickimi Syryjczykami a uczonymi greckimi, podczas której jakobici prawdopodobnie deklarowali „asyryjską” tożsamośćc ${ }^{38}$ oraz mówił o spaleniu ksiąg opowiadających o dawnych królach, gdyż historie o nich wymieszane były z „diabolicznymi opowieściami o ich pogańskości”239.

Niezależnie od zagadnienia faktycznego użycia, pytanie o etymologiczne relacje tych dwóch terminów zostało niedawno znów poruszone. Punkt sporny stanowiła kwestia, czy toponim „Syria” został ostatecznie wywiedziony od nazwy „Aszszur” (przeciwstawna teza mówiła o pochodzeniu od „Hurytów” ${ }^{240}$. Warto przedstawić główne tezy zwolenników i przeciwników szeroko rozumianej „tezy asyryjskiej”.

\subsubsection{Argumenty zwolenników tezy asyryjskiej}

Pierwszym nowożytnym autorem, który w 1871 roku sformułował teorię pochodzenia greckiego słowa „Syria” od „Asyrii”, był Theodor Nölde$\mathrm{ke}^{241}$. Mimo pewnych niejasności, większość pisarzy - nie tylko tych wywodzących współczesnych Asyryjczyków od starożytnych - uznaje tę teorię.

Wielkim zwolennikiem tezy asyryjskiej był W. A. Wigram, którego książki The Assyrians and Their Neighbours ${ }^{242}$ oraz Our Smallest Ally ${ }^{243}$ spo-

${ }^{236}$ Zob. L. van Rompay, Jacob of Edessa and the Early History of Edessa [w:] G. J. Reinink, A. C. Klugkist (red.), After Bardaisan: Studies on Continuity and Change in Syriac Christianity in Honour of Professor Han J. W. Drijvers, Groningen 1999, s. 277.

${ }^{237}$ J. B. Chabot (red.), Chronique de Michel le Syrien, Patriarche Jacobite d'Antioch (1166-1199), Paris 1899-1924, s. 32.

${ }^{238}$ Ibidem, s. 748 i 750.

${ }^{239}$ Ibidem, s. 446.

${ }^{240}$ R. Rollinger, The Terms „Assyria” and „Syria” Again, „Journal of Near Eastern Studies”, Vol. 65, No. 4, Chicago 2006, s. 283-287.

${ }^{241}$ Th. Nöldeke, op. cit., s. 443-468; idem, Ueber den namen Assyriens, „Zeitschrift für Assyriologie und verwandte Gebiete", 1, 1886, s. 268-273; E. Schwartz, Einiges über Assyrien, Syrien, Koilesyrien, „Philologus”, 86, 1931, s. 373-399; idem, Noch einmal über Assyrien und Syrien, „Philologus”, 87, 1932, s. 261-263, cyt. za: J. Messo, The Origin..., s. 1.

${ }^{242}$ W. A. Wigram, The Assyrians and Their Neighbours, London 1929.

${ }^{243}$ Idem, Our Smallest Ally: A Brief Account of the Assyrian Nation in the Great War, London-New York 1920. 
pularyzowały nazwę i zapoznały społeczność międzynarodową z tragedią Asyryjczyków. Pomiędzy wojnami świat wielokrotnie słyszał o Asyryjczykach dzięki artykułom w gazetach i na forum Ligi Narodów ${ }^{244}$.

W latach 90. XX wieku Richard Frye na nowo zrównał terminy „Asyria” i „Syria”, a w celu wykazania, że określenie „Asyryjczycy” na pewne chrześcijańskie grupy funkcjonowało jeszcze przed XIX stuleciem, przywołał źródła ormiańskie i perskie oraz - cytowanego już wcześniej - Michała Wielkiego. Jednak po artykule J. Josepha (którego argumenty omawiam szeroko w następnym podpunkcie) kwestia pozostaje otwarta. Obaj uczeni zgadzają się co do tego, że „zamieszanie wokół dwóch podobnych słów "Syria» i »Asyria" jest historyczne i trwa do dziš", przy czym obaj oskarżają się nawzajem o potęgowanie owego zamieszania ${ }^{245}$.

Obecnie znanym zwolennikiem teorii asyryjskiej jest S. Parpola, asyrio$\log \mathrm{z}$ Uniwersytetu w Helsinkach. W National and Ethnic Identity in the Neo-Assyrian Empire and Assyrian Identity in Post-Empire Times oraz Assyrian Identity in Ancient Times and Today pokazuje ciągłość asyryjskiej tożsamości narodowej - świadomie budowanej przez nowoasyryjskich władców, zachowanej w obrzędach i tradycjach po upadku imperium w częściowo niezależnych królestwach asyryjskich: Osrhoene, Adiabene ${ }^{246}$, Hatrze i Aszur, wzbogaconej od III wieku o silny komponent chrześcijaństwa (choć starożytna religia asyryjska przetrwała w Harranie do X wieku, a w Mardinie nawet do wieku XVIII) ${ }^{247}$.

Podobne poglądy głoszą Edward Y. Odisho i Konstantin Matwiejew ${ }^{248}$. Na Parpolę często powołuje się G. V. Yana (Bebla) w Ancient and Modern Assyrians $^{249}$, który także uważa, że Asyryjczycy przeżyli upadek imperium (szczególnie asyryjscy wieśniacy, z których nowi władcy mogli ściągać po-

${ }^{244}$ J. Joseph, op. cit., s. 15.

${ }^{245}$ R. Frye, Assyria and Syria: Synonyms, JAAS, Vol. XI, No. 2, 1997.

${ }^{246} \mathrm{~W}$ I wieku rodzina panująca w Adiabene dokonała konwersji na judaizm, co utorowało drogę późniejszemu rozprzestrzenianiu się chrześcijaństwa w regionie. To także powód, dla którego ciągle istnieje spora wspólnota żydowska posługująca się językiem wschodnioaramejskim, cyt. za: N. Awde, N. Lamassu, N. Al-Jeloo, op. cit., s. 6.

${ }^{247}$ S. Parpola, National and Ethnic Identity..., s. 17.

${ }^{248}$ Zob. E. Y. Odisho, The Ethnic, Linguistic and Cultural Identity of Modern Assyrians, http://www.aakkl.helsinki.fi/melammu/pdf/odisho2001.pdf, data wejścia 8.08.2009.

${ }^{249}$ G. V. Yana (Bebla), Ancient and Modern Assyrians. A Scientific Analysis. A Review of the Works of J. M. Fiey, and Prof. John Joseph. Includes a Political and Engineering History of Assyria, [United States] 2008. 
datki) i zburzenie swych głównych miast (Aszur, Niniwy i Nimrod) ${ }^{250}$, przetrwali w satrapii Athura (539-330 p.n.e. ${ }^{251}$ oraz jako chrześcijanie Adiabene (w północnym Iraku) ${ }^{252}$. W tym ujęciu starożytni Asyryjczycy i Aramejczycy - dwa odrębne ludy - dzielili się językiem i etnicznością ${ }^{253}$ do czasu, gdy Aramejczycy, jako asyryjscy poddani, w ciągu trzech pokoleń zostali zasyrianizowani, przyjmując wyższą kulturę asyryjską ${ }^{254}$. Zasyrianizowany język aramejski zastąpił akadyjski, elementy akadyjskiego przetrwaty przejęte przez aramejski ${ }^{255}$.

O mieszkańcach Adiabene, którzy czcili boga Aszura aż do okresu sasanidzkiego, Yana (Bebla) pisze: „Oczywiste jest, że byli to Asyryjczycy. Przeczy zdrowemu rozsądkowi uważanie tych ludzi wyłącznie za Aramejczyków, zamiast przyjmować bardziej logiczną odpowiedź, iż byli oni mieszanką Aramejczyków, Asyryjczyków oraz Babilończyków (...) Nie ma przekonywającej teorii, że to Aramejczycy, a nie Asyryjczycy czcili Aszura. Nawet gdyby Aramejczycy byli tak zasyrianizowani, że czciliby Aszura, to oznaczałoby, że przyjęli tożsamość asyryjską i stali się Asyryjczykami”"256.

Następnie autor dowodzi, że w pierwszych wiekach naszej ery Asyryjczycy nie odrzucili swego miana, mimo ciążącego nad nim starotestamentalnego przekleństwa (Izajasz 46,1 oraz 14,21-25) ${ }^{257}$. Jeśli palili księgi o starożytnych królach po nadejściu chrześcijaństwa (o czym pisał Michał Wielki), to znaczy, że do tego czasu zachowywali swoją tożsamośćc ${ }^{258}$. Dopiero wraz z przyjęciem Ewangelii Asyryjczycy zaczęli identyfikować się jako chrześcijanie, od tego momentu ich historia zlała się z historią chrześcijaństwa ${ }^{259}$, a więź z Asyrią została przyćmiona. Jednak Yana (Bebla) uważa, że używanie tego okresu niepamięci jako dowodu na odrzucenie tożsamości asyryjskiej jest nieuzasadnione ${ }^{260}$ i pyta dlaczego współcześni Asyryjczycy, gdyby nie byli prawdziwymi potomkami starożytnych, tęskniliby za Asyrią i Niniwą? ${ }^{261}$

${ }^{250}$ Ibidem, s. 21.

${ }^{251}$ Ibidem, s. 22.

${ }^{252}$ Ibidem, s. 19.

${ }^{253}$ P. Crone, M. Cook, Hagarism: The Making of the Islamic Word, Cambridge 1977,

s. 55, cyt. za: G. V. Yana (Bebla), op. cit., s. 42.

${ }^{254}$ G. V. Yana (Bebla), op. cit., s. 86.

${ }^{255}$ Ibidem, s. 111.

${ }^{256}$ Por. ibidem, s. 42 oraz S. Parpola, Assyrian Identity..., rozdz. 2.5.

${ }^{257}$ G. V. Yana (Bebla), op. cit., s. 38-39.

${ }^{258}$ Ibidem, s. 108.

${ }^{259}$ Ibidem, s. 44.

${ }^{260}$ Ibidem, s. 51.

${ }^{261}$ P. Crone, M. Cook, op. cit., s. 59, cyt. za: G. V. Yana (Bebla), op. cit., s. 43. 
W toku jego wywodu kilka razy pojawia się argument, z którym nie sposób się nie zgodzić - jedynie rozstrzygające byłoby badanie DNA wykonane na reprezentatywnej próbie współczesnych Asyryjczyków i porównanie go z materiałem genetycznym pozyskanym ze starożytnych grobowców asyryjskich. Problem w tym, że takiego badania dotychczas nie przeprowadzono.

\subsubsection{Argumenty przeciwników tezy asyryjskiej}

W latach 60. XX wieku Jean-Marie Fiey rozpoczął swój słynny artykuł ${ }^{262}$ od pytania: „Asyryjczycy” czy Aramejczycy? Jego główna teza sprowadzała się do tego, że nazwa „Asyryjczycy”, nadana w XIX wieku przez anglikańskie misje, została wtórnie zaadaptowana przez samych Syryjczyków. Do 1914 roku nazwa „Asyryjczycy” była używana po to, by uniknąć pejoratywnego terminu "nestorianie”. De facto misjonarze znalé́li ludzi, którzy nazywali siebie „Surjaje” lub „Suraje”, tj. Syryjczykami (w znaczeniu „chrześcijanami”). Na hipotetyczne pytanie, co stało się z Asyryjczykami, J. M. Fiey odpowiada: a co stało się z Babilończykami, Sumerami, Akadyjczykami, Hetytami, Partami? Stopili się wszyscy razem w tyglu, którym była Niniwa, gdyż byli „niczym piana na grzbiecie fali, która opada”263. Z kolei Rudolf Macuch zapewnia swych czytelników, że tak samo nieodpowiednie, jak nazywanie współczesnych Libańczyków „Fenicjanami”, zaś ich dialektu arabskiego „fenickim”, byłoby mianowanie Syryjczyków „Asyryjczykami”, a języka nowoaramejskiego - asyryjskim ${ }^{264}$.

Podobną argumentację przedstawia J. Joseph. W The Modern Assyrians of the Middle East pisze, że społeczność asyryjska, jako o wiele mniejsza od aramejskiej, uległa arameizacji; innymi słowy, przyjmując język aramejski, Asyryjczycy zostali wchłonięci przez żywioł aramejski ${ }^{265}$. Dopiero współcześnie bardziej wykształceni Syryjczycy zaczęli udowadniać, że termin Suraje (Syryjczycy) pochodzi od Aszuraje (Asyryjczycy), co jednak jest podążaniem fałszywym tropem za tymi uczonymi zachodnimi, których wprowadzili w błąd greccy i rzymscy historycy, mieszając terminy o różnym pochodzeniu („Syryjczyk” i „Asyryjczyk”) ${ }^{266}$. Ormianie nazywali

${ }^{262}$ J. M. Fiey, „Assyriens” ou Araméens?, „L'Orient Syrien”, Vol. 10, Paris 1965.

${ }^{263}$ Ibidem, s. 159.

${ }^{264}$ R. Macuch, Geschichte der spät- und neusyrischen Literatur [History of the Late and Modern Syriac Literature], Berlin-New York 1976, s. 90.

${ }^{265} \mathrm{~J}$. Joseph, The Modern Assyrians of the Middle East. Encounters with Western Christian Missions, Archeologists, and Colonial Powers, Leiden-Boston-Köln 2000, s. $11-12$.

${ }^{266}$ Idem, The Nestorians..., s. 12. 
Syryjczyków Asori (dla Asyryjczyków mieli inne określenie: Asorestantji). Rosjanie także nazywali ich Asori (termin zapożyczyli od Ormian), perskie Asuri w odniesieniu do nestorian również jest słowem zapożyczonym. Joseph zgadzał się z Wolfhartem Heinrichsem, że hipoteza straconego „a” ułatwia zadanie nacjonalistom, podając kontrargument, iż w ormiańskim owo „a” zostało ${ }^{267}$. Tymczasem według niego Asyryjczycy zapomnieli język i przeszłość, stracili więc swoją tożsamośćc6.

Z kolei w The Nestorians and Their Muslim Neighbors Joseph stwierdza, że nazwę „Asyryjczycy”, nadaną z różnych powodów politycznych syryjskim chrześcijanom przez brytyjskich misjonarzy w XIX wieku, wzmocniły archeologiczne odkrycia na terenach starożytnej Asyrii ${ }^{269}$. Według badacza zarówno „Asyryjczycy”, jak i „nestorianie” to nazwy, które pod pewnymi względami podkolorowały historię omawianej mniejszości ${ }^{270}$.

Joseph podaje również, że jako pierwszy terminu „Asyryjczycy” użył w odniesieniu do nestorian libański orientalista Giuseppe Luigi Assemani, który wcale nie chciał przez to powiedzieć, że byli oni potomkami starożytnych Asyryjczyków. Następnie określenia tego użył brytyjski historyk Edward Gibbon, jednak w znaczeniu geograficznym. Misja anglikańska wysłana do nestorian w drugiej połowie XIX wieku nazwana została „Misją Arcybiskupa Canterbury do Asyryjczyków chrześcijan”; to ona była odpowiedzialna za utożsamienie nestorian z Asyryjczykami. Arthur J. Maclean i William H. Browne wyjaśnili, że nazwa „Asyryjczycy” pojawiła się w celu rozróżnienia odłamu tych chrześcijan (nestoriańskich) od jakobitów (Syryjczyków) $)^{271}$.

${ }^{267}$ Idem, The Modern Assyrians..., s. 19-20. Z drugiej strony F. Aprim zauważa, że alfabet ormiański jest fonetyczny, tak jak łaciński, dlatego zachował „a”, inaczej jest z językami semickimi, zob. F. Aprim, op. cit., s. 106.

${ }^{268}$ Historyk G. Roux także widział preludium do ostatecznej asymilacji Asyryjczyków w utracie przez nich ojczystego języka - akadyjskiego, cyt. za: Ancient Iraq, London 1992. Więcej o arameizacji Asyryjczyków zob. m.in.: H. Tadmor, The Aramaization of Assyria: Aspects of Western Impact [w:] H. J. Nissan, J. Renger (red.), Mesopotamien und seine Nachbarn: Akten des XXV RAI, Vol. II, Berlin 1982, s. 449-470, cyt. za: J. Messo, The Aramean Identity..., s. 3.

${ }^{269}$ Gdy w 1842 i 1845 roku wykopaliska francuskiego konsula Paula-Émile’a Botty i Anglika Austena Henry'ego Layarda odkryły ruiny Niniwy, Europa była zafascynowana. Layard wykrzyknął, że Chaldejczycy i nestorianie „rzeczywiście są pozostałością Niniwy i Asyrii w takim stopniu, jak surowe kopce i zrujnowane pałace”, zaś J. P. Fletcher napisał, że „Chaldejczycy i nestorianie” są ,jedynym trwającym ludzkim pomnikiem Asyrii i Babilonii”, cyt. za: J. Joseph, The Nestorians..., s. 13. Zob też idem, The Bible and the Assyrians: It Kept Their Memory Alive, JAAS, No. 12, s. 70.

${ }^{270} \mathrm{~J}$. Joseph, The Nestorians..., s. ix.

${ }^{271}$ Ibidem, s. 14. 
Nestorianie zostali nazwani Asyryjczykami także dlatego, że psychogenetyka obu ludów jest bardzo podobna. Jednak rysy, zwyczaje oraz praktyki starożytnych Asyryjczyków są obecnie dzielone przez różnych mieszkańców Bliskiego Wschodu. Praktykowany przez współczesnych Asyryjczyków/ Aramejczyków trzydniowy post, upamiętniający podróż proroka Jonasza do asyryjskiej stolicy Niniwy - podawany jako dowód na nieprzerwaną ciągłość - został wprowadzony przez nestoriańskiego arcybiskupa dopiero w VI wieku; co więcej, Koptowie, Etiopczycy i Ormianie również go przestrzegają ${ }^{272}$.

Joseph optuje za terminem „nestorianie”, używanym już od VI wieku. O nestorianach pisał Kosma w 525 roku: Arabowie znali wschodnich Syryjczyków jako nestorian (nasturijjun) lub chrześcijan nestoriańskich (an-nasara an-nasturijja). Autor podkreśla, że przez pewnien czas wschodni chrześcijanie sami nazywali siebie nestorianami. Mar Abd Jeszu, nestoriański metropolita Nisibis z XIII wieku, spisał „Ortodoksyjne kredo nestorian”. Wspólnota określała się jako nestoriańska aż do XX wieku. Pod koniec XIX stulecia pojawiły się głosy sprzeciwu, kiedy to misjonarze anglikańscy uświadomili Asyryjczykom negatywne konotacje związane z terminem „nestorianie”. W oficjalnych dokumentach ich Kościół był odtąd nazywany „Kościołem Wschodu”"273.

Następnie Joseph śledzi historię określenia „chaldejski”, odnoszącego się obecnie do unickiej gałęzi Asyryjskiego Kościoła Wschodu. Ibn al-Ibri (Bar Hebraeus) jako pierwszy użył określenia „Chaldejczycy” w pejoratywnym sensie (mając na myśli „magów”, „czarnoksiężników” - w takim znaczeniu jak w Księdze Daniela 2:2,10). Kiedy unicka gałąz Kościoła nestoriańskiego została powołana do istnienia w XVII wieku, do nowego patriarchy zwracano się jako do „patriarchy Chaldejczyków Wschodu”, powodując terminologiczny chaos. Innym powodem, dla którego nestorianie zostali nazwani Chaldejczykami, było błędne utożsamianie języka syryjskiego (czyli aramejskiego) z tak zwanym językiem chaldejskim ${ }^{274}$. W XVII wieku Kościół rzymskokatolicki przestał nazywać członków odłamu unickiego heretyckim mianem „nestorian”, zwracając

${ }^{272}$ Ibidem, s. 16-17 oraz idem, The Bible..., s. 76.

${ }^{273}$ Idem, The Nestorians..., s. 3-5.

${ }^{274}$ Jak większość mieszkańców Bliskiego Wschodu, starożytni Chaldejczycy przyjęli aramejski w późniejszym okresie. Termin „chaldejski”, podobnie jak „nestoriański”, był używany na długo przed schizmą w odniesieniu do wschodnich Syryjczyków z powodu geograficznej lokalizacji głównej siedziby ich Kościoła, ibidem, s. 8-9. 
się do nich od tej pory zawsze jako do „Chaldejczyków” (w znaczeniu „katolików”), tym samym popularyzując tę nazwę jako określenie odłamu religijnego ${ }^{275}$.

Jeśli chodzi o nazwę „Syryjczycy”, to Joseph uważa, że być może wzięła się ona z syryjskiej liturgii lub historii Kościoła antiocheńskiego. Kiedy Kościół antiocheński uległ podziałowi, każdy z odłamów żądał prawa do nazwy „syryjski”, niemal synonimicznej z „ortodoksyjnie chrześcijańskim” ${ }^{276}$. W północnym Iraku wśród chrześcijańskiej ludności aramejskojęzycznej powszechne jest używanie terminu Suraja na oznaczenie chrześcijan jako takich. Podczas gdy słowo Suraja lub Surjaja w klasycznej formie nie oznacza mieszkańca Syrii, zdaniem Josepha nie określa też Asyryjczyka.

Wreszcie badacz pisze o tyglu, w którym język aramejski i chrześcijaństwo złączyły ludy i regiony, dlatego też pochodzenie genetyczne omawianej grupy, jak większości bliskowschodnich narodowości, pozostaje ukryte. Współcześni Asyryjczycy/Aramejczycy są mieszanką ras - prawdopodobnie płynie w nich krew asyryjska, ale wśród swoich przodków mają także muzułmańskich Arabów, Kurdów i Persów ${ }^{277}$.

Johny Messo idzie dalej w przeciwstawianiu się tezie asyryjskiej - uznając język za jeden z najważniejszych wyznaczników i nośników tożsamości, daleko wykraczający poza zwykłe narzędzie komunikacji ${ }^{278}$, optuje za uznaniem aramejskich korzeni - szczególnie mieszkańców Tur Abdinu. W swoich artykułach ukazuje starożytnych Aramejczyków, którzy wraz z przyjęciem chrześcijaństwa, zgodzili się niejako na drugą nazwę (Syryjczyków), zachowując przy tym aramejską tożsamośćc79. Współcześni

${ }^{275}$ Ibidem, s. 10. Zmarły patriarcha Kościoła Chaldejskiego Mar Raphael I Bidawid w wywiadzie dla „Assyrian Star”, 55/3 (Jesień 2003), s. 20, tak odniósł się do tej kwestii: „Osobiście uważam, że te [różne] nazwy przyczyniają się do zamętu. Pierwotna nazwa naszego Kościoła brzmiała: Kościół Wschodu... Gdy część Kościoła Wschodu stała się katolicka, nadano mu nazwę »chaldejskiego« od królów-magów, którzy z Chaldei przybyli do Betlejem. Nazwa "chaldejski« nie odpowiada etniczności... Musimy rozróżnić, co jest etnicznością, a co religią... Ja religijnie jestem Chaldejczykiem, ale etnicznie - Asyryjczykiem...", cyt. za: S. Parpola, National and Ethnic..., s. 18. Obecny patriarcha, Emmanuel III Delly, czuje się Chaldejczykiem.

${ }^{276} \mathrm{~J}$. Joseph, The Nestorians..., s. 11.

${ }^{277}$ Ibidem, s. 18-21.

${ }^{278}$ J. Messo, The Aramean Identity..., s. 3.

${ }^{279}$ Por. R. Macuch, Tur Abdin Through the Ages, „Abr-Nahrain”, 29, 1991, s. 92; E. Lipiński, The Linguistic Geography of Syria in Iron Age II (c. 1000-600 B.C.), „Ancient Near Eastern Studies - Supplement 7”, 2000, s. 136, cyt. za: J. Messo, The Aramean Identity..., s. 7 . 
Asyryjczycy/Aramejczycy powinni więc uznać przede wszystkim spuściznę aramejską.

\subsubsection{Spory w łonie samej wspólnoty oraz nazewnictwo w krajach imigracji}

Akademickie polemiki nie pozostają bez wpływu na debatę toczącą się wśród samych zainteresowanych. Z kolei polityczne i ideologiczne argumenty Asyryjczyków i/lub Aramejczyków wpływają na niektórych naukowców, którzy chcąc nie chcąc stają się stronami w sporze. Co do jednego badacze zagadnień asyryjskich/aramejskich są zgodni - opisywaną przez nich wspólnotę należy odróżnić od sąsiednich ludów - Arabów, Kurdów, Persów czy Turków. Tymczasem asyryjsko-aramejscy uchodźcy, którzy do nowych ojczyzn przybyli z paszportami kraju urodzenia, często byli brani za tych ostatnich.

To spowodowało, że pojawiła się wśród nich dyskusja wokół nazwy, pod jaką chcieliby być znani w przyjmujących ich krajach. Młodzi narodowcy wzięli na siebie ciężar informowania rządów krajów europejskich, a także organizacji międzynarodowych o odrębnym pochodzeniu etnicznym swojej wspólnoty. Ostatnio zaczęli wywierać naciski, aby w polityce zagranicznej, szczególnie dotyczącej Turcji czy Iraku, uwzględniać asyryjskie/aramejskie interesy. Kwestia praw Asyryjczyków/Aramejczyków w tych dwóch krajach jest obecnie najbardziej paląca. Pomimo faktu, że aktywiści w ruchu narodowym stanowią relatywnie małą grupę ludzi, to jednak torują oni ścieżkę dla narodowej tożsamości w diasporze, bez względu na to, jaką nazwę wybierają: Asyryjczyków czy Aramejczyków.

Wielu ludzi, szczególnie tych związanych z Syryjskim Kościołem Ortodoksyjnym, próbuje odciągnąć swoje dzieci od ideologii asyryjskiej. Owa opozycja spowodowała wykrystalizowanie się odrębnej grupy, promującej tożsamość aramejską, która rywalizuje z grupą asyryjską ${ }^{280}$. Oba ruchy uważają, że to ich linie programowe najlepiej służą interesowi narodowemu, tymczasem różnice ideologiczne doprowadziły do widocznego podziału w życiu społecznym wspólnoty; wyznawcy ideologii asyryjskiej nie wchodzą w związki małżeńskie ze zwolennikami ideologii aramejskiej, nie chodzą nawet na przyjęcia organizowane przez drugą

${ }^{280}$ Przykładem takiej rywalizacji w mediach może być obrazek na jednej ze stron internetowych przedstawiający Einsteina, który stawia znak równości pomiędzy słowem „Syryjczycy” a „Aramejczycy”, cyt. za: N. Atto, op. cit. 
grupę (i vice versa). Oba ruchy utworzyły własne świeckie organizacje, zaprojektowały różne flagi, wreszcie zajęły się studiowaniem historii narodowej w celu jej reinterpretacji ${ }^{281}$.

Od lat 80. XX wieku spór pomiędzy zwolennikami asyrianizmu a poplecznikami arameizmu stał się bardzo widoczny. W świetle tej dysputy określenie „Asyryjczyk” zaczęło oznaczać stronnika asyrianizmu. Z tego względu niektóre oficjalne źródła zaczęły używać neutralnej terminologii, jak Asyryjczycy/Chaldejczycy/Syriacy (ang. Assyrian/Chaldean/Syriac) w amerykańskim spisie powszechnym ${ }^{282}$, czy Asyryjczycy/Syryjczycy (szw. Assyrier) Syrianer) w szwedzkim spisie powszechnym ${ }^{283}$. Zresztą uchodźcy z Tur Abdinu w Szwecji często wolą być określani rodzimym terminem Surjoje (Suryoye) ${ }^{284}$, a ostatnio także jako Aramejczycy (szw. Araméer). Z kolei imigranci z tego samego regionu mieszkający w krajach niemieckojęzycznych chcą być nazywani Asyryjczykami (niem. Assyrer) lub Aramejczykami (niem. Aramäer). Asyryjczykami (ang. Assyrians) nazywają się wyznawcy Asyryjskiego Kościoła Wschodu, którzy przybyli z gór Hakkari i znad jeziora Urmia w Iranie przez Irak do Wielkiej Brytanii. Z drugiej strony Aramejczycy w języku angielskim określają się jako Syriacy (ang. Syriacs), czasem szerzej jako Syriacy-Aramejczycy (ang. Syriac-Aramaean) lub Aramejczycy-Syriacy (ang. Aramaean-Syriac).

Jak pisałam wcześniej, wybór konkretnej nazwy jest wyborem ideologicznym - określenie „Asyryjczyk” oznacza przeważnie przyznanie się do starożytnych korzeni, termin „Aramejczyk” wskazuje raczej na poszukiwanie przodków wśród lewantyńskich Aramejczyków. Wybór przeze mnie

${ }^{281}$ Ibidem.

${ }^{282}$ Podczas spisu powszechnego w 2000 roku Cyril Aprim Karim i Clemis Eugene Kaplan, arcybiskupi Syryjskiego Kościoła Ortodoksyjnego, wydali deklarację, że wolą określenie „Syriacy” (ang. Syriacs). Dlatego oficjalny cenzus uwzględnił trójczłonową nazwę. Niektórzy Maronici także wzięli udział w tym spisie (w odróżnieniu od libańskich Amerykanów), cyt. za: Assyrian Heritage of the Syrian Orthodox Church, http://www.christiansofiraq.com/joseph/reply2.html, data wejścia 16.07.2009. Można więc uznać, że to diaspora amerykańska jest odpowiedzialna za upowszechnienie się terminu „Syriac”.

${ }^{283}$ Pierwotnie szwedzkie władze nazywały ich wyłącznie „Asyryjczykami”, co spowodowało protesty wielu, którzy woleli rodzime określenie Surjoje (dziś nazywa się ich „Syryjczykami" - szw. Syrianer), M. Berntsson, Assyrier eller syrianer? Om fotboll, identitet och kyrkohistoria, Gränser. Humanistdagboken, No. 16, 2003, s. 51.

${ }^{284}$ Nazwa ta zjednuje sobie coraz więcej zwolenników pośród elity szwedzkich Asyryjczyków/Aramejczyków, np. organizatorzy IV Sympozjum „Suryoye 1-Suryoye” (które odbyło się 3-5 października 2008 roku w Sztokholmie) zastrzegli, że „na określenie naszego ludu tylko nazwa Surjojole będzie uznawana”. 
złożonego terminu „Asyryjczycy/Aramejczycy” w przypadku opisywania całej wspólnoty spowodowany był chęcią oddania współczesnej samoidentyfikacji dwóch głównych grup, które przebadałam. W części empirycznej pracy nazywam Asyryjczykami tych, którzy się za nich uważają, a Aramejczykami (Surjoje) tych, którzy wolą taką klasyfikację. Nie widzę powodu, dla którego miałabym jednym lub drugim odmawiać nazw, jakie sami dla siebie wybrali. Natomiast w części historycznej nazywam ich zgodnie ze standardami przyjętymi w piśmiennictwie epoki: od przyjęcia chrześcijaństwa do przełomu XIX/XX wieku - Syryjczykami, później zaś Asyryjczykami (ewentualnie Asyro-chaldejczykami, jeśli ma to uzasadnienie np. w prawie danego państwa), dopiero w czasach najnowszych Asyryjczykami i/lub Aramejczykami bądź wspólnotą asyryjsko-aramejską.

\subsection{Język}

Starożytni Asyryjczycy posługiwali się językiem akadyjskim (zwanym też asyro-babilońskim), językiem wschodniosemickim zapisywanym pismem klinowym. Ok. 1000-800 roku p.n.e. przyjęli - używany pierwotnie przez Aramejczyków - język aramejski (północno-zachodniosemicki) wraz z alfabetem głoskowym na bazie fenickiego. Grecy nazywali język aramejski syryjskim; nazwa ta przyjęła się na zachodzie, natomiast na wschodzie przetrwała nazwa oryginalna - liszana aramajalliszono oromojo (język aramejski) ${ }^{285}$.

Rozwój języka aramejskiego można podzielić w przybliżeniu na pięć okresów:

- staroaramejski, 925-700 p.n.e.,

- urzędowy język imperium asyryjskiego (jednolity aramejski), 700-200 p.n.e.,

- średni aramejski, 200 p.n.e.-200 n.e.,

- późny aramejski, 200-700 n.e.,

- współczesny aramejski, od roku 700 do naszych czasów ${ }^{286}$.

Przez prawie tysiąc lat aramejski pełnił funkcję lingua franca na obszarze całej Mezopotamii jako język handlu, rzemiosła i komunikacji. Aramejski z wpływami akadyjskimi ${ }^{287}$ został ogłoszony językiem pomocniczym przez

${ }^{285}$ P. D. Younan, Jezzyk aramejski, http://www.szlomo.alleluja.pl/tekst.php?nume$\mathrm{r}=25938$, data wejścia 23.07.2009.

${ }^{286}$ Ibidem.

${ }^{287} \mathrm{O}$ akadyjskich wpływach pisał m.in. G. Khan, Remarks on the Historical Background of the Modern Assyrian Language, JAAS, Vol. 21, No. 1, 2007; idem, Neo-Aramaic Dialect Studies, Piscataway 2008, s. 10. 
króla Aszur-nirari V w 752 roku p.n.e. Około 500 roku p.n.e. Persowie, którzy poszukiwali języka zrozumiałego dla wszystkich mieszkańców ich rozległego imperium, wybrali aramejski. Pod koniec pierwszego tysiąclecia p.n.e. aramejski dominował niepodzielnie (hebrajski i sumeryjski były martwe, akadyjski konał, a greki i perskiego używały tylko elity); przestał być językiem powszechnym dopiero w okresie hellenistycznym, pod panowaniem Seleucydów ${ }^{288}$, zaś od VII wieku zaczął być wypierany przez język arabski.

Termin „nowoaramejski” lub „współczesny aramejski” wyklucza odmiany aramejskiego, które są używane jedynie jako literackie bądź święte (np. aramejski targumiczny, klasyczny syryjski, zwany edeskim lub ktubunojo, czy klasyczny mandejski). Niemniej jednak te klasyczne języki wywierają wpływ na potoczne dialekty nowoaramejskie; grupa języków nowoaramejskich nie jest bowiem jednolita - wyraźna linia podziału biegła zawsze pomiędzy odmianami wschodnimi (madenhojo) ${ }^{289}$ a zachodnimi (marbojo ${ }^{290}$, przecinając Pustynię Syryjską z południowego wschodu na północny zachód. Pomiędzy gałęzią wschodnią a zachodnią istnieje duże podobieństwo ${ }^{291}$, przy czym tę pierwszą reprezentuje szesnaście dialektów, zaś druga, w formie wymieszanej z wyrazami arabskimi i tureckimi, używana jest w trzech niewielkich miejscowościach leżących na północ od Damaszku (Maluli, Bacha i Dżubbadin) ${ }^{292}$.

Jeśli chodzi o pismo aramejskie, to manuskrypty chrześcijańskie we wschodnioaramejskim zostały napisane starożytną czcionką nazywaną estrangelo (okrągłe, grube litery) bez oznaczania samogłosek. Po V wieku powstały dwa nowe rodzaje pisma: na zachodzie przyjęto czcionkę serto

${ }^{288}$ P. D. Younan, op. cit.

${ }^{289}$ Odmiana wschodnioaramejska: madenhojo/madinchaja (tzn. „współczesna” lub „zachodnia”), zwana też swadaja („mówiona”). Ludzie posługujący się tą odmianą najczęściej nazywają ją: surit, suret, cyt. za: N. Awde, N. Lamassu, N. Al-Jeloo, op. cit., s. 4 i 36. Czasem (błędnie) określają ją jako aturojo, asyryjską lub neoasyryjska.

${ }^{290}$ Odmiana zachodnioaramejska: marbojo/máerbojo lub turojo (tzw. górska - z Tur Abdinu). Mówiący nią ludzie określają ją jako surajt, ibidem. Można też spotkać określenie surjojo.

${ }^{291}$ P. D. Younan, op. cit.

${ }^{292}$ Dzisiejsi mieszkańcy Maluli mówią w języku, którego daleki przodek już w czasach Chrystusa był odrębnym dialektem. Z kolei dialekt, którym prawdopodobnie posługiwał się Chrystus, bardzo szybko zanikł, podobnie jak inne dialekty palestyńskie, stąd mówienie o kontynuacji języka Chrystusowego jest dużym uproszczeniem, cyt. za: T. Mikołajczak, Jezzyk Chrystusa w Syrii?, http://www.polskieradio.pl/nauka/artykul.aspx?id=15679, data wejścia 23.07.2009. 
(w której połowa liter jest inna niż w estrangelo), stosującą pięć greckich liter na oznaczenie samogłosek (zapisywanych nad lub pod linią albo obok spółgłosek), a na wschodzie czcionkę nazywaną madinchaja lub swadaja, w której jedynie pięć z dwudziestu dwóch liter zostało zmodyfikowanych. Na oznaczenie siedmiu samogłosek wykorzystano akcenty podobne do żydowskiego systemu samogłosek, stosowanego w Tyberiadzie lub w Babilonie ${ }^{293}$. Ciekawostkę stanowi garszuni (ewentualnie karszuni) - zapis w alfabecie aramejskim języka arabskiego (rzadziej tureckiego) ${ }^{294}$.

Istotnym dziełem sporządzonym w języku syryjskim ( $w$ dialekcie edeskim) jest przekład Pisma Świętego, zwany Peszittą (syr. prosta, zwyczajna, powszechna), który przetrwał do dziś w licznych manuskryptach ${ }^{295}$. Tę rewizję tłumaczenia starosyryjskiego rozpoczęli Żydzi, tworząc „Pentateuch syryjski”, ale dopiero po przejęciu go przez chrześcijan praca została dokończona (ok. 400 roku). Peszitta obejmuje Stary oraz Nowy Testament z wyjątkiem 2 i 3 Listu Jana, Listu Judy i Apokalipsy (żadna z tych ksiąg nie wchodziła w skład wczesnego kanonu syryjskiego). Posługują się nią Kościoły chrześcijańskiego Wschodu, które używały i nadal używają języka aramejskiego ${ }^{296}$.

Język bywał używany jako argument na pochodzenie współczesnych Asyryjczyków od starożytnych. A. H. Layard napisał, że nestorianie mówią „językiem swoich przodków”; jak słusznie zauważa J. Joseph - była to obserwacja, którą musiał zasłyszeć od asyriologa Hormuzda Rassama ${ }^{297}$. W rzeczywistości niektórzy z napotkanych przez Layarda autochtonów mówili dwoma dialektami syryjskiego - klasycznym, prestiżowym dialektem edeskim (ktubunojo), przyjętym jako język Kościoła, choć nigdy nieużywanym przez większość, oraz innym dialektem syryjskim (aramejskim) ${ }^{298}$. Co interesujące, amerykańskie misje, które przybyły do nestorian Persji,

${ }^{293}$ P. D. Younan, op. cit.

${ }^{294}$ Zob. N. Awde, N. Lamassu, N. Al-Jeloo, op. cit., s. 33.

${ }^{295} \mathrm{Ok} .350$ rękopisów NT, niektóre z nich pochodzą z V wieku i zawierają prawie nieskażony tekst. Najstarszym odpisem Peszitty jest Kodeks Ambrosianus z VI/VII wieku, cyt. za: Multimedialny świat Biblii, http://www.swiatbiblii.com/msb_db.php?nomenu=\&n=c/ c1_133.ugz\&o=Crfmvggn, data wejścia 23.07.2009.

${ }^{296}$ P. D. Younan, op. cit.

${ }^{297}$ J. Joseph, The Nestorians..., s. 17.

${ }^{298}$ Ibidem, s. 72. Współcześnie żaden z cenionych syrologów nie uznaje ani klasycznego syryjskiego, ani pozostałych aramejskich dialektów za bezpośrednie odłamy starożytnego języka Asyryjczyków. 
stwierdziły, że nie było ani jednej całej kopii Biblii w tej drugiej odmia$n^{2} e^{299}$. Jedyne książki, jakie nestorianie posiadali w tej właśnie odmianie aramejskiego, były tłumaczeniami katolickiego katechizmu i modlitwami. Podobnie jak świecka literatura ich sąsiadów, ta Asyryjczyków składała się z ludowych pieśni, powiedzeń, historii, wierszy; do schyłku XIX wieku chrześcijańskie pieśni dotyczyły wyłącznie tematów biblijnych bądź religijnych. Aby zaśpiewać świecką pieśń, Asyryjczycy musieli używać tureckiego lub kurdyjskiego ${ }^{300}$.

Jednym z powodów braku literatury w ojczystym języku były różnice w dialektach - nie sposób było napisać książkę po aramejsku zrozumiałą dla wszystkich. Jedynym wystandaryzowanym językiem był klasyczny syryjski, znany przez kler, który prowadził w nim korespondencję; w rezultacie bardzo niewielu świeckich było w stanie zrozumieć lub czytać język pisany ${ }^{301}$.

Kiedy amerykańscy misjonarze rozpoczęli pracę translatorską, wybrali jako standard ludową mowę Urmii (wschodni dialekt nowoaramejski). W celu nauczenia „nowego syryjskiego” przygotowali gramatyki, podręczniki i słowniki. Zasięg ich literackich wysiłków był o wiele szerszy niż literatura religijna i obejmował wiele dzieł poświęconych historii, etyce, edukacji itp. Do końca XIX wieku współczesny syryjski był w powszechnym użyciu jako środek literacki w Urmii ${ }^{302}$, lecz nie w górach. Jako język literacki stał się jednak symbolem kulturowej wartości i został przyjęty jako pożądana forma mowy przez wykształconych Asyryjczyków ${ }^{303}$.

Obecnie aramejski używany jest wyłącznie w domach, choć wielu miejskich unitów jest dwujęzycznych i/lub woli arabski od aramejskiego. Asyryjczycy/Aramejczycy często władają także językiem bądź językami swoich sąsiadów: ormiańskim, perskim, tureckim czy kurdyjskim ${ }^{304}$, lub też językami krajów zachodnich, w których mieszkają. Są świadomi zagrożenia swego języka wymarciem, czemu starają się zapobiec.

Szkółki przykościelne w diasporze natrafiają jednak na poważny problem, jakim jest wybór odmiany języka, jakiego mają uczyć - często każdy

${ }^{299}$ Ibidem, s. 73 .

${ }^{300}$ Sytuacja zmieniła się w ciągu ostatnich kilkudziesięciu lat. Dziś bardzo wielu piosenkarzy asyryjskich/aramejskich odwołuje się w swych utworach do tematyki miłosnej.

${ }^{301} \mathrm{Ibidem}$, s. 74 . Obecnie powstaje literatura w dialektach nowoaramejskich, czego przykładem jest chociażby Mały książę A. de Saint-Exupéry’ego, przetłumaczony w 2005 roku na turojo i opatrzony łacińską transkrypcją.

${ }^{302}$ J. Joseph, op. cit., s. 75.

${ }^{303}$ Ibidem, s. 76.

${ }^{304}$ Por. ibidem, s. 18. 
ze studentów zna nieco inną odmianę aramejskiego (w Szwecji i Niemczech jest to przeważnie turojo - zachodni dialekt nowoaramejski ${ }^{305}$ ). Niektórzy zresztą mówią tylko po arabsku, co jeszcze bardziej utrudnia sytuację $e^{306}$. Z drugiej strony, święty język, używany w liturgii ktubunojo, wymagałby poważnych modyfikacj, zanim mógłby być nauczany jako język współczesny. Dodatkowym problemem jest motywacja do nauki języka przydatnego jedynie w Kościele, i to w obrębie niewielkiej wspólnoty ${ }^{307}$.

Ciekawym eksperymentem jest wypracowana przez lingwistów zlatynizowana forma zapisu turojo, która mimo oporu duchowieństwa i niektórych nacjonalistów, staje się coraz powszechniejsza w diasporze. Pojawia się w telewizji oraz w mediach elektronicznych, chętnie używają jej ludzie młodzi ${ }^{308}$.

\subsection{Religia}

Szerokie omówienie tego tematu znajdziemy w Historii Kościołów Wschodnich Aziza S. Atiyi ${ }^{309}$. Znakomita większość Asyryjczyków/Aramejczyków to chrześcijanie, przede wszystkim obrządków wschodnich, choć niewielki odsetek stanowią wyznawcy islamu ${ }^{310}$. Asyryjczycy/Aramejczycy jako jeden

${ }^{305} \mathrm{O}$ szansach przetrwania i rozwoju tego dialektu zob. więcej J. Saouk, „Quo Vadis Turoyo? A description of the situation and the needs of Turoyo (or New West-Aramaic)", Presentation Symposium Syriacum, Malta 2012, niepublikowany tekst referatu.

${ }^{306}$ Nie powinno to dziwić w świetle faktu, że na Bliskim Wschodzie od średniowiecza żyli chrześcijanie, których przodkowie zostali ochrzczeni przez misjonarzy z Syrii i Mezopotamii - były to starożytne plemiona z okolic Nadżranu oraz Ghassanidzi, później osiedleni na północy, którzy aramejskiego używali jedynie w liturgii, cyt. za: L. Dzięgiel, Archeology and Martyrology: Sources of the Integration of Assyrian Christian Communities in the Contemporary World, „Hemispheres”, No. 5, 1988, s. 36.

${ }^{307}$ Ibidem, s. 37.

${ }^{308}$ G. Çiyan, A Report on: Assyrians/Syrians, the Situation in Upper Mesopotamia, Zarathustra News, EuroKurd Human Rights-EHR, nr 11, Sztokholm, February 2009, http:// eurokurd.net/data/upimages/subfolders/PDF/assyrianssyrians.pdf, s. 2-3, data wejścia 11.08.2009.

${ }^{309}$ Zob. także: A. Flis, B. Kowalska, Zapomniani bracia. Ginacy świat chrześsijan Bliskiego Wschodu, Kraków 2003; N. Pigulewska, Kultura syryjska we wczesnym średniowieczu, Warszawa 1989; R. Roberson, The Eastern Christian Churches, Rome 1986, polskie tłumaczenie: Chrześcijańskie Kościoły Wschodnie, Kraków 2005; W. Witakowski, Geneza chrześcijańskiej kultury syryjskiej, „Studia Theologica Varsaviensia”, nr 1, 1978.

${ }^{310} \mathrm{O}$ muzułmańskich Asyryjczykach/Aramejczykach zwanych Mhalmoje zob. J. Joseph, The Nestorians..., s. 154; F. Parhad, Assyrian Muslims v. Assyrian Christians, Fred Parhad's Reflections on Assyria, „Zinda Magazine”, 6, No. 37, http://www.zindamagazine. $\mathrm{com} / \mathrm{html} /$ archives/2001/zn013001.html, data wejścia 27.07.2009; M. S. Megalomma- 
z pierwszych ludów nieżydowskich przyjęli chrześcijaństwo, choć z widocznymi wpływami judaizmu rabinicznego oraz kultury mezopotamskiej. Stało się to pomiędzy I a $\mathrm{V}$ wiekiem i było powiązane ze zniszczeniem śladów po pogańskich przodkach ${ }^{311}$. Do podboju muzułmańskiego w VII wieku grupa pozostawała podzielona pomiędzy dwa imperia - sasanidzką Persję na wschodzie i Rzym/Bizancjum na zachodzie. Główne ośrodki religijnokulturalne stanowiły - oprócz silnie zhellenizowaniej Antiochii ${ }^{312}$ - Edessa, Nisibis, Ktezyfont.

W historii chrześcijaństwa syryjskiego najważniejszą rolę odegrały dwa sobory: efeski z 431 roku oraz chalcedoński z 451 roku. Asyryjski Kościół Wschodu (do 1976 roku znany jako Kościół Wschodu) oderwał się na (lub przed - w ujęciu samych zainteresowanych) pierwszym z nich. Spór był nie tyle teologiczny, co polityczny; sobór efeski potępił jako heretyka Nestoriusza $^{313}$, ucznia Teodora z Mopsuestii - niezwykle cenionego przez wschodnich chrześcijan ${ }^{314}$. Przez wieki wyznawców obecnego Asyryjskiego Kościoła Wschodu nazywano nestorianami (mimo że oficjalnie wypierają się oni poglądów Nestoriusza) i prześladowano, w wyniku czego większość z nich zbiegła do Persji, tworząc tam słynną szkołę w Nisibis (wcześniej ich ośrod-

tis, Aram Nahrin: the Aramaeans, the Bible, Christianity, and the West, http://evigalivet. bloggspace.se/r12178/Arameer-Syrianer, data wejścia 12.03.2010. O asyryjskich muzułmanach z Tur Abdinu pisał Özman Denho, z którym przeprowadziłam wywiad w Szwecji 30 czerwca 2007 r. Mój rozmówca twierdził, że zapomnieli oni niemal o swoich korzeniach, jednak pod wpływem programów telewizyjnych, m.in. nakręconych przez niego, przypominają je sobie. Byłaby to więc rekonstrukcja tożsamości.

${ }^{311}$ G. V. Yana (Bebla), op. cit., okładka.

${ }^{312}$ Najprawdopodobniej to w Antiochii w I wieku wyznawcy Chrystusa po raz pierwszy nazwali się „chrześcijanami”, cyt. za: Nowy Testament, Dzieje 11:26 oraz przekazy historyków wczesnego Kościoła.

${ }^{313}$ Nestoriusz był patriarchą Konstantynopola w latach 428-431 i twórcą nestorianizmu - doktryny głoszącej, że Jezus Chrystus był zwykłym człowiekiem, w którym dopiero później zamieszkał Bóg, jak posąg w świątyni. Chrystus miał więc dwie odrębne natury - ludzką i boską. Maryja nie była Matką Boga (gr. Theotokos), a tylko Matką Chrystusa (gr. Christotokos). Po soborze w Efezie Nestoriusz został uwięziony, zesłany do Bostry w Arabii, a następnie do Egiptu, gdzie umarł w nędzy. Jego największym oponentem był Cyryl Aleksandryjski, który obawiał się, że nauczanie Nestoriusza może doprowadzić do postrzegania Jezusa jako posiadającego dwie odrębne osobowości. Jednak, jak zauważa T. Ware, te różne perspektywy mogły wynikać z różnic w środowiskach teologicznych pomiędzy bardziej semicką szkołą antiocheńską a zhellenizowaną szkołą aleksandryjską (The Orthodox Church, London 1963, s. 24-25).

${ }^{314}$ Zob. A. S. Atiya, op. cit., s. 216. Chrystologia Teodora z Mopsuestii, wraz z naukami Diodora z Tarsu i wykładnią Babaja Wielkiego, do dziś stanowi podstawę nauczania Asyryjskiego Kościoła Wschodu. 
kiem była szkoła edeska) $)^{315}$. W Mezopotamii nestorianie utworzyli prężną wspólnotę - w VII wieku ich misjonarze dotarli nawet do Chin ${ }^{316}$ (o czym świadczy słynna stela z Xi'an ${ }^{317}$ ) i Indii (zakładając Kościół malabarski). Śmiertelny cios zadały im dopiero wojska Tamerlana, kładąc kres misyjnej ekspansji.

W 1553 roku w Kościele nestoriańskim doszło do rozłamu, gdy w wyniku przyjęcia unii z Rzymem przez patriarchę i niektórych biskupów powstał unicki Kościół Chaldejski. W XVII wieku część wiernych tego Kościoła, łącznie z patriarchą, powróciła do Kościoła nestoriańskiego z powodu sporu z Rzymem dotyczącego celibatu księży, jednak kolejny podział chrześcijan stał się faktem. W tym samym okresie wypowiedziała posłuszeństwo patriarsze nestoriańskiemu większość wiernych i duchownych Kościoła malabarskiego w Indiach.

Druga gałąź chrześcijaństwa syryjskiego oderwała się po soborze chalcedońskim w 451 roku. Wyznawcy Syryjskiego Kościoła Ortodoksyjnego, uważający się za spadkobierców Patriarchatu Antiochii, zostali okrzyknięci przez przeciwników jakobitami ${ }^{318}$ lub monofizytami ${ }^{319}$, chociaż sami zainteresowani odrzucają te nazwy, opowiadając się za mniej radykalnym miafizytyzmem. Część z nich weszła w unię z Kościołem rzymskokatolickim, tworząc Syryjski Kościół Katolicki. Z Kościołem jakobickim związany jest także jeden z odłamów chrześcijaństwa indyjskiego - Syro-Malankarski Jakobicki Kościół Ortodoksyjny. Od początku swego istnienia uznawał on

${ }^{315}$ Szkołę edeską ostatecznie zamknięto jako „heretycką” w 489 roku z rozkazu cesarza Zeno, cyt. za: W. S. McCullough, A Short History of Syriac Christianity to the Rise of Islam, Chico 1982, s. 127-128.

${ }^{316}$ Więcej o działalności misyjnej chrześcijan nestoriańskich w Chinach zob. L. Tang, East Syriac Christianity in Mongol-Yuan China, Orientalia Biblica et Christiana 18, Wiesbaden 2011.

${ }^{317}$ Jest to obelisk pochodzący z dynastii Tang, wzniesiony w 781 roku, pokryty inskrypcjami w językach chińskim i syryjskim, które wymieniają imiona stu dwudziestu ośmiu osób, m.in. kapłanów, i metropolitę o imieniu Adam, cyt. za: A. S. Atiya, op. cit., s. 226.

${ }^{318}$ Nazwa „jakobicki” pochodzi od Jakuba Baradeusza (aram. Burd'ono - „w łachmanach”), który wędrując po Syrii w przebraniu żebraka konsekrował w V wieku kilkudziesięciu biskupów i setki księży, tworząc tym samym organizację Kościoła.

${ }^{319}$ Monofizytyzm - kierunek w teologii chrześcijańskiej przyjmujący, że w Chrystusie jest tylko jedna natura boska, a ludzka natura zaraz po wcieleniu została wchłonięta przez boską. Pogląd ten został sformułowany przez mnicha z Konstantynopola, Eutychesa. Sobór chalcedoński w 451 roku odrzucił monofizytyzm, przyjmując diofizytzm, a więc wiarę w dwoistość natury Chrystusa - boską i ludzką, zjednoczoną w jednej osobie Jezusa Chrystusa (unia osobowa, hipostatyczna). 
zwierzchnictwo patriarchy jakobickiego, a w XVI wieku wszedł w unię z Rzymem, którą już w XVII wieku część wiernych porzuciła, powracając pod dawne zwierzchnictwo. Kościół Syro-Malankarski bywa uważany za część Kościoła jakobickiego, jakkolwiek związek obu tych odłamów z racji odległości jest raczej sprawą tradycji - oba Kościoły uważają się za założone przez świętego Tomasza Apostoła.

W latach 80. i 90. XX wieku miało miejsce podpisanie dwóch istotnych deklaracji chrystologicznych, mianowicie między Rzymem i Syryjskim Kościołem Ortodoksyjnym w 1984 roku (sygnowali Jan Paweł II i patriarcha Ignatius Zakka I Iwas) oraz między Rzymem i Asyryjskim Kościołem Wschodu w 1994 roku (sygnowali Jan Paweł II i patriarcha Mar Dinkha IV). Deklaracje te są ocenianie jako krok w kierunku interkomunii. W 1996 roku Mar Dinkha IV podpisał porozumienie o współpracy z chaldejskim patriarchą Bagdadu Raphaelem I Bidawidem. W 1997 roku rozpoczął rozmowy z Syryjskim Kościołem Ortodoksyjnym, w wyniku których oba Kościoły wycofały wzajemne ekskomuniki. [Il. 1]

$\mathrm{Na}$ skutek działalności brytyjskich i amerykańskich misjonarzy na początku XX wieku niewielka grupa Asyryjczyków należy do Kościołów protestanckich i dziś jest zorganizowana m.in. w Asyryjski Kościół Ewangeliczny czy Asyryjski Kościół Zielonoświątkowców. W czasach współczesnych różne protestanckie wyznania rozpoczęły na nowo wysyłanie swoich przedstawicieli do chrześcijan syryjskich, przyciągając ich do swoich wspólnot. Takie odłamy nie są jednak tradycyjnie zaliczane do „chrześcijaństwa syryjskiego".

Współcześni Asyryjczycy/Aramejczycy należą do następujących odłamów:

- obrządek zachodniosyryjski (zwany kiedyś błędnie jakobickim): ○ Syryjski Kościół Ortodoksyjny (niechalcedoński orientalny Kościół ortodoksyjny Antiochii i całego Wschodu) ${ }^{320}$;

- Malankarski Jakobicki Syryjski (Syriacki) Kościół Ortodoksyjny (niechalcedoński orientalny Kościół ortodoksyjny Indii, podlegający Syryjskiemu Ortodoksyjnemu Patriarchatowi),

○ Syro-Malankarski Kościół Ortodoksyjny (autokefaliczny, niechalcedoński orientalny Kościół ortodoksyjny Indii),

○ Syryjski Kościół Katolicki (zachodniosyryjski ryt wschodniego Kościoła katolickiego),

${ }^{320}$ Obecnym patriarchą Syryjskiego Kościoła Ortodoksyjnego jest Ignatius Zakka I Iwas, który ma swoją siedzibę w Damaszku, cyt. za: His Holiness Moran Mor Ignatius Zakka Iwas I, http://stmaryslynbrook.org/?page_id=37, data wejścia 3.08.2009. 
○ Kościół Maronicki (zachodniosyryjski ryt wschodniego Kościoła katolickiego),

○ Syro-Malankarski Kościół Katolicki (zachodniosyryjski ryt wschodniego Kościoła katolickiego z siedzibą w Kerali w Indiach),

○ Syro-Malankarski Kościół Mar Tuma/Kościół św. Tomasza (reformowany Kościół w unii z anglikańskim Kościołem z siedzibą w Kerali w Indiach);

- obrządek wschodniosyryjski (zwany kiedyś błędnie nestoriańskim):

○ Asyryjski Kościół Wschodu oraz Starożytny Kościół Wschodu (Wschodni Syryjczycy lub Asyryjczycy) ${ }^{321}$,

○ Syro-Malabarski Kościół Katolicki (wschodniosyryjski ryt wschodniego Kościoła katolickiego z siedzibą w Kerali w Indiach),

○ Chaldejski Kościół Katolicki (wschodniosyryjski ryt wschodniego Kościoła katolickiego: Chaldejczycy lub Asyro-chaldejczycy) ${ }^{322}$.

${ }^{321} \mathrm{Na}$ czele Asyryjskiego Kościoła Wschodu stoi patriarcha Mar Dinkha IV, rezydujący w Chicago, zaś Starożytnemu Kościołowi Wschodu przewodzi patriarcha Mar Addaj II, którego siedziba mieści się w Bagdadzie, ibidem.

${ }^{322}$ Mar Emmanuel III Delly jest patriarchą Chaldejskiego Kościoła Katolickiego, a jednocześnie pierwszym patriarchą będącym równocześnie kardynałem. Jego siedziba mieści się w Bagdadzie, ibidem. 


\section{Rozdział 2 \\ Asyryjczycy/Aramejczycy na Bliskim Wschodzie. Zarys historyczny i współczesność}

Proces ewolucji tożsamości asyryjsko-aramejskiej przedstawiony zostanie w kontekście historycznym, ponieważ rozważanie i przeformułowywanie przez Asyryjczyków/Aramejczyków swojej samoświadomości wspólnotowej wynikało w dużej mierze z presji wywieranych na nich na przestrzeni dziejów przez sąsiadów, lokalne rządy czy obce siły. Fakt, że różne władze prowadziły wobec Asyryjczyków/Aramejczyków politykę tłumienia, eksterminacji bądź koegzystencji, wskazuje na to, iż stanowili oni cele określonych działań ze strony większości. Z drugiej strony nie byli jedynie biernymi odbiorcami zewnętrznych wpływów, lecz również świadomymi autorami zmian. Innymi słowy, historia Asyryjczyków/Aramejczyków powinna być postrzegana jako wzajemne interakcje wspólnoty asyryjsko-aramejskiej z tymi grupami, które ją otaczały ${ }^{1}$.

\subsection{Początki}

Położenie geopolityczne w istotny sposób wpłynęło na ukształtowanie się współczesnej tożsamości asyryjsko-aramejskiej. Na początku XIX wieku Asyryjczycy/Aramejczycy zamieszkiwali obszary Tur Abdinu, Van, Siirt, Hakkari (w dzisiejszej południowo-wschodniej Turcji), Salmas i Urmii w perskim Azerbejdżanie (w północno-zachodnim Iranie) oraz część południowego Kurdystanu, włącznie z równiną na północ od Mosulu². Naj-

${ }^{1}$ Por. A. I. Laing-Marshall, op. cit., s. 6.

${ }^{2}$ J. Joseph, The Nestorians..., s. 23. Wymienione tereny zajmują powierzchnię o wiele większą niż „pierwotna Asyria, która była bardzo niewielkim krajem. Nie większym od (...) Walii czy Palestyny. Z grubsza zajmowała tereny wzdłuż środkowego Tygrysu. Jej północny kraniec sięgał Mosulu”, cyt. za: H. Saggs, The Might That Was Assyria, London 1984, s. 2. 
wyższym wzniesieniem ich rdzennych ziem była góra Dżilu (obecnie Cilo Dağı) o wysokości 4168 m n.p.m. ${ }^{3}$

Region ten był zaludniony od niepamiętnych czasów - stąd jego określenie jako „kolebki cywilizacji”. Trudno określić dokładną chronologię przyjmowania chrześcijaństwa przez zamieszkałych te ziemie Syryjczyków z powodu braku danych historycznych ${ }^{4}$. Legendarne przekazy mówią o korespondencji pomiędzy królem Abgarem Czarnym z Osroene (Edessy) i Chrystusem ${ }^{5}$. W jej wyniku oraz w rezultacie wizyty św. Tadeusza Apostoła (utożsamianego z Judą Tadeuszem - jednym z siedemdziesięciu dwóch uczniów Jezusa) władca miał się nawrócić, zaś chrześcijaństwo miało stać się oficjalną religią jego państwa, a wkrótce także okolicznych królestw ${ }^{6}$. Inne legendy mówią o św. Tomaszu ${ }^{7}$, który w drodze do Indii zatrzymał się nad jeziorem Urmia i ochrzcił niektórych spośród tamtejszych mieszkańców ${ }^{8}$. Jeszcze inny przekaz wspomina Bartłomieja i Addeusza (Tadeusza) i utrzymuje, że św. Mari, konwertyta pochodzący ze szlachetnego perskiego rodu, zastąpił tego ostatniego wśród perskich chrześcijan. Najbardziej romantyczna legenda przypisuje pochodzenie Syryjczyków mędrcom ze Wschodu, którzy podążali za gwiazdą do Betlejem?

Choć początki historii Syryjczyków niknąw pomroce dziejów, pewne jest, że na przełomie II/III wieku chrześcijanie zamieszkiwali tereny na wschód od Antiochii ${ }^{10}$. Niektórzy autorzy sugerują, że chrześcijańscy misjonarze

${ }^{3}$ N. Awde, N. Lamassu, N. Al-Jeloo, op. cit., s. 5.

${ }^{4}$ A. I. Laing-Marshall, op. cit., s. 17.

${ }^{5}$ Abgar (lub Agbar) V miał cierpieć na trąd. Zwrócił się do Jezusa, jako sławnego uzdrowiciela, z prośbą o nawiedzenie jego królestwa. Chrystus odpowiedział, że nie może tego uczynić, gdyż ma zadanie do wykonania, lecz przyśle swych uczniów. Obietnicę wypełnił Addaj (Tadeusz), uczeń Tomasza, który ofiarował królowi Mandylion (tkaninę $\mathrm{z}$ wizerunkiem Jezusa), po czym ochrzcił go wraz z poddanymi. Przed śmiercią Tadeusz wyznaczył swego następcę, ustanawiając tradycję apostolskiej sukcesji, zob. A. S. Atiya, op. cit., s. 211-212. Rozbudowaną wersję legendy zawiera kontrowersyjna Doktryna Addaja. Pierwszy raz zrelacjonował ją w IV wieku Euzebiusz z Cezarei, następnie historię powtórzył Efrem Syryjczyk.

${ }^{6}$ N. Awde, N. Lamassu, N. Al-Jeloo, op. cit., s. 6.

${ }^{7}$ Zob. apokryficzne Dzieje św. Tomasza, przypisywane edeskiemu autorowi Bardesanesowi (154-222).

${ }^{8}$ R. Le Coz, Historie de L'Église d'Orient: Chrétiens d'Irak, d'Iran et de Turquie, Paris 1995 , s. 21.

9 J. Joseph, The Nestorians..., s. 24. Pierwszym bez wątpienia chrześcijańskim królem Edessy był Abgar IX (179-214).

${ }^{10}$ Źródła potwierdzające ten fakt to m.in.: 1) epitafium biskupa Hieropolis (we Frygii), który podróżował pod koniec II stulecia do Syrii i północnej Mezopotamii, 2) Kronika Edessy, która podaje, że powódź zniszczyła chrześcijański kościół w 201 roku, 3) opowieść Euzebiusza o kontrowersjach wokół obchodów Wielkanocy z drugiej połowy II wieku. 
zamierzali pierwotnie nawrócić wspólnoty żydowskie na Wschodzie ${ }^{11}$, jednak wydaje się, iż to głównie syryjska oraz perska ludność odpowiedziała na ewangelizację ${ }^{12}$.

Pół tysiąclecia panowania Partów zakończyli w 224 roku Sasanidzi, generalnie tolerancyjni wobec swych chrześcijańskich poddanych, choć sporadycznie dopuszczający się prześladowań, podczas których Syryjczycy nie mogli liczyć na wsparcie Rzymian, widzących w nich sektę żydowską ${ }^{13}$. Zresztą do czasu wydania przez Konstantyna Wielkiego edyktu mediolańskiego w 313 roku chrześcijanie podlegali falom represji również ze strony Rzymu $^{14}$. W latach 330-379 sasanidzki władca Szapur II próbował narzucić swym poddanym zaratusztrianizm jako religię państwową ${ }^{15}$; zginęło wtedy trzech katolikosów ${ }^{16}$, wielu księży oraz ponad 16 tys. świeckich ${ }^{17}$.

Podejrzliwość względem Syryjczyków - jako potencjalnych konspiratorów - nasiliła się po ogłoszeniu przez Teodozjusza chrześcijaństwa oficjalną religią imperium rzymskiego. Chrześcijanie w Persji, chcąc umocnić swoją osłabioną pozycję, odcięli się od współwyznawców na zachodzie na płaszczyźnie hierarchii i doktryny. W 424 roku synod w Markabacie ogłosił katolikosa Seleucji-Ktezyfontu najwyższym autorytetem kościelnym ${ }^{18}$, zaś w 498 roku Kościół w Persji oderwał się ostatecznie - katolikos Babaj II przyjął bowiem tytuł patriarchy Wschodu, odrzucając wszelką zwierzchność Antiochii i Rzymu ${ }^{19}$.

Dystans pogłębiał fakt, że Kościół Wschodu zbliżył się do doktryny nestoriańskiej, a wielu prześladowanych na zachodzie zwolenników Nestoriu-

W. Hage zapewnia, że chrześcijaństwo przyjęło się wśród Syryjczyków już w pierwszej połowie II wieku, choć przyznaje, iż swoją opinię opiera na kwestionowanej Kronice Arbeli (Syriac Christianity in the East, Kottayam 1988, s. 2), cyt. za: A. I. Laing-Marshall, op. cit., s. 18.

${ }^{11}$ Por. R. Le Coz, op. cit., s. 22.

${ }^{12}$ Ibidem, s. 23; Ch. M. Drennon, „(Re)Inventing Macedonia: The Passage from Religious to Territorial Identity”, dysertacja obroniona na University of Texas, Austin 1998, s. 179, cyt. za: A. I. Laing-Marshall, op. cit., s. 18.

${ }^{13}$ W. S. McCullough, op. cit., s. 10-11, 18.

${ }^{14}$ Ibidem, s. 38.

${ }^{15}$ Władca działał z poduszczenia zaratusztriańskiego kleru, ibidem, s. 102-103.

${ }^{16}$ Katolikos (gr. katholikós - „powszechny”) to tytuł patriarchów Kościołów związanych historycznie z patriarchatem antiocheńskim poza Cesarstwem Rzymskim, m.in. nestoriańskiego, jakobickiego i syro-malabarskiego. Oznaczał pierwotnie hierarchę sprawującego władzę nad częścią Kościoła powszechnego. Obecnie bywa zwykle rozumiany jako tytuł zwierzchnika danego Kościoła i traktowany jest jako nadrzędny wobec tytułu patriarchy.

${ }^{17}$ N. Awde, N. Lamassu, N. Al-Jeloo, op. cit., s. 7.

${ }^{18}$ M. Moberg, The Patriarchal See of Antioch and Seleucia/Ktesiphon: Pattern of a Development that Frightens and Inspires Today, „The Harp 5”, No. 1-3, lipiec 1992, s. 106, cyt. za: A. I. Laing-Marshall, op. cit., s. 24.

${ }^{19}$ A. S. Atiya, op. cit., s. 219. 
sza znalazło schronienie pośród chrześcijan Persji. To właśnie teologiczny wybór, a nie kultura czy język ${ }^{20}$, stał się podstawą identyfikacji wyznawców Kościoła Wschodu. Ten ostatni stanowił tygiel różnych ludów: syryjskoi greckojęzycznych chrześcijan z imperium rzymskiego, którzy trafili do państwa Sasanidów jako jeńcy ${ }^{21}$, etnicznych Persów, Aramejczyków, Arabów itp. - wszyscy oni „zapomnieli” swe przedchrześcijańskie tożsamości do tego stopnia, że badacze nie są w stanie określić proporcji poszczególnych grup etnicznych ${ }^{22}$.

Podobnie teologiczny wybór (za monofizytyzmem lub raczej miafizytyzmem) stał się podstawą tożsamości zachodnich Syryjczyków. Duchowa i religijna tożsamość wczesnych Syryjczyków, będąca uniwersalną tożsamością chrześcijańską, widoczna jest $\mathrm{w}$ ich pismach, które przedstawiają wspólnotę jako „Nowy Lud” bądź „Naród”, zbiór członków różnych ludów i „narodów”23. Sasanidzi widzieli jednak w nestorianach i jakobitach wspólnoty kompetentne, by rozstrzygać sprawy nie tylko religijne, ale też świeckie czy polityczne. Gdy armie perskie okupowały Edessę, chrześcijanom dano wybór - mieli stać się nestorianami albo jakobitami (ponieważ ci nie mieli żadnych powiązań z zewnętrznymi potęgami) lub też zostać zabici $^{24}$. W ten sposób wydarzenia polityczne wpłynęły na kształtowanie się tożsamości syryjskiej.

\subsection{Pod panowaniem arabskim}

Bezpośrednio po podboju arabskim w VII wieku sytuacja chrześcijan obrządków wschodnich, którzy dobrze przyjęli zwycięzców ${ }^{25}$, nie zmieniła

${ }^{20}$ S. Brock zauważa, że choć syryjski był głównym językiem liturgii, to inne języki były ciągle używane, a nowe przyswajane (czasem nawet do celów kościelnych) przez syryjskich chrześcijan w odpowiedzi na wymagania otoczenia, cyt. za: idem, Christians in the Sasanian Empire: A Case of Divided Loyalties, „Syriac Perspectives on Late Antiquity”, IV, London 1984, s. 17-18.

${ }^{21}$ W. S. McCullough, op. cit., s. 113.

${ }^{22}$ H. Hill, The Assyrians: The Church of the East [w:] H. Hill (red.), Light From the East: A Symposium on the Oriental Orthodox and Assyrian Churches, Toronto 1988, s. 103, cyt. za: A. I. Laing-Marshall, op. cit., s. 25.

${ }^{23}$ S. Brock, Christians in the Sasanian..., s. 12; R. Murray, Symbols of Church and Kingdom: A Study in Early Syriac Tradition, London 1975, s. 41; S. J. Beggiani, Early Syriac Theology: With Special Reference to the Maronite Tradition, Lanham 1983, s. 79-80.

${ }^{24}$ J. Joseph, The Nestorians..., s. 25.

${ }_{25}$ Patriarcha Jeszujab III (zm. 659) pisał, iż „to Bóg dał Arabom zwycięstwo” oraz że „są oni powiernikami naszej wiary”. Odrzucał zarzuty, że Arabowie chcą nawracać chrześcijan; konwersje na islam według niego powodowała słabość chrześcijańskiego kleru, cyt. za: 
się na gorsze. Nadano im, co prawda, status zimmi (mniejszości chronionej) i zmuszono do płacenia podatku pogłównego - dżizji, co spowodowało konwersję na islam części syryjskich chrześcijan ${ }^{26}$. Ci jednak, którzy schronili się w górach, zachowali dużą autonomię ${ }^{27}$. Poza tym Syryjczycy, górujący nad Arabami pod względem kulturalnym, byli zasadniczo dobrze traktowani, niejednokrotnie powierzano im ważne urzędy. Wyłanianie się muzułmańskiej większości było procesem powolnym, rozciągniętym na przestrzeni blisko trzech stuleci.

Szczególnie tolerancyjnie podchodzono do nestorian, których legendy opowiadają o ustanowieniu uprzywilejowanych stosunków przez Jeszujaba II z prorokiem Muhammadem - miał on dać patriarsze dokument gwarantujący wschodnim Syryjczykom określone przywileje, potwierdzone później przez kalifów Umara i Alego ${ }^{28}$. Faktem jest, że Kościół Wschodu zachował wszystkie prawa i przywileje, którymi cieszył się za Sasanidów ${ }^{29}$.

Patriarcha nestoriański był najważniejszym chrześcijańskim dostojnikiem pod rządami Abbasydów ${ }^{30}$, zaś Nisibis, Dżundiszapur i Merw rozkwitły jako centra syryjskiej kultury; w tamtejszych szkołach uczono teologii, filozofii, historii, medycyny i nauk ścisłych. Starożytne pisma greckie tłumaczono na syryjski, a później na arabski ${ }^{31}$. Syryjczycy byli szanowani za pracę tłumaczy ${ }^{32}$, pisarzy oraz medyków na dworach kolejnych kalifów ${ }^{33}$.

S. Brock, Syriac Views of Emergent Islam [w:] G. Juynboll (red.), Studies on the First Century of Islamic Society, Carbondale 1982, s. 15. Z kolei patriarcha Tymoteusz I (780-823) zanotował, że „dziś Arabowie są w wielkim poważaniu u Boga i ludzi, gdyż wypierają się bałwochwalstwa i politeizmu, a czczą i wielbią Boga Jedynego", cyt. za: ibidem, s. 16. Takie stwierdzenie wskazywałoby, że na początku syryjscy chrześcijanie nie postrzegali nowych władców jako wyznawców odmiennej wiary.

${ }^{26}$ Warto tu jednak przytoczyć opinię Daniela C. Dennetta, który odkrył, że podatki nałożone przez muzułmanów na zimmi były jedynie niewiele wyższe od tych płaconych poprzednim władcom (Bizantyńczykom bądź Sasanidom). Mogły one skłaniać do konwersji w takim sensie, że obejmowały klasy wcześniej wyłączone z opłat, mianowicie arystokrację i kler, cyt. za: Conversion and the Poll Tax in Early Islam, Cambridge 1950.

${ }^{27}$ N. Awde, N. Lamassu, N. Al-Jeloo, op. cit., s. 8.

${ }^{28}$ A. S. Atiya, op. cit., s. 231.

${ }^{29}$ Ibidem, s. 230; S. Brock, Christians in the Sasanian..., s. 12.

${ }^{30} \mathrm{~J}$. Joseph, The Nestorians..., s. 26.

${ }^{31}$ To m.in. dzięki nim możliwy był renesans w Europie. Por. N. Awde, N. Lamassu, N. Al-Jeloo, op. cit., s. 8; W. S. McCullough, op. cit., s. 182.

${ }^{32}$ Najsłynniejszym tłumaczem był Hunajn Ibn Ishak (809-873), chrześcijanin obrządku wschodniosyryjskiego, który stał na czele słynnego Bajt al-Hikma (tj. Domu Mądrości, uczelni obejmującej także instytut zrzeszający tłumaczy) w Bagdadzie. Hunajn przetłumaczył około stu dziel, cyt. za: A. S. Atiya, op. cit., s. 232.

${ }^{33}$ Ibidem, s. 270-271; W. S. McCullough, op. cit., s. 182; R. Le Coz, op. cit., s. 157. 
Gdy w VII wieku nestoriański patriarcha przeniósł się z Seleucji-Ktezyfontu do Bagdadu, był ważną figurą polityczną - oprócz własnego ludu reprezentował również Greków, jakobitów i melkitów na ziemiach muzułmańskich $^{34}$. W takich warunkach, między VIII a X wiekiem, Kościoły syryjskie przeżywały swój największy rozkwit.

Świadectwem żywotności Kościoła Wschodu były jego misje wysyłane do Chin, Tybetu, Indii i Mongolii ${ }^{35}$; do 1318 roku wschodni Syryjczycy posiadali około trzydziestu biskupstw i dwustu diecezji od Egiptu i Cypru na zachodzie po Japonię i Indonezję na wschodzie. Z kolei Syryjski Kościół Ortodoksyjny miał dwadzieścia biskupstw i sto trzy diecezje, m.in. w Afganistanie, Turkiestanie czy Xinjiangu w Chinach. Szacuje się, że łączna liczba członków tych Kościołów wynosiła w opisywanym okresie $80 \mathrm{mln}$ (czyli więcej niż wyznawców Kościołów na zachodzie $)^{36}$.

Stopniowo jednak nestorianie, wraz z innymi chrześcijanami na Bliskim Wschodzie, tracili swoją silną pozycję. Hananjeszu II (744-749) przeniósł siedzibę patriarszą do Bagdadu - nowej stolicy kalifatu, co było znakiem zwiększającego się wpływu państwa na Kościół; wkrótce kalifowie wyznaczyli sobie rolę arbitrów w sporach kościelnych i decydentów w sprawach hierarchii. Z drugiej strony, patriarchowie zaczęli być wysyłani jako ambasadorzy kalifów na dwór bizantyński, co spowodowało ich przemianę w „świeckich urzędników”, czasem dopuszczających się nawet korupcji, by zdobyć wymarzone stanowisko ${ }^{37}$. Niższy kler, odrzucany przy nominacjach lub niedostatecznie opłacany, często przechodził na islam ${ }^{38}$. Co gorsza, stosunki między Syryjczykami wschodnimi i zachodnimi były pełne wzajemnych oskarżeń i sporów, a to pogłębiało wizerunek wspólnoty jako niepotrafiącej zadbać o samą siebie ${ }^{39}$.

Około IX wieku muzułmański charakter imperium zaczął być akcentowany, co zaowocowało marginalizacją niemuzułmanów ${ }^{40}$. Okresy prześla-

${ }^{34}$ R. Le Coz podaje, że Tymoteusz I, patriarcha Kościoła Wschodu, był głową wszystkich chrześcijan za panowania Abbasydów.

35 W Indiach wspólnota chrześcijańska założona przez Syryjczyków istniała już w IV wieku, cyt. za: A. S. Atiya, op. cit., s. 308.

${ }^{36}$ N. Awde, N. Lamassu, N. Al-Jeloo, op. cit., s. 9.

${ }^{37}$ A. S. Atiya, op. cit., s. 233-234.

${ }^{38}$ N. Levtzion, Conversion to Islam in Syria and Palestine and the Survival of Christian Communities [w:] M. Gervers, R. Bikhazi (red.), Conversion and Continuity: Indigenous Christian Communities in Islamic Lands, Eighth to Eighteenth Centuries, Toronto 1990, s. 304.

${ }^{39}$ R. Le Coz, op. cit., s. 208.

${ }^{40} \mathrm{~W}$ IX i X wieku proporcje muzułmanów w stosunku do chrześcijan zmieniły się - od tego czasu muzułmanie stanowili większość, A. I. Laing-Marshall, op. cit., s. 31. 
dowań miały miejsce już za Umara II (717-720) i później za Al-Mutawakkila (847-861). Dodatkowo krzyżowcy pozostawili spuściznę nienawiści wobec chrześcijan wschodnich, którzy mieli nadzieję, że upadek kalifatu abbasydzkiego odmieni ich życie na lepsze ${ }^{41}$. Mongolski władca, Hulaguchan, oszczędził chrześcijan, gdy w 1258 roku podbił Bagdad, gdyż jego ulubiona żona, Dokuz-chatun, była chrześcijanką (niektórzy mongolscy urzędnicy również byli chrześcijanami, zaś chrześcijanie mongolskiego pochodzenia byli wyświęcani jako przedstawiciele Kościoła nestoriańskiego). Z mongolskiego ludu pochodził jednak także Tamerlan, który w XIV wieku zadał Syryjczykom najstraszniejszy cios - zostali oni niemal do szczętu wybici, ich kościoły i klasztory zburzono. Ci, którzy przeżyli, schronili się w bezpiecznych górach Hakkari ${ }^{42}$, by w następnych stuleciach zasiedlić równiny wokół jeziora Urmia oraz region Mosulu ${ }^{43}$. W XIV wieku dynastia Ming wyparła Mongołów z Chin i rozpoczęła politykę oczyszczania kraju z wpływów cudzoziemskich, m.in. chrześcijańskich ${ }^{44}$. Rozpoczął się stopniowy upadek Syryjczyków ${ }^{45}$. Nic wartego zanotowania, oprócz kościelnych schizm, nie wydarzyło się przez następne cztery stulecia ${ }^{46}$.

Kontrowersje dotyczyły dostępu do najwyższego urzędu w kościelnej hierarchii. W 1450 roku patriarcha nestoriański wprowadził nowe prawo, zastrzegając najwyższy urząd kościelny tylko dla członków swojej rodziny. Ponieważ dostojnik żył w celibacie, urząd zwykle przechodził z wuja na bratanka bądź siostrzeńca ${ }^{47}$, często osobę nieposiadającą odpowiednich predyspozycji ani kwalifikacji, chociażby z powodu zbyt młodego wieku w momencie elekcji. Dziedziczenie urzędu było sprzeczne z kanonami Kościoła (żaden biskup nie powinien mianować swego następcy), ponadto zmieniało go ze wspólnoty społeczno-religijnej we wspólnotę społeczno-polityczną; spór nad tą kwestią doprowadził do schizmy wiek później ${ }^{48}$.

${ }^{41}$ J. Joseph, The Nestorians..., s. 28.

${ }^{42}$ A. S. Atiya, op. cit., s. 237-238. Ostatnie wzmianki o wspólnotach, które nie schroniły się w górach, pochodzą z XVI wieku - zanotowano, że w 1551 roku Asyryjczycy żyli w Tabrizie, w 1553 roku w Bagdadzie, w 1556 roku w Nisibis, ibidem, s. 277.

${ }^{43}$ A. I. Laing-Marshall, op. cit., s. 32.

${ }^{44}$ Kiedy misjonarze jezuiccy przybyli do Chin w XVI wieku, nie znaleźli śladu syryjskich misji, W. Hage, op. cit., s. 20.

${ }^{45}$ N. Awde, N. Lamassu, N. Al-Jeloo, op. cit., s. 9.

${ }^{46}$ J. Joseph, The Nestorians..., s. 29.

${ }_{47}$ Zrodził się również zwyczaj, że od chwili swego poczęcia kandydat na przyszłego patriarchę miał zabronione spożywanie mięsa (dotyczyło to więc również jego matki), M. Kropidłowski, Kościót Asyryjski (Asyriacki), http://www.magazyn.ekumenizm.pl/article.php?story=20040226132441981, data wejścia 1.08.2009.

${ }^{48}$ Por. A. S. Atiya, op. cit., s. 239-240. 
Gdy w 1551 roku dwunastoletni Mar Dinkha Szimun bar Mama odziedziczył tron patriarszy po wuju, niektóre wpływowe rodziny oraz część biskupów wybrały mnicha Hannę (Jana) Sulakę z klasztoru św. Hurmizda jako bardziej odpowiedniego kandydata ${ }^{49}$. Z pomocą franciszkańskich misjonarzy w Mosulu Sulakę wysłano do Jerozolimy i Rzymu, gdzie został wyświęcony jako pierwszy patriarcha unicki przez papieża Juliusza III $(1550-1555)^{50}$. Jednak po powrocie na Bliski Wschód został ujęty przez tureckiego paszę Diyarbakiru, uwięziony i stracony ${ }^{51}$. Linia Sulaki, zapoczątkowana w 1553 roku, zakończyła się w 1692 roku, gdy panujący patriarcha, Mar Szimun XIII, porzucił katolicyzm i przeniósł swoją stolicę do Kudszanis (Kochanes) w Hakkari ${ }^{52}$; od niego wywodzi się dzisiejszy Asyryjski Kościół Wschodu.

Natomiast pierwotna linia patriarchów, następców Mar Dinkhi Szimuna, którzy przybierali imię Mar Elijja (Eliasza), pogodziła się z Rzymem w 1607 roku (dlatego przez pewien czas istniały dwa nestoriańskie patriarchaty, oba unickie - jeden z siedzibą w Urmii w Azerbejdżanie i drugi w AlKusz niedaleko Mosulu ${ }^{53}$ ). Jednak już w 1692 roku następca Dinkhi, Mar Elijja X, zerwał unię z Rzymem. Linia Dinkhi skończyła się w 1804 roku, gdy Mar Elijja XIII zmarł, nie pozostawiając siostrzeńca ani bratanka. Jego brat, Hanna Hurmizd, będący katolikiem, zniósł dziedziczność tronu patriarszego $^{54}$ i został obwołany patriarchą Chaldejczyków w 1838 roku $^{55}$.

W 1844 roku unicki Kościół Chaldejski był już silny i niezależny od nestorian, Osmanowie uznali w nim odrębny millet chaldejski. Jednak poza tym formalnym przyporządkowaniem w głębi ducha ludzie z równiny Mosulu byli bardziej nestoriańscy niż katoliccy, zaś niektórzy patriarchowie chaldejscy byli ciągle emocjonalnie związani ze starym Kościołem i nie życzyli sobie zbyt wielu zmian w starożytnych zwyczajach. Aż do wybuchu I wojny światowej Chaldejczycy chętnie połączyliby się z Kościołem nesto-

${ }^{49}$ Sulaka przybrał po elekcji imię Jana VIII, cyt. za: R. Le Coz, op. cit., s. 328.

${ }^{50}$ A. S. Atiya, op. cit., s. 240.

${ }^{51}$ Atiya sugeruje, że stało się to przy współudziale Mar Szimuna.

52 J. F. Coakley, The Patriarchal List of the Church of the East [w:] G. J. Reiniuk, A. C. Klugkist (red.), After Bardaisan: Studies on Continuity and Change in Syriac Christianity in Honour of Professor Han J. W. Drijvers, Leuven 1999, s. 81.

${ }^{53}$ De facto w pewnym okresie istniały nawet trzy patriarchaty unickie - nestoriański biskup Diyarbakiru Jusuf w 1681 roku otrzymał od papieża Innocentego IX tytuł patriarchy (bez precyzowania kogo lub czego), zaś jego następca Jusuf II - tytuł patriarchy Babilonu. Ta linia skończyła się w 1828 roku.

${ }^{54}$ Jego następcy pochodzili ze zwykłego wyboru i byli zatwierdzani przez papieża.

55 J. Joseph, The Nestorians..., s. 31. 
riańskim, gdyby jego patriarcha Mar Szimun XIX mógł zapewnić im taką ochronę, jaką otrzymywali za pośrednictwem papieskiego delegata ${ }^{56}$.

Podziały wzdłuż linii religijnych (rozpad na Chaldejczyków i nestorian Asyryjczyków) uczynily syryjskich chrześcijan użytecznymi z punktu widzenia Zachodu, lecz także wystawiły ich na niebezpieczeństwo. Czerpiąc z doświadczeń, jedni z nich patrzyli na zachodnich misjonarzy z podejrz-

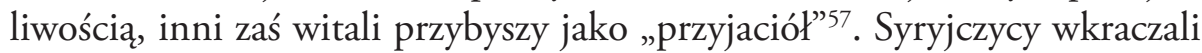
w XIX wiek jako dobrze zdefiniowana wspólnota religijna, która wybierała raczej izolację niż asymilację, $\mathrm{w}$ niewielkim stopniu przyczyniając się do rozwoju życia politycznego czy kulturalnego zamieszkiwanych państw ${ }^{58}$. Sytuacja zmieniła się diametralnie, gdy kolosowi na glinianych nogach zagroziła z północy carska Rosja, spoglądająca chciwym okiem na osmańskie tereny wokół Morza Czarnego, Kaukazu i Persji ${ }^{59}$.

\subsection{Wiek XIX}

Tymczasem na Zachodzie pojawiło się wielkie zainteresowanie Syryjczykami, których właśnie wtedy zaczęto nazywać Asyryjczykami. Owo zainteresowanie miało dwa źródła - polityczne i kulturowe. Potęgi europejskie, takie jak Wielka Brytania i Rosja, od dłuższego czasu wywierały wpływy polityczne i ekonomiczne w imperiach osmańskim i perskim; w XVII wieku dołączyły do nich brytyjskie, holenderskie i francuskie kompanie, które otrzymały przywileje handlowe na terenie Persji ${ }^{60}$. Wiek XIX przyniósł nasilenie interwencji europejskich; budziły one sprzeciw pewnych warstw lokalnych społeczeństw, szczególnie podatnych na rodzące się w Europie idee narodowe ${ }^{61}$. Państwa europejskie szukając na Bliskim Wschodzie sojuszników, zwróciły się ku miejscowym chrześcijanom, używając ich jako

${ }^{56}$ Ibidem, s. 32-33. Chaldejczycy w toku swojej historii otrzymywali wsparcie sił związanych z Kościołem rzymskokatolickim, przede wszystkim papiestwa, później zaś Francji. Asyryjczyków pomoc ta omijała, cyt. za: A. I. Laing-Marshall, op. cit., s. 36.

${ }^{57}$ A. I. Laing-Marshall, op. cit., s. 36.

${ }^{58}$ N. Awde, N. Lamassu, N. Al-Jeloo, op. cit., s. 9.

${ }^{59}$ Ibidem, s. 10. Persja między XIII a XVIII wiekiem przyjęła oficjalnie teologię szyicką, wyznawaną przez znakomitą większość etnicznych Persów, A. Ishaya, The Role of Minorities in the State [w: History of the Assyrian Experience, University of Manitoba Anthropology Papers No. 19, Winnipeg 1977, s. 43-44.

${ }^{60}$ Pod koniec XVII stulecia kupcy europejscy kontrolowali prawdopodobnie większość perskiego handlu, w konsekwencji otrzymując lwią część zysków z udziału tego kraju w międzynarodowych rynkach, por. I. M. Lapidus, A History of Islamic Societies, Cambridge 1988, s. 291.

${ }^{61}$ A. I. Laing-Marshall, op. cit., s. 42. 
pretekstu do wymuszania reform ${ }^{62}$ (w zamian nierzadko oferując polityczną ochronę i inne przywileje). Niemniej jednak otwarte lub ukryte dążenia Europejczyków zatruły stosunki w regionie pomiędzy panującą większością a podlegającymi jej mniejszościami ${ }^{63}$.

Z ekspansją polityczną Zachodu współgrała aktywność w sferze religii ${ }^{64}$ - do lat 30. XIX wieku misje i towarzystwa biblijne, poruszone ewangelizacyjnym duchem „Wielkiego Przebudzenia” ${ }^{65}$, rozpoczęły działalność w asyryjskich centrach w Turcji i Persji. Dały impuls do fundowania szkół, drukarni ${ }^{66}$ i bibliotek, które przyczyniły się do alfabetyzacji lokalnej społeczności chrześcijańskiej i w rezultacie do odrodzenia (a)syryjskiej kultury ${ }^{67}$. Edukacja zapewniona przez misjonarzy nie tylko przygotowała Asyryjczyków do poszukiwania pracy za granicą ${ }^{68} \mathrm{i}$ wykształciła w nich prozachodnią orientację, ale równocześnie położyła fundament pod narodową świadomość ${ }^{69}$.

${ }^{62}$ Chrześcijanie wschodni (Ormianie w Persji i Grecy w osmańskiej Anatolii) zwykle obsadzani byli przez rządy w roli pośredników pomiędzy lokalnymi władzami i Europejczykami; również Europejczycy woleli zatrudniać miejscowych chrześcijan. Innymi słowy, wschodni chrześcijanie byli postrzegani przez obie strony jako „tłumacze międzykulturowi”, cyt. za: J. McCarthy, The Ottoman Turks: An Introductory History to 1923, New York 1997, s. 203.

${ }^{63}$ Należy zauważyć, że trudności i tragedie, których doświadczyli Asyryjczycy, odnajdują paralele w losach Ormian, greckich ortodoksów, Kurdów i innych grup regionu spoza kręgu rządzących, cyt. za: A. I. Laing-Marshall, op. cit., s. 46.

${ }^{64}$ Misje rzymskokatolickie wysyłane przez papiestwo oraz Francję operowały wśród Asyryjczyków sporadycznie od XVI wieku; w ich interesie leżało przyłączenie wschodnich chrześcijan do jednego Kościoła.

${ }^{65}$ Dotyczyło ono brytyjskich i amerykańskich Kościołów protestanckich, które dzieliły pewne przeświadczenia co do wspólnoty asyryjskiej. Składały się na nie m.in.: reputacja Kościoła Wschodu jako Kościoła misyjnego, wyobrażenia na temat pochodzenia Asyryjczyków od dwóch zaginionych plemion Izraela, wiązanie współczesnych Asyryjczyków ze starożytnymi, cyt. za: A. I. Laing-Marshall, op. cit., s. 44. Misje protestanckie pragnęły „ożywić” Kościół asyryjski, by mógł ewangelizować swoich sąsiadów. Wszystkie, z wyjątkiem może misji anglikańskiej, chciały przyciągnąć Asyryjczyków do reprezentowanych przez siebie wyznań (choć Joseph uważa, że nie było to ich intencją, a odłamy Asyryjczyków-protestantów pojawiły się jako skutek uboczny działalności misji, zob. J. Joseph, The Nestorians..., s. 76-77).

${ }^{66}$ Pierwszą ufundowała misja rzymskokatolicka w Urmii, cyt. za: A. I. Laing-Marshall, op. cit., s. 45.

${ }^{67}$ N. Awde, N. Lamassu, N. Al-Jeloo, op. cit., s. 10.

${ }^{68}$ Być może największą rolę w westernizacji Asyryjczyków odegrało nauczenie ich przez misjonarzy zachodnich języków, cyt. za: E. Naby, The Assyrians of Iran: Reunification of a 'Millat'. 1906-1914, „International Journal of Middle East Studies”, 8, 1977, s. 239-240.

${ }^{69}$ Misjonarze nie promowali otwarcie żadnych zsekularyzowanych czy opartych na języku/pochodzeniu identyfikacji narodowych wśród Asyryjczyków, wyrażali za to milczącą zgodę na przewodnią rolę patriarchy, którego traktowali jako najwyższy miejscowy autorytet, cyt. za: A. I. Laing-Marshall, op. cit., s. 48. 
Ważną rolę odegrały tu asyryjskie periodyki wydawane po aramejsku przed I wojną światową ${ }^{70}$, choć ich unifikujące działanie osłabiały różne warianty transliteracji przyjęte przez poszczególne misje ${ }^{71}$. Począwszy od 1848 roku, zaczęło się ukazywać czasopismo w urmijskim syryjskim sponsorowane przez protestantów - „Zahrira d’Bahra” („Promień Światła”), które zawierało wieści ze świata oraz religijne eseje, ponadto zapoznawało Asyryjczyków z kulturowo-naukowymi osiągnięciami w Europie ${ }^{72}$. Inne czasopisma wyznaniowe to: rzymskokatolickie „Qala d'Sharara” („Głos Prawdy”) z 1896 roku i prawosławny (rosyjski) „Aurmih Artuduksyita” („Urmia Ortodoksyjna”) z początku XX wieku ${ }^{73}$. W latach 90. XIX wieku Mar Tuma Oddo z chaldejskiego episkopatu w Urmii zaczął wydawać broszury w nowoaramejskim, sławiące asyryjski „naród”; dodatkowo kilku przywódców wspólnoty zaczęło naciskać na przyjęcie terminu Aturaja (Asyryjczycy) na określenie wspólnoty syryjskiej $^{74}$ zamiast Surjaja z jego religijnymi konotacjami.

$\mathrm{Na}$ początku XX wieku zaczął ukazywać się niezależny (tj. niesponsorowany przez żadne wyznanie) tygodnik „Kokhva” („Gwiazda”). Od 1906 do 1918 roku oferował on swym czytelnikom informacje o Asyryjczykach w diasporze, lekcje historii, opinie na temat wagi tożsamości asyryjskiej ${ }^{75}$. Choć „Kokhva” nie stworzyła międzywyznaniowego asyryjskiego ruchu solidarnościowego, reprezentowała poglądy młodych, wyedukowanych na Zachodzie przedstawicieli wolnych zawodów z Urmii, którzy opowiadali się za nową, zsekularyzowaną tożsamością. Nawet jeśli nie były to poglądy większości, to sama ich dostępność stanowiła wyznacznik szerszego procesu pogłębiania się samoświadomości wspólnoty oraz transformacji tożsamości z czysto religijnej do bardziej etnicznej - opartej na języku i historii ${ }^{76}$.

W kreowaniu tej ostatniej pomogły niewątpliwie odkrycia archeologiczne. Kilka miesięcy po tym, jak Asahel Grant zainaugurował budowę

70 „Kulturowe odrodzenie” w dużo większym stopniu dotyczyło zamożniejszych Asyryjczyków z równin Urmii niż ich górskich braci (np. w górach nie wydawano żadnych czasopism), cyt. za: J. Joseph, The Modern Assyrians..., s. 62 oraz G. P. Badger, The Nestorians and Their Rituals, Vol. 1, London 1852.

${ }^{71}$ Każdemu z odłamów zależało na szerzeniu informacji wyłącznie na własny temat, por. E. Naby, op. cit., s. 242.

${ }^{72}$ R. W. De Kelaita, On the Road to Niniveh: A Brief History of Assyrian Nationalism, 1892-1990, JAAS, Vol. 8, No. 1, 1994, s. 8-9.

${ }^{73}$ E. Naby, op. cit., s. 241.

${ }^{74}$ R. W. De Kelaita nie pisze wyraźnie, czy wysiłki te podjęte były wyłącznie przez wschodnich Syryjczyków (tj. Asyryjczyków i Chaldejczyków), czy także przez zachodnich Syryjczyków, cyt. za: A. I. Laing-Marshall, op. cit., s. 45.

75 Jego wydawanie przerwał wybuch I wojny światowej, lecz do wznowienia nakładu doszło między 1917 a 1918 rokiem, cyt. za: R. W. De Kelaita, op. cit., s. 9.

${ }^{76}$ A. I. Laing-Marshall, op. cit., s. 38. 
amerykańskiej misji protestanckiej w Hakkari w 1842 roku, francuski konsul Paul-Émile Botta rozpoczął wykopaliska na miejscu starożytnej Niniwy. W kolejnym roku odkrył ruiny pałaców królów asyryjskich Sargona II (884-860 p.n.e.) oraz Aszurbanipala (668-ok. 626 p.n.e.) w Chorsabadzie. Zbiory tabliczek zapisanych pismem klinowym wysłano do muzeów w Londynie, Paryżu i Berlinie, a utracony rozdział historii został odzyskany - do tego czasu Niniwa i Babilon były znane Zachodowi jedynie ze Starego Testamentu, przekazów greckich i łacińskich pisarzy oraz opowieści podróżników ${ }^{77}$.

W latach 70. XIX wieku George Smith ogłosił odkrycie tabliczki zawierającej historię podobną do tej o potopie z Księgi Rodzaju. Inne tabliczki traktowały o początku świata, stworzeniu człowieka i zwierząt, upadku człowieka ze stanu bezgrzesznego. Wydana w połowie XIX stulecia książka Austena H. Layarda Nineveh and Its Remains ${ }^{78}$, której obszerne fragmenty autor poświęcił „nestorianom”, spowodowała, że z Londynu popłynęły comiesięczne supliki w sprawie „maleńkiej pozostałości najbardziej interesującej i starożytnej chrześcijańskiej wspólnoty, jedynych i nielicznych potomków Asyryjczyków"79. Kierowany zarówno interesami politycznymi, jak i rzeczywistym współczuciem, rząd brytyjski zainteresował się sytuacją Asyryjczyków ${ }^{80}$.

Tymczasem raporty konsularne potwierdzały niebezpieczeństwo, w jakim znaleźli się ci ostatni ${ }^{81}$, żyjący przez ostatnie stulecia we względnym spokoju $^{82}$ pośród swych kurdyjskich sąsiadów ${ }^{83}$. Okazało się, że pomimo

${ }^{77}$ J. Joseph, The Nestorians..., s. 93.

${ }^{78}$ A. H. Layard, Nineveh and Its Remains: With an Account of a Visit to the Chaldaean Christians of Kurdistan, and the Yezidis, or Devil-worshippers; And an Enquiry Into the Manners and Arts of the Ancient Assyrians, London 1848 [1849], polskie thumaczenie: W poszukiwaniu Niniwy, Warszawa 1983.

${ }^{79}$ Dr. Layard and the Last of the Chaldeans, „The New Monthly Magazine”, 87 (1849), s. 344 .

${ }^{80}$ J. Joseph, The Nestorians..., s. 94-95.

${ }^{81}$ Ibidem, s. 96.

${ }^{82}$ Większość Asyryjczyków zamieszkujących góry Kurdystanu podzielona była na niezależne od siebie plemiona, zwolnione z płacenia trybutu kurdyjskiemu amirowi i posiadające reprezentację w radzie plemion (składającej się z plemion asyryjskich i kurdyjskich); pozostali żyli pod bezpośrednią władzą asyryjskich malików (przywódców) a pośrednią amira, który w razie potrzeby pobierał od nich trybut, cyt. za: G. P. Badger, op. cit., s. 258-259 oraz A. Ishaya, op. cit., s. 37-38. Perscy Asyryjczycy z północno-zachodnich równin byli przeważnie rolnikami, którzy część swych plonów musieli oddawać tureckim panom, cyt. za: J. Joseph, The Modern Assyrians..., s. 62. Podobnie czynili asyryjscy rolnicy z równiny Mosulu, zarówno po stronie osmańskiej, jak i perskiej, cyt. za: A. Ishaya, op. cit., s. 39.

${ }^{83}$ Homogeniczne wioski były rzadkością - Asyryjczycy, Kurdowie i Ormianie mieszkali obok siebie, cyt. za: M. Al-Rasheed, Iraqi Assyrian Christians in London: The Construc- 
licznych więzi i podobieństw, chrześcijańskie i muzułmańskie wspólnoty w Anatolii i Persji nie stanowiły zintegrowanych całości, lecz egzystowały jako odrębne twory etniczno-religijne, dzielone koncepcją zimmi. Ten fakt wykorzystało tureckie zwierzchnictwo, dążące do centralizacji kosztem osłabienia władz prowincji. Nie tylko podniosło podatki ${ }^{84}$, lecz także - stosując zasadę „dziel i rządź” - podburzyło Kurdów, z rąk których w 1843 roku zginęło blisko 50 tys. Asyryjczyków ${ }^{85}$. W nadchodzących latach kurdyjska przemoc pozbawiała chrześcijan takich sum, że rocznie tracili oni „niemal równowartość całej posiadłości i bydła”. Sytuacja skomplikowała się jeszcze, gdy Asyryjczycy, widząc, że Anglia nie przedsięwzięła żadnych zdecydowanych kroków w ich obronie, zwrócili się o pomoc do Rosji - informacja ta zapowiadała trudności i niebezpieczeństwa nadchodzącej wojny pomiędzy osmańską Turcją a carską Rosją ${ }^{86}$.

To, czego Ministerstwo Spraw Zagranicznych Wielkiej Brytanii obawiało się od dekad, wreszcie się spełniło. W wygranej wojnie w latach 1877-1878 Rosja zajęła dużą część wschodniej Turcji, żądając reform, do wprowadzenia których Anglia zawsze Portę zachęcała. Londyn podpisał specjalny defensywny traktat z Turcją, zgodnie z którym broniłby jej przed przyszłymi interwencjami Rosji, a jednocześnie chroniłby chrześcijan; w zamian dostał pozwolenie na okupację Cypru. Aby wypełnić powyższe zobowiązania, rząd brytyjski wyznaczył konsulów militarnych do obserwowania Turków i Kurdów z różnych posterunków we wschodniej Turcji, co zostało zrozumia-

tion of Ethnicity, New York 1998, s. 34. Atiya przytacza tradycyjne kurdyjskie określenie stosunków kurydyjsko-asyryjskich: „Jednych od drugich dzielił tylko włos, podczas gdy góry wyrastały między nimi a Ormianami” (s. 283). Z kolei Joseph zauważa, że zdarzały się - choć niezmiernie rzadko - śluby mieszane pomiędzy Kurdami i Asyryjczykami czy próby wzajemnego nawrócenia (The Nestorians..., s. 36-37). Gdy Kurd nawracał się na chrześcijaństwo, zwykle zostawał wyznawcą Kościoła Wschodu; co więcej, w XIX wieku ciągle istniały asyryjskie wioski, w których mówiono wyłącznie po kurdyjsku oraz wioski kurdyjskie, które pamiętały, że wcześniej były chrześcijańskie (The Modern Assyrians..., s. 61). Zdarzali się też Kurdowie modlący się w chrześcijańskich świątyniach czy zabierający swoich chorych do kościołów z prośbą o uleczenie (The Nestorians..., s. 67).

${ }^{84} \mathrm{~J}$. Joseph, The Nestorians..., s. 97.

${ }^{85}$ N. Awde, N. Lamassu, N. Al-Jeloo, op. cit., s. 10; W. A. Wigram, op. cit., s. 4; G. P. Badger, op. cit., s. 269-271, 365-366, 368-374. W XIX wieku doszło do kilku masakr Asyryjczyków z rąk Kurdów bądź łączonych oddziałów kurdyjsko-tureckich (zob. J. Joseph, The Nestorians..., s. 64, 86, 98, 116-118). Masakra z roku 1843, pierwsza z serii przeprowadzonych przez Kurda Badra Chana Bega z Bohtanu, została opisana jako najstraszniejsza od czasów Tamerlana (A. S. Atiya, op. cit., s. 244).

${ }^{86}$ J. Joseph, The Nestorians..., s. $98-100$. 
ne jako inauguracja „Protektoratu Azji Mniejszej” i przywitane z radością, szczególnie przez miejscowych chrześcijan ${ }^{87}$.

Asyryjczycy, otoczeni misjonarzami anglikańskimi, z brytyjskim konsulem, który się o nich troszczył, żyli w pewnym oderwaniu od realiów politycznych, zachęcani do stworzenia niepodległego państwa pod obcą protekcją ${ }^{88}$. Gubernator prowincji Wan narzekał, że „amerykańscy misjonarze wzbudzali nadzieje górskich nestorian co do politycznej pomocy ze strony Anglii” (najprawdopodobniej przez „amerykańskie” miał na myśli „anglikańskie"). Gdy na scenie pojawił się konsul militarny, Kurdowie stali się okrutniejsi, mówili chrześcijanom: „Idźcie i powiedzcie swojemu konsulowi, żeby z nami negocjował"89. Wyjątkowe przywileje nadane Asyryjczykom zagroziły Kurdom i popchnęły ich do działania ${ }^{90}$.

W 1880 roku Kurdowie rozpoczęli kampanię przeciw Persji, najprawdopodobniej pod wpływem wyobrażenia o słabości tego kraju. Zaledwie miesiąc po przekroczeniu perskiej granicy wybuchły między nimi spory, wkrótce musieli więc uciekać, a dwa miesiące po inwazji wycofali się na terytorium tureckie. Perski rząd wywarł presję na władze brytyjskie i rosyjskie, by ukarały najeźdźców. Jednak wysiłki konsularne doprowadziły do niezbyt dobrych rezultatów, w efekcie konsule militarni wycofali się z Turcji zaledwie trzy lata od ich mianowania. W latach 1894-1896 zginęło około 55 tys. Asyryjczyków ${ }^{91}$.

Aby zdusić źródło problemów w przyszłości, sułtan Abdülhamid zwrócił się do kurdyjskich plemion. Tolerował lokalną niezależność posłusznych mu agów (tj. kurdyjskich właścicieli ziemskich), za to zorganizował mężczyzn w nieregularne formacje zwane „Kawalerią Hamidijja” (odpowiedniczkę ormiańskich organizacji rewolucyjnych), odpowiedzialną jedynie przed nim. Konsekwencją było narastające bezprawie - chaos, morderstwa, rabunki. Wyżsi urzędnicy osmańscy nie byli wrogo nastawieni do chrześcijan, lecz otoczenie ich przez uzbrojonych Kurdów sprawiło, że Asyryjczycy zaczęli wierzyć, iż Turcy używają Kurdów do ich celowej eksterminacji, jak miało to miejsce w przypadku Ormian. W 1908 roku brytyjski ambasador zacytował tureckie źródła, że „kurdyjski najazd pozostawił 11 tys. nestorian

${ }^{87}$ Ibidem, s. $102-104$.

${ }^{88}$ Ibidem, s. 105.

${ }^{89}$ An Eastern Statesman, Contemporary Life and Thought in Turkey, „Contemporary Review”, 37 (1880), 342, cyt. za: J. Joseph, op. cit., s. 106.

${ }^{90}$ Ibidem, s. 107.

${ }^{91}$ N. Awde, N. Lamassu, N. Al-Jeloo, op. cit., s. 10. 
bez domów"92. W 1909 roku zmasakrowano kolejne 3 tys. Asyryjczyków w Adanie w Cylicji ${ }^{93}$.

Plemiona kurdyjskie w dużym stopniu same padały ofiarą ciężkich warunków, w jakich przyszło im żyć. Podczas swej historii Kurdowie cierpieli na skutek rozdzielenia przez dwa lub trzy wrogie sobie mocarstwa. Europejskie potęgi myślały tylko o ich „ujarzmieniu”. W takich warunkach Kurdowie rozwinęli postawę antyrządową. W przypadku swoich chrześcijańskich sąsiadów byli zachęcani do wrogości ${ }^{94}$. Rząd turecki uznał bowiem za celowe wzmacnianie nastrojów antychrześcijańskich, które zwiększyły się jeszcze po proklamacji muzułmańsko-chrześcijańskiej równości przez młodoturków ${ }^{95}$.

Zwycięstwo rewolucji tych ostatnich w 1908 roku wywołało falę „żywiołowej radości" zarówno wśród muzułmanów, jak i chrześcijan, i doprowadziło do niejednego pojednania ponad podziałami wyznaniowymi ${ }^{96}$. Po raz pierwszy w świecie muzułmańskim podważona została perspektywa, według której ludzie dzielili się na trzy kategorie: wiernych, niewiernych i zimmi, zaś islam i osmańskośćc ${ }^{77}$ przestały być dominującymi wyznacznikami tożsamości ${ }^{98}$. Również w Persji zaszły daleko idące zmiany - rewolucja konstytucyjna w latach 1905-1911 doprowadziła do powołania

${ }^{92}$ J. Joseph, The Nestorians..., s. 116-117.

${ }^{93}$ N. Awde, N. Lamassu, N. Al-Jeloo, ibid.

${ }^{94}$ J. Joseph, The Nestorians..., s. 118-119.

${ }^{95}$ Ibidem, s. 130-131. Młodoturcy wywodzili się z tajnych stowarzyszeń kadetów szkół wojskowych i studentów. Byli członkami nacjonalistycznego i modernistycznego ruchu politycznego w Turcji na przełomie XIX i XX wieku, z którego wyrosła partia oficjalnie nosząca nazwę Komitetu Jedności i Postępu. Po bezkrwawej rewolucji w Salonikach, która doprowadziła do rezygnacji paszy, Komitet objął rządy i przeprowadził detronizację sułtana. Mimo iż zapowiadał równe traktowanie wszystkich mieszkańców imperium, po przejęciu całkowitej władzy w 1913 roku rozpoczął silnie nacjonalistyczną politykę. Z ruchem młodotureckim związany był Mustafa Kemal, zwany w Turcji Atatürkiem. O młodoturkach zob. B. Lewis, The Emergence of Modern Turkey, London 1961, polskie tłumaczenie: Narodziny nowoczesnej Turcji, Warszawa 1972.

${ }^{96}$ B. Lewis, op. cit., s. 256; J. Joseph, Muslim-Christian Relations and Inter-Christian Rivalries in the Middle East: The Case of Jacobites in an Age of Transition, New York 1983, s. 94-95.

${ }_{97}$ Turcy osmańscy promowali lojalność wobec imperium, postawy panosmańskie; z tego względu posiadali bardzo słabo rozwiniętą tożsamość turecką, por. B. Lewis, op. cit., s. 387-391. Choć Europejczycy często posługiwali się słowem „Turek”, to dla osmańskich pisarzy oznaczało ono „ignoranckiego nomada lub wieśniaka z Anatolii”, często używane było w pejoratywnym znaczeniu lub dla odróżnienia między tureckojęzycznymi Osmanami a tymi, którzy mówili innymi językami, cyt. za: D. Kushner, The Rise of Turkish Nationalism 1876-1908, London 1977, s. 2.

${ }^{98}$ Por. B. Lewis, op. cit., s. 384-386. 
parlamentu i zwróciła uwagę na „naród”. Choć nacjonalizm liberalnych konstytucjonalistów był bardziej terytorialnej niż etnicznej natury ${ }^{99}$, ich krótkotrwały ruch odegrał formatywną rolę - zasygnalizował świt nowej koncepcji tożsamości, która przeważyła podczas reżimu Rezy Szaha ${ }^{100}$.

Nie istnieją dostępne dowody na zaangażowanie Asyryjczyków czy to w rewolucję młodoturecką, czy w konstytucyjną, czy też w towarzyszące tej drugiej formowanie parlamentu ${ }^{101}$. Niemniej jednak dwie rewolucje nie były wyłącznie epizodami politycznymi, wpłynęły na rozwijające się poczucie świadomości narodowej u Asyryjczyków, dostarczając praktycznych przykładów nacjonalizmu w działaniu oraz bodźców do refleksji i teorii politycznych (idee płynęły z trzech źródeł: od rządu, zachodnich misjonarzy oraz sąsiadów - Kurdów, którzy rozwijali własny nacjonalizm ${ }^{102}$ ). W opisywanym okresie tożsamość „narodowa” ograniczona była jednak do wąskiej grupy asyryjskich elit intelektualnych; dopiero I wojna światowa przyniosła nowe możliwości kontaktu wewnątrz rozproszonej wcześniej wspólnoty, a przez to upowszechnienie (i zmianę) tożsamości zbiorowej ${ }^{103}$.

\subsection{I wojna światowa}

W latach 1914-1918 Bliski Wschód stanowił jeden z teatrów wojny, na którym europejskie potęgi rozgrywały swoje interesy; mieszkańcy regionu zostali wciągnięci w wir historii. Dla Asyryjczyków, podobnie jak dla Ormian, miało to tragiczne konsekwencje. Imperium osmańskie oficjalnie przyłączyło się do państw centralnych, zaś sułtan (który był również „kalifem”, tj. następcą proroka Muhammada i teoretycznie ziemskim przywód-

${ }^{99}$ M. Vaziri, Iran as Imagined Nation: The Construction of National Identity, New York 1993, s. 185.

${ }^{100}$ A. I. Laing-Marshall, op. cit., s. 53.

${ }^{101}$ W uzupełnieniu irańskiej konstytucji z 1907 roku Asyryjczykom i Chaldejczykom nadano prawo do wysyłania jednego delegata do centralnego Medżlisu (parlamentu); podobną prerogatywę posiadali Ormianie, Żydzi i zaratusztrianie. Wspólnota asyro-chaldejska nigdy nie wysłała żadnego delegata z powodu międzywyznaniowych waśni, jednak kwestia sposobu jego wyboru była dogłębnie dyskutowana w Urmii, cyt. za: E. Naby, op. cit., s. 245.

${ }^{102}$ R. Olson, The Emergence of Kurdish Nationalism and the Sheikh Said Rebellion, 1880-1925, Austin 1989. Olson akcentuje naczelną rolę nowych szkół wojskowych w procesie wykształcania się narodowej tożsamości u kurdyjskich oficerów w armii osmańskiej (s. 12) oraz stworzenie kurdyjskich organizacji narodowych niedługo po rewolucji 1908 roku (s. 15).

${ }^{103}$ A. I. Laing-Marshall, op. cit., s. 57. 
cą wszystkich muzułmanów) ogłosił dżihad ${ }^{104}$ przeciwko Sprzymierzonym i ich sojusznikom. Nie zaowocowało to - jak było planowane - powszechnym muzułmańskim wsparciem dla imperium i walką z jego wrogami, lecz dało pretekst do prześladowań niemuzułmańskich mniejszości ${ }^{105}$. Mimo wysiłków niektórych jednostek - zarówno po stronie muzułmańskiej, jak i chrześcijańskiej - by chronić wyznających inną wiarę, nie dało się powstrzymać fali międzywyznaniowej przemocy ${ }^{106}$ : ludobójstwa Ormian oraz Sejfo ${ }^{107}$, podczas którego w północnej Mezopotamii (w regionach Tur Abdinu, Hakkari, Wan, Siirt w dzisiejszej południowo-wschodniej Turcji oraz Urmii w północno-zachodnim Iranie) zamordowano 750 tys. Asyryjczyków, tj. jedną trzecią ówczesnej populacji ${ }^{108}$.

W 1915 roku Asyryjczycy, niepewni swej pozycji w państwie osmańskim i zachęcani przez potęgi europejskie, zdecydowali się przystąpić do wojny po stronie Sprzymierzonych, co postawiło ich w bezpośrednim konflikcie z siłami osmańskimi ${ }^{109}$. Jedyną ich ochronę stanowiła armia rosyjska, która wycofała się z Persji pod koniec 1914 roku. W lutym 1915 roku 36. i 37. dywizja armii osmańskiej wkroczyły do wiosek w Urmii i wzięły do niewoli 61 przywódców asyryjskich, żądając za nich wysokich okupów - francu-

${ }^{104}$ W znaczeniu „świętej wojny”. Dżihad jest bardzo ważną koncepcją w świecie muzułmańskim; w najszerszym rozumieniu oznacza każdy wysiłek podjęty w walce ze złem, włącznie ze złem w samym sobie.

${ }^{105}$ M. Al-Rasheed, op. cit., s. 45.

${ }^{106}$ J. Joseph, Muslim-Christian..., s. 97-98; R. Le Coz, op. cit., s. 364; S. D’Bait Mar Shimun, Assyrian Church Customs and the Murder of Mar Shimun, New York 1983, s. 69.

107 Sejfo (bądź Sajfo), skrócona forma aramejskiego wyrażenia szato d'sajfo - „rok miecza”. Źródła współczesne wydarzeniom mówiły o masakrze chrześcijan w imperium osmańskim, wymieniając łącznie ortodoksyjnych Greków, syryjskich oraz ormiańskich chrześcijan. Czasem używane są inne nazwy, jak aramejska ketla d'Ama Aturaja, znacząca dosłownie „zabijanie asyryjskiego ludu”, lub ktolkamo - „ludobójstwo”. Szeroko wydarzenia Sejfo w Anatolii opisuje D. Gaunt, Massacres, Resistance, Protectors: Muslim-Christian Relations in Eastern Anatolia during World War I, Piscataway 2006, zaś w Persji Y. H. Shahbaz, The Rage of Islam: An Account of the Massacre of Christians by the Turks in Persia, Philadelphia 1918. Ponadto o ludobójstwie z czasów I wojny światowej opowiada oparta na faktach powieść R. Malek-Yonan, The Crimson Field, Verdugo City 2005.

${ }^{108}$ N. Awde, N. Lamassu, N. Al-Jeloo, op. cit., s. 10; H. Anschütz, Die Gegenwartslage der „Apostolischen Kirche des Ostens” und ihre Beziehungen sur „assyrisschen” Nationalbewegung, „Ostkirchliche Studien” 18, 1969, s. 127-128; J. Yacoub i S. O. Dadesho mówią o eksterminacji nawet połowy ówczesnej populacji asyryjskiej, cyt. za: J. Yacoub, The Assyrian Community in Turkey [w:] O. Høiris, S. M. Yürükel (red.), Contrasts and Solutions in the Middle East, Aarhus 1997, s. 323; S. O. Dadesho, The Assyrian National Question at the United Nations: A Historical Injustice Redressed, Modesto 1987, s. 57.

${ }^{109}$ S. D’Bait, op. cit., s. 70-71. 
skim misjom udało się wykupić 20 mężczyzn, jednak pozostali zakładnicy zostali zabici. Wkrótce potem oddziały tureckie zastrzeliły niemal wszystkich mężczyzn z wioski Golpaszan; w Salamas 750 Ormian i Asyryjczyków chronili tureccy cywile - zostali zabici wraz z chrześcijanami.

Podczas zimy 1915 roku 4 tys. Asyryjczyków zmarło od chorób, głodu i wyczerpania, zaś tysiąc straciło życie w wioskach Urmii. W kwietniu armia osmańska zmasakrowała całą populację Gawaru w Hakkari i zastrzeliła 475 jeńców z Tel Mozilt; między Kurdami a osmańskimi oficerami wybuchły spory, co zrobić z pozostawionymi kobietami i sierotami.

Przerażeni Asyryjczycy chronili się w misjach - około 3 tys. we francuskiej i nie mniej niż 17 tys. w amerykańskiej, niektórzy w domach swych muzułmańskich sąsiadów i przyjaciół. Jednak to amerykańska misja okazała się prawdziwym zbawcą chrześcijan Persji ${ }^{110}$. Główna odpowiedzialność podczas tych dni spoczywała na dr. Williamie A. Sheddzie, urodzonym w Urmii, gdzie jego ojciec był przed nim misjonarzem. Pomagali mu współpracownicy i pracownicy Departamentu Stanu w Waszyngtonie. Równocześnie amerykańscy misjonarze polegali na dobrej woli i ochronie ze strony najważniejszych urmijskich muzułmanów i kilku kurdyjskich przywódców, z którymi zaprzyjaźnili się, niosąc pomoc medyczną oraz humanitarną.

Obrońcami Asyryjczyków byli też Rosjanie. Gdy po porażce Turków pod Sarikamisz powrócili do Urmii w maju 1915 roku $^{111}$, chrześcijanie, którzy porzucili swe domy, również zaczęli wracać. Rosjanie zapewniali pomoc, a czasem nawet osobiście pomagali Asyryjczykom w prywatnych wendettach na muzułmanach za niesprawiedliwości, które wydarzyły się pod turecką okupacją. Minęły trzy miesiące i Rosjanie jednak znów musieli się ewakuować się z Urmii, która wróciła we władanie Turków i nieregularnych oddziałów kurdyjskich. Pod koniec 1915 roku „batalion rzeźników” (tur. Kasap Taburu) wymordował dwudziestotysięczną populację asyryjską w prowincji Wan. W obliczu słabości Persji, która nie była w stanie wyegzekwować ogłoszonej przez siebie neutralności ${ }^{112}, 10$ tys. Asyryjczyków uciekło w panice na północ w kierunku Rosji, ginąc masowo po drodze. Po miesiącu turecki pochód został zahamowany, a wraz z nim ucieczka

${ }^{110}$ J. Joseph, The Nestorians..., s. 132.

${ }^{111}$ Ibidem, s. 133.

${ }_{112}$ Słabość rządu centralnego Persji w tym okresie oznaczała milczącą zgodę na okupację północnej i południowej części kraju odpowiednio przez Rosję oraz Wielką Brytanię, jak też niczym nieskrępowane tureckie rajdy na Asyryjczyków żyjących w jej graniach, cyt. za: S. D’Bait, op. cit., s. 76-77. 
chrześcijan. Z trudnością osiedlali się na nowo, gdy dołączyło do nich 35 tys. ich wygłodzonych i obdartych współziomków z Hakkari.

Pod przewodnictwem swego patriarchy Mar Szimuna XIX Asyryjczycy z gór szukali ucieczki w Salmas i Urmii, w obrębie zwierzchnictwa rosyjskiego. W ciągu następnych paru miesięcy jedna trzecia z nich zginęła z braku pożywienia, ubrań i schronienia. W ciągu następnego półtora roku sytuacja nieznacznie się poprawiła. Rosyjska armia na Kaukazie została poważnie wzmocniona. Rosjanie pomagali asyryjskim uchodźcom z Hakkari i zachęcali, by się do nich przyłączyli. Pod przywództwem jednego z własnych wodzów - Aghi Petrosa ${ }^{113}$, oddali nieocenione usługi jako przednie straże oraz wywiadowcy Rosjan ${ }^{114}$.

Zimą 1916 roku Rosjanie rozpoczęli ofensywę i zagrozili sercu azjatyckiej Turcji. Najdalej wyciągnięta linia rosyjska została jednak zatrzymana jesienią w Kut i Rosjanie zaczęli się stopniowo wycofywać, zostawiając za sobą dziedzictwo nienawiści i goryczy - po zrabowaniu bydła i zboża tysiące niewinnych muzułmanów zmarło z głodu (z kurdyjskiej populacji Rawanduz przetrwało jedynie 20\%). „Największym źródłem kłopotów” - pisał Shedd - ,jest armia rosyjska. Stanowi zagrożenie dla wspólnoty”"115.

W marcu 1917 roku wybuchła rewolucja przeciwko carowi Mikołajowi II i monarchii absolutnej, w związku z czym armii rosyjskiej nakazano wycofanie się z perskiej ziemi. Turcy byli w stanie odzyskać większość terytorium w Anatolii pomimo wysiłków ormiańskich, aby utrzymać linię od Morza Czarnego do Persji. Panturańskie sny odżyły. Wraz z rozpadem rosyjskich sił zbrojnych Asyryjczycy utracili główne wsparcie militarne. Myśleli o ucieczce do Rosji w trakcie lub zaraz po przybyciu Brytyjczyków $^{116}$. W tych okolicznościach kierownicy różnych misji wraz z przywódcami wspólnoty chrześcijańskiej próbowali opracować jakieś plany. Shedda w styczniu 1918 roku mianowano honorowym wicekonsulem Stanów Zjednoczonych w Urmii.

${ }^{113}$ Agha Petros wyróżnił się jako przywódca w czasie wojny, choć nie pochodził z tradycyjnej asyryjskiej elity - był wcześniej m.in. kupcem, cyt. za: R. W. De Kelaita, op. cit., s. 16-17. R. S. Stafford pisze o nim, że był jedynym człowiekiem zdolnym przewodzić wspólnocie w tamtym okresie i sam siebie nazywał "głównodowodzącym Asyryjczyków”. Dodaje także, że "generał" był „awanturnikiem” i mężem "wątpliwego pochodzenia” (The Tragedy of the Assyrians, London 1935, s. 40-41, 100). R. W. De Kelaita i S. O. Dadesho przywołują jednak dzisiejszą percepcję Aghi Petrosa pośród Asyryjczyków jako bohatera narodowego, bez czynienia żadnych negatywnych wzmianek.

${ }^{114}$ J. Joseph, The Nestorians..., s. 135.

${ }^{115}$ Ibidem, s. 136-139.

${ }^{116}$ Ibidem, s. 137-138. 
Czysto militarną akcję podjęły dwie setki oficerów i artylerzystów z Białej Armii, które stacjonowały w Urmii. Próbowano objąć kontrolę nad dawnymi nieregularnymi oddziałami asyryjskimi oraz ormiańskimi uchodźcami. Chrześcijanie odziedziczyli duże ilości broni i amunicji pozostawionej przez armię rosyjską. Rozpoznając bojowe umiejętności górskich Asyryjczyków, konferencja Sprzymierzonych w Tbilisi wysłała oficerów, także angielskich i francuskich, w celu przeszkolenia oddziałów chrześcijańskich ${ }^{117}$. Wysiłki, aby zorganizować i uzbroić chrześcijańską ludność, wznieciły silny resentyment wśród Persów w Azerbejdżanie, którzy szczególnie niechętnie patrzyli na asyryjskich górali z Hakkari. Persowie zdecydowali się na atak na kwatery chrześcijańskie w mieście Urmii w lutym 1918 roku. W rezultacie bitwy faktyczne dowództwo nad miastem przeszło w ręce Rady chrześcijańskiej (zwanej „radą mieszaną”, ponieważ oficjalnie składała się z równej liczby chrześcijan i muzułmanów, pod przywództwem muzułmańskiego gubernatora). Trzy tygodnie później, 3 marca 1918 roku, patriarcha Mar Szimun XIX, który prowadził ugodową politykę z Turkami, oraz kilkadziesiąt osób z jego eskorty zostało podstępnie zamordowanych przez kurdyjskiego wodza Simko ${ }^{118}$.

Wówczas Asyryjczcy z Hakkari pod wodzą Malika Choszaby wzięli odwet na muzułmańskiej ludności Dilmanu i większości wiosek Salmas. Simko i jego ludzie uciekli do Choju i zmasakrowali 3,5 tys. tamtejszych chrześcijan. Przez pewien czas brygady chrześcijańskie terroryzowały zarówno muzułmanów, jak i chrześcijan. Ludzie dobrej woli z obu stron robili wszystko, co mogli, aby powstrzymać przemoc, jednak ze słabym skutkiem.

Brytyjska misja, prowadzona przez generała brygady Lionela Ch. Dunsterville’a, przybyła do Persji. Celem ekspedycji znanej jako „Dunsterforce” był też Kaukaz. Dunsterville skontaktował się z Asyryjczykami w celu zwerbowania ich do swoich oddziałów. Asyryjsko-ormiańskie siły miały spotkać brytyjski konwój w lipcu 1918 roku. Brytyjczycy osiągnęli wyznaczone miejsce w odpowiednim czasie, ale Asyryjczycy przybyli spóźnieni - walczyli po drodze. Co gorsza, Agha Petros zabierając największą ilość sił zbrojnych ze sobą, pozostawił Urmię praktycznie niechronioną. Chodziły pogłoski o masowych mordach - wątłe siły pozostawione w Urmii nie mogły sprostać wrogowi. Dlatego też cała ludność cywilna wraz z dobytkiem

${ }^{117}$ Ibidem, s. 139.

${ }^{118}$ Ibidem, s. 134. Simko zwabił patriarchę obietnicą rozmów pokojowych, cyt. za: A. I. Laing-Marshall, op. cit., s. 58. 
ruszyła na południe, by połączyć się z Brytyjczykami, którzy przyjmowali wychodźców niechętnie, choć humanitarnie (tysiące Kurdów i Persów zmarło w tym czasie z powodu głodu w Persji) ${ }^{119}$.

Koniec I wojny światowej zastał Asyryjczyków zgrupowanych w nowo powstałym Iraku, przede wszystkim w obozie w Bakubie, żyjących jako uchodźcy pod auspicjami Brytyjczyków ${ }^{120}$. W Bakubie Asyryjczycy z dawnych imperiów perskiego i osmańskiego, górale i rolnicy z nizin, byli zmuszeni do kohabitacji ${ }^{121}$. Asyryjczycy wschodni i zachodni uświadomili sobie wspólne cechy; dowodem na to są międzywyznaniowe msze odprawiane jeszcze podczas „oblężenia” Urmii ${ }^{122}$ oraz śluby zawierane w czasie wojny między członkami różnych Kościołów i plemion ${ }^{123}$. Co więcej, jako wspólnota zmuszona walczyć i wędrować, aby przetrwać masakry, epidemie i wysiedlenia, Asyryjczycy dodali nowe doświadczenie do swej pamięci zbiorowej - przekuli je w opowieści i pieśni, przechowując je dla przyszłych pokolen ${ }^{124}$.

\subsection{Lata międzywojenne}

Okres między wojnami był czasem „budowania narodów” na Bliskim Wschodzie ${ }^{125}, \mathrm{~m}$.in. narodu tureckiego, irackiego i w jakimś sensie także irańskiego. Rozpad imperium osmańskiego ukazał niebezpieczeństwo, jakie dla reżimu stanowiły upolitycznione tożsamości poszczególnych grup; dlatego rządy i elity wymienionych krajów opowiedziały się za budowaniem silnych i zunifikowanych tożsamości narodowych, opartych odpowiednio na panturkizmie, panarabizmie oraz paniranizmie, wdrażanych za pomocą systemów edukacji ${ }^{126}$.

${ }^{119}$ J. Joseph, The Nestorians..., s. 141-144.

${ }^{120}$ A. I. Laing-Marshall, op. cit., s. 59.

${ }^{121}$ Górale i mieszkańcy równin różnili się dialektem, ubiorem, stylem życia; pielęgnowali te różnice dzięki endogamii, choć migracje zapobiegały całkowitej izolacji jednych od drugich, cyt. za: ibidem, s. 41.

${ }^{122}$ Y. H. Shahbaz, op. cit., s. 119.

${ }^{123}$ R. W. De Kelaita, op. cit., s. 16.

${ }^{124}$ M. Al-Rasheed, op. cit., s. 47.

${ }_{125}$ M. J. Esman, I. Rabionovich, The Study of Ethnic Politics in the Middle East [w:] M. J. Esman, I. Rabinovich (red.), Ethnicity, Pluralism, and the State in the Middle East, Ithaca 1988, s. 6.

${ }^{126}$ A. I. Laing-Marshall, op. cit., s. 68-69. 


\subsubsection{Turcja po I wojnie światowej}

W 1920 roku sułtan Mehmet VI rozwiązał parlament i zaakceptował surowe warunki traktatu z Sèvres. Mustafa Kemal stawił opór Sprzymierzonym i po zwycięstwie nad Grekami w 1922 roku renegocjował traktat z Francją i Związkiem Radzieckim, ratując tym samym turecką dumę. Do czasu podpisania traktatu z Lozanny w 1923 roku został wybrany na prezydenta i obrócił nacjonalistyczną wizję w czyn. Republika Turecka przeszła wiele reform: zniesienie kalifatu, sekularyzację, westernizację strojów, wprowadzenie alfabetu łacińskiego zamiast arabskiego oraz szwajcarskiego kodeksu cywilnego jako podstawy prawa rodzinnego i osobistego. Zunifikowano także system edukacji, wyrywając go spod kontroli duchownych; nowy miał „wyrabiać w studentach poczucie jedności tożsamości, języka, historii, etnicznego lub rasowego pochodzenia i wiary ${ }^{127 ”}$.

Wcielanie w życie zamiarów rządu napotykało trudności. Mimo sukcesów w zachodniej części kraju, która szybko się rozwijała ${ }^{128}$, we wschodniej części analfabetyzm był ciągle wysoki - do szkół nie uczęszczało 99\% dzieci w Hakkari, 96\% w Wan, 91\% w Mardinie i Diyarbakirze ${ }^{129}$ (tj. w regionach zamieszkanych przez nastawionych antyrządowo Kurdów i chrześcijan). W 1934 roku prawo tureckie zabroniło używania imion i nazwisk niebrzmiących tureckoo ${ }^{130}$. Mimo że konstytucja gwarantowała równość, nowy reżim wzmacniał podziały, np. w dowodach osobistych jedynie muzułmanów nazywano „Turkami”, niemuzułmanów zaś „obywatelami tureckimi" ${ }^{31}$. Pomimo wysiłków władz, by zneutralizować rolę religii, islam ciaggle odgrywał tu bardzo ważną rolę.

\subsubsection{Persja po I wojnie światowej}

Chaos i dezorganizacja rządu centralnego w Persji zaowocowały przewrotem w 1921 roku, który wyniósł do władzy Sajjida Ziję ad-Dina Tabatabajego (postrzeganego przez nacjonalistów jako pionka w rękach Brytyjczyków)

${ }^{127}$ J. S. Tiregol, The Role of Primary Education in Nation-State Building: The Case of the Early Turkish Republic (1923-1938), Princeton 1998, s. 90.

${ }^{128}$ W Ankarze, Stambule, Szmirze i Bursie do szkół uczęszczało 79\% dzieci, cyt. za: ibidem, s. 150.

${ }^{129}$ Ibidem.

${ }^{130}$ Asyryjczycy upominaja się o swoje - przynajmniej nazewnictwo, http://szlomo.pl/index.php, data wejścia 8.08.2009.

${ }^{131}$ B. Lewis, op. cit., s. 418. 
oraz pułkownika Rezę Chana. Ten ostatni dwa lata później został premierem, a w 1925 roku koronował się jako Reza Szah Pahlawi, ustanawiając dynastię Pahlawich, która miała rządzić Iranem do islamskiej rewolucji w latach 1978-1979. Reza Szah podziwiał Atatürka i podobnie jak turecki przywódca modernizował i westernizował kraj, wdrażając reformy edukacji, przemysłu, transportu, komunikacji, wojska oraz ubioru ${ }^{132}$. Cel stanowiła integracja zróżnicowanych pod względem etnicznym obywateli ${ }^{133}$.

W dziedzinie edukacji reżim Pahlawich narzucił wyjątkowo świecki program oraz perski jako język państwowy (nauczany w uystandaryzowanej, pozbawionej dialektalnych form wersji ${ }^{134}$ ). W szkołach wykładane były elementy europejskich teorii dotyczących rasy aryjskiej ${ }^{135}$, zaś na dworze szacha przebywało wielu niemieckich doradców. Częścią perskiego curriculum było recytowanie nacjonalistycznych wierszy, śpiewanie pieśni patriotycznych czy składanie przysięgi na wierność fladze ${ }^{136}$. Zabroniono mówienia oraz publikowania w językach etnicznych ${ }^{137}$, zmieniono nazwy kilku prowincji na „bardziej persko brzmiące” (np. Arabestan na Chuzestan) ${ }^{138}$.

Z drugiej strony powszechnie używano przedmuzułmańskiej symboliki zaratusztriańskiej, by podkreślić więzi kraju z jego starożytną przeszłością (przed przybyciem Arabów). Oczywiście islam ciągle odgrywał niezwykle istotną rolę - przykładowo lekcje religii w klasach nauczania początkowego zajmowały sześć godzin tygodniowo ${ }^{139}$. Choć trudno określić stopień, w jakim reformy Rezy Szaha wpłynęły na szerokie masy, to z pewnością był on znaczny w przypadku rosnącej miejskiej klasy średniej - modernizacja przełożyła się na ukształtowanie wśród niej postawy solidarności ${ }^{140}$.

\subsubsection{Irak po I wojnie światowej}

Królestwo Iraku zostało stworzone z trzech dawnych osmańskich prowincji: Bagdadu, Al-Basry i Mosulu, i oddane jako terytorium mandatowe

${ }^{132}$ R. W. Cottam, Nationalism in Iran, Pittsburgh 1964, s. 19-21.

${ }^{133}$ M. Vaziri, op. cit., s. 192.

${ }^{134}$ D. Menshari, Education and the Making of Modern Iran, Ithaca 1992, s. 91.

${ }^{135}$ M. Vaziri, op. cit., s. 194.

${ }^{136}$ Ibidem, s. 195.

${ }^{137}$ A. Ramezanzadeh, Internal and International Dynamics of Ethnic Conflict: The Case of Iran, Leuven 1996, s. 78.

${ }^{138}$ E. Sanasarian, Religious Minorities in Iran, Cambridge-New York 2000, s. 15.

${ }^{139}$ A. Sassani, Education in Iran, Washington 1963, s. 10.

${ }^{140}$ A. Ramezanzadeh, op. cit., s. 196-197. 
we władanie Brytyjczykom. Fajsal, syn szarifa Mekki, został koronowanym królem w 1921 roku. Przywiódł ze sobą byłych oficerów osmańskich, przeważnie wywodzących się z ziem irackich, którzy walczyli u jego boku podczas rewolty arabskiej; oni to pełnili funkcję administratorów Iraku do upadku monarchii w 1958 roku. Oficerowie byli głównie sunnitami, podczas gdy społeczeństwo wyznawało w większości szyizm ${ }^{141}$ i utrzymywało kontakty ze współwyznawcami w Iranie. Północny wschód Iraku zamieszkiwali Kurdowie (sunnicy muzułmanie), którzy dążyli do niepodległości. Chrześcijańskie i żydowskie wspólnoty żyły przeważnie w miastach; Asyryjczycy skupiali się w sąsiedztwie Bagdadu ${ }^{142}$.

Jak zauważa Liora Lukitz: „Irak był nowym krajem, pozbawionym wspólnych mitów i przodków, do których można by się odnosić lub wspólnych wspomnień historycznych. Nie było przeszłości do przyjęcia przez wszystkie grupy formujące jego ludność, ani też powszechnej chęci dla zbiorowego politycznego odkupienia ${ }^{143}$ ". Innymi słowy, nie istniała tożsamość unifikująca mieszkańców nowo powstałego państwa, a Brytyjczycy nie byli zainteresowani jej kształtowaniem, woleli prowadzić politykę „dziel i rządź”, by jak najdłużej utrzymać swą mandatową władzę ${ }^{144}$.

Iraccy przywódcy z kolei skupiali się na umacnianiu własnych pozycji w aparacie państwowym, chociażby negocjując anglo-iracki traktat z 1930 roku $^{145}$. Przeciw nim wyrosła opozycja, której przewodzili szejkowie, kupcy, właściciele ziemscy i szyiccy duchowni ${ }^{146}$. Gdy w 1932 roku Irak zyskał niepodległość, jego rząd nie był stabilny - pierwszy przewrót wojskowy miał miejsce w 1936 roku; od tego czasu iracką scenę polityczną zdominowały: panarabizm, iracki nacjonalizm oraz islam - wartości wyznawane przez oficerów Fajsala ${ }^{147}$.

${ }^{141}$ R. S. Simon, Iraq Between the Two World Wars: The Creation and Implementation of a Nationalist Ideology, New York 1986, s. 3.

${ }^{142}$ Ibidem, s. 2-3.

${ }^{143}$ L. Lukitz, Iraq: The Search for National Identity, London 1995, s. 79.

${ }^{144}$ S. Haj, The Making of Iraq 1900-1963: Capital, Power and Ideology, Albany 1997, s. 81 .

${ }^{145}$ R. S. Simon, op. cit., s. 3-4. Traktat dawał Wielkiej Brytanii przywileje militarne i ekonomiczne w zamian za obietnicę zakończenia mandatu.

${ }^{146}$ Ibidem, s. 51, 54-55.

${ }^{147}$ Simon przypisuje taką ich formację wpływom szkolących ich niemieckich oficerów, którzy wierzyli w kulturowy nacjonalizm i jego zdolność jednoczenia rozproszonych grup (ibidem, s. 7-9, 20-21). Niemieckie szkolenie pozostawiło w Irakijczykach preferencję rządów scentralizowanych oraz postrzeganie armii jako czynnika unifikującego kraj (ibidem, s. 9, 16-17). 
Niemniej jednak kraj poczynił postęp w dwóch dziedzinach - rozwinął edukację i armię̨ $^{148}$. Oczywiście edukacja miała pomóc zinternalizować wartości prezentowane przez irackie przywództwo; czuwał nad nią od 1921 roku dyrektor generalny Sati al-Husri, przez iracką opinię publiczną nazywany „Ojcem” ${ }^{149}$. Do 1930 roku liczba dzieci uczęszczających do szkół podstawowych podwoiła się, do szkół średnich wzrosła czterokrotnie ${ }^{150}$, choć ciągle dotyczyła mniejszości społeczeństwa irackiego. W 1932 roku Ministerstwo Edukacji zdecydowało o odrzuceniu subsydiów dla szkół prowadzonych przez mniejszości ${ }^{151}$; co więcej, szkoły te musiały uczyć z tekstów dostarczanych przez Ministerstwo. Wszystkie te kroki prowadziły do wydania w 1940 roku Prawa Edukacyjnego, według którego tylko nauczyciele zaaprobowani przez Ministerstwo mogli nauczać „narodowych” przedmiotów (tj. języka, historii, geografii, teorii praw obywatelskich), zaś studentów oceniano w specjalnych raportach pod względem lojalności względem reżi$\mathrm{mu}$ - antybrytyjskie postawy były mile widziane ${ }^{152}$.

Armia działała jak sprawne przedłużenie systemu edukacyjnego ${ }^{153}$, nacisk kładziony był na jej wzrost ilościowy. W momencie obejmowania władzy przez Brytyjczyków nie istniały oficjalnie żadne siły zbrojne, do 1932 roku liczyły one 11,5 tys. żołnierzy, do 1941 roku - 44 tys. ${ }^{154}$ Po kryzysie asyryjskim z 1933 roku popularność armii, zwłaszcza jej kadr oficerskich, wzrosła niepomiernie - siły zbrojne stały się nowym symbolem narodowym ${ }^{155} \mathrm{i}$ zapleczem politycznym władzy.

\subsubsection{Asyryjczycy po I wojnie światowej}

Asyryjczycy byli jedną z bliskowschodnich wspólnot, które po I wojnie światowej musiały stawić czoła wyłaniającym się tożsamościom narodo-

${ }^{148}$ A. I. Laing-Marshall, op. cit., s. 74.

${ }^{149}$ Al-Husri często jest porównywany z Ziyą Gökalpem, głównym teoretykiem tureckiego nacjonalizmu, który w dużym stopniu wpłynął na ukształtowanie się tureckiego systemu edukacyjnego. Al-Husri odrzucał jednak niemieckie teorie rasistowskie i promował ideały panarabskie w opozycji do wąskiego terytorialnego nacjonalizmu Republiki Tureckiej, cyt. za: ibidem, s. 75.

${ }^{150}$ R. S. Simon, op. cit., s. 83. Język arabski oraz historia Arabów wypełniały 50\% programu nauczania w szkołach podstawowych (s. 81).

151 Ibidem, s. 97.

${ }^{152}$ Ibidem, s. $107-108$.

${ }^{153}$ Ibidem, s. 108-112, 115.

${ }^{154}$ M. E. Yapp, The Near East Since the First World War, London 1991, s. 77.

155 R. S. Simon, op. cit., s. 122. 
wym nowo powstałych państw bliskowschodnich, na których terenach żyli od setek lat. Ze swą tożsamością zbiorową, wyniesioną z systemu milletowego, oraz doświadczeniem martyrologii nie czuli się członkami budowanych nacji. Szczególnie wyalienowani byli w Iraku, gdzie ich izolację pogłębiały uprzywilejowane relacje z zarządzającymi krajem Brytyjczykami. Traktowani jako społeczno-kulturalne anomalie, zasadniczo budzili wrogość większości arabskiej ${ }^{156}$.

Ochrona ich oraz innych mniejszości stanowiła jeden z najtrudniejszych problemów, który zarysował się przed społecznością międzynarodową po dezintegracji imperium osmańskiego. Dawny system milletów wspierał autonomię, lecz pozostawiał członków mniejszości w stosunku nierówności wobec panującej nacji. Zachodni koncept równości wszystkich obywateli próbowano zagwarantować w odpowiednich klauzulach, rezultatem był jednak nieadekwatny synkretyzm, rodzący rozczarowanie.

Najlepszym przykładem owego synkretyzmu był traktat z Sèvres, kończący I wojnę światową i rysujący na nowo mapę polityczną Bliskiego Wschodu ${ }^{157}$, który w art. 145 stwierdzał, że wszyscy obywatele tureccy będą równi wobec prawa i będą korzystać z tych samych politycznych i obywatelskich praw, zaś w art. 149 wzywał rząd turecki do potwierdzenia i podtrzymania „W całości prerogatyw oraz immunitetów kościelnej, edukacyjnej lub prawnej natury, nadanych przez sułtana niemuzułmanom na mocy specjalnych rozporządzeń bądź imperialnych dekretów”. Taka kombinacja przeczyła sama sobie. Przynależność jednostki do konkretnej grupy wyznaniowej pozostawała ciągle najważniejszą informacją na jej temat ${ }^{158}$.

Bardzo szerokie rozpowszechnienie idei narodowościowych w omawianym okresie było dodatkowym czynnikiem uniemożliwiającym rozwiązanie problemu mniejszości asyryjskiej. Zasada samostanowienia narodów, zapisana jako jeden z czternastu punktów Deklaracji Woodrowa Wilsona, była bowiem znana m.in. wśród beduinów południowego Iraku, górali w Dagestanie, nomadów w Kurdystanie czy tureckich nacjonalistów. Dlatego też angielsko-francuska deklaracja z 1918 roku, która przyrzekała utworzenie rdzennych rządów i administracji, „wzbudziła aspiracje pośród Ormian, Asyryjczyków, Chaldejczyków i chrześcijan syryjskich”, jak również wśród Kurdów ${ }^{159}$. Rzecz jasna, dążenia te często wzajemnie się wykluczały.

${ }^{156}$ A. I. Laing-Marshall, op. cit., s. 89.

157 Ibidem, s. 67.

${ }^{158}$ J. Joseph, The Nestorians..., s. 147-148.

${ }^{159}$ Ibidem, s. 149. 
Sami Asyryjczycy pragnęli przede wszystkim bezpiecznie wrócić do przedwojennych domów: górale do Hakkari, mieszkańcy Urmii na równiny Persji ${ }^{160}$. Ani jedni, ani drudzy nie postrzegali swojej przyszłości jako wspólnej. Trudno powiedzieć, czy w tamtym momencie pragnęli stworzyć państwo narodowe, choć na pewno pociągały ich wzmianki o samostanowieniu $^{161}$. Jedno jest pewne, żadne z państw regionu nie było zainteresowane ich przyjęciem: Kurdowie nie chcieli powrotu asyryjskich górali, rząd perski odmawiał wpuszczenia dawnych poddanych, zaś w Urmii panowały nastroje antychrześcijańskie, a jedyną władzę sprawował Simko ${ }^{162}$. W takiej sytuacji władze brytyjskie zasugerowały wspólnocie osiedlenie się w Kanadzie - Asyryjczycy odmówili ${ }^{163}$.

Na konferencję pokojową w Paryżu w 1919 roku wysłali delegacje reprezentujące interesy różnych podgrup - jedną w imieniu wspólnoty urmijskiej, inną od Asyryjczyków, którzy emigrowali na Kaukaz, gdy Rosjanie wycofywali się z Persji, jeszcze inną od Asyryjskiego Narodowego Stowarzyszenia Ameryki (Assyrian National Association of America - ANAA), a dodatkowo reprezentantów patriarchów - asyryjskiego i chaldejskiego (duchowni mieli zresztą największe doświadczenie polityczne). Nie jest jasna zawartość petycji przedstawionych przez poszczególnych delegatów, lecz wydaje się, że patriarcha chaldejski prosił o ojczyznę dla Chaldejczyków, Asyryjczyków i syryjskich ortodoksów, zaś patriarcha asyryjski jedynie dla wiernych swego Kościoła ${ }^{164}$.

Najbardziej nacjonalistyczna okazała się petycja ANAA, będąca szkicem „żądań asyryjskich” ${ }^{165}$. Wzywano w niej do stworzenia „asyryjskiego państwa, pod protektoratem jakieś potęgi mandatowej” w północnej części Mezopotamii ${ }^{166}$. Był to dokument napisany przez emigrantów rezydują-

${ }^{160}$ M. Al-Rasheed, op. cit., s. 46.

${ }^{161}$ J. Joseph, The Nestorians..., s. 151-152.

162 Ibidem, s. 158.

163 Odpowiedzieli, że osiedlą się w Kanadzie tylko wówczas, gdy nie będą mieli innego wyboru - nie będą mogli powrócić do swoich domów, ibidem, s. 156.

${ }^{164}$ W rejonie Mosulu-Dżaziry-Baszkali-Urmii, pod obcą protekcją, ibidem, s. 154; idem, The Modern Assyrians..., s. 158.

${ }^{165}$ Przez Asyryjczyków ANAA rozumiało nestorian, jakobitów, Chaldejczyków, Maronitów, jak również muzułmańskich Asyryjczyków z pewnych plemion kurdyjskich, mianowicie jezydów z Dżabal Sindżar, wreszcie niesprecyzowanych „innych”.

${ }^{166}$ J. Joseph, The Nestorians..., s. 154; S. O. Dadesho, op. cit., s. 62-64. Petycja zawierała wzmiankę o wysiłku i lojalności Asyryjczyków w czasie wojny, jak również o poniesionych przez nich stratach (był to element typowy dla wszystkich asyryjskich petycji). Interesujące jest jej zakończenie: „Żądania niniejsze pozostają w zgodzie z życzeniami Mar 
cych z dala od ojczyzny, w oderwaniu od rzeczywistości bliskowschodniej i sentymentów żywionych przez pozostawionych na miejscu współbraci.

W 1920 roku wspólnocie zabrakło przywódcy. Gdy zmarł Mar Szimun XX Paulus, który na dwa lata zastąpił zamordowanego brata, patriarchę Mar Szimuna XIX Benjamina, konsekrowano jego bratanka, Mar Eszaja Szimuna XXI, chłopca mającego w momencie wyboru zaledwie 12 lat. Szybko wyjechał on do Wielkiej Brytanii, by tam pobierać nauki ${ }^{167}$. Zniszczyło to pozycję patriarchy, który wcześniej sprawował władzę porównywalną do książęcej ${ }^{168}$. Jedyną pozostawioną na miejscu znaną osobistością z domu Mar Szimuna była ciotka ówczesnego patriarchy, Surma Chanum. Również ona wyjechała - by przedłożyć żądania asyryjskie na konferencji pokojowej ${ }^{169}$. Z powodu fizycznej nieobecności swoich przywódców Kościół Wschodu znalazł się w stanie totalnej dezorganizacji, narażony na większą niż kiedykolwiek krytykę ze strony wiernych ${ }^{170}$. [Il. 2]

W podobnie złej sytuacji znajdował się Syryjski Kościół Ortodoksyjny - na skutek wydarzeń Sejfo patriarcha Ignatius Elias III był zmuszony opuścić starożytną siedzibę w Dajr az-Zafaran w Mardinie (w 1924 roku przeniósł ją do Himsu w Syrii). Na konferencję pokojową w Paryżu wysłał późniejszego Ignatiusa Efrema I Barsuma, sam zaś wizytował wiernych w Diyarbakirze, Edessie, Aleppo, Himsie, Damaszku, Bejrucie i Stambule. W czasie wojny domowej w Turcji w 1922 roku przebywał w Jerozolimie ${ }^{171}$. W takich okolicznościach pojawiła się potrzeba świeckiego przywódcy.

Szimuna oraz wojowników [sic] i przywódców narodu asyryjskiego przekazanych w depeszach za pośrednictwem Departamentu Stanu w Waszyngtonie [sic] do przewodniczącego Asyryjskiego Narodowego Stowarzyszenia Ameryki”; podkreślenia A. I. Laing-Marshall, op. cit., s. 61.

167 J. F. Coakley, The Church of the East Since 1914, „Bulletin of the John Rylands Library", 78, 1996, s. 181.

${ }^{168}$ A. Ishaya opisuje władzę patriarchy w regionie Hakkari jako porównywalną jedynie z władzą udzielnego księcia. De facto prawo kanoniczne Kościoła Wschodu, Sunhadus, pełniło również funkcję prawa cywilnego, członkowie hierarchii kościelnej tworzyli tradycyjne zarządy miast i wsi, zaś w czasie wojny księża i biskupi byli pomiędzy asyryjskimi "generałami” (s. 37, 56), co skutkowało wysoką śmiertelnością wśród kleru.

${ }^{169}$ Choć wielu autorów opisuje Surmę jako zdolną reprezentować Asyryjczyków na forum międzynarodowym z powodu europejskiego wykształcenia, Atiya sugeruje, że nie potrafiła ona wykorzystać tradycji plemiennych swego ludu, zaś jej relacje z przywódcami plemiennymi nie były najlepsze, cyt. za: A. S. Atiya, op. cit., s. 245.

${ }^{170}$ R. S. Stafford, op. cit., s. 32, 100; S. O. Dadesho, op. cit., s. 77, 79; J. F. Coakley, op. cit., s. 182-183.

${ }^{171} \mathrm{Na}$ prośbę lorda Irwina, brytyjskiego wicekróla Indii, patriarcha przybył w 1931 roku do Kerali w celu zakończenia schizmy w Kościele malankarskim. W 1932 roku zmarł 
Został nim cieszący się reputacją patriarszego oponenta ${ }^{172}$ Agha Petros, wybrany przez Brytyjczyków w celu przeprowadzenia planu mającego zjednoczyć w Urmii wszystkich Asyryjczyków - uchodźców z Bakuby i innych - jako „naród asyryjski” ${ }^{173}$. Plan Aghi Petrosa został zaakceptowany przez większość Asyryjczyków (wszystkich pochodzących z Urmii oraz dwie trzecie górali), odrzucony zaś przez część kleru, która uważała, że należy czekać na zgodę domu patriarchy (m.in. Surmy przebywającej wtedy w Europie) ${ }^{174}$. Brytyjczycy zadecydowali, że najpierw dwa asyryjskie bataliony powinny zająć terytorium na wschód od Gawaru, kobiety i dzieci miały dołączyć później ${ }^{175}$. Przedsięwzięcie szybko okazało się porażką. Siły asyryjskie, liczące kilka tysięcy bojowników ${ }^{176}$, zostały zepchnięte przez Kurdów z powrotem do obozu uchodźców ${ }^{177}$, zaś Agha Petros utracił brytyjskie łaski i został zesłany na wygnanie do Francji ${ }^{178}$.

Innym przykładem ambitnej świeckiej próby sprawowania władzy był krótkotrwały asyryjski protektorat stworzony w regionie Al-Dżaziry, w północno-wschodniej Syrii, między rokiem 1919 a $1922^{179}$. Protektoratem, posiadającym własną flagę i armię, zarządzał Malik Kambar D’Malik Benjamin D’Bet-Malik Warda z plemienia Dżilu. Mimo obiecujących początków projekt został porzucony, a Malik Kambar wyjechał do Libanu (prawdopodobnie zaciągnął się tam do armii francuskiej) ${ }^{180}$. Wysiłki Aghi Petrosa

w klasztorze św. Stefana w Manjinikkarze, gdzie został pochowany, cyt. za: Ignatius III Elias [w:] W. Baum, Biographisch-Bibliographisches Kirchenlexikon, t. XXIV, Nordhausen 2005, s. 885-888.

${ }^{172}$ R. S. Stafford, op. cit., s. 41. S. O. Dadesho kwestionuje jednak istnienie sporu między Aghą Petrosem a rodziną patriarchy Mar Eszaja Szimuna; uważa, że historia ta została sfabrykowana przez Brytyjczyków w celu zdyskredytowania „generała” (s. 79).

${ }^{173}$ J. Joseph, The Nestorians..., s. 159.

${ }^{174}$ R. S. Stafford, op. cit., s. 41; R. W. De Kelaita, op. cit., s. 17.

${ }^{175}$ J. Joseph, The Nestorians..., s. 161. (s. 17).

${ }^{176}$ R. S. Stafford pisze o sześciu tysiącach (s. 42); R. W. De Kaleita o ośmiu tysiącach

${ }^{177}$ J. Joseph, The Nestorians..., s. 162.

${ }^{178}$ R. S. Stafford, op. cit., s. 43; R. W. De Kelaita, op. cit., s. 17. Po tych wydarzeniach Agha Petros brał jeszcze udział jako asyryjski negocjator w konferencji w Lozannie w 1923 roku. Zmarł w niewyjaśnionych okolicznościach we Francji w 1932 roku, cyt. za: F. D. Andrews (red.), The Lost Peoples of the Middle East: Documents of the Struggle for Survival and Independence of the Kurds, Assyrians, and Other Minority Races in the Middle East, Salisbury 1982, s. 102.

${ }^{179}$ Nie jest jasne, czy protektorat obejmował jedynie członków plemienia Dżilu, czy również innych plemion, jak sugeruje to S. O. Dadesho (s. 79).

${ }^{180}$ Ibidem, s. 80. 
i Malika Kambara nie przyniosły wymarzonych rezultatów, nie odeszły też daleko od dawnego modelu władzy, skupionej wokół Kościoła ${ }^{181}$. Niemniej jednak trzyletni protektorat w regionie Al-Dżaziry pozostaje jedynym geopolitycznym tworem powołanym do życia przez Asyryjczyków w czasach współczesnych oraz świadectwem poszukiwania bezpieczeństwa pod skrzydłami przywódcy nowego „narodowego” typu ${ }^{182}$.

Kolejny plan, zaaprobowany przez Brytyjczyków w 1921 roku, przewidywał „repatriację przez infiltrację”. Kilkuset Asyryjczyków z Barwari Bala (w Iraku, przy granicy z Turcja) powróciło na mocy przyjaznych porozumień z wodzami kurdyjskimi i odzyskało swe domy, „utrzymane w dobrym stanie przez Kurdów”'183. Inni, których siedziby leżały w Turcji, zostali osiedleni na równinie Mosulu pod auspicjami brytyjskimi. Mała grupa urmijskich Asyryjczyków wyemigrowała do Europy lub Ameryki, gdzie dołączyła do swoich znajomych bądź krewnych. Reszta, z wyjątkiem dwóch tysięcy, które zostały w Bagdadzie, ruszyła z powrotem do Persji z początkiem 1922 roku. Po tym, jak oddziały Rezy Chana zaatakowały i rozproszyły siły Simko w sierpniu tego roku, około połowa Asyryjczyków perskich powróciła do Urmii, pozostali dołączyli do nich później ${ }^{184}$.

Również amerykańskie misje powróciły do Urmii i próbowały przywracać normalność. Gdy problem asyryjski zdawał się sam rozwiązywać, tureccy nacjonaliści odrzucili traktat z Sèvres, zapewniający ochronę „Asyro-chaldejczykom”"185, i w 1921 roku przyjęli Pakt Narodowy, który określał politykę nowego ruchu. Artykuł pierwszy paktu sugerował utrzymanie pod tureckim panowaniem ziem zamieszkanych nie tylko przez Turków ${ }^{186}$. W 1924 roku oddziały tureckie wypchnęły Asyryjczyków ze świeżo odzyskanych domów, najprawdopodobniej w celu wzmocnienia pozycji przetargowej Turcji przed obradami Ligi Narodów co do granicznego wilajetu Mosulu, do którego pretensje rościła Wielka Brytania $^{187}$.

${ }^{181}$ Plan Aghi Petrosa przewidywał oparcie się na Sunhadusie jako kodeksie prawnym, choć państwo nie miało być kościelne, ibidem, s. 85. Prawdopodobnie chodziło o uniknięcie ewentualnych waśni z Kurdami, jezydami czy Ormianami, którzy mieli zaludnić ten sam region.

${ }^{182}$ A. I. Laing-Marshall, op. cit., s. 64-65.

${ }^{183}$ Report on Iraq Administration, 1920-22, Parliamentary Papers, London 1923, s. 108.

${ }^{184}$ J. Joseph, The Nestorians..., s. 163-164.

${ }^{185}$ N. Awde, N. Lamassu, N. Al-Jeloo, op. cit., s. 11.

${ }^{186}$ J. Joseph, The Nestorians..., s. 167.

${ }^{187}$ Ibidem, s. 176. 


\section{4}

Londyn z kolei myślał o wykorzystaniu Asyryjczyków z Hakkari przeciw Turcji poprzez włączenie ich do irackich Lewitów ${ }^{188}$ (wzorowanych na armii hinduskiej). Siły asyryjskie miały być używane do ochrony własnych uchodźców, a także do obrony północnej granicy ${ }^{189}$. Asyryjczycy początkowo unikali zaciągu, ponieważ „widzieli, iż dołączenie do Lewitów sprawi, że nie będą potem mogli żyć [w pokoju] obok Kurdów" ${ }^{190}$. W końcu jednak głód zmusił ich do zmiany decyzji - do 1928 roku formację tę tworzyli wyłącznie Asyryjczycy ${ }^{191}$, zakwaterowani w bazie lotnictwa brytyjskiego w Al-Habbanijji wraz z rodzinami ${ }^{192}$. Do osiągnięcia przez Irak niepodległości przez wspomniane oddziały przeszło 4 tys. Asyryjczyków, w szczytowym momencie służyło ich tu 2,5 tys. ${ }^{193}$ Doświadczenie to spowodowało, że w oczach Brytyjczyków Asyryjczycy zasłużyli na miana: „bojowej rasy”, „niezależnych górali”, „odwiecznych wojowników” oraz „śmiałych i zahartowanych żołnierzy" - przydomki kojarzone ze starożytnymi Asyryjczyka$\mathrm{mi}^{194}$. Te dumne wyobrażenia oraz paralele ze starożytnością zostały zinternalizowane przez żołnierzy służących w Lewitach i przekazane związanym z nimi osobom ${ }^{195}$. Jednocześnie odsunęły Asyryjczyków od reszty społeczeństwa irackiego, tym bardziej że Lewitów używano przeciw stanowiącym większość muzułmanom ${ }^{196}$. [Il. 3]

${ }^{188}$ Do 1921 roku formacja ta w całości składała się z Arabów, Turków i Turkmenów, cyt. za: ibidem, s. 165; R. S. Stafford, op. cit., s. 63.

${ }^{189}$ M. Al-Rasheed, op. cit., s. 48.

${ }^{190}$ J. Joseph, The Nestorians..., s. 166.

${ }^{191}$ R. S. Stafford, op. cit., s. 63, 65; M. Al-Rasheed, op. cit., s. 48.

${ }^{192}$ M. Al-Rasheed, op. cit., s. 48, 50. Asyryjskim rekrutom płacono więcej niż arabskim.

${ }^{193}$ R. S. Stafford, op. cit., s. 72. Jeśli założy się, że przeciętna rodzina składała się z czterech osób, to przynajmniej 16 tys. Asyryjczyków miało związek z Lewitami do 1932 roku, cyt. za: M. Al-Rasheed, op. cit., s. 49. Możliwe jest więc, że przez obóz w Al-Habbanijji przeszło ponad 30 tys. Asyryjczyków, cyt. za: A. I. Laing-Marshall, op. cit., s. 82. Lewici zostali rozwiązani w 1955 roku, większość byłych asyryjskich żołnierzy służących w ich oddziałach wstąpiła do armii irackiej na znak swej lojalności, cyt. za: J. Joseph, The Nestorians..., s. 218.

${ }^{194}$ R. S. Stafford, op. cit., s. 49-50, 65-66, 71-72.

${ }^{195}$ M. Al-Rasheed, op. cit., s. 50. Można spotkać głosy polemiczne, przekonujące o pochodzeniu od „bitnych”, starożytnych Asyryjczyków jeszcze przed wstąpieniem do Lewitów. Zob. G. Warda, rec. M. Al-Rasheed, Iraqi Assyrian Christians in London: The Construction of Ethnicity, New York 1998, JAAS, Vol. 14, No. 1, 2000, s. 86-87.

${ }^{196} \mathrm{Na}$ przykład w 1921 roku pokonali połączone siły turecko-kurdyjskie, które próbowały zyskać kontrolę nad terytorium irackim zamieszkanym przez większość turecko-kurdyjską; w latach 1924-1927 byli używani do operacji przeciwko kurdyjskiemu szejkowi Mahmudowi; w 1930 roku wraz z brytyjskim lotnictwem i armią iracką stłumili powsta- 
Wielka Brytania pozwoliła na wzrost lojalności Asyryjczyków wyłącznie względem siebie, a na wzrost antypatii ku tym, którzy mieli stać się ich rządzącymi. Kiedy stało się jasne, że przyszłość Asyryjczyków stanowi asymilacja w granicach Iraku, Brytyjczycy - miast proces przyśpieszyć - odmawiali przyznania Asyryjczykom obywatelstwa irackiego i werbowali ich do najemnych oddziałów, które tłumiły lokalne rebelie ${ }^{197}$.

Ostatnią próbę osiedlenia Asyryjczyków na ich ojczystych terenach w tureckich górach Hakkari podjęli Brytyjczycy na konferencji w Lozannie. Podczas spotkania Pierwszej Komisji w 1923 roku lord George Curzon mówił o Asyro-chaldejczykach jako o małym narodzie, którego historia, religia i cierpienia zasługują na szacunek. Jednak jego żądanie, aby Asyryjczycy powrócili do Turcji, spotkało się z całkowitą i zdecydowaną odmową tureckiego delegata ${ }^{198}$. Kiedy zagadnienie linii granicznej między Irakiem a Turcją było dyskutowane, Curzon zmienił swoje stanowisko i zaprezentował argumenty przeciwne do wcześniejszych. W obliczu tureckiego żądania całego wilajetu Mosulu użył Asyryjczyków jako powodu, dla którego nie można się zgodzić na owe roszczenia. Według niego Asyryjczycy woleli się raczej osiedlić w obcym, lecz bezpiecznym kraju, niż powrócić do Turcji - tak jak Kurdowie i Arabowie nie chcieli być częścią Turcji ${ }^{199}$. W rezultacie zgodzono się na zachowanie status quo na dyskutowanym terytorium Mosulu, a sam traktat lozański nie wymieniał Asyryjczyków, lecz ogólnie „mniejszości niemuzułmańskie”200. Negocjacje między Wielką Brytanią i Turcją odbywały się jeszcze w Stambule w 1924 roku, jednak konferencja ta niemal natychmiast utknęła w martwym punkcie ${ }^{201}$.

$\mathrm{Na}$ forum Ligi Narodów Wielka Brytania nadal naciskała na ustalenie granicy na północ od Mosulu, bez względu na fakt, że dyskutowaną kwestią była nie ojczyzna Asyryjczyków, ale los wilajetu Mosulu ${ }^{202}$. Turcy byli podejrzliwi co do powodów asyryjskiego zgromadzenia przy południowej granicy ich kraju. Po wysłuchaniu reprezentantów obu krajów Rada Ligi Narodów zadecydowała o powołaniu specjalnej ko-

nie kurdyjskie przeciw niepodległości Iraku; w 1941 roku bronili Al-Habbanijji przed iracką rebelią, cyt. za: A. I. Laing-Marshall, op. cit., s. 83.

${ }^{197}$ J. Joseph, The Nestorians..., s. 193.

198 Ibidem, s. 168-169.

${ }^{199}$ Ibidem, s. 170.

${ }^{200}$ Mimo tego, że podczas konferencji obecny był delegat asyryjski. Zob. N. Awde, N. Lamassu, N. Al-Jeloo, op. cit., s. 11.

${ }^{201}$ J. Joseph, The Nestorians..., s. 171.

${ }^{202}$ Ibidem, s. 175. 
misji w celu rozeznania faktów. Ta ostatnia po obszernych badaniach wydała osąd, że brytyjskie roszczenie do granicy poza Mosulem było nieuzasadnione ${ }^{203}$. Co do asyryjskich dystryktów na północ od wilajetu Mosulu członkowie komisji czuli, że tworzą one „terytorium bezdyskusyjnie należące do [Turcji]". W rezultacie w 1925 roku Liga Narodów przyznała północną część regionu Hakkari Turcji, zaś południową Irakowi, co zamknęło sprawę ewentualnego powrotu Asyryjczyków do ich górskich domostw ${ }^{204}$.

Asyryjczycy z Hakkari osiedleni w Iraku długo myśleli o sobie jako o uchodźcach, a swoją sytuację postrzegali jako przejściową; nawet w połowie lat 30. XX wieku nie integrowali się z resztą społeczeństwa, niewielu mówiło po arabsku, wielu pracowało w kontrolowanym przez Brytyjczyków przemyśle naftowym ${ }^{205}$. Kilku autorów wspomina o tym, że hakkaryjscy wygnańcy byli nieszczęśliwi, m.in. z powodu problemów zdrowotnych czy niedostatecznej żyzności ziemi ${ }^{206}$, choć inni wskazują na satysfakcję części asyryjskiej wspólnoty ${ }^{207}$.

Tymczasem asyryjscy przywódcy naiwnie nalegali na spełnienie obietnic Ligi Narodów. Nic dziwnego, że nacjonaliści iraccy spoglądali na nich z wrogością. Dla arabskich działaczy Asyryjczycy byli zaledwie uchodźcami, którzy bardzo wiele zawdzięczali Irakowi i nie powinni się ubiegać o żadne specjalne prawa ${ }^{208}$. Asyryjska lojalność wobec Brytyjczyków budziła podejrzliwość i rodziła oskarżenia o utrudnianie wyzwolenia się Iraku spod obcej zależności. Kiedy kraj stał się w końcu w pełni niepodległy, sytuacja Asyryjczyków zmieniła się dramatycznie na gorsze. We wrześniu 1932 roku asyryjski patriarcha, który skończył studia za granicą i powrócił na Bliski Wschód pięć lat wcześniej, wysłał do stałej komisji mandatowej petycję odnoszącą się do rekomendacji lokalnej autonomii dla Asyryjczyków, autorstwa komisji mosulskiej ${ }^{209}$. Stała komisja mandatowa przyjęła do wiadomości kwestię rekomendacji, choć cztery lata wcześniej uznała, że są ,niewykonalne”, wykazując tym samym brak konsekwencji i efektywności ${ }^{210}$.

${ }^{203}$ Ibidem, s. 176-177.

${ }^{204}$ A. I. Laing-Marshall, op. cit., s. 84.

${ }^{205}$ R. S. Stafford, op. cit., s. 60-61.

${ }^{206}$ S. O. Dadesho, op. cit., s. 87; J. Jospeh, The Modern Assyrians..., s. 190; R. S. Stafford, op. cit., s. 56-57.

207 R. S. Stafford, op. cit., s. 54-55.

${ }^{208}$ J. Joseph, The Nestorians..., s. 196.

${ }^{209}$ Ibidem, s. 190. To właśnie te rekomendacje sprawiły, że Asyryjczycy głosowali za Irakiem podczas plebiscytu w sprawie wilajetu Mosulu.

${ }^{210}$ Ibidem, s. 191-194. 
W październiku 1932 roku rząd poprosił patriarchę asyryjskiego o zaprzestanie aktywności $\mathrm{w}$ sprawach pozakościelnych (rodzina patriarsza znów stanowiła jedyne asyryjskie przywództwo uznawane zarówno przez Brytyjczyków, jak i Irakijczyków ${ }^{211}$, zaś Mar Eszaj Szimun uważał się za głównego politycznego reprezentanta swojego ludu). Konflikt między rządem a patriarchą zakończył się aresztem domowym tego ostatniego w Bagdadzie ${ }^{212}$, a w końcu wygnaniem na $\mathrm{Cypr}^{213}$. Nie powstrzymało to jednak Mar Eszaja Szimuna przed słaniem kolejnych petycji do Ligi Narodów ${ }^{214}$, choć ta otwarcie stwierdziła, że patriarcha ma się ograniczyć do spraw duchowych i odrzuciła asyryjskie żądania autonomicznej egzystencji lub osiedlenia się jako homogenicznej grupy. Wówczas frakcja propatriarsza zdecydowała się szukać azylu w Syrii, pod opieką rządu francuskiego ${ }^{215}$.

Około 700 uzbrojonych mężczyzn wiedzionych przez Jaku (tj. Jakuba), przywódcę największego plemienia z Hakkari, przekroczyło Tygrys w drodze do Syrii. Gdy Francuzi nie spełnili ich oczekiwań, emigranci zrozumieli, że muszą wracać. Przy przejściu przez rzekę napotkali siły irackie, które próbowały zapobiec ich powrotowi. Trudno stwierdzić, kto rozpoczął strzelaninę, lecz zginęło w niej bądź zostało rannych siedemdziesięciu irackich żołnierzy i oficerów ${ }^{216}$ oraz dwudziestu ludzi Jaku. Większość Asyryjczyków cofnęła się do Syrii, podczas gdy pozostali małymi grupkami wrócili do rodzin w Iraku, co nie powstrzymało wybuchu pogłosek o 1,5 tys. uzbrojonych Asyryjczyków włóczących się po kraju i szykujących do powstania.

${ }^{211}$ R. S. Stafford, op. cit., s. 102.

212 J. Joseph, The Nestorians..., s. 198-200. Rząd iracki nie widział innego sposobu na pozbycie się patriarchy, którego postrzegał jako główną przeszkodę w ostatecznym osiedleniu Asyryjczyków, cyt. za: R. S. Stafford, op. cit., s. 124.

${ }^{213}$ W 1940 roku Mar Eszaj Szimun wyemigrował do Stanów Zjednoczonych, przenosząc siedzibę patriarchatu do Chicago. Pisał i tłumaczył teksty na temat Kościoła Wscho$\mathrm{du}$, rozbudowywał organizację kościelną, ale nie angażował się politycznie. Ślub głowy Kościoła z kuzynką w drugiej linii w 1973 roku podzielił wspólnotę. W trakcie, gdy synod obradował nad jego przyszłością, patriarcha został zastrzelony 6 listopada 1975 roku w swoim domu w San Jose przez Davida Ismaila, syna słynnego Malika Ismaila - oficjalnie z powodu małżeństwa, a nieoficjalnie - zbyt małego zaangażowania w sprawę ,asyryjskiej ojczyzny”. Zob. więcej Mar Eshai Shimun, leader of Assyrians, „St. Petersburg Times”, 10.11.1975, s. 13.

${ }^{214}$ A. I. Laing-Marshall, op. cit., s. 88.

${ }^{215}$ J. Joseph, The Nestorians..., s. 201.

${ }^{216}$ Ibidem, s. 202. 
Po incydencie granicznym na początku sierpnia 1933 roku $^{217} \mathrm{~W}$ wiosce Simele miała miejsce masakra, w której zginęło 600 asyryjskich chłopów, zabitych przez iracką armię po tym, jak oddali swe strzelby lokalnej policji w zamian za przyrzeczenie, że będą bezpieczni pod opieką rządu. W ciągu kolejnych dziesięciu dni zginęło około 3 tys. asyryjskich cywili, a sześćdziesiąt pięć chrześcijańskich wsi zostało splądrowanych, zburzonych lub spalonych $^{218}$. Blisko 15 tys. Asyryjczyków zbiegło do Syrii w tym samym roku, co sprawiło, że wzdłuż rzeki Chabur wyrosło trzydzieści pięć nowych wiosek $^{219}$. Antyasyryjski generał Bakr Sidki został powitany w Bagdadzie jako bohater, który zgniótł „niezwyciężonych Asyryjczyków”220. Oficer wywiadu brytyjskiego pisał, że nienawiść Arabów do Asyryjczyków była większa niż do Anglików ${ }^{221}$. Prawdziwe działania irackiej armii ukryto przed opinią publiczną, zaś incydentu na rzece oraz sprawy asyryjskiej użyto, aby scalić podzielony naród ${ }^{222}$.

Z drugiej strony wydarzenia te zmobilizowały Ligę Narodów do szukania schronienia dla Asyryjczyków, którzy chcieli opuścić Irak. W grudniu 1933 roku Rada Ligi Narodów powołała „komitet asyryjski”, aby przygotował schemat emigracji i osadnictwa. Po czterech latach badań i prac komitet 29 września 1937 roku wydał rezolucję, która wyrażała głęboki żal, ponieważ osadnictwo Asyryjczyków poza Irakiem „nie wydawało się możliwe

${ }^{217}$ Różne źródła podają daty dzienne: 7 lub 11 sierpnia. Kurdyjskie bojówki zabiły około 120 mieszkańców dwóch asyryjskich wiosek w tygodniu między 2 a 9 sierpnia 1933 roku. Najwięcej osób zginęło 7 sierpnia, stąd data ta została w 1970 roku ogłoszona narodowym dniem żałoby przez Assyrian Universal Alliance. W 2004 roku rząd syryjski zabronił asyryjskim organizacjom politycznym obchodzenia uroczystości upamiętniających masakrę w Simele pod groźbą aresztowania, cyt. za: S. Abraham, Syrian Authorities Ban Assyrian Party from Commemorating Martyrs Day, "Good Morning Assyria”, Zinda 10.08.2004, http://www.zindamagazine.com/html/archives/2004/8.10.04/index_tue.php\#GoodMorningAssyria, data wejścia 3.08.2009. Z kolei 11 sierpnia 1933 roku kurdyjski generał Bakr Sidki poprowadził marsz na zamieszkany przez Asyryjczyków dystrykt Simele.

${ }^{218}$ Była to wyjątkowo okrutna masakra: księży ścinano lub palono żywcem, kobiety i dziewczynki pędzono nago przed muzułmańskimi dowódcami, potem gwałcono i podpalano żywcem, używając świętych ksiąg, ciężarnym przekuwano brzuchy bagnetami, dzieci rozjeżdżano wozami bojowymi, cyt. za: Kh. S. Husry, The Assyrian Affair of 1933, „International Journal of Middle East Studies” 2, 1974. Masakra w Simele zainspirowała R. Lemkina do ukucia terminu „ludobójstwo”, cyt. za: J. J. Martin, The Man Who Invented Genocide: The Public Career and Consequences of Raphael Lemkin, Costa Mesa 1984, s. 166.

${ }^{219}$ N. Awde, N. Lamassu, N. Al-Jeloo, op. cit., s. 11.

${ }^{220}$ J. Joseph, The Nestorians..., s. 203.

${ }^{221}$ M. Al-Rasheed, op. cit., s. 49.

222 J. Joseph, The Nestorians..., s. 204. 
do przeprowadzenia, podobnie jak zorganizowanie transferu gdziekolwiek indziej Asyryjczyków osiedlonych w dolinie Chaburu w Syrii”. Tak więc komitet zawiódł223.

W swoim ostatnim raporcie do Rady Zarząd Powierniczy Ligi mówił o Asyryjczykach w Syrii jako o prosperującej wspólnocie, która cieszyła się bezpieczeństwem. Z kolei raport rządu irackiego do Rady z września 1938 roku pokazywał, że autochtoniczni Asyryjczycy żyli w swych przedwojennych domach w Nirwa, Rajkan, Barwari Bala; Asyryjczycy z Hakkari osiedlili się głównie w Szajchanie, Amadijji, Dahuku oraz okręgu Mosulu - Zibarze, a także w dystrykcie Irbilu - Rawanduz. Z siedemdziesięciu trzech wiosek zasiedlonych przez hakkaryjczyków dwadzieścia cztery należały do rządu, a czterdzieści dziewięć do prywatnych właścicieli. Szczegółowe statystyki wskazywały, że Asyryjczykom nie powodziło się gorzej niż ich sąsiadom.

Informacje na temat perskich Asyryjczyków w dwudziestoleciu międzywojennym są skąpe, niewiele wiadomo o tym, jak przyjmowali inicjatywy reżimu Pahlawich. Prawdopodobnie udawało się im utrzymać dobre stosunki z rządem centralnym (być może z powodu geograficznego oddalenia), choć zachowali też poczucie odrębności ${ }^{224}$.

W przededniu II wojny światowej dla znakomitej większości Asyryjczyków podstawowymi troskami były bezpieczeństwo i przetrwanie, nie zaś budowanie własnego narodu. Lata międzywojenne były czasem ponownego objęcia władzy nad wspólnotą przez patriarchę i jego poświęcenia się sprawom politycznym - patriarcha jawił się w oczach społeczności międzynarodowej jako głowa „narodu” (według ówczesnych poglądów, nie definicji przedstawionych w Rozdziale 1). W imieniu „narodu” Mar Szimun Eszaj apelował o autonomię. Tym samym Asyryjczycy pozostawali wspólnotą polityczno-religijną, bardzo podobną do tradycyjnego milletu ${ }^{225}$.

\subsection{II wojna światowa}

W Urmii Asyryjczycy żyli bezpiecznie do II wojny światowej. Potem historia zdawała się powtarzać. Z powodu poparcia udzielonego Niemcom siły sprzymierzonych uznały za konieczną okupację Iranu: w 1941 roku jego północne prowincje zostały włączone do Związku Radzieckiego. Okupacja ta

${ }^{223}$ Ibidem, s. 206-208.

${ }^{224}$ E. Sanasarian, op. cit., s. 107; A. Ramezanzadeh, op. cit., s. 119.

${ }^{225}$ A. I. Laing-Marshall, op. cit., s. 90. 
miała być jednak „przejściowa”, traktowana jako czasowy środek zapobiegawczy $^{226}$. W Pakcie Trójstronnym z 1942 roku Związek Radziecki i Wielka Brytania zagwarantowały terytorialną jedność i polityczną niepodległość Iranowi. Gdy wojna się skończyła, oba państwa zgodziły się, że ewakuacja powinna zakończyć się do 2 marca 1946 roku. Zaledwie miesiąc po tym porozumieniu wybuchła separatystyczna rewolta w Azerbejdżanie, podczas której ZSRR zachęcił miejscowych Asyryjczyków i Ormian do wsparcia komunistycznej Partii Demokratycznej. W rezultacie powstał „narodowy rząd perskiego Azerbejdżanu", a rewolta szybko rozprzestrzeniła się na południe do perskiego Kurdystanu, co zaowocowało potyczkami między Kurdami a armią narodową ${ }^{227}$.

Po owych zamieszkach armia ZSRR ogłosiła, że jej oddziały pozostaną w Azerbejdżanie „do czasu wyjaśnienia sytuacji”. Iran wniósł sprawę przed Narody Zjednoczone; był to pierwszy poważny problem do rozważenia przez tę organizację. Związek Radziecki został zmuszony do wycofania swoich oddziałów, ale Teheran musiał oddać kontrolę nad polami naftowymi północnego Iranu w ręce radzieckiej kompanii. „Azerbejdżański Rząd Demokratyczny" zaakceptował status rady prowincji. Ugoda obiecywała Asyryjczykom i Ormianom "takie same przywileje jak Azerom”228.

Dwa miesiące później irańska armia wkroczyła niepowstrzymywana przez oddziały radzieckie; opór był znikomy, a Asyryjczycy znów padli ofiarą konfliktu. Słowa raportu prezbiteriańskiego zarządu cudzoziemskich misji przypominały informacje z dawnych dni: „Duża liczba asyryjskich wiosek została ogołocona niemal ze wszystkiego, domy zupełnie zniszczone... zwierzęta zostały ukradzione, a zapasy ziarna wyniesione"229. Tym razem Asyryjczycy z Urmii byli zmuszeni opuścić rodzinne wioski na zawsze i połączyć się ze swymi krewnymi w dużych miastach Iranu ${ }^{230}$.

Sytuacji Asyryjczyków w Iraku nie poprawiło poparcie przez nich aliantów podczas II wojny światowej, gdyż stawiało ich w opozycji do antyalianckiego rządu. W 1941 roku iracki rząd kazał zaatakować bazę w Al-Habbanijji, używaną przez siły europejskie jako istotny punkt przerzutowy na drodze z Indii do Europy ${ }^{231}$. Brytyjczycy stawili opór i sami zajęli Bagdad, przywracając rządy Haszymidów ${ }^{232}$. Nowi przywódcy iraccy przyjęli żądania brytyjskie w sprawie

\footnotetext{
${ }^{226}$ A. Ramezanzadeh, op. cit., s. 80.

227 J. Joseph, The Nestorians..., s. 209-211.

${ }^{228}$ Ibidem, s. 212-213.

${ }^{229}$ Annual Report of the Presbyterian Board of Foreign Missions, 1947, s. 50.

${ }^{230}$ J. Joseph, The Nestorians..., s. 213.

${ }^{231}$ R. S. Simon, op. cit., s. 135-136, 148, 150-151.

${ }^{232}$ F. D. Andrews (red.), op. cit., s. 28.
} 
tranzytu wojsk i zaopatrzenia, a w 1942 roku wypowiedzieli wojnę państwom Osi. Frustracja pokonanego tłumu obróciła się przeciwko mniejszościom etnicznym, szczególnie przeciw Żydom ${ }^{233}$, ale też Asyryjczykom. Nawet pod koniec 1945 roku asyryjscy przywódcy z Iraku ciągle wywierali presję na wspólnotę międzynarodową, aby umożliwiła ich społeczności emigrację z kraju ${ }^{234}$, jednak Zachód nie był zainteresowany udzieleniem pomocy - nie widział możliwości pozytywnego rozwiązania skomplikowanej sprawy, szacował koszty, poza tym zmieniło się teoretyczne podejście do mniejszości i asymilacji. Asyryjczycy mogli zostać w Iraku bądź emigrować jako jednostki ${ }^{235}$.

W Turcji podczas II wojny światowej muzułmanów i niemuzułmanów obciążono różnymi podatkami - tych drugich dziesięć razy wyższymi ${ }^{236}$. Za to w Syrii Asyryjczycy przestali być oficjalnie uchodźcami w 1941 roku, gdyż wtedy przyznano im obywatelstwa. W odróżnieniu od swych pobratymców w Iraku, którzy zamieszkiwali główne miasta, syryjscy Asyryjczycy zgrupowali się w wioskach według swojej przynależności plemiennej ${ }^{237}$.

\subsubsection{Turcja po II wojnie światowej}

Asyryjczycy, podobnie jak inne mniejszości etniczne w Turcji, poddani byli silnej turcyzacji. Kościoły i klasztory oddano pod rządową kuratelę, ich aktywność została ograniczona, działalności instytucji asyryjskich i chaldejskich zakazano; miejsca o historycznym znaczeniu dla chrześcijaństwa niszczały ${ }^{238}$. Pozostało fizyczne zagrożenie, spowodowane starciami między Kurdami a Turkami we wschodniej części kraju, dotykające mieszkańców regionu bez względu na ich pochodzenie i poglądy. Mimo konstytucyjnych praw, obejmujących wyznawców wszystkich religii, ciągle zdarzały się ataki, szczególnie wymierzone przeciw chrześcijanom ${ }^{239}$.

${ }^{233}$ Szczególnie przeciw Żydom - prawie dwustu zabito w zamieszkach w Bagdadzie przy praktycznym braku reakcji ze strony Brytyjczyków, cyt. za: R. S. Simon, op. cit., s. $153-154,158-160$.

${ }^{234}$ F. D. Andrews (red.), op. cit., s. 26-37.

235 A. I. Laing-Marshall, op. cit., s. 97.

${ }^{236}$ B. Lewis, op. cit., s. 353. Dwie pozostałe kategorie obejmowały sabatejskich konwertytów na islam, którzy płacili dwukrotność stawki muzułmańskiej, oraz cudzoziemców, płacących tyle co muzułmanie, cyt. za: A.I. Laing-Marshall, op. cit., s. 71.

${ }^{237}$ J. Joseph, The Nestorians..., s. 217.

${ }^{238}$ J. Yacoub, op. cit., s. 324-325.

${ }^{239}$ M. M. van Bruinessen, The Christians of Eastern Turkey, the State and the Local Power Structure, „ICMC Migration News”, No. 3-4, 1979, s. 43, 46. 
Asyryjczycy z Turcji również doświadczyli przesiedleń, gdy znaleźli się pomiędzy siłami rządowymi a Kurdyjską Partią Pracy (PKK). Między 1992 a 1996 rokiem ponad trzydzieści asyryjskich wiosek w Tur Abdinie i Bohtanie zostało ewakuowanych i zniszczonych. Wielu Asyryjczyków zaginęło w drodze do domu, wiele asyryjskich dzieci, przeważnie dziewczynek, zostało porwanych, a znaczna część przywódców wymordowana. W kolejnych latach pięćdziesiąt dwie asyryjskie wioski były w jakimś stopniu okupowane przez siły kurdyjskie. Kurdowie osiedlili się ponadto w prawie dwustu wcześniej zburzonych wsiach, które kiedyś należały do Asyryjczyków. Prawa człowieka były nagminnie łamane.

Mnożyły się niewyjaśnione morderstwa i ataki, jak również blokady asyryjskich regionów czy próby zlikwidowania klasztorów ${ }^{240}$. [Il. 4] Asyryjczycy w Turcji nigdy nie zostali uznani za mniejszość etniczną (oficjalnie figurują jako „chrześcijańscy Turcy”), dlatego nie mogli walczyć o swoje prawa, włącznie z prawem do otwarcia własnych placówek edukacyjnych i nauczania własnego języka. W praktyce nauczyciele aramejskiego często byli więzieni za swoją pracę. W 1957 roku utworzono komisję do zmian imion i nazw, w wyniku pracy której tysiące wiosek otrzymało nowe (tureckie) nazwy, zaś w latach 1983-2000 komisja nadała tureckie nazwy kolejnym dwustu miejscowościom ${ }^{241}$. Z 40 tys. chrześcijan, którzy zamieszkiwali południowo-wschodnią Turcję w 1974 roku, do czasów dzisiejszych przetrwały dwa tysiące ${ }^{242}$. Mieszkają głównie w Stambule, małe grupki w Tur Abdinie i Bohtanie $e^{243}$.

\subsubsection{Iran po II wojnie światowej}

Iran również doświadczył dramatycznych zmian po II wojnie światowej. W 1941 roku alianci pozbawili tronu Rezę Szaha; zastąpił go syn Mohammad Reza Pahlawi (znany jako Mohammad Reza Szah) ${ }^{244}$. Okres

${ }^{240}$ Ostatnio poczyniono próby skonfiskowania ziem najstarszego funkcjonującego klasztoru św. Gabriela, należącego do Syryjskiego Kościoła Ortodoksyjnego. Zob. więcej A. BarAbrahem, Nękanie asyryjskiego klasztoru Mor Gabriel przez Turków i Kurdów, http:// pixartmedia.home.pl/szlomo/index2.php?option=com_content\&do_pdf=1\&id=189, data wejścia 4.08.2009.

${ }^{241}$ Asyryjczycy upominaja się o swoje - przynajmniej nazewnictwo..., data wejścia 4.08.2009.

${ }^{242}$ N. Awde, N. Lamassu, N. Al-Jeloo, op. cit., s. 12-13.

${ }^{243}$ G. Çiyan, op. cit., s. 3.

${ }^{244}$ I. M. Lapidus, op. cit., s. 583. 
od abdykacji Rezy Szaha do 1953 roku (czyli powrotu silnej monarchii) był czasem rosnącej politycznej wolności - więźniowie polityczni zostali uwolnieni, powstawały i obradowały nowe partie, publikacje nie podlegały cenzurze $^{245}$. W 1951 roku premier Mohammad Mosaddegh znacjonalizował przemysł naftowy, jednak zachodni bojkot irańskiej ropy zmusił go do ustąpienia dwa lata później i przygotował grunt pod przewrót wspierany przez USA, który całą władzę oddał w ręce Mohammada Rezy Szaha.

Władca, podobnie jak jego ojciec, promował nacjonalizm poprzez edukację i prowadził politykę agresywnej modernizacji kraju - program reform zawierała tzw. Biała Rewolucja z 1963 roku, która wymagała dużych ofiar społecznych, szczególnie od mas rolniczych. Opozycja wobec szacha skupiała wieśniaków, ale też kupców, artystów, intelektualistów oraz uczonych muzułmańskich. W 1964 roku popularny duchowny ajatollah Ruhollah Chomejni został wygnany za swoją krytykę rządu - na emigracji rozbudował teorię władzy duchownych. Gdy w 1978 roku niezadowolenie objęło bardzo szerokie kręgi społeczeństwa i zaowocowało paraliżującą kraj rewolucją, szach uciekł, zaś Chomejni powrócił jako najwyższy autorytet nowego teokratycznego reżimu ${ }^{246}$ i w kolejnych latach przebudował społeczeństwo irańskie według zasad prawa muzułmańskiego.

Konsekwencją zmiany była zwiększona kontrola rządu nad życiem prywatnym obywateli oraz czystki ${ }^{247}$. Dla niemuzułmanów nastanie republiki muzułmańskiej oznaczało przedefiniowanie ich statusu. W programach szkolnych elementy przedmuzułmańskie zostały zredukowane do minimum, godziny poświęcone na naukę religii pomnożone ${ }^{248}$. Przywrócono kategorię zimmi i wprowadzono liczne regulacje mające na celu oddzielnie ich od muzułmanów oraz zachowanie dominacji i czystości tych ostatnich ${ }^{249}$. Niemuzułmanie doświadczali dyskryminacji społecznej, także w sferze zatrudnienia ${ }^{250}$. Oficjalnie nie wolno im było pełnić wyższych urzędów w życiu politycznym czy militarnym kraju ${ }^{251}$.

Z drugiej strony niektóre grupy, m.in. Asyro-chaldejczycy, zostali uznani za religijne mniejszości; jako tacy cieszyli się niemal zupełną wolnością kultu i mieli prawo posiadać jednego (wspólnego dla Asyryjczyków i Chal-

${ }^{245}$ A. Ramezanzadeh, op. cit., s. 81.

${ }^{246}$ I. M. Lapidus, op. cit., s. 585-586.

${ }^{247}$ E. Sansarian, op. cit., s. 18.

${ }^{248}$ M. Vaziri, op. cit., s. 199.

${ }^{249}$ E. Sansarian, op. cit., s. 23-24.

${ }^{250}$ Ibidem, s. 87-88.

${ }^{251}$ G. Çiyan, op. cit., s. 3. 
dejczyków) reprezentanta w parlamencie, któremu teoretycznie przysługiwały takie same prawa jak reprezentantom muzułmańskim ${ }^{252}$. Dychotomia owa była wynikiem tradycyjnie ambiwalentnej postawy duchownych muzułmańskich względem zimmich - rozdartych między autorytaryzmem a tolerancją 253 .

Do lat 60. XX wieku zwiększające się polityczne i ekonomiczne bezpieczeństwo zachęciło młodych Asyryjczyków do identyfikowania się z resztą społeczeństwa i marzenia o lepszej przyszłości ${ }^{254}$. Przed wybuchem rewolucji islamskiej Asyryjczycy chcieli jedynie „żyć w pokoju ze swymi sąsiadami" i nie szukali autonomii. Pod wpływem polityki Pahlawich mogli nawet poczuć się „Irańczykami”. Prawdopodobnie ich niewielka liczebność jako wspólnoty powodowała, że byli akceptowani zarówno przez irańskich, jak i kurdyjskich nacjonalistów ${ }^{255}$, inaczej niż miało to miejsce w przypadku Ormian i Żydów ${ }^{256}$. Wojna iracko-irańska dała im możliwość wykazania lojalności wobec rządu, i choć wielu emigrowało lub wysłało swoich synów za granicę, by uchronić ich przed służbą wojskową, to ci, którzy pozostali, szli na front, bądź płacili składki na cele wojenne. Zabitych nazywano na sposób szyicki „męczennikami”257 i pisano o nich wiersze, co wzmacniało poczucie jedności z muzułmańską większością.

Sukces Asyryjczyków w utrzymaniu pozytywnych relacji z rządem wyrażał się najdobitniej w przyjęciu nazwy „Asyryjczycy” na określenie całej wspólnoty. Przeciwnie niż w Iraku, gdzie większość Chaldejczyków rozwijała odrębną tożsamość, w Iranie wielu wolało identyfikację asyryjską ${ }^{258}$. Jednak podkreślana przez rząd muzułmańskość wykluczała Asyryjczyków z głównego nurtu życia społecznego, tym samym umacniając poczucie odrębności ${ }^{29}$ ciągle kurczącej się wspólnoty (w wyniku rewolucji islamskiej jej liczebność spadła w ciągu ćwierćwiecza z 80 tys. do 15 tys. w 2002 roku $\left.^{260}\right)$.

${ }^{252}$ D. Menashri, Khomeini's Policy Toward Ethnic and Religious Minorities [w:] M. J. Esman, I. Rabinovich (red.), Ethnicity, Pluralism, and the State in the Middle East, New York 1988, s. 222. Asyro-chaldejski deputowany najczęściej zabierał głos spośród reprezentantów mniejszości, cyt. za: E. Sanasarian, op. cit., s. 70.

${ }^{253}$ D. Menashri, op. cit., s. 30-33.

${ }^{254}$ J. Joseph, The Nestorians..., s. 213.

${ }^{255}$ R. W. Cottam, op. cit., s. 82-83. Cottam cytuje raport misjonarzy z lat 70. XX wieku, według którego Asyryjczycy w większości byli lojalni wobec rządu.

${ }^{256}$ D. Menashri, op. cit., s. 223-224; E. Sansarian, op. cit., s. 70.

257 E. Sansarian, op. cit., s. 143. Straty ludzkie pośród Ormian i Asyryjczyków były szczególnie wysokie (s. 75).

${ }^{258}$ Ibidem, s. 40-41, 177.

${ }^{259}$ A.I. Laing-Marshall, op. cit., s. 107.

${ }^{260}$ N. Awde, N. Lamassu, N. Al-Jeloo, op. cit., s. 13. 
Obecnie irańscy Asyryjczycy zamieszkują głównie Teheran, poza tym są rozproszeni po całym kraju ${ }^{261}$.

\subsubsection{Irak po II wojnie światowej}

Przewrót „Wolnych Oficerów” w 1958 roku przyniósł kres okupacji brytyjskiej oraz niepopularnej monarchii haszymidzkiejej ${ }^{262}$ Antagonizm między lewicą (irackimi nacjonalistami i komunistami) a prawicą (panarabistami z partii Al-Bas i naserystami) ${ }^{263}$ zakończyło przejęcie władzy przez basistów w 1963 roku. Nowy autorytarny rząd, odwołujący się w warstwie ideologicznej do haseł panarabskich (inny odłam partii Al-Bas rządził w Syrii), socjalistycznych oraz antyimperialistycznych, nie stronił od fizycznej eliminacji przeciwników politycznych ${ }^{264}$. Po pięciu latach osiągnął hegemonię, po dziewięciu znacjonalizował przemysł naftowy, zyskując środki na reformy, które przyniosły zasadniczą poprawę życia w Iraku ${ }^{265}$. Rozwojowi sektora publicznego i prywatnego towarzyszyło jednak rozbudowanie aparatu inwigilacji, przede wszystkim tajnej policji ${ }^{266}$.

Asyryjczycy stanowili w Iraku trzecią największą wspólnotę (po Arabach i Kurdach), dlatego też basiści nie mogli ich ignorować. Chcąc zjednoczyć wszystkich obywateli, rząd zaczął używać symboli przedmuzułmańskich, należących do ludów niegdyś zamieszkujących region, m.in. Babilończyków, Sumerów, Asyryjczyków i Chaldejczyków. Chętnie i otwarcie czerpano z mitologii i symboliki mezopotamskiej (np. przedstawiając postaci Hammurabiego, Nabuchodonozora, Gilgamesza czy skrzydlatych byków ${ }^{267}$. Prowincję Mosulu nazwano Niniwą, zaś Al-Hillę - Babilonem ${ }^{268}$.

Z czasem większość Asyryjczyków zaczęla się asymilować. Choć ich patriarcha przebywał na uchodźstwie, teoretycznie cieszyli się większością przywilejów nadanych oficjalnym grupom mniejszościowym ${ }^{269}$. Konstytucja z 1970 roku uznawała islam za religię państwową, przyznawała jednak

${ }^{261}$ G. Çiyan, op. cit., s. 3.

${ }^{262}$ S. Haj, op. cit., s. 111.

${ }^{263}$ M. Farouk-Sluglett, P. Sluglett, Iraq Since 1958: From Revolution to Dictatorship, London, New York 1987, s. 51, 60-61.

${ }^{264}$ Według Irackiej Partii Komunistycznej do 1961 roku zostało zabitych ponad 285 jej członków i sympatyków, ibidem, s. 65.

${ }^{265}$ Ibidem, s. 173.

${ }^{266}$ S. Haj, op. cit., s. 137-138.

${ }^{267}$ Saddam Husajn kontynuował tę tradycję po dojściu do władzy w latach 1975-1979, cyt. za: M. Farouk-Sluglett, P. Sluglett, op. cit., s. 179; R. S. Simon, op. cit., s. 167.

${ }^{268}$ A. Baram, Culture, History and Ideology in the Formation of Ba'thist Iraq, 1968-1989, New York 1991, s. 62.

${ }^{269}$ J. Jospeh, The Nestorians..., s. 216. 
„prawa wszelkim mniejszościom w obrębie irackiej jedności”. Dodatkowo dekret z 1972 roku nadawał trzem wspólnotom aramejskojęzycznym prawo do nauczania ich języka w szkołach, gdzie przynajmniej $25 \%$ dzieci było chrześcijanami, swobodnego odnawiania i wznoszenia kościołów czy brania udziału w uroczystościach religijnych oraz kształcenia duchowieństwa w seminariach ${ }^{270}$.

„Asyryjczycy, Chaldejczycy i Syryjczycy” mogli zakładać centra kulturalne i organizacje, nadawać programy radiowe i telewizyjne po aramejsku; funkcjonowała akademia, której celem było pielęgnowanie języka aramejskiego $^{271}$. Mimo cenzury drukowano dobre publikacje o kulturze asyryjsko-aramejskiej, jak „Myśl Chrześcijańska” („Al-Fikr al-Masihi”) i „Mezopotamia” („Bajn an-Nahrajn”). Chrześcijanie zajmowali eksponowane stanowiska, choć nigdy zbyt licznie ${ }^{272}$. Wszystkie te środki spowodowały, że w latach 60. XX wieku młodzi Asyryjczycy chętnie uczyli się arabskiego, a aramejski zaczął popadać w zapomnienie ${ }^{273}$. Gdy w 1975 roku ponownie zostały nałożone na Asyryjczyków restrykcje kulturalne (w związku ze wzrostem napięcia między rządem a Kurdami), nie spowodowały żadnej rewolty asyryjskiej.

W 1979 roku do władzy doszedł Saddam Husajn. W epoce jego dyktatury polityczna sytuacja chrześcijan, w szczególności chaldejskich ${ }^{274}$, była stosunkowo dobra, nie było otwartych prześladowań skierowanych przeciw całej wspólnocie. Preferowani jako pośrednicy w kontaktach z Zacho-

${ }^{270}$ R. J. Mouawad, Syria and Iraq - Repression, „The Middle East Qurtely”, Vol. VIII, No. 1, Winter 2001, http://www.meforum.org/article/17, data wejścia 3.08.2009.

${ }^{271}$ R. Le Coz, op. cit., s. 385-386; S. O. Dadesho, op. cit., s. 201.

${ }^{272}$ R. B. Betts, Christians in the Arab East: A Political Study, Atlanta 1975, s. 35, 182. Najbardziej prominentnym Asyryjczykiem w Iraku był wicepremier Tarik Aziz, chaldejski chrześcijanin, który zanim wstąpił do Partii, nazywał się Michail Juhanna, cyt. za: J. E. Lewis, Iraqi Assyrians: Barometer of Pluralism, „The Middle East Qurtely”, Vol. X, No. 3, Summer 2003, http://www.meforum.org/article/558, data wejścia 4.08.2009. Znany był z licznych wystąpień i kontaktów międzynarodowych, prowadził też kampanię dyplomatyczną, by odsunąć groźbę interwencji USA w 2003 roku; sam znajdował się na 43. miejscu listy 55 najbardziej poszukiwanych przez Amerykanów członków irackich władz. Poddał się Amerykanom 24 kwietnia 2003 roku i od tego czasu pozostaje prawdopodobnie w bagdadzkim więzieniu Camp Cropper, cyt. za: O. Craig, Dirty, Hunched and Hungry: Tariq Aziz Digs His Own Latrine, „Sunday Telegraph”, http:/www.telegraph.co.uk/news/ main.jhtml?xml=/news/2003/07/20/wirq220.xml, data wejścia 4.08.2009.

${ }^{273}$ J. Jospeh, The Nestorians..., s. 217. W praktyce suret, aramejski dialekt Asyryjczyków z Iraku, uczony był niemal wyłącznie w obrębie rodzin, na uniwersytetach oraz podczas lekcji katechezy w piątki, co powodowało powolny jego zanik, cyt. za R. J. Mouawad, op. cit.

${ }^{274} \mathrm{~W}$ odróżnieniu od Asyryjczyków, którzy posiadali opinię antyrządowych rebeliantów, wspólnota chaldejska relatywnie łatwo nawiązała pozytywne relacje z władzami centralnymi, cyt. za: J. Joseph, Muslim-Christian..., s. 115-117. 
dem, chrześcijanie pracowali w sektorze turystycznym, posiadali restauracje i hotele, trudnili się handlem, wreszcie byli przedstawicielami wolnych zawodów (stanowili około 20\% nauczycieli i wykładowców w Iraku przed rokiem 2003). Wielu z nich było także artystami lub wysoko wykwalifikowanymi rzemieślnikami czy handlowcami ${ }^{275}$.

Nie zmienia to faktu, że rządy Saddama Husajna charakteryzowały się próbami arabizacji Asyryjczyków i wymazania ich wyjątkowej tożsamości etnicznej. Zmuszano ich, by rejestrowali się jako Arabowie bądź Kurdowie podczas narodowego spisu powszechnego. Wszystkie organizacje nacjonalistyczne zeszły do podziemia, ukrywając swoją działalność. W późniejszych latach swych rządów Saddam zmuszał asyryjskich rodziców, by nadawali nowo narodzonym dzieciom arabskie lub muzułmańskie imiona ${ }^{276}$.

Jednak dopiero wybuch wojny iracko-irańskiej w 1980 roku (konflikty graniczne z Iranem miały miejsce od 1969 roku $^{277}$ ), w której po stronie irackiej służyło wielu Asyryjczyków ${ }^{278}$, spowodował falę masowej emigracji - około pół miliona chrześcijan opuściło wówczas kraj; kolejna fala nastąpiła po wprowadzeniu przez ONZ na początku lat 90. XX wieku embarga, które zakończyło okres relatywnego prosperity wspólnoty chrześcijańskiej. $\mathrm{Na}$ północy, w okolicach Mosulu, Asyryjczycy padali ofiarą konfliktu między rządem a Kurdami, z którymi zresztą często się identyfikowali (siły irackie nie odróżniały jednej mniejszości od drugiej) ${ }^{279}$. Szczególnie podczas kampanii „Al-Anfal” w latach 1986-1989 wielu Asyryjczyków spotkał ten sam los co ich kurdyjskich sąsiadów ${ }^{280}$. Iracki rząd zniszczył wtedy 189 wiosek na północy kraju. Setki ludzi straciło życie, prawie 5 tys. rodzin zostało wysiedlonych, a 80 starożytnych kościołów i klasztorów zrujnowanych ${ }^{281}$.

Nic dziwnego, że część Asyryjczyków wybrała aktywną walkę przeciw rządowi ${ }^{282}$. Asyryjski Ruch Demokratyczny (Assyrian Democratic Movement), tzw. Zowaa, powstał w 1979 roku. Jego celem było umocnienie

${ }^{275}$ R. J. Mouawad, op. cit.

${ }^{276}$ N. Awde, N. Lamassu, N. Al-Jeloo, op. cit., s. 12.

277 A. Baram, op. cit., s. 14.

${ }^{278}$ S. O. Dadesho, s. 221; J. Yacoub, op. cit., s. 191-192.

${ }^{279}$ J. Jospeh, The Modern Assyrians..., s. 214.

${ }^{280}$ Human Rights Watch/Middle East, Iraq's Crime of Genocide: The Anfal Campaign Against the Kurds, London 1995, s. 11, 14. W dniach 16-17 marca 1988 roku wojsko irackie przy pomocy broni chemicznej dokonało masakry 5 tys. mieszkańców kurdyjskiego miasta Halabdża, dalsze 10 tys. osób zostało rannych $(75 \%$ ofiar stanowiły kobiety i dzieci).

${ }^{281}$ N. Awde, N. Lamassu, N. Al-Jeloo, op. cit., s. 12.

${ }^{282}$ S. O. Dadesho, op. cit., s. 197. 
podstaw narodowej egzystencji Asyryjczyków na ich rdzennych ziemiach. Zowaa współdziałała z ruchem kurdyjskim i zyskała taką popularność, że jej przedstawiciele otrzymali cztery z pięciu miejsc przeznaczonych dla chrześcijan w kurdyjskiej strefie autonomicznej ustanowionej w północnym Iraku po pierwszej wojnie w Zatoce w 1991 roku $^{283}$. W irackim Kurdystanie Asyryjczycy po raz pierwszy od dziesięcioleci mogli działać w polityce, tworzyć partie, otwierać urzędy, publikować i nadawać w swoim języku, wreszcie nauczać na poziomie szkół podstawowych i średnich po aramejsku. Niestety, nieunikniona wojna domowa między Kurdyjską Partią Demokratyczną (KDP) oraz Patriotyczną Unią Kurdystanu (PUK) sprawiła, że ponownie znaleźli się w środku niechcianego konfliktu ${ }^{284}$.

Zamach 11 września 2001 roku i ogłoszona w jego rezultacie wojna z terroryzmem, która zaowocowała obaleniem Saddama Husajna, przyniosły tragiczne skutki dla chrześcijańskiej mniejszości Iraku. Chrześcijanie, jako „niewierni”, stali się celem prześladowań na tle religijnym, ekonomicznym i politycznym. Oskarżani o kolaborację z Zachodem, znów padali ofiarą ataków ekstremistów, mimo potępienia takich akcji przez najwyższych muzułmańskich przywódców duchowych. Porwania, wymuszenia okupu, grabieże, zamachy bombowe na kościoły oraz żądania dostosowania się w sferze ubioru i zwyczajów do muzułmańskiej większości stały się codziennością. Nowa konstytucja z 2005 roku uczyniła islam podstawowym źródłem ustawodawstwa. W obliczu bezsilności amerykańskiego wojska rozpoczął się jeszcze jeden exodus Asyryjczyków, przetartym uprzednio szlakiem do Jordanii, Syrii, Libanu i państw zachodnich ${ }^{285}$. [Il. 5]

Według ostatniego spisu powszechnego z 1987 roku Irak zamieszkiwało $1,4 \mathrm{mln}$ chrześcijan ${ }^{286}$. Bieda i wojna spowodowały, że w ciągu minionych lat wyjechało ich stamtąd ponad pół miliona i obecnie wszystkie chrześcijańskie wspólnoty liczą w przybliżeniu 700 tys. osób, stanowiąc tym samym około 3\% całej populacji kraju ${ }^{287}$.

${ }^{283}$ J. Jospeh, The Modern Assyrians..., s. 219.

${ }^{284}$ N. Awde, N. Lamassu, N. Al-Jeloo, op. cit., s. 13.

${ }^{285}$ Zob. więcej: M. Woźniak, Exodus mniejszości asyrochaldejskiej z Iraku po 11 września 2001 r. w mediach anglojęzycznych [w:] M. Abdalla (red.), Niemuzutmańskie mniejszości..., s. 241-257.

${ }^{286}$ M. Valentinas, Kidnapping of Catholic Archbishop Highlights Christians' Plight', RFE/RL, http://www.rferl.org/featuresarticle/2005/01/74eb1e20-ea60-4fd0-ad51-22dc3cf2e99b. html, data wejścia 3.08.2009.

${ }^{287}$ The Christians of Iraq, Al Jazeera, http://english.aljazeera.net/NR/exeres/1E5FAE568F8B-496E-86BB-136D2BBD0999.htm, data wejścia 3.08.2009. 


\subsubsection{Syria po II wojnie światowej}

Najwięcej Asyryjczyków przybyło do Syrii na początku mandatu francuskiego (w latach 1922 i 1924) jako uchodźcy z Turcji oraz z Iraku po roku $1933^{288}$. Liczebność populacji asyryjskiej wynosiła w połowie XX wieku około miliona, jednak zmniejszyła się przynajmniej dwukrotnie po przewrocie wojskowym w 1973 roku, gdy do władzy doszła partia Al-Bas. Asyryjczycy, podobnie jak inne mniejszości niemuzułmańskie, nie mają zagwarantowanych praw narodowych. W zamieszkanym w dużej mierze przez nich rejonie Al-Dżaziry (Al-Hasaka) na północnym wschodzie kraju rząd od dwudziestu lat wznieca animozje asyryjsko-kurdyjskie (oraz kurdyjskoarabskie), co owocuje sporadycznymi wybuchami międzyetnicznej agresji.

Mimo tego zagrożona mniejszość irackich chrześcijan ucieka głównie do Syrii, Jordanii i Libanu ${ }^{289}$. Dla ludzi, których status materialny znacznie ucierpiał, Syria - do wybuchu wojny domowej w 2011 roku - była najbardziej oczywistym wyborem ze względu na relatywne bezpieczeństwo, najniższe koszty utrzymania, podobieństwa kulturowe z Irakiem oraz politykę darmowego wydawania wiz dla obywateli innych państw arabskich ${ }^{290}$. Syryjskie władze oceniają, że w kraju przebywa około 300 tys. Irakijczyków ${ }^{291}$. Jednak jak podaje damasceńskie Biuro ds. Uchodźców, oficjalnie zarejestrowało się około 4 tys. irackich rodzin - uchodźców w Syrii. Pośród zarejestrowanych chrześcijanie to $20 \%$ całkowitej liczby imigrantów ${ }^{292}$. Chrześcijanie stanowią też większość korzystających z pomocy katolickich organizacji charytatywnych - zgodnie z danymi Centrum Migracyjnego Caritas w Damaszku 95\% zgłaszających się po pomoc stanowią iraccy chrześcijanie, którzy skarżą się, że życie w Syrii jest dla nich trudne, a nie ma nikogo, kto występowałby w ich imieniu ${ }^{293}$.

${ }^{288}$ Por. S. Solomon, 1933: The Assyrians of Khabur, Syria, „Nineveh Magazine”, http:// www.atour.com/history/1900/20001011b.html, data wejścia 11.08.2009.

${ }^{289}$ D. Gavlak, Iraq Christians Flee to Jordan, Syria in Response to Increased Persecution, „Baptist Press News”, http://www.bpnews.net/bpnews.asp?Id=19302, data wejścia 11.08.2009.

${ }^{290}$ K. Zoepf, Many Christians Flee Iraq, With Syria the Haven of Choice, „NY Times”, http://www.christiansofiraq.com/exodus.html, data wejścia 11.08.2009.

${ }^{291}$ D. Gavlak, op. cit.

${ }^{292}$ K. Zoepf, op. cit.

${ }^{293}$ D. Gavlak, op. cit. 


\section{ROZDZIAŁ 3 \\ Współcześni Asyryjczycy/Aramejczycy w diasporze}

\subsection{Diaspora}

Diaspora asyryjsko-aramejska powstała na skutek trudnej sytuacji w regionie - podczas gdy część Asyryjczyków/Aramejczyków pozostała na Bliskim Wschodzie i musiała wybierać między akceptacją wyznaczonych im przez społeczeństwo miejsc a konfrontacją z rządami, wielu ich współbraci zdecydowało się na opuszczenie swoich krajów. Choć rozkwit diaspory przypada na drugą połowę XX stulecia, to asyryjsko-aramejska emigracja nie była fenomenem dwudziestowiecznym - już w XIX wieku Asyryjczycy/ Aramejczycy masowo szukali zatrudnienia, edukacji i nowych możliwości w Europie, Rosji i Stanach Zjednoczonych. Początkowo byli to migrujący robotnicy, którzy po odłożeniu pieniędzy mieli zamiar powrócić do domów ${ }^{1}$. Niektórzy z nich pozostali jednak w wybranych państwach, a po I wojnie światowej posłali po swoje rodziny ${ }^{2}$, formując zaczyn diaspory.

I wojna światowa przyniosła zmiany we wzorze osadnictwa asyryjskoaramejskiego. Nie tylko powiększyła się liczba imigrujących, lecz także ich nastawienie - bliskowschodni chrześcijanie zaczęli przyjeżdżać kierowani chęcią osiedlenia się na stałe ${ }^{3}$; praktykę tę mieli kontynuować przez następne dziesięciolecia ${ }^{4}$. Większe fale asyryjskiej/aramejskiej migracji następowały

${ }^{1}$ E. Naby, op. cit., s. 247. Migracja zarobkowa była tak powszechna, że do 1900 roku wiele wsi urmijskich pustoszało na kilka miesięcy, cyt. za: ibidem, s. 62.

2 Ibidem; A. Ishaya, „Class and Ethnicity in Rular California: The Assyrian Community of Modesto-Turlock, 1910-1985”, dysertacja obroniona na University of California, Los Angeles 1985, s. 80.

${ }^{3}$ A. Ishaya, „Class and Ethnicity...”, s. 82.

${ }^{4}$ A. I. Laing-Marshall, op. cit., s. 108. 
pod wpływem wydarzeń w ojczyźnie: w latach 20. (po I wojnie światowej), w latach 70. (wybuch wrogości kurdyjsko-irackiej), w latach 80. (po rewolucji islamskiej w Iranie), w latach 90. (po wojnie w Zatoce) XX wieku i na początku XXI wieku (po obaleniu reżimu Saddama Husajna) ${ }^{5}$. Mimo że USA i pewne kraje Europy (Rosja, Francja, Wielka Brytania) były najbardziej popularnymi celami pierwszych emigrantów, to w kolejnych dekadach rozprzestrzenili się oni na cały świat, koncentrując się w Europie, Australii, Ameryce Północnej i niektórych częściach Ameryki Południowej. Według współczesnych danych liczebność Asyryjczyków/Aramejczyków w diasporze jest większa od tej na Bliskim Wschodzie ${ }^{6}$.

W niemal wszystkich krajach przyjmujących widoczny był podobny schemat akulturacyjny. Pierwsze pokolenie imigrantów zwykle pracowało w przemyśle czy na budowach, w najlepszym razie otwierało własne restauracje, drugie pokolenie studiowało i podejmowało pracę w rozmaitych sektorach, stosunkowo łatwo adaptując się do panujących warunków. Charakterystyczne było samozatrudnianie - firmy asyryjsko-aramejskie dawały pracę całym rodzinom, jak również znajomym właściciela ${ }^{7}$. Rodzinne i plemienne koneksje używane były, aby ułatwić imigrację do określonych krajów i dopomóc w organizacji życia w pobliżu pobratymców ${ }^{8}$.

Być może dzięki utrzymaniu tych silnych więzi wewnątrzwspólnotowych w niemal wszystkich państwach, do których trafiły większe ich grupy, Asyryjczycy/Aramejczycy byli i są odbierani jako cudzoziemcy, którzy osiągnęli gospodarczy sukces ${ }^{9}$. W odróżnieniu od współbraci, którzy zostali na Bliskim Wschodzie, ci z diaspory mogą przedstawiać swój punkt widzenia za pomocą wielu środków (dzienników, radia, szkół, telewizji) bez lęku przed rządowymi represjami ${ }^{10}$ - wolność panująca w krajach Zachodu pozwala im na promocję własnej kultury i języka. Z drugiej strony, jako mniejszość nieznana lub mało znana lokalnym społeczeństwom, Asyryjczycy/Aramejczycy muszą ciągle „wyjaśniać siebie” i swoją historię ${ }^{11}$. Wyjaśnianie wymusza zaś odnalezienie cech „narodowych”. Przydatne okazują

${ }^{5}$ A. Ishaya, „Class and Ethnicity...”, s. 60.

${ }^{6} \mathrm{~J}$. Yacoub, La diaspora assyro-chaldéene, „L'Éspace géographique” 23, No. 1, 1994, s. 29.

${ }^{7}$ M. Al-Rasheed, op. cit., s. 95.

${ }^{8}$ Ibidem, s. 98.

${ }^{9}$ Może z wyjątkiem Finlandii, gdzie spośród niemal 250 asyryjskich imigrantów, przybyłych głównie po 1991 roku, tylko nieliczni nie korzystają z państwowego zasiłku, cyt. za: A. Patrous, Assyrians in Finland, „Zinda Magazine”, http://www.zindamagazine.com/html/ archives/2001/11.12.01/index.php\#TheLighthouse, data wejścia 12.08.2009.

${ }^{10}$ A. I. Laing-Marshall, op. cit., s. 113.

${ }^{11}$ M. Al-Rasheed, op. cit., s. 107-108. 


\section{2}

się tu idee XIX-wiecznych intelektualistów z Urmii. Konceptualizując tożsamość swego ludu, dzisiejsze elity czerpią z tej spuścizny oraz doświadczeń wojennych, jak też z zachodnich teorii narodowych.

Emigranci kultywują martyrologię, poczucie bycia skrzywdzonymi, pamięć tragicznych wydarzeń Sejfo. W miejscowościach, w których się osiedlają, zakładają kluby i stawiają kościoły ${ }^{12}$, czasem nawet klasztory. Często mają też lokalne drużyny piłkarskie. Rozwijają media, wydają magazyny (drukowane po aramejsku oraz w językach krajów przyjmujących). Ich organizacje zwołują konferencje i seminaria, umożliwiają młodzieży asyryjskiej i aramejskiej poznanie się na wycieczkach i piknikach, budują świadomość narodową. Tym samym przyczyniają się w znaczącym stopniu do rozkwitu asyryjskości/aramejskości ${ }^{13} \mathrm{w}$ nowej konfiguracji - z naciskiem na elementy świeckie i „narodowe”.

Dokładny opis ich sytuacji przekracza ramy tej pracy, zwłaszcza że Asyryjczycy/Aramejczycy żyjący w diasporze pochodzą z różnych państw Bliskiego Wschodu, są wiernymi kilku Kościołów chrześcijańskich, a ich sytuacja ekonomiczna zależy od wielu czynników. Warto jednak przedstawić krótkie charakterystyki najważniejszych diaspor, po to chociażby, by unaocznić to wielkie zróżnicowanie.

\subsubsection{Ameryka Północna}

\subsubsection{Stany Zjednoczone}

Liczebność asyryjskiej/aramejskiej diaspory w USA szacuje się obecnie na 350 tys. osób ${ }^{14}$. Tym samym Stany Zjednoczone zamieszkuje największa po Iraku asyryjsko-aramejska wspólnota na świecie, będąca jednocześnie najzamożniejszą z diaspor. Główne centra asyryjskie/aramejskie to: Chicago (z pięcioma parafiami i siedzibą patriarszą ${ }^{15}$ ), Detroit, Illinois, Arizona oraz region Turlock-Modesto i San Diego w Kalifornii ${ }^{16}$.

${ }^{12}$ Kościoły były jednymi z najwcześniej i najczęściej wznoszonych budynków - pokazywały podział na Asyryjczyków, Chaldejczyków, Syryjczyków (Aramejczyków) i wyznawców protestantyzmu - wszyscy chcieli mieć własne miejsca kultu, cyt. za: A. Ishaya, „Class and Ethnicity...", s. 37-38.

${ }^{13}$ Por. L. Dzięgiel, op. cit., s. 41.

${ }^{14}$ Dane z 2001 roku cyt. za: J. Mangaliman, „San Jose Mercury News”, 2.09.2001. Według spisu powszechnego z 2000 roku było ich ponad 82 tys., a niektóre źródła podają nawet pół miliona osób. Rozbieżności mogą wynikać m.in. z zamieszania terminologicznego i uznania Syryjczyków (Syrians) za Arabów.

${ }^{15}$ Wcześniej siedziba patriarchy mieściła się w San Francisco.

${ }^{16}$ Niektórzy Asyryjczycy, ze względu na wysokie koszty utrzymania w Kalifornii, przenoszą się na emeryturę do Phoenix, Arizony i Vegas, cyt. za: A. Ishaya, Assyrian-Americans. 
Imigracja Asyryjczyków/Aramejczyków do Stanów Zjednoczonych rozpoczęła się już w drugiej połowie XIX wieku jako część szerszego procesu transferu siły roboczej z krajów Trzeciego Świata do industrialnych ośrodków Zachodu. Chrześcijańskie mniejszości, takie jak Asyryjczycy/Aramejczycy czy Ormianie, miały dodatkowy powód do opuszczenia ojczyzn w postaci narastającego wśród muzułmanów resentymentu wobec wrogich, zachodnich „sił chrześcijańskich”.

Jednym z dowodów na istnienie i działanie owych „sił” były katolickie, prawosławne i protestanckie misje, które włożyły dużo wysiłku w formację młodych bliskowschodnich chrześcijan, chętnych, by kontynuować edukację i zarabiać za granicą. Pod koniec XIX wieku kilkuletnie wyjazdy w celu zdobycia wykształcenia i kapitału stały się niemal obowiązkowe dla męskiej młodzieży asyryjskiej ${ }^{17}$, którą szczególnie opiekowali się amerykańscy misjonarze ${ }^{18}$.

Wśród pierwszych asyryjskich imigrantów w Stanach Zjednoczonych była grupa intelektualistów i gorliwych nacjonalistów - w nadchodzących latach mieli oni stanąć na czele wspólnoty w USA. O trudnych warunkach ich życia donosiła regularna kolumna pt. „Smutny emigrant” we wspomnianym wcześniej tygodniku „Kokhva”. Wielu robotników-emigrantów głęboko się rozczarowało - część zaginęła, część nigdy nie była w stanie wrócić do ojczyzny z powodów finansowych; tylko niektórzy zarobili dostatecznie dużo, by zainwestować w ziemię i nieruchomości ${ }^{19}$. „Kokhva” lamentowała, że „mężczyźni opuszczają Iran zdrowi, a wracają bladzi i słabi” i dodawała, iż „budowanie luksusowego domu w Iranie za taką cenę to narodowe nieszczęście”. Zachęcała też do studiowania wieczorami, by wyrwać się z kręgu najgorszych i najsłabiej opłacanych pracowników ${ }^{20}$.

Do roku 1906 z samej Urmii ${ }^{21}$ przyjechało do USA ponad 1000 Asyryjczyków - większość do Chicago, Filadelfii, Connecticut, Turlock, poza tym niewielkie grupki do New Britain i Hartford, Nowego Jorku (New Jersey),

A Study in Ethnic Reconstruction and Dissolution in Diaspora, http://www.nineveh.com/ ASSYRIAN-AMERICANS.html\#_ftn20, data wejścia 12.08.2009.

${ }^{17}$ Ibidem.

${ }^{18}$ Idem, „Class and Ethnicity...”, s. 60-61.

${ }^{19}$ Por. idem, From Contributions to Diaspora: Assyrians in the History of Urmia, Iran, JAAS, Vol. XVI, No. 1, 2002, s. 26.

20 „Kokhva”, No. 2/9, 1907, s. 98-101.

${ }^{21}$ Więcej o asyryjskiej emigracji z Urmii zob. G. Smith, „From Urmia to the Stanislaus: A Cultural-Historical Geography of Assyrian Christians in the Middle East and America", niepublikowna praca doktorska obroniona na University of California, Davis 1981. 


\section{4}

Yonkers (Massachusetts), Flint (Michigan) oraz Gary (Indiana) ${ }^{22}$. Na wieść o wybuchu I wojny światowej i masakrach współbraci asyryjscy robotnicy tymczasowi postanowili nie wracać. Poprosili krewnych, którzy uszli cało z pogromów, o przysłanie im narzeczonych z ojczyzny (do czego zresztą zachęcała „Kokhva”). Tym samym zaczęli nowy rozdział w historii asyryjskiego osadnictwa w Stanach Zjednoczonych.

Generalnie pierwsze pokolenie Asyryjczyków urodzonych w Ameryce wzrastało w środowisku rodzin robotniczych - w większości niewładających językiem angielskim, a tym bardziej nieorientujących się w amerykańskich realiach biznesowych. Imigranci, choć często znali w mowie i piśmie kilka języków bliskowschodnich i byli wykwalifikowanymi rzemieślnikami lub artystami, w USA zaczynali od najniższych pozycji i najgorszych prac. Kobiety po raz pierwszy były zmuszone pracować poza domem - sytuacja nie do pomyślenia na Bliskim Wschodzie. Mimo trudności lat 20. i kryzysu lat 30. XX wieku wspólnocie udało się osiągnąć ekonomiczne bezpieczeństwo, wyedukować dzieci na przedstawicieli wolnych zawodów, urzędników państwowych i biznesmenów, wreszcie przenieść się do lepszych dzielnic ${ }^{23}$.

Być może wysiłek, aby spełnić amerykański sen, powiódł się nawet za bardzo. Do lat 50. XX wieku stopień asymilacji był tak duży, że Asyryjczycy/Aramejczycy urodzeni w USA niemal nie potrafili pisać, czytać czy rozmawiać po aramejsku. Ich gazety w coraz większym stopniu drukowane były po angielsku, angielskiego jako języka komunikacji używały także asyryjskie/aramejskie organizacje. Etniczna odrębność była i jest podtrzymywana głównie przez nowych imigrantów, dopiero niedawno przybyłych z Bliskiego Wschodu. Z drugiej strony, według badań przeprowadzonych przez Arian Ishayę, w latach 70. XX wieku w Kalifornii dobrze sytuowane warstwy asyryjskie sprzeciwiły się próbom upolitycznienia przez nowo przybyłych nacjonalistów w obawie przed utratą społeczno-politycznej akceptacji Amerykanów ${ }^{24}$. Obecnie wspólnota jest coraz bardziej aktywna politycznie, jednak trudno mówić o jej jednomyślności, nadal utrzymuje się rozbicie klanowe i wyznaniowe.

Przedstawiciele poszczególnych Kościołów osiedlali się z premedytacją w różnych stanach; często członkowie tych samych rodzin lub sąsiedzi z wiosek na Bliskim Wschodzie zamieszkiwali obok siebie w USA.

\footnotetext{
22 „Kokhva”, No. 1/10, 1906, s. 1.

${ }^{23}$ A. Ishaya, Assyrian-Americans...

${ }^{24}$ Idem, „Class and Ethnicity...”, s. 171.
} 
Dla przykładu wyznawcy Syryjskiego Kościoła Ortodoksyjnego z Turcji i Syrii wybierali Nowy Jork, New Jersey, Rhodes Island i Massachusetts. Największe przemysłowe miasto środkowego Zachodu, Chicago, stało się siedzibą asyryjskich imigrantów z Iranu i Iraku. Górale asyryjscy z plemion Ahiret osiedli w miejscowości Flint w Michigan, zaś Turlock w Kalifornii jako jedyne nie zostało zasiedlone przez robotników, lecz farmerów.

Od początku separatystyczne skłonności przejawiał odłam chaldejski, który wymaga odrębnego omówienia. Chaldejczycy z północno-zachodniego Iranu osiedlali się w Connecticut, zaś Chaldejczycy z Iraku przybywali do Detroit, przyciągani możliwością pracy dla Forda. Wielu z nich otworzyło sklepy warzywne, które często rozrosły się do dużych sieci, przeważnie zatrudniających rodziny i znajomych właścicieli. W efekcie w samym Metropolitan Detroit mieszka obecnie 100 tys. irackich Chaldejczyków²5.

Za czasów reżimu basistowskiego miały miejsce próby przekupienia bądź zastraszenia tej społeczności. Kontrowersje wzbudziły opiewające na setki tysięcy dolarów ${ }^{26}$ dotacje Saddama Husajna dla chaldejskich kościołów w Detroit. W 1979 roku wielebny Jacob Yasso z chaldejskiej parafii Najświętszego Serca pogratulował Saddamowi wyboru na prezydenta; w zamian otrzymał 250 tys. dolarów na swój kościól. Taką samą kwotę otrzymał wielebny Najor w Turlock ${ }^{27}$. Za późniejsze irackie datki zbudowano Chaldejskie Centrum Ameryki oraz kilka kolejnych kościołów. Całe przedsięwzięcie było postrzegane jako próba zarabizowania Chaldejczyków, wielu Asyryjczyków oskarżono wówczas o szpiegowanie wspólnoty za irackie pieniądze ${ }^{28}$. Z drugiej strony mnożyły się pobicia, podpalenia, a nawet zabójstwa, których FBI nie było w stanie wyjaśnić, a o które Asyryjczycy oskarżali rząd iracki ${ }^{29}$. Te zarzuty nie stanęly jednak na przeszkodzie, by w latach 80 . XX wieku Saddam Husajn otrzymał z rąk burmistrza klucze do Detroit ${ }^{30}$.

${ }^{25}$ Większość nowo przybyłych Chaldejczyków kieruje się do Detroit na 7 Mile Road między Woodward Avenue oraz John R Street. W 1999 roku dzielnica ta została oficjalnie nazwana „Chaldejskim Miastem” (Chaldean Town).

${ }^{26}$ Niektóre źródła mówią nawet o 1,7 mln dolarów do 1980 roku, cyt. za: „Detroit Free Press" 1981, 3/1, s. 1A.

${ }^{27} \mathrm{Z}$ tragicznym rezultatem - w 1981 roku został postrzelony i ciężko ranny, cyt. za: „Turlock Daily Journal”, 12.11-23.12.1981; „San Francisco Chronicle” 1982, 1/18, s. 5.

28 „Detroit Free Press” 1981, 2/1, s. 15A.

29 „Ręka rewolucji sięga dostatecznie daleko, by dosięgnąć każdego, w każdym miejscu i czasie" - straszył chaldejskich imigrantów w Detroit iracki attaché w Stanach Zjednoczonych, cyt. za: „Detroit Free Press” 1981, 3/1, s. 1A.

${ }^{30}$ A. R. Moses, Saddam Once Received Key to Detroit, „Zinda Magazine”, http://www. zindamagazine.com/html/archives/2003/3.31.03/index.php, data wejścia 10.08.2009. 


\subsubsection{Kanada}

W Kanadzie, według cenzusu z 2006 roku, mieszka 8,5 tys. Asyryjczyków/Aramejczyków. Historia ich osadnictwa sięga roku 1902, gdy stu Asyryjczyków ze Stawropola w Rosji szukało możliwości zatrudnienia w North Battleford, Saskatchewan. Większość przybyła później: pierwsza fala po Sejfo, druga i największa - podczas wojny iracko-irańskiej (Asyryjczycy/Aramejczycy osiedlili się wtedy przede wszystkim w „etnicznych enklawach” Toronto, Montrealu, Vancouver, Calgary i Edmonton), trzecia - po wojnie w Zatoce. Aramejski jest nauczany w większości kościołów (asyryjskich, syryjskich i chaldejskich). Dla Asyryjczyków/Chaldejczyków/Aramejczyków urodzonych w Kanadzie pierwszym językiem jest jednak angielski. Pracują w wolnych zawodach, są drobnymi biznesmanami oraz pracownikami fabryk. Mają kilkanaście prężnie działających organizacji. Ich głównym ośrodkiem pozostaje Toronto ${ }^{31}$.

\subsubsection{Europa i Azja}

Migracja chrześcijan z Bliskiego Wschodu do Europy rozpoczęła się w tym samym okresie co do Stanów Zjednoczonych, tj. ponad sto lat temu. Obecnie liczebność populacji asyryjsko-aramejskiej na Starym Kontynencie szacuje się na ok. 250 tys. osób, przy czym 80-120 tys. Asyryjczyków zamieszkuje Szwecję, 90 tys. Niemcy, 25-35 tys. Holandię, 15 tys. Francję, 14 tys. Rosję, po 8 tys. Grecję, Belgię, Szwajcarię, 5 tys. Wielką Brytanię, ponad 3 tys. Armenię, Gruzję, Ukrainę ${ }^{32}$.

\subsubsection{Szwecja}

Za nieoficjalną stolicę asyryjską/aramejską w Europie uznawane jest Södertälje w Szwecji, z populacją 22 tys. Asyryjczyków/Aramejczyków (w całym okręgu sztokholmskim żyje ich ogółem 40 tys.), z którego nadają międzynarodowe stacje telewizyjne: „Suroyo TV” i „Suryoyo Sat”. Asyryjczycy/Aramejczycy mieszkają także w Västerås, Göteborgu, Norrköping, Linköping i Örebro. Przeważnie są wyznawcami Syryjskiego Kościoła Ortodoksyjnego, przybyłymi do Szwecji z Libanu, Turcji i Syrii w wyniku prześladowań.

Pierwsza fala migracji nastąpiła w 1967 roku i była zwana „krótkim lotem z Bejrutu”, bo na zaproszenie rządu szwedzkiego, Światowej Rady Kościo-

${ }^{31}$ Community Life and Culture, Multicultural Canada, http://www.multiculturalcanada.ca/Encyclopedia/A-Z/a24/3, data wejścia 10.08.2009.

${ }^{32}$ Dane te są bardzo przybliżone. G. Oussi, Assyrians Today, „Meltha Magazine Online”, http://melta4.tripod.com/conference_issue/Assyrians_today, data wejścia 2.02.2009. 
łów oraz Wysokiego Komisarza Narodów Zjednoczonych ds. Uchodźców do Göteborga przyleciało trzysta osób z Libanu. Druga fala migracji związana była z konfliktem cypryjskim w latach 1974-1975, zaś trzecia z wojną w Libanie (1977-1978). Rząd szwedzki postanowił wówczas, że będzie przyjmował wszystkich uchodźców ze względów humanitarnych, jednocześnie wprowadzając obowiązek wizowy dla obywateli tureckich; tym samym sytuacja w Szwecji była wówczas wyjątkowa na tle innych państw ${ }^{33}$.

Obecnie część imigrantów uważa się za Aramejczyków (Surjoje), zaś część optuje za identyfikacją asyryjską (pomimo przynależności do Syryjskiego Kościoła Ortodoksyjnego). W 1998 roku powstał Instytut Mezopotamski pod Sztokholmem, mieszczący kolekcję książek po szwedzku, aramejsku, angielsku i turecku ${ }^{34}$. W latach 2005-2006 w szwedzkim rządzie zasiadał asyryjsko-aramejski minister edukacji Ibrahim Baylan. Nie sposób nie wspomnieć o zawodowych asyryjskich i aramejskich drużynach piłki nożnej, które odnoszą głośne sukcesy: Assyriska Föreningen, Syrianska Botkyrka IF, Syrianska FC i Valsta Syrianska IK. Szwedzkiej wspólnocie asyryjskiej/aramejskiej zostały poświęcone obszerne opracowania Ulfa Björklunda $^{35}$, Deniza Fuata ${ }^{36}$, Önvera A. Cetreza ${ }^{37}$, a ponadto mniejsze Anniki Rabo $^{38}$, Sonera Öndera ${ }^{39}$, Davida Gaunta ${ }^{40}$ i Bernadet Mati ${ }^{41}$.

\subsubsection{Niemcy}

Asyryjczycy/Aramejczycy nie zawsze przybywali do Europy jako polityczni bądź religijni uchodźcy - 18 tys. osób przyjechało do zachodnich

${ }^{33}$ Wywiad z dwoma przedstawicielami Assyrian Democratic Movement, Szwecja, 29.06.2007.

${ }^{34}$ G. Çiyan, op. cit., s. 2.

${ }^{35}$ Zob. U. Björklund, North to Another Country: The Formation of the Suroyo Community in Sweden, Sztokholm 1981.

${ }^{36}$ D. Fuat, En minoritets odyssé: upprätthållande och transformation av etnisk identitet i förhållande till moderniseringsprocesser: det assyriska exemplet, Uppsala 1999.

37 Ö. A. Cetrez, Meaning-Making Variations in Acculturation and Ritualization. A Multi-Generational Study of Suroyo Migrants in Sweden, Sztokholm 2005.

${ }^{38}$ A. Rabo, "Without Our Church We Will Disappear. The Syrian Orthodox in Diaspora and the Family Law of the Church", 4th Global Conference: Diasporas - Exploring Critical Issues, Oxford 2011, niepublikowany referat.

39 S. Önder, „Applying 'Social Capital' Theory to the Assyrian Case in Sweden. A Study of Assyrians in Södertälje”, niepublikowane studium przygotowane w ramach zaawansowanego kursu politologii na Stockholm University, Sztokholm 2008.

${ }^{40}$ D. Gaunt, Identity Conflicts among Oriental Christian in Sweden, „Sens public”, http://www.sens-public.org/spip.php?article767\&lang=fr, data wejścia 7.08.2012.

${ }^{41}$ B. Mati, „Ett liv i många världar: Mångfalden av identiteter för assyrier som utvandrat och invandrat", Lund Universitet, Lund 2011, niepublikowana praca. 
Niemiec w latach 60. i 70. XX wieku do pracy w przemyśle. Zostali zrekrutowani w Turcji na mocy umowy międzynarodowej „Gastarbeiter”. Obecnie ich skupiska znajdują się w Augsburgu, Wiesbaden, Berlinie i Paderborn, czyli w zachodniej i południowej części kraju. 70 tys. należy do Syryjskiego Kościoła Ortodoksyjnego, a pozostałe 20 tys. do Asyryjskiego Kościoła Wschodu i Chaldejskiego Kościoła Katolickiego. Asyryjczycy/ Aramejczycy są uznawani za jedną z grup napływowych, którym udało się osiągnąc sukces. Młodzi, urodzeni w Niemczech, coraz bardziej interesują się kulturą swoich przodków, spotykają się w swoich klubach i kościołach na seminariach i warsztatach poświęconych problemowi zachowania dziedzictwa oraz pomocy pozostawionym w ojczyźnie rodakom. Preferują nazwę „Aramäer”, która pojawia się w nazwach ich organizacji, jak chociażby Föderation der Aramäer in Deutschland ${ }^{42}$.

\subsubsection{Holandia}

Holenderscy Asyryjczycy/Aramejczycy zamieszkują głównie wschodnią część kraju - przemysłową prowincję Overijssel (miasta Enschede, Hengelo, Almelo i Borne), która graniczy z Niemcami, gdzie większość z nich ma krewnych. Pierwsi uchodźcy przybyli tu w latach 70. XX wieku z Turcji, w latach 80. dołączyli do nich rodacy z Syrii, po wojnie w Zatoce zjawili się imigranci z Iraku. Od lat 80 . XX wieku rozwijają oni silne uczucia nacjonalistyczne, aktywnie uczestnicząc w projektach mających zachować ich tożsamość - w lekcjach języka udzielanych w holenderskich szkołach oraz biblijnych szkółkach niedzielnych, obozach młodzieżowych, zespołach muzycznych i tanecznych, chórach kościelnych, wykładach o budowaniu wspólnoty. Posiadają własny klasztor w Glanerbrugu i ruch młodzieżowy. Biorą udział w demonstracjach mających na celu zwrócenie uwagi na sytuację ich rodaków na Bliskim Wschodzie oraz zdobycie uznania dla Sejfo - dla pogłębienia wiedzy o tym wznieśli Centrum Sejfo ${ }^{43}$. Są bardzo dobrze zintegrowani, dlatego też prasa nie poświęca im negatywnych artykułów, jak ma to miejsce w przypadku innych grup imigranckich.

\subsubsection{Francja}

We Francji Asyro-chaldejczycy (Assyro-Chaldéens - taką nazwę najczęściej przyjmuja) żyją skoncentrowani w regionie Ile-de-France (departa-

${ }^{42}$ Föderation der Aramäer (Suryoye) in Deutschland (FASD), http://www.oromoye.de/, data wejścia 12.08.2009.

${ }^{43} \mathrm{Na}$ czele Centrum Sejfo stoi Sabri Atman. Zob. więcej: http://www.seyfocenter.se, data wejścia 12.08.2009. 
menty: Val d'Oise, Seine-Saint-Denis i Paryż), Rhône (Lyon), Bouches-duRhône (Marsylia) oraz Haute-Garonne (Saint-Jorry i Tuluza). Oni również są uchodźcami z południowo-zachodniej Turcji - przybyli po I wojnie światowej oraz w latach 80. XX wieku (szczególnie między rokiem 1983 a 1984). Większość z nich posiada obywatelstwo francuskie, pozostali oczekują na naturalizację. Przeważnie są właścicielami przedsiębiorstw i pracują w handlu. Młodzież uczy się i studiuje. Wspólnota jest postrzegana jako integrująca się „modelowo" ${ }^{4}$.

\subsubsection{Rosja}

Znaczna populacja asyryjska zamieszkuje Rosję ${ }^{45}$. Uchodźcy przybyli tu w trzech głównych falach: po traktacie rosyjsko-perskim z 1828 roku (wyznaczył on granice między imperiami, powodując, że wielu Asyryjczyków znalazło się po stronie rosyjskiej - ich rodziny dołączyły do nich przekraczając granicę), w czasie I wojny światowej oraz po II wojnie światowej (dwukrotne wycofanie sił radzieckich pozostawiło Asyryjczyków bez ochrony i popchnęło do emigracji ${ }^{46}$. W latach 30 . XX wieku jedynym państwem, w którym Asyryjczycy mogli posługiwać się swoim językiem, uczyć go w szkołach podstawowych i wydawać książki, był Związek Radziecki. Szybko jednak stracili te przywileje i zaczęli być prześladowani - wielu zesłano na Syberię i do Azji Centralnej ${ }^{47}$. Ponad tysiąc Asyryjczyków straciło życie w ZSRR za czasów reżimu stalinowskiego. Obecnie największe ich kolonie mieszkają w Krasnodarze, Rostowie nad Donem, Kijowie, Petersburgu i Moskwie ${ }^{48}$. Najbardziej znanym Asyryjczykiem w ZSRR/Rosji był Michaił Sado (1934-2010), lingwista i polityk, twórca tamtejszego asyryjskiego ruchu narodowego ${ }^{49}$.

\subsubsection{Grecja}

Do Grecji Asyryjczycy/Aramejczycy przybyli masowo w 1934 roku i osiedli się w dziś już niezamieszkałym rejonie Makronisos, jak również

${ }^{4}$ Présentation de la communauté assyro-chaldéenne de France, http://www.aacf.asso.fr, data wejścia 12.08.2009.

${ }^{45}$ Por. E. Naby, Les assyriens d'Union Soviétique, „Cahiers du monde russe et soviétique", 16/3-4, 1975, s. 445-457.

46 The Assyrians, http://russia.rin.ru/guides_e/7364.html, data wejścia 12.08.2009.

${ }^{47}$ N. Awde, N. Lamassu, N. Al-Jeloo, op. cit., s. 11.

${ }^{48}$ J. Joseph, The Modern Assyrians..., s. 219. O Asyryjczykach w ZSRR zob. K. P. Matwiejew, Istorija i etnografija assirijcew, Moskwa 1990.

${ }^{49}$ P. Goble, The Assyrians of Russia, AINA, http://www.aina.org/ata/20101224152140. htm, data wejścia 8.08.2012. 
w Keratsini (Pireus), Egaleo i Kalamata. Dziś jest ich ok. 6 tys. Znakomita większość żyje w Peristeri, na przedmieściach Aten. Część przebywa bez dokumentów (bezskutecznie starając się o azyl) i doświadcza marginalizacji. Około 100 młodych Asyryjczyków uczy się aramejskiego na kursach ${ }^{50}$.

\subsubsection{Belgia}

Asyryjczycy/Aramejczycy w Belgii są w większości uchodźcami z tureckich miast Midjat i Mardin w Tur Abdinie, wyznawcami Syryjskiego Kościoła Ortodoksyjnego lub Chaldejskiego Kościoła Katolickiego. Ich trzy główne skupiska znajdują się w Brukseli, Liège i Mechelen. Wspólnota, która w 2009 roku świętowała swoje 30-lecie, liczy obecnie 20 tys. ${ }^{51}$ osób. Flamandzki pisarz August Thiry poświęcił asyryjsko-aramejskim uchodźcom z Hassana w Turcji książkę Mechelen nad Tygrysem („Mechelen aan de Tigris") ${ }^{52}$.

\subsubsection{Szwajcaria}

Szwajcarscy Asyryjczycy/Aramejczycy pochodzą z Midjatu, Mardinu oraz Azah (obecnie Idil) w Tur Abdinie; większość z nich należy do Syryjskiego Kościoła Ortodoksyjnego (około 1,6 tys. rodzin). Zamieszkują głównie wschodni kanton St. Gallen (okolice Wil) oraz Baden, położone $20 \mathrm{~km}$ od Zurichu. Wielu żyje ponadto we włoskiej części Szwajcarii - w kantonie Ticino (Lugano i Locarno). Sporadycznie organizują manifestacje, m.in. wymierzone przeciw traktatowi lozańskiemu, który pozbawił ich praw w Turcji ${ }^{53}$, czy też prześladowaniom współbraci w Iraku ${ }^{54}$.

\subsubsection{Wielka Brytania}

W Wielkiej Brytanii uchodźcy ci pojawili się jeszcze przed II wojną światową i szybko osiągnęli wysoki status społeczny ${ }^{55}$. W czasach najnowszych przybywali głównie z Iraku po wojnie w Zatoce oraz po inwa-

${ }^{50}$ K. Tzilivakis, Iraq's Forgotten Christians Face Exclusion in Greece, „Athens News”, 10.05.2003, s. A14.

${ }^{51}$ Assyrian Community Celebrates 30 Years in Belgium, AINA, http://www.aina.org/ news/20091008154651.htm, data wejścia 8.08.2012.

${ }^{52}$ A. Thiery, Mechelen aan de Tigris, Berchem 2001.

${ }^{53}$ M. Arsan, Assyrians-Suryoye Occupy a Governmental Building in Lausanne-Switzerland, http://www.bethsuryoyo.com/currentevents/lusanne/Occupation1.html, data wejścia 8.08.2012.

${ }^{4}$ Assyrian Youth in Switzerland Light Candles for Assyrians in Iraq, ADO World, http:// en.ado-world.org/news/assyrian-news/article/assyrian-youth-in-switzerland, data wejścia 8.08.2012.

${ }^{55}$ L. Dzięgiel, op. cit., s. 41. 
zji z 2003 roku. Zamieszkują Greenford i Hanwell w londyńskim okręgu Ealing. Sami dzielą siebie na Aturaja (wyznawców Asyryjskiego Kościoła Wschodu) i Chaldanaja (Chaldejczyków); każdy z odłamów ma własny kościół. Obok różnic wyznaniowych wyraźne są podziały terytorialne. Według badań wśród londyńskich Asyryjczyków, przeprowadzonych w latach 90. XX wieku przez Madawi Al-Rasheed, mimo deklarowanej otwartości irackich imigrantów na irańskich współbraci, oba odłamy miały odrębne centra kulturowe i nie prowadziły żadnych łączonych inicjatyw ${ }^{56}$. Irańscy Asyryjczycy byli zresztą bardziej zamknięci ze względu na historyczny brak pozawspólnotowych kontaktów; najbardziej otwarci byli ci, którzy przeszli przez Al-Habbanijję. Młodzież asyryjska w Londynie wykazywała bardzo niewielką lub wręcz żadną znajomość języka aramejskiego ${ }^{57}$, kibicowała za to drużynie piłki nożnej w Londynie - FC Ealing Assyrians.

W ostatnich latach Asyryjczycy/Aramejczycy z Anglii otrzymywali wsparcie od kilku parlamentarzystów, szczególnie Stevena Pounda z Ealing i Lorda Hyltona. Sprawy, które były dyskutowane, to historia asyryjska/ aramejska po I wojnie światowej, z naciskiem na prześladowania ze strony Kurdów i Arabów. Media poświęciły wiele uwagi wspólnocie w związku z porwaniem i zabójstwem w Iraku chaldejskiego biskupa Paulosa Faradża Rahho w 2008 roku $^{58}$.

\subsubsection{Armenia}

Asyryjczycy w Armenii konstytuują trzecią największą mniejszość etniczną w państwie po jezydach i Rosjanach. Zamieszkują Verin Dvin, Arzni, Dimitrow i Erywań. Przybyli po wojnie rosyjsko-perskiej z lat 1826-1828 (z Urmii) i na początku XX wieku (z Hakkari) do rejonu, który postrzegali jako „chrześcijański raj”. Stosunki między nimi i Ormianami były przyjacielskie ze względu na podobne losy, praktykowanie chrześcijaństwa i prześladowania ze strony muzułmanów. Dość często zdarzały się małżeństwa mieszane, tendencja ta nasila się w diasporze mimo uznania Asyryjskiego Kościoła Wschodu (do którego należy większość imigrantów) za heretycki przez Ormiański Kościół Ortodoksyjny. W czasach radzieckich większość Asyryjczyków zapomniała swoich korzeni, dopiero po upadku ZSRR zaczęli do nich wracać. Obecnie odbywają się lekcje aramejskiego, działa

${ }^{56}$ M. Al-Rasheed, op. cit., s. 185; A. Ishaya, „Class and Ethnicity...”, s. 234-235.

${ }^{57}$ M. Al-Rasheed, op. cit., s. 120-121.

${ }^{58}$ Archbishop Kidnapped in Iraq Found Dead, „The Guardian”, http://www.guardian. co.uk/world/2008/mar/13/iraq.religion, data wejścia 12.08.2009. 
Młodzieżowe Centrum Asyryjskie w Erywaniu. W 2003 roku powstało Asyryjskie Centrum BetNahrain, którego celem jest studiowanie języka, kultury, historii i tradycji. Asyryjczycy armeńscy pracują w ogrodnictwie i rolnictwie, uprawiają winorośl. Według spisu ludności w 2001 roku było ich około 3,5 tys. - przed upadkiem ZSRR liczba ta była nawet dwukrotnie większa, ale zła sytuacja ekonomiczna w latach 90. XX wieku skłoniła ich do emigracji - przede wszystkim do Kazania i Moskwy ${ }^{59}$.

\subsubsection{Gruzja}

Historycznie pierwsi Asyryjczycy zawitali do Gruzji już w VI wieku - byli to mnisi znani jako „trzynastu świętych ojców asyryjskich” z Edessy. Wznieśli klasztor Shio-Mgvime, przykładając się tym samym do chrystianizacji kraju. Następny kontakt nastąpił w latach 60. XVIII wieku, gdy Asyryjczycy poprosili gruzińskiego króla o ochronę dla siebie i jezydów przed Osmanami. Podczas wojny rosyjsko-gruzińskiej poczyniono plany połączenia sił asyryjsko-gruzińskich, które jednak nie powiodły się. Do Gruzji napłynęła wówczas pierwsza fala asyryjskich uchodźców, druga - po podpisaniu traktatu z Turkmenczaju między Rosją i Persją (na jego mocy Asyryjczycy i Kurdowie z Persji mogli przybywać jako siła najemna). Najwięcej Asyryjczyków przybyło do Gruzji w drugiej połowie XIX wieku i między 1915 a 1917 rokiem. Według cenzusu z 2001 roku było ich ponad 3 tys. (choć niektóre źródła mówią nawet o 9-12 tys.), zamieszkałych głównie w Dzveli Kanda, Gardabani oraz w okolicach Tbilisi, z mniejszymi grupami w Kutaisi, Batumi, Senaki, Zugdidi oraz Zestaponi. W Dzveli Kanda i Tbilisi Asyryjczycy mają możliwość nauki aramejskiego (książki wysyłają rodacy z Iraku). Sytuacja tej diaspory pogorszyła się wraz z wprowadzeniem języka gruzińskiego jako oficjalnego - większość imigrantów znała rosyjski i obecnie trudno im znaleźć pracę, w związku z czym wielu emigruje do Kraju Krasnodarskiego i Moskwy ${ }^{60}$. W maju 2005 roku w Tbilisi miało miejsce spotkanie przywódców asyryjskich z George'em W. Bushem, podczas którego amerykański prezydent został poproszony o stworzenie autonomicznego regionu asyryjskiego w Iraku' ${ }^{61}$.

${ }^{59}$ T. Hakobyan, Armenia Is a Homeland for the Assyrians, Who Have No Homeland, AINA, http://www.aina.org/ata/20090327164710.htm, data wejścia 10.08.2010.

${ }^{60}$ I. Chikhladze, G. Chikhladze, The Yezidi Kurds and Assyrians of Georgia. The Problem of Diasporas and Integration into Contemporary Society, ,Journal of the Central Asia and the Caucasus", 3/21, 2003.

${ }^{61}$ Bush Meets Assyrian Delegation in Georgia, AINA, http://www.aina.org/news/2005051660356.pdf, data wejścia 10.08.2010. 


\subsubsection{Ameryka Południowa}

Asyryjsko-aramejska populacja Ameryki Południowej żyje w relatywnej izolacji od swoich rodaków w diasporze (utrzymując jednak kontakt z bliskowschodnimi ojczyznami), w mniejszym stopniu korzysta z dobrodziejstw nowoczesnych technologii komunikowania niż opisane powyżej diaspory, poza tym bardzo szybko integruje się z życzliwymi miejscowymi społeczeństwami, dlatego też trudniej znaleźć informacje na jej temat. Pewne jest, że Syryjski Kościół Ortodoksyjny posiada dwie archidiecezje na terenie Ameryki Południowej - w Brazylii i Argentynie. Poniższe dane zostały zebrane dzięki wywiadom przeprowadzonym z jego brazylijskimi członkami w dniach 18-28 sierpnia 2006 roku.

\subsubsection{Brazylia}

Brazylię zamieszkuje około 5 tys. Asyryjczyków/Aramejczyków. Pierwsi przybyli z Syrii (głównie z Hims i okolic) w 1905 roku oraz z Turcji (Tur Abdinu) po I wojnie światowej; wzmożona imigracja trwała do lat 30. XX wieku. Obecnie większe skupiska znajdują się w São Paulo, Campo Grande, Rio de Janeiro i Belo Horizonte. Starsi zajmują się handlem, młodsi studiują. Asymilacja przebiega szybko mimo wysiłków duchownych, aby zachować tożsamość, głównie z powodu bardzo wysokiego odsetka ślubów asyryjsko-brazylijskich, ale też braku zainteresowania młodzieży historią i kulturą przodków. W São Paulo kilka osób uczy się aramejskiego (zachodniego dialektu), jednak Asyryjczycy/Aramejczycy urodzeni w Brazylii generalnie nie znają go, mówią po portugalsku, czasem trochę po arabsku. Ich tożsamość jest tożsamością asyryjsko-aramejsko-arabską, o czym świadczy chociażby gotowanie arabskich potraw czy słuchanie arabskiej muzyki. Nie mają aramejskojęzycznych magazynów ani rozgłośni ${ }^{62}$. W latach 90. XX wieku pół tysiąca aramejskojęzycznych magazynów zostało wyrzuconych przez nieświadomych ich wartości członków wspólnoty ${ }^{63}$.

\subsubsection{Argentyna}

Według niepotwierdzonych danych Argentynę zamieszkuje kilka tysięcy Asyryjczyków/Aramejczyków (do 1919 roku przybyło 2 tys. młodych uchodźców z Turcji). Skupiają się głównie w Buenos Aires. Ulegają asymi-

${ }^{62}$ Wywiad z kapłanem Syryjskiego Kościoła Ortodoksyjnego w Campo Grande, Brazylia, 18.06.2006 oraz wywiad z biskupem tego Kościoła w Sáo Paulo, 28.08.2006.

${ }^{63}$ Wywiad z nauczycielem aramejskiego w São Paulo, 27.08.2006. 
lacji równie łatwo jak ich bracia w Brazylii. Nie mają organizacji ani mediów, choć pierwsza w Ameryce Południowej prasa drukarska z aramejskimi czcionkami należała do nacjonalisty Farida Nuzhy, który w 1934 roku powołał do życia Asyryjski Klub Efrema (Centro Afremico Asirio) w Argentynie; w tym samym roku ukazało się pierwsze wydanie miesięcznika „Stowarzyszenie Asyryjskie" (Al-Dżami’a as-Surjanijja) - początkowo po arabsku, później także po aramejsku i hiszpańsku. Na łamach pisma Farid Nuzha otwarcie atakował wyższy kler i walczył z podziałami wyznaniowymi wewnątrz wspólnoty, przypłacając to czasową ekskomuniką ${ }^{64}$.

\subsubsection{Australia i Nowa Zelandia}

Według cenzusu z 2006 roku Australię i Nową Zelandię zamieszkuje 26 tys. Asyryjczyków/Aramejczyków, wyznawców Asyryjskiego Kościoła Wschodu, Starożytnego Kościoła Wschodu i Chaldejskiego Kościoła Katolickiego. Skupiają się wokół swoich kościołów i klubów, najwięcej w rejonie Fairfield City, Mascot, Merrylands i Parramatta ${ }^{65}$. Australijscy Asyryjczycy/Aramejczycy zreszeni są w organizacjach, takich jak Assyrian Universal Alliance (AUA) Australian Chapter. W 2010 roku manifestowali przeciw zamachowi terrorystycznemu na syryjski kościół katolicki w Bagdadzie, w którym zginęło niemal 60 osób, a drugie tyle zostało rannych ${ }^{66}$.

Z inicjatywy Asyryjskiego Kościoła Wschodu buduje się w Sydney, w dzielnicy Poldding, osiedle nazywane „Wioską Asyryjską”, składające się z 300 domów szeregowych, przeznaczonych dla emerytów i osób w podeszłym wieku. Ma się nimi opiekować asyryjski personel, zaś wioska ma być wyposażona w obiekty powszechnego użytku. Przewiduje się budowę kolejnych segmentów dla rodzin o niskich i średnich dochodach. „Wioska Asyryjska” ma być pierwszym tego typu obiektem, z którego będą korzystać asyryjscy obywatele Australii. Plany cieszą się zainteresowaniem władz federalnych ${ }^{67}$.

${ }^{64}$ Farid Nuz'ha, an Assyrian Nationalist, http://www.christiansofiraq.com/faridnuzha. html, data wejścia 10.08.2009.

${ }^{65}$ Więcej informacji nt. Asyryjczyków w Australii zob. The Assyrian (Australian Assyrian News), http://theassyrian.com.au/.

${ }^{66}$ Assyrians in Australia Protest Church Bombings, „Assyria Times”, http://www.assyriatimes.com/engine/modules/news/article.php?storyid=3440, data wejścia 8.08.2012.

${ }^{67}$ Wioska asyryjska $w$ Australii, http://www.pixartmedia.home.pl/szlomo/index.php? option=com_content\&task=view\&id=238\&Itemid=1, data wejścia 11.08.2009. 


\subsubsection{Religia a polityka w diasporze}

Po II wojnie światowej Kościoły syryjskie powoli wycofywały się z zaangażowania politycznego. W petycji z 1947 roku wysłanej do ONZ patriarcha asyryjski Mar Eszaj Szimun domagał się już tylko sprawiedliwości dla swego ludu w Iranie, bez czynienia wzmianek o żądaniach narodowych. Rok 1948 wyznaczył koniec walki dostojnika o uznanie politycznie nacji - Światto ze Wschodu doniosło o jego wizycie w irańskiej i syryjskiej ambasadzie w Waszyngtonie w celu ustanowienia lepszych relacji z rządami tych państw ${ }^{68}$. W mowie wygłoszonej w 1952 roku w Królewskim Towarzystwie Środkowoazjatyckim w Wielkiej Brytanii patriarcha podkreślił wagę pomocy udzielanej przez rządy Asyryjczykom, ukrywając wszelkie negatywne relacje ze społecznościami bliskowschodnimi ${ }^{69}$. Doradzał swoim wiernym, by dostosowali się do okoliczności, jakiekolwiek by one były ${ }^{70}$. Niektórzy spekulowali, że ów odwrót patriarchy od polityki był spowodowany niechęcią społeczności międzynarodowej do działania na korzyść Asyryjczyków, inni natomiast uważali, że spowodowało go osłabienie jego Kościoła ${ }^{71}$.

Patriarcha, świadomy ograniczeń, jak również własnych duchowych zobowiązań $^{72}$, od końca lat 40. XX wieku skupił się na wypełnianiu tych ostatnich - odbudowywał strukturę Kościoła, konsekrował biskupów w Indiach, Syrii, Libanie, sam działał jako biskup w USA ${ }^{73}$. Tłumaczył, publikował i starał się przyciągnąć tych Asyryjczyków, którzy oddalili się od wspólnoty wiary $^{74}$. Osobiście nadzorował ustanowienie patriarchalnego instytutu aramejskiego w USA w 1950 roku; za jego pontyfikatu ufundowano również wydawnictwa w Indiach i Iraku oraz seminaria w Syrii i Iranie ${ }^{75}$. Rozpoczę-

${ }^{68}$ J. F. Coakley, op. cit., s. 186.

${ }^{69}$ Mar (Eshai) Shimun, Assyrians in the Middle East, "Journal of the Royal Central Asian Society", 40, 1953, s. 151-160.

${ }^{70}$ Ibidem, s. 157.

${ }^{71}$ Kościół borykał się z brakiem księży i biskupów, wielu z nich bowiem straciło życie podczas wojny. Ci, którzy przeżyli, nie byli w stanie efektywnie służyć rozproszonej wspólnocie. Ponadto jeszcze przed I wojną światową większość kleru była niepiśmienna, znała syryjski tylko na tyle, by odprawić mszę. Co gorsza, brakowało powołań, gdyż młodzi Asyryjczycy w diasporze mieli przed sobą wiele innych ścieżek kariery, cyt. za: J. F. Coakley, op. cit., s. 186-191.

${ }^{72}$ A. I. Laing-Marshall, op. cit., s. 118.

${ }^{73}$ J. F. Coakley, op. cit., s. 190.

${ }^{74}$ H. Anschütz, op. cit., s. 131.

${ }^{75}$ G. Yonan, Assyrer heute. Kultur, Sprache, Nationalbewegung der aramäisch sprechenden Christen im Nahen Orient, Hamburg-Wien 1978, s. 158. 
ty w 1964 roku synod pozwolił zreformować niektóre kościelne zwyczaje, by ułatwić Asyryjczykom życie na Zachodzie, np. wprowadzając kalendarz gregoriański i łacińskie daty dla świąt Wielkiej Nocy ${ }^{76}$. Były to znaczące zmiany w duchu ekumenizmu, prowadzące do integracji z resztą chrześcijaństwa, ale jednocześnie schizmy w łonie wspólnoty parę lat później.

Wewnętrzna rewolta miała miejsce w 1968 roku. „Starokalendarzowi” - jak ich nazywano - oponowali przeciw ustaleniom synodu z 1964 roku. Wybrali Mar Darmo (Mar Thomę, metropolitę Indii) na patriarchę; ten zaś zaczął wyświęcać biskupów w Iraku, dając początek Starożytnemu Kościołowi Wschodu. Rząd iracki najpierw uznał „starokalendarzowych”, potem zaś, widząc, że większość Asyryjczyków pozostaje wiernych Mar Szimunowi, odnowił z nim stosunki, prosząc o napisanie listu, w którym zachęcałby on wiernych, by stali się lojalnymi obywatelami irackimi. Po publikacji listu w 1970 roku patriarcha otrzymał wizę do Iraku - odwiedził go jeszcze tego samego roku. Mimo wycofania rządowego uznania członkowie Starożytnego Kościoła Wschodu prowadzili ekspansję poza Irakiem, zakładając wspólnoty wszędzie tam, gdzie przebywali Asyryjczycy. Sam Mar Szimun stał się źródłem kontrowersji, zakończonej jego zabójstwem w 1975 roku, które pokazało, jak daleko rozeszły się dwie drogi asyryjskiego wyrazu ${ }^{77}$. Następca patriarchy, Mar Dinkha IV, kontynuował jego linię otwierania Kościoła, finalizując odrzucenie nazwy „nestoriański”, zwiększając ekumeniczne zaangażowanie Kościoła, poprawiając relacje szczególnie z Chaldejczykami ${ }^{78}$, wprowadzając nowe reformy liturgiczne i utrzymując politykę „przetrwania przez dostosowanie się" na Bliskim Wschodzie ${ }^{79}$.

Podobną, tj. coraz bardziej duchową rolę odgrywali kolejni patriarchowie Syryjskiego Kościoła Ortodoksyjnego - Ignatius Efrem I Barsum (1933-1957), Ignatius Jakub III (1957-1980) oraz Ignatius Zakka I Iwas (od 1980 roku). Oprócz twórczości literackiej (wszyscy zostawili bogatą spuściznę poświęconą religii, historii i kulturze chrześcijańskiej), prężnie działali na niwie organizacyjnej, reformując również kalendarz dla współbraci w Ameryce i dopuszczając dziewczęta do nauki w szkółkach niedzielnych ${ }^{80}$. Dzięki nim Kościół posiada obecnie dwa seminaria, liczne szkoły

${ }^{76}$ Ibidem, s. 191.

${ }^{77}$ J. F. Coakley, op. cit., s. 191-195.

${ }^{78}$ R. Roberson, op. cit., s. 17-19.

${ }^{79}$ J. F. Coakley, op. cit., s. 196-197.

${ }^{80}$ Zmiany te zostały przyjęte na synodzie w klasztorze Mar Mataj w Iraku w 1930 roku, cyt. za: W. Baum, op. cit. 
średnie i inne instytucje, z których najważniejsze jest seminarium teologiczne św. Efrema, utworzone w 1934 roku w Zahle w Libanie (przeniesione w 1946 roku do Mosulu, obecnie mieszczące się w Bejrucie). Do Syryjskiego Kościoła Ortodoksyjnego należy ponadto międzynarodowe chrześcijańskie centrum edukacyjne, kobiecy zakon św. Jakuba Baradeusza oraz kilka klasztorów (m.in. Mar Mataj w Iraku, Mor Hananjo i Mor Gabriel w Turcji, Mar Musa i Mar Efrem w Syrii). Patriarcha syryjski pielęgnuje relacje ekumeniczne z Kościołem rzymskokatolickim i innymi Kościołami orientalnymi, od 1960 roku jest członkiem Światowej Rady Kościołów, zaś od 1998 roku spotyka się regularnie raz w roku z przywódcami Kościoła koptyjskiego i ormiańskiego.

Do lat 50. XX wieku, czyli w okresie kształtowania się ruchu narodowego, elity Syryjskiego Kościoła Ortodoksyjnego preferowały nazwę „Asyryjczycy”. Działo się tak za przyczyną patriarchy Ignatiusa Efrema I Barsuma $^{81}$, który popierał asyryjską ideologię do czasu, kiedy oficjalnie z nią zerwał, publikując artykuł Syryjski Kościót Antiochii: jego nazwa i historia. $\mathrm{W}$ artykule tym hierarcha argumentował za użyciem terminu „aramejski”, gdyż jego zdaniem adekwatniej pokazywał on pochodzenie etniczne jego rodaków (i dobitniej akcentował chrześcijańskie korzenie). W konsekwencji nazwa Kościoła została zmieniona na „syryjski” (ang. Syrian), a w 2000 roku na „syriacki” (ang. Syriac) ${ }^{82}$. Fakt ten ukazuje istotność roli, jaką odgrywa w kształtowaniu tożsamości wspólnoty kler syryjski ${ }^{83}$, odrzucający promowaną przez nacjonalistów „asyryjskość”.

Rozdźwięk między perspektywą świecką a kościelną można zrozumieć na płaszczyźnie postaw filozoficznych. Ruch świecki pragnął restauracji asyryjskiej wspólnoty (pod różnymi nazwami) w starożytnej ojczyźnie i wyrwania jej z „ciemnych wieków”, w których była pogrążona od upadku imperium asyryjskiego. Kościoły, choć oczywiście zależało im na bezpieczeństwie i dobrobycie wiernych, przede wszystkim szukały komunii z Bogiem. Nie

${ }^{81}$ Ignatius Efrem I Barsum, jeszcze jako biskup Syrii, reprezentował wspólnotę syryjską na konferencji paryskiej w 1919 roku - rozczarowany egoizmem potęg europejskich, bronił nie tylko praw Syryjczyków, ale i Arabów. Był apostolskim delegatem na światowej konferencji w Genewie i Lozannie w 1927 roku i emisariuszem w Stanach Zjednoczonych. Po wyświęceniu na patriarchę i upadku imperium osmańskiego zmuszony był przenieść swoją stolicę z Dajr az-Zafaran do Hims w Syrii. Pod koniec życia znany był z postawy proarabskiej (zyskał nawet przydomek „księdza Arabów”), podobnie jak obecny patriarcha Ignatius Zakka I Iwas, cyt. za: A. Giwargis, Assyrophobia, http://www.nineveh.com/ASSYROPHOBIA.html, data wejścia 11.08.2009.

${ }^{82}$ Ta ostatnia zmiana dotyczy wyłącznie języka angielskiego.

${ }^{83}$ N. Atto, op. cit. 
uważały, by konieczna była ziemska ojczyzna i nie były gotowe popychać swoich wyznawców do konfrontacji z reżimami bliskowschodnimi. Pozostawały jednak filarami tożsamości, a promując ważne figury ze swojej historii jako bohaterów narodowych, przyczyniły się do jej umacniania. Męczennicy za wiarę byli upamiętniani jako męczennicy narodowi, zresztą według nacjonalistów nie umierali wyłącznie za wiarę, ale i za naród.

Dodatkowo Kościoły nadawały biblijną perspektywę staraniom nacjonalistów - głosząc proroctwa odnoszące się do Asyrii z pism hebrajskich. Dla niektórych Asyryjczyków/Aramejczyków te fragmenty ukazują szczególną troskę Boga o ich lud ${ }^{84}$. Zgodnie z tym poglądem naród asyryjski/ aramejski nie może zginąć, ponieważ zostało mu nakazane przez Boga działanie dla dobra całej ludzkości. Asyryjska/aramejska tożsamość narodowa jest więc zgodna z boską wolą; by przeznaczenie mogło się wypełnić, należy odzyskać ziemię ojczystą (konieczną dla odrodzenia „chwały potężnego narodu”) oraz uznanie ${ }^{85}$. Jak widać z powyższego, Kościoły, jako depozytariusze „prawd odwiecznych”, były konieczne dla celów nacjonalistów, a jednocześnie stanowiły przeszkodę w ich realizacji.

Ambiwalentna rola religii wyznawanej w konkretnym obrządku syryjskim objawiała się w jeszcze innej sferze. $Z$ jednej strony oddzielała bowiem od muzułmanów, z drugiej - od członków siostrzanych Kościołów. $\mathrm{Z}$ punktu widzenia asyryjskiej większości odseparowanie się innych grup było zbędnym rozdrobnieniem, jednak z punktu widzenia wielu Aramejczyków utożsamianie ich z Asyryjczykami było nieuzasadnione ${ }^{86}$. Odrzucenie panasyryjskości przyszło przede wszystkim ze strony najbliższych Asyryjczykom Chaldejczyków (mimo akceptacji przez niektórych, również duchownych, idei asyrianizmu), głównie z powodu ich wyjątkowej pozycji i sytuacji w Iraku, gdzie rozwinęli bliższe relacje z rządem basistowskim, przez co funkcjonowali jako osobna kategoria ekonomiczna i polityczna - poczucie odrębności przenieśli do diaspory ${ }^{87}$.

Aby przezwyciężyć wspomniane podziały, niektórzy Asyryjczycy zaczęli promować pełną laicyzację. Wychodzili z przekonania, że Asyryjczycy mają wspólną tożsamość nie tylko z Chaldejczykami, ale i z syryjskimi ortodoksami, a nawet Maronitami - powinni być więc uznawani za jeden „naród”, posiadający wiele praktyk religijnych. Taka idea nie była niczym nowym,

\footnotetext{
${ }^{84}$ P. H. Talia, Between Hope and Hopelessness, Chicago 1985, s. 15, 40-41.

${ }^{85}$ Ibidem, s. 46.

${ }^{86}$ M. Al-Rasheed, op. cit., s. 114-116.

${ }^{87}$ A. Ishaya, „Class and Ethnicity...”, s. 135.
} 
nowe natomiast były w diasporze możliwości i środki jej szerzenia. Co więcej, ten inkluzywny pogląd został połączony z ruchem narodowościowym, pragnącym nadać swym dążeniom formę geopolityczną, przy czym zdecydowaną większosśc wysiłków podejmowano w bardziej zeświecczonej diasporze. Kościoły nie zostały odsunięte całkowicie - religia pozostała znacznikiem tożsamości, ale niższej rangi niż „cechy narodowe”

W konsekwencji opuszczenie szeregów któregokolwiek z Kościołów syryjskich przestało oznaczać rezygnację z etniczności ${ }^{89}$. Pod koniec XX stulecia dla narodowców koncept ojczyzny, choć istotny, nie mógł odgrywać przewodnej roli, gdyż do tych samych ziem na pograniczu Iranu, Iraku, Turcji i Syrii rościły sobie prawa inne ludy, zaś większość Asyryjczyków/Aramejczyków żyła w diasporze. Ruch narodowy docenił więc wagę języka i pochodzenia, jednak jego koncepcje nie spotkały się z powszechną akceptacją. Na poziomie teoretycznym znakomita część wspólnoty asyryjsko-aramejskiej zdaje się przyjmować założenia świeckiej, nacjonalistycznej świadomości w obrębie linii etnicznych oraz głosi nieistotność czynników religijnych, politycznych, ekonomicznych czy klasowych. W rzeczywistości te ostatnie odgrywają ważną rolę, dzieląc społeczność i sprawiając, że nie przemawia ona jednym głosem ${ }^{90}$, co wyraźnie ujawnia się w obliczu ambitnych planów powrotu na Bliski Wschód i stworzenia tam autonomicznego państwa. Większość Asyryjczyków/Aramejczyków nie dała się przekonać i zadowoliła żądaniem uznania ze strony państw imigracji oraz poprawianiem relacji z państwami emigracji ${ }^{91}$.

\subsubsection{Organizacje asyryjskie oraz aramejskie}

Obok nieformalnych wysiłków, by zachować dziedzictwo, wspólnota asyryjsko-aramejska utworzyła wiele klubów, organizacji i stowarzyszeń. Niemal od początku swego istnienia w diasporze promowała swój język, kulturę i edukację. Oprócz prowadzenia działalności społeczno-kulturalnej zakładano polityczne grupy i stowarzyszenia, mające na celu szerzenie świadomości i zabezpieczanie praw etniczno-narodowych"2 ${ }^{92}$ Najważniejsze asyryjskie/aramejskie organizacje to (chronologicznie):

\footnotetext{
${ }^{88}$ M. Al-Rasheed, op. cit., s. 184-185.

${ }^{89}$ A. I. Laing-Marshall, op. cit., s. 123.

${ }^{90}$ M. Al-Rasheed, op. cit., s. 87-89, 91, 101.

${ }^{91}$ Ibidem, s. 128.

92 J. Yacoub, op. cit., s. 34.
} 
- 1915 - Assyrian National Association (ANA), utworzona w Stanach Zjednoczonych, w związku ze zwiększającą się liczbą asyryjskich imigrantów, w New Britain; pomagała im znaleźć pracę, mieszkanie oraz zapewnić edukację dzieciom ${ }^{93}$;

- 1957 - Assyrian Democratic Organization (ADO), znana jako Mtakasta, założona w Syrii przez centrolewicowich intelektualistów, będąca największą asyryjską organizacją w tym państwie. ADO działa szczególnie prężnie w niektórych krajach europejskich: w Niemczech, Holandii, Szwecji, Belgii oraz Austrii. Została powołana jako ruch narodowy, polityczny i demokratyczny, mający na celu ochronę istnienia Asyryjczyków oraz realizację ich aspiracji narodowych, politycznych, kulturalnych i administracyjnych w historycznej ojczyźnie. Rząd syryjski niechętnie patrzy na niektóre działania organizacji (np. zabronił jej członkom upamiętniania Dnia Męczenników) ${ }^{94}$;

- 1968 - Assyrian Universal Alliance (AUA), Asyryjskie Przymierze Powszechne, zostało stworzone jako międzynarodowa asyryjska organizacja patronacka w celu szczerzenia wiedzy o Asyryjczykach, ochrony ich praw w ojczyźnie, utworzenia autonomicznego okręgu w Iraku; w jej skład weszły asyryjskie federacje i organizacje z całego świata ${ }^{95}$. W 1991 roku została członkiem Organizacji Narodów i Ludów Niereprezentowanych (Unrepresented Nations and Peoples Organization - UNPO). Jej obecnym sekretarzem generalnym jest Praidon Darmoo ${ }^{96}$;

- 1976 - Bet-Nahrain Democratic Party, asyryjska partia polityczna w Iraku, na czele której stoi Romeo Nissan Hakkari. Jednym z celów partii jest stworzenie autonomicznego regionu asyryjskiego w obrębie Iraku. Partia jest znana ze swego ekstremalnego nacjonalizmu co do nazwy (jedynie akceptowana opcja to „asyryjska”). Nie brała udziału w irackich wyborach do parlamentu w grudniu 2005 roku. Posiada stację radiową - KBSV, nadającą z Kalifornii ${ }^{97}$;

${ }^{93}$ M. BetGivargis-McDaniel, Assyrians of New Britain (Images of America: Connecticut), Charleston SC 2007, s. 85.

${ }^{4}$ Zob. Assyrian Democratic Organization, http://en.ado-world.org/, data wejścia 11.08.2009.

${ }^{95}$ Assyrian American National Federation, Assyrian Association of Armenia, Assyrian Australian National Federation, Assyrian National Congress of Georgia, Assyrian National Council of Iran, Assyrian Federation of Russia, cyt. za: Affliates, http://aua.net/index.php?option=com_content\&view=article\&id=96\&Itemid=86, data wejścia 12.08.2009.

${ }^{96}$ Ibidem.

${ }^{97}$ Bet-Nahrain Democratic Party's Declaration, „Assyria Times”, http://assyriatimes.com/ engine/modules/news/article.php?storyid=3236, data wejścia 12.08.2009. 
- 1978 - Shuraya Party, asyryjska organizacja polityczna powstała w Libanie, działająca także w Europie. Popiera powstanie państwa asyryjskiego w północnym Iraku. Nie jest związana z żadnym Kościołem, ale odrzuca zarzuty o bycie antychrześcijańską. Pragnie reprezentować interesy wszystkich orientalnych chrześcijan. Współpracowała z Falangą Libańską i Baszirem Dżemajelem. Od lat 80 . XX wieku wydaje własny periodyk „Shuraya” oraz nadaje program radiowy „Mój głos” na falach radia FM" ${ }^{98}$;

- 1979 - Assyrian Democratic Movement (ADM), znany też jako Zowaa, w 1982 roku rozpoczął aktywną walkę z reżimem Saddama Husajna. Ze względu na działania asyryjsko-amerykańskiego lobby oraz kongresmana Henry'ego Hyde'a, prezydent George W. Bush ogłosił ADM oficjalnie uznanym ruchem opozycyjnym w Iraku, a w 1998 roku podpisał ustawę umożliwiającą rządowi USA finansowanie ruchu oraz innych grup opozycyjnych. Obecnie ADM jest jedyną asyryjską partią polityczną w irackim parlamencie. Deklaruje, że ,jest demokratyczną organizacją polityczną - narodową i patriotyczną - broniącą naszego ludu i jego słusznych praw, walczącą pod sztandarem wolnego, demokratycznego Iraku”. Wzywa do „jedności naszego ludu o różnych tożsamościach: chaldejskiej, syryjskiej i asyryjskiej”. Popiera ideę Iraku jako federacji. Utrzymuje dobre relacje z innymi asyryjskimi/aramejskimi i kurdyjskimi grupami obecnymi w północnym Iraku, jak również z szyickimi przywódcami w południowej części kraju. Posiada swoją reprezentację w parlamencie Kurdystanu. Na czele organizacji stoi Yonadam Kanna (wcześniej członek Rady Rządzącej Iraku). Od upadku reżimu Saddama Husajna ruch stanowił kilkakrotnie cel zamachów. Z partią związane są media: „Ashur TV”, „Ashur Radio” oraz gazeta „Bahra”,

- 1983 - Assyrian National Congress (ANC), organizacja patronacka stworzona w Kalifornii; skupia wiele politycznych i religijnych odłamów asyryjskich. Celem ANC jest zachowanie asyryjskiej jedności i kultury, promowanie świadomości, zapewnienie „międzynarodowo uznanych praw” ${ }^{100}$ oraz stworzenie „asyryjskich

${ }^{98}$ Shuraya Party, http://www.shuraya.de.vu/, data wejścia 12.08.2009.

${ }_{99}$ Assyrian Democratic Movement, http://www.zowaa.org/, data wejścia 28.06.2009.

${ }^{100}$ Rozumieją przez to decyzje Ligi Narodów po I wojnie światowej, według których Asyryjczycy powinni być politycznie autonomicznym ludem. 
strażników do ochrony asyryjskiego ludu"101. Niemniej wielu Asyryjczyków odmawia jej tak prestiżowej roli ${ }^{102}$;

- 1983 - Syriac Universal Alliance (SUA), powołana do życia w New Jersey, jest organizacją patronacką Aramejczyków/Syryjczyków i ich organizacji na całym świecie. $\mathrm{Na}$ jej czele stoi Johny Messo $^{103}$. W 2011 roku zmieniła nazwę na World Council of Arameans (Syriacs);

- 1988 - Aramean Democratic Organization (ArDO), znana także jako At-Tanzim al-Arami ad-Dimukrati, została utworzona jako partia polityczna Aramejczyków/Syryjczyków w Libanie. Jej celem jest stworzenie narodu aramejskiego ${ }^{104}$ oraz niepodległego państwa aramejskiego na odwiecznych ziemiach Aramu, z bazą w Libanie. Pragnie głosić sprawę aramejską na poziomie międzynarodowym, bronić praw Aramejczyków, chronić ich dziedzictwo przed systematyczną rządową ,arabizacją, turcyzjacją, kurdyfikacją i islamizacją", pielęgnować język aramejski, zapobiegać asymilacji w diasporze. Liderem ArDO jest Gabi Gallo ${ }^{105}$. Podobne treści głosi nadająca z Holandii „Aramean TV”"106;

- 1991 - Assyrian Aid Society - organizacja charytatywna działająca w USA, Kanadzie, Wielkiej Brytanii, Szwecji, Australii i Nowej Zelandii, której celem jest zbieranie funduszy na poprawę warunków życiowych Asyryjczyków żyjących w Iraku. Aktualnym przewodniczącym AAS jest Napoleon Patto ${ }^{107}$.

${ }^{101}$ M. Al-Rasheed, op. cit., s. 58.

${ }^{102}$ F. Sarguis, rec. M. Al-Rasheed, Iraqi Assyrian Christians in London: The Construction of Ethnicity, New York 1998, JAAS, Vol. 14, No. 1, 2000, s. 90.

${ }^{103}$ Podlegają jej Syriac European Union oraz Syriac American Union (znane jako Aramaic American Association), cyt. za: Syriac Universal Alliance, http://www.sua-ngo.org/, data wejścia 12.08.2009.

${ }^{104} \mathrm{~W}$ skład tego narodu mieliby wejść syryjscy ortodoksi, syryjscy katolicy, Maronici, wschodni Syryjczycy (nestorianie i Chaldejczycy), rzymscy katolicy na Bliskim Wschodzie, syryjscy protestanci, melkici ortodoksyjni i katolicy na Bliskim Wschodzie, Mandejczycy, Aramejczycy z Syrii (z Damaszku, Maluli i okolic), cyt. za: Aramaic Democratic Organization, http://www.aramaic-dem.org/, data wejścia 12.08.2009.

105 Ibidem.

${ }^{106}$ Strona, na której można odbierać stację „Aramean TV”: http://www.arameantv.nl.tt, data wejścia 11.01.2010.

${ }_{107}$ Assyrian Aid Society, http://www.assyrianaidsociety.org/about_us.php, data wejścia 11.01.2010. 
To tylko niektóre większe organizacje asyryjskie i aramejskie, nie sposób wymienić wszystkich ${ }^{108}$. Należy przy tym zauważyć, że Asyryjczycy/Aramejczycy w Europie, mimo bardzo dużej aktywności na poziomie lokalnym, nie są tak zorganizowani na poziomie państwowym jak wspólnota w USA ${ }^{109}$. Zresztą na początku XXI wieku ta ostatnia również nie ma zbyt wielu osiągnięć, którymi mogłaby się poszczycić - AUA z pozycji organizacji patronackiej skurczyła się do partii politycznej reprezentującej jeden odłam. Przyczyny takiego stanu rzeczy są zarówno natury zewnętrznej, jak i wewnętrznej ${ }^{110}$.

Przede wszystkim brakuje liderów i opłacanych profesjonalistów - gdy ojcowie-założyciele organizacji odeszli na emeryturę, nie zastąpili ich młodzi działacze wychowani za granicą. Ster przejęli nowi imigranci, nieznający zachodnich realiów i nieposiadający klarownej wizji, a w obliczu braku funduszu narodowego pełniący swoje funkcje jako wolontariusze. Efektem była pusta retoryka zamiast konkretnych działań - domaganie się odgórnego zapewnienia dobrobytu przez rządy, bez mozołu pracy u podstaw. Trudno zresztą całą winę składać na barki przywódców - nie dysponowali przecież autorytetem przypominającym władzę państwową, by narzucać jedność, zaś cała społeczność wymagała edukacji co do mechanizmów politycznych panujących za granicą (poziom wiedzy w tej dziedzinie drastycznie wzrósł po upowszechnieniu Internetu). Dodatkowo nie byli oni wolni od politycznych presji - infiltrowali ich chociażby iraccy agenci, zainteresowani mnożeniem podziałów. W rezultacie do tej pory nie istnieją instytucje w wystarczający sposób chroniące etniczną odrębność i ciągłość asyryjskoaramejskiej wspólnoty ${ }^{111}$.

\subsubsection{Problem asymilacji}

Doświadczenie diaspory ma dwa oblicza - jest dobrodziejstwem dla wspólnoty zagrożonej eksterminacją, gwarantem jej fizycznego trwania, ale równocześnie niesie niebezpieczeństwo asymilacji. Część Asyryjczy-

${ }^{108}$ Rozszerzone listy asyryjskich/aramejskich organizacji znajdują się m.in. na stronach internetowych: http://www.aina.org/aol/link3.htm oraz http://www.edessa.com/assyorgs.htm.

${ }^{109}$ M. Al-Rasheed, op. cit., s. 58; J. Yacoub, op. cit., s. 30. Oczywiście czynione są pewne próby, np. po obaleniu reżimu Saddama Husajna powołano do życia Assyria Council of Europe (ACE) z siedzibą w Brukseli, która pragnie lobbować za sprawą asyryjskochaldejsko-syryjską przed instytucjami europejskimi, zob. http://www.assyriacouncil.eu, data wejścia 12.08.2009.

${ }^{110}$ A. Ishaya, Assyrian-Americans...

${ }^{111}$ Ibidem. 


\section{4}

ków/Aramejczyków, szczególnie dotyczy to osób urodzonych na Zachodzie, znających jedynie środowisko kulturalne swych przybranych ojczyzn ${ }^{112}$, świadomie wtapia się w społeczeństwa przyjmujące, aby nie być postrzeganym jako „obcy”. Nie dotyczy to wyłącznie sfery zewnętrznej (stroju, języka używanego w sytuacjach publicznych), lecz rozciąga się na sferę prywatną, np. rodzaj przygotowywanego jedzenia, wybór imion, język używany w domu ${ }^{113}$.

Asymilacji w diasporze sprzyjają warunki panujące w krajach przodków oraz poglądy żywione przez samych imigrantów, czujących, że zostali wygnani ze swych domów przez rządy i społeczeństwa bliskowschodnie. Niewielu przejawia chęć powrotu ${ }^{114}$. Przeważnie Asyryjczycy/Aramejczycy postrzegają kraje przyjmujące jako nowe domy i chcą udowodnić, że są ich pełnoprawnymi mieszkańcami ${ }^{115}$. W rezultacie, choć szukają uznania jako etnia, generalnie opierają się upolitycznieniu, gdyż żądania nacjonalistyczne mogą podważyć ich wizerunek jako spokojnych obywateli. Asyryjskim/aramejskim rodzicom zdarza się zniechęcać swoje dzieci do udziału w narodowościowych demonstracjach, marszach i innych zgromadzeniach ${ }^{116}$ (choć nie dotyczy to całej grupy).

Całkowita asymilacja, jeśli nastąpiła, to najczęściej w stosunku do tych najdawniejszych imigrantów, którym jeszcze w ojczyznach zagraniczni misjonarze zaszczepili prozachodnią orientację ${ }^{117}$. Niezadowolenie z własnego stylu życia oraz pozytywna wizja Zachodu ułatwiały i przyśpieszały wtapianie się w nowe społeczeństwa. Jednak na przestrzeni dekad pokolenia Asyryjczyków/Aramejczyków były coraz bardziej świadome własnej odrębności etnicznej, a jednocześnie sfrustrowane brakiem zainteresowania i pomocy ze strony Zachodu ${ }^{118}$. Poczucie opuszczenia prowadziło ich do przekonania o zdradzie przez Europejczyków, szczególnie przez Brytyjczyków. Doświadczenia I wojny światowej i powojenne trudy umocniły tożsamość zbiorową, która została wyeksportowana za granicę ${ }^{119}$.

Jej utrzymaniu służył wzorzec osiedleń - kolejni migranci dołączali do już utworzonych skupisk lub emigrowali całymi wioskami do pracy ${ }^{120}$.

${ }^{112}$ Idem, „Class and Ethnicity...”, s. 155.

${ }^{113}$ Idem, The Role of Minorities..., s. 101; idem, „Class and Ethnicity...”, s. 155-156, 201.

${ }^{114}$ M. Al-Rasheed, op. cit., s. 72-75.

115 Ibidem, s. 81-82.

116 Ibidem, s. 76.

117 A. Ishaya, „Class and Ethnicity...”, s. 64-73.

${ }^{118}$ Ibidem, s. 82-83.

${ }^{119}$ A. I. Laing-Marshall, op. cit., s. 110.

${ }^{120}$ A. Ishaya, The Role of Minorities..., s. 75, 78; idem, „Class and Ethnicity...”, s. 237. 
Niektóre grupy były w stanie odtworzyć swoje życie społeczne na niemalże niezmienionych zasadach, ponieważ zdolność wspólnoty do utrzymywania relacji przez socjalizację, celebracje, kult itp., pozostawała niezwykle duża. Poza tym istotną rolę odgrywały czynniki ekonomiczne - wspomniana wcześniej opłacalność asyryjskiego/aramejskiego samozatrudnienia, skontrastowana z obojętnością i/lub wrogością lokalnej populacji, skłaniała Asyryjczyków/Aramejczyków do polegania wyłącznie na sobie i wzmacniania wewnętrznych więzi ${ }^{121}$.

\subsubsection{Podsumowanie}

Choć Asyryjczycy/Aramejczycy emigrowali od XIX wieku, to w okresie po II wojnie światowej diaspora ta wyrosła na „rywalizujące” centrum życia asyryjskiego w stosunku do ośrodków na Bliskim Wschodzie. Stało się tak ze względu na promowane przez nią nowe zrozumienie tożsamości, opartej na etosie jedności krwi i języka, z Kościołami zredukowanymi do podtrzymujących filarów kulturowych ${ }^{122}$. Istniejący niemal od początku dystans między „bardziej świecką” diasporą, a „bardziej religijną” ojczyzną z czasem jeszcze się powiększał - mimo że większość emigrantów pozostawała nieupolityczniona, to w porównaniu z Bliskim Wschodem działało wśród nich zdecydowanie więcej nacjonalistów, czerpiących garściami z ideologii zachodnich.

Dzięki rozwojowi komunikacji Asyryjczycy/Aramejczycy z diaspory łatwiej mogą utrzymywać kontakt ze sobą niż ci, którzy zostali w „starych krajach”. Diaspora, mimo snucia mitów osadzonych w kontekście „ojczyzny" i deklarowanego zainteresowania problemami pozostawionych na Bliskim Wschodzie rodaków, w rzeczywistości ma z nimi ograniczony kontakt. Rozwija raczej „własne życie”, zorientowane na samą siebie, skoncentrowane wokół miejscowych aktywności i problemów. W większym stopniu czerpie siły z energii rozproszonych członków niż z rdzenia w ojczyźnie ${ }^{123}$. W efekcie ziemia stanowiąca punkt odniesienia jest de facto bardzo odległa od imigranckiej codzienności.

Bliskie i aktualne są natomiast podziały wzdłuż linii wyznaniowych i politycznych, przede wszystkim na Asyryjczyków i Aramejczyków. Pierwotna przyczyna tych podziałów to koncept nowej tożsamości, bardziej bazującej

${ }^{121}$ Idem, „Class and Ethnicity...”, s. 145-147.

${ }^{122}$ A. I. Laing-Marshall, op. cit., s. 91.

${ }^{123}$ M. Al-Rasheed, op. cit., s. 194. 
na języku i pochodzeniu, niż na byciu chrześcijaninem obrządku syryjskiego. Ziarna nacjonalistycznego myślenia zasadzone w Urmii w XIX wieku przekształciły się w ruch, który jednoczy coraz większą liczbę zwolenników $^{124}$. Idea stworzenia autonomicznego okręgu lub państwa w Mezopotamii powraca raz za razem, nigdy jednak nie zdobywając poparcia całej wspólnoty.

\subsection{Internet jako narzędzie kształtowania tożsamości}

Podobnie jak fizyczna przestrzeń, kulturalna i społeczna cyberprzestrzeń rozdziela się na przeróżne wirtualne krajobrazy ${ }^{125}$, takie jak elektroniczne biuletyny informacyjne, listy dyskusyjne, czaty, strony domowe - każdy z nich zapewnia nisze dla gwałtownie powiększającej się liczby „cyberobywateli”. W obrębie tych nisz kwitną zbiorowości łączące ludzi i tworzące systemy kulturowych znaczeń niemal w oderwaniu od ograniczeń czasu i przestrzeni ${ }^{126}$. Co jednak podkreślają cyberantropolodzy - poziomy online i offline to elementy tej samej rzeczywistości, nie coś z gruntu innego ${ }^{127}$, z tego względu nie można rozważać kwestii dotyczących konkretnych grup użytkowników Internetu bez poznania pozasieciowego kontekstu ich interakcji.

Awansowanie Internetu do roli środka masowej komunikacji w latach 90. XX wieku niezwykle przyczyniło się do rozwoju asyryjskiej/aramejskiej tożsamości. Korzystający z Internetu Asyryjczycy/Aramejczycy często zmuszani są bowiem do dokonania autoprezentacji, samookreślenia. W wyniku kontaktu z komputerem i siecią ich świadomość rozwija się i zmienia. Przetworzeniu ulega wyobrażenie o tym, jaka jest rzeczywistość. Taka sytuacja sprzyja formowaniu się tożsamości, tworzeniu obrazu samego siebie. Zygmunt Bauman zauważył, że „dzięki obcym można zdefiniować swoich”" ${ }^{128}$. Parafrazując - dzięki Internetowi łatwiej i bezpieczniej odnajduje się swoich ${ }^{129}$.

${ }^{124}$ A. I. Laing-Marshall, op. cit., s. 124-126.

125 Por. M. A. Smith, P. Kollock (red.), Communities in Cyberspace, London-New York 2005.

${ }^{126}$ M. Sökefeld, Alevism Online: Re-Imagining a Community in Virtual Space, „Diaspora: A Journal of Transnational Studies”, Vol. 11, No. 1, Spring 2002, s. 85-123, http://www. utpjournals.com/diaspora/diaspora111.html, data wejścia 1.09.2009.

${ }_{127}$ B. Braüchler, Comments on Jonathan's Skinner's Working Paper „At the Electronic Evergreen: A Computer Mediated Ethnography of a Newsgroup from Montserrat and Afar", s. 1, http://www.media-anthropology.net/braeuchler_comment.pdf, data wejścia 1.09.2009.

${ }_{128}$ Z. Bauman, Dwa szkice o moralności ponowoczesnej, Warszawa 1994, s. 15.

${ }^{129}$ R. Lis, Internet narzędziem kształtowania tożsamości jednostki [w:] I. Borowik, K. Leszczyńska, op. cit., s. 327. 
Z drugiej strony w Internecie, który niektórzy charakteryzują jako „królestwo anarchii” czy „egalitarne forum” ${ }^{130}$, procesy komunikowania oraz interakcje społeczne, będące podstawą kształtowania tożsamości, przebiegają nieco inaczej niż w świecie realnym. Amerykański psycholog John Suler podkreśla, że cyberprzestrzeń rządzi się własnymi prawami, a zjawiska w niej zachodzące ograniczane są przez brak doświadczeń sensorycznych. W Internecie występuje płynność tożsamości oraz anonimowość, jak również zrównanie statusów, dzięki czemu jednostka nie jest ograniczana przez swoje pochodzenie czy wykształcenie ${ }^{131}$. Suler wymienia ponadto pokonywanie ograniczeń przestrzennych, które umożliwia kontakt osobom o podobnych zainteresowaniach i potrzebach bez względu na miejsca, w jakich się znajdują. Inną cechą Internetu jest rozciągnięcie i koncentracja czasu - rozmowy w cyberprzestrzeni dają, z jednej strony, poczucie skondensowania upływu czasu, z drugiej - umożliwiają przemyślenie odpowiedzi. Internet oferuje dostępność wielu kontaktów, możliwość permanentnego zapisu większości procesów zachodzących w sieci oraz odmienne stany świadomości.

Wzmiankowane wyżej cechy Internetu mają przełożenie na zachowania jego użytkowników - zmieniając standardowe wzory postępowania najpierw w wirtualnej rzeczywistości, kreują nowe zachowania, które mogą, choć nie muszą, przeniknąć również do fizycznej rzeczywistości ${ }^{132}$.

\subsubsection{Cyber-Asyria/Cyber-Aram}

Pozbawieni państwowości Asyryjczycy/Aramejczycy próbują obecnie dokonać konstrukcji bądź rekonstrukcji swojej tożsamości narodowej. Korzystają przy tym w coraz większym stopniu ze środków masowego przekazu, głównie z Internetu. W ciągu ostatniego dziesięciolecia pojawiło się bardzo wiele asyryjskich i/lub aramejskich i/lub chaldejskich stron internetowych, linków, czatów, newsów, magazynów kulturalnych, nagrań, filmów itp. ${ }^{133}$ Ich lektura pokazuje zarówno tendencje unifikacyjne, jak i separatystyczne.

Szczególnie interesujące z punktu widzenia niniejszej książki są strony, które oficjalnie i programowo realizują misję budowy świadomości narodo-

${ }^{130}$ T. Morris-Suzuki, The Past within Us: Media, Memory, History, London-New York 2005, s. 211.

${ }^{131}$ R. Lis, op. cit., s. 328.

132 Ibidem, s. 329.

${ }^{133}$ W sierpniu 2012 roku Google wyświetlał ponad 36 mln wyników dla „Aramaic”, $28 \mathrm{mln}$ dla „Syriac”, $16 \mathrm{mln}$ dla „Assyrian”, 2,8 mln dla „Chaldean”, 1,5 mln dla „Aramean” (słowo „Syrian” nie zostało uwzględnione, gdyż większość wyników dotyczyłaby obywateli Syrii). 
wej. Przodują tu strony asyryjskie, aktywne od połowy lat 90. Przykładowo wydanie online magazynu „Zindy” otwierała w 1995 roku taka deklaracja:

Nareszcie jest: pierwszy numer „Zindy”. Jesteśmy gotowi, by surfować po falach Internetu z jednego krańca globu na drugi, szerząc nowinę o nowym asyrianizmie. Więcej o tym przeczytacie w naszych kolejnych numerach. Teraz cieszmy się nastaniem nowej ery - oto dzieci starożytnej Mezopotamii, które pisały na glinianych tabliczkach, komunikują się dzięki poczcie elektronicznej. Wkrótce „Zinda” będzie najefektywniejszym środkiem wymiany idei oraz wiadomości pomiędzy studentami, przedstawicielami wolnych zawodów oraz intelektualistami nowego asyryjskiego społeczeństwa. Żaden z otrzymywanych materiałów nie jest edytowany, a wszystkie opinie zostają zamieszczone bez cenzury. Obecnie prenumerują „Zindę" studenci i przedstawiciele wolnych zawodów z kilkunastu uniwersytetów oraz stowarzyszeń z sześciu europejskich i północnoamerykańskich krajów. A to dopiero początek. Chwyć więc swoją deskę i zacznij surfować na intelektualnej fali nowego asyryjskiego nacjonalizmu ${ }^{134}$.

W bardzo podobny ton uderzała o dwa lata młodsza Nineveh On-line. Twórcy tego portalu w 1997 roku kierowali do odwiedzających następujące słowa:

Witajcie w Asyrii, „Waszej ziemi w cyberprzestrzeni” (...) Czy Asyria istnieje? Czy jest państwem, narodem, organizacją? (...) „Asyria w cyberprzestrzeni”. To brzmi jak wizja przyszłości, jak gra wideo. Z możliwościami, jakie oferuje nam globalna sieć elektroniczna, nasze doświadczenie rzeczywistości się zmienia. Świat „rzeczywisty” ma rywala. Poprzez światy wirtualne, takie jak świat Internetu, jesteśmy zmuszeni rozważyć pytanie: czym w istocie jest naród, wspólnota, unia?

Czyż więc Asyria istnieje? Tak, lecz nie jako naród w dawnym znaczeniu tego słowa, gdy myślimy o państwie posiadającym geograficzne granice, wyjątkowy obszar zamieszkany przez ludzi, którzy zwą się Asyryjczykami. Owszem, starożytne imperium asyryjskie - „ziemia między rzekami” - Beth Nahrain czy Mezopotamia - ciagle może być wskazana na mapie. Lecz przez ponad 2500 lat teren ten jest w rękach innych narodów ${ }^{135}$.

Kilka lat później, na przełomie tysiącleci, pojawiły się w sieci deklaracje tożsamości aramejskiej, jak ta ze strony Arameans of Aram-Nahrin:

Aramejczycy z Mezopotamii są rdzennymi mieszkańcami Aram-Nahrin. Aramejczycy, których nie należy mylić z Ormianami, mówią po aramejsku, w języku Abrahama, Mojżesza i Jezusa Chrystusa. Dzisiejsi Aramejczycy są podzieleni na wiele wyznań i określani wieloma nazwami. (...) „Asyryjczycy”, „Chaldejczycy”, „Maronici” itp., wszyscy są Aramejczykami. Wszy-

134 „Zenda Magazine”, Vol. I, Issue I, February 6, 1995, http://www.zindamagazine. $\mathrm{com} / \mathrm{html} /$ archives/1995/zn020695.html, data wejścia 15.09.2009.

${ }^{135}$ Cyberland-Music, Nationalism \& Internet, http://www.visarkiv.se/mmm/media/assyrien/ cyber-e.htm, data wejścia 5.05.2008. 
scy chrześcijanie na Bliskim Wschodzie (z wyjątkiem Koptów w Egipcie) są Aramejczykami. Ich kultura, historia, język i wiara przyciągnęły uwagę wielu naukowców, artystów, lingwistów, księży i ludzi świeckich [tu wymieni zostali m.in. Jakub Sarudż (V-VI wiek), Bar Bahlul (X wiek), Michał Wielki (XII wiek), Bar Hebraeus (XIII wiek), potem dodano współczesne nazwiska włoskiego reżysera Giacomo Pezalli ${ }^{136}$ oraz Sebastiana Brocka, profesora uniwersytetu w Oksfordzie]. Konkluzja tych słynnych uczonych nie pozostawia cienia wątpliwości - Syryjczycy, znani pod różnymi nazwami, to Aramejczycy z Mezopotamii!

Następnie tekst pod nagłówkiem „Zachodnie misje i stworzenie mitycznych tożsamości... Duchowe ludobójstwo Aramejczyków...” tłumaczył: „Choć nazwa naszego ludu i jego historia są dobrze udokumentowane (...). Kościół rzymskokatolicki i misje anglikańskie czuły, że konieczne jest wszczepienie mitycznych nazw w umysły naszych ludzi (...). Dlatego też wschodnioaramejscy „nestorianie” wolą nazywać się "Asyryjczykami« i próbują za wszelką cenę narzucić ten termin innym wyznaniom aramejskim, szerząc fałszywe informacje o pochodzeniu i języku naszego ludu (...)"137. Strona nazywała Asyryjczyków „apostatami”, „kryminalistami” i „bandytami”, którzy terroryzują naród aramejski, dokonując na nim duchowego ludobójstwa ${ }^{138}$.

Z kolei www.CHALDEAN.org, powstała w tym samym czasie, stwierdzała jedynie, że jest stroną społecznościową dostępną dla każdego i wszędzie jako system Web 2.0, który otrzymał półtoramilionowy grant na „obywatelskie dziennikarstwo w Nowej Erze”. Grant został przyznany, aby stworzyć alternatywę dla tradycyjnych mediów, które dostarczają informacje interesujące tylko nielicznych, nie zaś całą wspólnotę ${ }^{139}$. Mimo tego strona jest wyraźnie chaldejska, odsyła do innych stron, które zawierają w nazwie wyłącznie przymiotnik „Chaldean”.

Oczywiście istnieją także portale skierowane do „wszystkich”, tj. Asyryjczyków/Chaldejczyków/Syryjczyków, np. arabskojęzyczny Assyrian4all ${ }^{140}$ (nazwa wskazuje jednak na preferencję „asyryjską”), z którego można ścią-

136 Twórcy filmu dokumentalnego z 2001 roku The Hidden Pearl: The Aramaic Heritage of the Syrian Orthodox Church, będącego częścią monumentalnego dzieła, składającego się z trzech tomów (autorstwa S. Brocka, D. G. K. Taylora, W. Witakowskiego) oraz trzech towarzyszących im nagrań wideo.

137 http://www.aramnaharaim.org, data wejścia 5.05.2009.

138 http://www.aramnahrin.org/English/Sweden_Aramean_Genocide_5_1_2008.htm, data wejścia 5.05.2009.

${ }^{139} \mathrm{http} / /$ www.chaldean.org, data wejścia 5.05.2009.

${ }^{140} \mathrm{http}: / /$ www.assyrian4all.net, data wejścia 5.05.2009. 
gać gry, filmy, zdjęcia, piosenki. Obok dużych portali informacyjnych, takich jak Assyrian International News Agency (AINA) ${ }^{141}$, Christians of Iraq ${ }^{142}$, Ankawa ${ }^{143}$, łatwo znaleźć wyspecjalizowane strony z kursami języka aramejskiego ${ }^{144}$, modlitwami ${ }^{145}$, relacjami z Bliskiego Wschodu, przepisami kulinarnymi, tańcami, a także portale towarzyskie czy nawet randkowe, jak Assyrian Match ${ }^{146}$, Assyrian Singles ${ }^{147}$ czy Assyrian Cupid ${ }^{148}$. Te ostatnie odgrywają niezwykle ważną rolę - ułatwiają zawieranie endogamicznych małżeństw w diasporze, tym samym chronią ją przed asymilacją i przyczyniają się do przekazania asyryjskich/aramejskich tradycji następnemu pokoleniu. Odrębną kategorię stanowią asyryjskie i aramejskie blogi.

Największe asyryjskie/aramejskie portale internetowe integrują Asyryjczyków/Aramejczyków na całym świecie, informując ich o bieżących wydarzeniach, w szczególności o prześladowaniach współbraci na Bliskim Wschodzie czy próbach uzyskania poparcia na forum międzynarodowym, ale również o celebracjach świąt, sukcesach sportowych ich drużyn piłkarskich, konferencjach i festiwalach, a nawet tradycyjnych przepisach kulinarnych. Tworzą w ten sposób nową jakość - formują asyryjską i/lub aramejską tożsamość narodową.

${ }^{141}$ Anglojęzyczny, skierowany przede wszystkim do Asyryjczyków, http://www.aina. org, data wejścia 5.05.2008.

${ }_{142}$ Jak wyżej, http://www.christiansofiraq.com, data wejścia 5.05.2009.

${ }^{143}$ Arabskojęzyczny, skierowany głównie do Chaldejczyków, http://www.ankawa.com, data wejścia 5.05.2009.

${ }^{144} \mathrm{Na}$ przykład http://learnassyrian.com/aramaic, data wejścia 5.05.2009.

${ }^{145} \mathrm{Na}$ przykład http://www.thenazareneway.com/lords_prayer.htm, data wejścia 5.05.2009.

146 http://www.assyrianmatch.com, data wejścia 5.05.2009.

${ }^{147} \mathrm{http}: / /$ www.assyriansingles.com, data wejścia 5.05.2009.

${ }^{148} \mathrm{http}: / /$ www.assyriancupid.com, data wejścia 5.05.2009. 


\section{ROZDZIAE 4 \\ Tożsamość i historia w świadomości współczesnych Asyryjczyków/Aramejczyków w świetle badań ankietowych}

\subsection{Metoda, techniki badań i procedura opracowywania wyników}

Obecnie w metodologii nauk społecznych panuje dualizm. Z jednej strony istnieje ilościowe badanie rzeczywistości, z drugiej zaś jakościowe ujmowanie zjawisk. Metody ilościowe służą przede wszystkim mierzeniu, w niewielkim stopniu generują nową wiedzę. Dlatego do analizy ilościowej należy przechodzić jedynie po uprzednim uzyskaniu wglądu w system pojęć badanej grupy respondentów; za pomocą metod ilościowych mierzy się wówczas zakres występowania obserwowanych zjawisk.

$\mathrm{Na}$ potrzeby tej pracy został wybrany model triangulacyjny, łączący badania ilościowe, które stanowią jego trzon, z badaniami jakościowymi, będącymi zarówno punktem wyjścia, jak i dopełnieniem tych pierwszych. W ramach badań jakościowych przeprowadzone zostały:

1) obserwacje uczestniczące ${ }^{1}$,

2) wywiady pogłębione (IDI) ${ }^{2}$ :

${ }^{1}$ Obserwacja uczestnicząca polega na celowej rejestracji autentycznych zachowań ludzi w naturalnych warunkach. Ma ułatwić zrozumienie zachowań badanych w prawdziwym otoczeniu, naturalnych sytuacjach i codziennych zdarzeniach. W tym celu badacz-obserwator nawiązuje bezpośredni kontakt z osobami poddanymi badaniu, bierze aktywny udział w obserwowanych sytuacjach, a nawet własnym zachowaniem prowokuje obserwowanych do określonych reakcji i działań.

${ }^{2}$ Bezpośredni wywiad pogłębiony to rozmowa z respondentem na podstawie scenariusza rozmowy lub niestandaryzowanego kwestionariusza wywiadu. Stanowi alternatywę w stosunku do wywiadów zogniskowanych, szczególnie w sytuacji, gdy zebranie grupy jest 
ad 1) Obserwacje obejmowały: uczestnictwo w konferencjach, przyjęciach, nabożeństwach, na których obecni byli Asyryjczycy/Aramejczycy ${ }^{3}$, rozmowy prywatne, wizyty w domach i kościołach oraz klubach kulturalnych w Syrii, Turcji, Niemczech, Szwecji i Brazylii;

ad 2) Trzynaście wywiadów pogłębionych z czternastoma respondentami ${ }^{4}$, przeprowadzone $\mathrm{w}$ języku angielskim lub arabskim od sierpnia 2006 roku do lipca 2007 roku. Poszczególne rozmowy trwały od godziny do prawie trzech godzin. Wśród respondentów były dwie kobiety i dwunastu mężczyzn. Dwanaście osób było przedstawicielami wolnych zawodów lub studentami, zaś dwie pracowały fizycznie. Trzech mężczyzn należało do stanu kapłańskiego, pozostałe to osoby świeckie. Trzy wywiady przeprowadziłam w Brazylii, dwa w Turcji, dwa w Niemczech, pozostałe w Szwecji. Wywiadów nie nagrywałam w związku z prośbami ankietowanych ${ }^{5}$; sporządzałam za to dokładne notatki.

Badani byli traktowani jako współuczestnicy procesu badawczego; wywiady koncentrowały się na ich subiektywnych odczuciach względem tożsamości, przeżyciach oraz doświadczeniach, które mogli swobodnie interpretować. Starałam się zadawać jak najwięcej pytań otwartych, gdyż pytania zamknięte oraz standaryzowane utrudniają lub wręcz zamykają możliwość ujawnienia się pewnych treści.

Ta część badań, poza uzyskaniem dodatkowego materiału przedstawionego w toku pracy, przede wszystkim pozwoliła na określenie głównych zagadnień badawczych, które znalazły wyraz w modelu ilościowym (scjentystycznym). Jeśli chodzi o technikę, to zastosowana została ankieta medialna (internetowa). Tym razem badani nie mieli wpływu na interpretację

trudne lub niemożliwe (jak ma to miejsce w przypadku Asyryjczyków/Aramejczyków). Bezpośredni wywiad pogłębiony zapewnia respondentom większy komfort, co jest szczególnie ważne, kiedy temat badań odnosi się do spraw intymnych, drażliwych lub osobistych doświadczeń badanego. Respondentów dobiera się według pewnych zróżnicowanych kryteriów, takich jak wiek, płeć lub inne ważne cechy.

${ }^{3}$ W dniach 2-3 listopada 2007 roku w Paderborn w Niemczech odbyła się okolicznościowa konferencja „Gemeinsam vorwärts” (Razem naprzód), zorganizowana przez redakcję asyryjskiego magazynu „Funoyo” („Odpowiedž”). Relację z tej konferencji umieściłam na portalu Arabia.pl: http://www.arabia.pl/content/view/290886/61/, data wejścia 9.01.2010. Poza tym wzięłam udział w konferencji Fundatio Nisbinsis w Berlinie 19 kwietnia 2008 roku oraz Symposium Syriacum w Grenadzie 22-27 września 2008 roku.

${ }^{4}$ Jeden wywiad przeprowadzany był symultanicznie z dwoma asyryjskimi politykami, reprezentantami tej samej partii politycznej.

${ }^{5}$ W Turcji zostałam wprost poproszona o nieujawnianie danych osobowych rozmówców ze względu na trudną sytuację polityczną mniejszości etnicznych w tym kraju. 
rzeczywistości, gdyż w badaniach ilościowych upoważniony jest do tego wyłącznie badacz. Dane zebrane w trakcie badań zostały poddane analizie statystycznej.

Ankieta medialna składała się z:

1) ankiety demograficznej własnej konstrukcji,

2a) kwestionariusza własnej konstrukcji, służącego do badania tożsamości asyryjskiej,

2b) kwestionariusza własnej konstrukcji, służącego do badania tożsamości aramejskiej:

ad 1) Ankieta demograficzna składała się z 11 pytań. Pytania ogólne zostały wzbogacone o pytania dotyczące konkretnie tematyki badań, jak np. o kraj pochodzenia żony/męża, czy o przynależność etniczną partnerów (znając odpowiedzi, można oszacować homogeniczność grupy).

Z kolei kwestionariusz zbudowany został z 38 pytań zainspirowanych nurtującymi mnie problemami badawczymi. Część z nich miała charakter otwarty (pyt. 6, 8, 9, 16, 20, 30, 37 i 38) i pozwalała na nieograniczoną długość wypowiedzi. Pozostałe pytania kwestionariusza miały formę testu jednokrotnego wyboru (pyt. 2, 4, 7, 10, 11, 12, 13, 14, 15, 17, 19, 21, 23, 24, 25, 26, 27, 28, 29, 31, 32, 33) lub testu wielokrotnego wyboru (pyt. $1,22,35)$. Dodatkowo zastosowałam skalogramy, które na skali od 1 do 5 mierzyły nasilenie danego zjawiska. Tą techniką badałam znajomość klasycznego języka syryjskiego (pyt. 3), języka aramejskiego (pyt. 5) oraz istotność zachowania tożsamości (pyt. 36). Wariant skalogramu pojawił się także w pyt. 18 i 34 .

Kolejność pytań nie była przypadkowa, miała przypominać rozmowę, która dotyka sukcesywnie poszczególnych kwestii związanych z tożsamością. Pytanie otwierające miało za zadanie sprawdzić, które wyznaczniki tożsamości wspólnoty są najważniejsze dla samych Asyryjczyków/Aramejczyków (kogo postrzegają oni jako członka swojej grupy). Większość tych wyznaczników została poddana dokładniejszej analizie w następnych pytaniach. Pytania od 2 do 9 dotyczyły języka, a właściwie języków używanych przez respondentów. Pytania od 10 do 15 badały uczestnictwo w kulturze asyryjskiej/aramejskiej i jej konkretne przejawy, jak prasa, telewizja, radio, Internet, jak również znajomość książek i sławnych rodaków. Każda odpowiedź była weryfikowana prośbą o podanie przykładów. Następna grupa pytań (od 16 do 20) dotyczyła tradycji, pytanie 21 znajomości historii rodzinnej, zaś pytania od 22 do 24 okazji do spotkań i celebracji świąt. 
Kolejna podgrupa to pytania o przynależność religijną, religijność, nasilenie praktyk religijnych (25 do 27). Pytania 28 i 29 były w istocie pytaniami o więź międzygrupową - prosiły o określenie zainteresowania życiem rodaków. Pytanie 30 sprawdzało percepcję symboli narodowych, zaś pytania od 31 do 33 stopień asymilacji (poparcie dla organizacji i klubów sportowych oraz integrację na trzech płaszczyznach: kulturowej, politycznej oraz religijnej). Pytanie 34 dotyczyło postaw i emocji: percepcji pochodzenia, zadowolenia z bycia Asyryjczykiem/Aramejczykiem, przekonania o starożytnych korzeniach, przynależności do historycznych ziem, pogłębiania wiedzy na temat swoich przodków, preferencji asyryjskiej/aramejskiej muzyki, kuchni, zwyczajów, wreszcie dumy ze swojej wspólnoty. Pytania od 35 do 37 dotykały bezpośrednio zagadnienia tożsamości, a dokładniej niebezpieczeństw, jakie jej grożą, jak również istotności i sposobów jej ocalenia. Zamykające ankietę pytanie 38 pozwalało na przekazanie wolnych wniosków oraz uwag.

Kwestionariusz „Assyrian Identity” konstruowany był na przełomie lat 2007/2008, pierwotnie w języku polskim, a następnie przetłumaczony na języki: angielski, niemiecki, francuski oraz rosyjski. Na początku 2008 roku przetestowałam kwestionariusz, po czym w marcu wysłałam link do niego wraz z wyjaśnieniem celu badań do kilku największych asyryjskich portali internetowych: www.hujada.com, www.aina.org, www.esna.se, www.assyrianchurcheast.com.

Sam proces umieszczania informacji o ankiecie, interakcje z redaktorami poszczególnych portali stanowiły materiał do przemyśleń. Moje apele do osób prywatnych bądź polityków asyryjskich, z którymi wcześniej przeprowadziłam wywiady, o rozesłanie linka, pozostały bez odpowiedzi. Redaktor www.assyrianchurcheast.com wyraził osobiste zainteresowanie projektem, lecz nie umieścił linka na stronie. Redakcja ESNA odmówiła, co motywowała w następujący sposób:

Po otrzymaniu Pani prośby, przedyskutowaliśmy ją w swoim gronie z intencją udzielenia pomocy. Niestety, doszliśmy do wniosku, że nie możemy opublikować ankiety na naszej stronie internetowej. Powodem tej decyzji jest to, że zbieranie informacji tego rodzaju, nawet przy gwarancji anonimowości, uważamy za delikatną i skomplikowaną sprawę. Nie mamy pewności, jak zareagują nasi czytelnicy i jak to wpłynie na wizerunek i pozycję ESNA, ponieważ taki rodzaj aktywności (ankieta) nie należy do naszej linii programowej. Szczerze przepraszamy, iż nie możemy pomóc, mając nadzieję, że rozumie Pani naszą decyzję. 
Entuzjastycznie zareagowały natomiast Hujada oraz AINA. Hujada zaproponowała wywiad za pośrednictwem poczty elektronicznej, na podstawie którego redaktorka napisała artykuł po szwedzku. Natomiast AINA poprosiła o cztero-, pięcioparagrafowy opis mojej pracy, który w formie niezmienionej umieściła na swoim portalu.

Ostatecznie wersja angielska ankiety została umieszczona na następujących portalach: za moją wiedzą na IINA $^{6}$ i Hujada ${ }^{7}$, natomiast bez mojej wiedzy na portalach ZINDA ${ }^{8}$, Christians of Iraq ${ }^{9}$, Tebayn $^{10}$; były to wszystko przedruki z AINA. Link do wersji niemieckiej wysłałam do HUYODO, ukazał się wraz z tłumaczeniem na niemiecki mojego artykułu z AINA ${ }^{11}$, bez mojej wiedzy wersja ta trafiła na YAUNO ${ }^{12}$ (tu pojawiła się zmiana słowa „Assyrische” na „Suryoyo”) oraz Turabdinberlin ${ }^{13}$.

Nie udało mi się uruchomić francuskiej wersji, gdyż redakcja strony Union des Assyro-Chaldéenes de France ${ }^{14}$ nie odpowiedziała na mój mail. Podobnie niepowodzeniem zakończyła się próba dotarcia do Asyryjczyków w Rosji. Redakcja Atranews ${ }^{15}$ nie ustosunkowała się do mojej prośby. Nie pomogło umieszczenie linka do rosyjskiej wersji ankiety na Vkontakte.ru (rosyjski odpowiednik Facebooka); nie spłynęła ani jedna odpowiedź.

Podsumowując - wersje angielska i niemiecka spotkały się z odzewem, wersje francuska i rosyjska zostały zignorowane przez redakcje tamtejszych portali asyryjskich, tym samym nie uzyskałam odpowiedzi w tych językach.

$\mathrm{Z}$ wynikami dotyczącymi grupy asyryjskiej pojechałam na X Symposium Syriacum, które odbyło się w Grenadzie w dniach 22-27 września 2008 roku $^{16}$, przynosząc przełom w podejściu do tematu pracy. Moje dotychczasowe badania spotkały się z dużym zainteresowaniem, ale i pewną

${ }^{6}$ http://www.aina.org/ata/20080320151756.htm, data wejścia 20.11.2009.

${ }^{7} \mathrm{http}: / /$ www.hujada.com/article.php?ar=740, data wejścia 20.11.2009.

${ }^{8} \mathrm{http}: / /$ www.zindamagazine.com/html/archives/2008/04.14.08/index_mon.php, data wejścia 20.11.2009.

${ }^{9}$ http://www.christiansofiraq.com/polishresearchermar218.html, data wejścia 20.11.2009.

${ }^{10} \mathrm{http}: / /$ www.tebayn.com/Tebayn\%20English/index.asp?pageID=1\&SID=9552\&Ln=En, data wejścia 20.11.2009.

${ }^{11} \mathrm{http}: / /$ www.huyodo.com/index.php?area=1\&p=news\&newsid=234, data wejścia 20.11.2009.

${ }^{12} \mathrm{http}: / /$ www.yauno.com/index.php? $m o d u l=\operatorname{article\& action}=$ show\&id=1118, data wejścia 20.11.2009.

${ }^{13}$ http://turabdinberlin.de/news/archives/630, data wejścia 20.11.2009.

${ }^{14}$ http://www.uacf.asso.fr, data wejścia 20.11.2009.

${ }^{15}$ http://www.atranews.com, data wejścia 20.11.2009.

${ }^{16}$ M. Woźniak, National and Social Identity Construction among the Modern Assyrians/ Syrians, „Parole de l'Orient”, Vol. 36, Kaslik 2011, s. 569-583. 
krytyką, dotyczącą pominięcia grupy aramejskiej. Z tego powodu postanowiłam rozszerzyć zakres analizy i przeprowadzić komparatystykę obu podgrup. W październiku 2008 roku przygotowałam analogiczną ankietę do „Assyrian Identity”, z tym, że przeznaczoną wyłącznie dla Aramejczyków i tylko w języku angielskim. Najistotniejsze zmiany dotyczyły wprowadzenia odmiennego nazewnictwa („Aramejczycy” zamiast „Asyryjczycy”, „Aram-Nahrain” zamiast „Asyria” itp.).

Po konsultacjach z działaczami aramejskimi nową ankietę zatytułowałam „Aramean (Suryoyo) Identity” i aktywowałam w listopadzie 2008 roku. Ci sami działacze przetłumaczyli mój artykuł na kilka języków. Link do ankiety aramejskiej ukazał się wraz z artykułem po angielsku na stronie Aramaic Democratic Organization ${ }^{17}$ oraz na Facebooku ${ }^{18}$, z artykułem po niemiecku na stronie Huyodo ${ }^{19}$ oraz Suryoyena ${ }^{20}$, dodatkowo po holendersku na Facebooku ${ }^{21}$.

Całe badanie za pośrednictwem Internetu trwało piętnaście miesięcy (od marca 2008 do maja 2009 roku). Każdy z uczestników został zapewniony o jego dobrowolności i anonimowości. Z ogólnej liczby 1541 prób wypełnienia kwestionariuszy 818 zakończyło się sukcesem. Z powodu braków w odpowiedziach zdyskwalifikowałam jednak 22 ankiety (18 „Assyrian Identity” i 4 „Aramean (Suryoyo) Identity”), co dało 796 poprawnie wypełnionych kwestionariuszy. Następnie, po wstępnej analizie treści ankiet, zdecydowałam się przenieść 4 ankiety asyryjskie do „Aramean (Suryoyo) Identity”, zaś 2 ankiety aramejskie do „Assyrian Identity” - w trakcie wypełniania ankiet respondenci wyraźnie zaznaczyli lub dali do zrozumienia, że ich identyfikacja pozycjonuje ich „po drugiej stronie”. Finalnie dalszej obróbce poddałam 796 ankiet, w tym 490 asyryjskich (przy czym 398 w wersji angielskiej, zaś $92 \mathrm{w}$ wersji niemieckiej) oraz 306 aramejskich (w języku angielskim). Uzyskane wyniki przedstawiłam dodatkowo w tabelach i na wykresach.

${ }^{17}$ http://www.aramaic-dem.org/English/History_culture/Aramean_\%28Suryoyo\%29_ Identity.htm, data wejścia 20.11.2009.

${ }^{18} \mathrm{gl}$-es.facebook.com/topic.php?uid=51313897386\& 2 topic=5883, data wejścia 20.11.2009.

${ }^{19} \mathrm{http}: / /$ huyodo.com/index.php?type=review\&area $=1 \& \mathrm{p}=$ articles $\& \mathrm{id}=5597$, data wejścia 20.11.2009.

${ }^{20}$ http://www.suryoyena.org/magazin.php?art=386, data wejścia 20.11.2009.

${ }^{21}$ gl-es.facebook.com/topic.php?uid= $51313897386 \&$ topic $=5885 \&$ post $=22278$, data wejścia 20.11.2009. 


\subsection{Charakterystyka badanych osób}

\subsubsection{Płeć}

Wśród 490 respondentów asyryjskich mężczyźni stanowią 64\%, zaś kobiety 36\%. Niemal identyczny rozkład charakteryzuje 306-osobową grupę aramejską, gdzie mężczyzn jest 63\%, a kobiet 37\%.

Wykres 1

Rozkład płci wśród respondentów asyryjskich i aramejskich

Rozkład płci (Asyryjczycy)

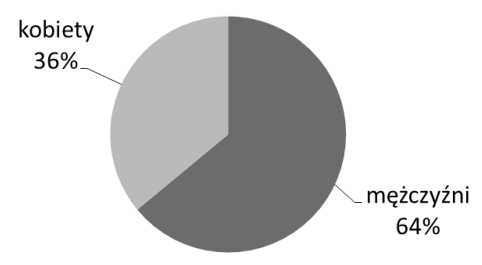

Rozkład płci (Aramejczycy)

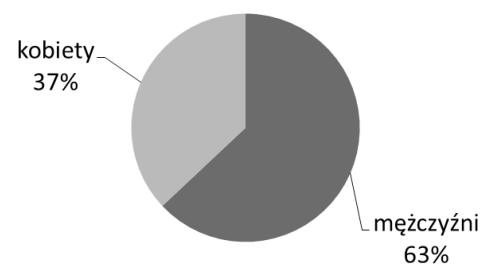

Takie wyniki wskazują na podobieństwo procesów zachodzących w obu podgrupach, jeśli chodzi o ewoluującą rolę kobiet. W ostatnich latach Asyryjki i Aramejki, tradycyjnie pozostające strażniczkami domowego ogniska, stają się coraz bardziej aktywne na niwie publicznej. Choć ciągle rzadko, w porównaniu do mężczyzn, pełnią funkcje reprezentacyjne czy przywódcze, to ich wkład w życie wspólnoty jest nie do przecenienia. W młodzieżówkach organizacji - czy to asyryjskich, czy aramejskich - oraz w redakcjach gazet i stron internetowych, widoczna jest praca młodych kobiet wyedukowanych na Zachodzie. Relatywnie wysoki odsetek respondentek może zaskakiwać, jeśli weźmie się pod uwagę bliskowschodnie korzenie grupy, $\mathrm{z}$ drugiej strony staje się zrozumiały przy uwzględnieniu bardziej partnerskich wzorców chrześcijańskich oraz wpływu społeczeństw przyjmujących.

\subsubsection{Wiek}

Zupełnie inaczej przedstawiają się natomiast histogramy wieku obu grup. Średni wiek respondenta asyryjskiego wynosi 35 lat, aramejskiego - 26 lat. Najstarszy respondent asyryjski ma 87 lat, aramejski - 56 lat, najmłodszy asyryjski ma 12 lat, najmłodszy aramejski - 14 lat. Uderza przede 
wszystkim młodość respondentów aramejskich, młodszych od asyryjskich średnio o 9 lat, oraz brak wśród nich przedstawicieli najstarszego pokolenia. Jednym z powodów takiego stanu rzeczy może być, oczywiście, mniejsze obycie seniorów z nowoczesnymi technologiami, jednak w świetle faktu, że elektroniczna forma ankiety nie stanowiła przeszkody dla starszych Asyryjczyków, nasuwa się inne wytłumaczenie. Otóż, świadomość aramejska zaczęła się wykształcać dopiero w ostatnich dekadach, toteż wpływ działaczy tej opcji zaznaczył się najwyraźniej w przypadku pokolenia średniego i najmłodszego.

Wykres 2

Histogram respondentów asyryjskich

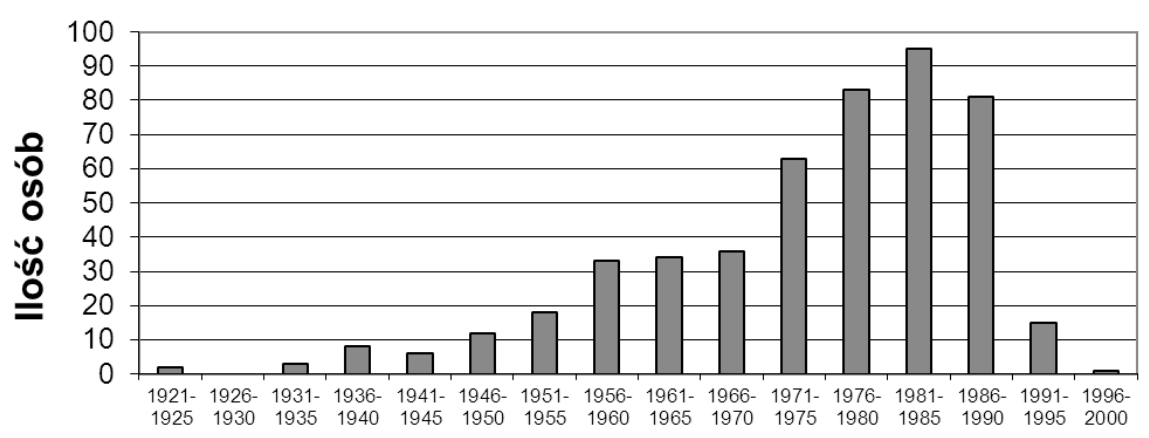

Lata urodzenia

Wykres 3

Histogram respondentów aramejskich

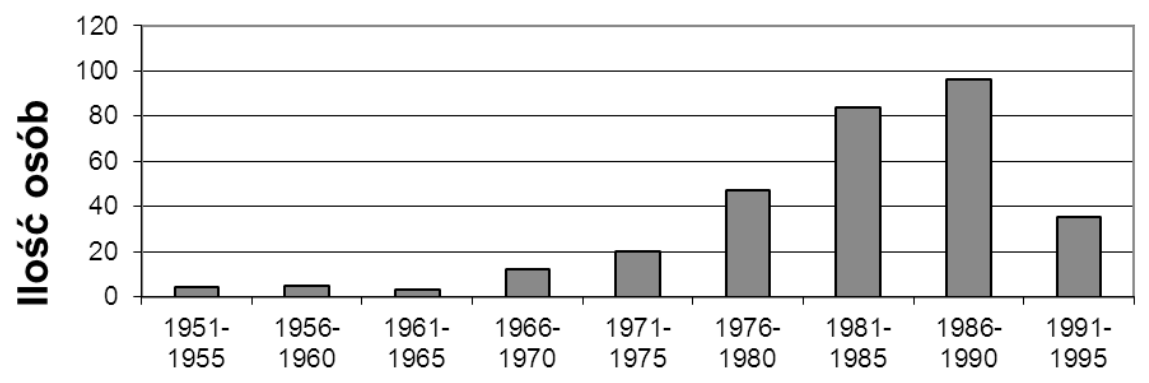

Lata urodzenia 


\subsubsection{Kraje pochodzenia}

Jeśli chodzi o kraje pochodzenia, sytuacja kształtuje się następująco: niemal jedna piąta Asyryjczyków pochodzi z Iraku, niewiele mniej z USA oraz Iranu. Liczne, na poziomie jednej dziesiątej całości, są odpowiedzi wskazujące na Niemcy, Turcję, Szwecję oraz Syrię. Aramejczycy pochodzą głównie ze Szwecji (niemal dwie piąte), z Niemiec (jedna piąta) oraz z Turcji (ponad jedna dziesiąta). Można więc mówić o pewnych tendencjach - ośrodki asyryjskie znajdują się w Stanach Zjednoczonych i Europie, aramejskie głównie w Europie. Gros pochodzących z Iranu i Iraku to Asyryjczycy. Aramejczycy, jeśli wywodzą się z Bliskiego Wschodu, to z Turcji, Syrii oraz Libanu. Uderza przy tym wielkie zróżnicowanie krajów urodzenia - Asyryjczycy wymienili 22 różne, zaś Aramejczycy 19. Jest to rezultat burzliwych dziejów grupy i owoc emigracji z tradycyjnych ziem.

Tabela 1

Kraje pochodzenia respondentów asyryjskich

\begin{tabular}{|l|c|c|}
\hline Kraj pochodzenia & $\mathrm{N}$ & $\%$ \\
\hline Irak & 93 & 19,0 \\
\hline USA & 84 & 17,1 \\
\hline Iran & 81 & 16,5 \\
\hline Niemcy & 52 & 10,6 \\
\hline Turcja & 49 & 10,0 \\
\hline Szwecja & 38 & 8,0 \\
\hline Syria & 37 & 7,7 \\
\hline Liban & 14 & 2,8 \\
\hline Wielka Brytania & 8 & 1,6 \\
\hline Szwajcaria & 7 & 1,4 \\
\hline Australia & 6 & 1,2 \\
\hline Kuwejt & 5 & 1,0 \\
\hline Kanada & 3 & 0,6 \\
\hline Gruzja & 2 & 0,4 \\
\hline Austria & 2 & 0,4 \\
\hline Holandia & 2 & 0,4 \\
\hline Grecja & 2 & 0,4 \\
\hline
\end{tabular}


Tabela $1 \mathrm{~cd}$.

\begin{tabular}{|l|r|r|}
\hline Kraj pochodzenia & $\mathrm{N}$ & $\%$ \\
\hline Arabia Saudyjska & 1 & 0,2 \\
\hline Armenia & 1 & 0,2 \\
\hline Indie & 1 & 0,2 \\
\hline Rosja & 1 & 0,2 \\
\hline Francja & 1 & 0,2 \\
\hline RAZEM & 490 & 100,0 \\
\hline
\end{tabular}

Tabela 2

Kraje pochodzenia respondentów aramejskich

\begin{tabular}{|l|r|r|}
\hline Kraj pochodzenia & N & $\%$ \\
\hline Szwecja & 115 & 37,7 \\
\hline Niemcy & 56 & 18,4 \\
\hline Turcja & 37 & 12,1 \\
\hline Syria & 25 & 8,2 \\
\hline Liban & 22 & 7,2 \\
\hline USA & 8 & 2,6 \\
\hline Holandia & 8 & 2,6 \\
\hline Szwajcaria & 8 & 2,6 \\
\hline Wielka Brytania & 5 & 1,6 \\
\hline Irak & 5 & 1,6 \\
\hline Belgia & 4 & 1,3 \\
\hline Francja & 3 & 1,0 \\
\hline Australia & 3 & 1,0 \\
\hline Kanada & 2 & 0,6 \\
\hline Jordania & 1 & 0,3 \\
\hline Austria & 1 & 0,3 \\
\hline Cypr & 1 & 0,3 \\
\hline Dania & 1 & 0,3 \\
\hline „Aram-Nahrin” & 306 & 0,3 \\
\hline RAZEM & & 100,0 \\
\hline
\end{tabular}




\subsubsection{Kraje zamieszkania}

Znaczne zróżnicowanie widać również $\mathrm{w}$ odpowiedziach dotyczących krajów zamieszkania. Tym razem jednak rzucają się w oczy duże skupiska Asyryjczyków w Stanach Zjednoczonych (prawie połowa respondentów) i Aramejczyków w Szwecji (ponad połowa). W Szwecji mieszka co siódmy respondent asyryjski. Niemcy stanowią przybraną ojczyznę dla niemal jednej piątej zarówno Asyryjczyków, jak i Aramejczyków.

W obrębie diaspor wyraźne są wzorce osiedlania, np. Asyryjczyków w USA można spotkać przede wszystkim w Kalifornii (47\% spośród amerykańskich respondentów), w Illinois (22\%) oraz Arizonie (9\%). Z kolei niemal wszyscy ankietowani z Wielkiej Brytanii mieszkają w Londynie.

Tabela 3

Kraje zamieszkania respondentów asyryjskich

\begin{tabular}{|l|r|r|}
\hline Kraj zamieszkania & $\mathrm{N}$ & $\%$ \\
\hline USA & 238 & 48,6 \\
\hline Niemcy & 83 & 17,0 \\
\hline Szwecja & 70 & 14,3 \\
\hline Australia & 30 & 6,1 \\
\hline Wielka Brytania & 14 & 2,9 \\
\hline Kanada & 12 & 2,5 \\
\hline Szwajcaria & 11 & 2,2 \\
\hline Holandia & 9 & 1,8 \\
\hline Austria & 6 & 1,2 \\
\hline Turcja & 5 & 1,0 \\
\hline Francja & 2 & 0,4 \\
\hline Belgia & 2 & 0,4 \\
\hline Irak & 2 & 0,4 \\
\hline Jordania & 1 & 0,2 \\
\hline Syria & 1 & 0,2 \\
\hline Iran & 1 & 0,2 \\
\hline Armenia & 1 & 0,2 \\
\hline Indie & 1 & 0,2 \\
\hline „Diaspora” & 1 & 0,2 \\
\hline RAZEM & & 100,0 \\
\hline
\end{tabular}


Tabela 4

Kraje zamieszkania respondentów aramejskich

\begin{tabular}{|l|c|c|}
\hline Kraj zamieszkania & $\mathrm{N}$ & $\%$ \\
\hline Szwecja & 166 & 54,4 \\
\hline Niemcy & 60 & 19,7 \\
\hline Holandia & 18 & 5,9 \\
\hline USA & 12 & 3,9 \\
\hline Szwajcaria & 10 & 3,3 \\
\hline Kanada & 7 & 2,3 \\
\hline Liban & 5 & 1,6 \\
\hline Turcja & 5 & 1,6 \\
\hline Belgia & 5 & 1,6 \\
\hline Wielka Brytania & 4 & 1,3 \\
\hline Francja & 3 & 1,0 \\
\hline Australia & 3 & 1,0 \\
\hline Austria & 2 & 0,6 \\
\hline Izrael & 2 & 0,6 \\
\hline Węgry & 2 & 0,6 \\
\hline Polska & 1 & 0,3 \\
\hline Syria & 1 & 0,3 \\
\hline RAZEM & 306 & 100,0 \\
\hline
\end{tabular}

Co interesujące, w pytaniu o kraj pochodzenia czterech respondentów asyryjskich nazwało swoją ojczyznę „Asyrią” lub „okupowaną Asyrią” (przy czym dwóch miało na myśli Irak, a dwóch Turcję); podobnie jeden Aramejczyk z Turcji użył nazwy „Asyria”, zaś inny wpisał „Aram-Nahrin” bez precyzowania kraju. Takie odpowiedzi świadczą o bardzo rozwiniętym nacjonalizmie, programowo wręcz nieuwzględniającym istniejącej rzeczywistości politycznej. Zaskakuje użycie nazwy „Asyria” przez Aramejczyka, jednak jest to pojedynczy przypadek; być może jednostka ta ma bardziej płynną - aramejsko-asyryjską świadomość.

W pytaniu o kraj zamieszkania również zdarzyła się odpowiedź „patriotyczna” - respondent nazwał Sztokholm Asyrią. Inny pozostał enigmatyczny, wpisując w rubrykę jedynie słowo „diaspora”. Zresztą znakomita większość 
respondentów pochodziła z diaspory. Asyryjczycy/Aramejczycy zamieszkujący rdzenne ziemie nie mają tak dobrego dostępu do Internetu, posługują się językami bliskowschodnimi, dodatkowo w obawie przed ewentualnymi reperkusjami wolą dokonywać autocenzury wypowiedzi. Nie znaczy to, że na Bliskim Wschodzie Asyryjczycy/Aramejczycy odcięci są od świata. Z dobrodziejstw technologii korzysta jednak zdecydowanie mniejsza ich grupa.

\subsubsection{Wykształcenie}

Dane dotyczące wykształcenia zostały zniekształcone elektroniczną formą ankiety (automatycznie ograniczyła respondentów do użytkowników nowoczesnych technologii komunikacyjnych). To tłumaczy, dlaczego znakomita większość respondentów, zarówno asyryjskich (79\%), jak i aramejskich (70\%), legitymuje się wykształceniem wyższym. Respondenci o wykształceniu średnim i podstawowym znajdują się w mniejszości; jest ich nieco więcej w próbie aramejskiej, jednak tłumaczy to doskonale niższy średni wiek respondentów aramejskich, spośród których bardzo wielu jeszcze się uczy lub studiuje.

Dużo bardziej realistyczne są dane uzyskane z wywiadów, według których starsi Asyryjczycy/Aramejczycy żyjący w diasporze to w $70 \%$ analfabeci. Młodsi faktycznie zdobywają wykształcenie, i to najczęściej wyższe ${ }^{22}$. Przepaść pokoleniową pogłębia więc w wielu przypadkach olbrzymia różnica w wykształceniu - w ciągu jednego pokolenia dokonał się bowiem „skok edukacyjny".

Wykres 4

Wykształcenie respondentów asyryjskich i aramejskich
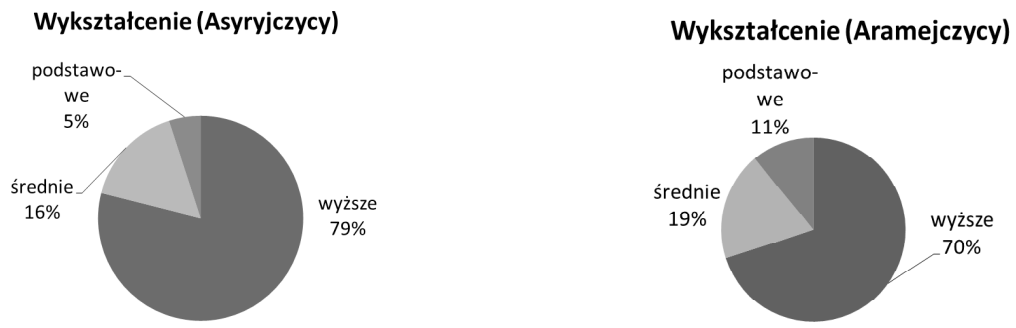

Do tej pory nie powstał, i w najbliższej przyszłości nie ma raczej szans powstać, uniwersytet asyryjski czy aramejski. Natomiast w Szwecji funkcjo-

${ }^{22}$ Wywiad z dwoma przedstawicielami Assyrian Democratic Movement, Szwecja, 29.06.2007. 
nuje Association of Assyrian-Syrian Academy (Stowarzyszenie AsyryjskoSyryjskiej Akademii), skupiające około 1400 młodych Asyryjczyków i Aramejczyków. Stowarzyszenie stanowi głównie platformę wymiany informacji i spotkań towarzyskich dla młodzieży studiującej ${ }^{23}$.

\subsubsection{Struktura zawodowa}

Jeśli chodzi o aktywność zawodową Asyryjczyków, pracuje 70,7\% - najwięcej jako menadżerowie, konsultanci, pracownicy HR oraz inspektorzy $(10,6 \%)$, w sektorze bankowym i w finansach $(9,6 \%)$, w branży komputerowej oraz IT $(7,1 \%)$, w zawodach związanych z medycyną (5,3\%). Tyle samo - 5,1\% - jest zatrudnionych w szeroko rozumianym biznesie, co $\mathrm{w}$ działach sprzedaży i marketingu; $3,9 \%$ pracuje $\mathrm{w}$ administracji, po $3,7 \% \mathrm{w}$ edukacji oraz jako inżynierowie; $2,4 \%$ to pracownicy przemysłu, mechanicy i budowlańcy; $2 \%$ związanych jest z mediami jako dziennikarze, pisarze, wydawcy, producenci filmowi i telewizyjni itp.; 1,8\% to prawnicy, 1\% artyści, 0,8\% lingwiści i tłumacze. Kategoria „inne” (6,5\%) mieści w sobie tak różne profesje, jak: tłumacz, wojskowy, ochroniarz, duchowny, polityk, pilot, ranczer, trener czy kosmetyczka. 22,6\% Asyryjczyków uczy się lub studiuje, przy czym na studiach doktoranckich jest aktualnie $1,4 \% ; 6,7 \%$ nie pracuje $(2,6 \%$ jest na emeryturze, pozostałe $4,1 \%$ to bezrobotni).

Wykres 5

Struktura zawodowa respondentów asyryjskich

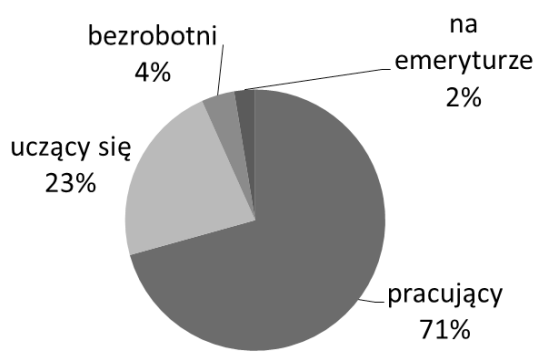

${ }^{23}$ Ibidem. 
Tabela 5

Struktura zawodowa respondentów asyryjskich (podział na branże)

\begin{tabular}{l|rrl|rc}
\hline \multicolumn{1}{c|}{ Zawód } & $\mathrm{N}$ & $\%$ & \multicolumn{1}{c|}{ Zawód } & $\mathrm{N}$ & $\%$ \\
\hline Menadżer/konsultant/HR & 52 & 10,6 & Administracja & 19 & 3,9 \\
Bankowość i finanse & 47 & 9,6 & Inżynier & 18 & 3,7 \\
Informatyka/IT & 35 & 7,1 & Nauczyciel i branża edukacyjna & 18 & 3,7 \\
Lekarz i branża medyczna & 26 & 5,3 & Przemysł/Mechanika/Budowa & 12 & 2,4 \\
Sprzedaż i marketing & 25 & 5,1 & Media & 10 & 2,0 \\
Biznes & 25 & 5,1 & Prawnik & 9 & 1,8 \\
\hline
\end{tabular}

Tylko 2,6\% Aramejczyków nie pracuje, za to aż 39,3\% uczy się. Spośród $58,1 \%$ pracujących przeważają zatrudnieni jako menadżerowie, konsultanci i pracownicy HR (podobnie jak w przypadku grupy asyryjskiej). Stanowią oni 7,5\% wszystkich zatrudnionych. Tylu samo Aramejczyków pracuje w finansach i bankowości, co jako inżynierowie (5,9\%). Po 4,3\% odnajduje się w edukacji bądź biznesie. $3 \%$ to informatycy i pracownicy IT. $1,6 \%$ pracuje $\mathrm{w}$ administracji, tylu samo jako pracownicy opieki społecznej. Po $1,3 \%$ respondentów znalazło zatrudnienie w branży medycznej, sprzedaży i marketingu, w restauracjach lub jako stażyści. Kategoria „inne” $(10,8 \%)$ obejmuje złotników, prawników, projektantów, tłumaczy, piłkarzy, sędziego sportowego, drukarza, wojskowego, kierowcę itp. 8,8\% to osoby, które zdawały się dobrze nie rozumieć pytania.

Wykres 6

Struktura zawodowa respondentów aramejskich

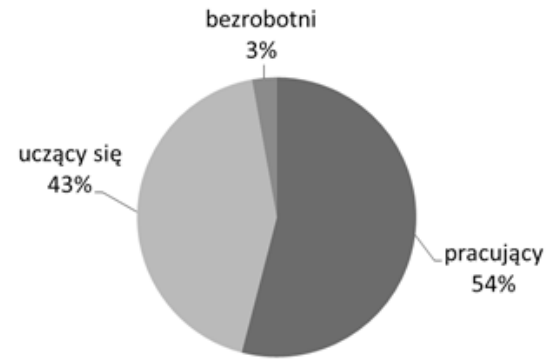


Tabela 6

Struktura zawodowa respondentów aramejskich (podział na branże)

\begin{tabular}{l|c|c|l|c|c}
\hline \multicolumn{1}{c|}{ Zawód } & $\mathrm{N}$ & $\%$ & \multicolumn{1}{|c|}{ Zawód } & $\mathrm{N}$ & $\%$ \\
\hline Menadżer/konsultant/HR & 23 & 7,5 & Administracja & 5 & 1,6 \\
\hline Bankowość i finanse & 18 & 5,9 & Pracownik opieki społecznej & 5 & 1,6 \\
\hline Inżynier & 18 & 5,9 & Lekarz i branża medyczna & 4 & 1,3 \\
\hline Biznes & 13 & 4,3 & Sprzedaż i marketing & 4 & 1,3 \\
\hline Nauczyciel i edukacja & 13 & 4,3 & Pracownik restauracji & 4 & 1,3 \\
\hline Informatyka/IT & 9 & 3,0 & Stażysta & 4 & 1,3 \\
\hline
\end{tabular}

Z porównania wynika, że wśród respondentów z obu grup przeważali przedstawiciele wolnych zawodów oraz pracownicy usług - przede wszystkim menadżerowie i konsultanci, a także zatrudnieni w bankowości i finansach. Wśród Asyryjczyków więcej było informatyków i lekarzy, zaś wśród Aramejczyków inżynierów i biznesmenów. Ponad jedna piąta asyryjskich respondentów ciągle uczyła się lub studiowała; uczęszczających do szkół Aramejczyków było niemal dwa razy więcej - tak wysoki odsetek uczących się spowodowany był relatywnie niskim wiekiem średnim aramejskich respondentów. Niewielu było bezrobotnych - ok. 4\% Asyryjczyków i ok. 2,5\% Aramejczyków. Nawet biorąc pod uwagę, że respondenci to w większości przedstawiciele klasy średniej, wyniki wskazują na sukces ekonomiczny grupy i przeczą stereotypom, jakoby wszyscy przedstawiciele mniejszości wywodzących się z Bliskiego Wschodu stanowili margines społeczeństw zachodnich.

\subsubsection{Pochodzenie rodziców respondentów}

Następną badaną kategorią było pochodzenie rodziców respondentów. Przeważająca większość urodziła się na Bliskim Wschodzie, na dawnych ziemiach zamieszkanych przez grupę, to znaczy na terenach Iraku, Iranu, Turcji i Syrii. 
Tabela 7

Kraje pochodzenia matek respondentów asyryjskich

\begin{tabular}{|c|c|c|}
\hline Kraj pochodzenia matki & $\mathrm{N}$ & $\%$ \\
\hline Irak & 133 & 27,1 \\
\hline Turcja & 130 & 26,5 \\
\hline Iran & 113 & 23,1 \\
\hline Syria & 65 & 13,3 \\
\hline USA & 14 & 2,9 \\
\hline Liban & 11 & 2,3 \\
\hline Rosja & 8 & 1,6 \\
\hline Niemcy & 3 & 0,6 \\
\hline Gruzja & 3 & 0,6 \\
\hline Polska & 2 & 0,4 \\
\hline Anglia & 2 & 0,4 \\
\hline Puerto Rico & 2 & 0,4 \\
\hline Australia & 1 & 0,2 \\
\hline Austria & 1 & 0,2 \\
\hline Armenia & 1 & 0,2 \\
\hline Indie & 1 & 0,2 \\
\hline RAZEM & 490 & 100,0 \\
\hline
\end{tabular}

Matki respondentów asyryjskich pochodziły głównie z Iraku, Turcji, Iranu oraz Syrii. Co ciekawe, dwanaście osób nazwało kraj pochodzenia matki „Asyrią” lub „dawną Asyrią” (w pięciu przypadkach chodziło o Irak, w sześciu o Turcję, w jednym o Syrię). 
Tabela 8

Kraje pochodzenia matek respondentów aramejskich

\begin{tabular}{|l|r|r|}
\hline Kraj pochodzenia matki & N & $\%$ \\
\hline Turcja & 197 & 64,4 \\
\hline Syria & 64 & 20,9 \\
\hline Liban & 19 & 6,2 \\
\hline Irak & 8 & 2,6 \\
\hline Izrael & 7 & 2,3 \\
\hline USA & 2 & 0,7 \\
\hline Rumunia & 1 & 0,3 \\
\hline Kanada & 1 & 0,3 \\
\hline Inne & 7 & 2,3 \\
\hline RAZEM & 306 & 100,0 \\
\hline
\end{tabular}

Ponad trzy piąte matek respondentów aramejskich urodziło się w Turcji, jedna piąta w Syrii, jedna dwudziesta w Libanie. Jeden respondent nazwał Turcję Mezopotamią. Siedem osób udzieliło odpowiedzi, które uniemożliwiły jednoznaczne zidentyfikowanie krajów pochodzenia matek; padały odpowiedzi „Mezopotamia”, „Asyria”, „Aram-Nahrain” lub nazwiska panieńskie matek.

Tabela 9

Kraje pochodzenia ojców respondentów asyryjskich

\begin{tabular}{|l|r|r|}
\hline Kraj pochodzenia ojca & $\mathrm{N}$ & $\%$ \\
\hline Turcja & 150 & 30,6 \\
\hline Irak & 139 & 28,5 \\
\hline Iran & 103 & 21,0 \\
\hline Syria & 56 & 11,4 \\
\hline Rosja & 12 & 2,5 \\
\hline Liban & 9 & 1,8 \\
\hline USA & 9 & 1,8 \\
\hline Indie & 2 & 0,4 \\
\hline Gruzja & 2 & 0,4 \\
\hline
\end{tabular}


Tabela $9 \mathrm{~cd}$.

\begin{tabular}{|l|c|c|}
\hline Kraj pochodzenia ojca & $\mathrm{N}$ & $\%$ \\
\hline Kanada & 1 & 0,2 \\
\hline Szwajcaria & 1 & 0,2 \\
\hline Palestyna & 1 & 0,2 \\
\hline Armenia & 1 & 0,2 \\
\hline Holandia & 1 & 0,2 \\
\hline Francja & 1 & 0,2 \\
\hline Niemcy & 1 & 0,2 \\
\hline Nieznane pochodzenie & 490 & 0,2 \\
\hline RAZEM & & 100,0 \\
\hline
\end{tabular}

Ojcowie respondentów asyryjskich pochodzili głównie z Turcji i Iraku, następnie z Iranu i w mniejszym stopniu z Syrii. Pięciu nazwało Turcję Asyrią, północną Asyrią lub zachodnią Asyrią, sześciu nazwało Irak Asyrią, okupowaną Asyrią albo dawną Asyrią, jedna osoba określiła tak Liban.

Tabela 10

Kraje pochodzenia ojców respondentów aramejskich

\begin{tabular}{|l|r|r|}
\hline \multicolumn{1}{|c|}{ Kraj pochodzenia ojca } & $\mathrm{N}$ & $\%$ \\
\hline Turcja & 210 & 68,6 \\
\hline Syria & 50 & 16,3 \\
\hline Liban & 17 & 5,6 \\
\hline Irak & 11 & 3,6 \\
\hline Izrael & 7 & 2,3 \\
\hline Jordania & 2 & 0,7 \\
\hline Armenia & 2 & 0,7 \\
\hline Szwecja & 1 & 0,3 \\
\hline Inne & 6 & 1,9 \\
\hline RAZEM & 306 & 100,0 \\
\hline
\end{tabular}

Niemal siedmiu na dziesięciu ojców respondentów aramejskich urodziło się w Turcji, prawie co szósty w Syrii. Jeden respondent nazwał Turcję Mezopotamią. Inne odpowiedzi, które padły, to Mezopotamia, Aram-Nahrain, Asyria, wreszcie nazwiska ojców. 
Z porównania grupy asyryjskiej i aramejskiej wypływa wniosek, że terenami, z których wywodzą się Asyryjczycy, są przede wszystkim Irak i Turcja (po około 30\% z każdego z nich), następnie Iran (ponad 20\%) oraz Syria (ponad 10\%). Z kolei ziemie rdzenne Aramejczyków to Turcja (około 65\%), Syria (15-20\%) i Liban (około 5\%). Oznacza to, że jednostki posiadające tożsamość asyryjską mają bardziej zróżnicowane pochodzenie niż jednostki rozwijające tożsamość aramejską. Wspólne dla obu grup jako kraje pochodzenia są Turcja i Syria; Irak oraz Iran wskazują raczej na Asyryjczyków, zaś Liban na Aramejczyków.

\subsubsection{Stan cywilny}

Wśród respondentów z obu grup przeważały osoby stanu wolnego wśród Aramejczyków stanowiły one znakomitą większość (niemal 80\%), wśród Asyryjczyków ponad połowę. Jedna piąta respondentów aramejskich pozostawała w oficjalnych związkach, to jest dwa razy mniej niż respondentów asyryjskich. Rozwiedzionych wśród Asyryjczyków było 4\%, zaś wśród Aramejczyków 1\%. Żaden z respondentów aramejskich nie był wdowcem lub wdową, wśród Asyryjczyków tacy respondenci nie przekraczali 1\%. Wyniki stanowią konsekwencję niższego wieku średniego respondentów aramejskich, ale wskazują także na pewne zjawiska - mianowicie na odsuwanie w czasie decyzji o małżeństwie na po studiach oraz dużą trwałość małżeństw, zarówno asyryjskich, jak i aramejskich. Są to w przeważającej mierze małżeństwa sakramentalne, potwierdzone powagą Kościoła. Nad ich trwałością czuwają dodatkowo członkowie obu rodzin, nieraz służący jako mediatorzy w przypadku nieporozumień między małżonkami. Rozwód ciągle postrzegany jest przez Asyryjczyków i Aramejczyków jako ostateczność.

Wykres 7

Stan cywilny respondentów asyryjskich i aramejskich

Stan cywilny (Asyryjczycy)

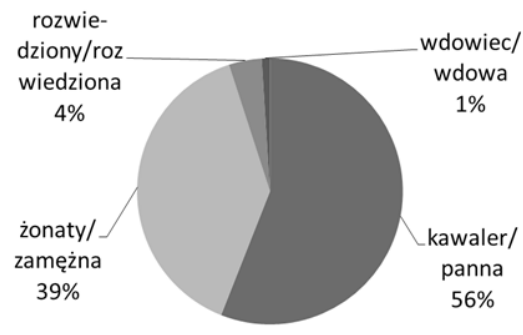

Stan cywilny (Aramejczycy)

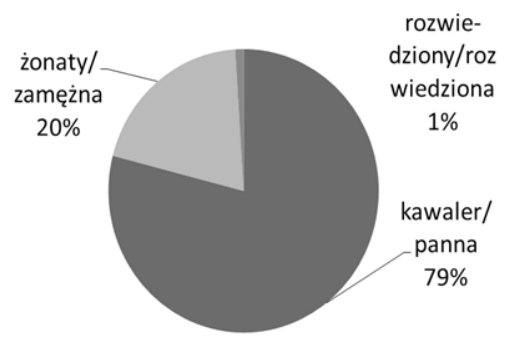




\subsubsection{Kraje pochodzenia partnerów}

Ponieważ większość Asyryjczyków pozostających w związkach należy do średniego pokolenia, nieraz będącego pierwszym pokoleniem emigracyjnym, również małżonkowie tych osób wywodzą się w większości (ponad 65\%) z krajów Bliskiego Wschodu: po jednej piątej z Iranu oraz Iraku, po ponad jednej dziesiątej z Turcji i Syrii. Jedynym krajem zachodnim, z którego pochodzi porównywalna liczba partnerów respondentów asyryjskich (prawie 20\%), są Stany Zjednoczone, następna jest Szwecja (5\%). Przy tym pytaniu jeden respondent nazwał Turcję Asyrią.

Tabela 11

Kraje pochodzenia partnerów respondentów asyryjskich

\begin{tabular}{|l|c|c|}
\hline Kraj pochodzenia partnera & $\mathrm{N}$ & $\%$ \\
\hline Irak & 43 & 20,1 \\
\hline Iran & 40 & 18,7 \\
\hline USA & 40 & 18,7 \\
\hline Syria & 26 & 12,1 \\
\hline Turcja & 23 & 10,7 \\
\hline Szwecja & 11 & 5,1 \\
\hline Liban & 6 & 2,8 \\
\hline Niemcy & 3 & 1,4 \\
\hline Australia & 3 & 1,4 \\
\hline Holandia & 2 & 0,9 \\
\hline Armenia & 2 & 0,9 \\
\hline Wietnam & 2 & 0,9 \\
\hline Rosja & 2 & 0,9 \\
\hline Wielka Brytania & 2 & 0,9 \\
\hline Francja & 1 & 0,5 \\
\hline Filipiny & 1 & 0,5 \\
\hline Kuwejt & 1 & 0,5 \\
\hline Irlandia & 1 & 0,5 \\
\hline Szwajcaria & 1 & 0,5 \\
\hline
\end{tabular}


Tabela $11 \mathrm{~cd}$.

\begin{tabular}{|l|r|r|}
\hline Kraj pochodzenia partnera & $\mathrm{N}$ & $\%$ \\
\hline Kanada & 1 & 0,5 \\
\hline Grecja & 1 & 0,5 \\
\hline Polska & 1 & 0,5 \\
\hline Inne & 214 & 0,5 \\
\hline RAZEM & 1 & 100,0 \\
\hline
\end{tabular}

Podobny wzorzec można zaobserwować u respondentów aramejskich - z Bliskiego Wschodu pochodzi niemal 60\% ich małżonków, z czego ponad połowa z Turcji, znaczna liczba z Libanu, Syrii oraz Iraku. Młodsi respondenci często pozostają w związkach z osobami urodzonymi w Szwecji (ponad 15\%). Przy tym pytaniu również jeden respondent nazwał Turcję Asyrią (co świadczy o jego hybrydalnej tożsamości).

Tabela 12

Kraje pochodzenia partnerów respondentów aramejskich

\begin{tabular}{|l|c|c|}
\hline Kraj pochodzenia partnera & N & $\%$ \\
\hline Turcja & 20 & 30,8 \\
\hline Szwecja & 11 & 16,9 \\
\hline Liban & 6 & 9,2 \\
\hline Syria & 5 & 7,7 \\
\hline Irak & 4 & 6,2 \\
\hline Wielka Brytania & 3 & 4,6 \\
\hline USA & 3 & 4,6 \\
\hline Holandia & 3 & 4,6 \\
\hline Rumunia & 2 & 3,0 \\
\hline Izrael & 2 & 3,0 \\
\hline Szwajcaria & 2 & 3,0 \\
\hline Niemcy & 1 & 1,6 \\
\hline Portugalia & 1 & 1,6 \\
\hline Maroko & 1 & 1,6 \\
\hline Inne & 1 & 1,6 \\
\hline RAZEM & 65 & 100,0 \\
\hline
\end{tabular}




\subsubsection{Pochodzenie partnerów}

Istotniejsze nawet od pytania o kraj pochodzenia partnera było stwierdzenie, jaki odsetek małżonków jest Asyryjczykami bądź Aramejczykami, a jaki nie. Wyniki dla obu grup były tu wyjątkowo zbieżne - niemal $80 \%$ małżonków należało do tej samej grupy etnicznej co badani. Świadczy to o dużej homogeniczności wspólnot. Jednocześnie należy zauważyć, że w wywiadach wstępnych, poprzedzających skonstruowanie ankiety, respondenci szacowali liczbę małżeństw egzogamicznych na poziomie $1-5 \%$. Ma to związek z kontekstem historycznym - ślub z osobą spoza własnej etni na Bliskim Wschodzie najczęściej oznaczał, i ciągle oznacza, wybór partnera muzułmańskiego, a tym samym utratę tożsamości.

Inaczej przedstawia się sytuacja $\mathrm{w}$ diasporze, gdzie liczba związków między Asyryjczykami i Aramejczykami oraz chrześcijanami rzymskokatolickimi czy protestanckimi ciągle rośnie, i to mimo promowanych przez poszczególne Kościoły związków wyłącznie pomiędzy swoimi wiernymi. Niemniej jednak niektórzy Asyryjczycy/Aramejczycy mieszkający w diasporze rozmyślnie wybierają sobie żony spośród rodaczek z Bliskiego Wschodu, szczególnie z Syrii, Libanu i Turcji. Ich motywacja jest podwójna - po pierwsze, chcą pomóc tym kobietom, często niezbyt wykształconym, „wyrwać je” z trudnych warunków i zagwarantować lepsze życie ${ }^{24}$, po drugie, zapewnić ciagłość kultury asyryjskiej/aramejskiej. To matki są bowiem pierwszymi wychowawczyniami dzieci, w największym stopniu odpowiedzialnymi za ich akulturację $e^{25}$.

Obecnie opisywane zjawisko nie jest już tak silne jak w latach 80. XX wieku, kiedy można było mówić wręcz o specjalnej polityce łączenia rodzin, tj. emigracji spowodowanej żenieniem się i pobieraniem w obrębie tych samych rodzin asyryjskich/aramejskich ${ }^{26}$. Sporadycznie zdarzają się śluby z muzułmanami z Bliskiego Wschodu, którym czasem towarzyszą symulowane konwersje na chrześcijaństwo w celu uspokojenia rodzin ${ }^{27}$.

${ }^{24}$ Przywiezione z Bliskiego Wschodu małżonki najczęściej doceniają komfort zapewniany im w nowych ojczyznach. Pochodząca z Syrii respondentka wspominała, jak po przyjeździe do Szwecji ucieszyła się z nieograniczonego dostępu do bieżącej wody oraz udogodnień kuchennych, cyt. za: wywiad z Asyryjką z Syrii, żoną wolontariusza w „Suroyo TV”, Szwecja, 29.06.2007.

${ }^{25} \mathrm{Na}$ podstawie rozmowy z prof. W. Witakowskim, Szwecja, 27.06.2007.

${ }^{26}$ Wywiad z dwoma przedstawicielami Assyrian Democratic Movement, Szwecja, 29.06.2007.

${ }^{27}$ Ibidem. 
Wykres 8

Pochodzenie partnerów respondentów asyryjskich i aramejskich

Pochodzenie partnera

(Asyryjczycy)

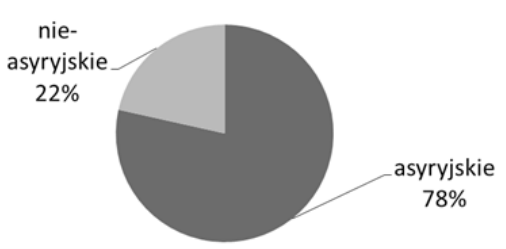

Pochodzenie partnera

(Aramejczycy)

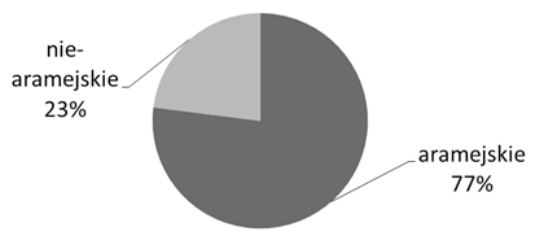

\subsubsection{Dzieci}

Tradycyjne rodziny asyryjskie i aramejskie były wielodzietne. Potomstwo było traktowane jako dar od Boga, błogosławieństwo. Sytuacja zmieniła się w ciągu ostatniego półwiecza pod wpływem procesów westernizacji, rozwoju świadomości seksualnej, zmieniającej się roli kobiet oraz dążenia do osiągnięcia wyższego poziomu życia, chociażby poprzez wydłużenie okresu nauki. Obecnie średnia dzietność rodziny asyryjskiej wynosi 2,29, zaś rodziny aramejskiej 2,53, czyli niewiele więcej ponad poziom gwarantujący zastępowalność pokoleń (współczynnik dzietności ponad 2,1). Jest to bardzo ważny wskaźnik, gdyż ukazuje - negatywną z punktu widzenia biologicznego przetrwania Asyryjczyków i Aramejczyków - tendencję spadkową.

Wykres 9

Dzieci respondentów asyryjskich i aramejskich

Dzieci (Asyryjczycy)

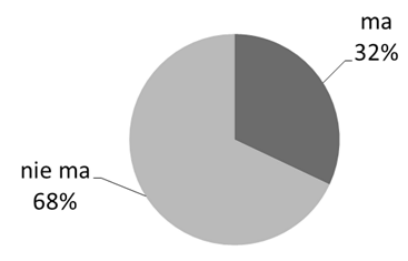

Dzieci (Aramejczycy)

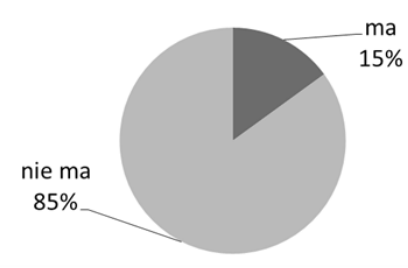




\subsection{Badania właściwe}

\subsubsection{Tożsamość}

Właściwą ankietę rozpoczynało fundamentalne pytanie, mające na celu stwierdzenie, jakie czynniki konstytuują tożsamość asyryjską bądź aramejską według samych zainteresowanych. Dla ponad czterech piątych o asyryjskości decyduje urodzenie w asyryjskiej rodzinie, dla niemal trzech piątych - kultywowanie asyryjskich tradycji i obrzędów. Prawie połowa ankietowanych uważa, że prawdziwy Asyryjczyk powinien czynnie uczestniczyć w życiu kulturalnym, religijnym i politycznym swojej wspólnoty, po około dwóch piątych, że musi być chrześcijaninem jednego z asyryjskich obrządków oraz znać język aramejski. Niecałe 15\% obstaje przy konieczności zamieszkiwania tradycyjnych ziem asyryjskich.

W kategorii „Inne” najczęściej pojawiała się odpowiedź, że jest to ktoś, kto czuje się Asyryjczykiem (3\%), poza tym wiele odpowiedzi dublowało te z sugerowanych kategorii, a więc: znajomość języka, wyznanie chrześcijańskie, posiadanie korzeni (choćby „jednej kropli krwi asyryjskiej”), pracę dla wspólnoty. Kolejne wypowiedzi podkreślały konieczność znajomości asyryjskiej historii, dumę z niej, poszanowanie tradycji, jednak bez popadania w ekstremizm. Zdarzyły się też odpowiedzi bardzo zawężające definicję, jak np. „członek Zowaa” czy „osoba wierząca w asyrianizm” lub „amerykański Asyryjczyk”. Ponadto padły bardzo generalne stwierdzenia, jak: „wszyscy pochodzą od Asyryjczyków” czy „sens mojego życia”. Jedna respondentka z całą mocą podkreśliła, że nie chce nazywać samej siebie Asyryjką, lecz Chaldejką ${ }^{28}$.

Jeśli chodzi o respondentów aramejskich, to bardzo podobnie zaznaczyli oni dwie pierwsze kategorie, tj. dokładnie cztery piąte stwierdziło istotność urodzenia w rodzinie aramejskiej, zaś trzy piąte - kultywowanie aramejskich tradycji i obrzędów. Natomiast o 17 punktów procentowych więcej uważa, że prawdziwy Aramejczyk musi być chrześcijaninem jednego z aramejskich obrządków, z czego płynie wniosek o większym znaczeniu komponentu religijnego (przynajmniej na poziomie deklaratywnym) niż u Asyryjczyków. O 5 punktów procentowych mniej uważa, że konieczne jest

${ }^{28} \mathrm{~W}$ trakcie badań terenowych i przeprowadzania wywiadów często spotykałam osoby o silnie rozwiniętej tożsamości chaldejskiej - przeważnie pochodzące z Iraku. Najczęściej wykazywały one zdystansowanie w stosunku do Asyryjczyków, np. wywiad z młodym Chaldejczykiem, pracownikiem restauracji orientalnej, Niemcy, 12.09.2007. 
czynne uczestnictwo w życiu kulturalnym, religijnym i politycznym swojej wspólnoty, co z kolei może być konsekwencją mniejszego zorganizowania grupy. O 8 punktów procentowych mniej deklaruje obowiązkową znajomość języka aramejskiego, co sugeruje, że jego znajomość wśród Aramejczyków jest nieco niższa niż u Asyryjczyków. O 6 punktów procentowych mniej twierdzi, że konieczne jest zamieszkiwanie tradycyjnych ziem aramejskich.

Wykres 10

-urodzenie się w asyryjskiej
rodzinie
qkultywowanie asyryjskich
tradycji i obrzędów
qczynne uczestnictwo w życiu
kulturalnym, religijnym i
politycznym społeczności
asyryjskiej
abycie
chrześcijaninem/chrześcijanką
jednego z asyryjskich
obrzadków
qposługiwanie się językiem
aramejskim

azamieszkiwanie asyryjskiego
terytorium

\section{Czynniki decydujące o asyryjskiej tożsamości}

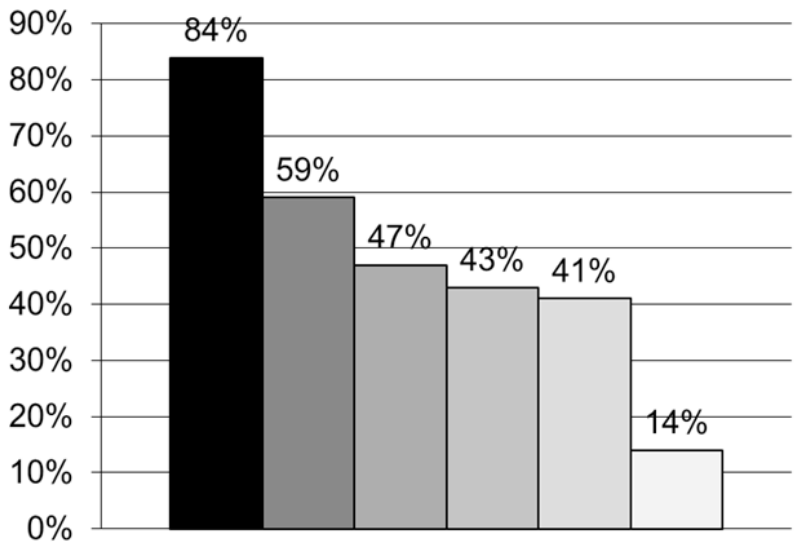

Wśród odpowiedzi „innych” pojawia się także argument czucia się Aramejczykiem czy znajomości kultury aramejskiej. Oprócz tego powtarzają się wypowiedzi o aktywnej partycypacji w życiu wspólnoty, zachowaniu tradycji, urodzeniu się w rodzinie aramejskiej, dumie z przynależności do tej grupy etnicznej. Z odpowiedzi zawężających definicję pojawiają się stwierdzenia o pochodzeniu z aramejskiej rodziny kanaanickiej, przynależności do Aramejskiej Organizacji Demokratycznej w Szwecji, studiowaniu aramejskiego, trzymaniu się z dala od wpływów muzułmańskich. Zaskakują uwagi o konieczności mówienia po arabsku czy bycia arabskim chrześcijaninem - wskazują one na hybrydalną, arabsko-aramejską tożsamość. Pojawiają się także próby odniesienia się do Asyryjczyków, np. poprzez zapis takiej równości: „Asyryjczyk/Syryjczyk/Chaldejczyk = Surjojo lub Surjaja”, 
czy wyraźne stwierdzenie, że „dzisiejsi Asyryjczycy to Aramejczycy, Asyryjczycy wyginęli w 614 roku p.n.e, ci dzisiejsi to pseudo-Asyryjczycy”.

Wykres 11

Czynniki decydujące o aramejskiej tożsamości

\begin{tabular}{|c|}
\hline $\begin{array}{l}\text {-urodzenie się w aramejskiej } \\
\text { rodzinie }\end{array}$ \\
\hline $\begin{array}{l}\text { akultywowanie aramejskich } \\
\text { tradycji i obrzędów }\end{array}$ \\
\hline $\begin{array}{l}\text { abycie } \\
\text { chrzescijaninem/chrześcijanką } \\
\text { jednego z aramejskich } \\
\text { obrządków }\end{array}$ \\
\hline $\begin{array}{l}\text { 口czynne uczestnictwo w życiu } \\
\text { kulturalnym, religijnym i } \\
\text { politycznym spolecznosci } \\
\text { aramejskiej }\end{array}$ \\
\hline $\begin{array}{l}\text { aposługiwanie się językiem } \\
\text { aramejskim }\end{array}$ \\
\hline $\begin{array}{l}\text { Qzamieszkiwanie aramejskiego } \\
\text { terytorium }\end{array}$ \\
\hline
\end{tabular}

\section{Czynniki decydujące o aramejskiej tożsamości}

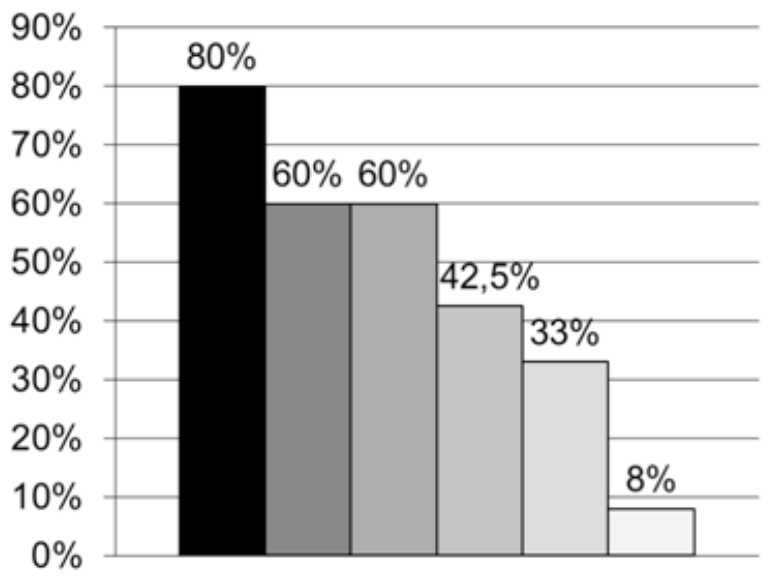

Odpowiedzi dotyczące istotności zamieszkiwania asyryjskiego/aramejskiego terytorium wskazują na to, że trudno mówić o patriotyzmie asyryjskim czy aramejskim, jeśli przez patriotyzm rozumie się lojalność w stosunku do określonego terytorium. Respondenci deklarują lojalność, ale względem swoich współbraci, zaś lojalność względem ludzi wskazuje na uczucia nacjonalistyczne.

\subsubsection{Kwestie językowe}

\subsubsection{Znajomość syryjskiego języka klasycznego}

Dokładnie dwie piąte Aramejczyków deklaruje znajomość klasycznego języka syryjskiego - o 6 punktów procentowych więcej niż Asyryjczyków. Tę niewielką przewagę może tłumaczyć większy nacisk kładziony przez Aramejczyków na kwestie związane z religią - syryjski używany jest przecież głównie jako język liturgii. 
Znajomość klasycznego syryjskiego

przez respondentów asyryjskich i aramejskich

\section{Znajomość klasycznego syryjskiego (Asyryjczycy)}

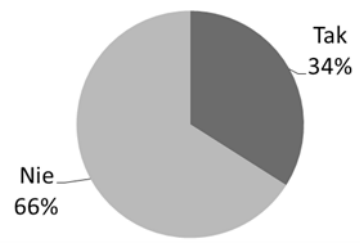

Znajomość klasycznego syryjskiego

(Aramejczycy)

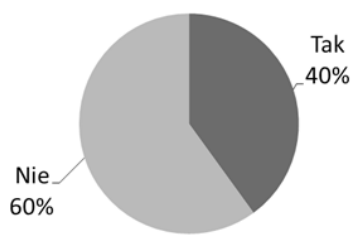

\subsection{Stopień opanowania klasycznego jezyka syryjskiego}

Niemal identycznie wygląda natomiast sytuacja, jeśli chodzi o stopień opanowania klasycznego języka syryjskiego - w obu badanych grupach najwięcej, bo około jednej trzeciej, odpowiedzi wskazywało na średnią jego znajomość, następnie ponad jedna piąta na słabą. Mniej niż jedna piąta respondentów chlubiła się odpowiednio dobrym i bardzo dobrym opanowaniem języka syryjskiego. Najmniej, bo około jednej dziesiątej, było respondentów przyznających się do bardzo słabej znajomości tego języka.

Wykres 13

Stopień opanowania klasycznego syryjskiego przez respondentów asyryjskich i aramejskich
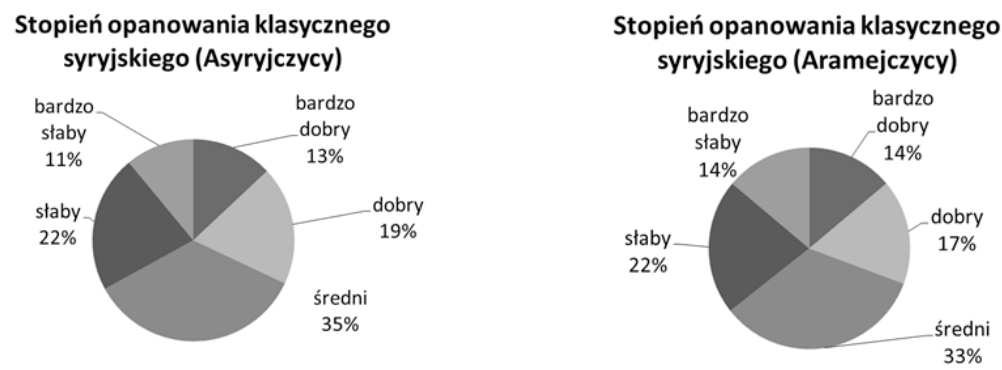

\subsubsection{Znajomość języka aramejskiego}

Zdecydowanie więcej respondentów zna język aramejski - przy czym tu sytuacja jest odwrotna, istnieje przewaga 8 punktów procentowych po stro- 
nie asyryjskiej (82\% do 74\%). Taki wynik z kolei może wskazywać na nieco większą asymilację Aramejczyków.

W tym miejscu należy podkreślić, że większość Asyryjczyków nazywała w toku ankiety język aramejski asyryjskim (niektórzy nawet wyraźnie stwierdzili, że nie posługują się aramejskim, ale asyryjskim), co, choć nie jest poprawne z historycznego i lingwistycznego punktu widzenia, to jednak wskazuje na próbę wyrugowania komponentu aramejskiego - chociażby z nazwy własnego języka. Z pewnością w jakiejś mierze odpowiedzialna jest za to prasa asyryjska, stosująca w angielskiej nomenklaturze wyrażenie „Assyrian language” na określenie nowoaramejskiego.

Wykres 14

Znajomość aramejskiego przez respondentów asyryjskich i aramejskich

\section{Znajomość aramejskiego \\ (Asyryjczycy)}

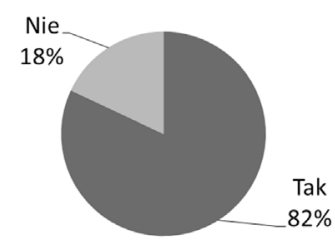

\section{Znajomość aramejskiego \\ (Aramejczycy)}

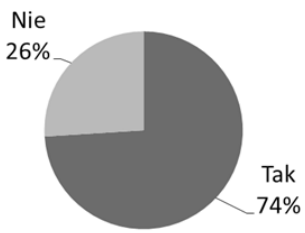

\subsection{Stopień opanowania jezyka aramejskiego}

Przewaga asyryjska w tej kategorii staje się jeszcze wyraźniejsza, gdy pod uwagę weźmie się stopień opanowania języka aramejskiego. Jedna trzecia respondentów asyryjskich zadeklarowała, że zna ten język bardzo dobrze, w grupie aramejskiej jedynie 2\%. Najliczniejsza grupa Asyryjczyków (dokładnie dwie piąte) włada aramejskim w stopniu dobrym, dla porównania wśród Aramejczyków tylko 7\%. Niemal połowa tych ostatnich zna aramejski w stopniu średnim (v. jedna piąta Asyryjczyków), dwie piąte w stopniu słabym (v. jedna dwudziesta Asyryjczyków). Bardzo słabo znających aramejski jest w obu grupach po $2 \%$. 
Wykres 15

Stopień opanowania aramejskiego przez respondentów asyryjskich i aramejskich

Stopień opanowania aramejskiego
(Asyryjczycy)

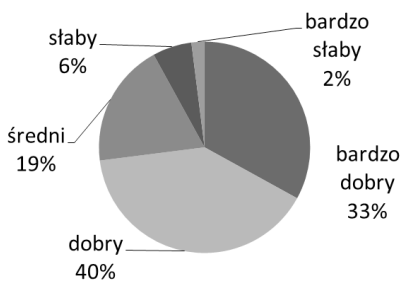

Stopień opanowania aramejskiego

(Aramejczycy)

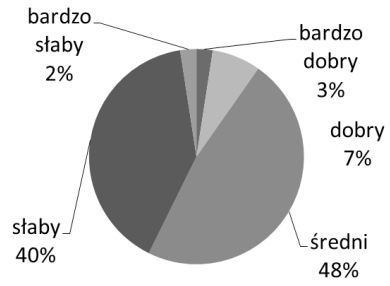

\subsection{Znajomość dialektów aramejskiego}

Pytanie o znajomość dialektów języka aramejskiego było pytaniem otwartym. Jednak po zapoznaniu się z odpowiedziami zdecydowałam się podzielić je na cztery kategorie, które wskazywałyby odpowiednio opanowanie dialektu zachodniego, wschodniego, obu lub innego dialektu (tutaj często kwalifikowały się odpowiedzi zbyt generalne, wymijające lub błędne). Uzyskane wyniki pozostają w ścisłej korelacji z ziemiami pochodzenia przodków respondentów - mianowicie w grupie asyryjskiej panuje równowaga pomiędzy władającymi dialektem zachodnim i wschodnim (ok. 35\%), z jedną dziesiątą respondentów, którzy posługują się oboma dialektami. Natomiast w grupie aramejskiej przytłaczająca jest przewaga osób znających dialekt zachodni (prawie 70\%), tylko 3\% włada wyłącznie wschodnim dialektem, oboma-7\%. Nie dziwi to w świetle faktu, że Aramejczycy pochodzą głównie z Turcji i Syrii (czyli ziem, gdzie mówiło się dialektem zachodnim), zaś Asyryjczycy, poza wskazanymi terenami, pochodzą również z Iranu i Iraku (czyli obszaru, gdzie panuje dialekt wschodni).

Wykres 16

Znajomość dialektów aramejskiego przez respondentów asyryjskich i aramejskich
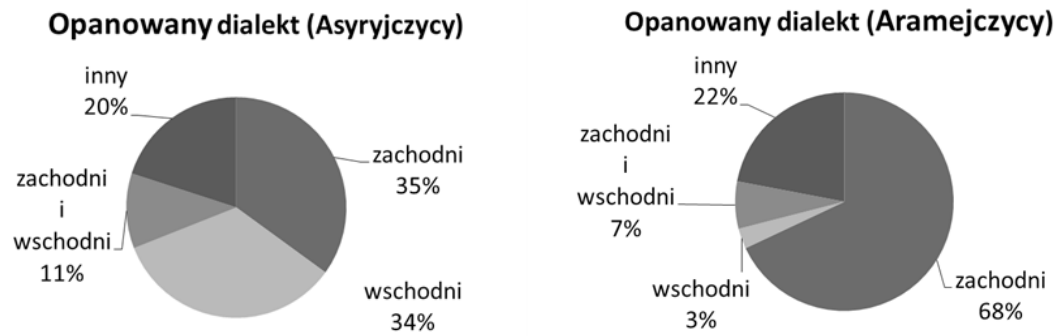


\subsection{Sposoby uczenia się aramejkkiego}

Znakomita większość, bo około czterech piątych, respondentów, zarówno asyryjskich, jak i aramejskich, nauczyła się języka aramejskiego od swoich rodziców, a 2-3\% nauczyli dziadkowie. Wśród Aramejczyków było o 3 punkty procentowe więcej tych, którzy przyswoili język w szkole (6\%). Po 13\% respondentów z obu grup nauczyło się aramejskiego w inny sposób, często na zasadzie metody mieszanej - od znajomych, w kościele, na kursie. Takie odpowiedzi pokazują, że to rodzina pozostaje głównym źródłem poznania języka, a tym samym nadania tożsamości.

Wykres 17

Sposoby nauczenia się aramejskiego przez respondentów asyryjskich i aramejskich
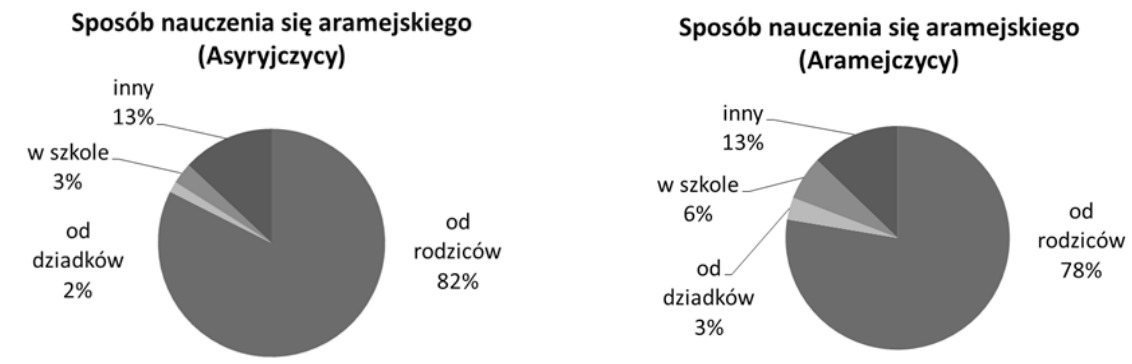

\subsubsection{Znajomość języków używanych w konkretnych interakcjach}

Język aramejski jest tak istotnym elementem tożsamości zarówno asyryjskiej, jak i aramejskiej, że warto przeanalizować dokładnie, w jakich sytuacjach i z jakimi osobami respondenci komunikują się w nim.

\subsection{Jezzyk komunikacji z rodzicami}

Odpowiedzi wykazują, że dużo więcej Asyryjczyków komunikuje się ze swoimi rodzicami wyłącznie lub częściowo po aramejsku (90\%) w porównaniu do Aramejczyków (niecałe 70\%). Oznacza to, że młode pokolenie Aramejczyków szybciej zatraca w diasporze znajomość aramejskiego.

Jeśli chodzi o języki poza aramejskim, to Asyryjczycy z rodzicami rozmawiają jeszcze po angielsku (16\%), niemiecku (5\%), arabsku (5\%), zaś Aramejczycy po arabsku (17\%), szwedzku (10\%), niemiecku (6\%) i kurdyjsku (4\%). To pokazuje, że pewnego odsetka Aramejczyków dotyczy częściowa arabizacja lub kurdyzacja, datująca się na czasy sprzed przybycia do diaspory. 
Wykres 18

Język komunikacji z rodzicami respondentów asyryjskich i aramejskich

\section{Język komunikacji z rodzicami (Asyryjczycy)}

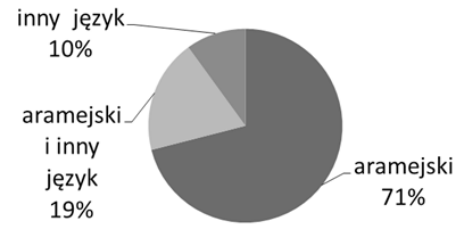

Język komunikacji $z$ rodzicami (Aramejczycy)

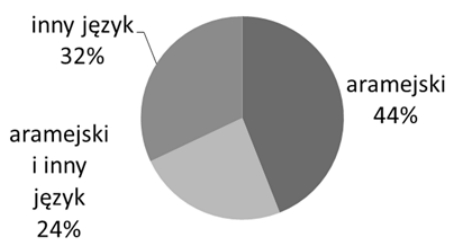

Wykres 19

Języki komunikacji z rodzicami respondentów asyryjskich

\section{Języki komunikacji z rodzicami (Asyryjczycy)}

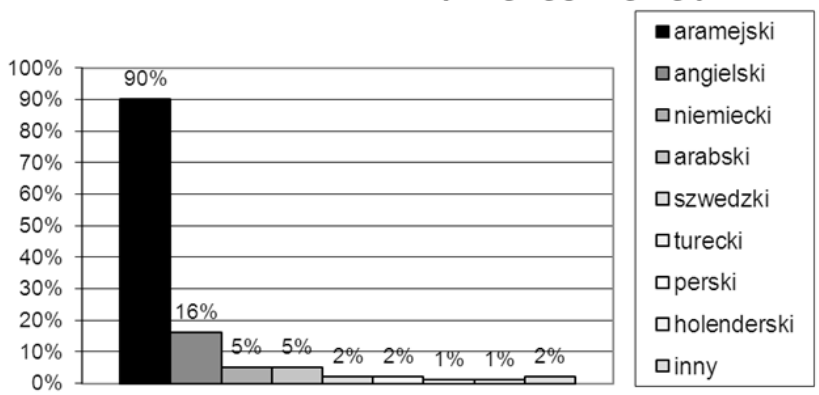

Wykres 20

Języki komunikacji z rodzicami respondentów aramejskich

\section{Języki komunikacji z rodzicami (Aramejczycy)}

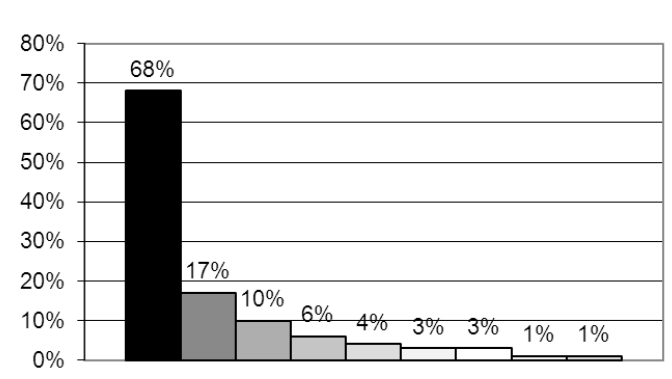

aramejski
aarabski
aszwedzki
aniemiecki
akurdyjski
aangielski
aturecki
$\square$ francuski
ainny




\subsection{Jezyk komunikacji z dziadkami}

Pytanie o język komunikacji z dziadkami, którzy w znakomitej większości nie władają językami zachodnimi, uwypukla wspomnianą tendencję - 86\% respondentów asyryjskich rozmawia z dziadkami wyłącznie lub częściowo po aramejsku, to jest prawie o 20 punktów procentowych więcej niż respondentów aramejskich. Poza aramejskim Asyryjczycy w rozmowach z dziadkami używają angielskiego (5\%), zaś Aramejczycy arabskiego (26\%), kurdyjskiego $(8 \%)$ oraz tureckiego (5\%). Oznacza to, że dziadkowie tych ostatnich najprawdopodobniej nie znali aramejskiego, a jedynie języki krajów, które zamieszkiwali lub grup etnicznych, wśród których żyli.

Wykres 21
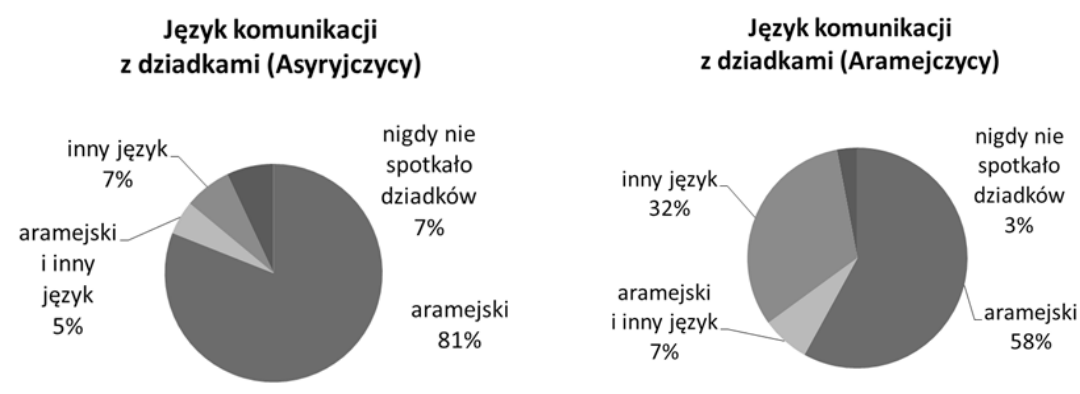

Wykres 22

Języki komunikacji z dziadkami respondentów asyryjskich

\section{Języki komunikacji z dziadkami (Asyryjczycy)}

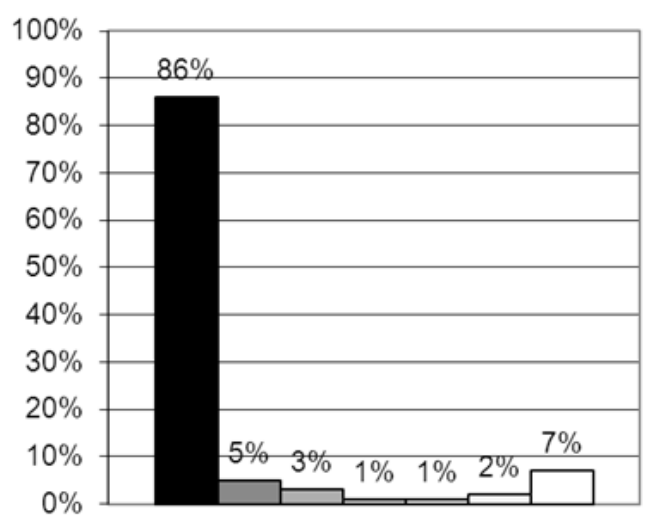

\section{- aramejski}

口angielski

口arabski

口niemiecki

口kurdyjski

ainny

unie spotkało dziadków 
Języki komunikacji z dziadkami respondentów aramejskich

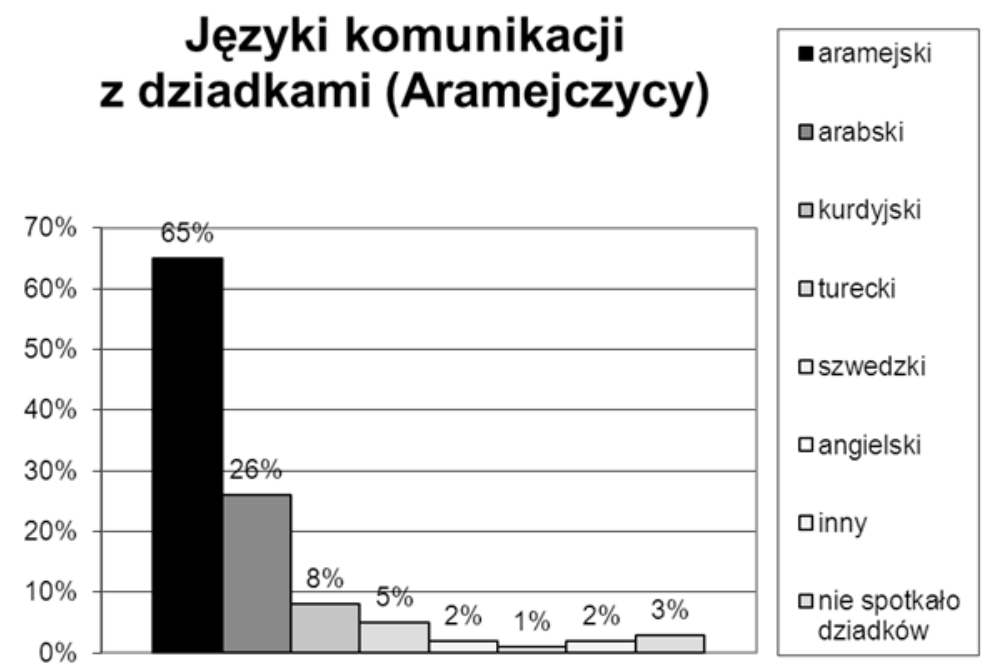

\subsection{Język komunikacji z rodzeństwem}

Podczas gdy w przypadku rodziców i dziadków używanie aramejskiego lub innego języka bliskowschodniego może być wymuszone nieznajomością przez starsze pokolenia języków zachodnich, to taka sytuacja raczej nie występuje, jeśli chodzi o rodzeństwo respondentów - podobnie, jak oni wychowane $\mathrm{w}$ diasporze. Znając język komunikacji z rodzeństwem, można ocenić preferencje językowe badanych. Tu także wyraźna jest preferencja języka aramejskiego przez Asyryjczyków (około 70\%) v. niecałe 50\% Aramejczyków. Inny język w komunikacji z rodzeństwem wybiera tylko jedna czwarta Asyryjczyków, dla porównania ponad połowa Aramejczyków. Ten inny język w przypadku Asyryjczyków to angielski (33\%), niemiecki (15\%), szwedzki (7\%), zaś Aramejczyków - szwedzki (33\%), niemiecki (29\%), arabski (19\%) i angielski (11\%); czyli ciągle aramejski jest głównym językiem komunikacji z rodzeństwem, jednak coraz więcej respondentów asyryjskich i aramejskich wybiera inne języki. Można z dużym prawdopodobieństwem zakładać, że ta ostatnia tendencja będzie się nasilać. 
Wykres 24

Język komunikacji z rodzeństwem respondentów asyryjskich i aramejskich
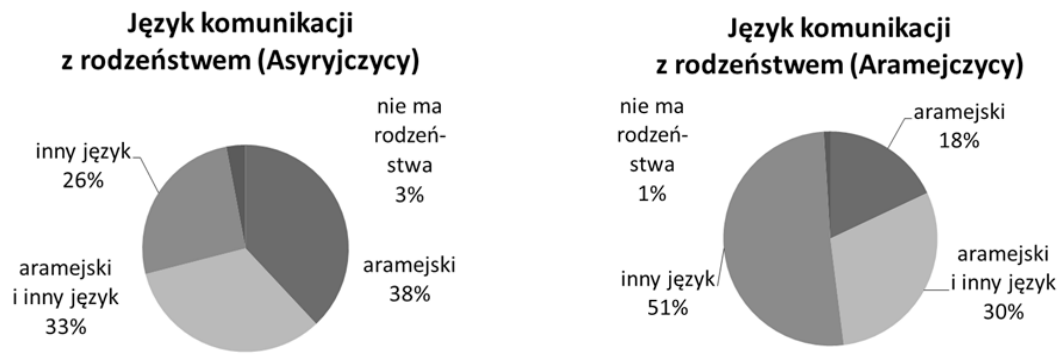

Wykres 25

Języki komunikacji z rodzeństwem respondentów asyryjskich

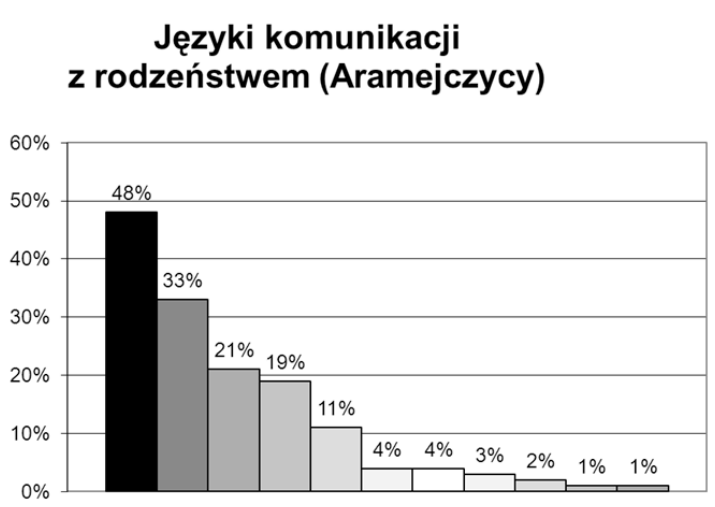

\begin{tabular}{|c|}
\hline - aramejski \\
\hline 口 szwedzki \\
\hline 口niemiecki \\
\hline 口arabski \\
\hline 口angielski \\
\hline 口holenderski \\
\hline$\square$ francuski \\
\hline 口turecki \\
\hline 口kurdyjski \\
\hline 口inny \\
\hline $\begin{array}{l}\text { 口nie ma } \\
\text { rodzeństwa }\end{array}$ \\
\hline
\end{tabular}

Wykres 26

Języki komunikacji z rodzeństwem respondentów aramejskich

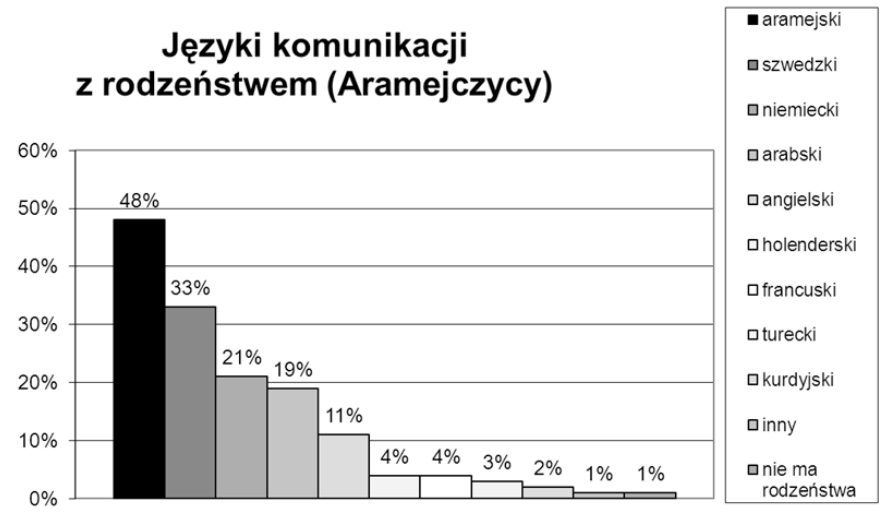




\subsection{Jezzk komunikacji w szkolelpracy}

Zgodnie z przewidywaniami poprzedzającymi skonstruowanie ankiety, bardzo niewielu (ok. jednej dziesiątej) respondentów posługuje się aramejskim w miejscu pracy bądź szkole. 90\% zarówno Asyryjczyków, jak i Aramejczyków używa na co dzień innego języka. W przypadku Asyryjczyków jest to angielski (61\%), niemiecki (19\%), szwedzki (14\%) i arabski (7\%), zaś Aramejczyków - szwedzki (52\%), angielski (24\%), niemiecki (23\%), francuski (6\%), holenderski (6\%) oraz arabski (5\%).

Wykres 27

Język komunikacji w szkole/pracy respondentów asyryjskich i aramejskich

Język komunikacji w szkole/pracy (Asyryjczycy)

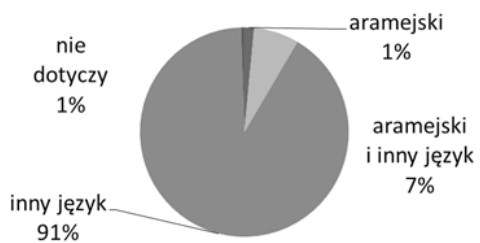

Język komunikacji w szkole/pracy (Aramejczycy)

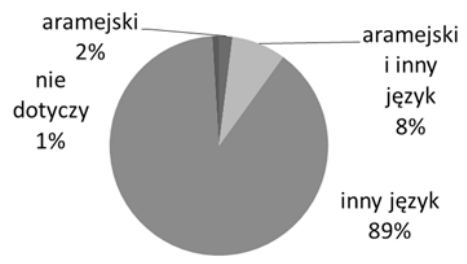

Wykres 28

Języki komunikacji w szkole/pracy respondentów asyryjskich

\section{Języki komunikacji w szkole/pracy (Asyryjczycy)}

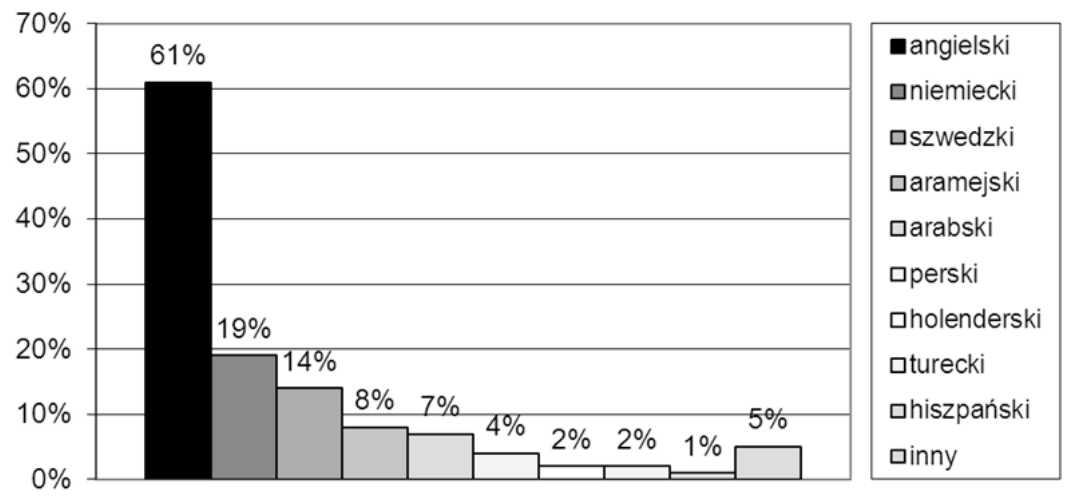


Wykres 29

Języki komunikacji w szkole/pracy respondentów aramejskich

\section{Języki komunikacji w szkole/pracy (Aramejczycy)}

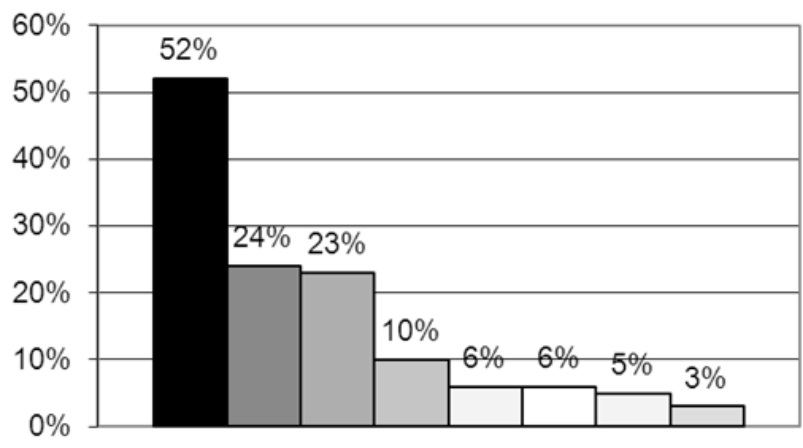

\begin{tabular}{|c|}
\hline 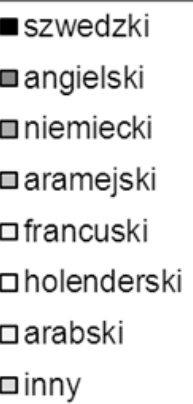 \\
\hline
\end{tabular}

\subsection{Jezyk komunikacji w innych sytuacjach}

W sytuacjach poza pracą i szkołą również więcej Asyryjczyków niż Aramejczyków używa aramejskiego, mianowicie 55\% v. 32\%. Poza aramejskim Asyryjczycy posługują się angielskim (58\%), niemieckim (20\%), arabskim (12\%) i szwedzkim (12\%), natomiast Aramejczycy szwedzkim (44\%), angielskim (27\%), niemieckim (23\%), arabskim (14\%), francuskim (6\%) i holenderskim (6\%).

Wykres 30

Język komunikacji w innych sytuacjach respondentów asyryjskich i aramejskich

Język komunikacji w innych sytuacjach (Asyryjczycy)

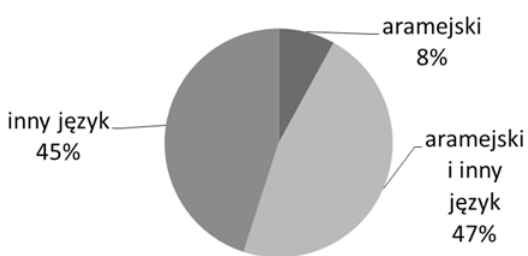

Język komunikacji w innych sytuacjach (Aramejczycy)

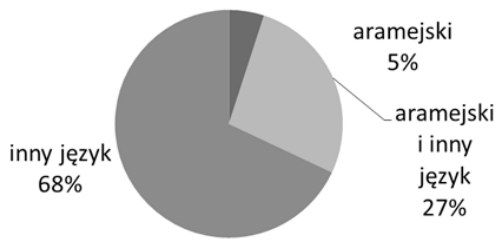


Języki komunikacji w innych sytuacjach respondentów asyryjskich

\section{Języki komunikacji w innych sytuacjach (Asyryjczycy)}

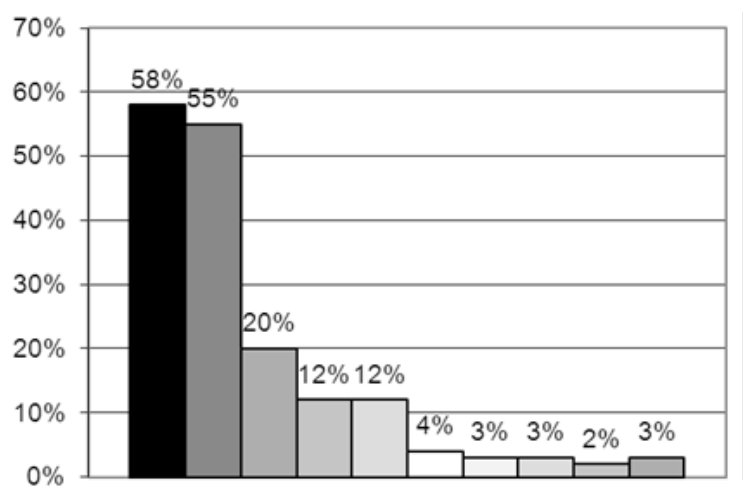

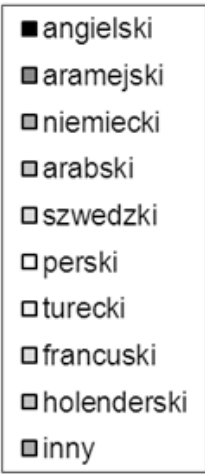

Wykres 32

Języki komunikacji w innych sytuacjach respondentów aramejskich

\section{Języki komunikacji w innych sytuacjach (Aramejczycy)}

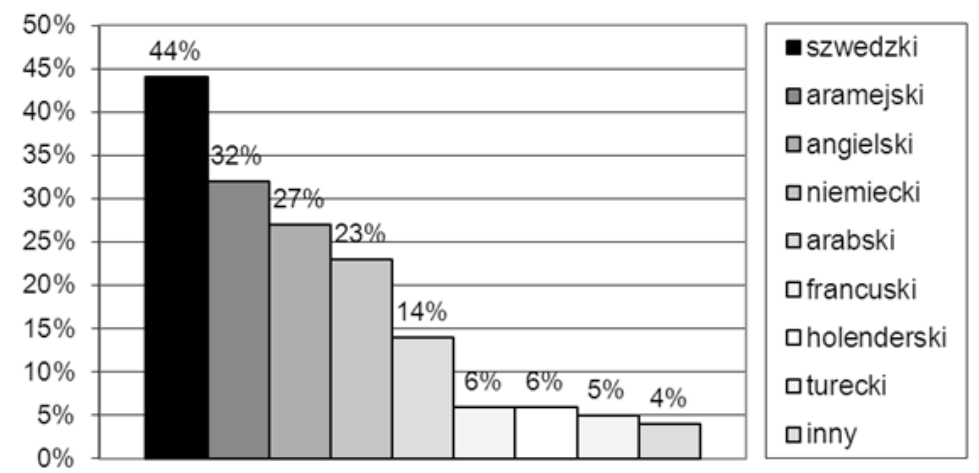

$\mathrm{Z}$ analizy odpowiedzi na pytanie o język komunikacji wyłania się wzorzec, według którego Aramejczycy słabiej znają aramejski, rzadziej go też używają. Aramejski najpowszechniej używany jest w komunikacji z najstarszym pokoleniem, tj. dziadkami, następnie z pokoleniem średnim - ro- 
dzicami, w stopniu najmniejszym z rodzeństwem. Niewielu Asyryjczyków i Aramejczyków ma możliwość korzystania z aramejskiego w miejscu pracy bądź szkole. W tzw. sytuacjach innych aramejski jest drugim najpowszechniej używanym językiem (po angielskim w przypadku Asyryjczyków, a po szwedzkim w przypadku Aramejczyków). Inne języki, którymi włada badana grupa, pozostają w ścisłej relacji bądź z krajami pochodzenia, bądź państwami zamieszkania. I tak pośród Asyryjczyków najpowszechniejsza jest znajomość języka angielskiego, potem niemieckiego, szwedzkiego i arabskiego, natomiast wśród Aramejczyków - szwedzkiego, angielskiego, niemieckiego, arabskiego, francuskiego i holenderskiego. Oprócz aramejskiego powtarzają się zatem języki: angielski, niemiecki, szwedzki oraz arabski jako najpowszechniej używane przez Asyryjczyków i Aramejczyków.

\subsubsection{Rodzaje znajomości języków}

Kolejne pytanie miało sprawdzić biegłość językową respondentów w mowie i piśmie, a także zbadać - o ile to możliwe - w jakim języku najchętniej myślą (jaki jest ich ,język podstawowy”?).

\subsection{Pisanie}

Znakomita większość Asyryjczyków pisze po angielsku (prawie 70\%), następnie po aramejsku (niecałe 40\%), niemiecku (prawie jedna czwarta),

Wykres 33

\section{Język - pisanie (Asyryjczycy)}

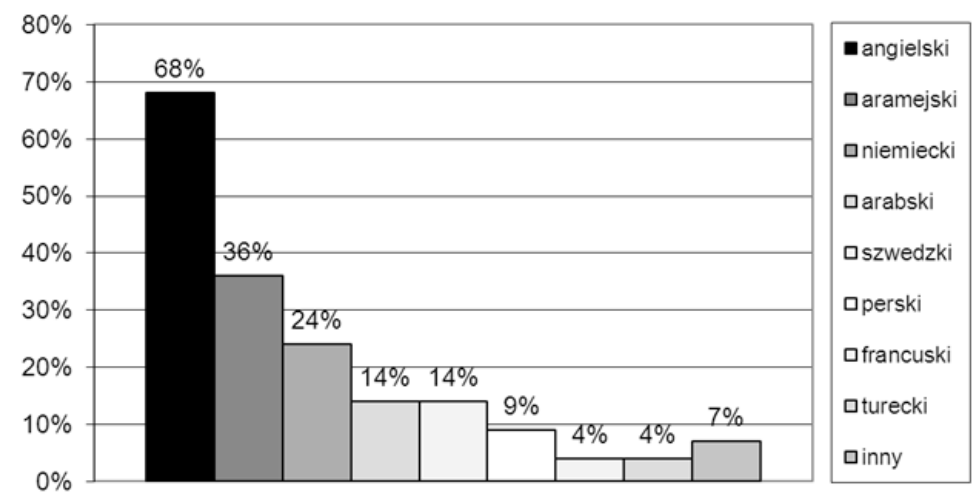


arabsku i szwedzku (po 14\%), persku (niemal jedna dziesiąta). Aramejczycy piszą przede wszystkim po szwedzku (55\%), angielsku (46\%), niemiecku (28\%), aramejsku (jedna piąta), arabsku (ponad jedna dziesiąta), francusku (8\%), holendersku (6\%) oraz turecku (5\%). Głównym językiem komunikacji pisanej jest więc dla Asyryjczyków język angielski, zaś dla Aramejczyków szwedzki i angielski.

Wykres 34

\section{Język - pisanie (Aramejczycy)}

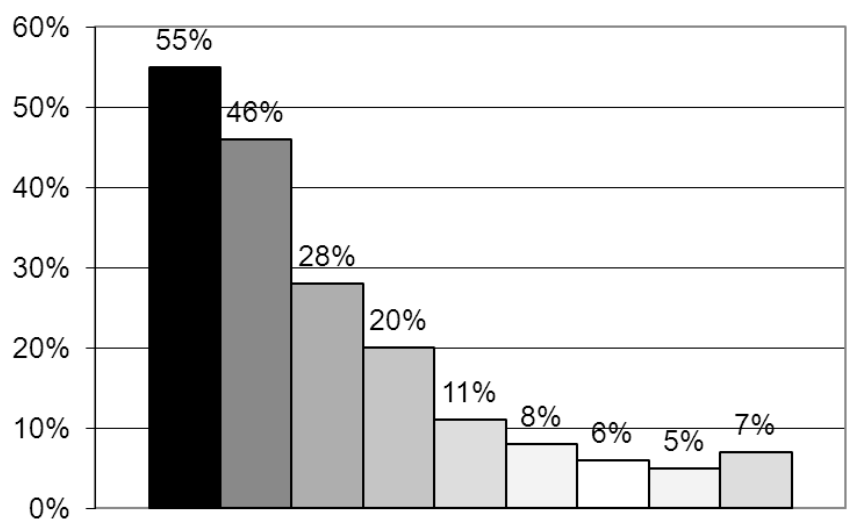

- szwedzki

口angielski

口niemiecki

口aramejski

口arabski

$\square$ francuski

$\square$ holenderski

口turecki

口inny

\subsection{Czytanie}

Analogicznie wyglądają odpowiedzi dotyczące czytania, z tym że często są o punkt procentowy czy dwa wyższe od poprzednich - kilka procent respondentów potrafi czytać $\mathrm{w}$ danym języku, ale ma trudności z pisaniem w nim. Najbardziej rzuca się to w oczy w przypadku 7-punktowej różnicy w znajomości pisania i czytania w języku aramejskim wśród Aramejczyków.

\subsection{Myślenie}

Odpowiedzi na to pytanie najjaskrawiej ukazują wyższy stopień asymilacji grupy aramejskiej w porównaniu do grupy asyryjskiej - prawie 70\% respondentów asyryjskich odpowiedziało, że myśli po aramejsku, zaś wśród respondentów aramejskich odsetek ten wyniósł niecałe 40\%. Tym samym 
Wykres 35

\section{Język - czytanie (Asyryjczycy)}

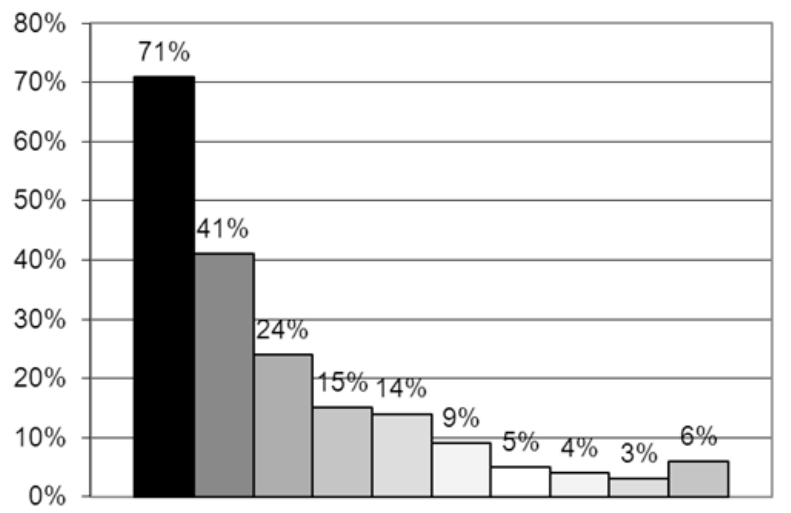

- angielski

口aramejski

口niemiecki

口arabski

口szwedzki

口perski

口francuski

口turecki

口hiszpański

口inny

Wykres 36

\section{Język - czytanie (Aramejczycy)}

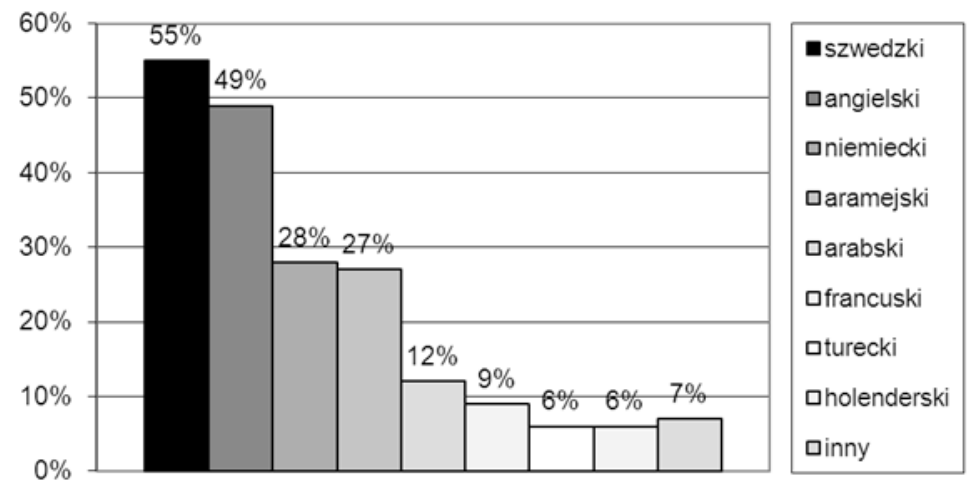

aramejski jest językiem, w którym myśli większość Asyryjczyków, natomiast dopiero drugim, w którym myślą Aramejczycy; 45\% tych ostatnich myśli bowiem przeważnie po szwedzku. Kolejne języki nie zaskakują - u Asyryjczyków są to angielski (prawie połowa), niemiecki (niemal jedna piąta), 
szwedzki (ponad jedna dziesiąta) i arabski (ponad jedna dwudziesta), a u Aramejczyków niemiecki (ponad jedna piąta), angielski (jedna piąta), arabski (prawie jedna dziesiąta) i holenderski (jedna dwudziesta).

Dwóch respondentów asyryjskich napisało - trudno ocenić, na ile żartobliwie, a na ile nacjonalistycznie - iż myśli po akadyjsku.

Wykres 37

\section{Język - myślenie (Asyryjczycy)}

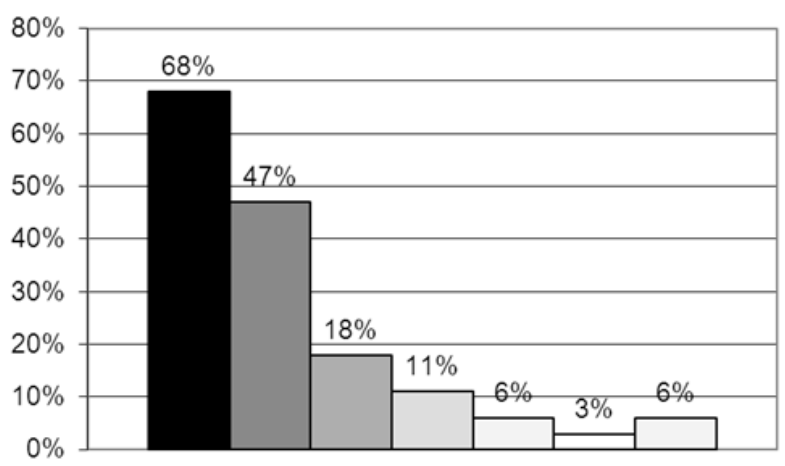

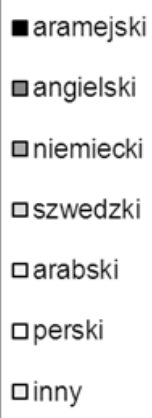

Wykres 38

\section{Język - myślenie (Aramejczycy)}

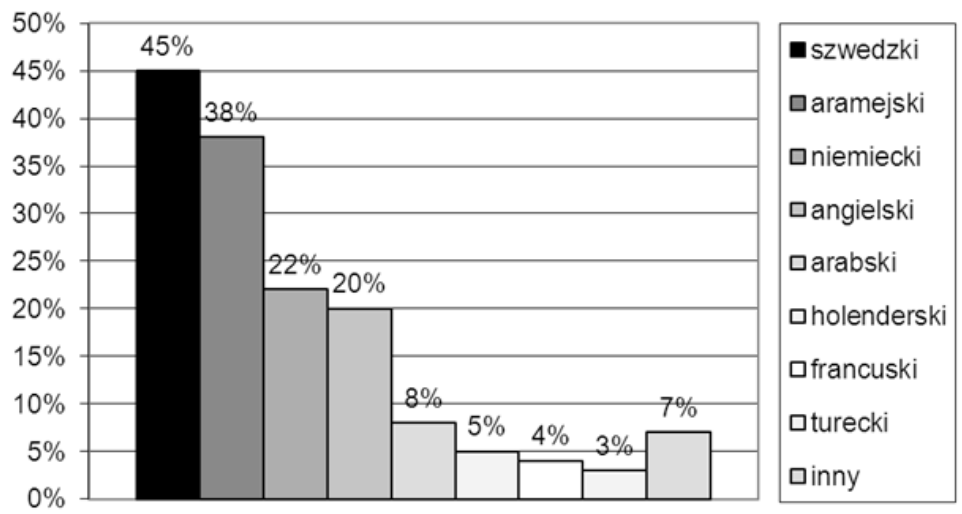


Podsumowując tę część ankiety, należy zwrócić uwagę na zróżnicowanie języków, jakimi posługują się Asyryjczycy i Aramejczycy. Szczególnie dotyczy to diaspory europejskiej. Respondenci najczęściej mają opanowane dwa, trzy, a często więcej języków. Klasyczny syryjski jest językiem niemalże martwym, biegle zna go zaledwie kilka procent najlepiej wykształconych respondentów (nieco więcej Aramejczyków), natomiast aramejski ciągle jest powszechnie używany, przede wszystkim przez Asyryjczyków, którzy znali go jeszcze przed wyemigrowaniem z Bliskiego Wschodu. Od nich języka uczą się ich dzieci, podobnie żony (nawet te cudzoziemskie) oraz, co interesujące, imigranci z krajów dawnej Jugosławii, którzy mieszkają w Södertälje w Szwecji. Natomiast Asyryjczycy i Aramejczycy, którzy w krajach pochodzenia porozumiewali się wyłącznie po arabsku, turecku czy kurdyjsku, nie mówią po aramejsku, ich dzieci raczej też nie, choć niektóre z nich zaczynają się uczyć języka przodków w szkołach, kościołach i organizacjach, co jest nowym zjawiskiem. Nauka aramejskiego nie jest nigdzie obowiązkowa (kiedyś jako nauka języka ojczystego była wymagana przez prawo szwedzkie, ale zmieniono przepisy, by przyśpieszyć asymilację). Brakuje nauczycieli oraz podręczników (niewielka ich część drukowana jest w diasporze, gros w Syrii i Libanie ${ }^{29}$ ).

Zasadniczo jednak reprezentanci młodszego pokolenia, zwłaszcza ci urodzeni w diasporze, coraz częściej myślą, mówią i piszą w językach zachodnich, tj. po angielsku, szwedzku, niemiecku, francusku, holendersku itp. Choć nie wynika to z ankiety, to nie można pominąć znacznej diaspory mówiącej po rosyjsku, ormiańsku itp. To wielkie zróżnicowanie lingwistyczne utrudnia komunikację wewnątrz wspólnoty. Podział aramejskiego na odmianę zachodnią i wschodnią nie pozwala zaś na stworzenie jednego, narodowego języka.

\subsubsection{Uczestnictwo w kulturze}

\subsubsection{Prasa}

Niemal połowa Asyryjczyków czyta asyryjskie gazety, podczas gdy aramejskie znajdują czytelnika jedynie w co piątym Aramejczyku.

${ }^{29}$ Wywiad z dwoma przedstawicielami Assyrian Democratic Movement, Szwecja, 29.06.2007. 
Wykres 39

Czytelnictwo gazet asyryjskich i aramejskich

\section{Czytelnictwo asyryjskich gazet}

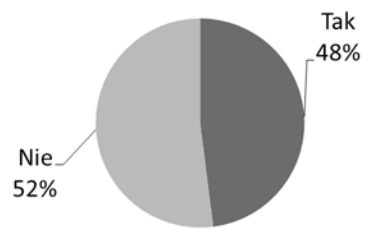

\section{Czytelnictwo aramejskich gazet}

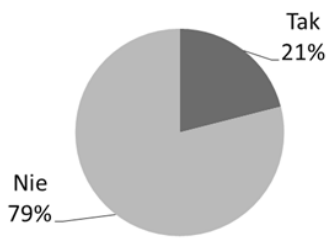

Najpoczytniejsze gazety asyryjskie to anglojęzyczny tygodnik „Zinda” (aram. Iskra) oraz „Hujada” (aram. Jedność), magazyn szwedzkiej asyryjskiej federacji narodowej, wychodzący po szwedzku i aramejsku. Oba periodyki czyta prawie jedna trzecia respondentów ${ }^{30}$. Jedna dziesiąta badanych wymieniła AINA (Assyrian International News Agency), będącą w rzeczywistości portalem internetowym. Tyle samo osób wskazało na „Qenneshrin” (aram. Orle gniazdo), organ prasowy „Suroyo TV”, który ukazuje się w czterech

Wykres 40

\section{Gazety asyryjskie}

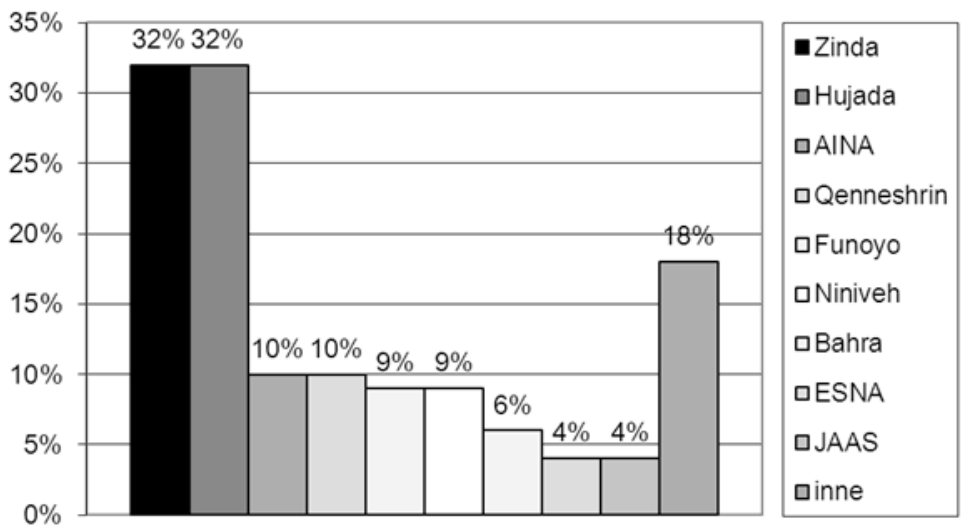

${ }^{30}$ Jedna trzecia spośród tych, którzy udzielili odpowiedzi twierdzącej na poprzednie pytanie. W tej części opracowania, w pytaniach szczegółowych, procenty nie odnoszą się do całej próby, lecz wyłącznie do tych respondentów, którzy korzystają z oferty kulturalnej. 
wersjach językowych: po niemiecku, angielsku, szwedzku i turecku. Niewielu mniej respondentów czyta niemieckojęzyczne „Funoyo” (Odpowiedź) oraz „Niniveh Magazine”. [Il. 6]

Najpowszechniej czytaną gazetą aramejską jest „Bahro Suryoyo”, wydawana w pięciu językach (po aramejsku, arabsku, angielsku, turecku i szwedzku), na którą wskazało prawie dwie piąte respondentów. Jedna piąta czyta „Mardutho d-Suryoye” - magazyn aramejskiej federacji w Niemczech, ponad jedna dziesiąta "Qenneshrin”, nieco mniej niż jedna dziesiąta miesięcznik Syryjskiego Kościoła Ortodoksyjnego „Kolo Suryoyo” i „Kifa Magazine”. Niewiele więcej niż jedna dwudziesta badanych sięga po „Funoyo” oraz „Lebo”. [Il. 7]

Wykres 41

\section{Gazety aramejskie}

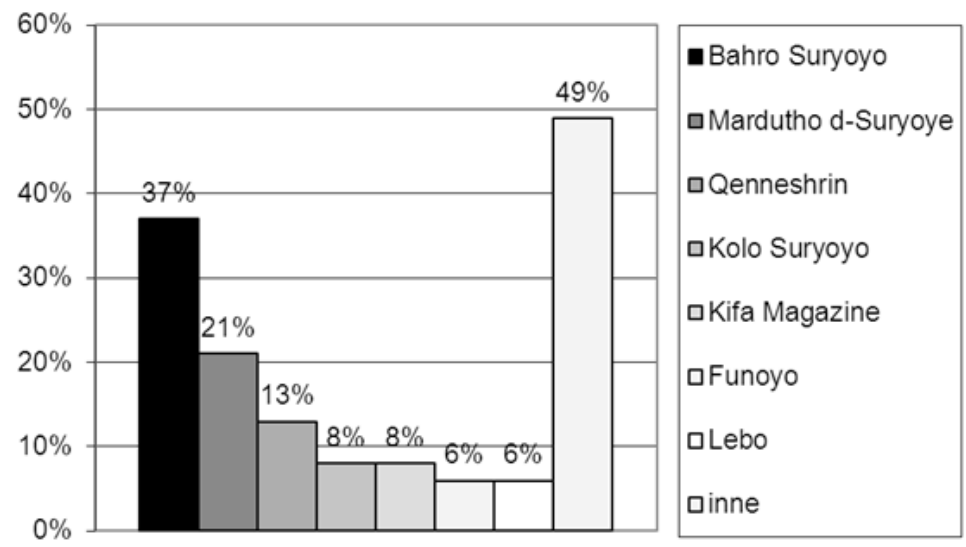

Z porównania płynie wniosek, że powtarzają się jedynie dwa tytuły: "Qenneshrin”, który zresztą nosi podtytuł „Wolny Głos AsryjczykówAramejczyków-Chaldejczyków-Syryjczyków” oraz „Funoyo”. Te dwa magazyny, nieposiadające wcale największej liczby czytelników, nastawione są na jednoczenie wszystkich odłamów badanej grupy. Jednak zdecydowanie bardziej poczytne są „wyspecjalizowane” gazety i magazyny, kierujące swoje teksty do sprecyzowanego - bądź to asyryjskiego, bądź aramejskiego - odbiorcy. 


\subsubsection{Telewizja}

Ponad trzy piąte Asyryjczyków ogląda telewizję asyryjską, widownia aramejska jest jeszcze większa - wynosi niemal trzy czwarte badanych. Podobnie jak w przypadku gazet, definicje „telewizja asyryjska” oraz „telewizja aramejska” stanowią zbiory o części wspólnej, przy czym więcej elementów - kanałów telewizyjnych - znajduje się w zbiorze asyryjskim.

Wykres 42

Oglądalność telewizji asyryjskiej i aramejskiej

Oglądalność telewizji asyryjskiej

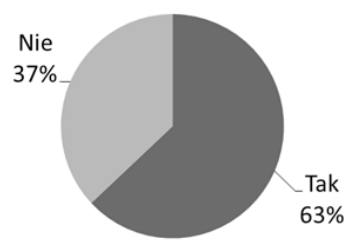

\section{Oglądalność telewizji aramejskiej}

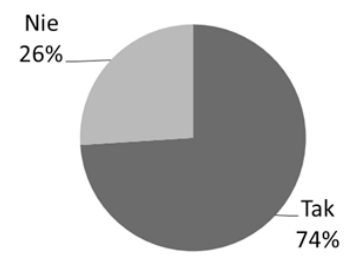

Ponad połowa respondentów asyryjskich ogląda „Suroyo TV”, ponad dwie piąte „Isztar TV”, dokładnie jedna czwarta "Suryoyo Sat”, jedna siódma „Ashur TV”, około jednej dziesiątej „Bet Nahrain” oraz „Assyria Sat”.

Wykres 43

\section{Asyryjskie kanały telewizyjne}

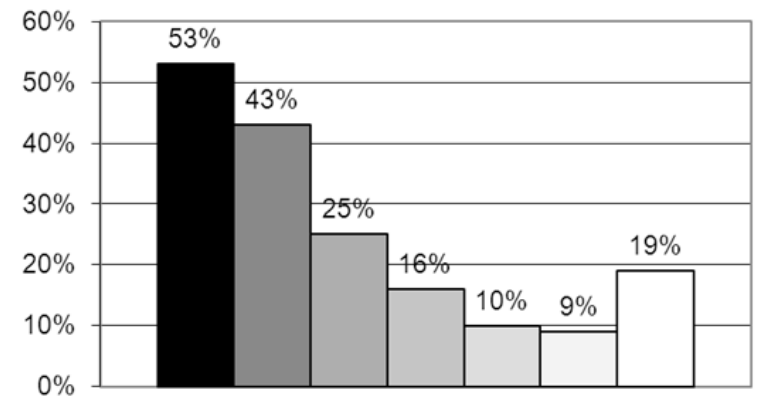

-Suroyo TV

口ishtar TV

ם Suryoyo Sat

口Ashur TV

$\square$ Bet Nahrain

口Assyria Sat

ainne 
Niewątpliwie najpopularniejszym wśród Aramejczyków kanałem telewizyjnym jest „Suryoyo Sat”, który ogląda ponad cztery piąte respondentów. Ponad dwie trzecie badanych to widzowie „Suroyo TV”, co piętnasty Aramejczyk ogląda „Isztar TV”.

Wykres 44

\section{Aramejskie kanały telewizyjne}

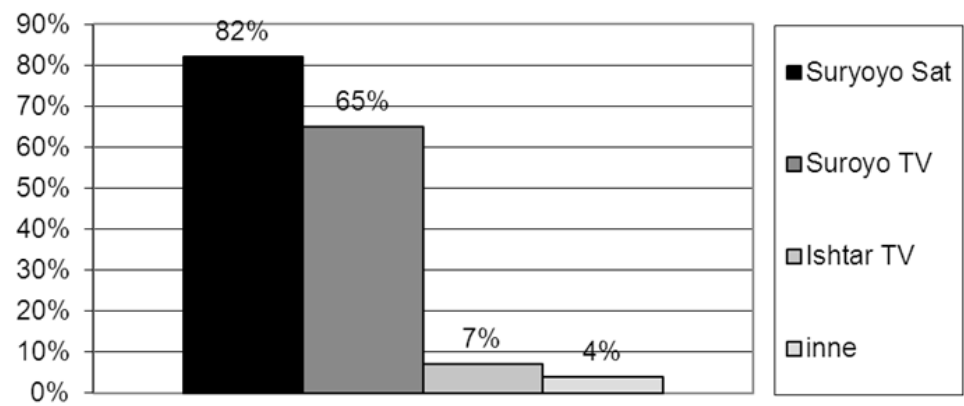

Największą łączną widownię gromadzi - deklarująca się jako telewizja chaldejsko-asyryjsko-syryjska o chrześcijańskiej linii programowej - „Suroyo TV”31. Ogląda ją ponad połowa zarówno Asyryjczyków, jak i Aramejczyków. Jej rola w jednoczeniu wszystkich odłamów omawianej grupy jest nie do przecenienia. Od 2004 roku „Suroyo TV” oferowała półgodzinne programy dwa razy na tydzień, głównie wiadomości, obecnie codziennie emitowane są cztery godziny nowego programu, który jest powtarzany dwa razy w ciągu dnia (co daje razem dwanaście godzin na dobę). Siedziba stacji mieści się w Södertälje, gdzie znajdują się dwie główne sale nagraniowe, zaś w Kamiszli w Syrii działa filia, której pracownicy konsultują jednak swoje pomysły z centralą. Stałych pracowników jest około trzydziestu, kilkudziesięciu pracuje jako korespondenci na świecie, m.in. w Holandii czy Niemczech. Programy „Suroyo TV” docierają ze Szwecji do niemal 90 krajów świata w pięciu językach: po aramejsku, arabsku, szwedzku, angielsku i turecku. [Il. 8]

${ }^{31}$ Oficjalna strona stacji: http://www.suroyotv.com, data wejścia 19.12.2009. 
Zarząd „Suroyo TV” z zasady nie cenzuruje treści wypowiadanych przez gości w programach politycznych. Natomiast raz ocenzurował program ze względu na nieodpowiedzialne zachowanie prowadzącego, który wypowiadał się na temat polityki w sposób obraźliwy. Pewna autocenzura jest konieczna, jednak w zamyśle telewizja ma stanowić forum wolnej wymiany myśli.

Główne problemy, z jakimi boryka się stacja, to za małe środki i za mało czasu antenowego. „Suroyo TV” utrzymuje się częściowo z reklam (których jest niewiele, ponieważ wielu rzeczy nie można w Szwecji reklamować, zakaz obejmuje m.in. alkohol, papierosy, pornografię), a częściowo z datków ludzi dobrej woli i donacji bogatszych Asyryjczyków. Czasem umierający bezdzietnie Asyryjczyk zapisuje swój majątek stacji zamiast Kościołowi.

Osoby zaangażowane w działalność „Suroyo TV” postrzegają ją jako "pracę u podstaw”, tworzenie fundamentu, na którym będą mogły budować przyszłe pokolenia. Wiedzą, że to, co oferują, nie jest na światowym poziomie, mimo iż oni sami posiadają odpowiednie know-how. Jednak skromny budżet odbija się ujemnie na jakości programów - nieraz piętnastominutowy materiał trzeba rozciąnnąć do godziny. W istocie, gdyby wszystkie asyryjskie i/lub aramejskie stacje się zjednoczyły, byłyby w stanie nadawać dobre programy przez całą dobę. Jest to jednak niemożliwe. Mimo że "Suroyo TV” ma umowę z „Isztar TV”, stacje rzadko pożyczają sobie programy. Stosunki z innymi stacjami nie są najlepsze, można mówić wręcz o ich skonfliktowaniu ${ }^{32}$.

Głównym rywalem „Suroyo TV” jest nadający od 2006 roku „Suryoyo Sat”33, którego gros odbiorców stanowią - jak to zostało stwierdzone wcześniej - Aramejczycy (choć jeden z nich nazwał ten kanał „rasistowskim”). To kanał programowo aramejski, nadawany ze Szwecji w zachodnim dialekcie aramejskiego (czasem po angielsku i arabsku). Dociera do 80 krajów świata. Jego celem jest jednoczenie Aramejczyków i Asyryjczyków i kształtowanie jednej - aramejskiej (syryjskiej) - tożsamości. [Il. 9]

Dużo mniejszą oglądalnością cieszą się pozostałe stacje, przede wszystkim ze względu na uboższą ofertę programową. „Ishtar TV”34 jest kanałem typowo asyryjskim, nadawanym od 2005 roku z Ankawy w Iraku po aramejsku, ale także po arabsku i kurdyjsku. „Ashur TV” to druga stacja asyryjska, nadająca z Iraku (z Bagdadu); swoje programy kieruje do „narodu”, który

\footnotetext{
${ }^{32} \mathrm{Na}$ podstawie wywiadu z członkiem zarządu „Suroyo TV”, Szwecja, 30.06.2007.

${ }^{33}$ Stacja posiada stronę internetową: http://www.suryoyosat.com, data wejścia 19.12.2009.

${ }^{34}$ Strona stacji: http://www.ishtartv.com, data wejścia 19.12.2009.
} 
określa jako „chaldejsko-asyryjsko-syryjski”. „Bet Nahrain” oraz „Assyria Sat” to z kolei stacje asyryjskie odbierane w Stanach Zjednoczonych.

\subsubsection{Radio}

W porównaniu do telewizji radio znajduje zdecydowanie mniej odbiorców - tylko co czwarty Asyryjczyk i co szósty Aramejczyk słucha asyryjskich bądź aramejskich programów radiowych.

Wykres 45

Słuchalność radia asyryjskiego i aramejskiego

\section{Słuchalność radia asyryjskiego}

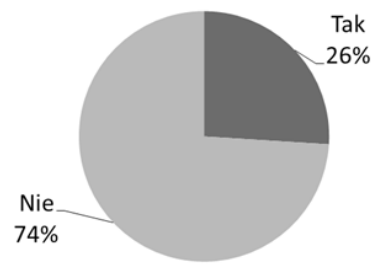

\section{Słuchalność radia aramejskiego}

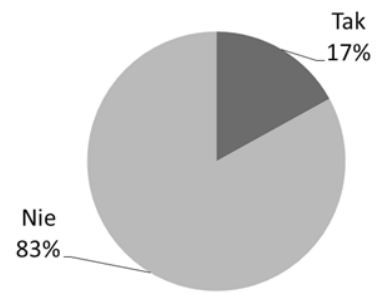

Wykres 46

\section{Asyryjskie rozgłośnie radiowe}

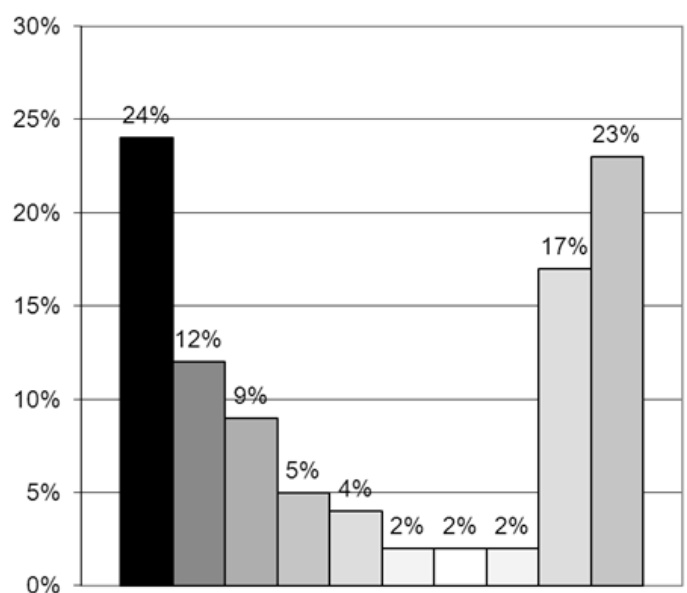

Q Qolo
az Chicago
az Sydney
aTurlock
aKBSV
ankawa
asssyrische Stimme
Wiesbaden
aWonx
ainne
anie potrafiło wymienić
stacji

Niemal wszyscy respondenci, którzy zadeklarowali, że słuchają asyryjskich stacji radiowych, wskazali na radio "Qolo” - nadawane ze Szwecji w zachodniej odmianie aramejskiego, a docierające za pośrednictwem In- 
ternetu do krajów na całym świecie. Pozostałe asyryjskie programy można określić jako regionalne lub niszowe, jak asyryjskie radio z Chicago, z Sydney, Turlock, KBSV. Jedna piąta respondentów, którzy zadeklarowali, że słuchają asyryjskiego radia, nie potrafiła sobie przypomnieć ani nazwy stacji, ani tytułu programu.

Jeszcze większe problemy z odpowiedzią na to pytanie mieli badani z próby aramejskiej. Jedna piąta wskazała na radio, które może być odbierane wyłącznie za pośrednictwem Internetu, mianowicie www.suryoyo.nl. Co szósty respondent aramejski słucha wzmiankowanego już wcześniej radio „Qolo”. Tylu samo odbiera za pośrednictwem Internetu www.suryoyozone.com. Co ósmy respondent wybiera radio „Suryoyo FM”, co dwudziesty „Suryoyo Sat Radio”, niewielu mniej „Aramäische Stimme”.

\section{Aramejskie rozgłośnie radiowe}

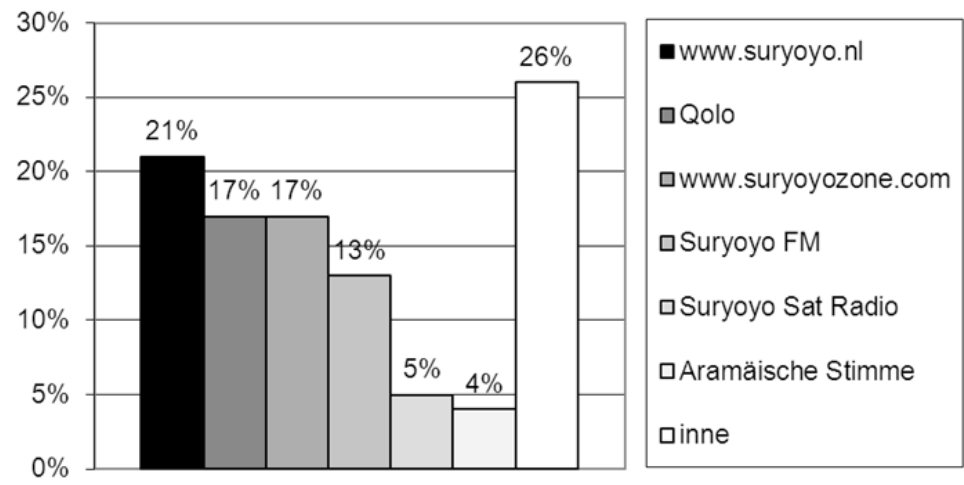

Oznacza to, że najpopularniejszym radiem jest „Qolo”, ideologicznie związane bardziej ze stroną asyryjską, jednak słuchane i przez Asyryjczyków, i przez Aramejczyków.

\subsubsection{Internet}

Ponad cztery piąte asyryjskich i aramejskich badanych zadeklarowało odwiedzanie asyryjskich lub aramejskich stron internetowych (3 punkty 
procentowe więcej Asyryjczyków odwiedza „swoje” strony internetowe w porównaniu do Aramejczyków).

Wykres 48

Odwiedzanie asyryjskich i aramejskich stron internetowych
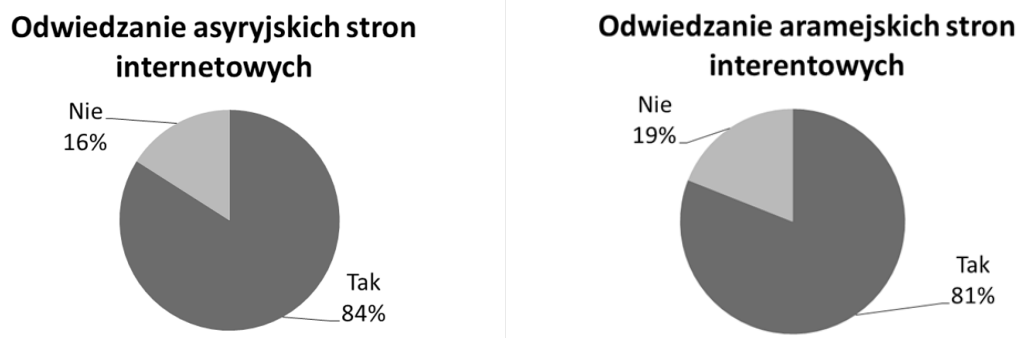

Analiza konkretnych asyryjskich stron internetowych ukazuje ich wielkie zróżnicowanie. Na pierwszym miejscu plasuje się międzynarodowy portal informacyjny www.aina.org, następnie strona wspomnianego wcześniej magazynu „Zinda” - www.zindamagazine.com; oba używają terminu „Asyryjczyk”. Jednak już trzecia pod względem popularności www.yauno.com traktuje o „Syryjczykach” - czyta ją co ósmy Asyryjczyk. Około jedna dziesiąta respondentów wchodzi na strony www.assyrianvoice.net, www.hujada.com, www.huyodo.com (również skierowaną do Syryjczyków), www.ankawa.com oraz www.bethnahrin.de. Najpopularniejsze strony asyryjskie można określić jako informacyjne.

Tabela 13

Asyryjskie strony internetowe

\begin{tabular}{|l|c|c|}
\hline \multicolumn{1}{|c|}{ Nazwa asyryjskiej strony internetowej } & N & $\%$ \\
\hline www.aina.org & 113 & 27 \\
\hline www.zindamagazine.com & 101 & 25 \\
\hline www.yauno.com & 53 & 13 \\
\hline www.assyrianvoice.net & 45 & 11 \\
\hline www.hujada.com & 44 & 11 \\
\hline www.huyodo.com & 43 & 10 \\
\hline www.ankawa.com & 39 & 10 \\
\hline www.bethnahrin.de & 38 & 9 \\
\hline
\end{tabular}


Tabela $13 \mathrm{~cd}$.

\begin{tabular}{|c|c|c|}
\hline Nazwa asyryjskiej strony internetowej & $\mathrm{N}$ & $\%$ \\
\hline www.auf.nu & 32 & 8 \\
\hline www.nineveh.com & 31 & 7 \\
\hline www.assyria.se & 23 & 6 \\
\hline www.zowaa.org & 22 & 5 \\
\hline www.themesopotamian.org & 19 & 5 \\
\hline www.ajm-online.com & 18 & 4 \\
\hline www.suryoyena.com & 16 & 4 \\
\hline www.bethsuryoyo.com & 15 & 4 \\
\hline www.esna.se & 13 & 3 \\
\hline www.betnahrain.org & 12 & 3 \\
\hline www.qeenatha.com & 10 & 2 \\
\hline www.assyrianchurch.com & 10 & 2 \\
\hline www.zahrira.com & 9 & 2 \\
\hline www.furkono.com & 8 & 2 \\
\hline www.assyrer.eu & 8 & 2 \\
\hline www.aas.net & 8 & 2 \\
\hline www.ngauk.com & 7 & 2 \\
\hline www.assyrianmarket.com & 6 & 1 \\
\hline www.assyrianaid.org & 5 & 1 \\
\hline www.assyrian4all.net & 4 & 1 \\
\hline www.suryaniler.com & 4 & 1 \\
\hline www.aua.net & 4 & 1 \\
\hline www.wawallap.com & 4 & 1 \\
\hline www.atour-online.com/forum/ & 4 & 1 \\
\hline www.ado-world.com & 3 & 1 \\
\hline www.learnassyrian.com & 3 & 1 \\
\hline www.nurikino.com & 3 & 1 \\
\hline www.christiansofiraq.com & 3 & 1 \\
\hline
\end{tabular}




\begin{tabular}{|l|r|c|}
\hline \multicolumn{1}{|c|}{ Nazwa asyryjskiej strony internetowej } & N & $\%$ \\
\hline www.acsa.nu & 3 & 1 \\
\hline www.saais.org & 3 & 1 \\
\hline www.banipal.com & 3 & 1 \\
\hline www.khabour.com & 3 & 1 \\
\hline www.chaldean.org & 3 & 1 \\
\hline www.assyrianism.com & 3 & 1 \\
\hline Inne & 76 & 18 \\
\hline
\end{tabular}

Tabela 14

Aramejskie strony internetowe

\begin{tabular}{|l|c|c|}
\hline \multicolumn{1}{|c|}{ Nazwa aramejskiej strony internetowej } & N & $\%$ \\
\hline www.suryoyena.org (.de i .org) & 64 & 26 \\
\hline www.syrianska.fc.com (aif.com, -riks.org) & 63 & 25 \\
\hline www.suryoyozone.com (.se) & 53 & 22 \\
\hline www.yauno.com & 33 & 13 \\
\hline www.soku.org (.se) & 25 & 10 \\
\hline www.saaf.info & 17 & 7 \\
\hline www.aramaic-dem.org & 15 & 6 \\
\hline www.ungsyrian.nu & 12 & 5 \\
\hline www.arameiska.se (.com) & 10 & 4 \\
\hline www.suryoyo.nl (.com) & 10 & 4 \\
\hline www.noturo.com & 9 & 4 \\
\hline www.platformaram.nl & 8 & 3 \\
\hline www.melthodhaye.com & 7 & 3 \\
\hline www.huyoydo.de (.com) & 7 & 3 \\
\hline www.suryoye.be (.de) & 6 & 2 \\
\hline www.auf.nu & 6 & 2 \\
\hline www.suryoyosat.com (.de i .eu) & 5 & 2 \\
\hline www.midyatcity.com & & 2 \\
\hline www.saais.org & 6 & 2 \\
\hline
\end{tabular}


Tabela $15 \mathrm{~cd}$.

\begin{tabular}{|l|c|c|}
\hline \multicolumn{1}{|c|}{ Nazwa aramejskiej strony internetowej } & N & 2 \\
\hline www.u-i.nu & 4 & 2 \\
\hline www.urhoy.info & 4 & 2 \\
\hline sor.cua.edu & 4 & 2 \\
\hline www.aramnaharaim.org & 4 & 2 \\
\hline www.bethnahrin.nl (.de) & 4 & 1 \\
\hline www.bethmardutho.org & 3 & 1 \\
\hline www.suryoyo-online.org & 3 & 1 \\
\hline suf.org & 3 & 1 \\
\hline www.ankawa.com & 3 & 1 \\
\hline www.ajm-online.com & 3 & 1 \\
\hline www.hujada.com & 3 & 1 \\
\hline www.aramesebeweging.nl & 3 & 1 \\
\hline www.oromoye.com & 3 & 1 \\
\hline www.syriacmusic.com & 3 & 24 \\
\hline Inne & 60 & 13 \\
\hline Odpowiedź „wiele” lub „nie pamiętam” & 31 & \\
\hline
\end{tabular}

Aramejczycy najchętniej odwiedzają ewidentnie aramejski portal www. suryoyena.org (ponad jedna czwarta) oraz portal poświęcony drużynie piłkarskiej www.syrianska.fc.com (około jednej czwartej respondentów), jak również www.suryoyozone.com (ponad jedna piąta). Czwarta pod względem popularności jest www.yauno.com; co ciekawe, czyta ją dokładnie taki sam odsetek respondentów aramejskich, jak i asyryjskich. Jedna dziesiąta badanych wchodzi na stronę Syryjskiego Kościoła Ortodoksyjnego w Szwecji www.soku.org. Tym samym w pierwszej piątce, obok portali informacyjnych, znajdują się dwa specjalistyczne - jeden poświęcony sportowi, drugi związany z konkretnym Kościołem, co wskazuje na istotność sportu i religii w konstruowaniu aramejskiej tożsamości.

Nawet z pobieżnego przeglądu wymienionych w tabelach adresów stron internetowych można wyciąnąć trzy wnioski. Po pierwsze, jest ich bardzo dużo - respondenci, zarówno asyryjscy, jak i aramejscy wymienili łącznie około 200 różnych portali. Po drugie, strony przeważnie redagowane są w językach zachodnich, dużo rzadziej we wschodnich (jak arabskojęzycz- 
na www.ankawa.com), często zawierają kilka wersji językowych. Po trzecie, z małymi wyjątkami ${ }^{35}$, Asyryjczycy i Aramejczycy nie odwiedzają tych samych stron - wchodzą raczej na „swoje” strony, tj. opatrzone odpowiednimi flagami lub logami. Oczywiście są też strony, które stosują podwójną lub potrójną (uwzględniającą jeszcze Chaldejczyków) nomenklaturę i programowo dążą do zjednoczenia, jednak nie należą one do najczęściej odwiedzanych. Oznacza to, że w Internecie następuje w większym stopniu konstrukcja dwóch odrębnych wspólnot - „Cyber-Asyrii” i „Cyber-Aramu” niż jednego asyryjsko-aramejskiego narodu.

\subsubsection{Książki}

Niemal trzy piąte Asyryjczyków zadeklarowało, że zna asyryjskie książki, o wiele więcej niż Aramejczyków, spośród których z aramejskimi książkami nie spotkała się ponad połowa.

Wykres 49

Czytelnictwo asyryjskich i aramejskich książek

\section{Czytelnictwo asyryjskich książek}

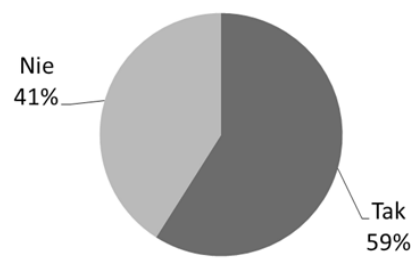

\section{Czytelnictwo aramejskich książek}

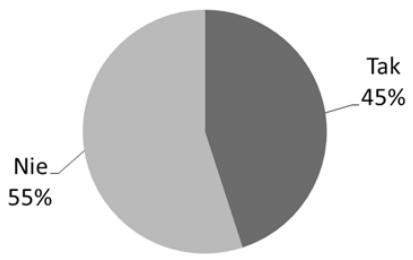

Choć wymienienie poprawnych tytułów lub konkretnych autorów nastręczyło badanym sporo trudności, to padło łącznie ponad 100 nazw. $\mathrm{Na}$ pierwszym miejscu uplasowała się powieść historyczna Rosie MalekYonan The Crimson Field („Szkarłatne pole”), którą wymieniła jedna piąta respondentów. Niemal jedna dziesiąta pytanych wskazała na również dotyczą historii Asyryjczyków książkę Freda Aprima Assyrians: The Continous Saga („Asyryjczycy. Niekończąca się saga”) i tego samego autora Assyrians: From Bedr Khan to Saddam Hussein („Asyryjczycy. Od Badra Chana do Saddama Husajna"). [Il. 10]

35 Oprócz www.yauno.com, powtórzyły się jeszcze www.hujada.com, www.ankawa.com, www. ajm-online.com. 
Książki asyryjskie

\begin{tabular}{|l|c|c|}
\hline \multicolumn{1}{|c|}{ Tytuł i/lub autor książki } & $\mathrm{N}$ & $\%$ \\
\hline The Crimson Field, Rosie Malek-Yonan & 57 & 20 \\
\hline Assyrians: The Continous Saga, Fred Aprim & 26 & 9 \\
\hline Assyrians: From Bedr Khan to Saddam Hussein, Fred Aprim & 17 & 6 \\
\hline En minoritets odyssé, Fuat Deniz & 11 & 4 \\
\hline Qateeni Gabara, William Daniel & 9 & 3 \\
\hline Mount Semele & 9 & 3 \\
\hline The Flickering Light of Asia & 7 & 2 \\
\hline The Church of the East, Christopher Baumer & 6 & 2 \\
\hline Remnants of Heroes & 6 & 2 \\
\hline Assyrian Tragedy, Shall this Nation Die? & 5 & 2 \\
\hline Lexicon. Assyrian-Swedish dictionary & 5 & 2 \\
\hline Music Pearls of Beth-Nahrin & 4 & 1 \\
\hline Look Beyond the Fire: Daily Struggles Under Saddam's Regime & 4 & 1 \\
\hline Seyfo & 4 & 1 \\
\hline Indigenous People Under the Rule of Islam, F. P. Isaac & 4 & 1 \\
\hline Vergessenes Blut, Numan Qarabashi & 3 & 1 \\
\hline The Assyrian Revelation, John Booko & 3 & 1 \\
\hline Mardutho d'Suryoye & 3 & 1 \\
\hline Darbo & 3 & 1 \\
\hline Not even my name & 3 & 1 \\
\hline Gilgamesz & 106 & 37 \\
\hline Inne & & \\
\hline
\end{tabular}

Żadna książka ani autor nie są znani przez więcej niż jedną dziesiątą respondentów aramejskich. Spośród 60 tytułów książek i/lub nazwisk autorów najwięcej osób wymieniło ogólnie św. Efrema, następnie książkę Sleymana Henno (Sulejmana Hinno) Die Verfolgung und Vernichtung der Syro-Aramäer im Tur Abdin 1915 („Prześladowanie i zagłada Syro-aramejczyków w Tur Abdinie w 1915”). Co dwunasty respondent wskazał na któreś z dzieł Bar Hebraeusa. Tylu samo na jedną z wersji językowych Ukrytej 
Perty („The Hidden Pearl”/„Den dolda pärlan”/„Die verborgene Perle”). Co trzynasty badany wymienił aramejskie książki kościelne i liturgiczne. [Il. 11]

Tabela 16

Książki aramejskie

\begin{tabular}{|l|c|c|}
\hline \multicolumn{1}{|c|}{ Tytuł i/lub autor książki } & $\mathrm{N}$ & $\%$ \\
\hline Mor Afram (św. Efrem) & 13 & 9 \\
\hline $\begin{array}{l}\text { Die Verfolgung und Vernichtung der Syro-Aramäer im Tur } \\
\text { Abdin 1915, Sleyman Henno }\end{array}$ & 12 & 9 \\
\hline Hewath Hehkmetha, Makhtbhanuth Zabhne, Bar Hebraeus & 11 & 8 \\
\hline $\begin{array}{l}\text { The Hidden Pearl: The Syrian Orthodox Church And Its Ancient } \\
\text { Aramaic Heritage/Den dolda pärlan/Die verborgene Perle }\end{array}$ & 11 & 8 \\
\hline Książki kościelne i liturgiczne & 10 & 7 \\
\hline $\begin{array}{l}\text { Berule Bdhire, The Scattered Pearls: History of Syriac Litera- } \\
\text { ture and Sciences/De spridda pärlorna, The Syrian Church of } \\
\text { Antioch, It's Name and History, Ignatius I Afram Barsoum }\end{array}$ & 10 & 7 \\
\hline Med döden som skugga/ With Death as Shadow, Besim Aydin & 6 & 4 \\
\hline Efrem Syriern hans liv och verk, Assad Sauma Assad & 5 & 4 \\
\hline Die dunkle Seite der Liebe, Rafik Schami & 5 & 4 \\
\hline Deutsch Aramäisch Wörterbuch, Sabo Hanna i Aziz Bulut & 5 & 4 \\
\hline Biblia & 4 & 3 \\
\hline Against the Armenians, Bar Salibi & 4 & 3 \\
\hline Chronicles of Michael the Syrian, Patriarcha Michał Wielki & 4 & 3 \\
\hline En minoritets odyssé, Fuat Deniz & 4 & 3 \\
\hline Shimo (modlitewnik) & 3 & 2 \\
\hline Ein vergessener HolocaustlForgotten Holocaust, Gabriele Yonan & 3 & 2 \\
\hline Välgörarna, Nuri Kino & 3 & 2 \\
\hline Inne & 62 & 45 \\
\hline Odpowiedź „wiele” lub „nie pamiętam” & 25 & 18 \\
\hline
\end{tabular}

Odpowiedzi na to pytanie pokazały, że istnieje duża różnica pomiędzy czytelnikami asyryjskimi oraz aramejskimi. Pierwsi generalnie czytają więcej literatury „narodowej” i lepiej pamiętają tytuły książek. Najbardziej poczytne dzieła asyryjskie powstały niedawno i dotyczą przeważnie najnowszej historii grupy. Natomiast Aramejczycy pamiętają raczej nazwiska autorów, 
przy czym często są to autorzy religijni - jak św. Efrem czy Bar Hebraeus; określenia „książki kościelne i liturgiczne” nie można uznać za precyzyjne. Podobnie, jak ma to miejsce w przypadku Asyryjczyków, Aramejczycy znają wybrane dzieła traktujące o historii, prześladowaniach - szczególnie podczas Sejfo. W obu grupach powtarza się jedynie socjologiczne studium Fuata Deniza En minoritets odyssé („Odyseja mniejszości”). Jest to kolejny dowód na odrębne kształtowanie tożsamości asyryjskiej i aramejskiej przez intelektualistów oraz duchowieństwo.

\subsubsection{Znani rodacy}

Trzy czwarte Asyryjczyków twierdzi, że zna sławnych rodaków, do znajomości wybitnych Aramejczyków przyznaje się nieznacznie ponad trzy piąte respondentów.

Wykres 50

Znajomość sławnych rodaków przez respondentów asyryjskich i aramejskich

\section{Znajomość sławnych Asyryjczyków}

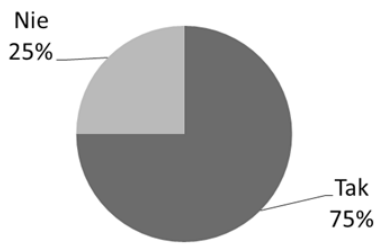

Znajomość sławnych Aramejczyków

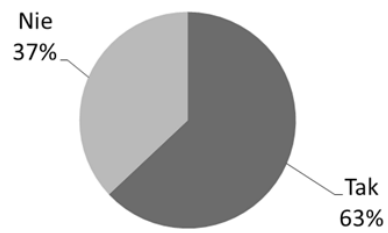

Najwięcej, bo jedna siódma badanych, za najsławniejszego Asyryjczyka uważa Andre Agassiego (fora asyryjskie pełne są sporów co do jego korzeni) ${ }^{36}$. Niewiele mniej badanych wskazało na Aghę Petrosa, przywódcę Asyryjczyków z czasów I wojny światowej, oraz Nauma Faika, żyjącego w latach 1868-1930 pioniera asyryjskiej myśli narodowej. Co ósmy badany wymienił Rosie Malek-Yonan, asyryjską aktorkę, reżyserkę, działaczkę społeczną i pisarkę. Jedna dziesiąta respondentów przywołała nazwisko Nuriego Kino, asyryjskiego dziennikarza i reżysera pracującego w Szwecji. Niemal tylu samo uznało za sławnych piosenkarzy i muzyków asyryjskich. [Il. 14]

${ }^{36}$ W rzeczywistości ojciec Andre, Emmanuel „Mike” Aghassian, był ormiańsko-asyryjskiego pochodzenia i pochodził z Iranu, który reprezentował jako bokser w czasie igrzysk olimpijskich w 1948 i 1952 roku, przed swoim przybyciem do USA. 
Tabela 17

Słynni Asyryjczycy

\begin{tabular}{|l|c|c|}
\hline \multicolumn{1}{|c|}{ Imię i/lub nazwisko stynnego Asyryjczyka } & $\mathrm{N}$ & $\%$ \\
\hline Andre Agassi & 53 & 14 \\
\hline Agha Petros & 48 & 13 \\
\hline Naum Faik & 48 & 13 \\
\hline Rosie Malek-Yonan & 43 & 12 \\
\hline Nuri Kino & 36 & 10 \\
\hline Yonadam Kanna & 27 & 7 \\
\hline Linda George & 21 & 6 \\
\hline Kennedy Bakircioglü & 19 & 5 \\
\hline Hanna Dolabani & 19 & 5 \\
\hline Juliana Jendo & 18 & 5 \\
\hline Ashur Bet Sargis & 18 & 5 \\
\hline Evin Agassi & 18 & 5 \\
\hline Mar Szimun Benjamin & 17 & 5 \\
\hline Sabri Atman & 16 & 4 \\
\hline Ashur Yousef & 16 & 4 \\
\hline Freydun Atturaya & 13 & 3 \\
\hline Mar Dinkha IV & 13 & 3 \\
\hline Habib Mousa & 10 & 3 \\
\hline Ninos Aho & 10 & 3 \\
\hline Sargon Gabriel & 10 & 3 \\
\hline Sarkis Aghajan & 10 & 3 \\
\hline Attiya Grami & 9 & 2 \\
\hline Anna G. Eshoo & 7 & 2 \\
\hline Janan Sawa & 7 & 2 \\
\hline Tarik Aziz & & 2 \\
\hline Gabriel Afram & 7 \\
\hline św. Efrem & 7 \\
\hline F. Murray Abraham & 7 \\
\hline
\end{tabular}


Tabela $17 \mathrm{~cd}$.

\begin{tabular}{|l|r|r|}
\hline \multicolumn{1}{|c|}{ Imię i/lub nazwisko słynnego Asyryjczyka } & $\mathrm{N}$ & $\%$ \\
\hline Ibrahim Baylan & 6 & 2 \\
\hline Vincent Oshana & 6 & 2 \\
\hline William Daniel & 6 & 2 \\
\hline Fuat Deniz & 5 & 1 \\
\hline Fred Aprim & 5 & 1 \\
\hline Ammo Baba & 5 & 1 \\
\hline John Nemrod & 5 & 1 \\
\hline Walter Aziz & 5 & 1 \\
\hline Inne & 242 & 66 \\
\hline Piosenkarze/muzycy & 35 & 9 \\
\hline Królowie & 21 & 6 \\
\hline Przywódcy partyjni & 8 & 2 \\
\hline Przywódcy kościelni & 6 & 2 \\
\hline Odpowiedź „wielu” lub „nie pamiętam” lub „ktoś z rodziny” & 33 & 9 \\
\hline
\end{tabular}

Największa liczba respondentów aramejskich, jedna siódma, za najsłynniejszego Aramejczyka uznała św. Efrema. Trochę mniej niż jedna dziesiąta Ibrahima Baylana, szwedzkiego polityka, członka Riksdagu, byłego ministra szkolnictwa, oraz Abgara Barsouma, szwedzkiego piłkarza. Dokładnie co dziesiąty respondent odpowiedział, że słynni są piosenkarze aramejscy. [Il. 13]

Tabela 18

Słynni Aramejczycy

\begin{tabular}{|l|c|c|}
\hline \multicolumn{1}{|c|}{ Imię i/lub nazwisko słynnego Aramejczyka } & $\mathrm{N}$ & $\%$ \\
\hline Mor Afram (św. Efrem) & 25 & 13 \\
\hline Ibrahim Baylan & 18 & 9 \\
\hline Abgar Barsoum & 15 & 8 \\
\hline Hasyo (Hana) Dolabani & 11 & 6 \\
\hline Kennedy Bakircioglü & 10 & 5 \\
\hline Bar Hebraeus & 10 & 5 \\
\hline Josef Özer & 10 & 5 \\
\hline
\end{tabular}


Tabela $18 \mathrm{~cd}$.

\begin{tabular}{|c|c|c|}
\hline Imię i/lub nazwisko słynnego Aramejczyka & $\mathrm{N}$ & $\%$ \\
\hline Naum Faik & 10 & 5 \\
\hline Josef Fares & 8 & 4 \\
\hline Sharbel Toma & 8 & 4 \\
\hline Ignatius Zakka I Iwas & 6 & 3 \\
\hline Lolo (Luay) Chanko & 6 & 3 \\
\hline Assad Sauma & 6 & 3 \\
\hline Fares Fares & 5 & 3 \\
\hline Juliana Jendo & 5 & 3 \\
\hline Ishok Jakub & 5 & 3 \\
\hline Jan Karat & 5 & 3 \\
\hline Suleyman Suleyman & 5 & 3 \\
\hline Ahikar (król Abgar) & 5 & 3 \\
\hline Mor Julius Isa Cicek & 5 & 3 \\
\hline Fadi Karat & 4 & 2 \\
\hline Thomas Demir & 4 & 2 \\
\hline Mor Michael Rabo (Michał Wielki) & 4 & 2 \\
\hline Aram/Abraham & 4 & 2 \\
\hline Habib Mousa & 4 & 2 \\
\hline Jacob Dinc & 4 & 2 \\
\hline Khalil Gibran (Chalil Dżubran) & 4 & 2 \\
\hline Christian Demirtas & 4 & 2 \\
\hline Yilmaz Kerimo & 3 & 1 \\
\hline Rafik Schami & 3 & 1 \\
\hline Pascal & 3 & 1 \\
\hline Johny Messo & 3 & 1 \\
\hline Adnan Mermertas & 3 & 1 \\
\hline Fairuz & 3 & 1 \\
\hline Jezus Chrystus & 3 & 1 \\
\hline Bar Salibi & 3 & 1 \\
\hline
\end{tabular}




\begin{tabular}{|l|r|r|}
\hline \multicolumn{1}{|c|}{ Imię i/lub nazwisko słynnego Aramejczyka } & $\mathrm{N}$ & $\%$ \\
\hline Daniel Boyacioglu & 3 & 1 \\
\hline Inne & 147 & 76 \\
\hline Piosenkarze/muzycy & 20 & 10 \\
\hline Piłkarze & 11 & 6 \\
\hline Święci/biskupi/ojcowie Kościoła & 9 & 5 \\
\hline Odpowiedź „wielu” lub „nie pamiętam” & 12 & 6 \\
\hline
\end{tabular}

Odpowiedzi na to pytanie obnażyły poważny problem, który istnieje w obu podgrupach, choć w większym stopniu w podgrupie aramejskiej. Otóż zarówno Asyryjczykom, jak i Aramejczykom brakuje słynnych, znanych poza ich grupą reprezentantów, brakuje też powszechnie uznanych autorytetów. Andre Agassi wskazany na pierwszym miejscu przez Asyryjczyków jest Asyryjczykiem tylko w jednej czwartej, zresztą nie przyznaje się wcale do swojej „asyryjskości”. Z kolei św. Efrem - o przydomku Syryjczyk - kaznodzieja, diakon i poeta z IV wieku, jest znany przede wszystkim wiernym Kościołów orientalnych (mimo że jest doktorem Kościoła rzymskokatolickiego, mało kto słyszał o nim np. w Europie). Co więcej, ani tenisista, ani komentator Pisma Świętego z pewnością nie mogą stanowić wzorów do naśladowania dla całej wspólnoty.

Wybrani przez Asyryjczyków na drugim i trzecim miejscu Agha Petros oraz Naum Faik mają więcej wspólnego z konstruowaniem narodu w klasyczny sposób (jako wódz militarny oraz ideolog) niż wytypowani przez Aramejczyków polityk Ibrahim Baylan i piłkarz Abgar Barsoum - obaj żyjący i obaj związani ze Szwecją. Te nazwiska pokazują, że budowa asyryjskiej świadomości narodowej ma mocniejsze punkty zaczepienia w postaci zmitologizowanych już nieco figur z przeszłości niż budowa analogicznej świadomości u Aramejczyków, która rozpięta jest między pierwszymi wiekami naszej ery a czasem teraźniejszym.

Do refleksji skłania również fakt, że bardzo wiele nazwisk pojawiło się tylko raz, niektórzy respondenci wskazywali na siebie bądź członków swoich rodzin i znajomych. $Z$ jednej strony pokazuje to względność terminu „sławny”, z drugiej przekonanie o własnej wyjątkowości w ramach wspólnoty. 


\subsubsection{Tradycja i historia}

\subsubsection{Znaczenie tradycji}

Jeden $\mathrm{z}$ respondentów napisał, że pytanie o to, czym jest tradycja, mija się z celem, gdyż definicję łatwo można znaleźć w słowniku. Mnie jednak nie chodziło o poprawną definicję tradycji, a o wolne asocjacje respondentów, o zobaczenie, które jej elementy są dla nich najważniejsze - przychodzą do głowy jako pierwsze. Dzięki temu mogłam sprawdzić, czy w pytaniach szczegółowych ankiety nie przeoczyłam jakiegoś ważnego elementu.

Wśród badanych asyryjskich niemal jedna piąta dostrzegła aspekt ciągłości, tego, że tradycja jest czymś przekazywanym z pokolenia na pokolenie. Prawie tylu samo podkreśliło znaczenie zwyczajów i obyczajów, następnie kultury i języka. Co siódmy respondent odwołał się do przodków. Dla takiej samej liczby ważna jest kuchnia (niektórzy podawali przykłady konkretnych potraw, np. zupy cebulowej gotowanej na Boże Narodzenie w Tur Abdinie ${ }^{37}$, inni mieli na myśli po prostu kuchnię regionalną, o czym świadczy wspominanie dolmy - rodzaju gołąbków z liści winogron, popularnych we wszystkich byłych krajach imperium osmańskiego, Iranie i południowo-centralnej Azji). Kolejne elementy - uszeregowane malejąco pod względem liczby wzmianek to: rodzina, muzyka i pieśni, tańce, Kościół, śluby i wesela, Asyryjski Nowy Rok, historia. Na pozostałe elementy wskazała mniej niż jedna dwudziesta badanych.

Tabela 19

Tradycja asyryjska

\begin{tabular}{|l|c|c|}
\hline \multicolumn{1}{|c|}{ Czym jest tradycja (asyryjska)? } & N & $\%$ \\
\hline Coś przekazywanego z pokolenia na pokolenie & 91 & 19 \\
\hline Zwyczaj/obyczaj & 89 & 18 \\
\hline Kultura & 81 & 17 \\
\hline Język & 77 & 16 \\
\hline Przodkowie/dziadkowie/ojcowie & 66 & 13 \\
\hline Kuchnia & 65 & 13 \\
\hline Rodzina & 41 & 8 \\
\hline
\end{tabular}

${ }^{37}$ Wywiad z dwoma przedstawicielami Assyrian Democratic Movement, Szwecja, 29.06.2007. 
Tabela $19 \mathrm{~cd}$.

\begin{tabular}{|l|c|c|}
\hline \multicolumn{1}{|c|}{ Czym jest tradycja (asyryjska)? } & $\mathrm{N}$ & $\%$ \\
\hline Muzyka/pieśni & 37 & 8 \\
\hline Tańce & 32 & 7 \\
\hline Kościół & 32 & 7 \\
\hline Śluby/wesela & 25 & 5 \\
\hline Asyryjski Nowy Rok & 25 & 5 \\
\hline Historia & 24 & 5 \\
\hline Rytuały/ceremonie & 22 & 4 \\
\hline Święta & 21 & 4 \\
\hline Religia & 20 & 4 \\
\hline Dziedzictwo/korzenie & 20 & 4 \\
\hline Boże Narodzenie & 15 & 3 \\
\hline Wielkanoc & 14 & 3 \\
\hline Styl życia & 13 & 3 \\
\hline Wiara & 12 & 2 \\
\hline Chrześcijaństwo & 10 & 2 \\
\hline Ubiór & 5 & 1 \\
\hline Msze & 50 & 6 \\
\hline Post (Niniwy) & 5 & 1 \\
\hline Inne & 72 & 4 \\
\hline
\end{tabular}

U Aramejczyków pojawily się te same elementy, choć w nieco innej kolejności. Co szósty respondent wskazał na znaczenie przodków oraz kultury, co siódmy języka oraz Boga, modlitwy i religii, a więc duchowości, zaraz potem Kościoła (kategorię tę traktuję odrębnie od duchowości niezorganizowanej). Więcej niż jedna dziesiąta badanych zauważyła aspekt ciągłości pomiędzy pokoleniami, dla dokładnie jednej dziesiątej tradycja wiązała się z rodziną oraz zwyczajami i obyczajami. Ponad jedna piąta respondentów wymieniła ponadto: kuchnię, Boże Narodzenie, styl życia, dziedzictwo i korzenie, historię, muzykę i pieśni, Wielkanoc. 
Tabela 20

Tradycja aramejska

\begin{tabular}{|l|c|c|}
\hline \multicolumn{1}{|c|}{ Czym jest tradycja (aramejska)? } & $\mathrm{N}$ & $\%$ \\
\hline Przodkowie/dziadkowie/ojcowie & 49 & 16 \\
\hline Kultura & 49 & 16 \\
\hline Język & 40 & 13 \\
\hline Religia/Bóg/modlitwa & 39 & 13 \\
\hline Kościół & 38 & 12 \\
\hline Coś przekazywanego z pokolenia na pokolenie & 35 & 11 \\
\hline Rodzina & 32 & 10 \\
\hline Zwyczaj/obyczaj & 30 & 10 \\
\hline Kuchnia & 26 & 8 \\
\hline Boże Narodzenie & 21 & 7 \\
\hline Styl życia & 21 & 7 \\
\hline Dziedzictwo/korzenie & 19 & 6 \\
\hline Historia & 19 & 6 \\
\hline Muzyka/pieśni & 18 & 6 \\
\hline Wielkanoc & 17 & 6 \\
\hline Coś, co jednoczy & 15 & 5 \\
\hline Taniec & 13 & 4 \\
\hline Śluby/wesela & 12 & 4 \\
\hline Święta & 11 & 4 \\
\hline Rytuały/ceremonie & 10 & 3 \\
\hline Regularne spotkania/kontakt & 10 & 3 \\
\hline Wartości moralne & 8 & 3 \\
\hline Chrześcijaństwo & 7 & 2 \\
\hline Coś, co odróżnia od innych wspólnot & 6 & 2 \\
\hline Posty & 4 & 2 \\
\hline Szacunek dla starszych, rodziców & 4 & 2 \\
\hline Uczęszczanie na przyjęcia aramejskie & 4 & 1 \\
\hline Mentalność & 4 \\
\hline Duma & 7 \\
\hline Wiara & 7 \\
\hline
\end{tabular}


Tabela $20 \mathrm{~cd}$.

\begin{tabular}{|l|r|c|}
\hline \multicolumn{1}{|c|}{ Czym jest tradycja (aramejska)? } & $\mathrm{N}$ & $\%$ \\
\hline Chrzest & 3 & 1 \\
\hline Folklor & 3 & 1 \\
\hline Inne & 17 & 6 \\
\hline Odpowiedź „wszystko”, „nie wiem”, „tradycja”, „naród” & 52 & 17 \\
\hline
\end{tabular}

$\mathrm{Z}$ powyższego porównania wyłania się obraz dość podobnego postrzegania tradycji przez obie grupy, z akcentem na język, kulturę, obyczaje, święta, lecz także kuchnię i muzykę. Warto skupić się na drobnych różnicach - w grupie aramejskiej w warstwie deklaratywnej pojawia się większe dowartościowanie duchowości, religijności. Respondenci asyryjscy wymieniają Asyryjski Nowy Rok, którego Aramejczycy z zasady nie świętują (to przypomnienie pogańskiego święta, element tradycji przedchrześcijańskiej). Delikatnie zarysowuje się więc opozycja - odwołania do dawnych, pogańskich korzeni v. ich odrzucenie. [Il. 14]

Istnieje jednak grupa Asyryjczyków/Aramejczyków, którzy zapytani o specyficznie asyryjskie/aramejskie tradycje, różniące ich od bliskowschodnich sąsiadów, nie potrafili odpowiedzieć czy podać przykładów, do czego otwarcie się przyznawali ${ }^{38}$. Szczególnie prości Asyryjczycy/Aramejczycy, pytani w wywiadach o takie rzeczy, odsyłali do swojego „abuny”, tj. księdza.

\subsubsection{Istotność tradycji}

Dla obu grup tradycja jest ważna, przy czym o 10 punktów procentowych więcej Aramejczyków niż Asyryjczyków twierdzi, że jest bardzo ważna. Nieznaczny ułamek sądzi, że jest w ogóle nieważna.

Wykres 51

Istotność tradycji asyryjskiej i aramejskiej

Istotność tradycji asyryjskiej

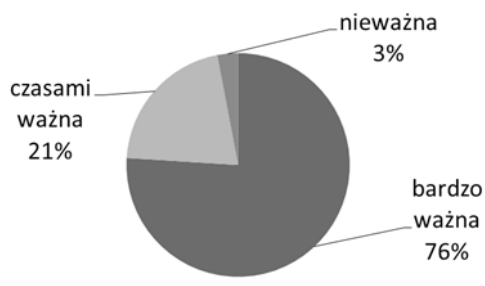

Istotność tradycji aramejskiej

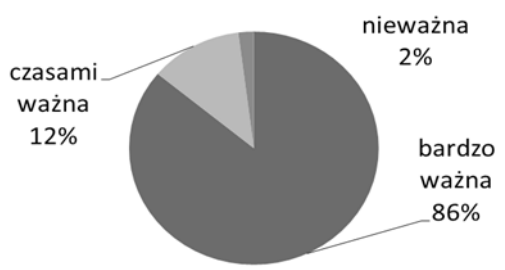

${ }^{38} \mathrm{Na}$ przykład wywiad z Asyryjką z Syrii, żoną wolontariusza w „Suroyo TV”, Szwecja, 29.06.2007. 


\subsubsection{Elementy tradycji}

Spośród pięciu zasugerowanych elementów tradycji dla Asyryjczyków najważniejsze były mity i legendy, następnie muzyka ${ }^{39} \mathrm{i}$ taniec, potem przysłowia i mądrości ludowe, wreszcie kuchnia, zaś na końcu strój ludowy. Dla Aramejczyków również mity i legendy stanowiły najważniejszy element, jednak na miejscu drugim znalazły się przysłowia i mądrości ludowe, zaraz za nimi kuchnia, dopiero później muzyka i taniec, a na ostatnim miejscu strój ludowy.

Obie grupy wytypowały więc identycznie najważniejszy i najmniej ważny element (pozycja tego ostatniego nie dziwi w świetle niezwykle skąpych danych co do jego wyglądu ${ }^{40}$ ). Interesujący jest wysoki status kuchni u Aramejczyków, którzy cenią ją bardziej niż przysłowia i mądrości ludowe. Prawdopodobnie ma to związek z gorszą znajomością języka aramejskiego, a tym samym brakiem możliwości zapoznania się z istniejącymi w nim powiedzeniami. Kuchnia natomiast jest egalitarna, jednoczy lepiej i gorzej wykształconych - przyrządzanie tradycyjnych dań, szczególnie na obczyźnie, jest swego rodzaju dowodem na ciągłość grupy. Z drugiej strony potrawy uważane za typowo „asyryjskie” czy „aramejskie” częstokroć są po prostu typowe dla kuchni bliskowschodniej.

Wykres 52

Asyryjskie i aramejskie muzyka i taniec
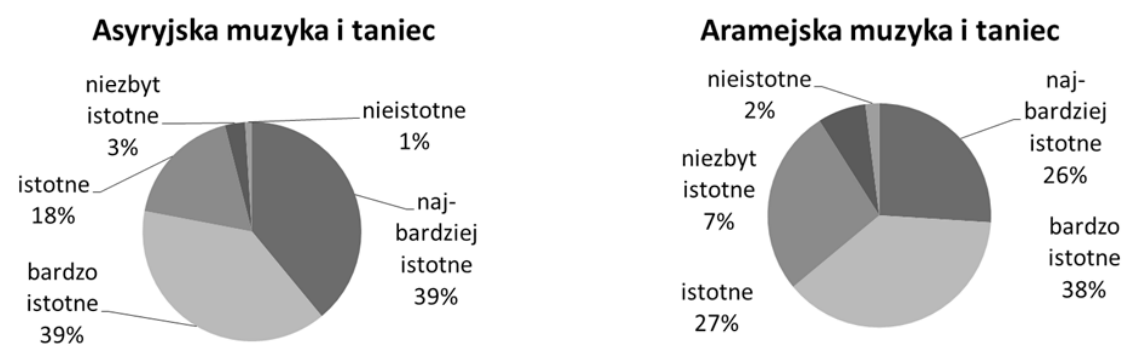

${ }^{39} \mathrm{~W}$ Turcji śpiewanie po aramejsku na przyjęciach było zabronione. Dopiero w diasporze nastąpił rozkwit asyryjskiej/aramejskiej muzyki. Wywiad z Asyryjczykiem z Syrii, wolontariuszem w „Suroyo TV”, Szwecja, 30.06.2007.

${ }^{40}$ Co najwyraźniej nie przeszkadza Asyryjczykom przywdziewającym różne „stroje ludowe" podczas podniosłych celebracji, przede wszystkim Asyryjskiego Nowego Roku. Nie znalazłam natomiast żadnych zdjęć przedstawiających Aramejczyków ubranych w „stroje ludowe”. Pokazuje to większe zaangażowanie artystów asyryjskich w tworzenie folkloru, który także stanowi element tożsamości. 
Wykres 53

Asyryjski i aramejski strój ludowy

Asyryjski strój ludowy

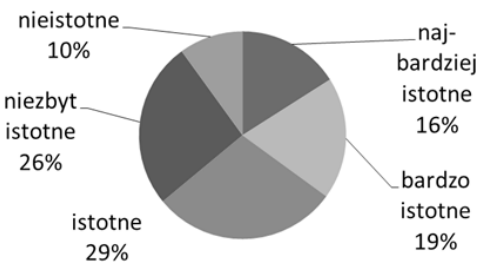

Aramejski strój ludowy

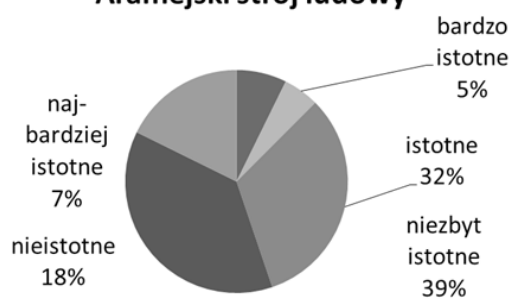

Wykres 54

Asyryjska i aramejska kuchnia
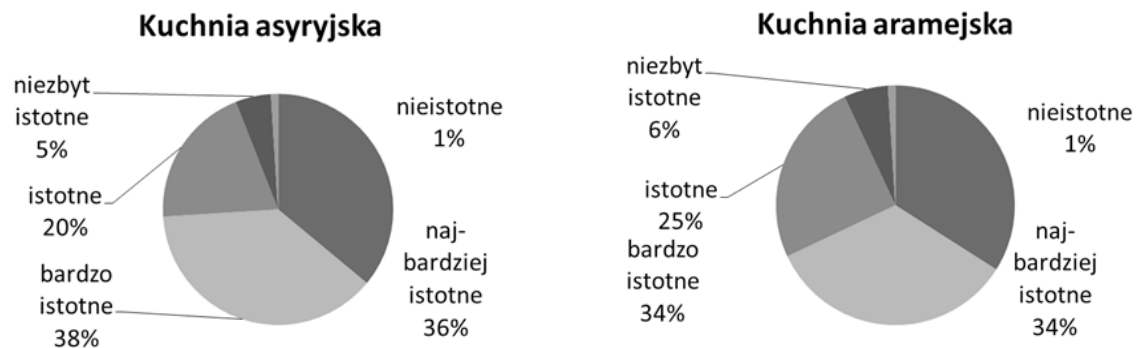

Wykres 55

Asyryjskie i aramejskie przysłowia i mądrości ludowe
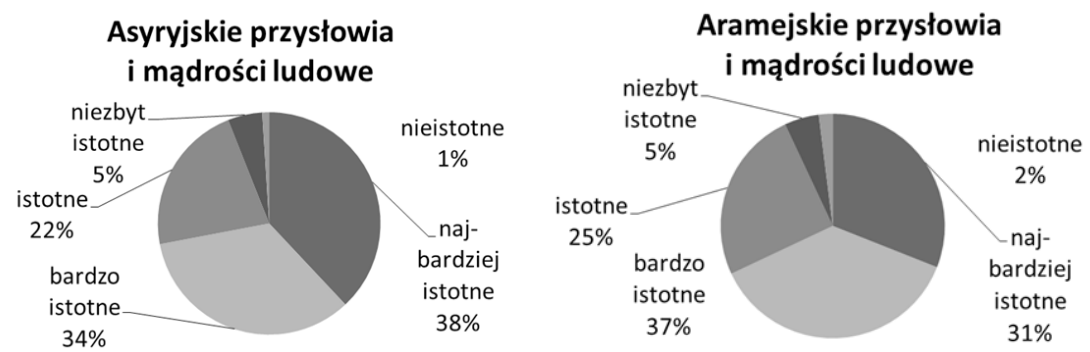
Wykres 56

Asyryjskie i aramejskie mity i legendy

Asyryjskie mity i legendy

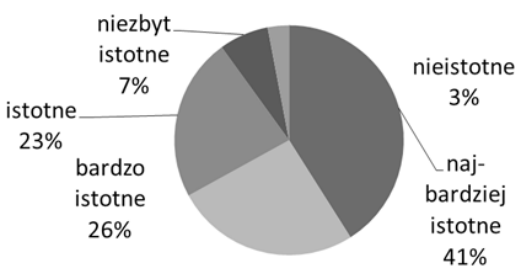

\section{Aramejskie mity i legendy}

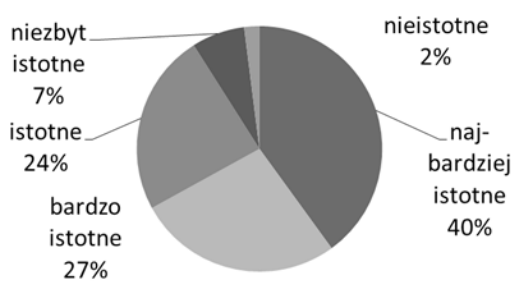

\subsubsection{Przestrzeganie tradycji}

Znakomita większość respondentów deklaruje, że przestrzega tradycji w swojej rodzinie - dziewięć dziesiątych Asyryjczyków i o pięć punktów procentowych więcej Aramejczyków.

Przestrzeganie tradycji w rodzinach asyryjskich i aramejskich
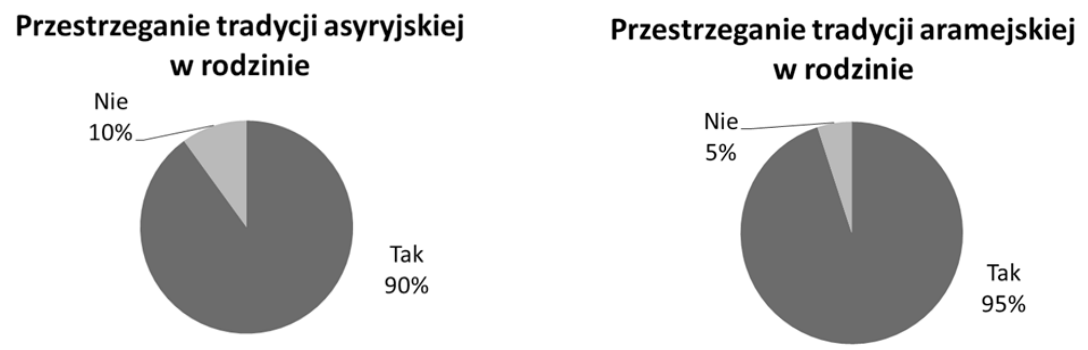

Ankietowani deklarowali, że pielęgnują tradycję przodków, z wywiadów wyłaniał się jednak obraz zapominania bądź zaniechiwania przynajmniej niektórych zwyczajów, np. chrześcijanie z Tur Abdinu po pięćdziesięciu dniach ścisłego Wielkiego Postu przez pierwsze trzy dni świąt Wielkanocy nie jedli produktów mięsnych, spożywali wyłącznie jajka oraz mleko i jogurt. W diasporze szwedzkiej tego nie przestrzegają, jedzą jajka, a oprócz tego szynkę, co jest elementem lokalnej tradycji skandynawskiej ${ }^{41}$. Zmiany następują jednak stopniowo i większość respondentów nie zdaje sobie sprawy, które z tradycji ich przodków zostały zaniechane.

${ }^{41}$ Wywiad z dwoma przedstawicielami Assyrian Democratic Movement, Szwecja, 29.06.2007. 


\subsubsection{Sposoby pielęgnowania tradycji}

Choć Aramejczycy zdawali się bardziej doceniać bliskowschodnią kuchnię, w pytaniu o sposoby pielęgnowania tradycji to więcej Asyryjczyków - prawie jedna trzecia - przyznała się do przyrządzania asyryjskich dań. Jedna piąta zaznaczyła, że bierze udział w asyryjskich świętach i festiwalach. Niewiele mniej pielęgnuje tradycję przez muzykę i taniec, następnie przez używanie języka aramejskiego, uczęszczanie do kościoła, tańce, świętowanie Asyryjskiego Nowego Roku, uczestnictwo w ślubach i weselach itp.

Tabela 21

Sposoby pielęgnowania tradycji asyryjskiej

\begin{tabular}{|l|c|c|}
\hline \multicolumn{1}{|c|}{ Sposoby pielęgnowania tradycji asyryjskiej } & N & $\%$ \\
\hline Kuchnia & 129 & 29 \\
\hline Święta/festiwale & 93 & 21 \\
\hline Muzyka/pieśni & 78 & 18 \\
\hline Posługiwanie się językiem aramejskim & 71 & 16 \\
\hline Religia/Kościół & 65 & 15 \\
\hline Tańce & 65 & 15 \\
\hline Świętowanie Asyryjskiego Nowego Roku/Ha Nissan & 61 & 14 \\
\hline Śluby/wesela & 48 & 11 \\
\hline Wielkanoc & 35 & 8 \\
\hline Boże Narodzenie & 33 & 7 \\
\hline Przyjęcia/spotkania & 30 & 7 \\
\hline Posty & 26 & 6 \\
\hline Przysłowia, powiedzenia & 15 & 3 \\
\hline Pogrzeby & 8 & 2 \\
\hline Legendy & 7 & 2 \\
\hline Ubiór & 5 & 1 \\
\hline Modlitwa & 5 & 1 \\
\hline Inne & 15 & 3 \\
\hline
\end{tabular}

Dla Aramejczyków najistotniejszym sposobem pielęgnowania tradycji jest uczestnictwo we mszy świętej, następnie posługiwanie się językiem ara- 
mejskim. Kuchnia aramejska tym razem została wspomniana przez nieco mniej niż jedną dziesiątą respondentów.

Tabela 22

Sposoby pielęgnowania tradycji aramejskiej

\begin{tabular}{|l|c|c|}
\hline \multicolumn{1}{|c|}{ Sposoby pielęgnowania tradycji aramejskiej } & $\mathrm{N}$ & $\%$ \\
\hline Religia/Kościół & 49 & 17 \\
\hline Język & 32 & 11 \\
\hline Kuchnia & 26 & 9 \\
\hline Święta & 16 & 6 \\
\hline Przyjęcia/spotkania & 11 & 4 \\
\hline Wielkanoc & 10 & 3 \\
\hline Boże Narodzenie & 10 & 3 \\
\hline Śluby/wesela & 10 & 3 \\
\hline Muzyka/pieśni & 10 & 3 \\
\hline Taniec & 7 & 2 \\
\hline Historia (uczenie jej/uczenie się) & 7 & 2 \\
\hline Posty & 6 & 2 \\
\hline Chrzty & 5 & 2 \\
\hline Pogrzeby & 4 & 1 \\
\hline Mity i legendy & 3 & 1 \\
\hline Modlitwy & 3 & 1 \\
\hline Kultura & 3 & 1 \\
\hline Inne & 24 & 8 \\
\hline Odpowiedź „wszystko” lub „nie wiem” & 29 & 10 \\
\hline
\end{tabular}

Odpowiedzi na pytanie o sposoby zachowania tradycji wskazują na realizowanie tego celu w szerszym zakresie przez Asyryjczyków. Aramejczycy ciągle opierają się na Kościele jako instytucji będącej bastionem ich tożsamości. Choć wymieniają praktycznie te same, alternatywne w stosunku do religii, sposoby pielęgnowania tradycji co Asyryjczycy, to o wiele rzadziej przywołują konkretne działania. 


\subsubsection{Znajomość historii rodzinnej}

Zaledwie kilka procent respondentów asyryjskich i aramejskich przyznaje się do nieznajomości historii swojej rodziny. Jest to ważna wskazówka, gdyż pokazuje, że istnieje ciagłość między pokoleniami, młodzi wiedzą, skąd pochodzili ich przodkowie, dlaczego opuścili rodzinne ziemie. Często ich zainteresowanie podsycane jest dodatkowo przez lubiących dociekania genealogiczne amerykańskich lub europejskich przyjaciół $1^{42}$.

Warto przy tym zaznaczyć, że w większości historie te są niezwykle podobne i zawierają silny komponent martyrologiczny - trudno znaleźć Asyryjczyka czy Aramejczyka, który nie straciłby w czasie I wojny światowej choć jednego członka rodziny. Historie indywidualne przekuwane są w historię zbiorową, ujednoliconą, „pamiętaną” przez wszystkich.

Wykres 58

Znajomość asyryjskiej i aramejskiej historii rodzinnej
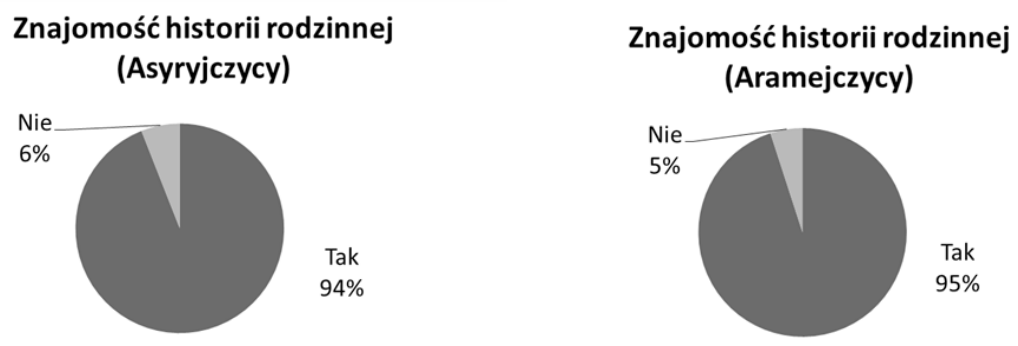

\subsubsection{Spotkania rodzinne i święta}

Asyryjczycy i Aramejczycy są bardzo familijni, tradycyjnie kolektywistyczni, choć zmienia się to w diasporze - więzi łączące wspólnotę, która nie musi walczyć o przetrwanie, gdyż egzystuje w relatywnym dobrobycie, powoli ulegają osłabieniu na rzecz coraz większego indywidualizmu. Niemniej jednak rodziny w szerokim sensie, obejmującym dalekich kuzynów i wujów, ciągle stanowią najważniejsze punkty odniesienia dla swoich członków. Rodzinne interesy, rodzinne rozwiązywanie problemów, pomoc ekonomiczna, osiedlanie się w pobliżu - wszystko to konsekwencje tradycyjnej struktury rodziny asyryjskiej/aramejskiej.

${ }^{42}$ Wywiad z dwoma przedstawicielami Assyrian Democratic Movement, Szwecja, 29.06.2007. 


\subsubsection{Okazje do spotkań rodzinnych}

Najpopularniejszą okazją do spotkań Asyryjczyków są śluby i towarzyszące im wesela, na które zapraszanych jest zwykle kilkaset spokrewnionych i spowinowaconych ze sobą osób, nieraz przyjeżdżających z bardzo daleka. Następnie dziewięć dziesiątych respondentów deklaruje uczestnictwo w pogrzebach. Święta kościelne i urodziny są obchodzone przez ponad trzy czwarte badanych. Asyryjski Nowy Rok celebruje ponad połowa pytanych.

Wykres 59

\section{Okazje do spotkań (Asyryjczycy)}

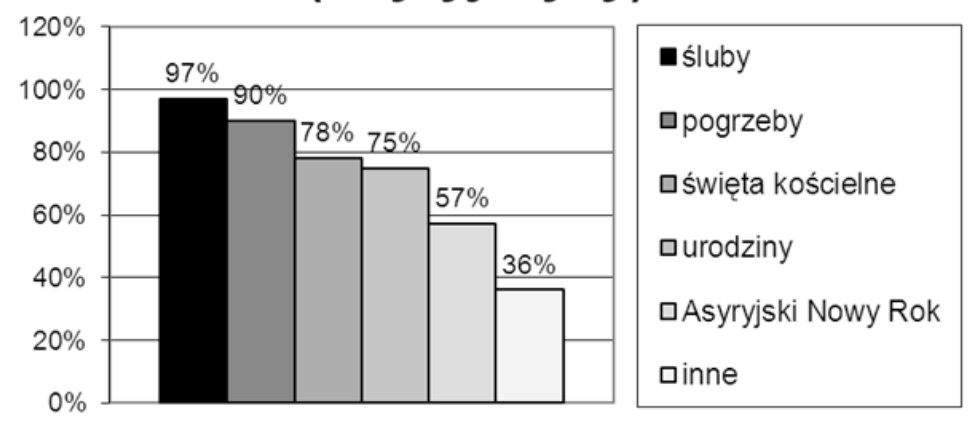

Niemal identyczne odpowiedzi padły ze strony respondentów aramejskich, z tym, że udział w świętach kościelnych zadeklarowała większa o 10 punktów procentowych liczba osób, tym samym pogrzeby przesunęly się z drugiego na trzecie miejsce. Dwie piąte badanych stwierdziło, że bierze udział w Surjojo (Syryjskim) Nowym Roku. Ta odpowiedź jest jednak ambiwalentna, ponieważ nie istnieje Syryjski Nowy Rok, a jedynie Asyryjski Nowy Rok (Ha Nissan); nie mogłam go jednak tak nazwać w ankiecie skierowanej do Aramejczyków. Zakładając, iż pytani zrozumieli, że chodzi o uroczystości obchodzone 1 kwietnia, ich udział w celebracjach wskazywałby na mieszaną, aramejsko-asyryjską tożsamość. Należy jednak wziąć także pod uwagę możliwość, że przynajmniej część badanych przez Surjojo Nowy Rok zrozumiała błędnie „Sylwestra”, świętowanie nowego roku kalendarzowego. 
Wykres 60

\subsubsection{2}

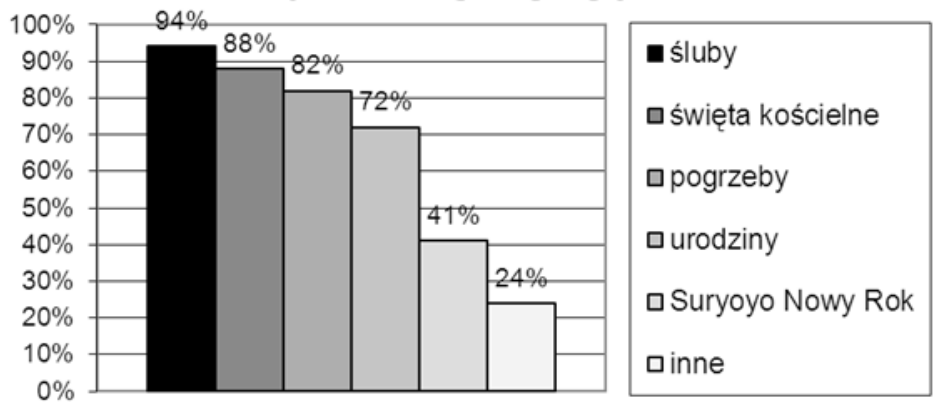

Święta są ważne dla ponad czterech piątych respondentów - zarówno asyryjskich, jak i aramejskich $-\mathrm{z}$ niewielką (3 punkty procentowe) przewagą tych ostatnich.

Wykres 61

Istotność świąt dla respondentów asyryjskich i aramejskich

Istotność świąt (Asyryjczycy)

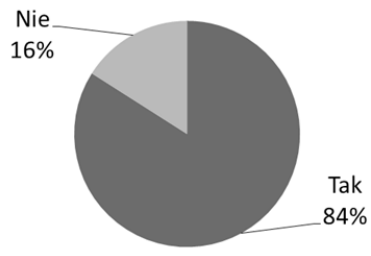

\section{Istotność świąt (Aramejczycy)}

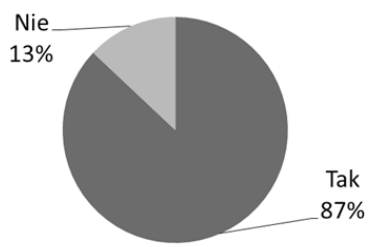

Dla niemal połowy Asyryjczyków święta są okazją do odwiedzenia rodziny i znajomych. Prawie jedna trzecia dostrzega w nich szansę na utożsamienie się ze swoją grupą narodową. W tym miejscu konieczna jest uwaga, że najprawdopodobniej, gdyby pytanie było otwarte, taka odpowiedź nie padłaby wcale lub bardzo niewiele razy - trudno przypuszczać bowiem, by przy świątecznym stole co trzeci Asyryjczyk myślał przede wszystkim o wspólnocie narodowej, a nie o własnej rodzinie czy znajomych. Jednak 
to, że spośród zasugerowanych odpowiedzi tak duża liczba badanych wybrała właśnie tę opcję, świadczy o procesie nadawania sensu a posteriori, o chęci, by tak było. Jedna dziesiąta pytanych nie ukrywa, że nigdy nie zastanawiała się nad znaczeniem świąt, dla co trzynastego to po prostu dzień wolny od szkoły lub pracy, dla kilku procent czas zadumy i refleksji.

Wykres 62

\section{Znaczenie świąt (Asyryjczycy)}

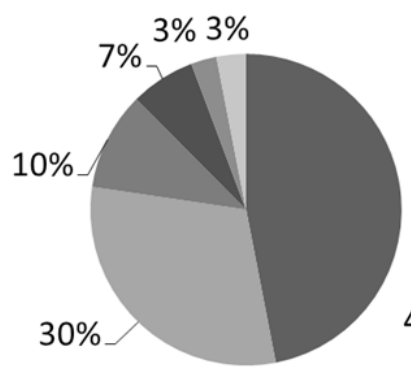

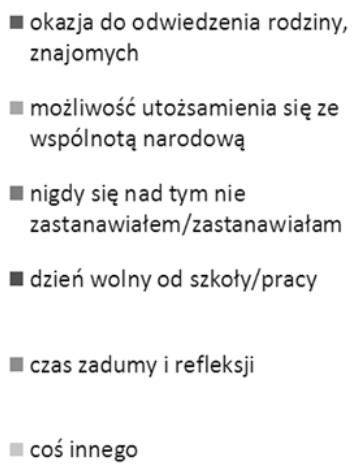

- okazja do odwiedzenia rodziny,

możliwość utożsamienia się ze pólnotą narodową

W przypadku Aramejczyków święta również stanowią przede wszystkim okazję do odwiedzenia rodziny i znajomych, potem zaś do utożsamienia się ze wspólnotą narodową. Ponad jedna dziesiąta nigdy nie myślała o znaczeniu świąt. Tylko $2 \%$ traktuje je jako dni wolne od pracy czy szkoły.

Wykres 63
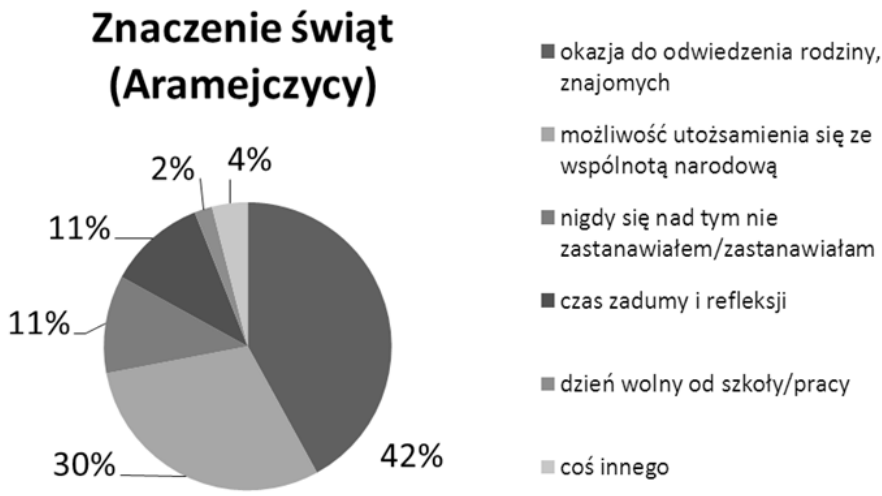
Jedyną różnicą w przypadku odpowiedzi na to pytanie jest nieco większy odsetek Aramejczyków, dla których święta to czas zadumy i refleksji, w porównaniu z Asyryjczykami, spośród których więcej uważa święta za dni wolne od pracy i szkoły. Ta niewielka różnica może wynikać z innego stosunku do świąt w Europie oraz w Stanach Zjednoczonych - refleksyjnego na Starym Kontynencie, świeckiego/rozrywkowego na Nowym.

\subsubsection{Religijność}

\subsubsection{Przynależność religijna}

Niezwykle istotnym pytaniem jest to o przynależność religijną, gdyż bycie Asyryjczykiem lub Aramejczykiem najczęściej oznacza uczęszczanie do konkretnego kościoła orientalnego.

Jedna trzecia badanych Asyryjczyków należy do Asyryjskiego Kościoła Wschodu, dokładnie tyle samo do Syryjskiego Kościoła Ortodoksyjnego. Co ósmy respondent jest wyznawcą Chaldejskiego Kościoła Katolickiego, co trzynasty któregoś z Kościołów protestanckich. Niewielka liczba pytanych wskazała na Starożytny Kościół Wschodu, Kościół rzymskokatolicki oraz Syryjski Kościół Katolicki.

Wykres 64

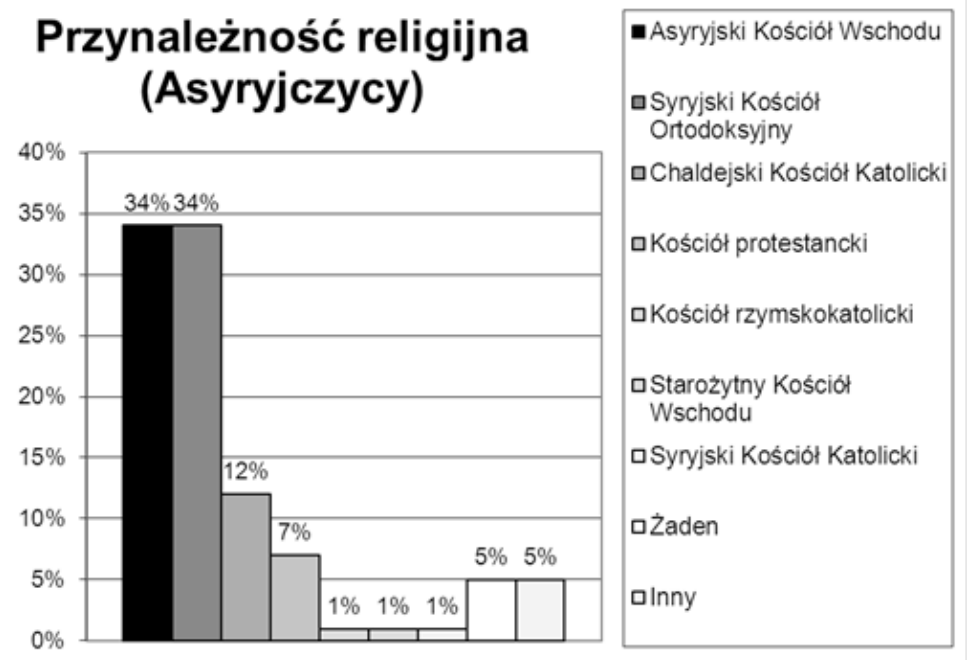


Zupełnie inaczej kształtuje się przynależność religijna w przypadku Aramejczyków - 90\% stanowią tu członkowie Syryjskiego Kościoła Ortodoksyjnego. Żaden z pozostałych Kościołów - chaldejski, maronicki, protestancki - nie gromadzi nawet jednej trzydziestej wspólnoty.

Wykres 65

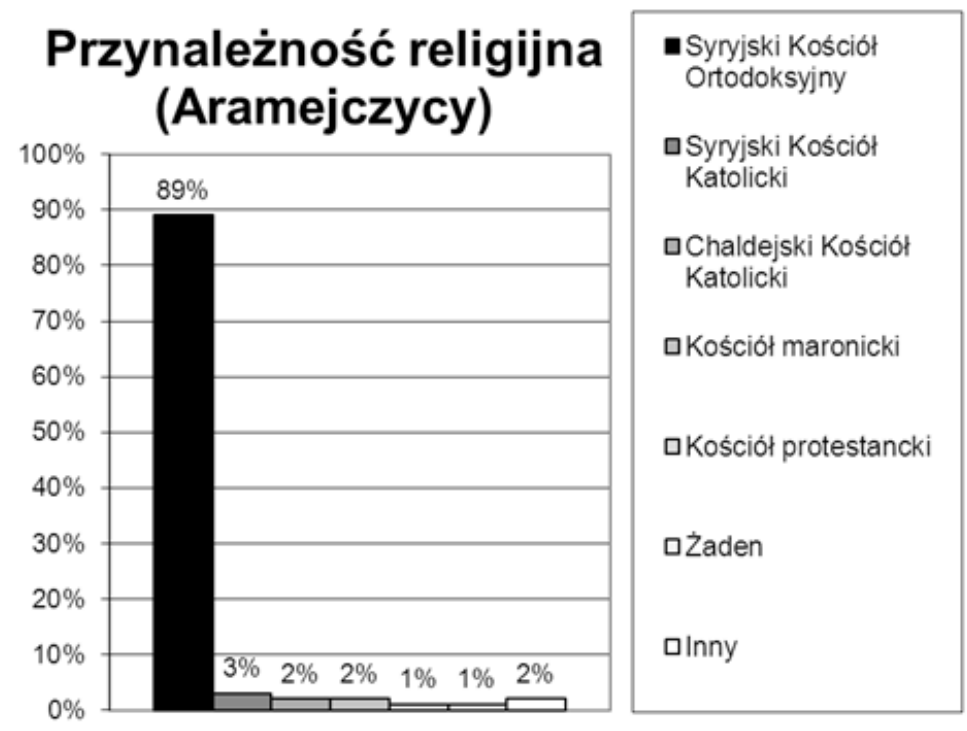

$\mathrm{Na}$ podstawie tego porównania wyraźnie widać, że wierny Asyryjskiego Kościoła Wschodu prawie na pewno będzie identyfikował się jako Asyryjczyk, natomiast członek Syryjskiego Kościoła Ortodoksyjnego może być równie dobrze Asyryjczykiem, jak i Aramejczykiem. Chaldejczycy przeważnie utożsamiają się z Asyryjczykami, zaś Maronici niemal wyłącznie z Aramejczykami (o ile nie uważają się za libańskich czy też arabskich chrześcijan). Wśród jednej i drugiej grupy zdarzają się protestanci oraz syryjscy katolicy.

Żaden z badanych nie zadeklarował się jako muzułmanin, choć tacy istnieją - Asyryjczycy żyli na ziemiach, które jako pierwsze uległy podbojowi muzułmańskiemu. Podobieństwo języka, religii i zwyczajów, połączone z nawracaniem mieczem, sprawiły, że wielu z nich przeszło na islam, zachowując pewną odrębność na płaszczyźnie kultury materialnej i niematerialnej. Mimo tego nie są uznawani za „prawdziwych” Asyryjczyków przez wielu swoich chrześcijańskich współbraci. 
Żyjący w Szwecji, choć pochodzący z Turcji, Asyryjczyk Özmen Denho, wychodząc z założenia, że religia nie decyduje o przynależności do danego narodu, zaś chrześcijanie nie mają przyszłości na Bliskim Wschodzie, próbował założyć stowarzyszenie Asyryjczyków-muzułmanów. Przedsięwzięcie to nie powiodło się w Stambule - potencjalnie zainteresowani za bardzo bali się nagłośnienia sprawy - za to udało się w Midjacie w Turcji, gdzie jest około sześćdziesięciu działaczy asyryjsko-muzułmańskich, z którymi sympatyzują wykształceni Asyryjczycy-chrześcijanie. Jednak prości ludzie nie ufają ani konwertytom, ani potomkom konwertytów. Sam Özmen padł zresztą ofiarą pewnego ostracyzmu społecznego - jego dawni znajomi, tureccy profesorowie uniwersyteccy, zerwali lub ograniczyli z nim kontakty ${ }^{43}$.

Zasadniczo jednak kwestia Asyryjczyków-muzułmanów jest traktowana jako marginalna przez intelektualistów. Z problemem tym w ogóle się nie spotkałam.

\subsubsection{Praktyki religijne}

Interesujące jest sprawdzenie poziomu deklarowanej religijności respondentów. Otóż więcej Aramejczyków (trzy czwarte) uważa się za wierzących praktykujących w porównaniu do nieco ponad połowy Asyryjczyków. Spośród tych ostatnich (niemal jedna trzecia) to wierzący niepraktykujący; wierzy, lecz nie praktykuje co piąty badany Aramejczyk. Wśród Asyryjczyków jest więcej niewierzących niepraktykujących oraz osób, które nie identyfikują się z żadną religią, choć uznają istnienie sił nadprzyrodzonych.

Wykres 66

Religijność respondentów asyryjskich i aramejskich
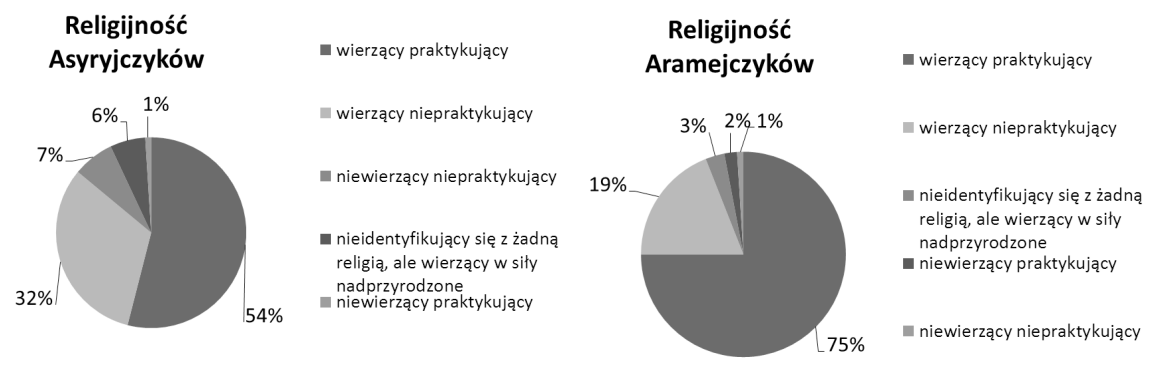

${ }^{43}$ Wywiad z Özmenem Denho, Szwecja, 30.06.2007. 
W przypadku tego pytania odpowiedzi wskazują na większe przywiązanie Aramejczyków do Kościoła, w ich przypadku równoznacznego z Syryjskim Kościołem Ortodoksyjnym. Asyryjczycy jawią się jako bardziej zlaicyzowani, choć i tak odsetek ludzi wierzących jest wśród nich przytłaczający.

\subsubsection{Nasilenie praktyk religijnych}

Pytanie o nasilenie praktyk religijnych miało w pewnym sensie zweryfikować poprzednie. Po przeanalizowaniu uzyskanych danych na temat częstotliwości partycypowania w mszach świętych okazało się, że Asyryjczycy nie są wcale dużo bardziej zlaicyzowani od Aramejczyków, choć się za takich uważają (co też jest symptomatyczne). Mniej więcej jedna trzecia respondentów uczestniczy w nabożeństwach regularnie - w każdą niedzielę lub częściej. Prawie połowa pojawia się w kościele kilka razy do roku, co dziesiąta osoba tylko podczas specjalnych okazji, co dwudziesta jedynie podczas świąt. Jedyna znaczniejsza różnica to o 5 punktów procentowych większa liczba Asyryjczyków nigdy niepojawiających się w świątyni.

$\mathrm{Z}$ drugiej strony, nie sposób nie zauważyć laicyzacji, która dotyka Asyryjczyków i Aramejczyków w diasporze, szczególnie europejskiej (dla porównania, w każdą niedzielę bierze udział w mszy ok. 20\% respondentów asyryjskich w Europie, zaś aż 40\% w USA). Znakomita większość uczęszczających regularnie do kościoła to ludzie starsi, młodszych religia nie interesuje, ulegają wpływowi swoich ateistycznych lub agnostycznych znajomych spoza wspólnoty etnicznej ${ }^{44}$.

Wykres 67

Nasilenie praktyk religijnych wśród respondentów asyryjskich i aramejskich
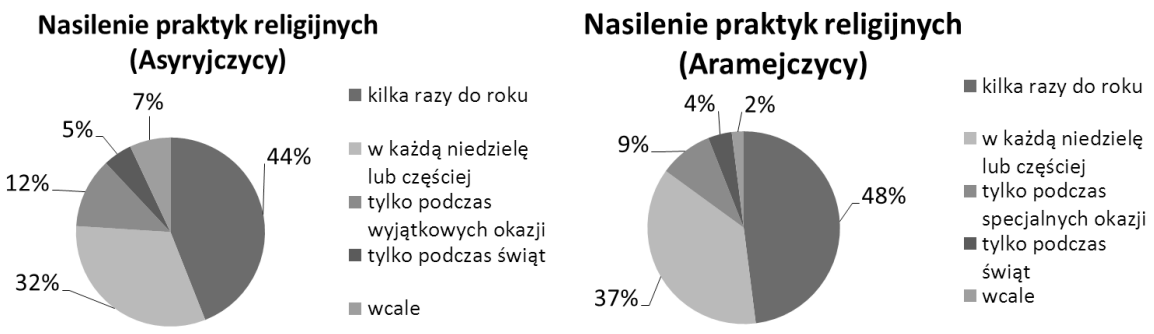

${ }^{44}$ Wywiad z dwoma przedstawicielami Assyrian Democratic Movement, Szwecja, 29.06.2007. 
Trudno powiedzieć, czy forma nabożeństw odprawianych przynajmniej częściowo po syryjsku (a więc w języku coraz mniej zrozumiałym), czy ich długość (około trzech godzin) ma wpływ na odsuwanie się od Kościoła młodych, którzy „nie chcą tracić czasu w weekend”. Z pewnością msze, jak we wszystkich obrządkach ortodoksyjnych, nastawione są na rytuał: kapłan, ubrany w wyjątkowo zdobne szaty liturgiczne, sprawuje ofiarę przed zasłoniętym ołtarzem, wierni bardzo często wykonują znak krzyża, dość swobodnie wstają bądź siadają, przy czym kobiety czynią to po lewej stronie kościoła, z włosami przeważnie przykrytymi koronkowymi chustami, mężczyźni zaś po prawej stronie z głowami odkrytymi. Eucharystia (pod dwiema postaciami - chleba i wina) zarezerwowana jest na największe święta lub udzielana na wyraźne indywidualne żądanie, za to sakrament namaszczenia chorych jest popularny (polega na kilkugodzinnych modłach, połączonych z okadzaniem chorego i kładzeniem Pisma Świętego na jego głowie $)^{45}$.

\subsubsection{Więzi społeczne}

\subsubsection{Zainteresowanie życiem rodaków}

Znakomita większość Asyryjczyków i Aramejczyków jest zainteresowana życiem swych rodaków, jako wyjątki potwierdzające regułę można potraktować tych, którzy nie wyrażają takiego zainteresowania.

Wykres 68

Zainteresowanie życiem rodaków wyrażane przez respondentów asyryjskich i aramejskich

\section{Zainteresowanie życiem innych Asyryjczyków}

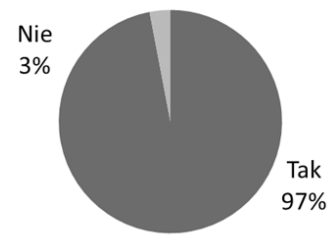

\section{Zainteresowanie życiem innych Aramejczyków}

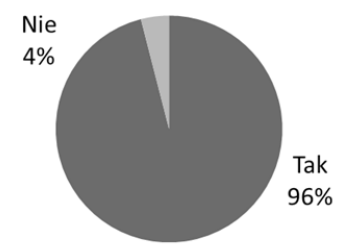

${ }^{45}$ Msza w syryjskim kościele ortodoksyjnym w Szwecji, obserwacja uczestnicząca, 1.07.2007. 


\subsection{Geograficzne rozłożenie zainteresowania}

Zazwyczaj nie jest to zainteresowanie nastawione na jakąś konkretną grupę Asyryjczyków czy Aramejczyków - przynajmniej dziewięć dziesiątych badanych twierdzi, że obchodzą go rodacy żyjący zarówno w ojczyźnie, jak i w diasporze. Nieco więcej (o 5 punktów procentowych) Asyryjczyków przejawia zainteresowanie jedynie swoimi współbraćmi na Bliskim Wschodzie. W przypadku obu grup odsetek osób szukających wyłącznie danych na temat diaspory jest bardzo znikomy.

Wykres 69

Geograficzne rozłożenie zainteresowania życiem rodaków wyrażanego przez respondentów asyryjskich i aramejskich
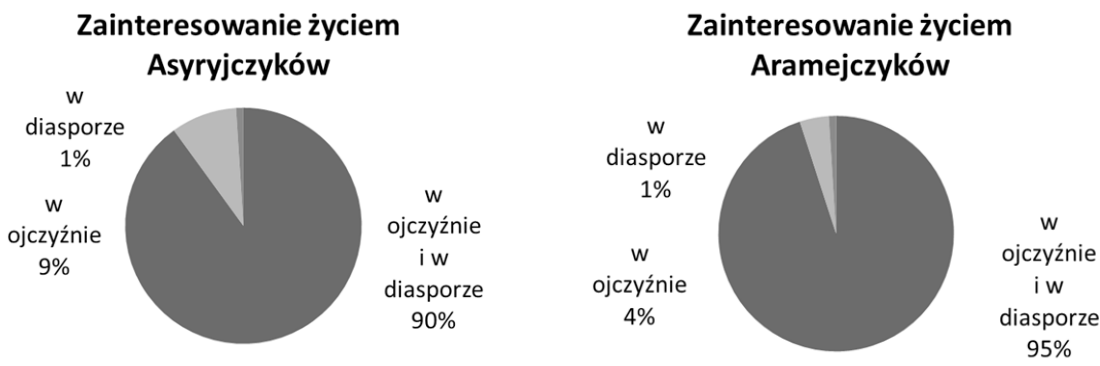

\subsubsection{Symbole narodowe}

Symbole narodowe reprezentują stosunkowo nowy rozdział $\mathrm{w}$ historii symbolizmu zbiorowości. $\mathrm{Na}$ wiele lat zanim powstały narody, plemiona i klany używały znaków, które pozwalały im odróżnić się od innych. Takimi znakami stały się totemy - materialne znaki grupowej osobowości, oznaczające wszystko, co do wspólnoty należało - jej własność, święte miejsca i ludzi. Z kolei totemizm starożytny i średniowieczny obrazował narzucenie władzy konkretnych rodów ich poddanym, stąd zdobycie proporca władcy oznaczało pozbawienie go władzy ${ }^{46}$. Narodziny narodów oznaczały nową fazę totemizmu. W XVIII wieku pojawiły się zestawy symboli: hymny, stolice, monety, flagi, bohaterowie, święta, pomniki, motta, świątynie itp. Była to kombinacja egalitaryzmu najdawniejszych totemów i elitaryzmu tych ze starożytności i średniowiecza, innymi słowy, demokratyzacja kolektywnego

${ }^{46}$ K. A. Cerulo, op. cit., s. 12. 
symbolizmu. Z jednej strony, symbole narodowe zaczęły identyfikować polityczne przywództwo, z drugiej - stały się szeroko dostępne ${ }^{47}$.

Pytanie o symbole nastręczyło trudności zarówno Asyryjczykom (jedna szósta nie potrafiła udzielić żadnych odpowiedzi), jak i Aramejczykom (jedna piąta nie poradziła sobie $\mathrm{z}$ tym zagadnieniem).

Najbardziej rozpoznawany symbol asyryjski jest niedawnej proweniencji. Wymieniona przez ponad połowę badanych flaga, znana jako Ata D’Atur, zaprojektowana została przez George’a Atanosa w 1968 roku, zaś trzy lata później zaakceptowana przez Assyrian Universal Alliance, Assyrian National Federation oraz Bet-Nahrain Democratic Party. W centrum flagi asyryjskiej znajduje się złoty krąg, który reprezentuje słońce. Otaczająca go czteroramienna gwiazda symbolizuje ziemię, błękitny kolor oznacza spokój. Faliste wstęgi odchodzące od środka do czterech rogów to trzy główne rzeki Asyrii: czerwony Tygrys (symbol odwagi), ciemnobłękitny Eufrat (obfitość) i biała Zawa (pokój). Pojawiająca się czasami czerwona skrzydlata sylwetka na górze flagi to dodany przez partię Bet-Nahrain przedchrześcijański bóg asyryjski - Aszur, znany głównie z ikonografii epoki żelaza ${ }^{48}$. [Il. 15]

Wcześniej, jeszcze przed I wojną światową, wspólnota asyryjska w kontaktach z zachodnimi potęgami używała innej flagi - składającej się z trzech poziomych pasów: łososiowego, białego i czerwonego. Trzy białe gwiazdy w lewym górnym rogu flagi symbolizowały główne Kościoły: Kościół Wschodu, Chaldejski Kościół Katolicki oraz Syryjski Kościół Ortodoksyjny ${ }^{49}$. [Il. 16]

W latach 1915-1923 armia asyryjska używała flagi przypominającej szwajcarską, przedstawiającą biały krzyż na czerwonym tle. Różniła się dodatkową okrągłą pieczęcią w lewym górnym roku - osobistym znakiem Aghi Petrosa ${ }^{50}$. [Il. 17]

Jedna trzecia respondentów jako symbol asyryjski wymieniła lamas$s u$, czyli byka asyryjskiego. Lamassu wywodzi się z tradycji sumeryjskiej, do sztuki asyryjskiej przeniknął za pośrednictwem Hetytów. Jest to posąg wyobrażający skrzydlatego byka o ludzkiej, brodatej twarzy, czyli tzw. istotę zoomorficzną. Tiara z rogów symbolizuje potęgę, broda - inteligencję, zaś pas opasujący tułów - magiczną moc. Lamassu wywodzące się z najpóźniej-

\footnotetext{
${ }^{47}$ Ibidem, s. 13 .

48 The Meaning of the Assyrian Flag, AINA, http://www.aina.org/aol/flag.htm, data wejścia 14.01.2010.

${ }^{49}$ Ibidem.

${ }^{50}$ Ibidem.
} 
szej tradycji miały czasem lwie łapy, co nadawało im cech tego zwierzęcia. Tradycyjnie jednak przedstawiano lamassu z pięcioma byczymi nogami, tak aby posąg z przodu wyglądał na statyczny, z boku zaś na dynamiczny, kroczący. Jego funkcją było ochranianie wejść do pałaców, w kulturze mezopotamskiej był duchem opiekuńczym. [Il. 18]

Jedna piąta badanych wymieniła gwiazdę asyryjską. [Il. 19] Ta ośmioramienna gwiazda wywodzi się z okresu nowobabilońskiego, w którym oznaczała planetę Wenus i związaną z nią boginię miłości i wojny - Inanę/Isztar. Z kolei na pieczęciach z okresu nowoasyryjskiego górna połowa ciała Isztar otoczona jest gwiazdami ${ }^{51}$. [Il. 20]

Niewiele mniej badanych rozpoznaje boga Aszura, asyryjskiego boga wojny, słońca i stwórcę świata. Główny ośrodek jego kultu istniał w mieście Aszur w dzisiejszym Iraku. Atrybutami Aszura była uskrzydlona tarcza, tiara z rogami oraz napięty łuk. [Il. 21] Ponad jedna dziesiąta pytanych rozpoznaje również boską małżonkę Aszura - Isztar. [Il. 22]

Dokładnie jedna dziesiąta respondentów wymieniła krzyż, niektórzy sprecyzowali, że chodzi o krzyż „asyryjski”, który ma trzy ramiona zakończone na podobieństwo kwiatów lotosu lub granatów - motywów zdobniczych używanych przez starożytnych Asyryjczyków. Taki krzyż pojawiał się, na przykład, na koronach noszonych przez anioły w przedchrześcijańskiej Mezopotamii, zaś po nadejściu chrześcijaństwa przedstawiano go z dwoma aniołami po bokach. [Il. 23]

Kolejne symbole odsyłały przeważnie do sztuki starożytnej Asyrii, były to: posagi władców, takich jak Sargon, Aszurbanipal czy Hammurabi, drzewo życia (tajemniczy symbol pojawiający się w otoczeniu orłogłowego boga, kapłanów bądź króla), orzeł (lub raczej bóg o głowie orła), asyryjskie słońce lub dysk itp.

Tabela 23

Symbole asyryjskie

\begin{tabular}{|l|c|c|}
\hline \multicolumn{1}{|c|}{ Symbol } & N & $\%$ \\
\hline Flaga asyryjska & 250 & 51 \\
\hline Lamassu/byk asyryjski & 227 & 46 \\
\hline Gwiazda asyryjska & 97 & 20 \\
\hline
\end{tabular}

${ }^{51}$ J. Black, A. Green, Gods, Demons and Symbols of Ancient Mesopotamia. An Illustrated Dictionary, London 1998, s. 169. 
Tabela $23 \mathrm{~cd}$.

\begin{tabular}{|l|c|c|}
\hline \multicolumn{1}{|c|}{ Symbol } & $\mathrm{N}$ & $\%$ \\
\hline Bóg Aszur & 86 & 18 \\
\hline Bogini Isztar & 55 & 11 \\
\hline Krzyż & 47 & 10 \\
\hline $\begin{array}{l}\text { Starożytni władcy (Sargon, Aszurbanipal, Hammurabi, } \\
\text { Semiramida, Abgar Wielki) }\end{array}$ & 36 & 7 \\
\hline Drzewo życia & 34 & 7 \\
\hline Orzeł & 30 & 6 \\
\hline Asyryjskie słońce/dysk & 29 & 6 \\
\hline Mury Babilonu & 20 & 4 \\
\hline Wieża Babel & 13 & 3 \\
\hline Gilgamesz & 11 & 2 \\
\hline Półksiężyc Sin & 10 & 2 \\
\hline Upadek Niniwy & 10 & 2 \\
\hline Lew & 10 & 2 \\
\hline Symbole organizacji/partii/klubów/Kościołów & 10 & 2 \\
\hline Alfabet & 8 & 2 \\
\hline Szamasz (mezopotmamski bóg słońca) & 7 & 1 \\
\hline Rzeki Eufrat i Tygrys & 6 & 1 \\
\hline Kwiat w kształcie rozety & 6 & 1 \\
\hline Cherub & 6 & 1 \\
\hline Logo Zowaa & 62 & 13 \\
\hline Asyryjscy bogowie & & 17 \\
\hline Inne & 6 & 1 \\
\hline Odpowiedź „wiele” lub „nie wiem”/,nie rozumiem” & 3 & \\
\hline
\end{tabular}

Niemal dwie piąte badanych Aramejczyków wymieniło jako najważniejszy symbol orła Surjojo, prawie jedna trzecia flagę aramejską. W rzeczywistości jest to jeden i ten sam symbol. Projekt flagi opiera się na reliefie odkrytym przez André Dupont-Sommera w Tell Halaf w Syrii. Relief przedstawia dwóch mężczyzn z głowami byków podtrzymujących uskrzydlony dysk solarny. W przypadku flagi słońce zastąpiono płomieniem lub 
zniczem, symbolizującym Ducha Świętego. Czerwony kolor tła przywołuje skojarzenia z Sejfo. Kolor żółty wyraża nadzieję na własne państwo. [Il. 24] Jedna czwarta badanych za typowo aramejski symbol uznała krzyż. Następne wskazania nie były już tak liczne i przypadały na bardzo ogólną kategorię „symbole chrześcijańskie”. Pojawiały się również symbole ewidentnie asyryjskie, np. Isztar, lamassu, flaga asyryjska (sic!) lub związane z innymi etnosami, jak cedr libański.

Tabela 24

Symbole aramejskie

\begin{tabular}{|l|c|c|}
\hline \multicolumn{1}{|c|}{ Symbol } & N & $\%$ \\
\hline Orzeł Surjojo & 118 & 39 \\
\hline Flaga aramejska & 97 & 32 \\
\hline Krzyż & 77 & 25 \\
\hline Symbole chrześcijańskie & 19 & 6 \\
\hline Słońce/dysk ze skrzydłami & 11 & 4 \\
\hline Skrzydlaty byk & 7 & 2 \\
\hline Uskrzydlony wieczny ogień & 6 & 2 \\
\hline Isztar & 6 & 2 \\
\hline Aram (ojciec wszystkich Aramejczyków) & 5 & 2 \\
\hline Święci syryjscy (św. Efrem, św. Szarbel) & 5 & 2 \\
\hline Sejfo & 5 & 2 \\
\hline Alfabet & 5 & 2 \\
\hline Jezus & 5 & 2 \\
\hline Język (aramejski) & 4 & 1 \\
\hline Lamassu & 4 & 1 \\
\hline Król Abgar & 4 & 1 \\
\hline Flaga asyryjska & 4 & 1 \\
\hline Cedr libański & 4 & 1 \\
\hline Tur Abdin & 3 & 1 \\
\hline Historyczni władcy aramejscy & 3 & 1 \\
\hline Lew & & 1 \\
\hline
\end{tabular}


Tabela $24 \mathrm{~cd}$.

\begin{tabular}{|l|c|c|}
\hline \multicolumn{1}{|c|}{ Symbol } & $\mathrm{N}$ & $\%$ \\
\hline Wieża Babel & 3 & 1 \\
\hline Inne & 51 & 17 \\
\hline Odpowiedź „nie wiem”/,nie rozumiem” & 64 & 21 \\
\hline
\end{tabular}

Pytanie o symbole ujawniło pogłębiającą się różnicę między tożsamością asyryjską a aramejską przy większej spójności tej pierwszej - Asyryjczycy nie wymieniali aramejskich symboli, Aramejczykom zdarzało się wyliczać symbole ewidentnie asyryjskie (jak Isztar czy lamassu) lub należące do innych nacji (cedr libański). Ta ostatnia odpowiedź wskazuje zresztą na ciążenie w kierunku libańskich Maronitów. Zaskakuje duża liczba respondentów, którzy nie potrafili wymienić żadnych symboli - najczęściej członkowie narodów o dobrze wykrystalizowanych tożsamościach nie mają z tym problemu. To, że najwięcej głosów zdobyły flagi zaprojektowane w drugiej połowie XX wieku, jest dowodem na nasilenie się procesu konstrukcji tożsamości w ostatnich latach.

\subsubsection{Stopień asymilacji}

\subsubsection{Poparcie dla organizacji}

Ponad trzy czwarte respondentów aramejskich zadeklarowało poparcie dla swoich organizacji - o 10 punktów procentowych więcej, niż miało to miejsce w przypadku badanych Asyryjczyków. Taka korzystniejsza dla Aramejczyków proporcja może być spowodowana faktem, że jako statystycznie młodsi, są oni nastawieni bardziej idealistycznie - wierzą, że ich organizacje faktycznie mogę wpłynąć na rzeczywistość.

Wykres 70

Poparcie dla asvrviskich i aramejskich organizacji
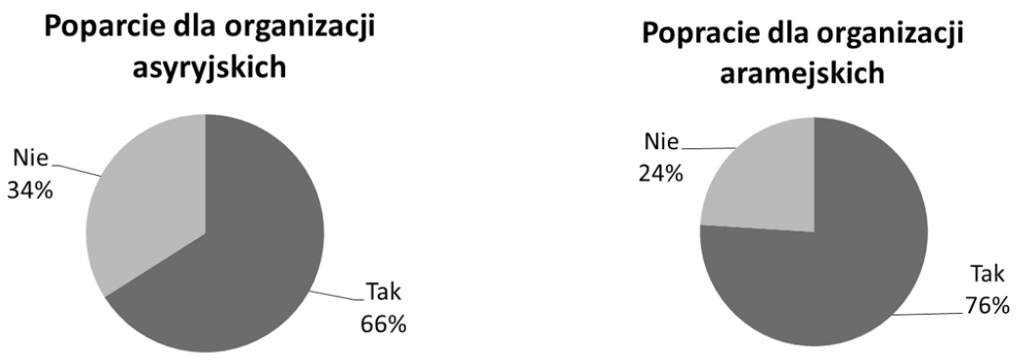


\subsubsection{Poparcie dla klubów sportowych}

Podobnie wytłumaczyć można jeszcze większą przewagę aramejską w pytaniu o poparcie dla klubów sportowych. Kibicuje im ponad połowa Aramejczyków i około dwóch piątych Asyryjczyków - sport jest domeną ludzi młodych. Kolejny czynnik, który może mieć tu znaczenie, to fakt, że większość badanych aramejskich pochodzi z Europy, w Szwecji zaś grają najbardziej znane drużyny piłkarskie - zarówno asyryjska, jak i aramejska. Tym samym sport, a konkretnie piłka nożna, zdecydowanie bardziej porusza, czasem wręcz antagonizuje grupę w Europie niż w Stanach Zjednoczonych.

Wykres 71

Poparcie dla asyryjskich i aramejskich klubów sportowych
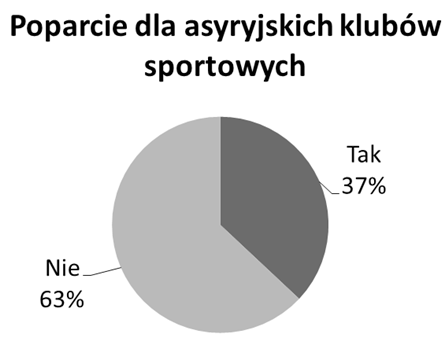

Poparcie dla aramejskich klubów sportowych

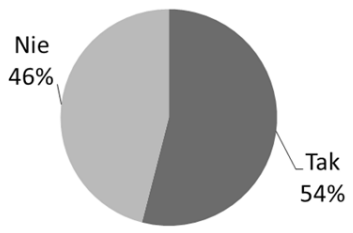

Niekwestionowanym liderem wśród klubów sportowych jest założona w 1974 roku asyryjska drużyna piłki nożnej z Södertälje, Assyriska FF, której kibicuje niemal trzy piąte badanych Asyryjczyków. Dla porównania, jej powstały trzy lata później aramejski odpowiednik - Syrianską FC - dopinguje mniej niż jedna trzecia Aramejczyków. Taki rozkład tłumaczyć mogą wyniki Assyriskiej FF, która jako pierwsza emigrancka drużyna trafiła w 1992 roku do szwedzkiej drugiej ligi, zaś w 2004 roku zanotowała awans do pierwszej ligi, gdzie między innymi pokonała IFK Goteborg 3:0 (obecnie gra znów w drugiej lidze, marząc o powrocie do najwyższej). Assyriska cieszy się zresztą wielką popularnością na całym Bliskim Wschodzie, jej mecze transmitowane są w 80 krajach, klub dofinansowują kibice z Iraku, Iranu i Syrii, promuje go popowa piosenka Assyrian team - the team of my dream, zaś niemal każdy Asyryjczyk marzy o pójściu na mecz Assyriskiej ${ }^{52}$.

${ }^{52}$ Najdziwniejsze derby świata. A przynajmniej Szwecji, http://www.zczuba.pl/zczuba /1,90957,7096013,Najdziwniejsze_derby_swiata_A_przynajmniej_Szwecji.html, data wejścia 10.01.2010. 
Tymczasem Syrianska FC nie pozostaje daleko w tyle; przez lata powoli pięła się w górę, by w 2009 roku zmierzyć się z potężniejszą Assyriską FF. Rozgrywające się w Szwecji derby to coś więcej niż spotkanie dwóch drużyn - to konfrontacja nieformalnych reprezentacji dwóch „nacji” - asyryjskiej i aramejskiej. Nigdzie konflikt między dwoma grupami nie jest bardziej widoczny niż w Södertälje, gdzie w latach 90. XX wieku bójki pomiędzy kibicami bywały tak gwałtowne, że odwoływano mecze, sportowi prominenci słali sobie listy z pogróżkami, w komitecie walczyły ze sobą klany, zaś gracze bywali zastraszani, i to mimo faktu, że w tym samym czasie obie drużyny straciły swój etniczny charakter, odchodząc od zatrudniania piłkarzy wyłącznie odpowiedniego pochodzenia ${ }^{53}$. [Il. 25]

Wykres 72

\section{Asyryjskie kluby sportowe}
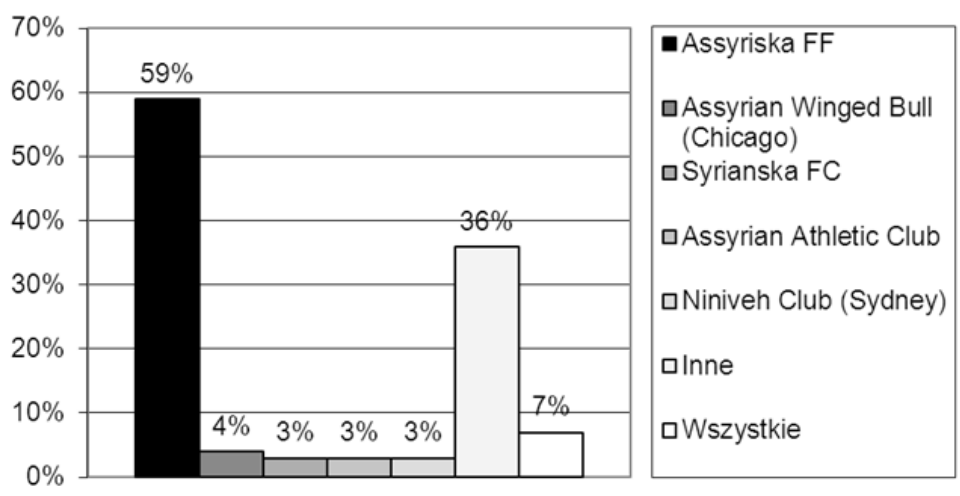

Podczas derbów w 2009 roku Syrianska pokonała Assyriską 1:0 $0^{54}$, obecnie obie drużyny dzieli jedno miejsce w tabeli (Assyriska jest czwarta, Syrianska piąta). Niektórzy marzą o tym, by zespoły się połączyły, zamiast walczyć o tych samych sponsorów, gdyż emocje związane z dopingowaniem

53 The Strangest Football Derby in the World, http://www.christiansofiraq.com/two-assyrian-soccore-teams.html, data wejścia 10.01.2010.

${ }^{54}$ Więcej o tym wydarzeniu oraz wpływie sportu na kształtowanie tożsamości asyryjskiej/syryjskiej zob. C. Rommel, Assyrians or Syriacs? Middle Eastern Identity Formation Through Football in Sweden, Middle East Institute Viewpoints: Sport and the Middle East, USA 2010, s. 20-23. 
konkretnej drużyny potrafią skłócić całe rodziny. Jednocześnie zdarzają się fani, którzy dopingują „wrogie” drużyny - w ankiecie 3\% Asyryjczyków przyznało się do popierania Syrianskiej, dokładnie tylu samo Aramejczyków napisało, że kibicuje Assyriskiej. Z drugiej strony połączenie drużyn spowodowałoby z pewnością utratę wielu kibiców zarówno wśród zadeklarowanych Asyryjczyków, jak i Aramejczyków, gdyż obie grupy budują swoją tożsamość podczas spektakli sportowych, które po części zastępują spektakle militarne. [Il. 26] Pozostałe dyscypliny sportowe, np. siatkówka czy koszykówka, nie budzą już takich kontrowersji, tym samym liczba ich fanów jest zdecydowanie mniejsza.

Wykres 73

\section{Aramejskie kluby sportowe}

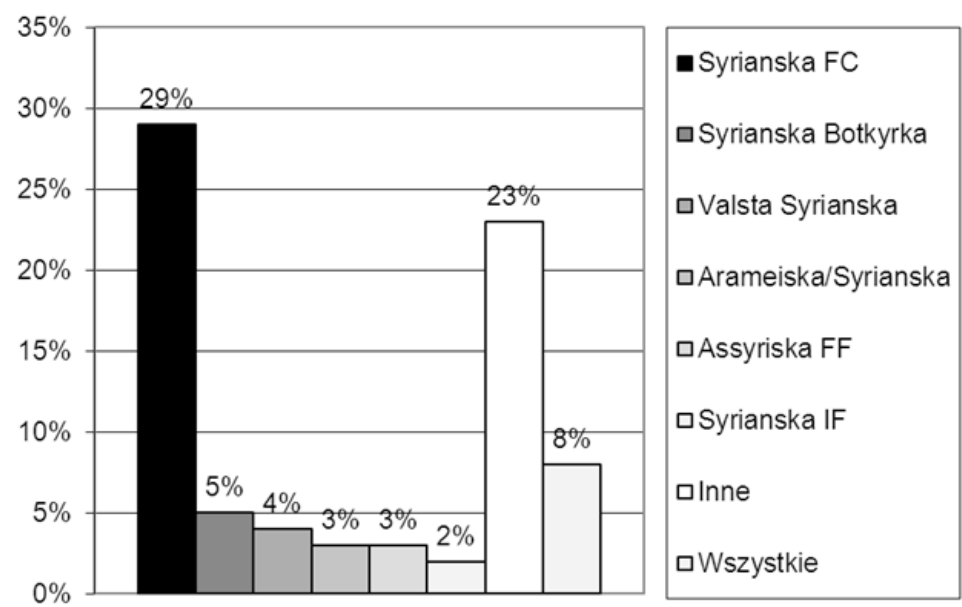

\subsubsection{Integracja w krajach zamieszkania}

Kwestia integracji w krajach zamieszkania została rozważona w trzech aspektach, mianowicie jako integracja na płaszczyźnie kulturalnej, politycznej oraz religijnej. Wszystkie wskaźniki były nieco wyższe wśród grupy asyryjskiej, poza tym widoczny był ten sam schemat - respondenci deklarowali przede wszystkim udział w życiu kulturalnym krajów przyjmujących (około trzech czwartych Asyryjczyków do trzech piątych Aramejczyków), następ- 
nie w życiu politycznym (ponad połowa do niecałej połowy), na samym końcu zaś w życiu religijnym (niecałe dwie piąte do ponad jednej trzeciej). Takie odpowiedzi nie dziwią, gdyż korzystanie z oferty kulturalnej krajów zamieszkania nie wiąże się z żadnymi wymogami natury formalnej, nie wymaga też przewartościowywania tradycyjnej religijności wschodniej. Z kolei, aby w pełni uczestniczyć w życiu politycznym danego państwa, należy być jego obywatelem - zaś niektórzy Asyryjczycy/Aramejczycy ciągle czekają na naturalizację. Dodatkowo, niektórych z nich problemy polityczne krajów pobytu mogą nie interesować w takim stopniu, jak interesowałyby ich w przypadku własnego państwa. Jeśli chodzi o życie religijne, to większość Asyryjczyków i Aramejczyków pozostaje wiernymi swoich obrządków i uczęszcza do kościołów orientalnych (o ile takie zostały wzniesione w pobliżu miejsca ich zamieszkania). W przypadku niemożności skorzystania z właściwego kościoła, wybierają inną świątynię chrześcijańską. Oczywiście nie dotyczy to wąskiej grupy asyryjskich i aramejskich protestantów oraz katolików, którzy w tym przypadku automatycznie niejako trafiają poza obręb swoich wspólnot etnicznych.

Zasadniczo jednak deklarowany poziom integracji jest dość wysoki, zaś Kościoły syryjskie pozostają tradycyjnymi bastionami tożsamości zarówno asyryjskiej, jak i aramejskiej.

Wykres 74

Poziom integracji respondentów asyryjskich

\section{Udział w nieasyryjskim}

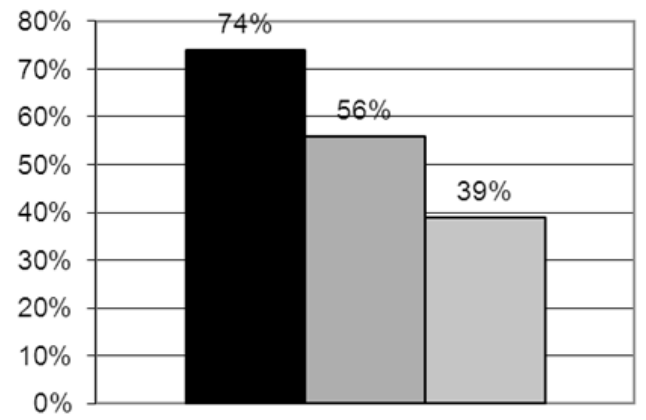

-życiu kulturalnym

ロżyciu politycznym

口życiu religijnym 
Poziom integracji respondentów aramejskich

\section{Udział w niearamejskim}

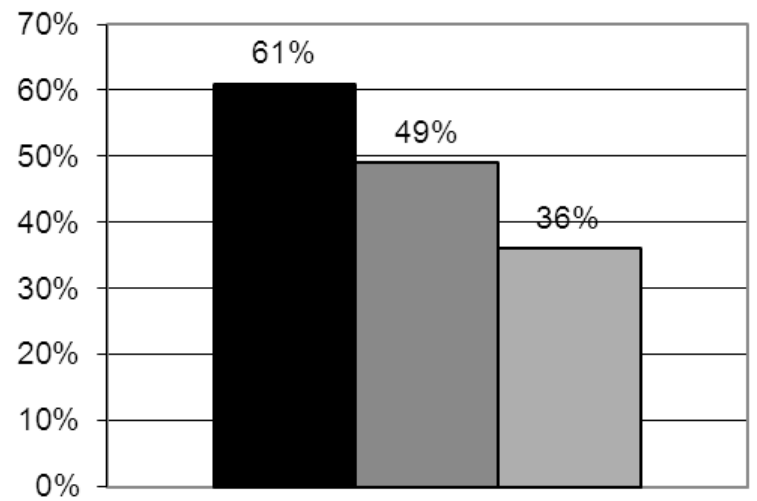

-życiu kulturalnym

$\square \dot{y}$ ciu politycznym

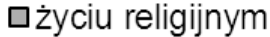

\subsubsection{Przekonania i emocje}

Kolejne pytanie miało za zadanie przybliżyć asyryjskie i aramejskie przekonania na temat własnego pochodzenia oraz związane z tym emocje. Nasilenie przekonań oraz emocji mierzyła pięciostopniowa skala. Do porównania użyto odpowiedzi respondentów, którzy całkowicie zgadzali się z wysuniętymi stwierdzeniami, w celu wyostrzenia różnic (przy uwzględnieniu odpowiedzi tych, którzy zgadzali się w jakimś stopniu, różnice byłyby mniej wyraźne).

\subsubsection{1. Świadomość pochodzenia}

Ponad cztery piąte Asyryjczyków twierdzi, że ma świadomości swojego pochodzenia i tego, co ono znaczy. Takie przekonanie żywi dwie trzecie Aramejczyków. Pozostaje to w zgodzie z wcześniejszymi obserwacjami i pytaniami - Asyryjczycy mają bardziej wykrystalizowaną świadomość pochodzenia, Aramejczycy zaczynają dokonywać autodefinicji. 
Świadomość pochodzenia respondentów asyryjskich i aramejskich
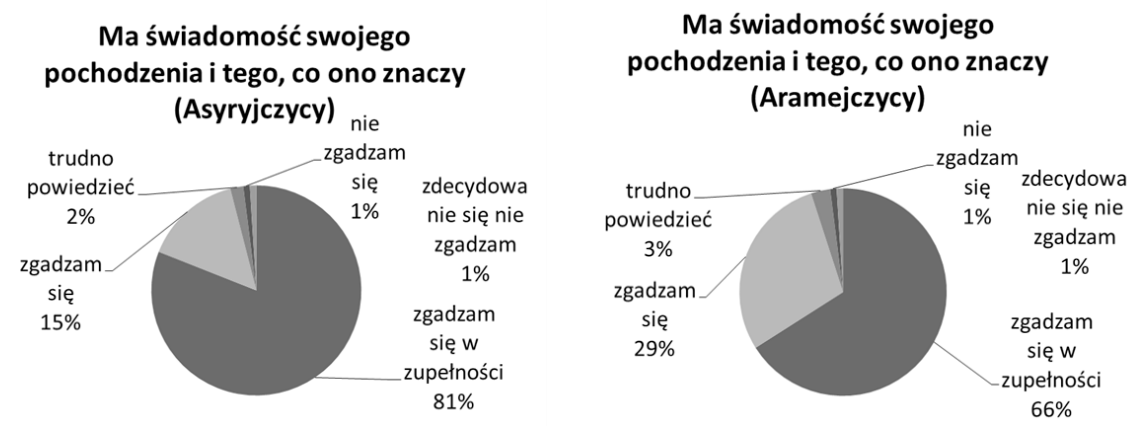

4.3.10.2. Poczucie szczęścia z przynależności do wspólnoty

Bardzo podobny odsetek respondentów stwierdził, że przynależność do wspólnoty go uszczęśliwia - ponad cztery piąte. Tak wysoki wskaźnik może sugerować, że w przyszłości obie grupy będą obstawały przy wybranych przez siebie identyfikacjach zbiorowych.

Wykres 77

Poczucie szczęścia z przynależności do wspólnoty asyryjskiej i aramejskiej
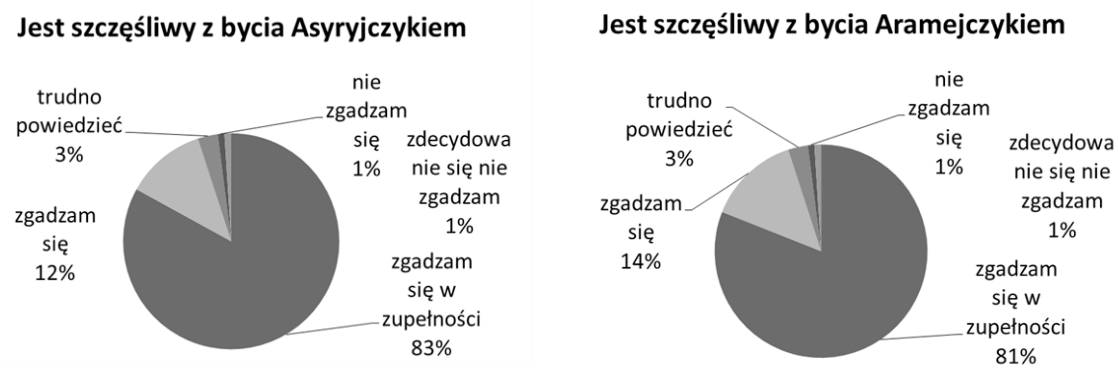

4.3.10.3. Pochodzenie od starożytnych imienników

Pytanie o pochodzenie od starożytnych imienników trafiało w sedno problemu. Dokładnie 70\% respondentów asyryjskich nie miało cienia wątpliwości, że pochodzi od starożytnych Asyryjczyków, odpowiednio taki poziom pewności co do aramejskich przodków wyrażała ponad połowa aramejskich badanych. W obu grupach było po kilkanaście procent 
niezdecydowanych lub przeciwnych takiemu stwierdzeniu, co pokazuje, że historyczni przodkowie odgrywają bardzo ważną rolę w konstruowaniu współczesnej tożsamości, a właściwie dwóch odrębnych tożsamości badanych. Starożytni antenaci zdają się istotniejsi dla Asyryjczyków, Aramejczycy częściej dopuszczają myśl o tym, że w ich żyłach płynie mieszanka krwi różnych ludów semickich.

Wykres 78

Pochodzenie od starożytnych imienników - Asyryjczyków i Aramejczyków

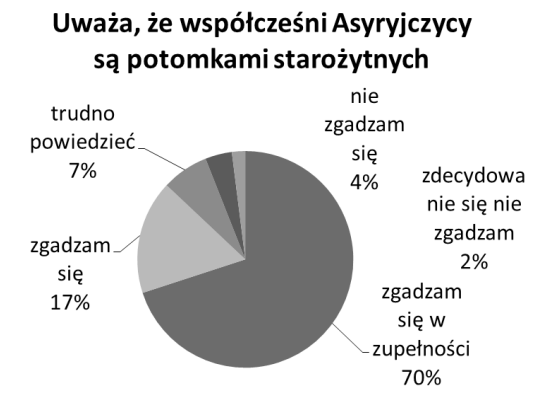

\section{Uważa, że współcześni Aramejczycy są potomkami starożytnych}

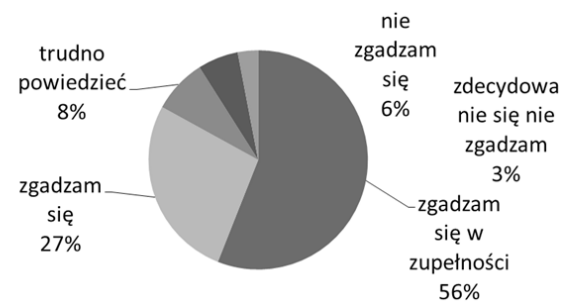

\subsubsection{Poczucie przynależności do rdzennych ziem}

Duże przywiązanie do ziem nazywanych Asyrią bądź Aram-Nahrain deklaruje niemal dwie trzecie badanych asyryjskich i ponad połowa aramejskich. Jest to kolejne pytanie pokazujące rolę pewnych tworów wyobrażonych, w tym przypadku ojczyzn(y), w kształtowaniu się współczesnych tożsamości. Również i ten element wykorzystywany jest w większym stopniu przez Asyryjczyków. Obu podgrupom chodzi o mniej więcej te same, zmitologizowane tereny Iraku, Iranu, Syrii i Turcji.

Wykres 79

Poczucie przynależności do rdzennych ziem - Asyrii i Aram-Nahrain

\section{Ma silne poczucie przynależności do starożytnych ziem Asyrii}

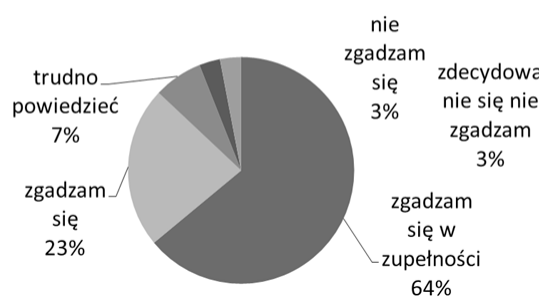

\section{Ma silne poczucie przynależności do strożytnych ziem Aram-Nahrain}

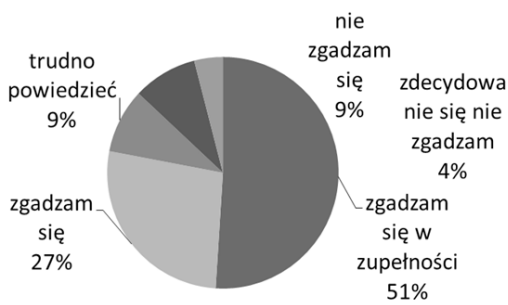




\subsubsection{Indywidualne dociekania historii przodków}

Punkt ten miał za zadanie dopełnić padające wcześniej w ankiecie pytanie o znajomość historii rodziny poprzez sprawdzenie, czy respondenci podejmują wysiłek, aby ową historię poznać - konkretnie zaś, czy korzystają z przekazów ustnych. Okazało się, że czyni tak dokładnie trzy piąte badanych asyryjskich i nieco ponad połowa aramejskich (wraz z respondentami, którzy zgodzili się, choć z mniejszym przekonaniem, liczba ta bliska jest 90\%). Jest to więc kolejne potwierdzenie większego aktywizmu grupy asyryjskiej.

Wykres 80

Indywidualne dociekania historii przodków przez respondentów asyryjskich i aramejskich

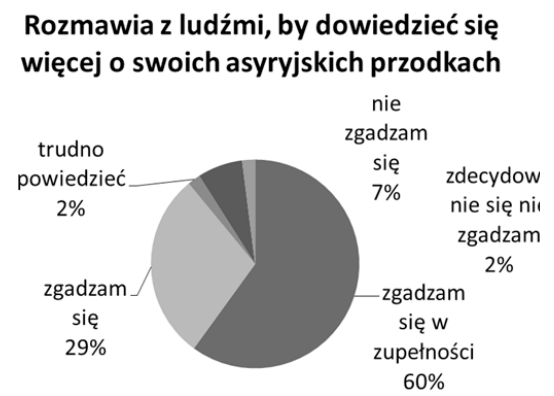

\section{Rozmawia z ludźmi, by dowiedzieć się więcej o swoich aramejskich przodkach}

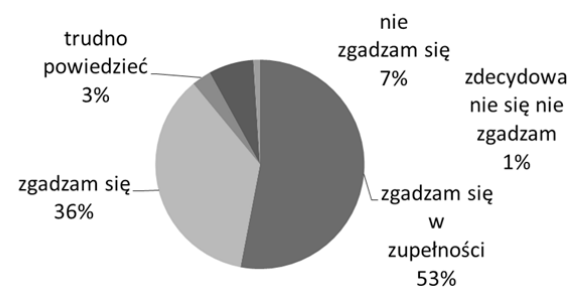

4.3.10.6. Preferencja tradycyjnej kuchni, muzyki, zwyczajów

Zdecydowaną preferencję tradycyjnej kuchni, muzyki i zwyczajów, a więc codziennych przejawów kultury, także niższej, zadeklarowała podobna liczba badanych asyryjskich i aramejskich, mianowicie niecałe trzy piąte.

Wykres 81

Preferowanie tradycyjnej kuchni, muzyki, zwyczajów przez respondentów asyryjskich i aramejskich
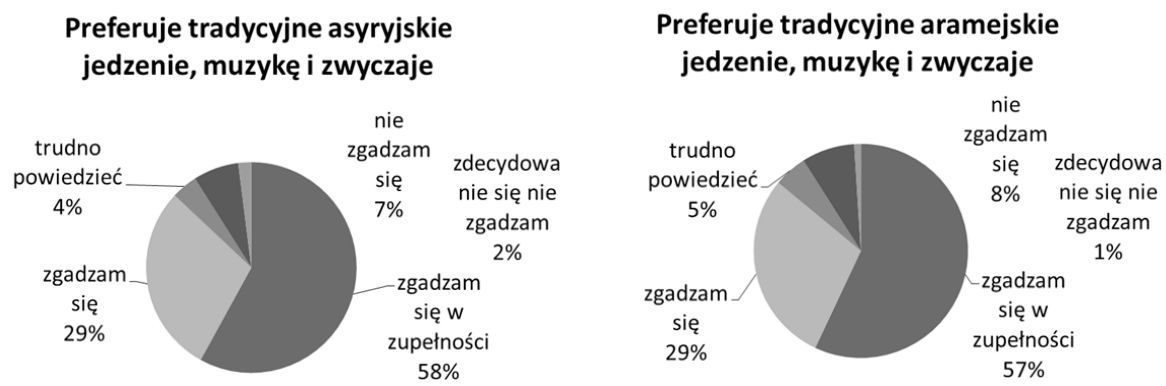


\subsubsection{Duma ze wspólnoty}

Wbrew antycypowanej przewagi asyryjskiej także w tej kategorii, to więcej Aramejczyków (dwie trzecie) zdecydowanie czuje się dumnymi ze swojej wspólnoty, dla porównania taki stopień pewności charakteryzuje nieco ponad połowę Asyryjczyków. Być może spowodowane jest to większym krytycyzmem starszych respondentów asyryjskich oraz idealizowaniem swojej grupy przez Aramejczyków.

Wykres 82

Duma ze wspólnoty asyryjskiej i aramejskiej
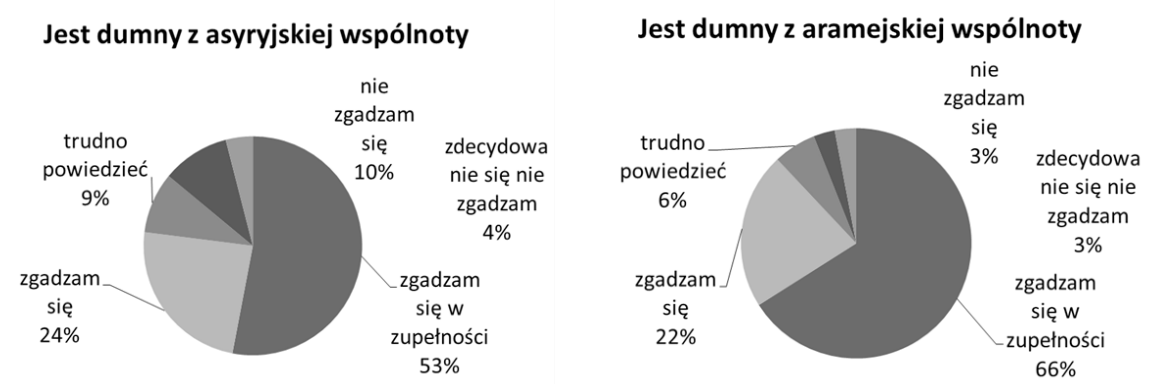

\subsubsection{Tożsamość}

\subsubsection{Najważniejsze zagrożenia dla tożsamości}

Jedni i drudzy respondenci za największe zagrożenie dla swojej tożsamości zbiorowej uznali zapomnienie języka (niemal trzy czwarte badanych z obu grup). Asyryjczycy jako drugie pod względem istotności zagrożenie widzą polityczne i społeczne niepokoje w ojczyźnie (tak odpowiedział prawie co siódmy pytany), natomiast Aramejczycy - porzucenie tradycji. To ciekawa różnica, gdyż wskazuje na to, że Asyryjczycy widzą problem poza sobą, zaś Aramejczycy w sobie - ci ostatni zdają sobie sprawę z tego, jak bliscy są zaniechania tradycji. Trzecie zagrożenie - na poziomie trzech piątych badanych - to asymilacja w diasporze. Za tak samo poważny problem Asyryjczycy uznali emigrację z ojczyzny, dla Aramejczyków ważniejsza jest utrata więzi wewnątrz wspólnoty aramejskiej (co wskazuje na ich większą niepewność względem spójności grupy). Podobna liczba głosów badanych asyryjskich padła na wymienione wcześniej przez Aramejczyków porzucenie tradycji oraz utratę więzi wewnatrzwspólnotowej (miejsce piąte 
i szóste), natomiast nieco mniej Aramejczyków wskazało na niepokoje w ojczyźnie (ponad połowa) i emigrację z niej (dwie piąte). Na ostatnim miejscu uplasowała się utrata kontaktu z ojczyzną, wymieniona przez ponad dwie piąte badanych asyryjskich i dokładnie jedną trzecią aramejskich.

Wykres 83

\section{Zagrożenia dla asyryjskiej tożsamości}

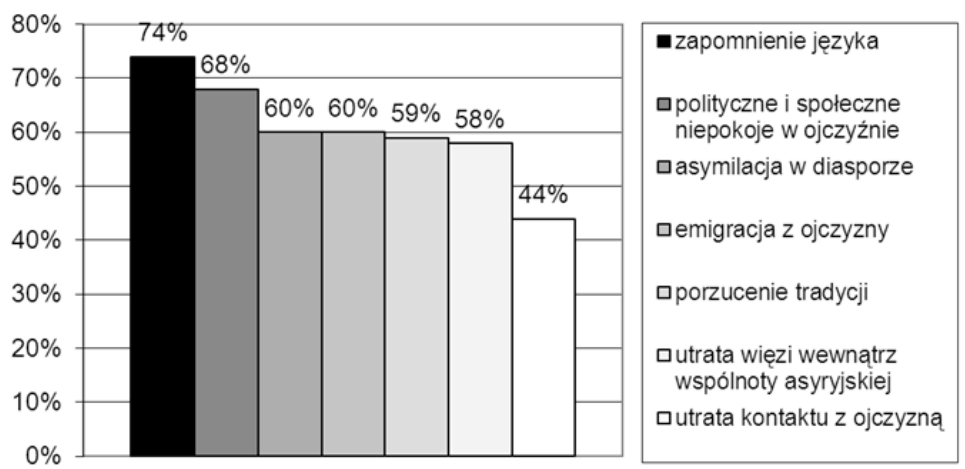

Z ogólnego porównania wyłania się obraz podobnej percepcji zagrożeń przez obie grupy (przy odrobinę inaczej rozmieszczonych akcentach i nieco bardziej wyostrzonych problemach w oczach grupy asyryjskiej). Znakomita większość respondentów najbardziej boi się zapomnienia języka - głównego wyróżnika spośród innych etnosów, zaś najmniej utraty kontaktu z ojczyzną (w dobie Internetu i rozwiniętego transportu lotniczego jest on zdecydowanie ułatwiony).

Zagrożenie, które nie zostało wymienione $\mathrm{w}$ ankietach, ale pojawiło się w wywiadach, jest przeciwieństwem asymilacji. Chodzi mianowicie o gettoizację, konkretnie zaś o gettoizację mniejszości asyryjsko-aramejskiej w Szwecji. Z jednej strony do wspomnianego zjawiska miałby prowadzić fakt zamknięcia społeczeństwa szwedzkiego. Przeciętny Szwed utrzymuje kontakt z dwoma, trzema przyjaciólmi z dzieciństwa, co powoduje, że młody Asyryjczyk czy Aramejczyk przyjeżdżający z Bliskiego Wschodu praktycznie nie ma szans znaleźć przyjaciół wśród miejscowej ludności. 
W rezultacie ma miejsce socjologiczne zjawisko powstawania mentalności „oblężonej twierdzy” - Asyryjczycy/Aramejczycy garną się do siebie, czując się odrzuceni przez Szwedów. Zresztą nie ma zbyt wielu możliwości integracji, według samych zainteresowanych w Södertälje 90-95\% uczniów uczęszczających do szkół stanowią Asyryjczycy/Aramejczycy, zaś pozostałe 5-10\% to nie szwedzka klasa średnia, a dzieci innych imigrantów (Hindusów, Afrykańczyków itp. $)^{55}$.

Wykres 84

\section{Zagrożenia dla aramejskiej tożsamości}

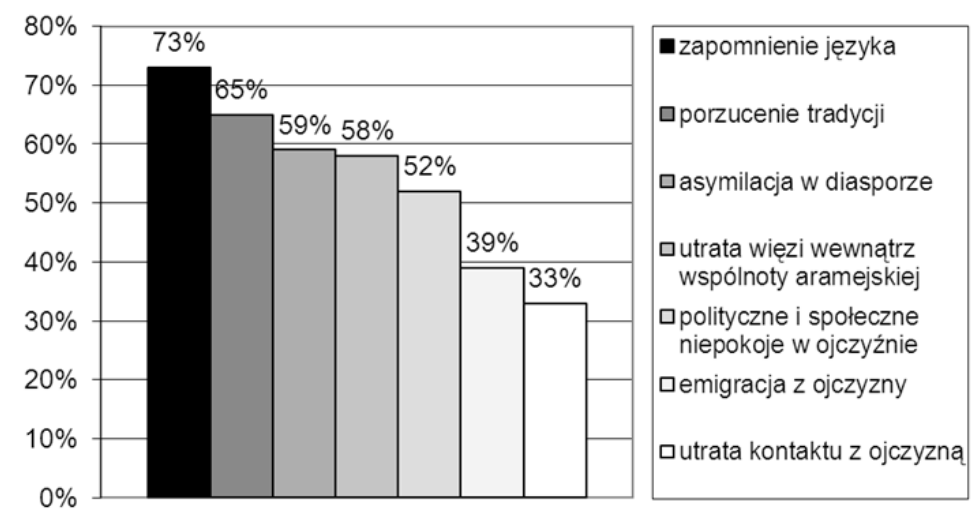

Asyryjczycy/Aramejczycy często postrzegają Szwedów jako leniwych i uprzedzonych; tym ostatnim zaś zdarza się określać wszystkich imigrantów z Południa i Wschodu „czarnogłowymi”. Według respondentów to pejoratywne i bolesne określenie wskazuje na brak zainteresowania poszczególnymi grupami etnicznymi, na traktowanie ich zbiorowo jako niechcianych „obcych”56.

Z drugiej strony niektórzy badani zauważają negatywny wpływ społeczeństw zachodnich na własną grupę etniczną, jeśli chodzi o styl życia. W dwóch wywiadach przeprowadzonych w Szwecji pojawiła się nostalgia za latami 90. XX wieku, kiedy świeżo przybyli imigranci byli bardziej zin-

55 Wywiad z dwoma przedstawicielami Assyrian Democratic Movement, Szwecja, 29.06.2007.

${ }^{56}$ Wywiad z Asyryjczykiem z Syrii, wolontariuszem w „Suroyo TV”, Szwecja, 30.06.2007. 
tegrowani, garnęli się do siebie, pomagali sobie. Ta idealna według respondentów sytuacja została skontrastowana z obecną, kiedy każdy zamyka się we własnym domu, coraz niechętniej spotyka się z rodakami. Jako przykład został podany budynek, w którym mieszka pięć rodzin asyryjskich - ich wzajemne kontakty ograniczają się do zdawkowych pozdrowień wymienianych w windzie. Źródłem pogorszenia stosunków jest podział na Syryjczyków (Aramejczyków) i Asyryjczyków, ale również wyższy status materialny wspólnoty, który powoduje, że ścisła współpraca pomiędzy jej członkami nie jest już konieczna ${ }^{57}$. Tradycyjne cotygodniowe spotkania kobiet asyryjskich/aramejskich po nabożeństwie także nie dają im takiej satysfakcji, jak kiedyś, zaś oglądanie telewizji coraz częściej wygrywa z odwiedzinami u znajomych ${ }^{58}$.

\subsubsection{Istotność zachowania tożsamości}

Nie powinien dziwić fakt, że dla dokładnie czterech piątych badanych aramejskich zachowanie tożsamości jest bardzo istotne; dla czterech punktów procentowych więcej Asyryjczyków jest to sprawa pierwszej wagi. Trzeba przy tym zauważyć, że to, co znakomita większość percypuje jako „zachowanie tożsamości”, dla wąskiej grupy intelektualistów-nacjonalistów jest jej „konstruowaniem” - projektem, który dopiero niedawno zaczął być wdrażany.

Wykres 85

Istotność zachowania asyryjskiej i aramejskiej tożsamości

Zagrożenia dla asyryjskiej tożsamości

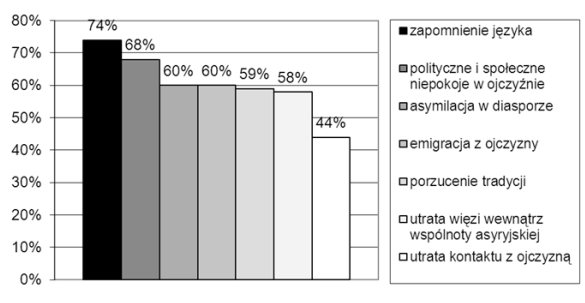

Zagrożenia dla aramejskiej tożsamości

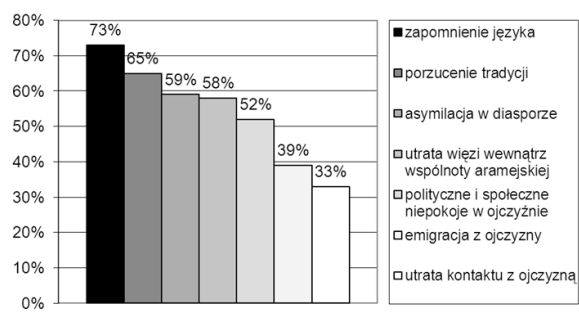

${ }^{57}$ Ibidem.

${ }^{58}$ Wywiad z Asyryjką z Syrii, żoną wolontariusza w „Suroyo TV”, Szwecja, 29.06.2007. 


\subsubsection{Sposoby zachowania tożsamości}

Pytanie o sposoby zachowania tożsamości było pytaniem otwartym, niemniej jednak duża część respondentów zasugerowała się wcześniejszym punktem o zagrożeniach dla ich tożsamości zbiorowej. Odpowiedzi zostały pogrupowane $\mathrm{w}$ kategorie; znakomita ich większość pojawiła się w przypadku grupy zarówno asyryjskiej, jak i aramejskiej. Z poważniejszych różnic - wśród respondentów asyryjskich podniosły się głosy za ograniczeniem roli Kościoła i księży (apele zupełnie obce Aramejczykom), zaś badani aramejscy żądali uznania Sejfo (czego z kolei nie werbalizowali explicite Asyryjczycy).

Najczęściej sugerowanym sposobem zachowania tożsamości było pielęgnowanie języka wskazane przez jedną trzecią badanych asyryjskich i ponad jedną czwartą aramejskich. Także kolejne proponowane rozwiązanie było identyczne - nauczanie historii i zachowanie tradycji oraz zwyczajów; opowiedziała się za nim jedna czwarta Asyryjczyków i jedna piąta Aramejczyków. Edukacja, kultura, zjednoczenie, odpowiednie wychowanie młodzieży - te sposoby wskazała więcej niż jedna dziesiąta respondentów asyryjskich. Tymczasem niemal co piąty badany Aramejczyk zasugerował oparcie się na Kościele (Syryjskim Kościele Ortodoksyjnym) i religii, zaś więcej niż co dziesiąty - rozwój edukacji i patriotyczną formację młodzieży. Oznacza to, że obie grupy rozumieją wagę przekazania tradycji młodemu pokoleniu, gdyż to od niego w istocie zależy przetrwanie grupy.

Jeśli chodzi o stworzenie własnego niepodległego państwa bądź uzyskanie chociaż autonomii, to takie postulaty wysuwało zdecydowanie więcej Asyryjczyków . Powtarzało się przy tym wyrażenie safe haven (wariantywnie safe heaven), oznaczające „azyl”, „schronienie” lub „bezpieczne niebiosa”, na określenie wymarzonego kraju, najlepiej w północnym Iraku (co sugeruje, że pytani pisali pod wpływem przekazów tych samych mediów asyryjskich $^{59}$ ). Odsetek Aramejczyków pragnących niepodległości, ewentualnie autonomii, był znikomy, zaś ich opinie co do preferowanego położenia geograficznego własnego kraju wahały się między Irakiem a Libanem. Za to zdecydowanie więcej Aramejczyków uważało, że sprawa jest przesądzona

${ }^{59} \mathrm{~Np}$. Assyrian Called for Safe Heaven since WWII, http://www.betnahrain.org/bbs/index.pl/noframes/read/1519, The Advantages of a Governate Region Versus Safe Heaven, http:// www.christiansofiraq.com/governate.html, AINA: Appeal for a ChaldoAssyrian Safe Haven in Northern Iraq, http://www.christiansofiraq.com/Aina.html, data wejścia 12.01.2010. 
i ich tożsamości nie da się uratować lub też nie było w stanie wymyślić żadnych środków zaradczych.

W jednej i drugiej grupie tendencje integrystyczne (wyrażane np. naciskiem na małżeństwa wewnątrz podgrup etnicznych) walczyły z chęcią otwarcia się na świat - ta druga tendencja zdecydowanie przeważała. Za zupełnym brakiem asymilacji odpowiedział się 1\% badanych aramejskich, w grupie asyryjskiej taka odpowiedź padła tylko raz.

Trzech respondentów asyryjskich jako sposób zachowania tożsamości wymieniło nadawanie dzieciom imion kojarzących się ze starożytną Asyrią, np. Sargon, Aszur, Semiramida, Isztar ${ }^{60}$. W istocie tendencja ta się nasila, np. cytowany już wcześniej Özmen Denho z pełną świadomością nazwał jednego ze swoich synów Enki ${ }^{61}$. Jednak jego drugi syn dostał na chrzcie imię Georges ${ }^{62}$, czyli typowe dla wschodniego chrześcijanina, popularne również wśród Aramejczyków, którzy preferują zachodnio brzmiące miana.

Tabela 25

Sposoby zachowania tożsamości asyryjskiej

\begin{tabular}{|l|c|c|}
\hline \multicolumn{1}{|c|}{ Sposoby zachowania tożsamości asyryjskiej } & $\mathrm{N}$ & $\%$ \\
\hline Zachowanie języka & 167 & 34 \\
\hline Nauczanie historii i zachowanie tradycji/zwyczajów & 125 & 26 \\
\hline Edukacja (szkoły) i świadomość aramejska & 64 & 13 \\
\hline Zachowanie/rozwój kultury & 62 & 13 \\
\hline Zjednoczenie i współpraca/rozwiązanie kwestii nazwy & 60 & 12 \\
\hline Przyciąganie/formowanie dzieci i młodzieży w diasporze & 52 & 11 \\
\hline Autonomia asyryjska (najlepiej w północnym Iraku) & 45 & 9 \\
\hline Własne niepodległe państwo & 43 & 9 \\
\hline Oparcie się na Kościołach/religii & 35 & 7 \\
\hline Informowanie świata o Asyryjczykach, pomoc z zewnątrz & 35 & 7 \\
\hline Zapewnienie bezpieczeństwa w ojczyźnie & 30 & 6 \\
\hline Przestawanie z innymi Asyryjczykami & 27 & 6 \\
\hline Więzi/powroty do ojczyzny & 22 & 5 \\
\hline
\end{tabular}

${ }^{60}$ Co ciekawe, niektórzy młodzi respondenci twierdzili, że są Asyryjczykami, gdyż noszą asyryjskie imiona.

${ }^{61}$ Enki był starożytnym sumeryjskim bogiem wód i mądrości, stwórcą człowieka.

${ }^{62}$ Wywiad z Özmenem Denho, Szwecja, 30.06.2007. 
Tabela $25 \mathrm{~cd}$.

\begin{tabular}{|l|c|c|}
\hline \multicolumn{1}{|c|}{ Sposoby zachowania tożsamości asyryjskiej } & $\mathrm{N}$ & $\%$ \\
\hline Infrastruktura i aktywności (przyjęcia, mecze) & 18 & 4 \\
\hline Małżeństwa tylko wewnątrz wspólnoty asyryjskiej & 16 & 3 \\
\hline $\begin{array}{l}\text { Ograniczenie lub zreformowanie roli Kościołów i księży oraz } \\
\text { oddzielenie religii od polityki }\end{array}$ & 16 & 3 \\
\hline Więcej demokratycznych organizacji & 13 & 3 \\
\hline Media asyryjskie & 10 & 2 \\
\hline Duma narodowa & 9 & 2 \\
\hline Integracja ze światem współczesnym & 5 & 1 \\
\hline Większa polityczna aktywność & 4 & 1 \\
\hline Inne & 18 & 4 \\
\hline Odpowiedzi „nie wiem” lub „nie da się” & 29 & 6 \\
\hline
\end{tabular}

Tabela 26

Sposoby zachowania tożsamości aramejskiej

\begin{tabular}{|l|c|c|}
\hline \multicolumn{1}{|c|}{ Sposoby zachowania tożsamości aramejskiej } & $\mathrm{N}$ & $\%$ \\
\hline Zachowanie języka & 81 & 26 \\
\hline Nauczanie historii i zachowanie tradycji/zwyczajów & 63 & 21 \\
\hline Oparcie się na Kościołach/religii & 54 & 18 \\
\hline Przyciąganie/formowanie dzieci i młodzieży w diasporze & 48 & 16 \\
\hline Edukacja (szkoły) i świadomość aramejska & 35 & 11 \\
\hline Zjednoczenie i współpraca/rozwiązanie kwestii nazwy & 26 & 8 \\
\hline Informowanie świata o Aramejczykach, pomoc z zewnątrz & 19 & 6 \\
\hline Własne niepodległe państwo & 18 & 6 \\
\hline Infrastruktura i aktywności (przyjęcia, mecze) & 18 & 6 \\
\hline Zachowanie/rozwój kultury & 17 & 6 \\
\hline Więcej demokratycznych organizacji & 15 & 5 \\
\hline Przestawanie z innymi Aramejczykami & 15 & 5 \\
\hline Więzi/powroty do ojczyzny & 13 & 4 \\
\hline Małżeństwa tylko wewnątrz wspólnoty aramejskiej & 10 & 3 \\
\hline Większa polityczna aktywność & 10 & 3 \\
\hline Media aramejskie & 9 & 3 \\
\hline
\end{tabular}


Tabela $26 \mathrm{~cd}$.

\begin{tabular}{|l|c|c|}
\hline \multicolumn{1}{|c|}{ Sposoby zachowania tożsamości aramejskiej } & N & $\%$ \\
\hline Zapewnienie bezpieczeństwa w ojczyźnie (w Iraku, Turcji) & 7 & 2 \\
\hline Uznanie Sejfo i przeprosiny ze strony Turków i Kurdów & 6 & 2 \\
\hline Duma narodowa & 5 & 2 \\
\hline Autonomia aramejska (w Iraku lub Libanie) & 4 & 1 \\
\hline Brak asymilacji & 4 & 1 \\
\hline Oparcie się na rodzinie & 4 & 1 \\
\hline Integracja ze światem współczesnym & 4 & 1 \\
\hline Inne & 13 & 4 \\
\hline Odpowiedzi „na wiele sposobów” & 6 & 2 \\
\hline Odpowiedzi „nie wiem” lub „nie da się”j jż+,m & 53 & 17 \\
\hline
\end{tabular}

\subsubsection{Wolne wnioski}

W wolnych wnioskach padały najróżniejsze stwierdzenia, przy czym niemal każdy argument był równoważony przez kontrargument. Najliczniejsze były podziękowania za samo przeprowadzenie ankiety, jednak zdarzały się też głosy niezadowolonych z jej formy lub polemizujące z jej domniemanymi wynikami (wymówki w rodzaju - dlaczego tożsamość asyryjska jest jedyną ciągle kwestionowaną na świecie?), jak również neutralne sugestie stron internetowych i książek.

Obok odniesień do Boga, cytatów z Biblii (np. Drzemią pasterze twoi, [królu asyryjski]; zasnęli twoi mocarze - lud twój rozproszył się po górach, i nie ma, kto by [go] zgromadził ${ }^{13}$ ) i odwołań do szczególnej, mesjańskiej roli narodu asyryjskiego (bez którego świat nie przetrwa) lub aramejskiego (który mówi językiem Jezusa Chrystusa), pojawiały się opinie, że modły to strata czasu, gdyż należy działać. [Il. 27]

Oprócz nawoływania do zjednoczenia lub wręcz deklarowania swojego mieszanego, aramejsko-asyryjskiego pochodzenia (w grupie aramejskiej), obecne były wypowiedzi pokazujące nienawiść między Asyryjczykami a Aramejczykami, jak link do strony, gdzie można zobaczyć Aramejczyków palących asyryjską flagę ${ }^{64}$, czy uwagi, że badanej grupie tak naprawdę nie zależy na jedności.

${ }^{63}$ Ksiegga Nahuma 3,18.

${ }^{64}$ Syriac Burning Assyrian Flag - Aramäer brennen Assyrer Flagge, http://www.youtube. com/watch?v=nhuy-0wVq6A, data wejścia 14.01.2010. Wśród Asyryjczków pojawiły się 
Respondenci mieli także różne zdania co do tego, gdzie leży problem - jedni byli dumni ze swojej wspólnoty i uważali, że to zachodnie społeczeństwa powinny im pomóc, inni, że problem stanowią właśnie ich rodacy - kłótliwi i zazdrośni (pewien badany napisał, że jest dumny tylko $\mathrm{z}$ aramejskich świętych). Mimo tego rzadkością były wypowiedzi, z których można było wysnuć wniosek na temat krytycznego nastawienia autora lub autorki do powstającej na ich oczach konstrukcji tożsamości (wyjątkowo padały stwierdzenia, że analizowana mniejszość nie jest dość rozwinięta, by ją badać, lub że ich pobratymcy zafałszowują historię).

Cenna była uwaga respondenta, który zauważył, że jego rodacy doskonale wiedzą, co należy robić, aby zachować swoją tożsamość, a jednak nie są $\mathrm{w}$ to zaangażowani. Podobnie dużo wnosił wpis o poszukiwaniu równowagi między asymilacją a zachowaniem tożsamości - między poszanowaniem tradycji a nie byciem nią „obsesyjnie opętanym”, tak by nie zdyskredytować się w oczach społeczeństw przyjmujących. Innymi słowy, badany poszukiwał sposobu na zredukowania napięcia, które pojawia się przy próbie połączenia dwóch tożsamości - aspirującej, kosmopolitycznej oraz tradycyjnej, lokalnej.

\subsection{Analiza}

Mimo przeciwnej opinii dużej liczby badaczy, wielu Asyryjczyków i Aramejczyków postrzega swoją grupę w kategoriach narodu etnicznego, a tym samym uważa, że proces, który obecnie zachodzi, to „budzenie się narodu”. Niemal wszystkie elementy narodu-etnosu wyraźniej rysują się wśród podgrupy asyryjskiej: epos asyryjski sięga dalej w głąb historii (niemal siedem tysięcy lat wstecz), wydobywa z niej większą liczbę szacownych antenatów i barwnych legend, w większym stopniu kultywuje logos (język aramejski), silniej akcentuje genom (pochodzenie od starożytnych Asyryjczyków) i mocniej przeżywa topos (generalnie Asyria jest nośniejszą ideą niż AramNahrain). Jedynie etos, tj. sakralizacja norm i instytucji, zdaje się bardziej dotyczyć Aramejczyków, głęboko przywiązanych do Syryjskiego Kościoła Ortodoksyjnego. [Il. 28]

Ponieważ jednak każdy proces narodowotwórczy jest zarówno żywiołowy, jak i celowy, również w omawianym przypadku istnieją elity, które

głosy, że była to kurdyjska prowokacja, której to teorii nie wszyscy jednak dali wiarę, cyt. za: The Burning of the Assyrian flag by Kurds, http://www.betnahrain.org/bbs/index.pl/noframes/ $\mathrm{read} / 35559$, data wejścia 14.01.2010. 
częściowo lub w pełni świadomie starają się stworzyć narody asyryjski oraz aramejski, m.in. poprzez ukazywanie celowości powołania do życia własnego państwa, ewentualnie uzyskania chociażby autonomii. Należy przy tym zauważyć, że wielu Asyryjczyków i Aramejczyków dopiero w ostatnich dziesięcioleciach zdało sobie sprawę ze swej odrębności (faza izolacji), identyfikując znaczących Innych (np. Arabów, Kurdów i Turków). Trudności nastręcza natomiast faza integracji - do tej pory skutecznie blokuje ją rozbicie na frakcje asyryjską, aramejską oraz chaldejską. Choć powody rozbicia $\mathrm{w}$ największym stopniu spowodowane są różnicami $\mathrm{w}$ łonie samej wspólnoty, część jej członków dopatruje się działania demonicznych sił trzecich, nieraz snując teorie spiskowe. Jednocześnie rozbicie to poważnie blokuje „wyjście z tła”, to znaczy skuteczne występowanie na forum międzynarodowym. O tym, że wspólnota asyryjsko-aramejska znajduje się właśnie pomiędzy tymi dwoma fazami świadczy dodatkowo niepełna internalizacja symboli narodowych, co do których istnieje spora ambiwalencja, szczególnie wśród Aramejczyków.

Pamiętając o tym, że ideologia nacjonalizmu niekoniecznie musi zdążać w jakimś kierunku, można zaryzykować twierdzenie, iż nacjonalizm asyryjski w swym najbardziej świadomym wydaniu stawia sobie za cel stworzenie narodu asyryjskiego i zapewnienie mu własnego, niepodległego państwa, ewentualnie autonomii na Bliskim Wschodzie, natomiast nacjonalizm aramejski wyrasta jako swoista opozycja - aspiruje do stworzenia narodu aramejskiego, choć nie ma raczej ambicji związanych z państwowością.

Nacjonalizm asyryjsko-aramejski traktowany zbiorczo gatunkowo przypomina wschodnioeuropejski, tj. etniczno-językowy, co tłumaczy jego wewnętrzną konfliktogenność. Równolegle do nacjonalizmu w znaczeniu ideologii integracyjnej istnieją dawniejsze więzi klanowe i rodzinne, których w przypadku Asyryjczyków/Aramejczyków nie można zignorować - często identyfikacje "niższego rzędu” wygrywają bowiem z interesami na poziomie „narodowym”. Pamiętać należy o roli Kościołów orientalnych, które mimo osłabienia swojej pozycji, pozostają ważnymi dostarczycielami sensu i autoidentyfikacji. Jeśli zaś chodzi o nacjonalizm jako program polityczny, dążący do stworzenia państwa lub autonomii w Iraku bądź innym kraju bliskowschodnim, to dotyczy on wąskiej grupy badanych. W świetle nieistnienia państwa asyryjsko-aramejskiego jest to nacjonalizm oddolny, inicjowany przez intelektualistów i działaczy społecznych. 
Nacjonalizm asyryjsko-aramejski, jak każdy etnonacjonalizm, najlepiej rozkwita w czasie ucisku - stąd jego nasilenie po upadku reżimu Saddama Husajna. Wyjątkowo trudna sytuacja chrześcijan w Iraku ma przełożenie na ich współbraci w diasporze, stanowi impuls jeśli nie do działań, to choć do przemyśleń i dyskusji nad kondycją „narodową”. Wraz z wybuchem tzw. Arabskiej Wiosny w stabilnej przez ostatnie dekady Syrii swój stosunek do reżimu Baszszara al-Asada musieli określić miejscowi chrześcijanie ${ }^{65}$. Skutkiem ubocznym destablizacji Bliskiego Wschodu jest narastająca niechęć wobec muzułmanów oraz umacnianie przekonania o własnej wyższości - również wśród młodzieży asyryjskiej/aramejskiej, która żyjąc w diasporze, nigdy nie doświadczyła osobiście wrogości ze strony wyznawców islamu.

Najpoważniejszą alternatywą dla asyryjsko-aramejskiego nacjonalizmu są większe wspólnoty - narody, pośród których przyszło żyć Asyryjczykom/Aramejczykom; szczególnie niebezpieczny jest amerykański „tygiel”. Jak zauważa jeden z respondentów: „To wybór pomiędzy byciem członkiem nieistniejącego narodu a byciem obywatelem najpotężniejszego państwa na świecie”. Ponieważ patriotyzm jest pojęciem odrębnym od narodu, można być asyryjskim czy aramejskim nacjonalistą, jednocześnie będąc szwedzkim czy amerykańskim patriotą. W Kalifornii dzieci asyryjskich imigrantów przemaszerowały w koszulkach z napisem „100\% Assyrian” (100\% Asyryjczycy). Gdy córka jednego z badanych poszła do szwedzkiej szkoły w koszulce z flagą asyryjską, inne dziecko asyryjskie powiedziało: „To jest najpiękniejsza flaga na świecie”. Respondent pouczył wówczas córkę, że powinna czuć się szwedzką Asyryjką, zintegrowaną, ale nie zasymilowaną

Niemniej jednak trudno oczekiwać ślepego przywiązania do ojczyzny ideologicznej - zwanej bądź to Asyrią, bądź Aram-Nahrain - od osób legitymujących się amerykańskim lub zachodnioeuropejskim paszportem; najczęściej wykształcają oni złożoną tożsamość, gdzie jedną z warstw stanowi asyryjskość/aramejskość. Tym bardziej że młodzież asyryjska i aramejska poddawana jest różnorakim socjalizacjom - czasami wykluczają się one wzajemnie (np. liberalne zachowania, typowe dla amerykańskich nastolatków, przeważnie nie cieszą się aprobatą wychowanych na Bliskim

${ }^{65}$ Ciekawe rozważania na temat tego, co powinni zrobić Asyryjczycy w obliczu wojny domowej w Syrii - czy poprzeć rząd, czy wystąpić przeciw niemu zob. A. Sada, Should Assyrians in Syria Side with the Government or Against It?, „Assyrian Voice Emagazine”, http://assyrianvoice.net/emagazine/?p=638, data wejścia 7.08.2012.

${ }^{66}$ Wywiad z Asyryjczykiem z Iraku, doktorantem asyriologii na Uppsala Universitet, 27.06.2007. 
Wschodzie rodziców). Komunikaty płynące z domu, szkoły i Kościoła nie są tymi samymi; większość młodych Asyryjczyków/Aramejczyków szybko uczy się odnajdywać w sytuacjach wymagających od nich różnych autodefinicji (czemu częstokroć towarzyszy zmiana języka komunikacji).

Jednocześnie następuje mitologizacja historii, opowiedzenie jej w sposób nadający sens narodowym porażkom i wzlotom, z podkreśleniem zasług bohaterów. Zachowania patriotyczne definiuje się na podstawie ustalonych zagrożeń płynących ze strony „obcych”. Jak stwierdzono wcześniej, w przypadku Asyryjczyków/Aramejczyków rolę „obcych/Innych” często odgrywają bliskowschodni muzułmanie - Kurdowie, Turcy, Arabowie.

Proces mitologizacji zachodzi przede wszystkim w diasporze. Bezpieczna na poziomie materialnym, fizycznie oderwana od rdzennych ziem diaspora żyje wyidealizowanym wyobrażeniem utraconej ojczyzny. Dzięki nowoczesnym środkom masowego przekazu przekuwa swoje wizje w obrazy, które promieniują na całą wspólnotę, docierając także do rodaków zasiedlających rdzenne tereny. Podobnie politycy asyryjscy czy aramejscy cieszą się nieporównanie większą swobodą w diasporze, choć oczywiście regionalni liderzy także odgrywają pewną rolę (np. Sargis Agajan, będący ministrem finansów w Kurdyjskim Rządzie Regionalnym).

Tak długo jak diaspora pozostaje świadoma swojej diasporyczności, nie ulega pełnej integracji w kraju przyjmującym - pozostaje zawieszona między nim a tym, co utracone lub pozostawione w sensie geograficznym, ale też historycznym. Jednym z narzędzi jest dialektyka przypominania/zapominania w interpretacji andersonowskiej - wielu młodych Asyryjczyków i Aramejczyków nie „pamiętałoby” o tragicznych wydarzeniach Sejfo, gdyby nie ciagłe przypominanie o nich (pomniki, Centrum Sejfo). Istnieją przy tym dwie narracje - asyryjska i aramejska, które czasem konkurują na niwie martyrologii (kto został bardziej dotknięty przez los), a czasem łączą się i uzupełniają (holocaust asyryjsko-chaldejsko-syryjski). [Il. 30]

Narracja asyryjska chętnie wchłonęłaby całkowicie narrację aramejską, ta z kolei dąży do wyodrębnienia się i uniezależnienia. Intelektualiści asyryjsko-aramejscy dzielą się na zwolenników jednej lub drugiej opcji albo odmawiają opowiadania się po którejkolwiek ze stron, propagując jedną wspólną tożsamość. Istnieje relacja między tymi „ideologiami” a praktykami mas, obejmującymi szerokie spektrum zachowań - od wrogości i incydentalnych wybuchów agresji wewnątrzgrupowej do równie sporadycznego jednoczenia się w obliczu zagrożenia. Tym samym proces "flagowania” 
narodu czasem dotyczy Asyryjczyków, Chaldejczyków i Aramejczyków traktowanych łącznie, czasem zaś odnosi się do poszczególnych podgrup. Podobnie „banalny nacjonalizm” po części jednoczy, a po części różnicuje badaną wspólnotę, np. tradycyjna kuchnia bazuje na tych samych daniach (zróżnicowanych geograficznie), muzykę aramejską od asyryjskiej dzieli wąska granica samookreślenia wykonawców, jednak np. sport, a konkretnie istnienie dwóch odrębnych drużyn piłkarskich, przyczynia się w bardzo dużym stopniu do utrzymania podziału na Asyryjczyków i Aramejczyków.

Kontynuując wątek „banalnego nacjonalizmu” - jeśli chodzi o kulturę materialną, to w ostatnich latach następuje „wytwarzanie” narodu asyryjskiego także poprzez gadżety i przedmioty codziennego użytku: breloczki i krawaty z lamassu, plakaty, znaczki, koszulki, buty, kubki, torby, fartuchy, podkładki pod myszy z asyryjskimi symbolami, napisami, flagami (współczesną i historyczna), nawet ubranka dla psów obwieszczające światu, że właściciele tych czworonogów są Asyryjczykami. Wszystkie te przedmioty zostają więc nasycone treściami narodowymi, co według Edensora stanowi aspekt procesu przejścia od rytuału politycznego do rytuału komercyjnego. [Il. 31]

Podobne zjawisko, choć może na nieco mniejszą skalę, zachodzi w przypadku grupy aramejskiej. Najczęściej wykorzystywanym symbolem pozostaje flaga aramejska, ewentualnie tekst modlitwy „Ojcze Nasz” zapisanej po aramejsku. Zdarzają się też drukowane deklaracje: „Kocham (język) aramejski” (I love Aramaic). [Il. 32]

$\mathrm{Na}$ obecnym etapie naród asyryjski i/lub aramejski świadomie konstruowany jest przez relatywnie niewielką grupę ludzi, w skład której wchodzą jednak bardzo rozmaite podmioty - politycy, intelektualiści, pisarze, dziennikarze i kapłani. $\mathrm{Na}$ asyryjskich i aramejskich konferencjach pojawiają się przeważnie te same nazwiska. W sposób mniej świadomy, lecz równie istotny, do tej konstrukcji przyczyniają się sportowcy (szczególnie z Assyriskiej FF i Syrianskiej FC) oraz artyści (głównie piosenkarze). Odbiorcy asyryjscy/aramejscy nie zawsze pozostają bierni - wyrazem ich przemyśleń są chociażby wpisy na forach internetowych. Ich wpływ nie jest jednak zbyt wielki, to raczej wąska grupa zainteresowanych, rekrutujących się z elity, próbuje stworzyć asyryjski i/lub aramejski naród. Oczywiście w obrębie tej wąskiej grupy występuje płynność ról - wczorajsi odbiorcy mogą stać się dzisiejszymi nadawcami i vice versa.

Głównym sposobem konstruowania pozostaje reinterpretacja historii $\mathrm{w}$ duchu narodowym (historia traktowana jako budulec). Tematem 
wspólnym i łączącym Asyryjczyków oraz Aramejczyków jest Sejfo, tematem wspólnym, lecz antagonizującym - kwestia nazwy. Ta ostatnia z kolei związana jest z percepcją przodków i korzeni. Kolejny temat to relacje świeckich przywódców z Kościołem, a właściwie Kościołami - ukazywane bądź to jako współdziałanie, bądź konflikt na linii religia-naród. Odrębne wątki dyskursu stanowią relacje z innymi grupami wywodzącymi się z Bliskiego Wschodu, jak też „zdrada” przez Europejczyków lub szerzej Zachód. Wreszcie ważną kwestią (choć przez większość Asyryjczyków/Aramejczyków traktowaną jako utopia) jest możliwość stworzenia własnego państwa, ewentualnie sezonowych powrotów na rdzenne ziemie ${ }^{67}$.

W tym miejscu należy wspomnieć o tematach przemilczanych lub traktowanych zdawkowo, a są nimi np. napaści na muzułmanów w Szwecji ${ }^{68}$ oraz przemoc, której Asyryjczycy dopuścili się w aktach zemsty po Sejfo, jak również służąc w irackich Lewitach (podważają one wizję samych siebie jako wiecznych ofiar). Niewielu Asyryjczyków/Aramejczyków wie o ciemnych stronach życia i działalności uważanego za bohatera narodowego Aghi Petrosa, czy o kulisach zabójstwa patriarchy Mar Eszaja Szimuna. „Budzący się" naród nie potrzebuje ambiwalencji, ale świetlanych postaci przywódców i bohaterów o wyidealizowanych życiorysach.

Jeśli chodzi o style i figury retoryczne, to odnajdujemy tu wiele patosu, słownictwa religijnego, przywoływania imienia Boga, plastycznych metafor w stylu bliskowschodnim, wyrażeń emfatycznych, w przypadku Asyryjczyków także zapożyczeń z mitologii. Na przykład dziennikarz AINA, z którym korespondowałam, podpisywał się jako Sługa Asyrii (Servant of Assyria).

Ma to swoje odpowiedniki w przekazie wizualnym - chętne sięganie po elementy ze sztuki starożytnej Asyrii i Babilonii: lamassu, Gilgamesza, bramę Isztar, wiszące ogrody Semiramidy itp. W przypadku grupy aramejskiej wizualnym wyróżnikiem pozostaje flaga aramejska oraz symbolika związana z Syryjskim Kościołem Ortodoksyjnym. Obie podgrupy często korzystają z symboliki męczeńskiej - jak na obrazie upamiętniającym masakrę w Simele z 1933 roku: młoda kobieta w białej zakrwawionej sukni,

${ }^{67}$ Szczególnie Asyryjczycy zachęcają się nawzajem do kupowania posiadłości w Turcji, w swoich rodzinnych wioskach, i spędzania tam wakacji. Pojawiają się pomysły „rotacyjnego" przebywania w tych wsiach lub chociaż inwestowania w miejscowe przedsiębiorstwa asyryjskie w celu odzyskania więzi z ojczyzną. Cyt. za: http://www.assyrianvoice.net/forum/index.php?topic=36689.0, data wejścia 6.01.2010.

${ }^{68}$ Södertälje: Muslims Fee Assyrian Attacks, Islam in Europe, http://islamineurope.blogspot. com/2009/04/sodertalje-muslims-flee-assyrian.html, data wejścia 9.08.2010. 
z twarzą przykrytą krwawą chustą, przykuta do złamanej kolumny (odwróconego krzyża?) symbolizuje umęczony naród, nad którym unoszą się gołębie pokoju. Wartości estetyczne nie odgrywają tu żadnej roli, ważny jest ładunek emocjonalny. Na drugim z przedstawień widnieje Francis Szabo, członek ADM zabity w 1993 roku w Dahuku, przedstawiony jako męczennik strzeżony przez lamassu ${ }^{69}$. [Il. 33]

Stosunkowo łatwe jest wyśledzenie „wynalezionych tradycji” w obrębie wspólnoty asyryjskiej właśnie na poziomie wizualnym. Jedną z takich „tradycji” są stroje ubierane chociażby na Asyryjski Nowy Rok - bardzo luźno oparte na starożytnych (w rzeczywistości nikt nie wie, jak one wyglądały, projekty bazują na wyobrażeniach z reliefów). [Il. 34]

Drugą są asyryjskie kościoły - wznoszone zupełnie współcześnie na kształt budowli starożytnych, nawiązujące m.in. do Bramy Isztar w Babilonie ${ }^{70}$ czy Bramy Nergala w Niniwie ${ }^{71}$. Dla niezorientowanych w temacie owe podobieństwa architektoniczne mogą zdać się dowodem na ciągłość, tymczasem są one dowodem, tyle że na umacnianie się wspólnoty wyobrażonej. Zresztą uczęszczający do owych kościołów są przekonani o zasadności takiego kształtu, tym samym architektura sakralna przez odwołania do sztuki przedchrześcijańskiej zostaje zaprzęgnięta w służbę nacjonalizmu. [Il. 35]

Schematy argumentacyjne są ściśle związane z wyznawaną ideologią - asyryjską bądź aramejską (ewentualnie chaldejską), czasem podążają tropem „unionistycznym” (nawoływanie do zjednoczenia, zanim będzie za późno ${ }^{72}$ ). Jeśli chodzi o stereotypy, to najczęściej spotykany jest pozytywny autostereotyp własnej podgrupy, skontrastowany z negatywnym stereotypem podgrupy przeciwnej (przy czym częściej Aramejczycy upatrują w Asyryjczykach źródła zła, Asyryjczycy częściej ignorują dążenia Aramejczyków bądź traktują ich protekcjonalnie). W skład tego autostereotypu

${ }^{69}$ Jest on jednym z „bohaterów ADM, którzy poświęcili życie dla asyryjskiego ruchu narodowego”. Na stronie ADM znajduje się lista „męczenników” wraz z ich szkicowymi wizerunkami opatrzonymi logo Zowaa, http://www.atour.com/news/assyria/20031220a.html, data wejścia 14.01.2010.

${ }^{70}$ Na przykład kościół asyryjski pod wezwaniem św. Jerzego w Kamiszli, w Syrii, cyt. za: A. Flis, B. Kowalska, op. cit., s. 102.

${ }^{71} \mathrm{Na}$ przykład kościół asyryjski pod wezwaniem św. Józefa w Teheranie, w Iranie, cyt. za: Cyrus, Assyrian Church of Saint Joseph, Tehran, Iran, http://www.skyscrapercity.com/showthread.php?t=429802, data wejścia 10.01.2010.

${ }^{72}$ Por. konkluzja przemówienia Freda Aprima („Zjednoczeni przetrwamy, podzieleni upadniemy") wygłoszonego z okazji Genocide Awareness Day (Dnia Upamiętniającego Sejfo) w Kanadzie, http://christiansofiraq.com/Assygenocidecanada08.html, data wejścia 14.01.2010. 
wchodzi przekonanie o przynależności do „lepszej rasy”, o szczególnej, wyznaczonej przez Boga roli narodu asyryjskiego/aramejskiego, który stoi na straży pradawnej kultury i języka, o szlachetności, świętości, pracowitości, waleczności bądź pacyfizmie (w zależności od wymogu chwili) jego synów i córek. W przypadku „unionistów” lub osób o tożsamości hybrydowej często obecne są uprzedzenia wobec innych grup etnicznych, takich jak Turcy czy Kurdowie, którzy niejednokrotnie przedstawiani są jako chciwi, pozbawieni skrupułów i wyższych uczuć, brutalni, okrutni, destrukcyjni itp.

Jeśli chodzi o miejsce, czas i okoliczności, w jakich dochodzi do formułowania i przekazywania kulturowych reprezentacji narodu, to w coraz większym stopniu dzieje się to w cyberprzestrzeni - rzeczywiste konferencje, które odbywają się w Europie bądź Ameryce, wraz z wygłoszonymi na nich hasłami, w Internecie zyskują drugie życie. W wygładzonej i skondensowanej wersji docierają do asyryjskich i aramejskich odbiorców na podobieństwo fal - czasem niemal natychmiast, czasem po paru godzinach, dniach, miesiącach, a nawet latach. Ci, którzy mogą odbierać asyryjską/aramejską telewizję, w jeszcze większym stopniu wystawieni są na wpływ owych reprezentacji, które działają najsilniej, jeśli są osadzone w kontekście ojczyzny ideologicznej i w dramatycznych okolicznościach.

Asyryjczycy/Aramejczycy, podobnie jak wiele innych grup etnicznych, nieszczęścia spadające na ich współbraci w przeszłości i obecnie wykorzystują do podtrzymywania swojej odmienności, co wpisuje się w kategorię „trajektorii” Fritza Schützego, według której bezładne procesy społeczne wypełnione cierpieniem są interpretowane jako dowód na własną narodową bądź etniczną wyjątkowość. Ma to związek ze specyficznym rodzajem myślenia mitycznego, gdy mit symboliczny zostaje zastąpiony przez mit socjo-polityczny. Ten ostatni ma za zadanie podtrzymywać poczucie sensowności świata - w omawianym przypadku wskazując na konieczność powrotu na rdzenne ziemie, choć znakomita większość Asyryjczyków i Aramejczyków nie wierzy w taką możliwość ${ }^{73}$. [Il. 36]

Uderzają paralele do sytuacji Żydów sprzed stworzenia państwa Izrael $^{74}$ - obie grupy charakteryzują: bogata kultura, własny język, prześladowania i holocaust jako doświadczenia spajające ${ }^{75}$. Dodatkowo współczesny świat

\footnotetext{
${ }^{73}$ Por. M. Al-Rasheed, op. cit., s. 81.

${ }^{74}$ Analogie zauważają zresztą sami Asyryjczycy/Aramejczycy - część uważa, że należy wzorować się na Żydach, część podkreśla, iż w żadnym wypadku nie powinno się ich naśladować.

${ }^{75}$ N. Maraha, The Vioce and Myth of Gabriel Afram, http://www.bethsuryoyo.com/ articles/MalfonoGabrielAfram/MalfonoGabrielAfram.html, data wejścia 9.01.2010.
} 
kurczy się, granice państwowe przestają odgrywać taką rolę jak niegdyś, środki masowego przekazu zbliżają członków wspólnoty, kreując w nich przeświadczenie o dzieleniu tej samej tożsamości.

Jednak analogia do narodu żydowskiego nie jest całkowita - niezwykle istotnym aspektem jest bowiem czynnik czasu. Państwo żydowskie powstało w wyjątkowym momencie, można powiedzieć, że wykorzystało swoją historyczną szansę. Trudno sobie wyobrazić, aby obecnie społeczność międzynarodowa dopuściła do powstania jeszcze jednego tworu państwowego w tym tak konfliktogennym regionie, jakim jest Bliski Wschód. Poza tym większość Asyryjczyków/Aramejczyków zdaje sobie sprawę z zagrożeń płynących z osiedlenia się na tych terenach, jak też z trudności w rządzeniu państwem bez wyszkolonych kadr i wypracowanych procedur. Ponad połowę pierwszego Knesetu w Izraelu stanowili aszkenazyjscy Żydzi, którzy mieli okazję zapoznać się ze sposobami rządzenia w Europie, gdzie w latach międzywojennych należeli do różnych partii. Asyryjczycy/Aramejczycy o takich kwalifikacjach to jednostki. Żydów z Europy wygnał holocaust, ci Asyryjczycy/Aramejczycy, którzy schronili się na Zachodzie, wreszcie są bezpieczni. Pragną być członkami krajów, w których żyją, a z drugiej strony zachować swoje dziedzictwo ${ }^{76}$.

W tym miejscu należy zauważyć, że państwa przyjmujące mają różne modele asymilacji. Według jednego z moich rozmówców w Europie dominują dwa modele: łaciński (obowiązujący w krajach frankofońskich, tj. Francji, Belgii) oraz niemiecki (według niego funkcjonujący też w Szwecji). Model łaciński polega na tym, że pełna asymilacja jest tylko kwestią czasu; poprzez przymusową naukę francuskiego „roztopienie” w społeczeństwie miejscowym następuje relatywnie szybko. Natomiast model niemiecki obrazuje metafora pociaggu - poszczególne wagony to etniczne grupy żyjące oddzielnie i połączone jedynie w niewielkim stopniu, szanujące się nawzajem, ale raczej niemieszające się ze sobą. Szwedzka polityka jest z kolei wynikiem porażki na polu asymilacji imigrantów, tak niegdyś potrzebnych (na co dowodem są specjalne osiedla budowane dla przybyszy, takie jak Södertälje) ${ }^{77}$.

Nie można przy tym generalizować, imigranci bowiem wywodzą się z różnych kultur i środowisk. Imigranci europejscy najczęściej szybko się

${ }^{76}$ Por. M. Al-Rasheed, op. cit., s. 81.

77 Wywiad z dwoma przedstawicielami Assyrian Democratic Movement, Szwecja, 29.06.2007. 
asymilują (różnice kulturowe nie są zbyt duże), zupełnie inaczej niż pozaeuropejscy i najczęściej niechrześcijańscy przybysze. Asyryjczycy/Aramejczycy na tej skali szybkości asymilacji znajdują się pośrodku - nie są Europejczykami, ale są chrześcijanami. Ten pierwszy element opóźnia asymilację, drugi ją przyspiesza. Czynnikiem hamującym jest również postawa Europejczyków, przywiązanych do idei swoich państw narodowych i narodów jako wspólnot krwi. Zupełnie inna sytuacja ma miejsce chociażby w Brazylii, do której emigracja nastąpiła sto lat temu, w innych historycznych uwarunkowaniach, gdzie społeczeństwo przyjmujące było i jest chętne „przygarnąć” Asyryjczyków/Aramejczyków - tam asymilacja zachodzi szybko. Stany Zjednoczone również stanowią swoisty „tygiel”, jednak amerykańscy Asyryjczycy/Aramejczycy dysponują siecią kościołów i klubów, które starają się chronić ich tożsamość ${ }^{78}$.

Bez względu na kraj zamieszkania znakomitą większość Asyryjczyków/ Aramejczyków charakteryzuje lęk przed islamem i jego wyznawcami. W czasie wywiadów pojawiał się kilkakrotnie wątek Europy niedostrzegającej muzułmańskiego zagrożenia, słabej moralnie, nieoferującej atrakcyjnego chrześcijaństwa ${ }^{79}$. Jeden respondent stwierdził otwarcie, że islam ma strategię - rozmnażać się i islamizować. Drugi miał za złe Szwedom, że nalegają, by wszystkich traktować jak „ludzi”, choć muzułmanie wcale nie traktują chrześcijan na Wschodzi jak „ludzi”, wręcz przeciwnie, traktują ich z góry („mają inną mentalność - oko za oko, ząb za ząb, a nie - jak chrześcijanie - nadstaw drugi policzek") ${ }^{80}$. Strach i rozgoryczenie badanych są symptomatyczne dla budowania tożsamości przez opozycję - w odróżnieniu od tożsamości opartej na akceptacji, choć z pewnością respondenci nie negują wszystkiego (np. nie podważają wartości dobrodziejstw, z których korzystają na Zachodzie).

Bardzo przydatne dla zrozumienia zagadnienia asyryjskiej/aramejskiej tożsamości są niektóre rozważania Amina Maaloufa. Większość Asyryjczyków/Aramejczyków posiada bowiem wiele różnych przynależności, spośród których częstokroć najbardziej cenią właśnie ów asyryjski bądź aramejski komponent. Mimo tego grupie jako całości w większym stopniu grozi asymilacja niż zepchnięcie w „tożsamość plemienną" (choć i takiej opcji

${ }^{78}$ Ibidem.

${ }^{79}$ Wywiad z Özmanem Denho, Szwecja, 30.06.2007.

${ }^{80}$ Wywiad z Asyryjczykiem z Syrii, wolontariuszem w „Suroyo TV”, Szwecja, 30.06.2007. 
- przynajmniej w stosunku do pewnych jednostek - wykluczyć nie można). Maalouf optymalnego rozwiązania szuka w pogłębianiu „dziedzictwa poziomego", pochodzącego od współczesnych jednostce. Większość młodych Asyryjczyków/Aramejczyków mieszkających w diasporze ochoczo pogłębia swe „dziedzictwo poziome”, co naraża ich jednak na utratę „dziedzictwa pionowego".

Według Maaloufa panaceum na „plemienne, zabójcze tożsamości” mają stanowić szersze tożsamości, chociażby „tożsamość bliskowschodnia” czy „tożsamość globalna”. Ta pierwsza idea nie ma szansy zyskać popularności wśród większości Asyryjczyków/Aramejczyków, którzy w obawie o swoje życie emigrują z Bliskiego Wschodu. Natomiast druga idea, choć znajduje zwolenników pośród pojedynczych Asyryjczyków/Aramejczyków ${ }^{81}$, jest zbyt abstrakcyjna i futurystyczna, by mogła stanowić poważną alternatywę dla obecnego „tożsamościowego przekładańca”.

81 „Jestem zupełnie zadowolony z nazywania Ziemi swoim domem” - pisze asyryjski internauta o nicku ultoMa na forum http://www.assyrianvoice.net/forum/index.php?topic $=36689.0$, data wejścia 6.01.2010. 


\section{Zakończenie}

Przyjęcie chrześcijaństwa przez syryjską populację imperiów rzymskiego i perskiego zaznaczyło początek wyróżnienia się wspólnoty, która dziś znana jest pod postacią różnych wyznań aramejskojęzycznych. Asyryjski Kościół Wschodu odegrał decydującą rolę w kształtowaniu się tożsamości wschodnich Syryjczyków (Asyryjczyków), zaś Syryjski Kościół Ortodoksyjny - zachodnich Syryjczyków (Aramejczyków). Do XIX wieku patriarchowie byli także przywódcami politycznymi, sytuacja zmieniła się po I wojnie światowej, gdy wyrośli pierwsi liderzy świeccy, którzy do tradycyjnej tożsamości wyznaniowej dodali nowe elementy: język, kulturę, postrzeganą etniczność oraz pamięć historyczną ${ }^{1}$.

Interakcje z Europejczykami, ich polityczne i edukacyjne zaangażowanie w regionie, nasiliły poczucie wyjątkowości Asyryjczyków, a elity zapoznały z teoriami narodowościowymi, choć to wykopało przepaść między nimi a ich sąsiadami i zaowocowało wybuchem wrogości muzułmańskiej podczas I wojny światowej. Asyryjczycy poparli aliantów, zostali zdziesiątkowani, wyrzuceni ze swych domów, pozbawieni dobytku, wreszcie znaleźli się jako uchodźcy w Iraku. Zachowali jednak solidarność grupową - połączyli wspomnienia górali i ludzi z nizin, dodali nowe formy kulturowego wyrazu. Pieśni, historie i wspólne modły w obozowych kościołach zbliżyły ich do siebie. Mimo późniejszego rozproszenia, ziarna etnicznej świadomości kiełkowały, powoli rozsadzając tożsamość milletową2.

Tymczasem Iran, Irak i Turcja zaczęły budować swoje narody, ich cel stanowiły modernizacja i unifikacja. Asyryjczycy nie chcieli się łatwo podporządkować (czego wyraźnym znakiem byli Lewici), powodując resentyment władz i stawiając pod znakiem zapytania swoją przyszłość. W tym okresie żyli pod auspicjami rodziny patriarszej. Liderzy świeccy zawiedli jako alternatywa, zaś patriarcha asyryjski, wziąwszy na siebie główną od-

\footnotetext{
${ }^{1}$ A. I. Laing-Marshall, op. cit., s. 127.

${ }^{2}$ Ibidem, s. 128.
} 
powiedzialność reprezentowania wspólnoty na forum międzynarodowym, żądał „praw narodowych”, choć chodziło mu raczej o powrót do milletu ${ }^{3}$.

Po II wojnie światowej pojawiły się dwie nowości - pierwszą był trend do polityki asymilacyjnej $\mathrm{w}$ tradycyjnych ojczyznach, wzbogaconych przez przychody z wydobycia ropy, tym samym dysponujących większą siłą nacisku. Asyryjczycy, mimo samoograniczenia, stali się celem restrykcji. Druga nowość polegała na masowej emigracji do chrześcijańskich krajów Zachodu, co naraziło wspólnotę na załamanie ricoeurowskiej l’ipséité (różnicy względem innych) ${ }^{4}$, ale też zapewniło dostęp do wolności i środków komunikacji. To przeformułowało tożsamość ${ }^{5}$ na bardziej świecką. Asyryjczycy na Zachodzie i Asyryjczycy na Wschodzie zaczęli funkcjonować jako równoległe, czasem rywalizujące centra świadomości i życia, choć jedni i drudzy czerpali z kompensacyjnego mitu powrotu do utraconych ziem ${ }^{6}$. Podczas gdy Asyryjczycy na Bliskim Wschodzie wyraźnie dzielili się na irackich, irańskich, tureckich i syryjskich, Asyryjczycy w diasporze zaczęli się mieszać i upodabniać do siebie. Wtedy jednak zaostrzył się podział na Asyryjczyków i Aramejczyków oraz Chaldejczyków, podział, który zamiast zatrzeć się z czasem, zaczął nabierać coraz większego znaczenia.

Tożsamość asyryjsko-aramejska przeszła ewolucję od milletu - religijnej wspólnoty z językowymi i etnicznymi rysami, definiowanej na bazie teologii - do etnicznej wspólnoty ze wspólnym językiem, krwią i dziedzictwem. Kościoły raz pomagały, raz szkodziły w tej nowej formacji. Owe interakcje, nieraz burzliwe, pokazują skomplikowane więzi między tożsamością religijną a narodową, która, co należy zaznaczyć, nie jest akceptowana przez wszystkich zainteresowanych ${ }^{7}$. Dla wielu Asyryjczyków/Aramejczyków pojęcie „narodu” jawi się jako abstrakcyjne, ciągle żyją bowiem w rzeczywistości rodzinnej, klanowej oraz wyznaniowej. Młodzi chca jednak być postrzegani jako Asyryjczycy lub Aramejczycy, uważają, że mają prawo identyfikować się w kategoriach narodowych, i to mimo przeciwnej opinii wielu naukowców ${ }^{8}$. Na myśl przychodzą tu słowa Taylora, że „świat płynnej tożsamości to świat, w którym uznanie okazuje się najwyższą stawką" 9 .

${ }^{3}$ Ibidem, s. $128-129$.

${ }^{4}$ Z. Bauman, Dwa szkice..., s. 9.

${ }^{5}$ A. I. Laing-Marshall, op. cit., s. 129.

${ }^{6}$ Por. F. Deniz, op. cit., s. 481.

${ }^{7}$ A. I. Laing-Marshall, op. cit., s. 130.

${ }^{8}$ F. Deniz, op. cit., s. 484.

${ }^{9} \mathrm{Za}$ J. Karczewska, Odkrywanie wielokulturowości i wspótczesne ideologie. Rozważania wstępne [w:] M. Kempy A. Kapciak, S. Łozińska (red.), U progu wielokulturowości. Nowe oblicza społeczeństwa polskiego, Warszawa 1997, s. 41. 
Podobnie jak niezliczone inne wspólnoty, współcześni Asyryjczycy/Aramejczycy pragną zewnętrznego uznania dla swej nowo powstającej tożsamości narodowej ${ }^{10}$. Poważną przeszkodą w jej konstruowaniu jest brak konsensusu, czy ma ją tworzyć naród asyryjski, aramejski, chaldejski, czy będący hybrydą wszystkich powyższych. Jeśli każda z wymienionych grup będzie konsekwentnie realizowała swój program budowy narodu poprzez wymyślane przez siebie i propagowane różnymi kanałami teorie, to mogą skończyć jako dwie czy nawet trzy oddzielne polityczne całości ${ }^{11}$, lub - w najgorszym scenariuszu - zniknąć i roztopić się w globalnym tyglu. Tymczasem jednak to, co trwa i umacnia się, to „wirtualna Asyria”, głoszona przez zwolenników asyrianizmu, a przez wyznawców arameizmu postrzegana jako zagrożenie dla przyszłej egzystencji ludzi, którzy sami siebie określają jako Surjoje $e^{12}$.

Zresztą elity, zarówno asyryjskie, jak i aramejskie są wewnętrznie zantagonizowane. Tradycyjni przywódcy i kler mają inne koncepcje niż współcześni intelektualiści i artyści ${ }^{13}$. Wszyscy oni starają się za pomocą mediów, w tym Internetu, kształtować przeszłość wyobrażoną lub raczej przeszłości wyobrażone. Dotarcie do historycznej prawdy wymaga wysiłku, czasem podważenia istniejących paradygmatów. Jednak wszelka wiedza społeczna jest refleksyjna, co wynika także z tego, że podmiot poznania nauk społecznych jest zarazem integralną częścią przedmiotu. Wyniki badań i teorie są przyswajane przez członków społeczeństwa, w tym przypadku przez Asyryjczyków/Aramejczyków, wpływają na ich wiedzę, postawy i odczucia, a tym samym przyczyniają się do zmiany relacji społecznych.

Pomimo stosunkowo małej liczebności wspólnoty asyryjsko-aramejskiej na scenie międzynarodowej, badania jej współczesnej tożsamości pozwalają na poczynienie pewnych istotnych obserwacji co do dynamiki nacjonalizmu oraz narodowych filiacji wraz z poprzedzającymi je wspólnotowymi wyobrażeniami, jak również znaczenia stosunków pomiędzy większościami a mniejszościami dla rozwoju historii. W odniesieniu do budzenia się świadomości typu narodowego czerpała ona z wielu takich samych elementów konstrukcyjnych w różnych wiekach, choć różnie je składała w odpowiedzi na zmieniające się okoliczności ${ }^{14}$. Mimo że nie do końca można mówić

\footnotetext{
${ }^{10}$ A. I. Laing-Marshall, op. cit., s. 22.

${ }^{11} \mathrm{~J}$. Messo, The Identity..., s. 9.

12 Ibidem, s. 3.

${ }^{13}$ F. Deniz, op. cit., s. 472.

${ }^{14}$ A. I. Laing-Marshall, op. cit., s. 5.
} 
o świadomej i konsekwentnie wdrażanej strategii przetrwania, to z pewnością Asyryjczycy i Aramejczycy starają się jakoś odpowiedzieć na wyzwania współczesności - świadczą o tym chociażby ich kluby, oferujące programy edukacyjne i kursy językowe, czy drużyny sportowe ${ }^{15}$.

Opisywane nacjonalizmy - zarówno asyrianizm, jak i arameizm - są nacjonalizmami mniejszościowymi. Tak jak wszystkie inne nacjonalizmy, zarówno łączą, jak i dzielą. Nic nie zapowiada ich rychłego końca. Rację ma Smith, gdy pisze: „Dziś tożsamość narodowa jest główną formą zbiorowej identyfikacji. Jakiekolwiek byłyby odczucia jednostek, zapewnia dominujące kryteria kultury i tożsamości, samą podstawę rządu oraz główny cel społecznej i ekonomicznej działalności” ${ }^{16}$. Z drugiej strony, wszystko wskazuje na to, że państwo narodowe jako pewien projekt polityczny i kulturowy znajduje się w odwrocie w otoczeniu determinowanym przez procesy globalizacyjne ${ }^{17}$.

Tragedia Asyryjczyków/Aramejczyków polega na tym, że domagają się uznania swej tożsamości narodowej w momencie kryzysu państw narodowych, gdy bardziej niż kiedykolwiek w ciągu swej długiej historii narażeni są na asymilację. I choć posiadanie własnej ziemi nie jest dla nich tak ważne, jak bycie szanowanymi, chronionymi i niedyskryminowanymi, to z pewnością brak ojczyzny nie ułatwia procesu nacjogenezy. W dobie globalizacji wykształceni i władający językami Asyryjczycy i Aramejczycy mogą bez przeszkód poruszać się po świecie, ale nie są uznawani za odrębny naród - na czym im zależy. Paradoksalnie, w sile tego niezrealizowanego pragnienia upatruję szansy na zachowanie przez nich odrębności i przekucia jej w niekwestionowaną tożsamość narodową. Współcześni Asyryjczycy oraz Aramejczycy stoją dziś na rozdrożu. Od nich samych w największym stopniu zależy, czy wspólnota międzynarodowa ujrzy w nich naród jeszcze w XXI wieku.

${ }^{15}$ Por. F. Deniz, op. cit., s. 481.

${ }^{16}$ A. D. Smith, National Identity..., s. 170.

${ }^{17}$ M. Kwiek, Demokracja a państwo narodowe, „Decydent. Pismo Lobbingowe”, nr 7-8/2001. 



\section{Spis tabel}

Tabela 1. Kraje pochodzenia respondentów asyryjskich ................................. 169

Tabela 2. Kraje pochodzenia respondentów aramejskich ................................. 170

Tabela 3. Kraje zamieszkania respondentów asyryjskich................................. 171

Tabela 4. Kraje zamieszkania respondentów aramejskich ............................... 172

Tabela 5. Struktura zawodowa respondentów asyryjskich

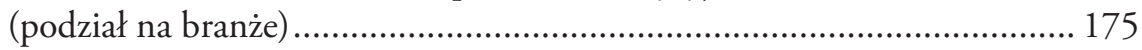

Tabela 6. Struktura zawodowa respondentów aramejskich

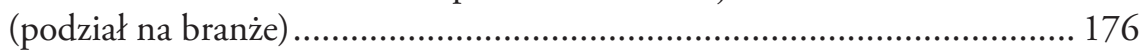

Tabela 7. Kraje pochodzenia matek respondentów asyryjskich ........................ 177

Tabela 8. Kraje pochodzenia matek respondentów aramejskich ..................... 178

Tabela 9. Kraje pochodzenia ojców respondentów asyryjskich ....................... 178

Tabela 10. Kraje pochodzenia ojców respondentów aramejskich.................... 179

Tabela 11. Kraje pochodzenia partnerów respondentów asyryjskich................ 181

Tabela 12. Kraje pochodzenia partnerów respondentów aramejskich ............. 182

Tabela 13. Asyryjskie strony internetowe ........................................................ 211

Tabela 14. Aramejskie strony internetowe...................................................... 213

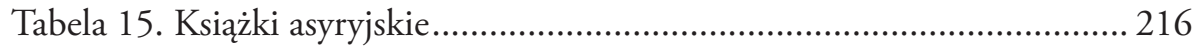

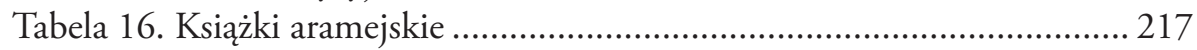

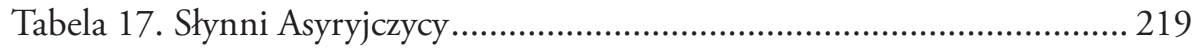

Tabela 18. Słynni Aramejczycy ………....................................................... 220

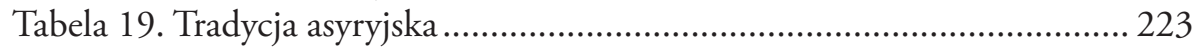

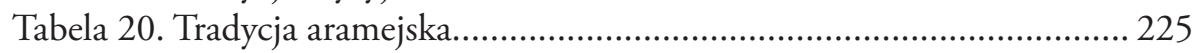

Tabela 21. Sposoby pielęgnowania tradycji asyryjskiej.................................. 230

Tabela 22. Sposoby pielęgnowania tradycji aramejskiej ................................. 231

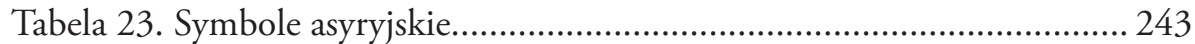

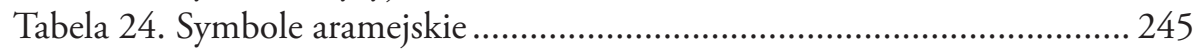

Tabela 25. Sposoby zachowania tożsamości asyryjskiej................................ 260

Tabela 26. Sposoby zachowania tożsamości aramejskiej ................................. 261 



\section{Spis wykresów}

Wykres 1. Rozkład płci wśród respondentów asyryjskich i aramejskich......... 167

Wykres 2. Histogram respondentów asyryjskich ......................................... 168

Wykres 3. Histogram respondentów aramejskich......................................... 168

Wykres 4. Wykształcenie respondentów asyryjskich i aramejskich.................. 173

Wykres 5. Struktura zawodowa respondentów asyryjskich ............................ 174

Wykres 6. Struktura zawodowa respondentów aramejskich............................ 175

Wykres 7. Stan cywilny respondentów asyryjskich i aramejskich................... 180

Wykres 8. Pochodzenie partnerów respondentów asyryjskich i aramejskich .. 184

Wykres 9. Dzieci respondentów asyryjskich i aramejskich............................... 184

Wykres 10. Czynniki decydujące o asyryjskiej tożsamości .............................. 186

Wykres 11. Czynniki decydujące o aramejskiej tożsamości ............................ 187

Wykres 12. Znajomość klasycznego syryjskiego przez respondentów asyryjskich

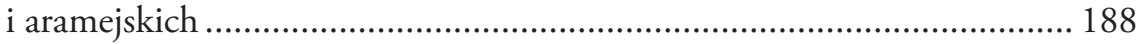

Wykres 13. Stopień opanowania klasycznego syryjskiego przez respondentów asyryjskich i aramejskich ..................................................................... 188

Wykres 14. Znajomość aramejskiego przez respondentów asyryjskich i aramejskich

Wykres 15. Stopień opanowania aramejskiego przez respondentów asyryjskich i aramejskich

Wykres 16. Znajomość dialektów aramejskiego przez respondentów asyryjskich i aramejskich

Wykres 17. Sposoby nauczenia się aramejskiego przez respondentów asyryjskich i aramejskich

Wykres 18. Język komunikacji z rodzicami respondentów asyryjskich i aramejskich

Wykres 19. Języki komunikacji z rodzicami respondentów asyryjskich........... 192

Wykres 20. Języki komunikacji z rodzicami respondentów aramejskich ......... 192

Wykres 21. Język komunikacji z dziadkami respondentów asyryjskich i aramejskich 
Wykres 22. Języki komunikacji z dziadkami respondentów asyryjskich.......... 193

Wykres 23. Języki komunikacji z dziadkami respondentów aramejskich ........ 194

Wykres 24. Język komunikacji z rodzeństwem respondentów asyryjskich i ara-

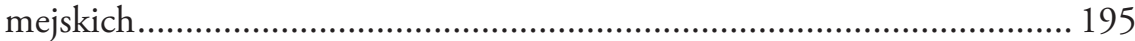

Wykres 25. Języki komunikacji z rodzeństwem respondentów asyryjskich .... 195

Wykres 26. Języki komunikacji z rodzeństwem respondentów aramejskich... 195

Wykres 27. Język komunikacji w szkole/pracy respondentów asyryjskich i ara-

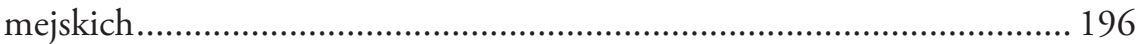

Wykres 28. Języki komunikacji w szkole/pracy respondentów asyryjskich..... 196

Wykres 29. Języki komunikacji w szkole/pracy respondentów aramejskich ... 197

Wykres 30. Język komunikacji w innych sytuacjach respondentów asyryjskich

i aramejskich

Wykres 31. Języki komunikacji w innych sytuacjach respondentów asyryjskich

Wykres 32. Języki komunikacji w innych sytuacjach respondentów aramejskich

Wykres 33. Języki, w których piszą respondenci asyryjscy …........................... 199

Wykres 34. Języki, w których piszą respondenci aramejscy............................. 200

Wykres 35. Języki, w których czytają respondenci asyryjscy ............................ 201

Wykres 36. Języki, w których czytają respondenci aramejscy........................... 201

Wykres 37. Języki, w których myślą respondenci asyryjscy............................. 202

Wykres 38. Języki, w których myślą respondenci aramejscy ........................... 202

Wykres 39. Czytelnictwo gazet asyryjskich i aramejskich ............................... 204

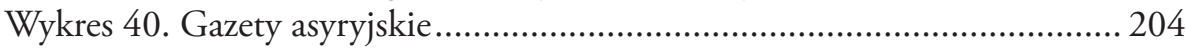

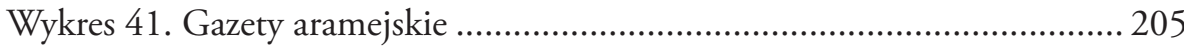

Wykres 42. Oglądalność telewizji asyryjskiej i aramejskiej............................. 206

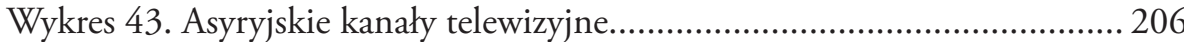

Wykres 44. Aramejskie kanały telewizyjne ..................................................... 207

Wykres 45. Słuchalność radia asyryjskiego i aramejskiego .............................. 209

Wykres 46. Asyryjskie rozgłośnie radiowe ………........................................... 209

Wykres 47. Aramejskie rozgłośnie radiowe ................................................... 210

Wykres 48. Odwiedzanie asyryjskich i aramejskich stron internetowych....... 211

Wykres 49. Czytelnictwo asyryjskich i aramejskich książek............................ 215

Wykres 50. Znajomość sławnych rodaków przez respondentów asyryjskich i ara-

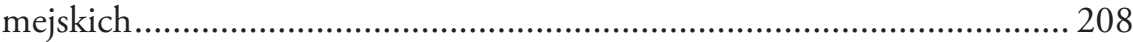

Wykres 51. Istotność tradycji asyryjskiej i aramejskiej................................. 226

Wykres 52. Asyryjskie i aramejskie muzyka i taniec ................................... 227

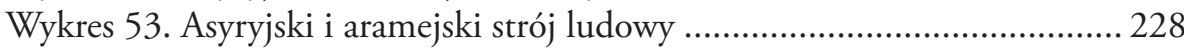

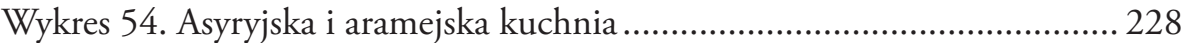

Wykres 55. Asyryjskie i aramejskie przysłowia i mądrości ludowe .................. 228 
Wykres 56. Asyryjskie i aramejskie mity i legendy 229

Wykres 57. Przestrzeganie tradycji w rodzinach asyryjskich i aramejskich ..... 229

Wykres 58. Znajomość asyryjskiej i aramejskiej historii rodzinnej................. 232

Wykres 59. Okazje do asyryjskich spotkań.................................................... 233

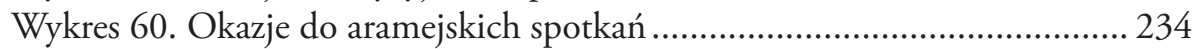

Wykres 61. Istotność świąt dla respondentów asyryjskich i aramejskich ........ 234

Wykres 62. Znaczenie świąt dla respondentów asyryjskich............................ 235

Wykres 63. Znaczenie świąt dla respondentów aramejskich .......................... 235

Wykres 64. Przynależność religijna respondentów asyryjskich........................ 236

Wykres 65. Przynależność religijna respondentów aramejskich ..................... 237

Wykres 66. Religijność respondentów asyryjskich i aramejskich...................... 238

Wykres 67. Nasilenie praktyk religijnych wśród respondentów asyryjskich i aramejskich......

Wykres 68. Zainteresowanie życiem rodaków wyrażane przez respondentów asyryjskich i aramejskich

Wykres 69. Geograficzne rozłożenie zainteresowania życiem rodaków wyrażane-

go przez respondentów asyryjskich i aramejskich

Wykres 70. Poparcie dla asyryjskich i aramejskich organizacji........................ 246

Wykres 71. Poparcie dla asyryjskich i aramejskich klubów sportowych ......... 247

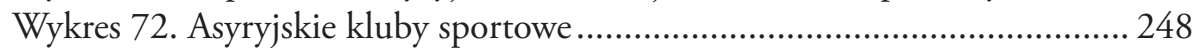

Wykres 73. Aramejskie kluby sportowe …………........................................ 249

Wykres 74. Poziom integracji respondentów asyryjskich.............................. 250

Wykres 75. Poziom integracji respondentów aramejskich .............................. 251

Wykres 76. Świadomość pochodzenia respondentów asyryjskich

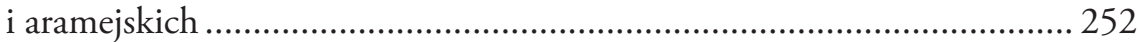

Wykres 77. Poczucie szczęścia z przynależności do wspólnoty asyryjskiej

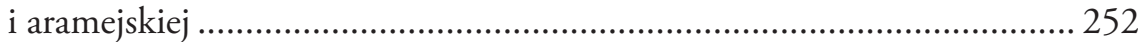

Wykres 78. Pochodzenie od starożytnych imienników - Asyryjczyków i Aramejczyków

Wykres 79. Poczucie przynależności do rdzennych ziem - Asyrii i Aram-Nahrain

Wykres 80. Indywidualne dociekania historii przodków przez respondentów asyryjskich i aramejskich 254

Wykres 81. Preferowanie tradycyjnej kuchni, muzyki, zwyczajów przez respon-

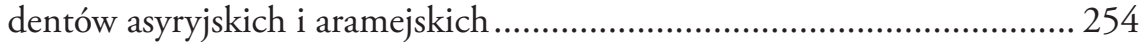

Wykres 82. Duma ze wspólnoty asyryjskiej i aramejskiej ............................. 255

Wykres 83. Zagrożenia dla tożsamości asyryjskiej ...................................... 256

Wykres 84. Zagrożenia dla tożsamości aramejskiej...................................... 257

Wykres 85. Istotność zachowania asyryjskiej i aramejskiej tożsamości ........... 258 



\section{Spis ilustracji}

Ilustracja 1. Mar Emmanuel III Delly, Mar Dinkha IV, Ignatius Zakka I Iwas http://de.academic.ru/pictures/dewiki/80/Patriarch.jpg, http://churchoftheeast-

flint.org/sitebuildercontent/sitebuilderpictures/, http://www.zindamagazine. com/iraqi_documents/doc_graphics/image019.jpg.

Ilustracja 2. Mar Eszaj Szimun, Surma Chanum http://www.aina.org/books/fla/3f70d24e.jpg, http://upload.wikimedia.org/wikipedia/commons/thumb/0/0a/Lady_Surrma.jpg/759px-Lady_Surrma.jpg.

Ilustracja 3. Lewici

http://assyrianlevies.info/uploads/3/2/5/0/3250046/8447147_orig.jpg, http://assyrianlevies.info/uploads/3/2/5/0/3250046/4847220_orig.jpg, http://assyrianlevies.info/attachments/Image/Odisho_Moshe.jpg.

Ilustracja 4. Klasztor Mor Gabriel http://upload.wikimedia.org/wikipedia/commons/6/61/Morgabrieltowers.jpg, http://en.wikipedia.org/wiki/Mor_Gabriel_Monastery\#mediaviewer/File:Deyrulumur_P1040804_20080425103239.JPG.

Ilustracja 5. Zniszczony kościół w Iraku http://www.aina.org/images/church10.jpg.

Ilustracja 6. Okładki magazynów „Zinda” i „Funoyo” http://www.zindamagazine.com, http://www.zindamagazine.com/html/archives/2005/12.17.05/pix/Funoyo.jpg.

Ilustracja 7. Okładka „Bahro Suryoyo” http://profile.ak.fbcdn.net/hprofile-ak-snc4/27521_363339854021_5721_n. jpg. 
Ilustracja 8. Logo „Suroyo TV”

http://upload.wikimedia.org/wikipedia/en/thumb/2/23/Suroyo_TV_Logo. jpg/799px-Suroyo_TV_Logo.jpg.

Ilustracja 9. Logo „Suryoyo Sat”

http://www.suryoyo-sat.eu/content/images/ssatlogo.jpg.

Ilustracja 10. Okładki książek: The Crimson Field, Assyrians: The Continous

Saga, Assyrians: From Bedr Khan to Saddam Hussein

http://www.thecrimsonfield.com/catalog/images/The\%20Crimson \%20Field.jpg,

http://www.christiansofiraq.com/continuous.jpg,

http://www.atour.com/ fred/images/Assyrians-100.jpg.

Ilustracja 11. Okładka książki o Bar Hebraeusie

http://www.aramaic-dem.org/English/History/ Evidences_of_our_Aramean_origin/BarHebraeus.jpg.

Ilustracja 12. Andre Agassi, Agha Petros, Naum Faik, Roie Malek-Yonan, Nuri Kino

http://pl.wikipedia.org/wiki/Plik:Andre_Agassi_Indian_Wells_2006.jpg, http://www.zindamagazine.com/html/archives/2005/5.14.05/pix/sardanapal/

General\%20Agha\%20Petrus\%202003.jpg, http://en.wikipedia.org/wiki/File:Naumfaik.jpg,

http://www.zindamagazine.com/html/archives/2005/4.27.05/pix/Rosie\%20Malek-Yonan2.jpg,

http://www.attiyatunc.nl/wp-content/uploads/2007/09/nuri-kinnoattiya.jpg.

Ilustracja 13. Św. Efrem Syryjczyk, Ibrahim Baylan, Abgar Barsom http://en.wikipedia.org/wiki/File:Mor_Ephrem_icon.jpg,

http://upload.wikimedia.org/wikipedia/commons/4/40/Ibrahim_Baylan_2009_04_19_B.jpg, http://upload.wikimedia.org/wikipedia/commons/3/30/Abgar_Barsom_och_ Riad_Bachir.JPG.

Ilustracja 14. Obchody Akitu - Asyryjskiego Nowego Roku http://www.aina.org/images/akitu2010au1.jpg, http://www.aina.org/images/akitu2010au0.jpg, http://www.aina.org/images/20140321142057.jpg. 
Ilustracja 15. Flaga asyryjska

http://wiki-images.enotes.com/thumb/0/06/FlagofAssyria.svg/300pxFlagofAssyria.svg.png.

Ilustracja 16. Dawna flaga asyryjska http://upload.wikimedia.org/wikipedia/commons/thumb/b/b4/Old_Assyrian_ Flag.svg/800px-Old_Assyrian_Flag.svg.png.

Ilustracja 17. Flaga Aghi Petrosa

http://en.wikipedia.org/wiki/File:FlagofAssyria_1913-1923.svg.

Ilustracja 18. Lamassu - starożytny i współczesne nawiązania

http://upload.wikimedia.org/wikipedia/commons/2/2a/Louvre_assyrian_gate_ DSC00911.jpg,

http://www.ngs.noaa.gov/external/IGRS/pictures/lamassu_A4.gif.

Ilustracja 19. Gwiazda asyryjska

http://www.aina.org/images/starcol.gif.

Ilustracja 20. Bogini Isztar

http://www.gutenberg.org/files/42224/42224-h/images/fig292.png.

Ilustracja 21. Relief z bogiem Aszurem

http://upload.wikimedia.org/wikipedia/commons/6/64/Ashur_god.jpg.

Ilustracja 22. Różne przedstawienia Isztar

http://upload.wikimedia.org/wikipedia/commons/thumb/2/22/British_Museum_Queen_of_the_Night.jpg/300px-British_Museum_Queen_of_the_ Night.jpg,

http://upload.wikimedia.org/wikipedia/commons/thumb/c/ca/Ishtar_Eshnunna_Louvre_AO12456.jpg/225px-Ishtar_Eshnunna_Louvre_AO12456.jpg, http://upload.wikimedia.org/wikipedia/commons/thumb/6/6a/Ishtar_vase_Louvre_AO17000-detail.jpg/225px-Ishtar_vase_Louvre_AO17000-detail.jpg.

Ilustracja 23. Asyryjski/Syryjski krzyż

http://en.wikipedia.org/wiki/File:Western_Syriac_Cross.svg, http://en.wikipedia.org/wiki/File:Assyrian_Patriarch.jpg.

Ilustracja 24. Flaga aramejska http://en.wikipedia.org/wiki/File:Flag_of_the_Syriac-Aramaic_People.svg. 
Ilustracja 25. Logo Assyriskiej FF oraz Syrianskiej FC

http://upload.wikimedia.org/wikipedia/en/thumb/e/e7/Assyriska.svg/225px-

Assyriska.svg.png,

http://upload.wikimedia.org/wikipedia/en/thumb/4/40/Syrianska.svg/255px-

Syrianska.svg.png.

Ilustracja 26. Wspólny stadion Assyriskiej FF oraz Syrianskiej FC w Södertälje w Szwecji

Zdjęcia autorki.

Ilustracja 27. Kolaż nawołujący do jedności

http://www.huyodo.com/uploads/cheat_images/unity.jpg.

Ilustracja 28. Przedstawienia związane z konstrukcją tożsamości asyryjskiej oraz aramejskiej

http://www.assyrie.nl/cms/uploads/images/Flyeranatoliefestival.jpg,

http://upload.wikimedia.org/wikipedia/commons/2/24/Assyrian_Genocide_Memorial_Wall_and_Plaque_at_St._Mary\%27s_Parish_in_Tarzana_CA_17February2007.jpg,

http://www.huyodo.com/uploads/newsbilder/2010/namen_und_uebernahmen. png.

Ilustracja 29. T-shirt z flagą asyryjską i napisem „100\% Asyryjczyk” http://www.zazzle.co.uk/assyrian_tee_shirts-235240637544116550.

Ilustracja 30. Plakat informujący o obchodach rocznicy asyryjskiego holokaustu oraz wspólna manifestacja asyryjsko-chaldejsko-aramejska upamiętniająca Sejfo

http://www.zindamagazine.com/graphics/ZindaAds/24JunePoster.jpg, http://www.zindamagazine.com/html/archives/2005/4.27.05/pix/SeyfoDem3. JPG.

Ilustracja 31. Przedmioty budujące tożsamość asyryjską http://www.zazzle.co.uk/assyrian_hat-148589526653991359, http://www.zazzle.co.uk/assyrian_flag_mug-168502262253034289, http://www.zazzle.co.uk/historical_assyrian_flag_before_wwi_tee_shirts235262315523975547 ,

http://www.zazzle.co.uk/assyrian_writing_mouse_mats-144995667175985457, http://www.zazzle.co.uk/word_t_shirt-235765334556250420?pt=bag149079124803017540 , 
http://www.zazzle.co.uk/my_owner_is_assyrian_pet_tshirt-155351615937231591.

Ilustracja 32. Przedmioty budujące tożsamość aramejską http://www.zazzle.co.uk/syriac_aramaic_flag_mugs-168386915270540492, http://www.zazzle.co.uk/syriac_aramaic_flag_tote_bags-149416467162955997, http://www.zazzle.co.uk/syriac_aramaic_flag_trucker_hats-148419634768069891, http://www.zazzle.co.uk/syriac_aramaic_people_syria_flag_t_shirts235109783445868731,

http://www.zazzle.co.uk/aboun_dbashmayo_mouse_pad- 144367301803395321, http://www.zazzle.co.uk/i_love_aramaic_greeting_card-1378015614217444463?pt=dog_shirt-155127032618504676.

Ilustracja 33. Kolaż ze zdjęcia Francisa Szabo i wizerunku głowy lamassu http://www.aina.org/images/Francis_shabo.jpg.

Ilustracja 34. Asyryjczycy w strojach folklorystycznych w Holandii http://upload.wikimedia.org/wikipedia/en/5/5d/Assyriansinholland.jpg.

Ilustracja 35. Asyryjski kościół NMP w Moskwie, asyryjski kościół św. Józefa w Teheranie, asyryjski kościół w Irbilu

http://upload.wikimedia.org/wikipedia/commons/thumb/5/5e/\%D0\%A6$\% \mathrm{D} 0 \% \mathrm{~B} 5 \% \mathrm{D} 1 \% 80 \% \mathrm{D} 0 \% \mathrm{BA} \% \mathrm{D} 0 \% \mathrm{BE} \% \mathrm{D} 0 \% \mathrm{~B} 2 \% \mathrm{D} 1 \% 8 \mathrm{C} \_\% \mathrm{D} 0 \% \mathrm{C}$ $\% \mathrm{D} 0 \% \mathrm{~B} 0 \% \mathrm{D} 1 \% 82 \_\% \mathrm{D} 0 \% 9 \mathrm{C} \% \mathrm{D} 0 \% \mathrm{~B} 0 \% \mathrm{D} 1 \% 80 \% \mathrm{D} 1 \% 8 \mathrm{C} \% \mathrm{D} 1$ \%8F\%D0\%BC_\%D0\%BD\%D0\%B0_\%D0\%94\%D1\%83D0\%B1\%D $1 \% 80 \% \mathrm{D} 0 \% \mathrm{BE} \% \mathrm{D} 0 \% \mathrm{~B} 2 \% \mathrm{D} 0 \% \mathrm{BA} \%$

D0\%B5.jpg/400px-\%D0\%A6\%D0\%B5\%D1\%80\%D0\%BA\%D0\%BE\%D $0 \% \mathrm{~B} 2 \% \mathrm{D} 1 \% 8 \mathrm{C} \_\% \mathrm{D} 0 \% 9 \mathrm{C} \% \mathrm{D} 0 \% \mathrm{~B} 0 \% \mathrm{D} 1 \% 82 \_\% \mathrm{D} 0 \% 9 \mathrm{C} \% \mathrm{D} 0 \% \mathrm{~B} 0 \% \mathrm{D}$ $1 \% 80 \% \mathrm{D} 1 \% 8 \mathrm{C} \% \mathrm{D} 1 \% 8 \mathrm{~F} \% \mathrm{D} 0 \% \mathrm{BC} \_\% \mathrm{D} 0 \% \mathrm{BD} \% \mathrm{D} 0 \% \mathrm{~B} 0 \_\% \mathrm{D} 0 \% 94 \% \mathrm{D}$ 1\%83\%D0\%B1\%D1\%80\%D0\%BE\%D0\%B2\%D0\%BA\%D0\%B5.jpg, http://www.rt.com/files/news/iran-people-church-tv/Assyrian-Church-inTehran--click-to-enlarge-.jpg, http://upload.wikimedia.org/wikipedia/commons/6/6a/Assyrian_Christian_ Church,_Erbil,_Iraqi_Kurdistan.jpg.

Ilustracja 36. Mapa Iraku z wpisaną w nią flagą asyryjską http://www.zindamagazine.com/html/archives/2006/11.14.06/pix/cpc1.jpg. 


\section{Bibliografia}

\section{Książki}

Abdalla M., Kultura żywienia dawnych i wspótczesnych Asyryjczyków. Uwarunkowania spoteczno-kulturowe, Dialog, Warszawa 2001.

Anderson B., Imagined Communities: Reflections of the Origin and Spread of Nationalism, Verso, London 1983. Polskie tłumaczenie: Wspólnoty wyobrażone. Rozważania o źródtach i rozprzestrzenianiu się nacjonalizmu, Znak, Kraków 1997.

Andrews F. D. (red.), The Lost Peoples of the Middle East: Documents of the Struggle for Survival and Independence of the Kurds, Assyrians, and Other Minority Races in the Middle East, Documentary Publications, Salisbury 1982.

Annual Report of the Presbyterian Board of Foreign Missions, Published for the board, 1947. Aprim F., Assyrians. Continuous Saga, Xlibris Corporation, Philadelphia 2004.

Armstrong J. A., Nations before Nationalism, University of North Carolina Press, North Carolina 1982.

Atto N., Hostages in the Homeland, Orphans in the Diaspora: Identity Discourses Among the Assyrian/Syriac Elites in the European Diaspora, Leiden University Press, Leiden 2011.

Awde N., N. Lamassu, N. Al-Jeloo, Modern Aramaic (Assyrian/Syriac) Dictionary \& Phrasebook, Hippocrene Books, New York 2007.

Badger G. P., The Nestorians and Their Rituals, Vol. 1, Joseph Masters, London 1852.

Baram A., Culture, History and Ideology in the Formation of Ba'thist Iraq, 1968-1989, St. Martin's Press, New York 1991.

Barth F. (red.), Ethnic Groups and Boundaries, Little, Brown and Co., Boston 1996.

Bauman Z., Dwa szkice o moralności ponowoczesnej, Instytut Kultury, Warszawa 1994.

Beggiani S. J., Early Syriac Theology: With Special Reference to the Maronite Tradition, University Press of America, Lanham 1983.

Berger P. L., T. Luckmann, The Social Construction of Reality: A Treatise in the Sociology of Knowledge, Anchor, Garden City, NY 1967. Polskie tłumaczenie: Społeczne tworzenie rzeczywistości, PIW, Warszawa 1983.

BetGivargis-McDaniel M., Assyrians of New Britain (Images of America: Connecticut), Arcadia Publishing, Charleston SC 2007.

Betts R. B., Christians in the Arab East: A Political Study, SPCK, Atlanta 1975.

Bhabha H. K. (red.), Nation and Narration, Routledge, New York 1990. 
Billig M., Banal Nationalism, Sage Publications Ltd, London 1995. Polskie tłumaczenie: Banalny Nacjonalizm, Znak, Kraków 2008.

Björklund U., North to Another Country: The Formation of the Suroyo Community in Sweden, University of Stockholm, Sztokholm 1981.

Black J., Green A., Gods, Demons and Symbols of Ancient Mesopotamia. An Illustrated Dictionary, University of Texas Press, London 1998.

Bokszański Z., Tożsamości zbiorowe, PWN, Warszawa 2005.

Bonnell V. E., Hunt L. (red.), Beyond the Cultural Turn: New Directions in the Study of Society and Culture, University of California Press, Berkeley 1999.

Bourdieu P., J.-C. Passeron, Reproduction: In Education, Society and Culture, SAGE Publications, London 1977. Polskie tłumaczenie: Reprodukcja. Elementy teorii systemu nauczania, PWN, Warszawa 1990.

Boski P., Jarymowicz M., Malewska-Peyre H., Tożsamość a odmienność kulturowa, Instytut Psychologii PAN, Warszawa 1992.

Breuilly J., Nationalism and the State, Manchester University Press, New York 1982.

Castells M., The Power of Identity, Blackwell Publishers Inc, Malden-Oxford-Carlton 2004, polskie tłumaczenie: Siła tożsamości, Warszawa 2008.

Cerulo K. A., Identity Designs: The Sights and Sounds of a Nation, Rutgers University Press, New Brunswick-New Jersey 1995.

Cetrez Ö. A., Meaning-Making Variations in Acculturation and Ritualization. A multi-generational study of Suroyo migrants in Sweden, Coronet Books Inc, Sztokholm 2005.

Chabot J. B. (red.), Chronique de Michel le Syrien. Patriarche Jacobite d'Antioch (11661199), Culture et Civilisation, Paris 1899-1924.

Chaillot Ch., The Syrian Orthodox Church of Antioch and All the East: A Brief Introduction to Its Life and Spirituality, Inter-Orthodox Dialogue, Geneva 1998.

Chatterjee P., Nationalist Thought and the Colonial World: A Derivative Discourse, University of Minnesota Press, Minneapolis 1986.

Chatterjee P., The Nation and Its Fragments: Colonial and Postcolonial Histories, Princeton University Press, Princeton 1993.

Cottam R. W., Nationalism in Iran, University of Pittsburgh Press, Pittsburgh 1964.

Crone P., Cook M., Hagarism: The Making of the Islamic Word, Cambridge University Press, Cambridge 1977.

D'Bait Mar Shimun S., Assyrian Church Customs and the Murder of Mar Shimun, Vehicle, New York 1983.

Dadesho S.O., The Assyrian National Question at the United Nations: A Historical Injustice Redressed, Bet Nahrain, Modesto 1987.

Danecki J., Kultura islamu. Stownik, WSiP, Warszawa 1977.

Delsol Ch., Éloge de la singularité, essai sur la modernité tardive, La Table Ronde, Paris 2000. Polskie tłumaczenie: Esej o człowieku późnej nowoczesności, Znak, Kraków 2003.

Dennett D. C., Conversion and the Poll Tax in Early Islam, Harvard University Press, Cambridge 1950 .

Deutsch K. W., Nationalism and Social Communication, The MIT Press, Cambridge 1966.

DeVos G., Ethnic Identity: Creation, Conflict, and Accommodation, AltaMira Press, Chicago 1975. 
Edensor T., National Identity, Popular Culture, and Everyday Life, Berg, New York 2002. Polskie tłumaczenie: Tożsamość narodowa, kultura popularna i życie codzienne, Kraków 2004. Eley G., Suny R. G. (red.), Becoming National: A Reader, Oxford University Press, New York 1996.

Encyclopedia Britannica, CD-ROM Edition 2002.

Erikson E., Identity and the Life Cycle. Selected Papers, International Universities Press, New York 1959.

Erikson E., Identity: Youth and Crisis, W. W. Norton \& Co., New York 1968.

Farouk-Sluglett M., Sluglett P., Iraq since 1958: From Revolution to Dictatorship, I. B. Tauris, London-New York 1987.

Flis A., B. Kowalska, Zapomniani bracia. Ginacy świat chrześcijan Bliskiego Wschodu, WAM, Kraków 2003.

Fromm E., The Forgotten Language: An Introduction to the Understanding of Dreams, Fairy Tales, and Myths, Grove Pr, New York 1957. Polskie tłumaczenie: Zapomniany jezzyk. Wstęp do rozumienia snów, baśni i mitów, PIW, Warszawa 1977.

Fuat D., En minoritets odyssé: upprätthållande och transformation av etnisk identitet i förhållande till moderniseringsprocesser: det assyriska exemplet, Uppsala University, Uppsala 1999.

Gaunt D., Massacres, Resistance, Protectors: Muslim-Christian Relations in Eastern Anatolia During World War I, Gorgias Press, Piscataway 2006.

Gellner E., Nations and Nationalism, Cornell University Press, Oxford 1983. Polskie tłumaczenie: Narody i nacjonalizm, PWN, Warszawa 1991.

Giddens A., Modernity and Self-Identity: Self and Society in the Late Modern Age, Stanford University Press, Stanford 1991. Polskie tłumaczenie: Nowoczesność i tożsamość. "Ja" i społeczeństwo w epoce późnej nowoczesności, PWN, Warszawa 2001.

Giddens A., The Consequences of Modernity, Polity Press, Cambridge 1990. Polskie tłumaczenie: Konsekwencje nowoczesności, Wydawnictwo Uniwersytetu Jagiellońskiego, Kraków 2008.

Glaser B., Strauss A. L., The Discovery of Grounded Theory: Strategies for Qualitative Research, Aldine Transaction, Chicago 1967.

Hage W., Syriac Christianity in the East, St. Ephrem Ecumenical Research Institute, Kottayam 1988.

Haj S., The Making of Iraq 1900-1963: Capital, Power and Ideology, State University of New York Press, Albany 1997.

Hammersley M., Atkinson P., Ethnography: Practices and Principles, Routledge, New York 1995. Polskie tłumaczenie: Metody badań terenowych, Zysk i S-ka, Poznań 2000.

Hayes C., Essays on Nationalism, Russell\&Russell Pub, New York 1954.

Hayes C., Nationalism: a Religion, The Macmillan Company, New York 1960.

Hayes C., The Historical Evolution of Modern Nationalism, Russell\&Russell Pub, New York 1931.

Herodot, Dzieje, Czytelnik, Warszawa 1954.

Hobsbawm E., Nations and Nationalism Since 1780, Cambridge University Press, Cambridge 1990 .

Hobsbawm E., Ranger T. (red.), The Invention of Tradition, Cambridge University Press, Cambridge 1983. Polskie tłumaczenie: Tradycja wynaleziona, Wydawnictwo Uniwersytetu Jagiellońskiego, Kraków 2008. 
Hroch M., Social Preconditions of National Revival in Europe, Columbia University Press, New York 2000. Polskie tłumaczenie: Małe narody Europy, Ossolineum, Wrocław 2003.

Human Rights Watch/Middle East, Iraq's Crime of Genocide: The Anfal Campaign Against the Kurds, Human Rights Watch, London 1995.

Huntington S., The Clash of Civilizations and the Remaking of World Order, Simon \& Schuster, New York 1996. Polskie tłumaczenie: Zderzenie cywilizacji i nowy kształt tadu światowego, PWN, Warszawa 1997.

James W., The Principles of Psychology, Dover Publications, New York 1890.

Joseph J., Muslim-Christian Relations and Inter-Christian Rivalries in the Middle East: The Case of Jacobites in an Age of Transition, Harvard University Press, New York 1983.

Joseph J., The Modern Assyrians of the Middle East. Encounters with Western Christian Missions, Archeologists, and Colonial Powers, Brill, Leiden-Boston-Köln 2000.

Joseph J., The Nestorians and Their Muslim Neighbors. A Study of Western Influence on Their Relations, Princeton University Press, Princeton, New Jersey 1961.

Jung C. G., Archetypy i symbole. Pisma wybrane, Czytelnik, Warszawa 1981.

Kaim A., Kościót Chaldejski. Dziedzic Objawienia i źródto charyzmatu, Pallottinum, Poznań 2001.

Kellner D., Media Culture. Cultural Studies, Identity and Politics between the Modern and Postmodern, Routledge, London 1995.

Khan G., Neo-Aramaic Dialect Studies, Gorgias Press, Piscataway 2008.

Kilias J., Wspólnota abstrakcyjna. Zarys socjologii narodu, IFiS PAN, Warszawa 2004.

Kłoskowska A., Kultury narodowe u korzeni, PWN, Warszawa 1996.

Kozielecki J., Koncepcja transgresyjna człowieka. Analiza psychologiczna, PWN, Warszawa 1987.

Kohn H., Nationalism. Its Meaning and History, D. Van Nostrand, Princeton 1955.

Kohn H., Prelude to Nation-States. The French and German Experience, 1789-1815, D. Van Nostrand, Princeton 1967.

Kohn H., Prophets and Peoples: Studies in Nineteenth Century Nationalism, Octagon Books, New York 1946.

Kohn H., The Age of Nationalism: The First Era of Global History, Greenwood Press, New York 1962.

Kohn H., The Idea of Nationalism: A Study in Its Origins and Background, Transaction Publishers, New York 1944.

Konecki K. T., Studia z metodologii badań jakościowych. Teoria ugruntowana, PWN, Warszawa 2000.

Kushner D., The Rise of Turkish Nationalism 1876-1908, Routledge, London 1977.

Lapidus I. M., A History of Islamic Societies, Cambridge University Press, Cambridge 1988.

Layard A. H., Nineveh and Its Remains: With an Account of a Visit to the Chaldaean Christians of Kurdistan, and the Yezidis, or Devil-worshippers; And an Enquiry Into the Manners and Arts of the Ancient Assyrians, John Murray, London 1848 [1849]. Polskie tłumaczenie: W poszukiwaniu Niniwy, Wyd. Artystyczne i Filmowe, Warszawa 1983.

Le Coz R., Historie de L'Église d'Orient: Chrétiens d'Irak, d'Iran et de Turquie, Cerf, Paris 1995.

Lévi-Strauss C., Anthropologie structurale, Plon, Paris 1958. Polskie tłumaczenie: Antropologia strukturalna, Wydawnictwo KR, Warszawa 2000.

Lewis B., The Emergence of Modern Turkey, Oxford University Press, London 1961. Polskie tłumaczenie: Narodziny nowoczesnej Turcji, PWN, Warszawa 1972. 
Lukitz L., Iraq: The Search for National Identity, Routledge, London 1995.

Maalouf A., Les Identités Meurtrières, Paris 1998. Polskie tłumaczenie: Zabójcze tożsamości, Warszawa 2002.

Macuch R., Geschichte der spät- und neusyrischen Literatur [History of the Late and Modern Syriac Literature], De Gruyter, Berlin, New York 1976.

Malek-Yonan R., The Crimson Field, Pearlida Publishing, Verdugo City 2005.

Malinowski B., Mit, magia, religia, Dzieła, t. VII, PWN, Warszawa 1990.

Mamzer H., Tożsamość w podróży, Wydawnictwo Naukowe UAM, Poznań 2002.

Martin J. J., The Man Who Invented Genocide: The Public Career and Consequences of Raphael Lemkin, Institute for Historical Review, Costa Mesa 1984.

Mathews G., Global Culture/Individual Identity: Searching for Home in the Cultural Supermarket, Routledge, London 2000. Polskie tłumaczenie: Supermarket kultury. Kultura globalna a tożsamość jednostki, PIW, Warszawa 2005.

Matwiejew K. P., Istorija i etnografija assirijcew, U.S.S.R. Academy of Sciences, Moskwa 1990.

May R., The Cry for Myth, Delta, Norton (New York) 1991. Polskie tłumaczenie: Btaganie o mit, Wydawnictwo Zysk i S-ka, Poznań 1997.

McCarthy J., The Ottoman Turks: An Introductory History to 1923, Longman, New York 1997.

McCullough W. S., A Short History of Syriac Christianity to the Rise of Islam, Scholars Press, Chico 1982.

Menshari D., Education and the Making of Modern Iran, Cornell University Press, Ithaca 1992.

Merton R., Barber E., The Travels and Adventures of Serendipity, Princeton University Press, Princeton 2004.

Miles M. B., Huberman M. A., Qualitive Data Analysis: An Expanded Source Book, Sage, Thousand Oaks 1994. Polskie tłumaczenie: Analiza danych jakościowych, Trans Humana, Białystok 2000.

Misztal B., Teoria socjologiczna i praktyka społeczna, Universitas, Kraków 2000.

Morris-Suzuki T., The Past Within Us: Media, Memory, History, Verso, London-New York 2005.

Mosse G., The Nationalization of the Masses: Political Symbolism and Mass Movements in Germany from the Napoleonic Wars through the Third Reich, Cornell University Press, New York 1975.

Murray R., Symbols of Church and Kingdom: A Study in Early Syriac Tradition, Gorgias Press, London 1975.

Nikitorowicz J., Kreowanie tożsamości dziecka. Wyzwania edukacji międzykulturowej, Gdańskie Wydawnictwo Psychologiczne, Gdańsk 2005.

Nikitorowicz J., Pogranicze. Tożsamość. Edukacja międzykulturowa, Trans Humana, Białystok 1995.

Olson R., The Emergence of Kurdish Nationalism and the Sheikh Said Rebellion, 1880-1925, University of Texas Press, Austin 1989.

Ossowski S., Analiza socjologiczna pojęcia ojczyzny, Biblioteczka Myśli Współczesnej, Łódź 1946.

Ossowski S., O ojczyźnie i narodzie, PWN, Warszawa 1984.

Peterson-Royce A., Ethnic Identity, Indiana University Press, Bloomington 1982.

Pigulewska N., Kultura syryjska we wczesnym średniowieczu, PAX, Warszawa 1989.

Popper K., The Open Society and Its Enemies, Routledge, London 1945. Polskie tłumaczenie: Społeczeństwo otwarte i jego wrogowie, PWN, Warszawa 2006. 
Ramezanzadeh A., Internal and International Dynamics of Ethnic Conflict: The Case of Iran, Katholieke Universiteit Leuven, Leuven 1996.

Al-Rasheed M., Iraqi Assyrian Christians in London: The Construction of Ethnicity, The Edwin Mellen Press, New York 1998.

Report on Iraq Administration, 1920-22, Parliamentary Papers, London 1923.

Ricoeur P., Soi-même comme un autre, L'Ordre Philosophique, Paris 1990. Polskie tłumaczenie: O sobie samym jako innym, PWN, Warszawa 2005.

Riesman D., The Lonely Crowd, Yale University Press, New Haven 1950. Polskie tłumaczenie: Samotny ttum, PWN, Warszawa 1971.

Roberson R., The Eastern Christian Churches, USCCB Publishing, Rome 1986. Polskie tłumaczenie: Chrześcijańskie Kościoły Wschodnie, Homini, Kraków 2005.

Roux G., Ancient Iraq, Penguin, London 1992.

Saggs H., The Might That Was Assyria, Sidgwick \& Jackson Ltd., London 1984.

Sanasarian E., Religious Minorities in Iran, Cambridge University Press, Cambridge-New York 2000.

Sassani A., Education in Iran, U.S. Dept. of Health, Education, and Welfare, Office of Education, Washington 1963.

Seton-Watson H., Nations and States, Westview Press, London 1977.

Shahbaz Y. H., The Rage of Islam: An Account of the Massacre of Christians by the Turks in Persia, Williams Press, Philadelphia 1918.

Simon R. S., Iraq Between the Two World Wars: The Creation and Implementation of a Nationalist Ideology, Columbia University Press, New York 1986.

Skarga B., Tożsamość i różnica: eseje metafizyczne, Znak, Kraków 1997.

Smith A. D., Myths and Memories of the Nation, Oxford University Press, New York 1999.

Smith A. D., National Identity, Harmondsworth: Penguin, London 1991.

Smith A. D., Nationalism and Modernism: A Critical Survey of Recent Theories of Nations and Nationalism, Routledge, London-New York 1998.

Smith M. A., Kollock P. (red.), Communities in Cyberspace, Routledge, London-New York 2005.

Stafford R. S., The Tragedy of the Assyrians, Allen and Unwin, London 1935.

Strauss A. L., Mirrors and Masks, The Sociology Press, San Francisco 1959.

Stryjek T., Jakiej przesztości potrzebuje przysztość? Interpretacje dziejów narodowych w historiografii i debacie publicznej na Ukrainie 1991-2004, Rytm, Warszawa 2007.

Synak B., Kaszubska tożsamość, ciagłość i zmiana, Wydawnictwo Uniwersytetu Gdańskiego, Gdańsk 1998.

Talia P. H., Between Hope and Hopelessness, s.n., Chicago 1985.

Tang L., East Syriac Christianity in Mongol-Yuan China, Orientalia Biblica et Christiana 18, Wiesbaden 2011.

Taylor Ch., Sources of the Self: The Making of the Modern Identity, Cambridge University Press, Cambridge 1989. Polskie tłumaczenie: Źródła podmiotowości. Narodziny tożsamości nowoczesnej, PWN, Warszawa 2001.

Thiery A., Mechelen aan de Tigris, EPO, Berchem 2001.

Tiregol J.S., The Role of Primary Education in Nation-State Building: The Case of the Early Turkish Republic (1923-1938), Princeton University Press, Princeton 1998.

Van Dijk J., Hacker K. L. (red.), Digital Democracy: Issues of Theory and Practice, Sage Publications Ltd, London 2001. 
Vaziri M., Iran as Imagined Nation: The Construction of National Identity, Marlowe \& Co., New York 1993.

Ware T., The Orthodox Church, Penguin, London 1963.

Wigram W. A., Our Smallest Ally: a Brief Account of the Assyrian Nation in the Great War, Society for Promoting Christian Knowledge, The Macmillan Company, London, New York 1920.

Wigram W. A., The Assyrians and Their Neighbours, G. Bell \& Sons, London 1929.

Wnuk-Lipiński E., Świat międzyepoki. Globalizacja, demokracja, państwo narodowe, Znak i ISP PAN, Kraków 2004.

Yana (Bebla) G.V., Ancient and Modern Assyrians. A Scientific Analysis. A Review of the Works of J.M. Fiey, and Prof. John Joseph. Includes a Political and Engineering History of Assyria, Xlibris Corporation, [United States] 2008.

Yapp M.E., The Near East Since the First World War, Longman, London 1991.

Yonan G., Assyrer heute. Kultur, Sprache, Nationalbewegung der aramäisch sprechenden Christen im Nahen Orient, Ges. für Bedrohte Völker, Hamburg-Wien 1978.

Zenderowski R., Stosunki międzynarodowe. Vademecum, Atla 2, Wrocław 2006.

Zerubavel Y., Recovered Roots: Collective Memory and the Making of the Israeli National Tradition, University Of Chicago Press, Chicago 1995.

Zientara B., Świt narodów europejskich, PIW, Warszawa 1996.

Żelazny W., Etniczność - tad, konflikt, sprawiedliwość, Wydawnictwo Poznańskie, Poznań 2004.

\section{Artykuły/rozdziały w książkach}

Abdalla M., Asyryjczycy $w$ Tur Abdinie między kurdyjskim młotem a tureckim mieczem [w:] I. Kabzińska-Stawarz, S. Szynkiewicz (red.), Konflikty etniczne. Źródta - Typy - Sposoby rozstrzygania, PAN, Warszawa 1996.

Abdalla M., Asyryjscy imigranci w Szwecji między tradycją a wspótczesnościa [w:] J. Mucha, W. Olszewski (red.), Dylematy tożsamości europejskich pod koniec drugiego tysiąclecia, Uniwersytet Mikołaja Kopernika, Toruń 1997.

Abdalla M., O chrześcijaństwie asyryjskim wśród Arabów przed islamem. Zarys problematyki [w:] S. Wojciechowski (red.), Irak wczoraj i dziś, Wyższa Szkoła Nauk Humanistycznych i Dziennikarstwa, Poznań 2005.

Abdalla M., Problemy kultury ludności asyryjskiej na pograniczu syryjsko-turecko-irackim [w:] T. Smolińska (red.), Pogranicze jako problem kultury, Uniwersytet Opolski, Opole 1994.

Al-Husri S., Al-Kaumijja wa-ad-din fi al-bilad al-arabijja [w:] Ma hija al-kaumijja? Abhas wa-dirasat ala dau al-ahdas wa-an-nazarijjat, Dar al-Kuds, Bejrut 2001.

Banaszak-Karpińska E., Kategoria tożsamości zbiorowej w socjologii [w:] I. Szlachcicowa (red.), Biografia a tożsamość, Wydawnictwo Uniwersytetu Wrocławskiego, Wrocław 2003.

Bauman Z., Tożsamość - jaka była, jest i po co? [w:] A. Jawłowska (red.), Wokót problemów tożsamości, Wydawnictwo LTW, Warszawa 2001.

Bauman Z., Tożsamość. Wtedy, teraz, po co? [w:] E. Nowicka, M. Chałubiński (red.), Idee a urządzanie świata społecznego. Księga jubileuszowa dla Jerzego Szackiego, PWN, Warszawa 1999.

Baumer Ch., The Church of the East: An Illustrated History of Assyrian Christianity, London-New York 2006. 
Bokszański Z., Tożsamość narodowa: pojęcie i problematyka badawcza [w:] M. Czyżewski, A. Piotrkowski, A. Rokuszwska-Pawłek (red.), Biografia a tożsamość narodowa, Katedra Socjologii Kultury, Łódź 1997.

Bokszański Z., Tożsamość [w:] Encyklopedia socjologii, t. 4, Oficyna Naukowa, Warszawa 2002. Brah A., Cartographies of Diaspora. Contesting Identities, London 1996.

Brock S., Syriac Views of Emergent Islam [w:] G. Juynboll (red.), Studies on the First Century of Islamic Society, Southern Illinois University Press, Carbondale 1982.

Burszta W., Postowie [w:] K. Bondyra, S. Lisiecki (red.), Odmiany polskich tożsamości, Humaniora, Poznań 2002.

Chlewiński Z., Tożsamość a tolerancja [w:] J. Kłoczkowski, S. Łukasiewicz (red.), Tożsamość, odmienność, tolerancja a kultura pokoju, Instytut Europy Środkowo-Wschodniej, Lublin 1998.

Cichocki P., Tożsamość narodowa a post-narodowa konstelacja [w:] M. Golka (red.), Kłopoty $z$ tożsamościa, „Człowiek i społeczeństwo”, t. XXVI, Wydawnictwo Naukowe UAM, Poznań 2006.

Coakley J. F., The Patriarchal List of the Church of the East [w:] G. J. Reiniuk, A. C. Klugkist (red.), After Bardaisan: Studies on Continuity and Change in Syriac Christianity in Honour of Professor Han J.W. Drijvers, Orientalia Lovaniensia Analecta 89, Leuven 1999.

Dekker H., D. Malová, The Concept of Nationalism [w:] M. Cross (red.), Nationalism, Ethnic Conflict and Conceptions of Citizenship and Democracy in Western and Eastern Europe, Vol. 1: Theories and Concepts, ERCOMER, Utrecht 1995.

Dekker H., Nationalism, Its Conceptualization and Operationalization [w:] K, Phalet \& A. Örkény (red.), Ethnic Minorities and Inter-Ethnic Relations, Ashgate Pub. Ltd., Farnham, Surrey 2001.

Esman M. J., I. Rabionovich, The Study of Ethnic Politics in the Middle East [w:] M. J. Esman, I. Rabinovich (red.), Ethnicity, Pluralism, and the State in the Middle East, Cornell University Press, Ithaca 1988.

Gilroy P., Diaspora and the Detours of Identity [w:] K. Woodward (red.), Identity and Difference, Sage Publications, London 1997.

Grysa B., Asyryjski klasztor Mār Mātāy (św. Mateusza) w pótnocnym Iraku [w:] M. Abdalla (red.), Niemuzutmańskie mniejszości Iraku. Historia - kultura - problemy przetrwania, Wydawnictwo Poznańskie, Poznań 2008.

Grysa B., Sytuacja Asyryjczyków w pótnocnym Iraku po obaleniu Saddama Husajna [w:]A. Kapiszewski, Świat arabski w procesie przemian, Księgarnia Akademicka, Kraków 2008.

Heinrichs W., The Modern Assyrians - Name and Nation [w:] R. Contini i in. (red.), Semitica: Serta Philologica Constantino Tsereteli dicata, Silvio Zamorani, Torino 1993.

Hill H., The Assyrians: The Church of the East [w:] H. Hill (red.), Light From the East: A Symposium on the Oriental Orthodox and Assyrian Churches, Anglican Book Centre, Toronto 1988.

Holy L., Kulturowe tworzenie tożsamości etnicznej [w:] Z. Mach, A. K. Paluch (red.), Sytuacja mniejszościowa a tożsamość, Uniwersytet Jagielloński, Kraków 1992.

Ignatius III Elias [w:] W. Baum, Biographisch-Bibliographisches Kirchenlexikon, t. XXIV, Traugott-Bautz, Nordhausen 2005.

Ishaya A., The Role of Minorities in the State [w:] History of the Assyrian Experience, University of Manitoba Anthropology Papers, No. 19, Winnipeg 1977. 
Jawłowska A., Tożsamość na sprzedaż [w:] A. Jawłowska (red.), Wokót problemów tożsamości, Wydawnictwo LTW, Warszawa 2001.

Karczewska J., Odkrywanie wielokulturowości i wspótczesne ideologie. Rozważania wstępne [w:] M. Kempy A. Kapciak, S. Łozińska (red.), U progu wielokulturowości. Nowe oblicza społeczeństwa polskiego, Oficyna Naukowa, Warszawa 1997.

Karczmarek A., Tęsknota za tożsamością [w:] M. Golka (red.), Kłopoty z tożsamościa, „Człowiek i społeczeństwo", t. XXVI, Wydawnictwo Naukowe UAM, Poznań 2006.

Kłoskowska A. M., Mit jako czynnik nadajacy tożsamość [w:] I. Borowik, K. Leszczyńska (red.), Wokót tożsamości: teorie, wymiary, ekspresje, Nomos, Kraków 2007.

Kociuba J., Narracyjna koncepcja tożsamości [w:] I. Borowik, K. Leszczyńska (red.), Wokót tożsamości: teorie, wymiary, ekspresje, Nomos, Kraków 2007.

Kołakowski L., O tożsamości zbiorowej [w:] K. Michalski (red.), Tożsamość w czasach zmiany. Rozmowy w Castel Gandolfo, Znak, Kraków-Warszawa 1995.

Krzysztofek K., Tendencje globalnej dyfuzji u progu XXI wieku [w:] A. Tyszka (red.), Róża wiatrów Europy, Oficyna Naukowa, Warszawa 1999.

Levtzion N., Conversion to Islam in Syria and Palestine and the Survival of Christian Communities [w:] M. Gervers, R. Bikhazi (red.), Conversion and Continuity: Indigenous Christian Communities in Islamic Lands, Eighth to Eighteenth Centuries, Pontifical Institute of Mediaeval Studies, Toronto 1990.

Lis R., Internet narzędziem kształtowania tożsamości jednostki [w:] I. Borowik, K. Leszczyńska (red.), Wokót tożsamości: teorie, wymiary, ekspresje, Nomos, Kraków 2007.

Macuch R., Assyrians in Iran [w:] E. Yarshater (red.), Encyclopedia Iranica, Vol. IV, Routledge \& Kegan Paul, London-New York 1987.

Menashri D., Khomeini's Policy Toward Ethnic and Religious Minorities [w:] M. J. Esman, I. Rabinovich (red.), Ethnicity, Pluralism, and the State in the Middle East, Cornell University Press, New York 1988.

Misztal B., Tożsamoś́ jako pojęcie i zjawisko społeczne w zderzeniu z procesami globalizacji [w:] E. Budakowska (red.), Tożsamość bez granic, Wydawnictwo UW, Warszawa 2000.

Morawski W., Globalizacja: wyzwania i problemy [w:] M. Marody (red.), Wymiary życia społecznego. Polska na przetomie XX i XXI wieku, Wydawnictwo Naukowe, Warszawa 2002.

O’Brien M., Esej o plynnej tożsamości [w:] A. Jawłowska (red.), Wokół problemów tożsamości, Wydawnictwo LTW, Warszawa 2001.

Porter B., Podzwonne dla badań nad nacjonalizmem w: W. Burszta, K. Jaskułowski, J. Nowak (red.), Naród - tożsamość - kultura. Między koniecznością a wyborem, SOW, Warszawa 2005.

Spaemann R., Tożsamość religijna [w:] K. Michalski (red.), Tożsamość w czasach zmiany. Rozmowy w Castel Gandolfo, Znak, Kraków-Warszawa 1995.

Tadmor H., The Aramaization of Assyria: Aspects of Western Impact [w:] H. J. Nissan, J. Renger (red.), Mesopotamien und seine Nachbarn: Akten des XXV RAI, Vol. II, Berliner Beiträge zum Vorderen Orient, Berlin 1982.

Taylor Ch., Źródta wspótczesnej tożsamości [w:] K. Michalski (red.), Tożsamość w czasach zmiany. Rozmowy w Castel Gandolfo, Znak, Kraków-Warszawa 1995.

Van Rompay L., Jacob of Edessa and the Early History of Edessa [w:] G. J. Reinink, A. C. Klugkist (red.), After Bardaisan: Studies on Continuity and Change in Syriac Christianity 
in Honour of Professor Han J. W. Drijvers, Orientalia Lovaniensia Analecta 89, Groningen 1999.

Wolbromski C. J., Tożsamość spoteczna: typowość czy wspólność, bezbarwność czy przejrzystość? [w:] J. Mizińska (red.), Tożsamość podmiotu zbiorowego, Wydawnictwo Adam Marszałek, Toruń 2002.

Woźniak M., Exodus mniejszości asyrochaldejskiej z Iraku po 11 września 2001 r. w mediach anglojezzycznych [w:] M. Abdalla (red.), Niemuzutmańskie mniejszości Iraku. Historiakultura - problemy przetrwania, Wydawnictwo Poznańskie, Poznań 2008.

Woźniak M., National and Social Identity Construction among the Modern Assyrians/Syrians, Parole de l'Orient, Vol. 36, Université Saint-Esprit, Kaslik 2011.

Wysocka E., Podstawowe wyznaczniki ksztattowania się tożsamości w percepcji mtodzieży studenckiej [w:] I. Borowik, K. Leszczyńska (red.), Wokót tożsamości: teorie, wymiary, ekspresje, Nomos, Kraków 2007.

Yacoub J., The Assyrian Community in Turkey [w:] O. Høiris, S. M. Yürükel (red.), Contrasts and Solutions in the Middle East, Aarhus University Press, Aarhus 1997.

\section{Artykuły w czasopismach}

Abdalla M., Asyryjska diaspora, „Sprawy Narodowościowe - Seria nowa” 3/1 (4), 1994.

Abdalla M., Losy Asyryjczyków, „Sprawy Narodowościowe - Seria nowa” 2/1 (2), 1993.

Abdalla M., O Kościele asyryjskim i męczeństwie chrześcijan Kościołów Wschodnich, „Mozaika Obrzańska” nr 40/1, 1999.

Abdalla M., W kręgu asyryjskiej tradycji, „Poznaj świat” nr 1, 1985.

Abdalla M., Z kręgu folkloru chrześcijańskich Asyryjczyków, „Literatura Ludowa” nr 4-6, 1986.

An Eastern Statesman, Contemporary Life and Thought in Turkey, „Contemporary Review”, 37 (1880).

Anschütz H., Die Gegenwartslage der 'Apostolischen Kirche des Ostens' und ihre Beziehungen sur 'assyrisschen' Nationalbewegung, „Ostkirchliche Studien” 18, 1969.

Berntsson M., Assyrier eller syrianer? Om fotboll, identitet och kyrkohistoria, Gränser. Humanistdag-boken nr 16, 2003.

Brock S., Christians in the Sasanian Empire: A Case of Divided Loyalties, „Syriac Perspectives on Late Antiquity" IV, Londyn 1984.

Chikhladze I., G. Chikhladze, The Yezidi Kurds and Assyrians of Georgia. The Problem of Diasporas and Integration into Contemporary Society, „Journal of the Central Asia and the Caucasus" 3/21, 2003.

Çiyan G., A Report on: Assyrians/Syrians, the Situation in Upper Mesopotamia, Zarathustra News, EuroKurd Human Rights-EHR, nr 11, Sztokholm, February 2009.

Coakley J.F., The Church of the East Since 1914, „Bulletin of the John Rylands Library” 78, 1996.

De Kelaita R.W., On the Road to Niniveh: A Brief History of Assyrian Nationalism, 18921990, JAAS, Vol. 8, No. 1, 1994.

Dekker H., D. Malová, S. Hoogendoorn, Nationalism and Its Explanations, „Political Psychology", Vol. 24, No. 2, Special Issue: National Identity in Europe, June 2003.

„Detroit Free Press” 1981, 2/1; 3/1. 
Dr. Layard and the Last of the Chaldeans, „The New Monthly Magazine”, 87 (1849).

Dudziak M., rec. pracy Naród - Tożsamość-Kultura. Między koniecznościa a wyborem, red. W.J. Burszta, K. Jaskułowski, J. Nowak, Warszawa 2005, „Studia z Filologii Polskiej i Słowiańskiej" 41/2006.

Dylematy tożsamości, „Horyzonty Wychowania”, 4/2005 (7).

Dzięgiel L., Archeology and Martyrology: Sources of the Integration of Assyrian Christian Communities in the Contemporary World, „Hemispheres” nr 5, 1988.

Fiey J. M., „Assyriens” ou Araméens?, L'Orient Syrien, t. 10, Paris 1965.

Fine G., J. Deegan, Three Principles of Serendip: Insight, Chance, and Discovery, „Qualitative Research Studies Education" nr 9, 1996.

Frey R., Assyria and Syria: Synonyms, JAAS, Vol. XI, No. 2, 1997.

Hobsbawm E.J., Ethnicity and Nationalism in Europe Today, „Anthropology Today”, Vol. 8, No. 1, February 1992.

Husry Kh. S., The Assyrian Affair of 1933, „International Journal of Middle East Studies” 2, 1974.

Isajiw V., Definitions of Ethnicity, „Ethnicity”, No. 1, 1974.

Ishaya A., From Contributions to Diaspora: Assyrians in the History of Urmia, Iran, JAAS, Vol. XVI, No. 1, 2002.

Joseph J., The Bible and the Assyrians: It Kept Their Memory Alive, JAAS, No. 12.

Khan G., Remarks on the Historical Background of the Modern Assyrian Language, JAAS, Vol. 21, No. 1, 2007.

Kłoskowska A., Tożsamość $i$ identyfikacja narodowa w perspektywie historycznej $i$ psychologicznej, „Kultura i Społeczeństwo” nr 1, 1992.

Kwiek M., Demokracja a państwo narodowe, „Decydent. Pismo Lobbingowe” nr 7-8/2001.

„Kokhva” nr 1/10, 1906; 2/9, 1907.

Lipiński E., The Linguistic Geography of Syria in Iron Age II (c. 1000-600 B. C.), „Ancient Near Eastern Studies - Supplement 7”, 2000.

Macuch R., Tur 'Abdin Through the Ages, „Abr-Nahrain” 29, 1991.

Mangaliman J., „San Jose Mercury News”, 2 September 2001.

Mar (Eshai) Shimun, Assyrians in the Middle East, "Journal of the Royal Central Asian Society" 40, 1953.

Mar Eshai Shimun, leader of Assyrians, „St. Petersburg Times”, 10.11.1975.

Mar Raphael I Bidawid, (wywiad w) „Assyrian Star” 55/3 (Jesień 2003).

Moberg M., The Patriarchal See of Antioch and SeleucialKtesiphon: Pattern of a Development that Frightens and Inspires Today, "The Harp 5” nr 1-3, lipiec 1992.

Moczydłowski Ł., Powrót idei. Czym jest a czym nie jest nacjonalizm?, „Magazyn Kulturalny Phalanx" nr 3/2002.

Naby E., Les assyriens d'Union Soviétique, „Cahiers du monde russe et soviétique” 16/3-4, 1975.

Naby E., The Assyrians of Iran: Reunification of a 'Millat'. 1906-1914, „International Journal of Middle East Studies" 8, 1977.

Nijakowski L. M., Znaczenie analizy dyskursu dla socjologii narodowości, „Kultura i Społeczeństwo" nr 1, 2004.

Nöldeke Th., Assyrios Syrios Syros, „Hermes” 5, 1871. 
Nöldeke Th., Die Namen der aramäischen Nation und Sprache, „Zeitschrift der Deutschen Morgenländischen Gesellschaft” 25, 1871.

Nöldeke Th., Ueber den namen Assyriens, „Zeitschrift für Assyriologie und verwandte Gebiete" 1, 1886.

Parpola S., National and Ethnic Identity in the Neo-Assyrian Empire and Assyrian Identity in Post Empire Times, JAAS, Vol. 18, No. 2, 2004.

Renan E., Co to jest naród?, „Res Publica Nowa”, rocznik XVIII, nr 1 (183), Warszawa 2005.

Rollinger R., Assyrios, Syrios, Syros und Leukosyros, „Die Welt des Orients” 36, 2006.

Rollinger R., The Terms „Assyria” and „Syria” Again, „Journal of Near Eastern Studies”, Vol. 65, No. 4, Chicago 2006.

Rommel C., Assyrians or Syriacs? Middle Eastern Identity Formation Through Football in Sweden, „Middle East Institute Viewpoints: Sport and the Middle East”, USA 2010, s. 20-23.

„San Francisco Chronicle” 1982, 1/18.

Sarguis F., rec. M. Al-Rasheed, Iraqi Assyrian Christians in London: The Construction of Ethnicity, New York 1998, JAAS, Vol. 14, No. 1, 2000.

Schütze F., Trajektorie cierpienia jako przedmiot badań socjologii interptetatywnej, „Studia Socjologiczne" 1/1997.

Schwartz E., Einiges über Assyrien, Syrien, Koilesyrien, „Philologus” 86, 1931.

Schwartz E., Noch einmal über Assyrien und Syrien, „Philologus” 87, 1932.

Sériot P., Ethnos i demos: dyskursywne konstruowanie zbiorowej tożsamości, „Teksty Drugie” nr $1 / 1994$.

Sökefeld M., Alevism Online: Re-Imagining a Community in Virtual Space, „Diaspora: A Journal of Transnational Studies", Vol. 11, No. 1, Spring 2002.

Starnawski M., Naród, ojczyzna, tożsamość. O iluzjach urzeczywistnionych, „Recykling Idei” nr 7, 20 kwietnia 2006.

Szacki J., O tożsamości (zwłaszcza narodowej), „Kultura i Społeczeństwo” nr 3, 2004.

„Turlock Daily Journal” 12 listopad-23 grudzień 1981.

Tzilivakis K., Iraq's Forgotten Christians Face Exclusion in Greece, „Athens News”, 10 May 2003.

Van Bruinessen M.M., The Christians of Eastern Turkey, the State and the Local Power Structure, „ICMC Migration News”, No. 3-4, 1979.

Warda G., rec. M. Al-Rasheed, Iraqi Assyrian Christians in London: The Construction of Ethnicity, New York 1998, JAAS, Vol. 14, No. 1, 2000.

Witakowski W., Geneza chrzésijańskiej kultury syryjskiej, „Studia Theologica Varsaviensia” nr 1, Warszawa 1978.

Yacoub J., La diaspora assyro-chaldéene, „L'Éspace géographique” 23, No. 1, 1994.

Ziółkowski M., Dziedziczenie i wybór. Zwiększenie możliwości wyboru, nierówności społeczne i problemy społecznej tożsamości, „Studia Socjologiczne” nr 3, 2002.

\section{Niepublikowane teksty referatów i prac magisterskich oraz doktorskich}

Atto N., „Perception of Identity Among Suroye in European Diaspora”, Presentation Symposium Syriacum, Sayyidat al-Bir 2004, niepublikowany referat.

Atto N., „We have come here and left all the shame and sin behind there': Changes in the understanding of Shame and Sin among Suryoye in Europe", Presentation Symposium Syriacum, Malta 2012, niepublikowany referat. 
Burçak A., „Assyrian Transnational Politics: Activism From Europe Towards Homeland”, niepublikowana praca magisterska obroniona na Middle East Technical University, Cypr Północny 2011.

Drennon Ch.M., „(Re)Inventing Macedonia: The Passage from Religious to Territorial Identity", niepublikowana dysertacja obroniona na University of Texas, Austin 1998.

Georges R.H., „The Chaldeans between Religion and Politics: The Struggle of Iraq's Minority and US National Security", niepublikowana praca magisterska obroniona na San Diego State University, San Diego (USA) 2010.

Hanoosh Y. S., „The Politics of the Minority. Chaldeans between Iraq and America”, niepublikowana praca doktorska obroniona na University of Michigan, Michigan (USA) 2008.

Helm P. R., „'Greeks' in the Neo-Assyrian Levant and 'Assyria' in Early Greek Writers”, niepublikowana praca doktorska obroniona na University of Pennsylvania, Pennsylvania (USA) 1980.

Ishaya A., „Class and Ethnicity in Rular California: The Assyrian Community of Modesto-Turlock, 1910-1985”, dysertacja obroniona na University of California, Los Angeles 1985.

Laing-Marshall A. I., „Modern Assyrian Identity and the Church of the East: An Exploration of Their Relationship and the Rise of the Assyrian Nationalism, From the World Wars to 1980 ", niepublikowana praca magisterska, Department of History, University of Saint Michael's College, Toronto School of Theology, Toronto 2001.

Mati B., „Ett liv i många världar: Mångfalden av identiteter för assyrier som utvandrat och invandrat”, Lund Universitet 2011, niepublikowana praca.

Messo J., „The Origin of the Terms 'Syria(n)' \& Sūryoyo once again”, Presentation Symposium Syriacum, Grenada 2008, niepublikowany referat.

Moch M., „Kształtowanie się i rozwój palestyńskiego nacjonalizmu i tożsamości narodowej”, niepublikowana praca magisterska obroniona w Instytucie Orientalistycznym, Uniwersytet Warszawski, Warszawa 2005.

Önder S., „Applying 'Social Capital' Theory to the Assyrian Case in Sweden. A Study of Assyrians in Södertälje”, niepublikowane studium przygotowane w ramach zaawansowanego kursu politologii na Stockholm University, Sztokholm 2008.

Rabo A., „Without Our Church We Will Disappear. The Syrian Orthodox in Diaspora and the Family Law of the Church", 4th Global Conference: Diasporas - Exploring Critical Issues, Oxford 2011, niepublikowany referat.

Saouk J., „Quo Vadis Turoyo? A description of the situation and the needs of Turoyo (or New West-Aramaic)", Presentation Symposium Syriacum, Malta 2012, niepublikowany referat.

Smith G., „From Urmia to the Stanislaus: A Cultural-Historical Geography of Assyrian Christians in the Middle East and America”, niepublikowna praca doktorska obroniona na University of California, Davis 1981.

\section{Artykuły w Internecie}

Abraham S., Syrian Authorities Ban Assyrian Party from Commemorating Martyrs Day, „Good Morning Assyria”, Zinda 10, sierpień 2004, http://www.zindamagazine.com/ html/archives/2004/8.10.04/index_tue.php\#GoodMorningAssyria.

Affiliates, http://aua.net/index.php?option=com_content\&view=article\&id=96\&Itemid=86. AINA: Appeal for a ChaldoAssyrian Safe Haven in Northern Iraq, http://www.christiansofiraq.com/Aina.html. 
Alkhas W., Assyrian Calender, Niniveh On Line, http://www.nineveh.com/Assyrian\%20 Calendar.html.

Aramaic Democratic Organization, http://www.aramaic-dem.org.

Archbishop kidnapped in Iraq found dead, "The Guardian”, http://www.guardian.co.uk/ world/2008/mar/13/iraq.religion.

Arsan M., Assyrians-Suryoye Occupy a Governmental Building in Lausanne-Switzerland, http://www.bethsuryoyo.com/currentevents/lusanne/Occupation1.html.

Assyrian Aid Society, http://www.assyrianaidsociety.org/about_us.php.

Assyrian called for Safe Heaven since WWII, http://www.betnahrain.org/bbs/index.pl/noframes/read/1519.

Assyrian Community Celebrates 30 Years in Belgium, AINA, http://www.aina.org/ news/20091008154651.htm.

Assyrian Democratic Movement, http://www.zowaa.org/.

Assyrian Youth in Switzerland Light Candles for Assyrians in Iraq, ADO World, http:// en.ado-world.org/news/assyrian-news/article/assyrian-youth-in-switzerland.

Assyrians in Australia Protest Church Bombings, „Assyria Times”, http://www.assyriatimes. $\mathrm{com} /$ engine/modules/news/article.php? storyid=3440.

Asyryjczycy upominaja się o swoje - przynajmniej nazewnictwo, http://szlomo.pl/index.php.

BarAbrahem A., Nękanie asyryjskiego klasztoru Mor Gabriel przez Turków i Kurdów, http:// pixartmedia.home.pl/szlomo/index2.php?option=com_content\&do_pdf=1\&id=189.

Bet-Nahrain Democratic Party's Declaration, „Assyria Times”, http://assyriatimes.com/engine/modules/news/article.php?storyid=3236.

Braüchler B., Comments on Jonathan's Skinner's working paper „At the Electronic Evergreen: a computer mediated ethnography of a newsgroup from Montserrat and afar", http://www. media-anthropology.net/braeuchler_comment.pdf.

Bush Meets Assyrian Delegation in Georgia, AINA, http://www.aina.org/news/20050516160356.pdf.

Community Life and Culture, Multicultural Canada, http://www.multiculturalcanada.ca/ Encyclopedia/A-Z/a24/3. Craig O., Dirty, hunched and hungry: Tariq Aziz digs his own latrine, „Sunday Telegraph”, http://www.telegraph.co.uk/news/main.jhtml?xml=/ news/2003/07/20/wirq220.xml.

Cyberland-Music, Nationalism \& Internet, http://www.visarkiv.se/mmm/media/assyrien/ cyber-e.htm.

Cyrus, Assyrian Church of Saint Joseph, Tehran, Iran, http://www.skyscrapercity.com/ showthread.php? $\mathrm{t}=429802$.

Farid Nuz'ha, an Assyrian Nationalist, http://www.christiansofiraq.com/faridnuzha.html.

Föderation der Aramäer (Suryoye) in Deutschland (FASD), http://www.oromoye.de/.

Gaunt D., Identity conflicts among Oriental Christian in Sweden, „Sens public”, http:// www.sens-public.org/spip.php?article767\&lang=fr.

Gavlak D., Iraq Christians Flee to Jordan, Syria in Response to Increased Persecution, „Baptist Press News", http://www.bpnews.net/bpnews.asp?Id=19302.

Giwargis A., Assyrophobia, http://www.nineveh.com/ASSYROPHOBIA.html.

Goble P., The Assyrians of Russia, AINA, http://www.aina.org/ata/20101224152140.htm.

Hakobyan H., Armenia is a Homeland for the Assyrians, Who Have No Homeland, AINA, http://www.aina.org/ata/20090327164710.htm. 
His Holiness Moran Mor Ignatius Zakka Iwas I, http://stmaryslynbrook.org/?page_id=37. Ishaya A., Assyrian-Americans. A Study in Ethnic Reconstruction and Dissolution in Diaspora, http://www.nineveh.com/ASSYRIAN-AMERICANS.html\#_ftn20.

Konecki K. T., Teoria ugruntowana a kontekst odkrycia. Naturalna historia pewnego badania, qsr.webd.pl/KKonecki/publikacje/publikacja27.doc.

Kropidłowski M., Kościót Asyryjski (Asyriacki), http://www.magazyn.ekumenizm.pl/article.php?story=20040226132441981.

Laskowski T., Karl Rajmund Popper i jego filozofia nauki, http://vharijjen.w.interia.pl/content/Popper.html.

Lewis J. E., Iraqi Assyrians: Barometer of Pluralism, „The Middle East Qurtely”, Vol. X, No. 3, Summer 2003, http://www.meforum.org/article/558.

Maraha N., The Vioce and Myth of Gabriel Afram, http://www.bethsuryoyo.com/articles/ MalfonoGabrielAfram/MalfonoGabrielAfram.html.

Megalommatis M.S., Aram Nahrin: the Aramaeans, the Bible, Christianity, and the West, http://evigalivet.bloggspace.se/r12178/Arameer-Syrianer.

Messo J., The Aramean Identity of Tur Abdin and its Native Population, http://www. midyatcity.com/articles/turabdin_aramean.pdf.

Messo J., The Identity of the People Described in the Writings of Gabriele Yonan, http://www. midyatcity.com/articles/gyonan_messo.pdf.

Mikołajczak T., Jezzyk Chrystusa w Syrii?, http://www.polskieradio.pl/nauka/artykul.aspx?i$\mathrm{d}=15679$.

Moses A. R., Saddam Once Received Key to Detroit, „Zinda Magazine”, http://www.zindamagazine.com/html/archives/2003/3.31.03/index.php.

Mouawad R. J., Syria and Iraq - Repression, „The Middle East Qurtely”, Vol. VIII, No. 1, Winter 2001, http://www.meforum.org/article/17.

Multimedialny swiat Biblii, http://www.swiatbiblii.com/msb_db.php?nomenu=\&n=c/ c1_133.ugz\&o=Crfmvggn.

Najdziwniejsze derby swiata. A przynajmniej Szwecji, http://www.zczuba.pl/zczuba /1,90957,7096013,Najdziwniejsze_derby_swiata_A_przynajmniej_Szwecji.html.

Nijakowski L. M., Analiza dyskursu na temat mniejszości narodowych i etnicznych w polskich mediach, http://www.racjonalista.pl/kk.php/s, 4820.

Odisho E. Y., The Ethnic, Linguistic and Cultural Identity of Modern Assyrians, http://www. aakkl.helsinki.fi/melammu/pdf/odisho2001.pdf.

Oussi G., Assyrians Today, „Meltha Magazine Online”, http://melta4.tripod.com/conference_issue/Assyrians_today.

Parhad F., Assyrian Muslims v. Assyrian Christians, Fred Parhad's Reflections on Assyria, „Zinda Magazine" 6, No. 37, http://www.zindamagazine.com/html/archives/2001/zn013001.html.

Parpola S., Assyrian Identity in Ancient Times and Today, http://www.aina.org/articles/assyrianidentity.pdf.

Patrous A., Assyrians in Finland, „Zinda Magazine”, http://www.zindamagazine.com/ html/archives/2001/11.12.01/index.php\#TheLighthouse.

Présentation de la communauté assyro-chaldéenne de France, http://www.aacf.asso.fr.

Ross K. L., Note on the Modern Assyrians, „The Proceedings of the Friesian School”, http:// web.archive.org/web/20000816221217/http://www.friesian.com/notes/note-n.htm. 
Sada A., Should Assyrians in Syria side with the government or against it?, "Assyrian Voice Emagazine", http://assyrianvoice.net/emagazine/?p=638.

Shuraya, http://www.shuraya.de.vu/.

Solomon S., 1933: The Assyrians of Khabur, Syria, „Nineveh Magazine”, http://www.atour. com/history/1900/20001011b.html.

Södertälje: Muslims flee Assyrian attacks, Islam in Europe, http://islamineurope.blogspot. com/2009/04/sodertalje-muslims-flee-assyrian.html, data wejścia 9.08.2010.

Syriac burning Assyrian Flag - Aramäer brennen Assyrer Flagge, http://www.youtube.com/ watch? $=$ nhuy- $0 \mathrm{wVq} 6 \mathrm{~A}$.

Syriac Universal Alliance, http://www.sua-ngo.org/.

The Advantages of a Governate Region Versus Safe Heaven, http://www.christiansofiraq.com/ governate.html.

The Assyrian (Australian Assyrian News), http://theassyrian.com.au/.

The Assyrians, http://russia.rin.ru/guides_e/7364.html.

The Burning of the Assyrian flag by Kurds, http://www.betnahrain.org/bbs/index.pl/noframes/read/35559.

The Christians of Iraq, Al Jazeera, http://english.aljazeera.net/NR/exeres/1E5FAE56-8F8B-496E-86BB-136D2BBD0999.htm.

The Meaning of the Assyrian Flag, AINA, http://www.aina.org/aol/flag.htm.

The Strangest Football Derby in the World, http://www.christiansofiraq.com/two-assyriansoccore-teams.html.

Valentinas M., Kidnapping of Catholic Archbishop Highlights Christians' Plight', http:// www.rferl.org/content/article/1056922.html.

Wioska asyryjska $w$ Australii, http://www.pixartmedia.home.pl/szlomo/index.php?optio$\mathrm{n}=$ com_content\&task=view\&id=238\&Itemid=1.

Younan P. D., Jezzyk aramejski, http://www.szlomo.alleluja.pl/tekst.php?numer=25938.

„Zenda Magazine”, Vol. I, Issue I, February 6, 1995, http://www.zindamagazine.com/ html/archives/1995/zn020695.html.

Zoepf K., Many Christians Flee Iraq, With Syria the Haven of Choice, „NY Times”, http:// www.christiansofiraq.com/exodus.html.

\section{Strony internetowe}

gl-es.facebook.com/topic.php?uid=51313897386\&topic $=5883$

gl-es.facebook.com/topic.php?uid=51313897386\& topic $=5885 \&$ post $=22278$

http://christiansofiraq.com/Assygenocidecanada08.html

http://learnassyrian.com/aramaic

http://turabdinberlin.de/news/archives/630

http://www.aina.org

http://www.aina.org/aol/link3.htm

http://www.aina.org/ata/20080320151756.htm

http://www.ankawa.com

http://www.aramaic-dem.org/English/History_culture/Aramean_\%28Suryoyo\%29_

Identity.htm 
www.atranews.com

http://www.arameantv.nl.tt

http://www.aramnaharaim.org

http://www.aramnahrin.org/English/Sweden_Aramean_Genocide_5_1_2008.htm

http://www.assyriacouncil.eu

http://www.assyrian4all.net

http://www.assyriancupid.com

http://www.assyrianmatch.com

http://www.assyriansingles.com

http://www.assyrianvoice.net/forum/index.php?topic=36689.0

http://www.atour.com/news/assyria/20031220a.html

http://www.chaldean.org

http://www.christiansofiraq.com

http://www.christiansofiraq.com/polishresearchermar218.html

http://www.edessa.com/assyorgs.htm

http://www.geocities.com/iamthespark

http://www.hujada.com/article.php?ar=740

http://www.huyodo.com/index.php?area=1\&p=news\&newsid=234

http://www.seyfocenter.se

http://www.shuraya.com

http://www.suroyotv.com

http://www.suryoyena.org/magazin.php?art=386

http://www.tebayn.com/Tebayn\%20English/index.asp?pageID=1\&SID=9552\&Ln=En

http://www.thenazareneway.com/lords_prayer.htm

http://www.uacf.asso.fr

http://www.utpjournals.com/diaspora/diaspora111.html

http://www.yauno.com/index.php? modul=article\&action=show\&id=1118

http://www.zindamagazine.com/html/archives/2008/04.14.08/index_mon.php 
308 
Aneksy 


\section{Aneks 1: Ankieta „Tożsamość asyryjska”}

Niniejsza ankieta przeprowadzana jest w celu zebrania danych do części empirycznej pracy doktorskiej poświęconej asyryjskiej tożsamości. Praca ta powstaje na Uniwersytecie Łódzkim (Polska). Autorce zależy na szczerych odpowiedziach oraz wszelkich dodatkowych komentarzach. Ankieta jest anonimowa - nie ma potrzeby jej podpisywać. $\mathrm{Z}$ podziękowaniem za poświęcony czas,

mgr Marta Woźniak

Katedra Bliskiego Wschodu

i Północnej Afryki UŁ

1. Płeć:

\section{Metryczka}

1) Mężczyzna

2) Kobieta

2. Rok urodzenia:

3. Kraj i miejsce urodzenia:

4. Kraj pobytu i miejscowość zamieszkania:

5. Wykształcenie:

1) podstawowe

2) średnie

3) wyższe

6. Zawód wykonywany:

7. Z jakiego kraju i miejscowości pochodzi:

1) Pana/Pani matka....

2) Pana/Pani ojciec 
8. Stan cywilny:

1) kawaler/panna $\rightarrow$ proszę przejść do pytania 1. Ankiety

2) rozwiedziony/rozwiedziona

3) wdowiec/wdowa

4) żonaty/mężatka

9. Z jakiego kraju i miejscowości pochodzi Pana/Pani żona/mąż

10. Pana/Pani żona/mąż jest Asyryjką/Asyryjczykiem:
1) tak
2) nie

11. Czy ma Pan/Pani dzieci?

1) tak, ile?

2) nie

\section{Ankieta}

1. Według Pan/Pani bycie Asyryjczykiem/Asyryjką to (można zaznaczyć więcej niż jedna odpowiedź):

1) urodzenie się w asyryjskiej rodzinie

2) bycie chrześcijaninem/chrześcijanką jednego z asyryjskich obrządków

3) zamieszkiwanie asyryjskiego terytorium

4) posługiwanie się językiem aramejskim

5) kultywowanie asyryjskich tradycji i obrzędów

6) czynne uczestnictwo w życiu kulturalnym, religijnym i politycznym społeczności asyryjskiej

7) coś innego, co?

2. Czy zna Pan/Pani syryjski język klasyczny (ktubunojo)?

1) tak

2) nie $\rightarrow$ prosze przejsć do pytania 5. 
3. Proszę ocenić na skali stopień opanowania ktubunojo:

słaby

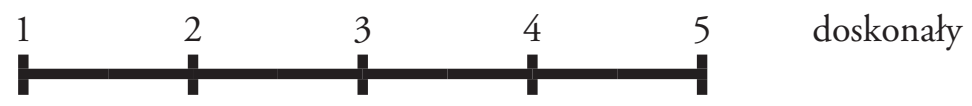

4. Czy zna Pan/Pani język aramejski (surjojo/suret)?

1) tak

2) nie $\rightarrow$ proszęprzejsć do pytania 8.

5. Proszę ocenić na skali stopień opanowania języka aramejskiego:

słaby

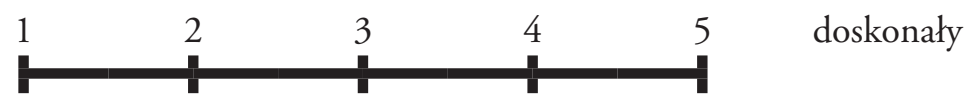

6. Jaki(e) zna Pan/Pani dialekt(y) języka aramejskiego?

7. W jaki sposób nauczył(a) się Pan/Pani języka aramejskiego?

1) od rodziców

2) od dziadków

3) w szkole

4) w inny sposób (jaki?)

8. Jakim(i) językiem/językami posługuje się Pan/Pani podczas rozmowy z:

1) rodzicami.

2) dziadkami

3) rodzeństwem

4) w szkole/pracy

5) w innych sytuacjach

9. W jakim/jakich języku/językach Pan/Pani:

1) pisze?

2) czyta?

3) myśli? 
10. Czy czyta Pan/Pani prasę asyryjską (gazety, czasopisma)?

1) tak, jaką?

2) nie

11. Czy ogląda Pan/Pani telewizję asyryjską?

1) tak, jaką?

2) nie

12. Czy słucha Pan/Pani asyryjskiej rozgłośni radiowej?

1) tak, jakiej?

2) nie

13. Czy odwiedza Pan/Pani w Internecie asyryjskie portale informacyjne?

1) tak, jakie?

2) nie

14. Czy może Pan/Pani wymienić tytuły książek napisanych przez Asyryjczyków?

1) tak, jakich?

2) nie

15. Czy zna Pan/Pani jakichśsławnych Asyryjczyków?

1) tak, jakich?

2) nie

16. Czym jest dla Pana/Pani tradycja?

17. Czy tradycja i jej kultywowanie jest dla Pana/Pani istotne? (prosze zaznaczyć tylko jedna odpowiedź):

1) tak, bardzo ważna

2) tylko przy specjalnych okazjach np. świętach

3) w ogóle nie ma dla mnie znaczenia 


\begin{tabular}{|c|c|c|c|c|c|}
\hline $\begin{array}{l}\text { 18. W jakim stopniu Pana/Pani zdaniem na } \\
\text { asyryjską tradycję składają się poniższe elementy? } \\
\text { (proszę zaznaczyć wtaściwe odpowiedzi wstawiając } \\
\text { „x") }\end{array}$ & 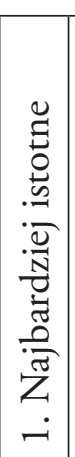 & 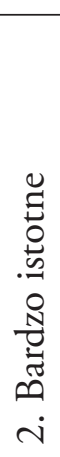 & $\begin{array}{l}\mathscr{\Xi} \\
\stackrel{\Xi}{0} \\
\stackrel{\Xi}{\oplus} \\
\dot{n}\end{array}$ & 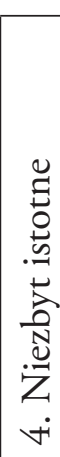 & 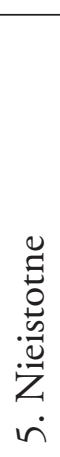 \\
\hline 1) asyryjska muzyka i tańce & & & & & \\
\hline 2) asyryjskie stroje ludowe & & & & & \\
\hline 3) kuchnia asyryjska & & & & & \\
\hline 4) asyryjskie przysłowia i mądrości ludowe & & & & & \\
\hline 5) asyryjskie mity i legendy & & & & & \\
\hline
\end{tabular}

19. Czy w Pana/Pani domu rodzinnym pielęgnowane są tradycje asyryjskie? 1) tak

2) nie $\rightarrow$ proszę przejść do pytania 21.

20. W jaki sposób pielęgnowane są w Pana/Pani domu tradycje asyryjskie?

21. Czy zna Pan/Pani dzieje swojej rodziny?

1) tak

2) nie 
22. Proszę wybrać te okoliczności, podczas których spotyka się Pana/Pani rodzina (można wybrać więcej niż jedna odpowiedź):
1) święta kościelne
2) asyryjski Nowy Rok (Ha Nissan)
3) urodziny
4) wesela
5) pogrzeby
6) inne, jakie?

23. Czy w Pana/Pani domu istotną rolę odgrywają święta?
1) tak
2) nie

24. Czym są dla Pana/Pani święta? (proszę zaznaczyć tylko jedna odpowiedź):

1) okazją do odwiedzenia rodziny, znajomych

2) dniem wolnym od szkoły/pracy

3) czasem zadumy i refleksji

4) dają mi możliwość utożsamienia się z moją wspólnotą narodową

5) nigdy się nad tym nie zastanawiałem/zastanawiałam

6) czymś innym, czym?

25. Do jakiego kościoła Pan/Pani należy?

1) Asyryjskiego Kościoła Wschodu

2) Syryjskiego Kościoła Ortodoksyjnego

3) Chaldejskiego Kościoła Katolickiego

4) Syryjskiego Kościoła Katolickiego

5) Kościoła protestanckiego

6) żadnego

7) innego, jakiego?

26. Jest Pan/Pani osobą:

1) wierzącą praktykującą

2) wierzącą niepraktykującą

3) niewierzącą praktykującą

4) niewierzącą niepraktykującą

5) nieidentyfikującą się z żadną formą religii, ale wierzącą w istnienie sił nadprzyrodzonych 
27. Jak często bierze Pan/Pani udział we mszy świętej?

1) regularnie w każdą niedzielę lub częściej

2) nieregularnie kilka razy do roku

3) tylko z wyjątkowych okazji takich jak śluby, pogrzeby

4) tylko z okazji świąt

5) w ogóle nie uczestniczy

28. Czy interesuje się Pan/Pani życiem Asyryjczyków?

1) tak

2) nie $\rightarrow$ proszęprzejść do pytania 30 .

29. Interesuje Pana/Panią życie Asyryjczyków (proszęzaznaczyć tylko jedna odpowiedź):

1) w ojczyźnie

2) w diasporze

3) w ojczyźnie i w diasporze

30. Proszę wymienić znane sobie symbole asyryjskie:

31. Czy popiera Pan/Pani działania organizacji/stowarzyszeń asyryjskich?

1) tak

2) nie

32. Czy kibicuje Pan/Pani asyryjskiemu klubowi sportowemu?

1) tak, jakiemu?

2) nie

33. Czy w kraju zamieszkania bierze Pan/Pani udział w nieasyryjskim życiu:
1) politycznym?
tak
nie
2) kulturalnym?
tak
nie
3) religijnym?
tak
nie 


\begin{tabular}{|c|c|c|c|c|c|}
\hline $\begin{array}{l}\text { 34. Czy zgadza się Pan/Pani z następującymi } \\
\text { stwierdzeniami: (prosze zaznaczyć właściwe } \\
\text { odpowiedzi wstawiajqc „, } x ” \text { ) }\end{array}$ & 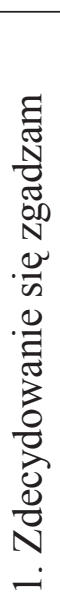 & 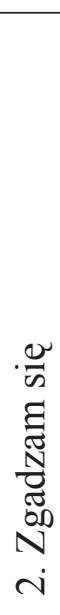 & 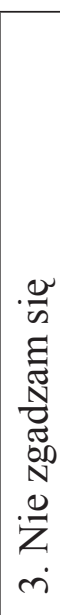 & 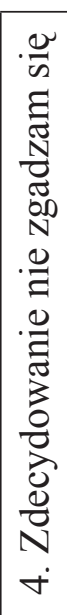 & 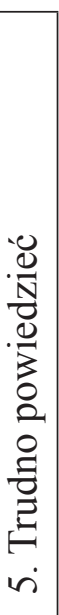 \\
\hline $\begin{array}{l}\text { 1) Mam świadomość swojego pochodzenia } \\
\text { i tego, co ono dla mnie znaczy }\end{array}$ & & & & & \\
\hline $\begin{array}{l}\text { 2) Jestem szczęśliwy/szczęśliwa, że jestem Asy- } \\
\text { ryjczykiem/Asyryjką }\end{array}$ & & & & & \\
\hline $\begin{array}{l}\text { 3) Według mnie współcześni Asyryjczycy po- } \\
\text { chodzą od starożytnych Asyryjczyków }\end{array}$ & & & & & \\
\hline $\begin{array}{l}\text { 4) Mam silne poczucie przynależności do histo- } \\
\text { rycznych ziem Asyrii }\end{array}$ & & & & & \\
\hline $\begin{array}{l}\text { 5) Rozmawiam z innymi ludźmi, by dowiedzieć } \\
\text { się więcej na temat swoich przodków }\end{array}$ & & & & & \\
\hline $\begin{array}{l}\text { 6) Preferuję asyryjskie tradycyjne potrawy, mu- } \\
\text { zykę, zwyczaje }\end{array}$ & & & & & \\
\hline $\begin{array}{l}\text { 7) Jestem dumny/dumna z asyryjskiej społecz- } \\
\text { ności }\end{array}$ & & & & & \\
\hline
\end{tabular}

35. Jakie według Pana/Pani jest największe zagrożenie dla tożsamości asyryjskiej? (można zaznaczyć więcej niż jedna odpowiedź):

1) polityczne i społeczne niepokoje w ojczyźnie

2) emigracja z ojczyzny

3) asymilacja w diasporze

4) porzucenie tradycji

5) zapomnienie języka

6) utrata więzi wewnątrz asyryjskiej wspólnoty

7) utrata kontaktu z ojczyzną

8) inne (jakie?) 
36. Jak ważne jest dla Pana/Pani zachowanie asyryjskiej tożsamości?

W ogóle

nie jest

ważne

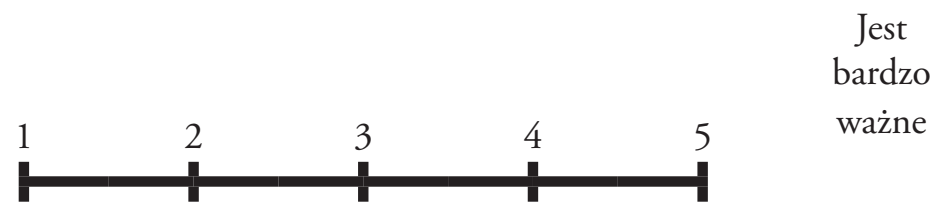

37. W jaki sposób można przyczynić się do zachowania asyryjskiej tożsamości?

38. Czy ma Pan/Pani jakieś dodatkowe uwagi?

Serdecznie dziękuję za udzielenie odpowiedzi! 


\section{Aneks 2: Ankieta „Tożsamość aramejska”}

Niniejsza ankieta przeprowadzana jest w celu zebrania danych do części empirycznej pracy doktorskiej poświęconej asyryjskiej tożsamości. Praca ta powstaje na Uniwersytecie Łódzkim (Polska). Autorce zależy na szczerych odpowiedziach oraz wszelkich dodatkowych komentarzach. Ankieta jest anonimowa - nie ma potrzeby jej podpisywać. $Z$ podziękowaniem za poświęcony czas,

mgr Marta Woźniak

Katedra Bliskiego Wschodu

i Północnej Afryki UŁ

\section{Metryczka}

1. Płeć:

1) Mężczyzna

2) Kobieta

2. Rok urodzenia:

3. Kraj i miejsce urodzenia:

4. Kraj pobytu i miejscowość zamieszkania:

5. Wykształcenie:
1) podstawowe
2) średnie
3) wyższe

6. Zawód wykonywany:

7. Z jakiego kraju i miejscowości pochodzi:

1) Pana/Pani matka

2) Pana/Pani ojciec 
8. Stan cywilny:

1) kawaler/panna $\rightarrow$ prosze przejsć do pytania 1. Ankiety

2) rozwiedziony/rozwiedziona

3) wdowiec/wdowa

4) żonaty/mężatka

9. Z jakiego kraju i miejscowości pochodzi Pana/Pani żona/mąż?

10. Pana/Pani żona/mąż jest Aramejką/Aramejczykiem (Surjojo):

1) tak

2) nie

11. Czy ma Pan/Pani dzieci?

1) tak, ile?

2) nie

\section{Ankieta}

1. Według Pan/Pani bycie Aramejczykiem/Aramejką (Surjojo) to (można zaznaczyć więcej niż jedną odpowiedź):

1) urodzenie się w aramejskiej/surjojo rodzinie

2) bycie chrześcijaninem/chrześcijanką jednego z aramejskich/surjoje obrządków

3) zamieszkiwanie aramejskiego/surjojo terytorium

4) posługiwanie się językiem aramejskim

5) kultywowanie aramejskich/surjoje tradycji i obrzędów

6) czynne uczestnictwo w życiu kulturalnym, religijnym i politycznym społeczności aramejskiej/surjojo

7) coś innego, co?

2. Czy zna Pan/Pani syryjski język klasyczny (aramejski edeski)?

1) tak

2) nie $\rightarrow$ proszę przejsć do pytania 5 . 
3. Proszę ocenić na skali stopień opanowania klasycznego języka syryjskiego:

słaby

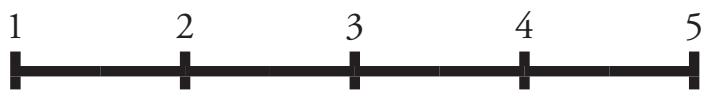

5 doskonały

4. Czy zna Pan/Pani język aramejski (surjojo i/lub surajt/suret)?

1) tak

2) nie $\rightarrow$ proszę przejść do pytania 8 .

5. Proszę ocenić na skali stopień opanowania języka aramejskiego: słaby

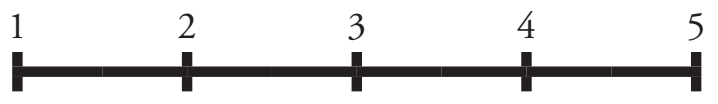

doskonały

6. Jaki(e) zna Pan/Pani dialekt(y) języka aramejskiego?

7. W jaki sposób nauczył(a) się Pan/Pani języka aramejskiego?

1) od rodziców

2) od dziadków

3) w szkole

4) w inny sposób (jaki?)

8. Jakim(i) językiem/językami posługuje się Pan/Pani podczas rozmowy z:

1) rodzicami

2) dziadkami.

3) rodzeństwem

4) w szkole/pracy

5) w innych sytuacjach

9. W jakim/jakich języku/językach Pan/Pani:

1) pisze?

2) czyta?

3) myśli? 
10. Czy czyta Pan/Pani prasę aramejską/surjojo (gazety, czasopisma)?

1) tak, jaką?

2) nie

11. Czy ogląda Pan/Pani telewizję aramejską/surjojo?

1) tak, jaką?

2) nie

12. Czy słucha Pan/Pani aramejskiej/surjojo rozgłośni radiowej?

1) tak, jakiej?.

2) nie

13. Czy odwiedza Pan/Pani w Internecie aramejskie/surjoje portale informacyjne?

1) tak, jakie?

2) nie

14. Czy może Pan/Pani wymienić tytuły książek napisanych przez Aramejczyków?

1) tak, jakich?

2) nie

15. Czy zna Pan/Pani jakichś sławnych Aramejczyków?

1) tak, jakich?

2) nie

16. Czym jest dla Pana/Pani tradycja?

17. Czy tradycja i jej kultywowanie jest dla Pana/Pani istotne? (prosze $z a-$ znaczyć tylko jedna odpowiedź):

1) tak, bardzo ważna

2) tylko przy specjalnych okazjach np. świętach

3) w ogóle nie ma dla mnie znaczenia 


\begin{tabular}{|c|c|c|c|c|c|}
\hline $\begin{array}{l}\text { 18. W jakim stopniu Pana/Pani zdaniem na } \\
\text { aramejską tradycję składają się poniższe elementy? } \\
\text { (proszę zaznaczyć właściwe odpowiedzi wstawiając } \\
\text { „x") }\end{array}$ & 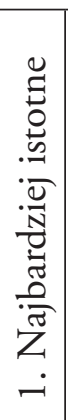 & 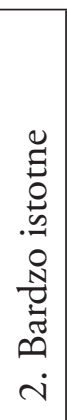 & 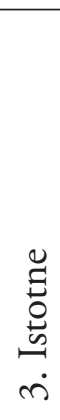 & 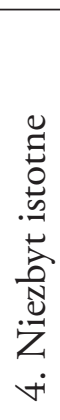 & 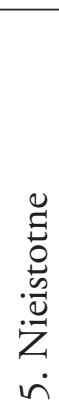 \\
\hline 1) aramejska/surjojo muzyka i tańce & & & & & \\
\hline 2) aramejskie/surjoje stroje ludowe & & & & & \\
\hline 3) kuchnia aramejska/surjojo & & & & & \\
\hline $\begin{array}{l}\text { 4) aramejskie/surjoje przysłowia i mądrości lu- } \\
\text { dowe }\end{array}$ & & & & & \\
\hline 5) aramejskie/surjoje mity i legendy & & & & & \\
\hline
\end{tabular}

19. Czy w Pana/Pani domu rodzinnym pielęgnowane są tradycje aramejskie/surjoje?

1) tak

2) nie $\rightarrow$ prosze przejsć do pytania 21 .

20. W jaki sposób pielęgnowane są w Pana/Pani domu tradycje aramejskie/surjoje?

21. Czy zna Pan/Pani dzieje swojej rodziny?

1) tak

2) nie 
22. Proszę wybrać te okoliczności, podczas których spotyka się Pana/Pani rodzina (można wybrać więcej niż jedna odpowiedź):

1) święta kościelne

2) Surjojo [Syryjski] Nowy Rok

3) urodziny

4) wesela

5) pogrzeby

6) inne, jakie?

23. Czy w Pana/Pani domu istotną rolę odgrywają święta?
1) tak
2) nie

24. Czym są dla Pana/Pani święta? (proszę zaznaczyć tylko jedna odpowiedź):

1) okazją do odwiedzenia rodziny, znajomych

2) dniem wolnym od szkoły/pracy

3) czasem zadumy i refleksji

4) dają mi możliwość utożsamienia się z moją wspólnotą narodową

5) nigdy się nad tym nie zastanawiałem/zastanawiałam

6) czymś innym, czym?

25. Do jakiego kościoła Pan/Pani należy?

1) Asyryjskiego Kościoła Wschodu

2) Syryjskiego Kościoła Ortodoksyjnego

3) Chaldejskiego Kościoła Katolickiego

4) Syryjskiego Kościoła Katolickiego

5) Kościoła protestanckiego

6) żadnego

7) innego, jakiego?

26. Jest Pan/Pani osobą:

1) wierzącą praktykującą

2) wierzącą niepraktykującą

3) niewierzącą praktykującą

4) niewierzącą niepraktykującą

5) nieidentyfikującą się z żadną formą religii, ale wierzącą $w$ istnienie sił nadprzyrodzonych 
27. Jak często bierze Pan/Pani udział we mszy świętej?
1) regularnie w każdą niedzielę lub częściej
2) nieregularnie kilka razy do roku
3) tylko z wyjątkowych okazji takich jak śluby, pogrzeby
4) tylko z okazji świąt
5) w ogóle nie uczestniczy

28. Czy interesuje się Pan/Pani życiem Aramejczyków/Surjoje?
1) tak
2) nie $\rightarrow$ prosze przejsć do pytania 30 .

29. Interesuje Pana/Panią życie Aramejczyków/Surjoje (proszę zaznaczyć tylko jedna odpowiedź):
1) w ojczyźnie
2) $\mathrm{w}$ diasporze
3) w ojczyźnie i w diasporze

30. Proszę wymienić znane sobie symbole aramejskie/surjoje:

31. Czy popiera Pan/Pani działania organizacji/stowarzyszeń aramejskich/ surjoje?
1) tak
2) nie

32. Czy kibicuje Pan/Pani aramejskiemu/surjojo klubowi sportowemu?

1) tak, jakiemu?

2) nie

33. Czy w kraju zamieszkania bierze Pan/Pani udział w niearamejskim/ nie-surjoje życiu:
4) politycznym?
tak
nie
5) kulturalnym?
tak
nie
6) religijnym?
tak
nie 


\begin{tabular}{|c|c|c|c|c|c|}
\hline $\begin{array}{l}\text { 34. Czy zgadza się Pan/Pani z następującymi } \\
\text { stwierdzeniami: (proszę zaznaczyć wtaściwe od- } \\
\text { powiedzi wstawiając „x") }\end{array}$ & 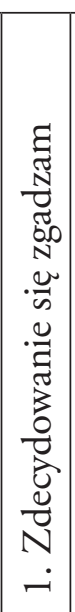 & 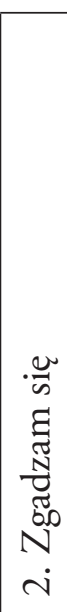 & 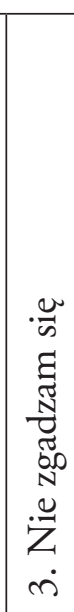 & 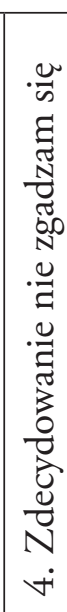 & 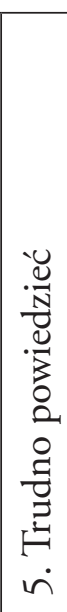 \\
\hline $\begin{array}{l}\text { 1) Mam świadomość swojego pochodzenia } \\
\text { i tego, co ono dla mnie znaczy }\end{array}$ & & & & & \\
\hline $\begin{array}{l}\text { 2) Jestem szczęśliwy/szczęśliwa, że jestem Ara- } \\
\text { mejczykiem/Aramejką (Surjojo) }\end{array}$ & & & & & \\
\hline $\begin{array}{l}\text { 3) Według mnie współcześni Aramejczycy (Sur- } \\
\text { joje) pochodzą od starożytnych Aramejczyków }\end{array}$ & & & & & \\
\hline $\begin{array}{l}\text { 4) Mam silne poczucie przynależności do histo- } \\
\text { rycznych ziem Aram-Nahrain (Mezopotamii) }\end{array}$ & & & & & \\
\hline $\begin{array}{l}\text { 5) Rozmawiam z innymi ludźmi, by dowiedzieć } \\
\text { się więcej na temat swoich przodków }\end{array}$ & & & & & \\
\hline $\begin{array}{l}\text { 6) Preferuję aramejskie/surjoje tradycyjne potra- } \\
\text { wy, muzykę, zwyczaje }\end{array}$ & & & & & \\
\hline $\begin{array}{l}\text { 7) Jestem dumny/dumna z aramejskiej/surjojo } \\
\text { społeczności }\end{array}$ & & & & & \\
\hline
\end{tabular}

35. Jakie według Pana/Pani jest najwięlksze zagrożenie dla tożsamości aramejskiej/surjojo? (można zaznaczyć więcej niż jedna odpowiedź):

1) polityczne i społeczne niepokoje w ojczyźnie

2) emigracja z ojczyzny

3) asymilacja w diasporze

4) porzucenie tradycji

5) zapomnienie języka

6) utrata więzi wewnątrz asyryjskiej wspólnoty

7) utrata kontaktu z ojczyzną

8) inne (jakie?). 
36. Jak ważne jest dla Pana/Pani zachowanie aramejskiej/surjojo tożsamości?

W ogóle nie jest

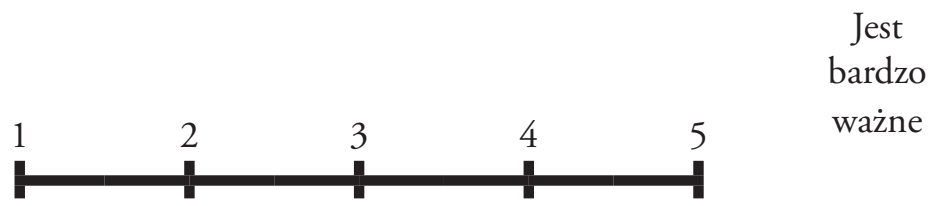

37. W jaki sposób można przyczynić się do zachowania aramejskiej/surjojo tożsamości?.

38. Czy ma Pan/Pani jakieś dodatkowe uwagi? 


\section{Aneks 3: Ankieta „Assyrian Identity”}

The purpose of this survey is to gather the information about Assyrian identity for the empirical part of the doctoral thesis, the research for which has been in progress at the University of Lodz (Poland). The authoress asks for sincere responds and additional commentaries. The questionnaire is anonymous - there is no need to sign it. Thank you for committing your time,

Marta Wozniak M.A.

The Department of Middle East

and North Africa Studies

\section{Personal data}

1. Sex:

1) Male

2) Female

2. Year of birth:

3. State and place of birth:

4. State and place of residence:

5. Education:

1) primary

2) secondary

3) higher

6. Current occupation:

7. From which state and place comes your:

1) mother

2) father 
8. Marital status:

1) single $\rightarrow$ go to Question 1. of Survey

2) divorced

3) widowed

4) married

9. From which state and place comes your husband/wife?

10. Your husband/wife is an Assyrian:
1) Yes
2) No

11. Do you have children?

1) Yes, how many?

2) No

\section{Survey}

1. According to you an Assyrian is a person who (you can choose more than one answer):
1) was born in Assyrian family
2) is a Christian of one of Assyrian Churches
3) lives in former Assyrian lands
4) speaks Aramaic
5) shares Assyrian traditions and customs
6) actively participates in cultural, religious and political life of Assyrian community
7) other (what?)

2. Do you know Classical Syriac (Kthobonoyo)?
1) Yes
2) No $\rightarrow$ go to Question 5 . 
3. Please rate your fluency on the scale:

little

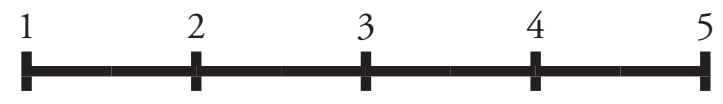

perfect

4. Do you know Aramaic (Suryoyo/Sureth)?

1) Yes

2) No $\rightarrow$ go to Question 8 .

5. Please rate your fluency on the scale:

little

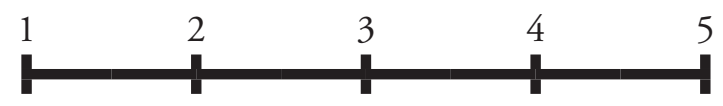

perfect

6. Which dialect(s) of Aramaic do you know?

7. How have you learnt Aramaic?

1) from your parents

2) from your grandparents

3) in school

4) other (how?)

8. In which language do you speak (or used to speak) with:

1) your parents

2) your grandparents

3) siblings

4) in school/work

5) in other situations.

9. In which language(s)

1) do you write?

2) do you read?

3) do you think? 
10. Do you read Assyrian newspapers/magazines?

1) Yes, which titles?

2) No

11. Do you watch Assyrian television?

1) Yes, which channels?

2) No

12. Do you listen to Assyrian radio?

1) Yes, which channels?

2) No

13. Do you visit Assyrian web-sites?

1) Yes, which ones?

2) No

14. Do you know any books written by Assyrians?

1) Yes, which ones?

2) No

15. Do you know any famous Assyrians?

1) Yes, which ones?

2) No

16. What is a tradition according to you?

17. Is the tradition important to you? (please mark only one answer):

1) yes, very important

2) only occasionally (e.g. during feasts)

3) it has no importance to me 


\begin{tabular}{|c|c|c|c|c|c|}
\hline $\begin{array}{l}\text { 18. To what extant the elements mentioned below } \\
\text { constitute the Assyrian tradition according to you? } \\
\text { (please mark the correct answers by „x"): }\end{array}$ & 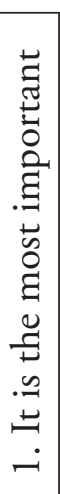 & 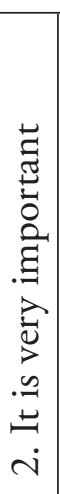 & 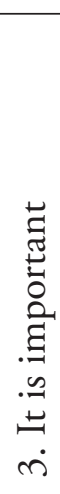 & 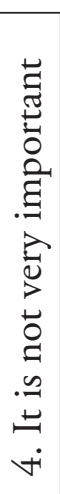 & 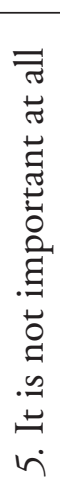 \\
\hline 1) Assyrian music and dance & & & & & \\
\hline 2) Assyrian folk dress & & & & & \\
\hline 3) Assyrian cuisine & & & & & \\
\hline 4) Assyrian proverbs and folk sayings & & & & & \\
\hline 5) Assyrian myths and legends & & & & & \\
\hline
\end{tabular}

19. Do you share Assyrian traditions in your family?

1) Yes

2) No $\rightarrow$ go to Question 21 .

20. In what ways are the Assyrian traditions followed by your family?

21. Do you know the history of your family?

1) Yes

2) No 
22. Choose the occasions when your family meets (you can choose more than one answer):
1) church feasts
2) Assyrian New Year (Ha Nissan)
3) birthdays
4) weddings
5) funerals
6) other (what?)

23. Do feasts play important role in your home:
1) Yes
2) No

24. For you feasts are (please mark only one answer):
1) good occasion for meeting the family
2) day off from school/work
3) time of reflection
4) important for self-identifying with the national group
5) I have never thought about it
6) other (what?)

25. You belong to:
1) Assyrian Church of the East
2) Syrian Orthodox Church
3) Chaldean Catholic Church
4) Syrian Catholic Church
5) Protestant Church
6) none
7) other (what?)

26. You are a:
1) practising believer
2) non-practising believer
3) practising non-believer
4) non-practising non-believer
5) person who does not identify with any religion but believes in supernatural powers 
27. How often do you attend Mass?

1) each Sunday or more frequently

2) few times a year

3) only on special occasions like weddings or funerals

4) only during feasts

5) I do not attend at all

28. Are you interested in lives of Assyrians?

1) Yes

2) No $\rightarrow$ go to Question 30 .

29. You are interested in lives of Assyrians:

1) in the homeland

2) in the diaspora

3) in both - the homeland and the diaspora

30. Mention Assyrian symbols which you know:

31. Do you support the activities of any Assyrian organizations?

1) Yes

2) No

32. Do you support any Assyrian sport club(s)?

1) Yes, which ones?

2) No

33. In the country of your residence do you participate in non-Assyrian:
1) political life?
Yes
No
2) cultural life?
Yes
No
3) religious life?
Yes
No 


\begin{tabular}{|c|c|c|c|c|c|}
\hline $\begin{array}{l}\text { 34. Do you agree with the statements below? } \\
\text { (please mark the correct answers by „x”): }\end{array}$ & 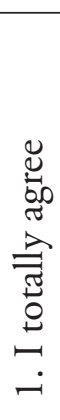 & 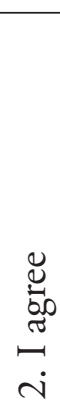 & 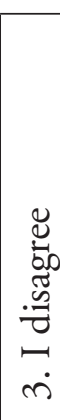 & 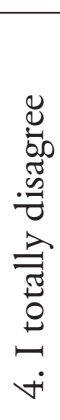 & 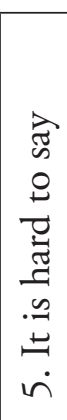 \\
\hline $\begin{array}{l}\text { 1) I am conscious of my origin and how much it } \\
\text { means to me }\end{array}$ & & & & & \\
\hline 2) I am happy to be an Assyrian & & & & & \\
\hline $\begin{array}{l}\text { 3) I think that the modern Assyrians are } \\
\text { descendants of ancient Assyrians }\end{array}$ & & & & & \\
\hline $\begin{array}{l}\text { 4) I have a strong sense of belonging to the } \\
\text { ancient lands of Assyria }\end{array}$ & & & & & \\
\hline $\begin{array}{l}\text { 5) I have talked with other people to learn more } \\
\text { about my ancestors }\end{array}$ & & & & & \\
\hline $\begin{array}{l}\text { 6) I prefer traditional Assyrian meals, music and } \\
\text { customs }\end{array}$ & & & & & \\
\hline 7) I am proud of Assyrian community & & & & & \\
\hline
\end{tabular}

35. What is the biggest threat to the Assyrian identity according to you? (you can choose more than one answer):
1) political and social disturbance in the homeland
2) emigration from the homeland
3) assimilation in the diaspora
4) abandoning the tradition
5) abandoning the language
6) losing the ties with the Assyrian community
7) losing contact with the homeland
8) other (what?) 
36. How important is to preserve the Assyrian identity for you?

$\begin{gathered}\text { it is not } \\ \text { impor- } \\ \text { tant }\end{gathered}$
ant

37. How the Assyrian identity can be preserved?

38. Do you have any additional comments?

Thank you for answering the questions! 


\section{Aneks 4: Ankieta „Aramean (Suryoyo) Identity”}

The purpose of this survey is to gather the information about Aramean (Suryoyo/Syriac) identity for the empirical part of the doctoral thesis, the research for which has been in progress at the University of Lodz (Poland). The authoress asks for sincere responds and additional commentaries. The questionnaire is anonymous - there is no need to sign it. Thank you for committing your time,

Marta Wozniak M.A.

The Department of Middle East

and North Africa Studies

\section{Personal data}

1. Sex:

3) Male

4) Female

2. Year of birth:

3. State and place of birth:

4. State and place of residence:

5. Education:

1) primary

2) secondary

3) higher

6. Current occupation:

7. From which state and place comes your:

1) mother

2) father. 
8. Marital status:

1) single $\rightarrow$ go to Question 1. of Survey

2) divorced

3) widowed

4) married

9. From which state and place comes your husband/wife?

10. Your husband/wife is an Aramean (Suryoyo):

1) Yes

2) No

11. Do you have children?

1) Yes, how many?

2) No

\section{Survey}

1. According to you an Aramean (Suryoyo) is a person who (you can choose more than one answer):

1) was born in Aramean (Suryoyo) family

2) is a Christian of one of Aramean (Suryoye) Churches

3) lives in former Aramean (Suryoye) lands

4) speaks Aramaic

5) shares Aramean (Suryoye) traditions and customs

6) actively participates in cultural, religious and political life of Aramean (Suryoyo) community

7) other (what?)

2. Do you know Classical Syriac (Edessan Aramaic)?

1) Yes

2) No $\rightarrow$ go to Question 5 . 
3. Please rate your fluency on the scale:

little

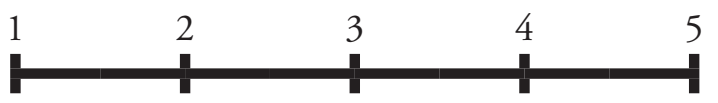

perfect

4. Do you know Aramaic (Suryoyo and/or Surayt/Sureth)?

1) Yes

2) No $\rightarrow$ go to Question 8.

5. Please rate your fluency on the scale:

little

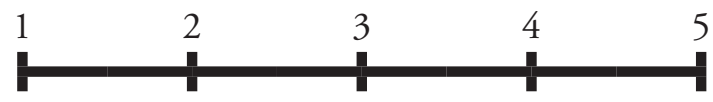

perfect

6. Which dialect(s) of Aramaic do you know?

7. How have you learnt Aramaic?

1) from your parents

2) from your grandparents

3) in school

4) other (how?)

8. In which language do you speak (or used to speak) with:

1) your parents

2) your grandparents

3) siblings

4) in school/work.

5) in other situations

9. In which language(s)

1) do you write?

2) do you read?

3) do you think? 
10. Do you read Aramean (Suryoye) newspapers/magazines?

1) Yes, which titles?

2) No

11. Do you watch Aramean (Suryoyo) television?

1) Yes, which channels?

2) No

12. Do you listen to Aramean (Suryoyo) radio?

1) Yes, which channels?

2) No

13. Do you visit Aramean (Suryoye) web-sites?

1) Yes, which ones?

2) No

14. Do you know any books written by Arameans (Suryoye)?

1) Yes, which ones?

2) No

15. Do you know any famous Arameans (Suryoye)?

1) Yes, which ones?

2) No

16. What is a tradition according to you?

17. Is the tradition important to you? (please mark only one answer):

1) yes, very important

2) only occasionally (e.g. during feasts)

3) it has no importance to me 


\begin{tabular}{|c|c|c|c|c|c|}
\hline $\begin{array}{l}\text { 18. To what extant the elements mentioned } \\
\text { below constitute the Aramean (Suryoyo) tradition } \\
\text { according to you? } \\
\text { (please mark the correct answers by „x"): }\end{array}$ & 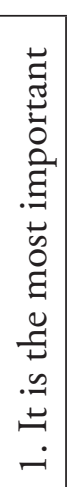 & 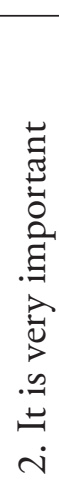 & 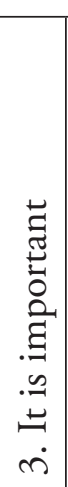 & 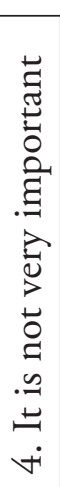 & 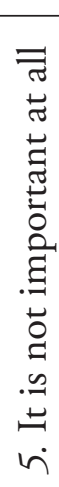 \\
\hline 1) Aramean (Suryoyo) music and dance & & & & & \\
\hline 2) Aramean (Suryoyo) folk dress & & & & & \\
\hline 3) Aramean (Suryoyo) cuisine & & & & & \\
\hline 4) Aramaic (Suryoye) proverbs and folk sayings & & & & & \\
\hline 5) Aramean (Suryoye) myths and legends & & & & & \\
\hline
\end{tabular}

19. Do you share Aramean (Suryoye) traditions in your family?

1) Yes

2) No $\rightarrow$ go to Question 21 .

20. In what ways are the Aramean (Suryoye) traditions followed by your family?

21. Do you know the history of your family?

1) Yes

2) $\mathrm{No}$ 
22. Choose the occasions when your family meets (you can choose more than one answer):
1) church feasts
2) Suryoyo New Year
3) birthdays
4) weddings
5) funerals
6) other (what?)

23. Do feasts play important role in your home:
1) Yes
2) No

24. For you feasts are (please mark only one answer):

1) good occasion for meeting the family

2) day off from school/work

3) time of reflection

4) important for self-identifying with the national group

5) I have never thought about it

6) other (what?)

25. You belong to:

1) Assyrian Church of the East

2) Syrian Orthodox Church

3) Chaldean Catholic Church

4) Syrian Catholic Church

5) Protestant Church

6) none

7) other (what?)

26. You are a:

1) practising believer

2) non-practising believer

3) practising non-believer

4) non-practising non-believer

5) person who does not identify with any religion but believes in supernatural powers 
27. How often do you attend Mass?

1) each Sunday or more frequently

2) few times a year

3) only on special occasions like weddings or funerals

4) only during feasts

5) I do not attend at all

28. Are you interested in lives of Arameans (Suryoye)?

1) Yes

2) No $\rightarrow$ go to Question 30.

29. You are interested in lives of Arameans (Suryoye):

1) in the homeland

2) in the diaspora

3) in both - the homeland and the diaspora

30. Mention Aramean (Suryoye) symbols which you know:

31. Do you support the activities of any Aramean (Suryoye) organizations?

1) Yes

2) No

32. Do you support any Aramean (Suryoye) sport club(s)?

1) Yes, which ones?

2) No

33. In the country of your residence do you participate in non-Aramean (non-Suryoyo):
1) political life?
Yes
No
2) cultural life?
Yes
No
3) religious life?
Yes
No 


\begin{tabular}{|l|l|l|l|l|l|}
\hline 34. Do you agree with the statements below? & & & & \\
(please mark the correct answers by „x"): & & & & \\
& & & & \\
\hline 1) I am conscious of my origin and how much it & & & & & \\
means to me & & & & & \\
\hline 2) I am happy to be an Aramean (Suryoyo) & & & & & \\
\hline 3) I think that the modern Arameans (Suryoye) are & & & & & \\
descendants of ancient Arameans & & & & \\
\hline $\begin{array}{l}\text { 4) I have a strong sense of belonging to the } \\
\text { ancient lands of Aram-Naharain (Mesopotamia) }\end{array}$ & & & & & \\
\hline 5) I have talked with other people to learn more & & & & & \\
about my ancestors & & & & & \\
\hline $\begin{array}{l}\text { 6) I prefer traditional Aramean (Suryoye) meals, } \\
\text { music and customs }\end{array}$ & & & & & \\
\hline 7) I am proud of Aramean (Suryoyo) community & & & & & \\
\hline
\end{tabular}

35. What is the biggest threat to the Aramean (Suryoyo) identity according to you? (you can choose more than one answer):

1) political and social disturbance in the homeland

2) emigration from the homeland

3) assimilation in the diaspora

4) abandoning the tradition

5) abandoning the language

6) losing the ties with the Aramean (Suryoyo) community

7) losing contact with the homeland

8) other (what?) 
36. How important is to preserve the Aramean (Suryoyo) identity for you? it is not important

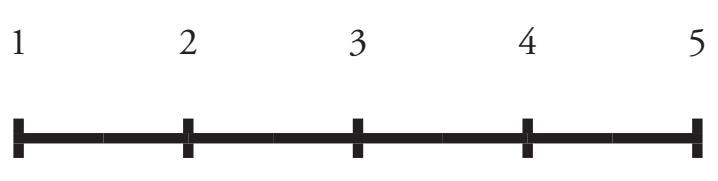

It is very important

37. How the Aramean (Suryoyo) identity can be preserved?

38. Do you have any additional comments?

\section{Thank you for answering the questions!}




\section{Aneks 5: Ankieta „Assyrische Identität”}

Diese Umfrage wird gehalten um die Daten zum empirischen Teil der Doktorarbeit über assyrischen Identität zu sammeln. Diese Arbeit wird an der Universität in Lodz (Polen) entstanden. Der Autorin liegt sehr daran, dass Sie die ehrliche, freimütige Antworten und die zusätzliche Kommentare geben. Die Umfrage ist anonymisch - es gibt kein Bedarf sie zu unterschreiben. Dankbar für gewidmete Zeit.

Magister Marta Woźniak

Lehrstuhl für Nahen Osten und Nordafrika,

Universität in Łódź

1. Das Geschlecht:

\section{Persönliche Angaben}

1) der Mann

2) die Frau.

2. Das Geburtsjahr:

3. Das Geburtsland und der Geburtsort

4. Das Land und die Ortschaft der ständigen Aufenthalt

5. Die Ausbildung:

1) die Elementarbildung

2) die Mittelschulbildung

3) die Hochschulbildung

6. Der ausgeübte Beruf:

7. Aus welcher Staat und Ortschaft stammt

1) Ihre Mutter

2) Ihr Vater 
8. Der Familiemstand

1) ledig $\rightarrow$ bitte gehen Sie zur Frage 1. der Umfrage

2) geschieden

3) verwitwed

4) verheiratet

9. Aus welcher Staat und Ortschaft stammt Ihre Frau/Ihr Mann?

10. Ihre Frau/Ihr Mann ist eine Assyrin/ein Assyre

1) ja

2) nein

11. Haben Sie Kinder?

1) ja, wieviel?

2) nein

\section{Die Umfrage}

1. Dem Assyren/der Assyrin zu sein bedeutet Ihrer Meinung nach (Sie können mehr als eine Antwort markieren):

1) in der assyrischen Familie geboren zu sein

2) Zugehörigkeit zu einer der assyrischen christlichen

Konfessionen

3) ein assyrisches Gebiet zu bewohnen

4) die aramäische Sprache zu verwenden

5) die assyrischen Sitten und Bräuche zu pflegen

6) an dem kulturellen, religiösen und politischen Leben der assyrischen Gesellschaft teilzunehmen

7) etwas anderes, was?

2. Kennen Sie die klassische syrische Sprache (khtobonoyo)?

1) ja

2) nein $\rightarrow$ bitte gehen Sie zur Frage 5 . 
3. Bitte bewerten Sie auf der Skala das Niveau, in dem Sie khtobonoyo beherrscht haben:

schlecht

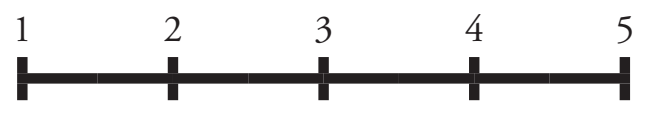

ausgezeichnet

4. Kennen Sie die aramäische Sprache (suroyo/suret)?

1) ja

2) nein $\rightarrow$ bitte gehen Sie zur Frage 8 .

5. Bitte bewerten Sie auf der Skala das Niveau, in dem Sie die aramäische Sprache beherrscht haben:

schlecht

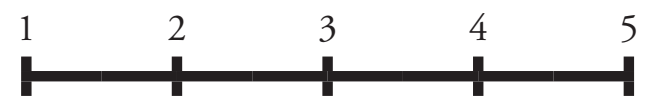

ausgezeichnet

6. Welche(r) Dialekt(e) der aramäischen Sprache kennen Sie?

7. Wie haben Sie die aramäische Sprache gelernt?

1) von den Eltern

2) von den Großeltern

3) in der Schule

4) anders, wie?

8. Welche(n) Sprache(n) sprechen Sie bei Gespräch mit:

1) den Eltern

2) den Großeltern

3) den Geschwister

4) in der Schule/ in der Arbeit

$5)$ in den anderen Situationen

9. In welche(r) Sprache(n) Sie:

1) schreiben?

2) lesen?.

3) denken? 
10. Lesen Sie die assyrische Presse (die Zeitungen, die Zeitschriften)?

1) ja, welche?

2) nein

11. Sehen Sie das assyrische Fernsehen?

1) ja, welches?

2) nein

12. Hören Sie den assyrischen Rundfunk?

1) ja, welcher?

2) nein

13. Besuchen Sie im Internet die assyrischen Informationsportale?

1) ja, welche?

2) nein

14. Können Sie die Titeln der von den Assyren geschriebenen Bücher nennen?

1) ja, welcher?

2) nein

15. Kennen Sie irgendwelchen behrümten Assyren?

1) ja, welchen?...

2) nein

16. Was bedeutet für Sie die Tradition?

17. Ist die Tradition und das Pflegen der Tradition für Sie wichtig?

1) ja, sehr wichtig

2) bei den besonderen Gelegenheiten, z.B. Feiertagen

3) sie hat für mich überall keine Bedeutung 


\begin{tabular}{|c|c|c|c|c|c|}
\hline $\begin{array}{l}\text { 18. In welchem Ausmaß besteht die assyrische } \\
\text { Tradition Ihrer Meinung nach aus den nieder } \\
\text { genannten Elementen? (bitte markieren Sie die } \\
\text { richtigen Antworten mit „x”) }\end{array}$ & 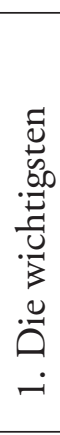 & 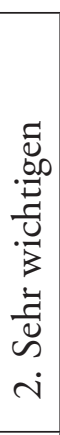 & 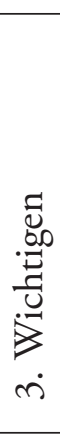 & 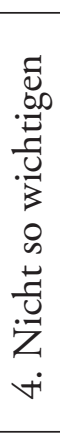 & 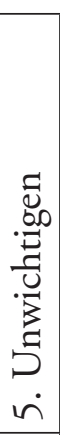 \\
\hline 1) die assyrische Musik und Tanzen & & & & & \\
\hline 2) die assyrische Volkstrachten & & & & & \\
\hline 3) die assyrische Küche & & & & & \\
\hline $\begin{array}{l}\text { 4) die assyrischen Sprichwörter und } \\
\text { Volksweisheiten }\end{array}$ & & & & & \\
\hline 5) die assyrischen Mythen und Legenden & & & & & \\
\hline
\end{tabular}

19. Pflegt man in Ihrem Familienhaus die assyrischen Traditionen?

1) ja

2) nein $\rightarrow$ bitte gehen Sie zur Frage 21 .

20. Wie pflegt man in Ihrem Haus die assyrischen Traditionen?

21. Kennen Sie die Geschichte Ihrer Familie?

1) ja

2) nein 
22. Wählen Sie bitte die Gelegenheiten, bei denen sich Ihre Familie zusammentrifft (Sie können mehr als eine Antwort wählen):

1) die kirchliche Feiern

2) das assyrische Neues Jahr (Ha Nissan)

3) die Geburtstage

4) die Hochzeiten

5) die Beerdigungen

6) anderen, welche?

23. Spielen die Feiertage in Ihrer Familie eine grosse Role?

1) ja

2) nein

24. Was bedeuten für Sie die Feiertage?

1) eine Gelegenheit die Familie, Freunden zu besuchen

2) freier Tag

3) eine Zeit der Versonnenheit und des Nachdenkens

4) geben mir die Möglichkeit sich mit meiner nationalen

Gemeinschaft zu identifizieren

5) ich habe daran nie gedacht

6) etwas anderes, was?

25. Zu welcher Kirche gehören Sie?

1) Assyrischen Kirche des Ostens

2) Syrisch-Orthodoxen Kirche

3) Chaldäisch-Katholischen Kirche

4) Syrisch-Katholischen Kirche

5) Protestantischen Kirche

6) keiner

7) anderen Kirche, welcher?

26. Sie sind:

1) gläubig und kirchlich tätig

2) gläubig aber nicht kirchlich tätig

3) ungläubig und kirchlich tätig

4) ungläubig und nicht kirchlich tätig

5) eine Person, die sich mit keiner Religion identifiziert, die aber an übernatürliche Kräfte gläubt 
27. Wie oft nehmen Sie an der Heiligen Messe teil?

1) regelmäßig am jeden Sonntag oder öfter

2) unregelmäßig ein paar Mal im Jahr

3) nur bei den besonderen Gelegenheiten, z.B. die Hochzeiten, die Beerdigungen

4) nur während der Feiertage

5) ich nehme an den Heiligen Messen nie teil

28. Interessieren Sie sich für das Leben von den Assyren?

1) ja

2) nein $\rightarrow$ bitte gehen Sie zur Frage 30 .

29. Sie interessieren sich für das Leben von den Assyren (bitte markieren Sie nur eine Antwort):
1) im Vaterland
2) im Diaspora
3) im Vaterland und im Diaspora

30. Nennen Sie bitte die assyrischen Symbole, die Ihnen bekannt sind:

31. Unterstützen Sie die Tätigkeit der assyrischen Organisationen/ Gesellschaften?
1) ja
2) nein

32. Sind Sie ein Kiebitz von einem der assyrischen Sportkluben?

1) ja, von welchem?

2) nein

33. Nehmen Sie teil an dem nicht assyrischen Leben im Land der ständigen Aufenthalt:
1) politischen
ja
nein
2) kulturellen
ja
nein
3) religiösen
ja
nein 


\begin{tabular}{|c|c|c|c|c|c|}
\hline $\begin{array}{l}\text { 34. Sind Sie mit den folgenden Feststellungen } \\
\text { einverstanden (bitte markieren Sie die richtigen } \\
\text { Antworten mit „x"): }\end{array}$ & 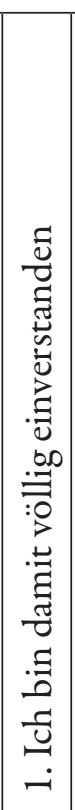 & 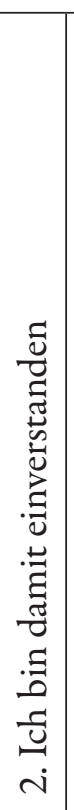 & 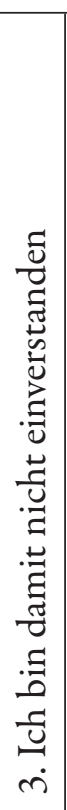 & 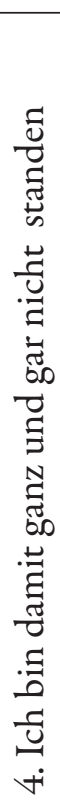 & 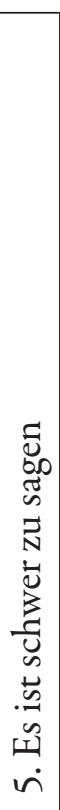 \\
\hline $\begin{array}{l}\text { 1) Ich habe das Bewußtsein von meiner } \\
\text { Herkunft und was sie für mich bedeutet }\end{array}$ & & & & & \\
\hline $\begin{array}{l}\text { 2) Ich freue mich, dass ich ein Assyre/eine } \\
\text { Assyrin bin }\end{array}$ & & & & & \\
\hline $\begin{array}{l}\text { 3) Meiner Meinung nach stammen } \\
\text { die gegenwärtigen Assyren von den } \\
\text { altertümlichen Assyren }\end{array}$ & & & & & \\
\hline $\begin{array}{l}\text { 4) Ich habe ein starkes Gefühl der } \\
\text { Zugehörigkeit zu den historischen } \\
\text { assyrischen Länder }\end{array}$ & & & & & \\
\hline $\begin{array}{l}\text { 5) Ich unterhalte mich mit den anderen } \\
\text { Leuten, um sich mehr nach meinen } \\
\text { Vorfahren zu erkundigen }\end{array}$ & & & & & \\
\hline $\begin{array}{l}\text { 6) Ich bevorzüge die traditionellen Speisen, } \\
\text { Musik, Sitten und Bräuche }\end{array}$ & & & & & \\
\hline 7) Ich bin stoltz auf assyrische Gemeinde & & & & & \\
\hline
\end{tabular}


35. Was ist Ihrer Meinung nach die grösste Bedrohung für die assyrische Identität? (Sie können mehr als eine Antwort markieren)

1) die politische und gesellschaftliche Unruhe im Vaterland

2) die Auswanderung aus dem Vaterland

3) die Assimilation im Diaspora

4) der Traditionsverlust

5) das Sprachvergessen

6) der Verlust der Verbundenheit innerhalb der assyrischen

Gemeinschaft

7) der Kontaktverlust mit dem Vaterland

8) andere, welche?

36. Wie wichtig ist für Sie das Bewahren der assyrischen Identität? es ist nicht 12 3 4 sehr wichtig

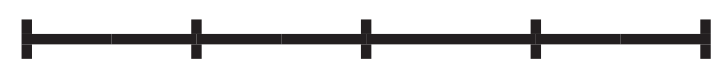

37. Wie kann man sich zum Bewahren der assyrischen Identität beitragen?

38. Haben Sie irgendwelche zusätzliche Bemerkungen?

\section{Herzlichen Dank für die gegebenen Antworten!}




\section{Ilustracje}





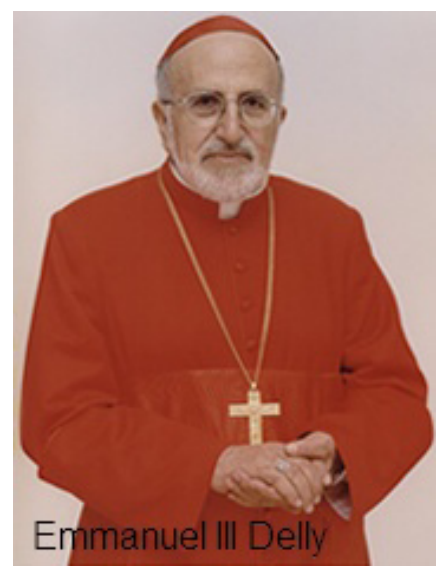

Il. 1
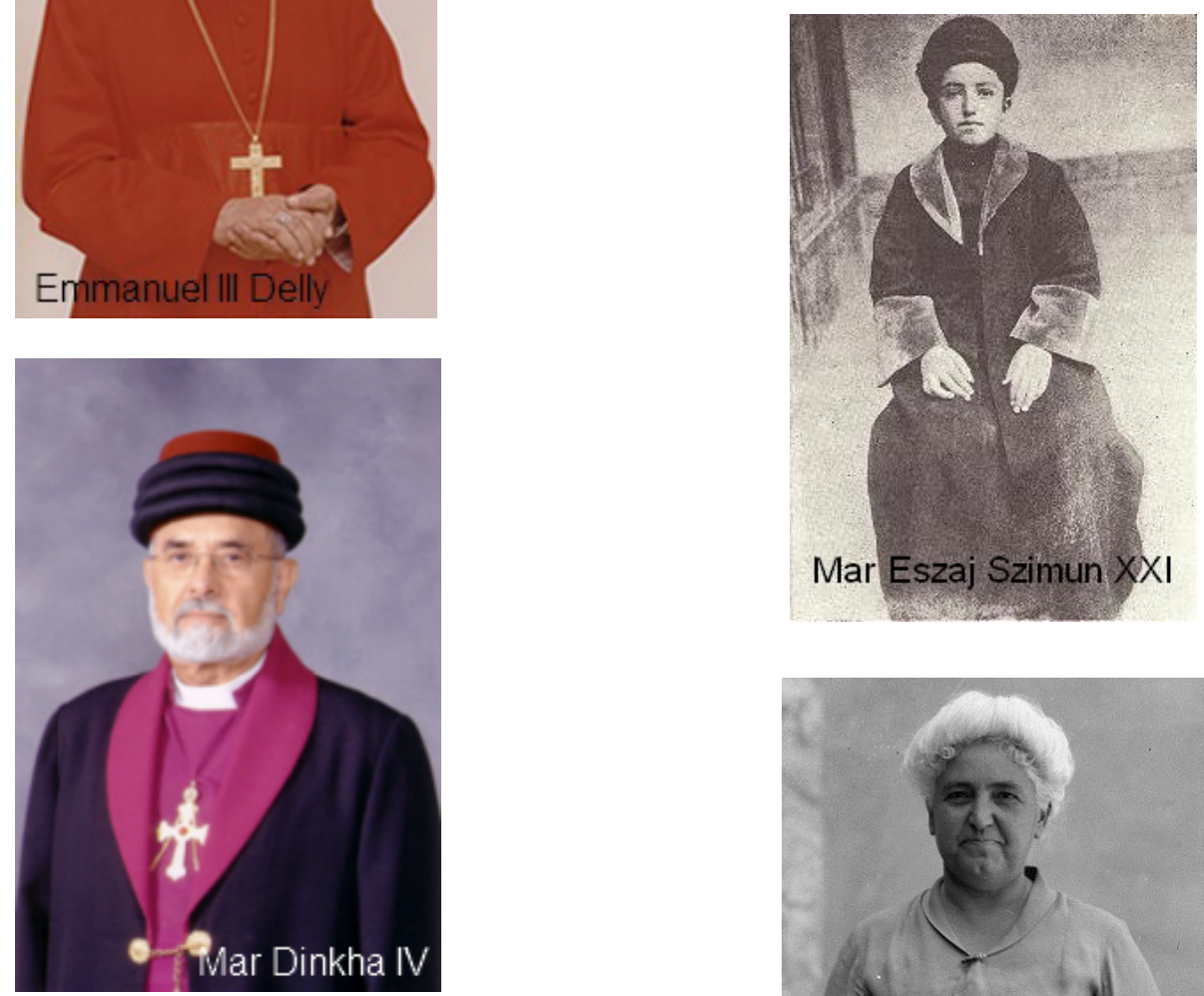

Il. 2

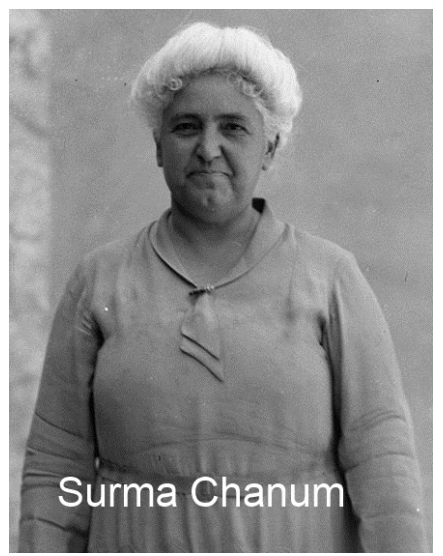

Ignatius Zakka I Iwas 

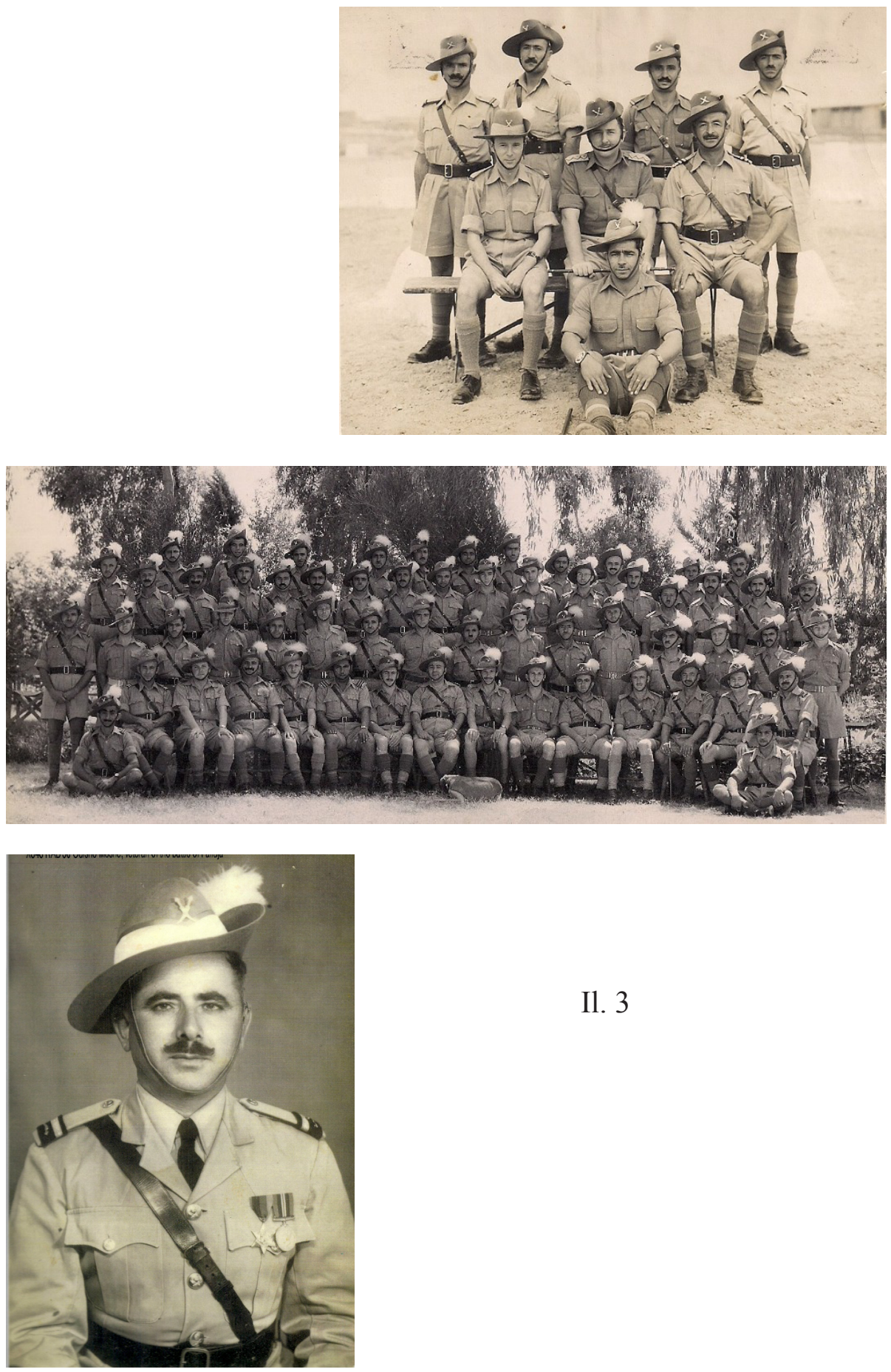

Il. 3 

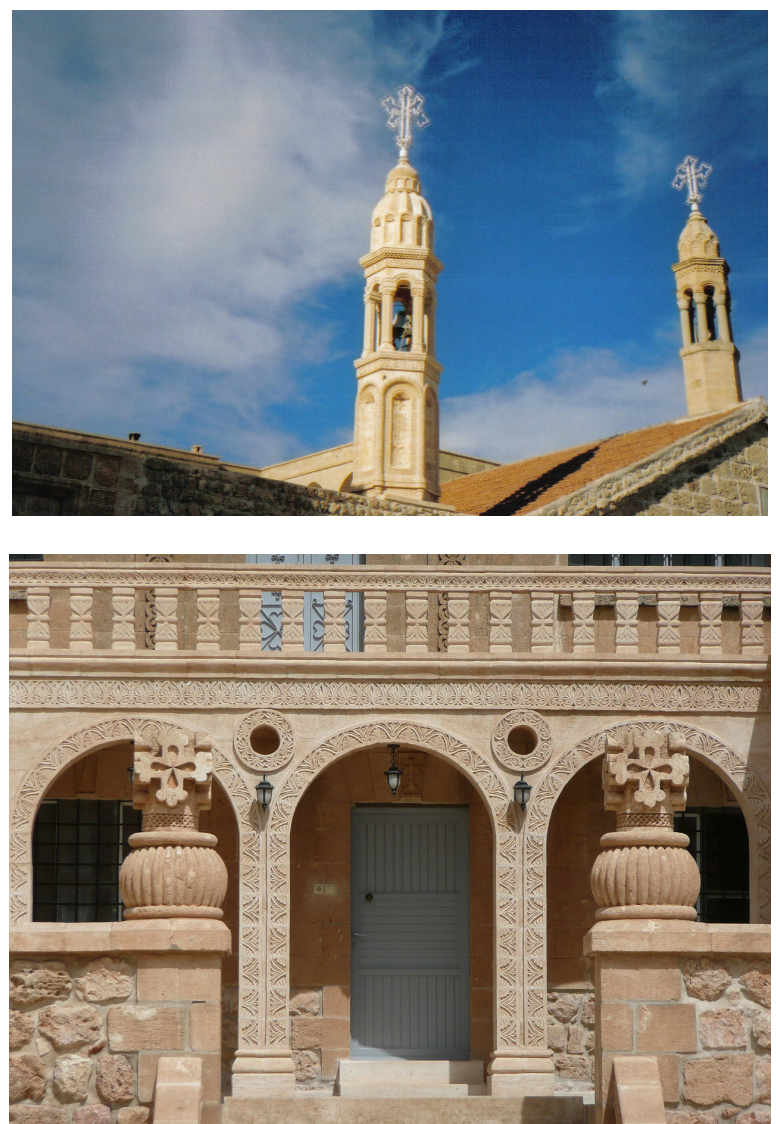

Il. 4

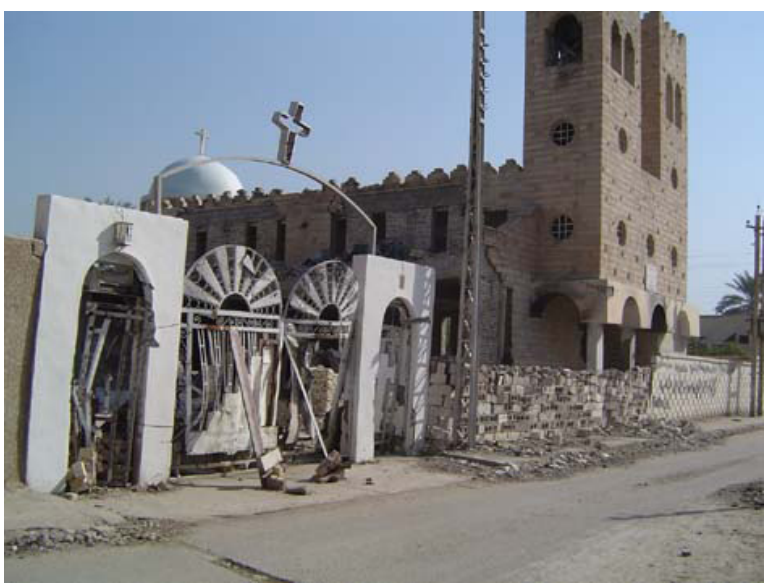

Il. 5 

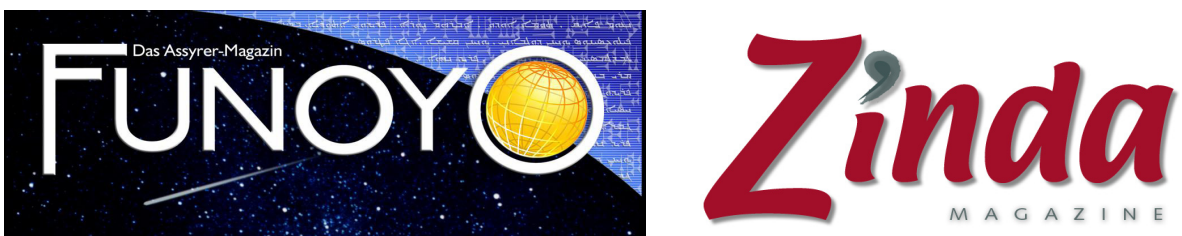

\section{-VISION von einer}

neuen asisyrischen Zeitschrift

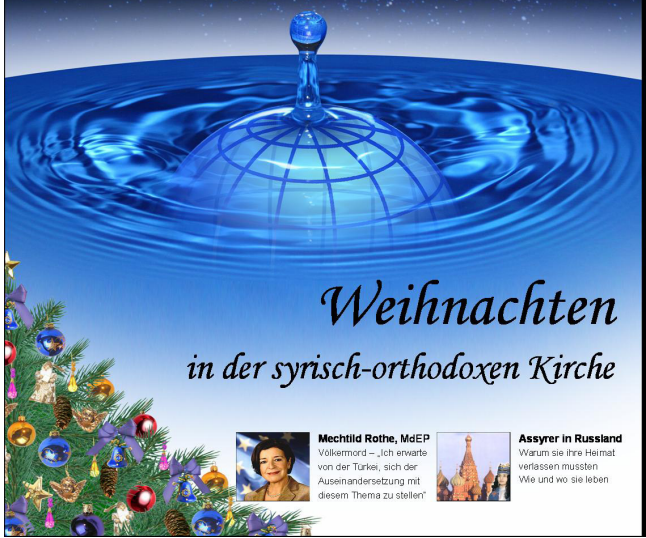

Il. 6

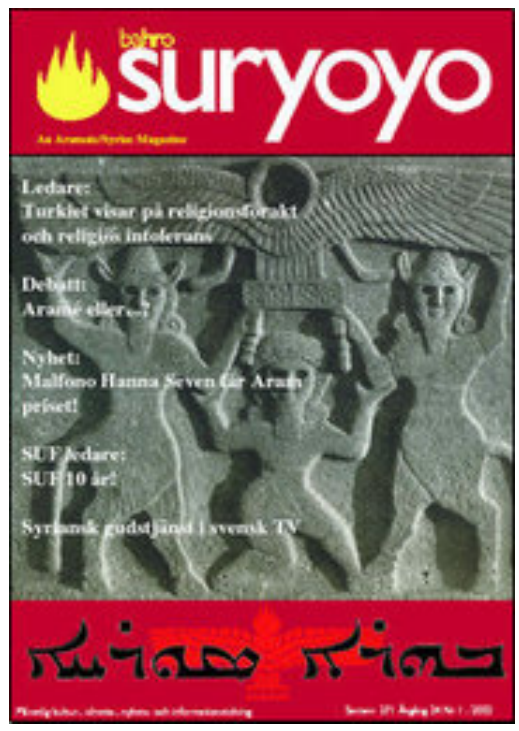

Il. 7

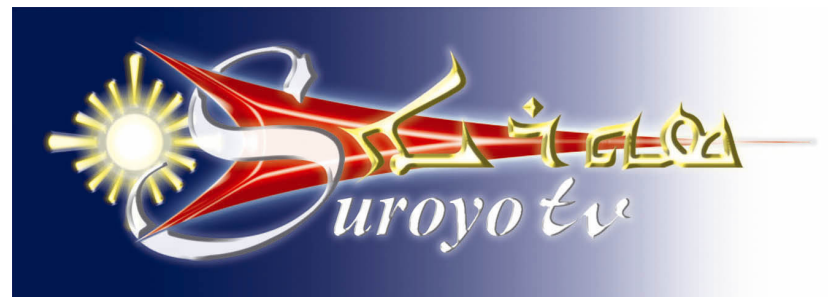

Il. 8

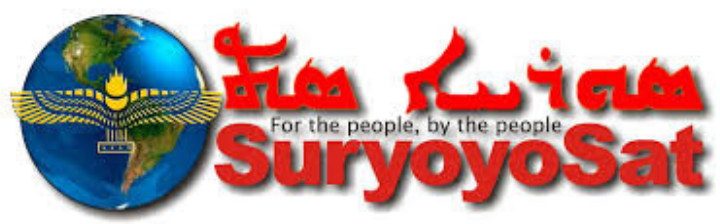

Il. 9 


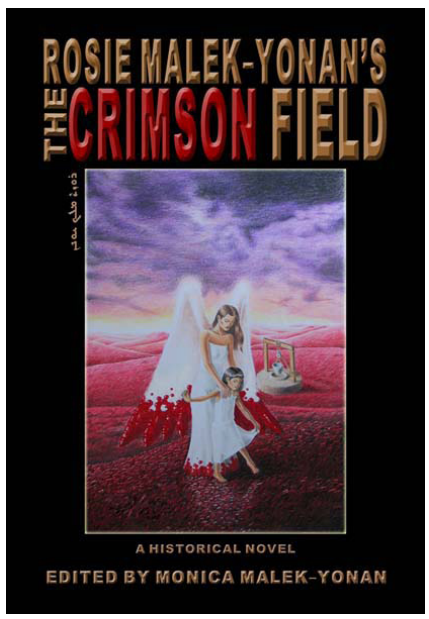

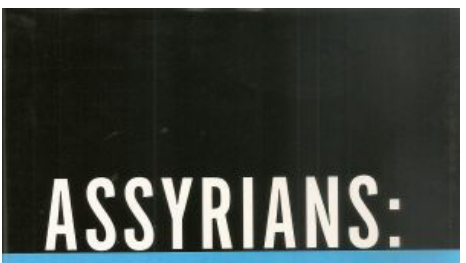

\section{THE CONTINUOUS SAGA}

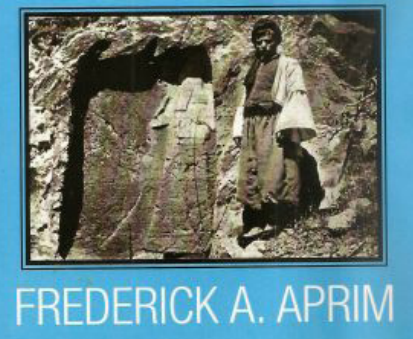

Il. 10
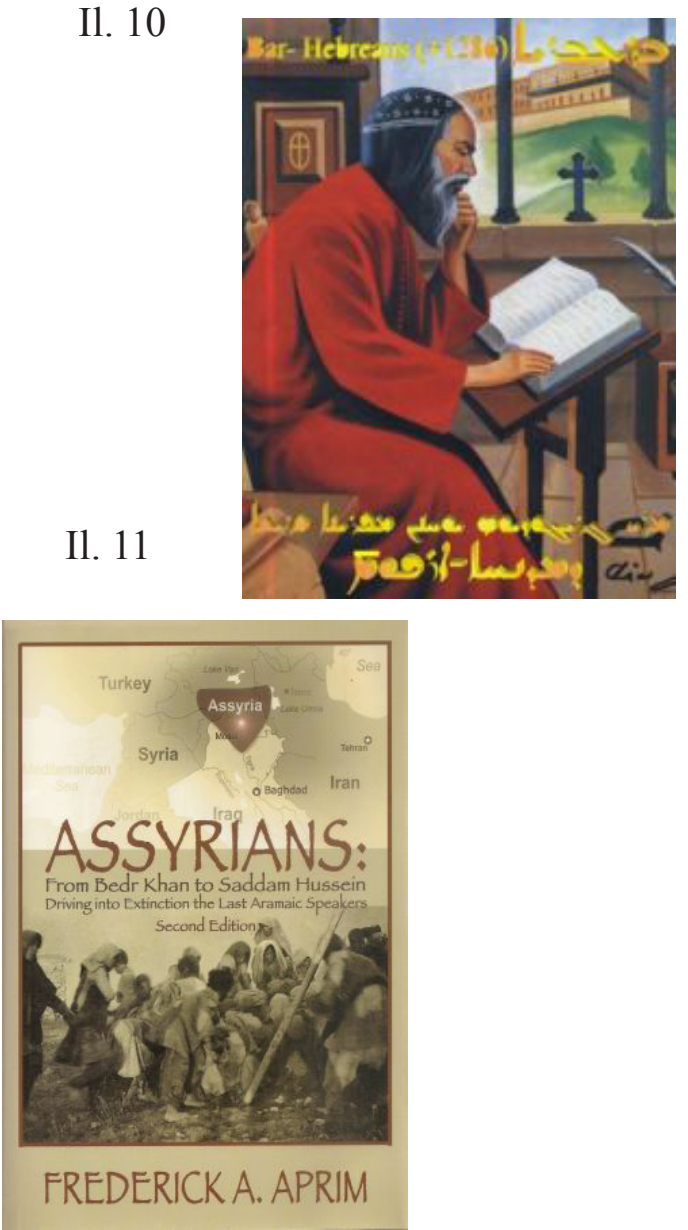

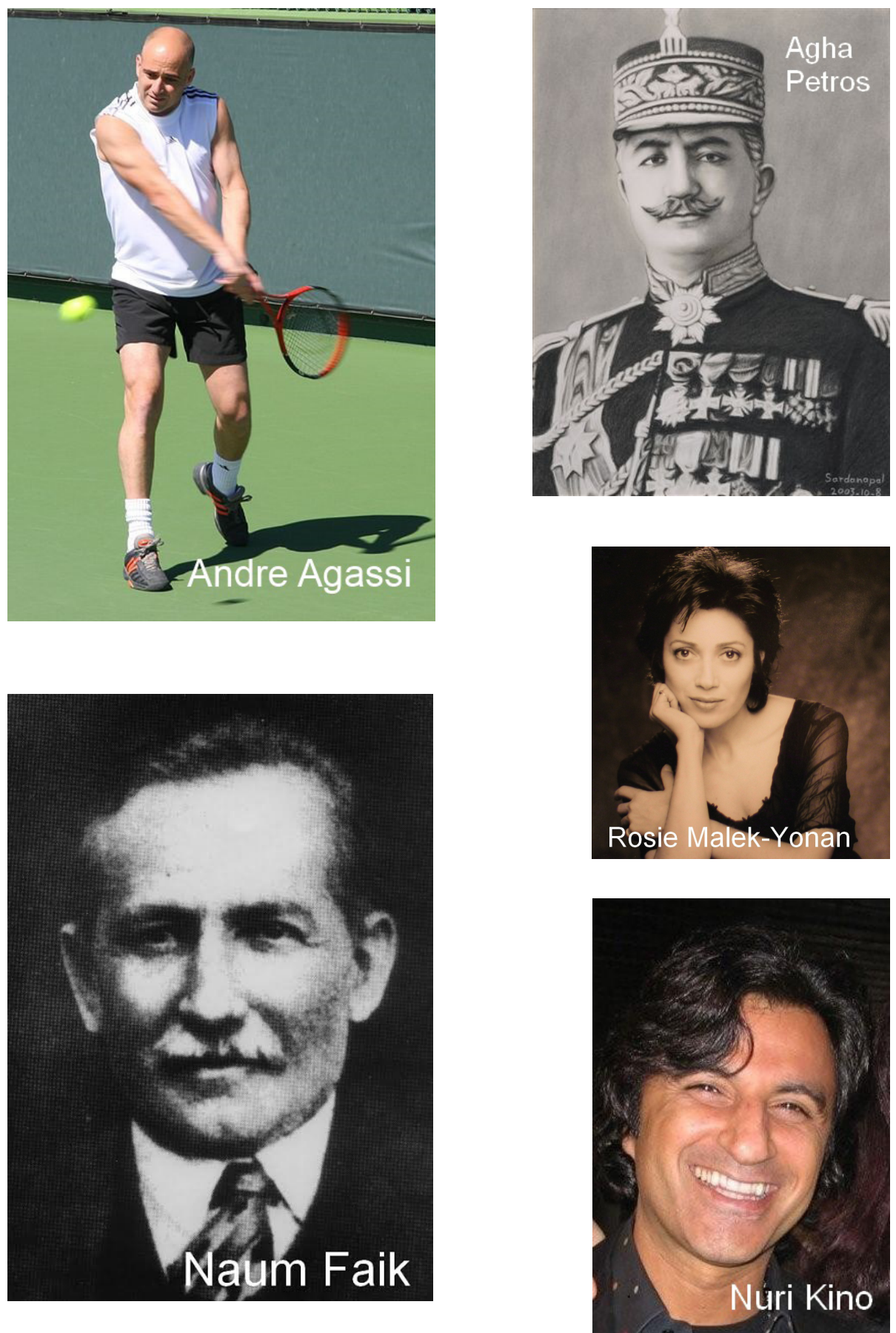

Il. 12 

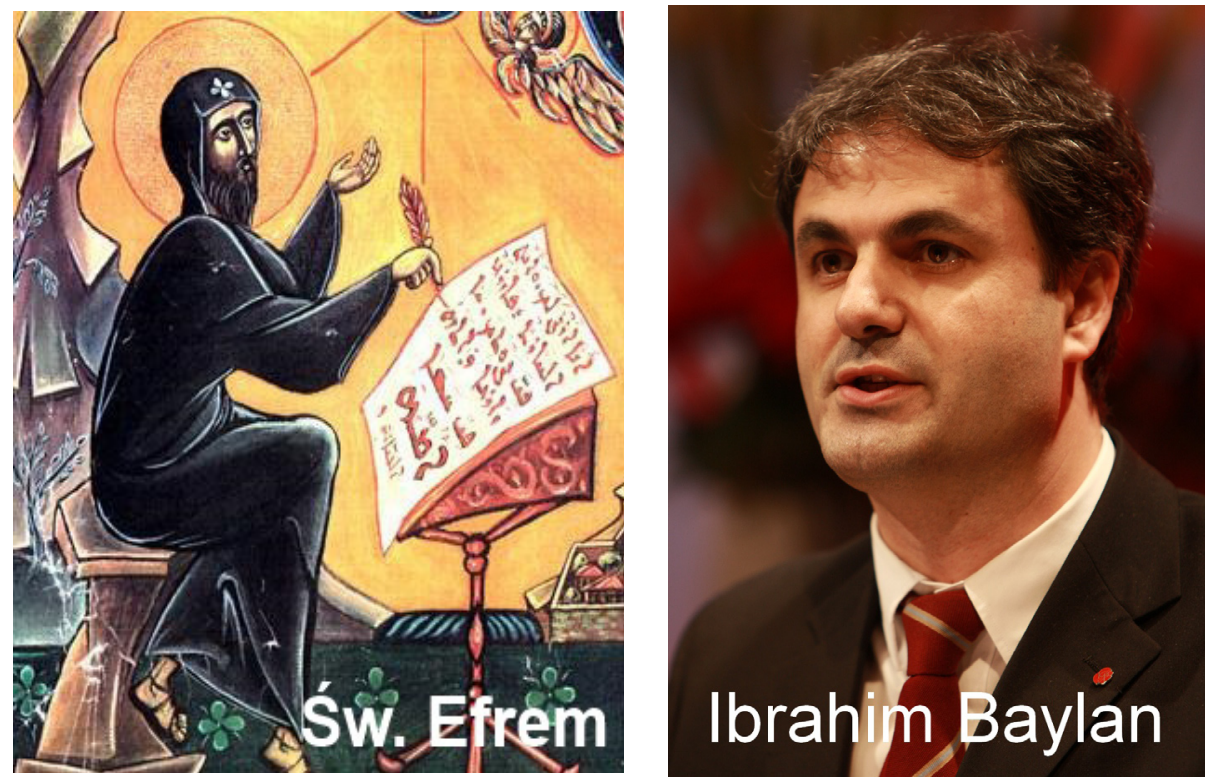

Il. 13

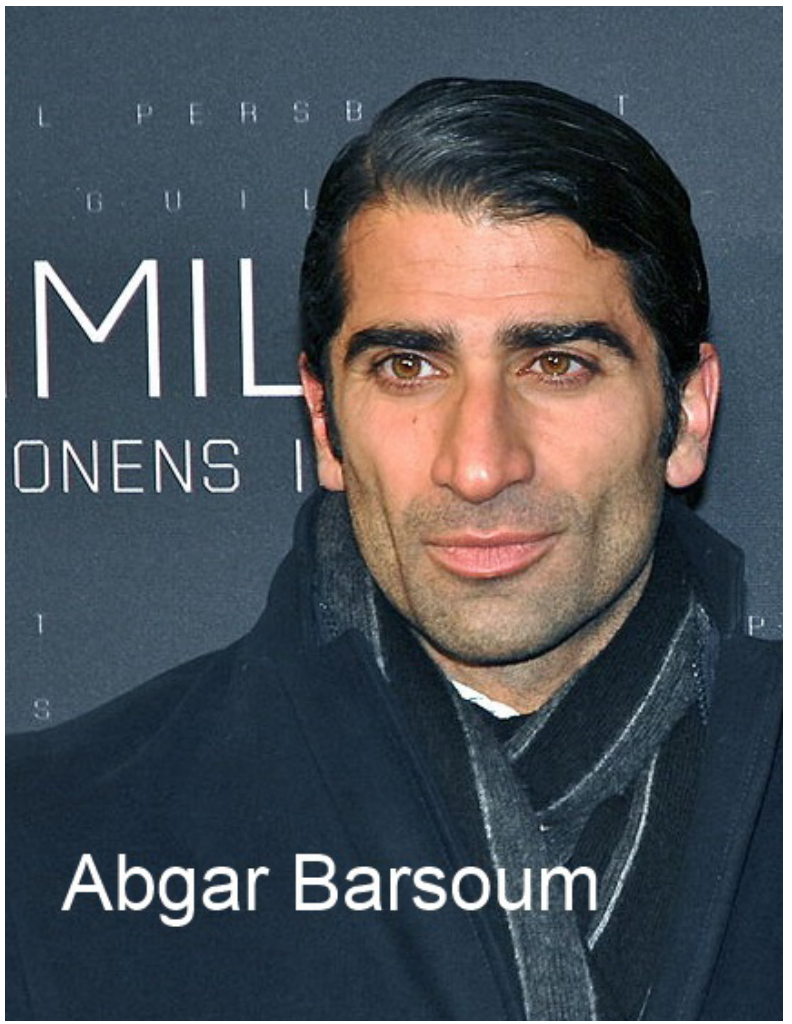



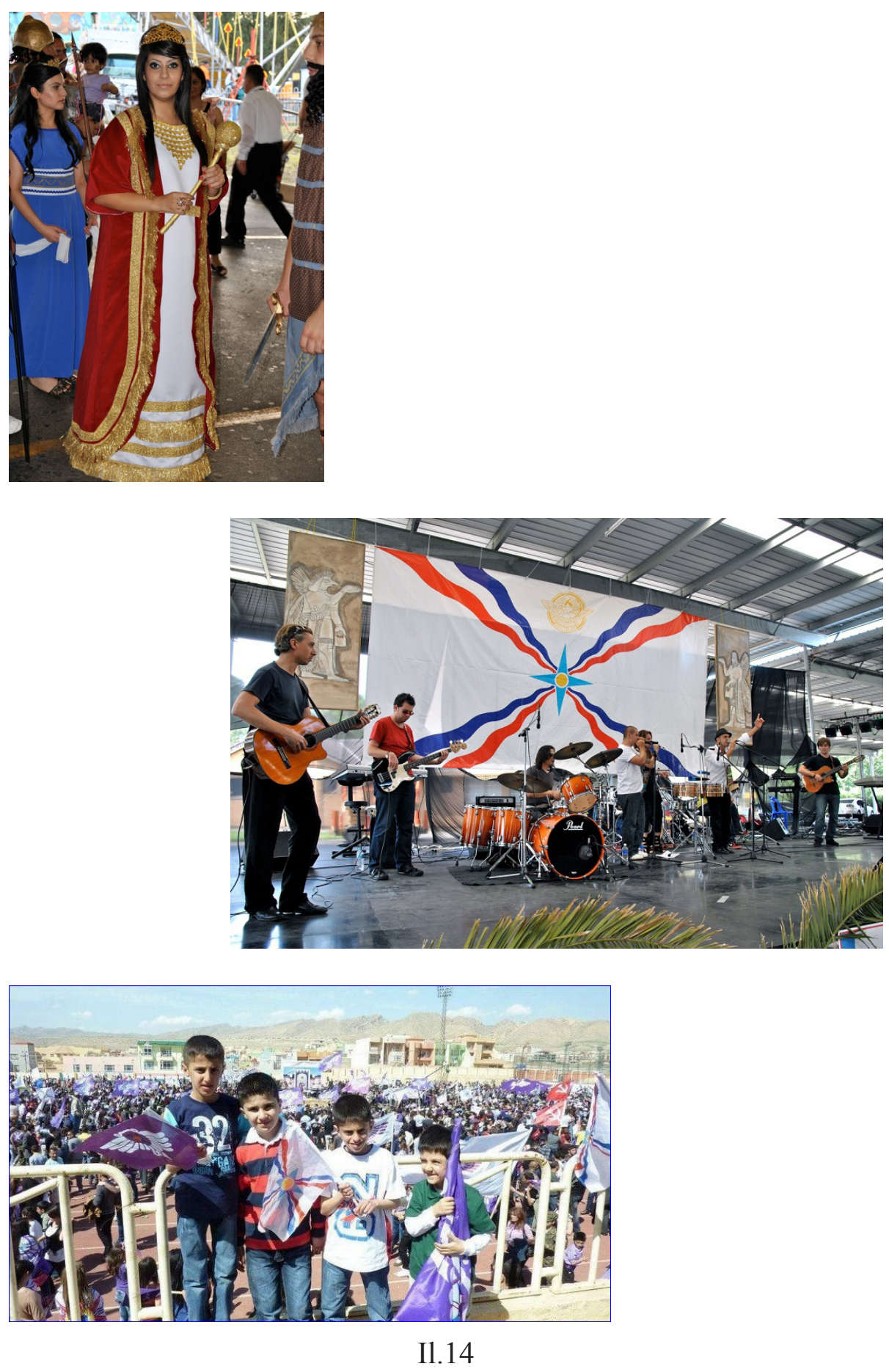


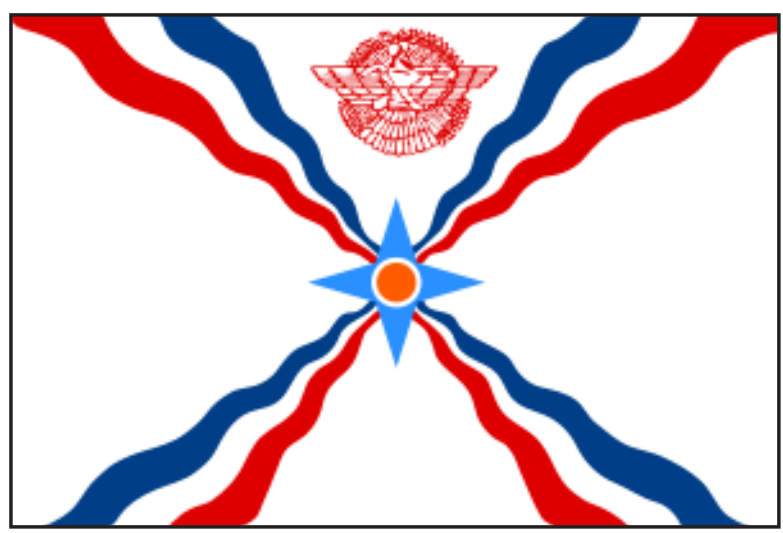

Il. 15

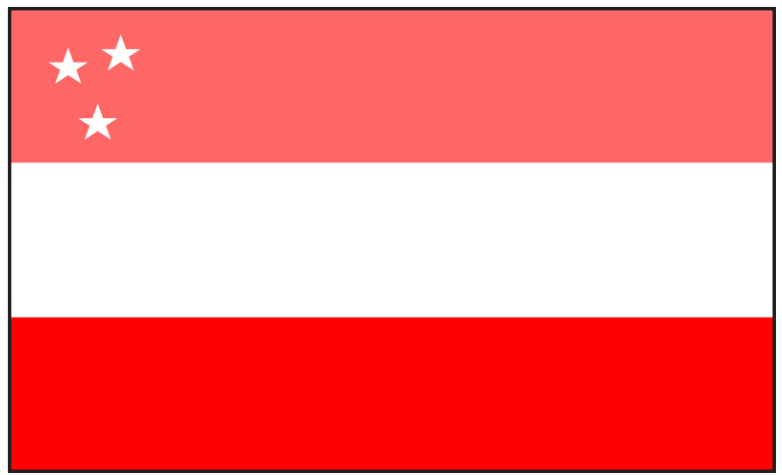

Il. 16

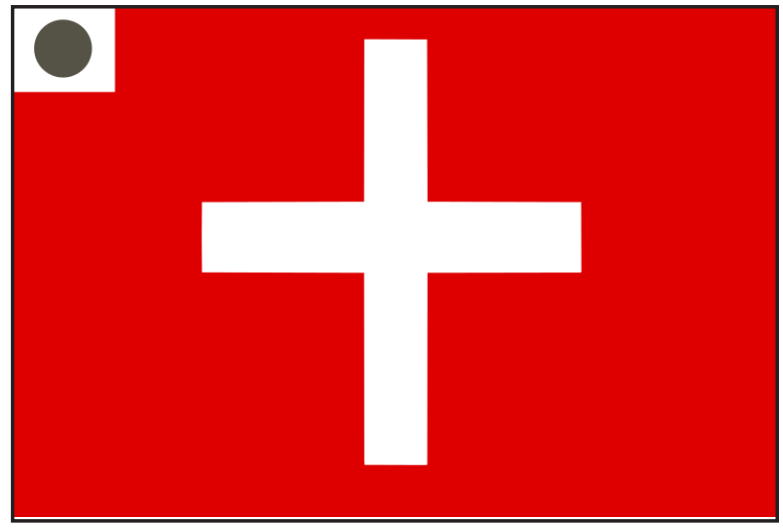

Il. 17 
366
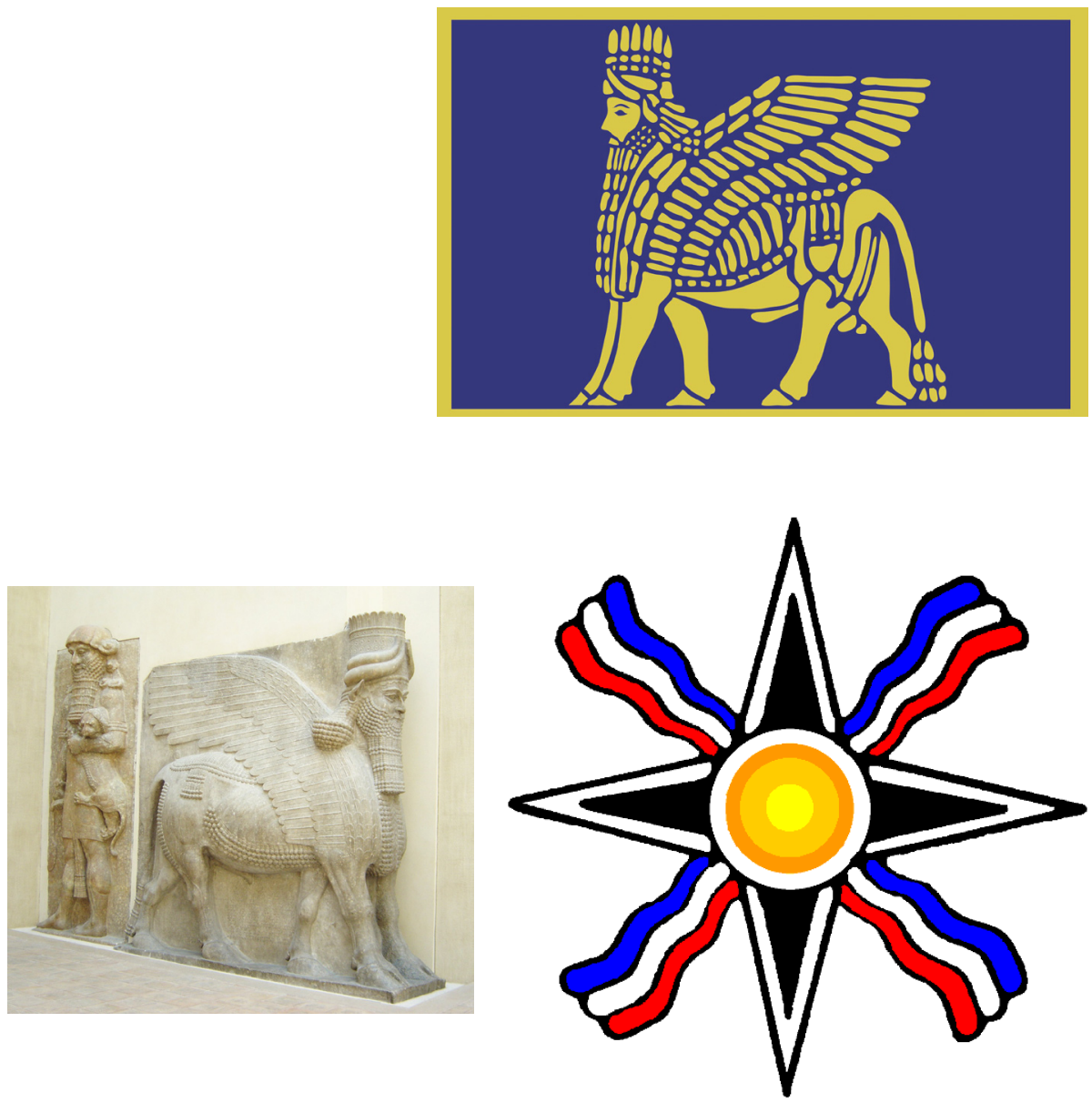

Il. 18

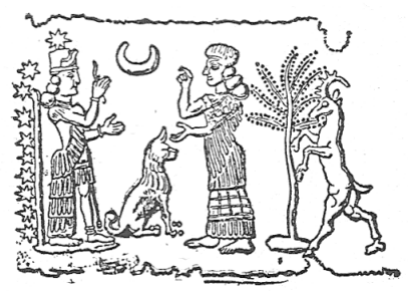

Il. 20

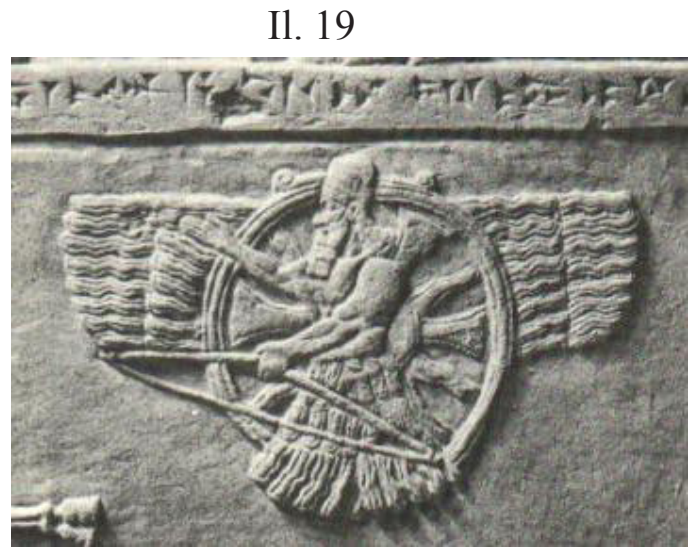

Il. 21 

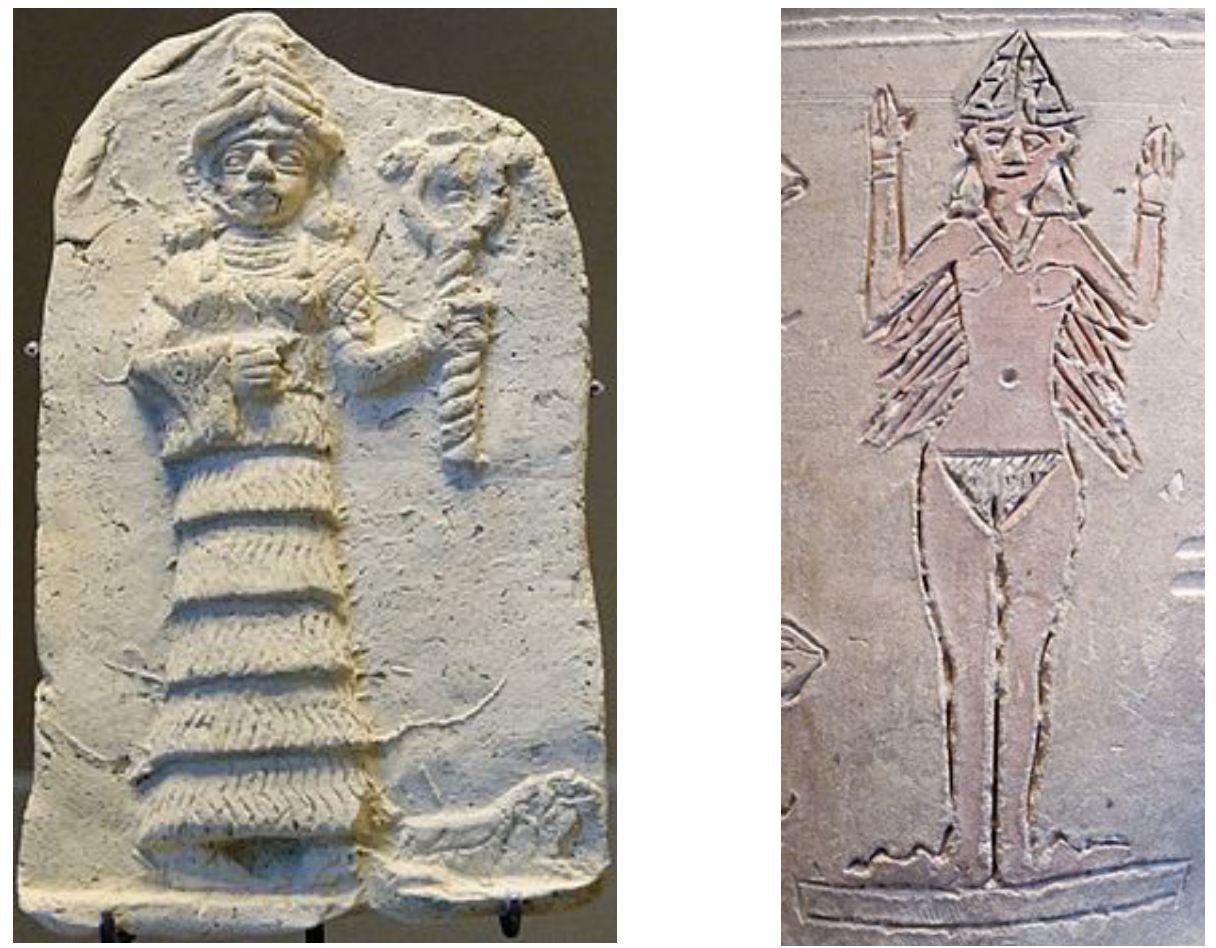

Il. 22
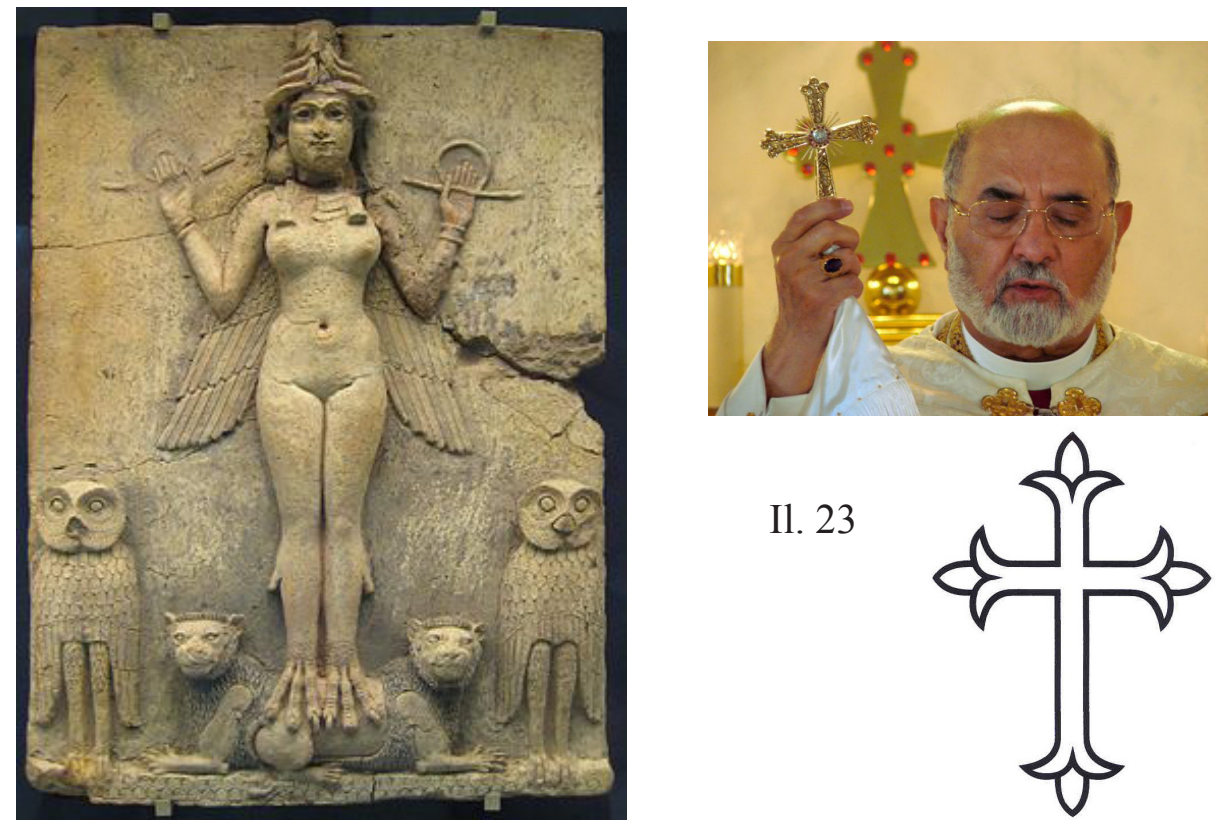


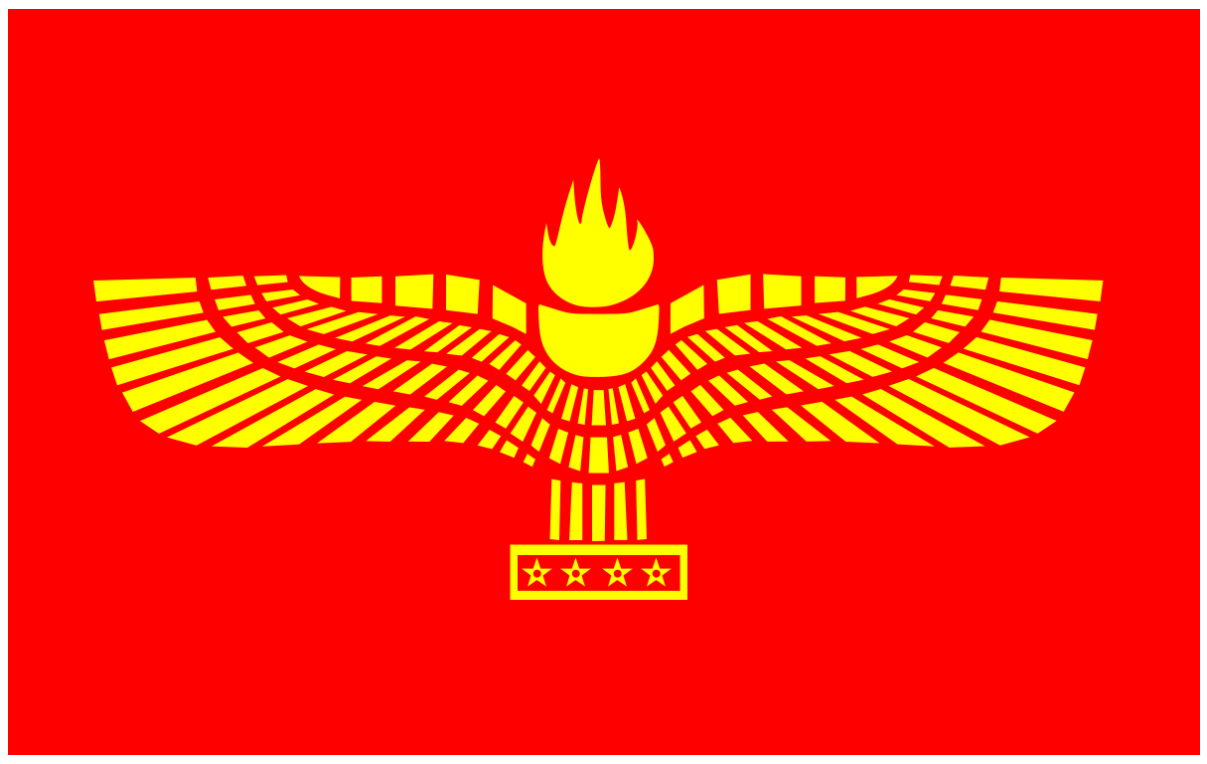

Il. 24

\section{ASSYRISKA} SÖDERTÄLJE
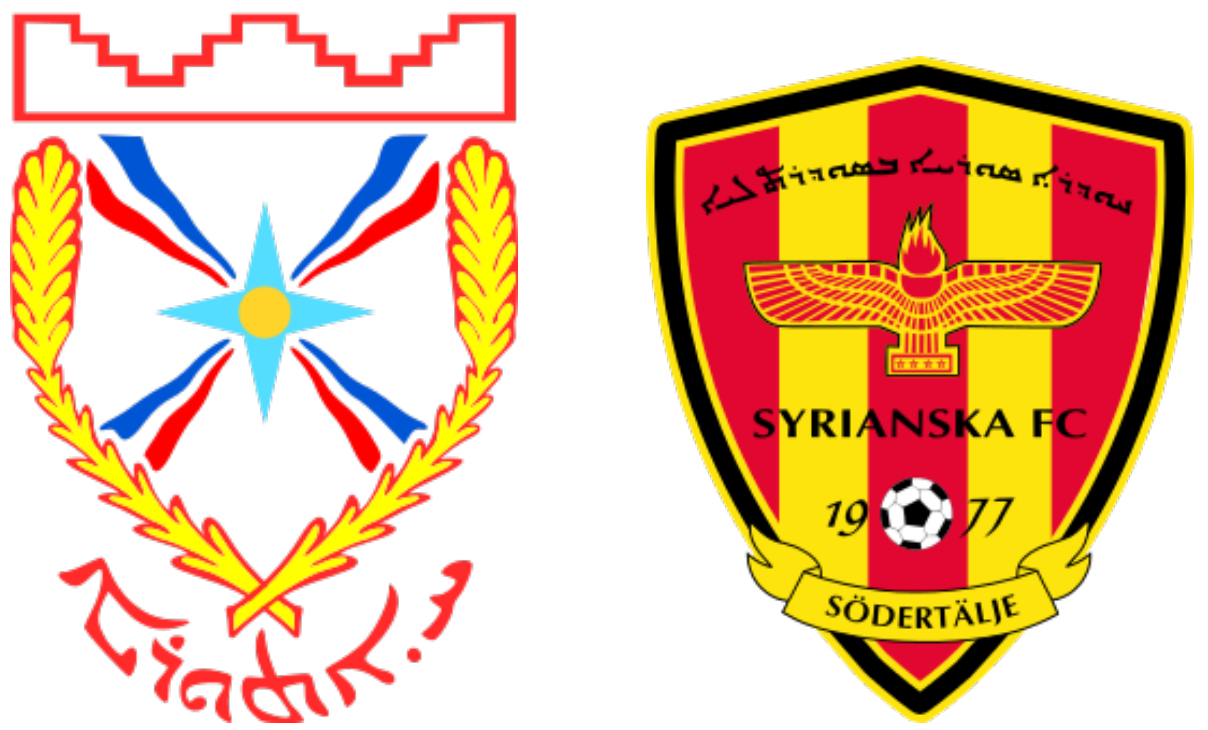

Il. 25 


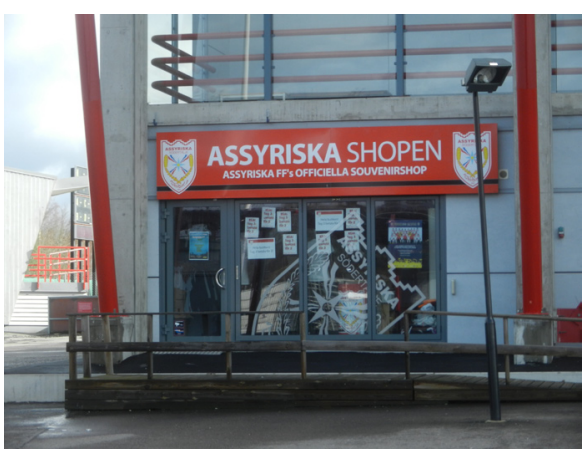

Il. 26
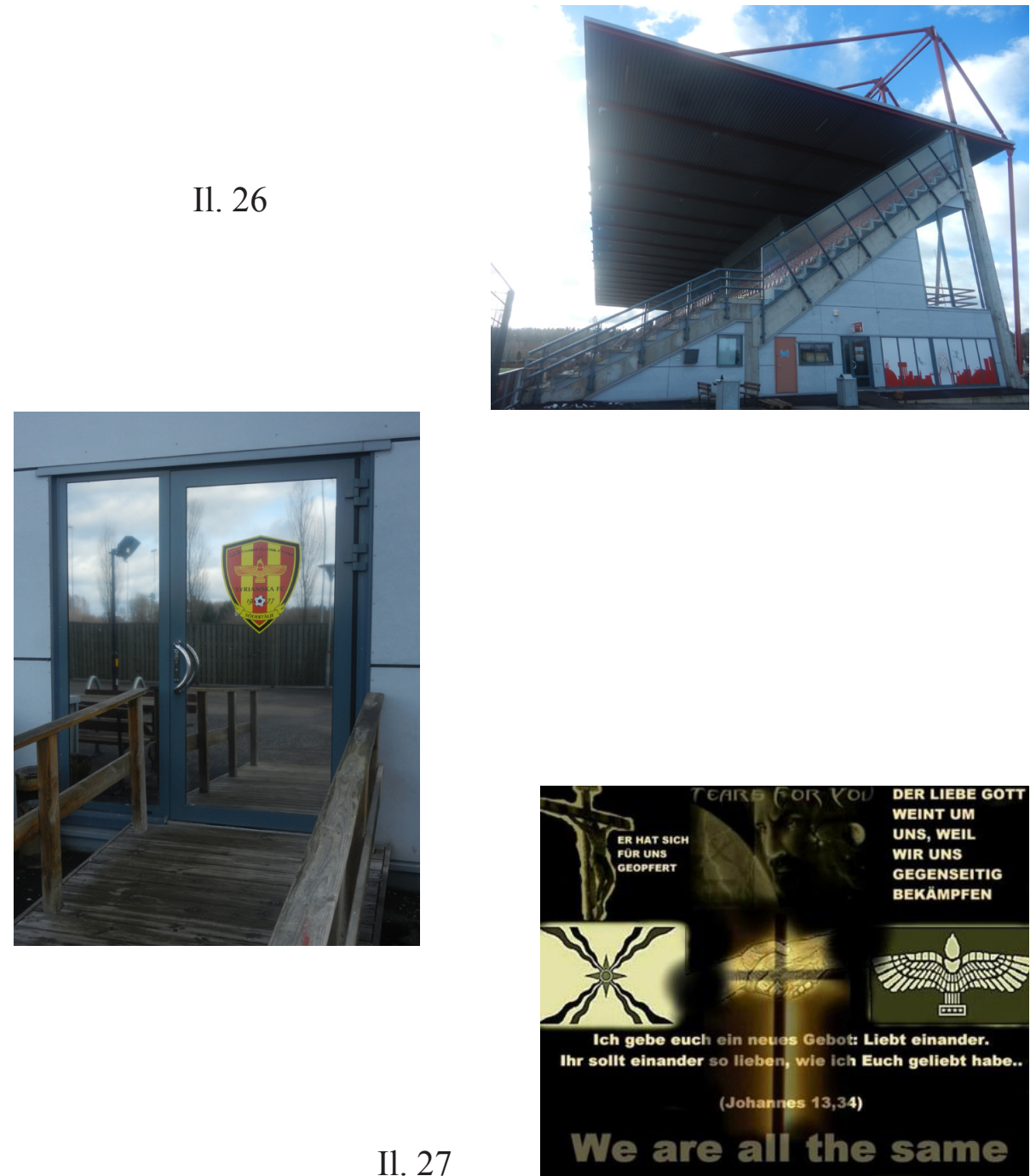

Il. 27 

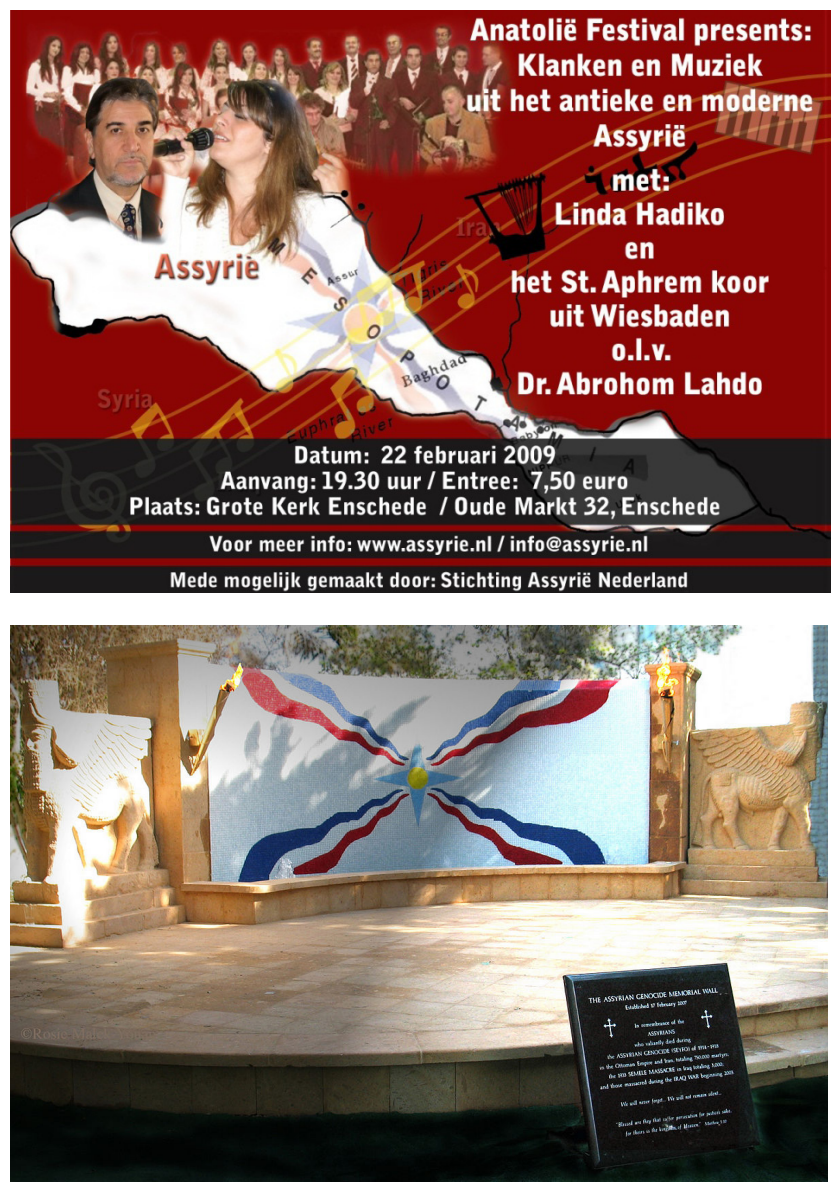

Il. 28
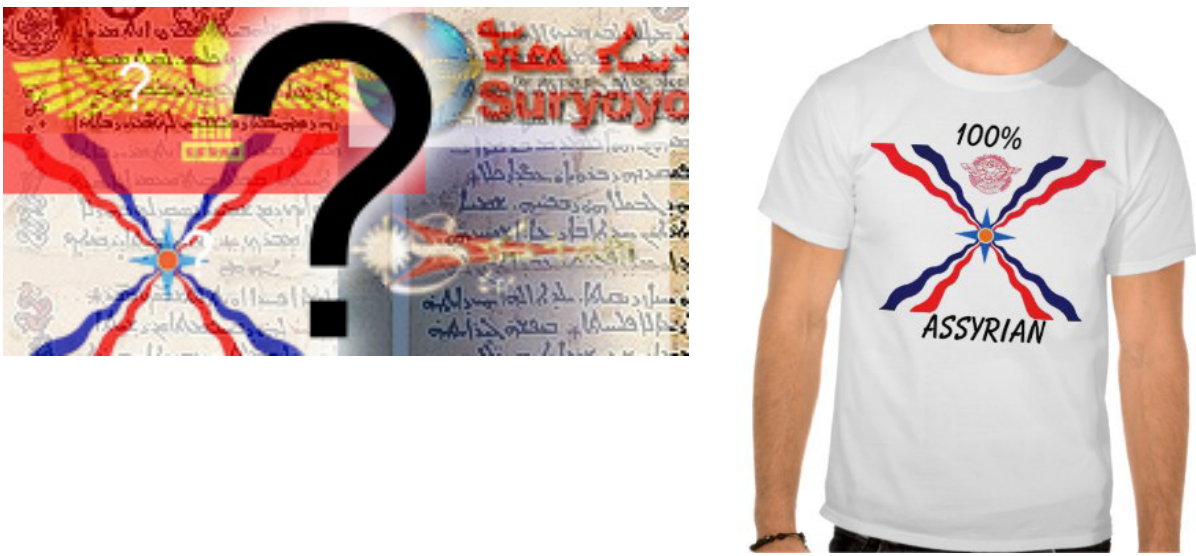

Il. 29 

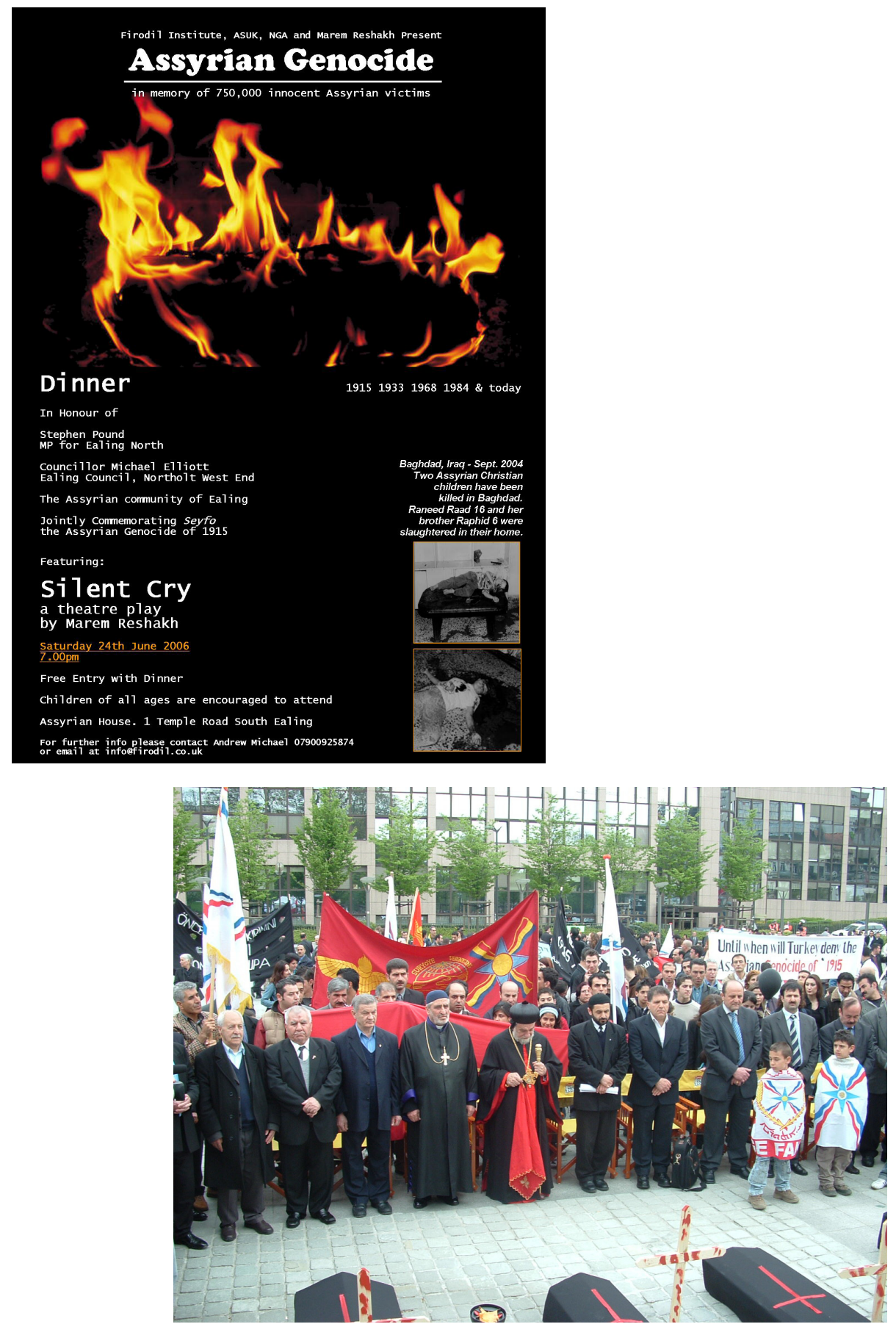

Il. 30 

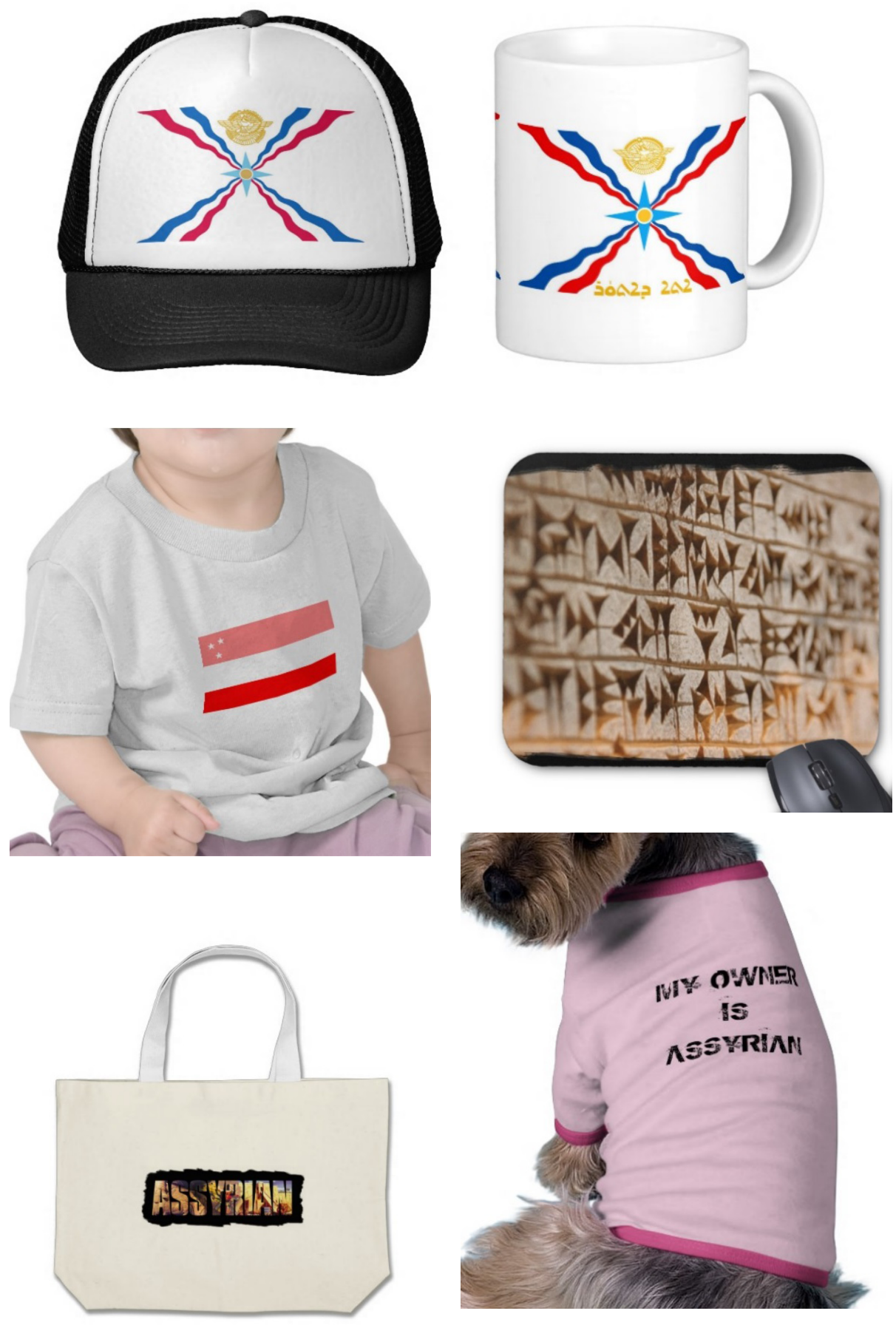

Il. 31 

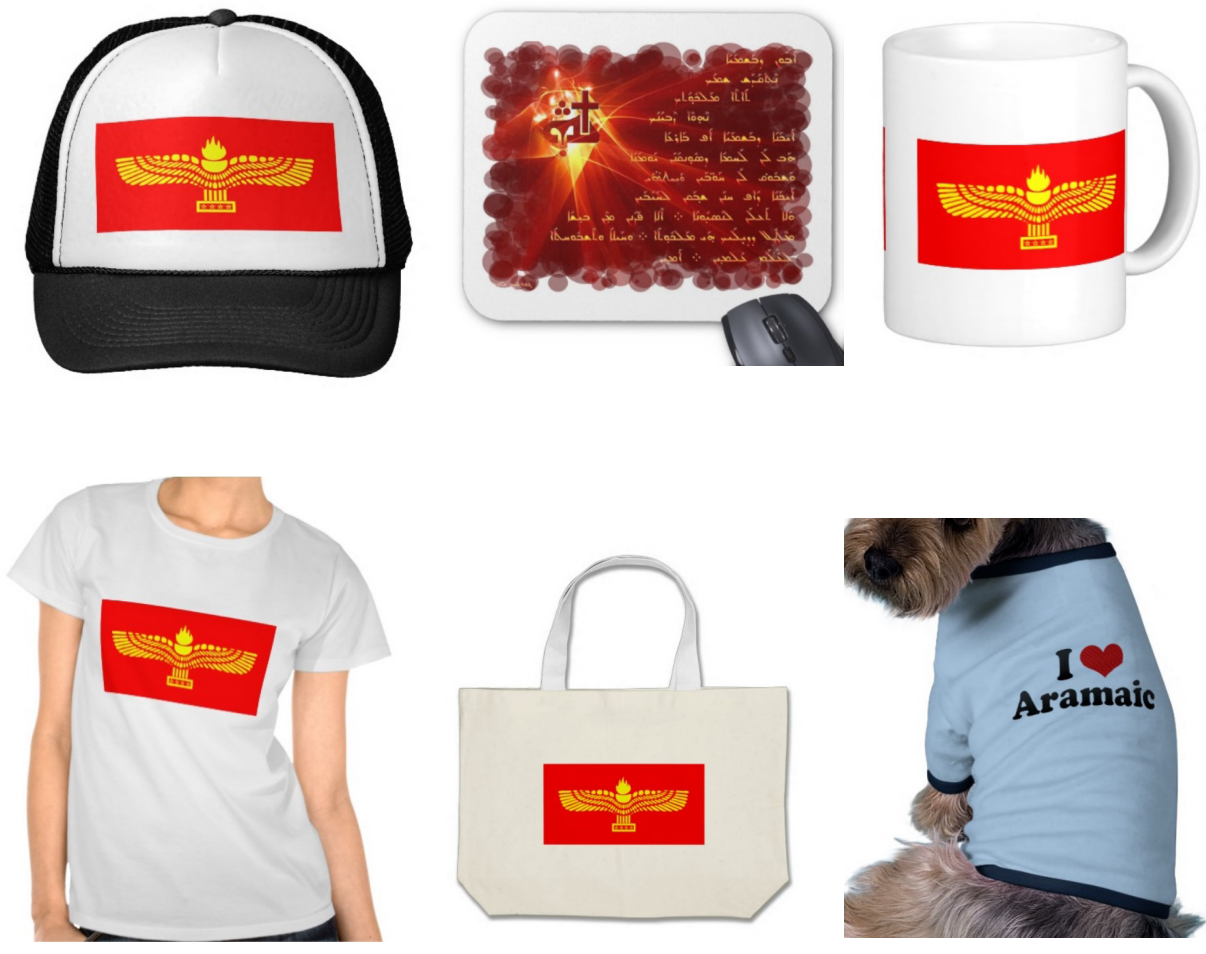

Il. 32

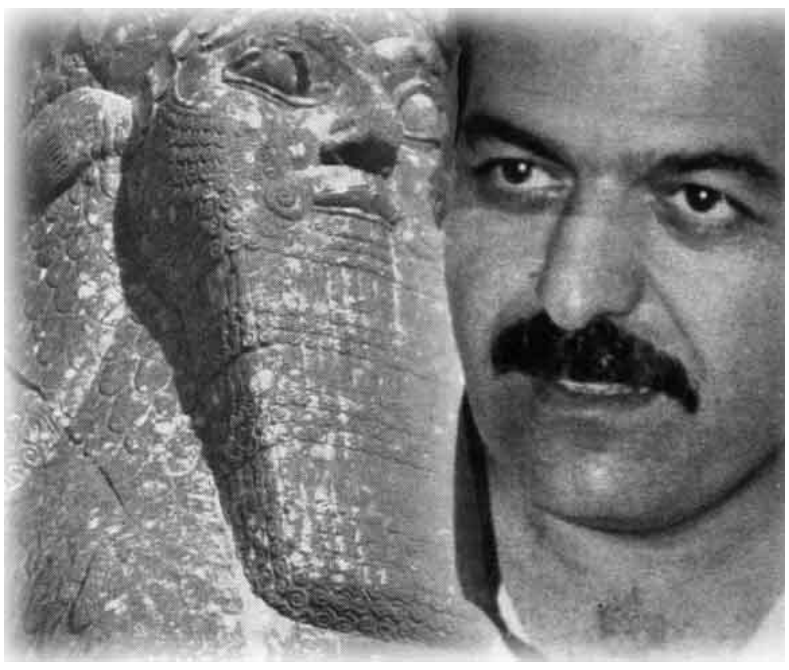

Il. 33 


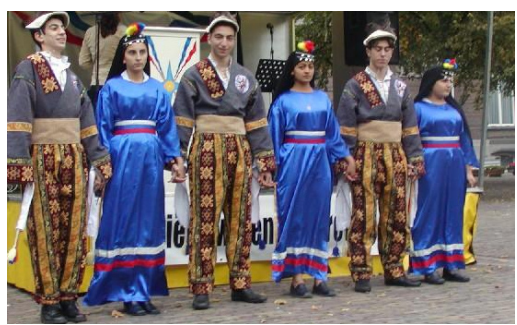
Il. 34
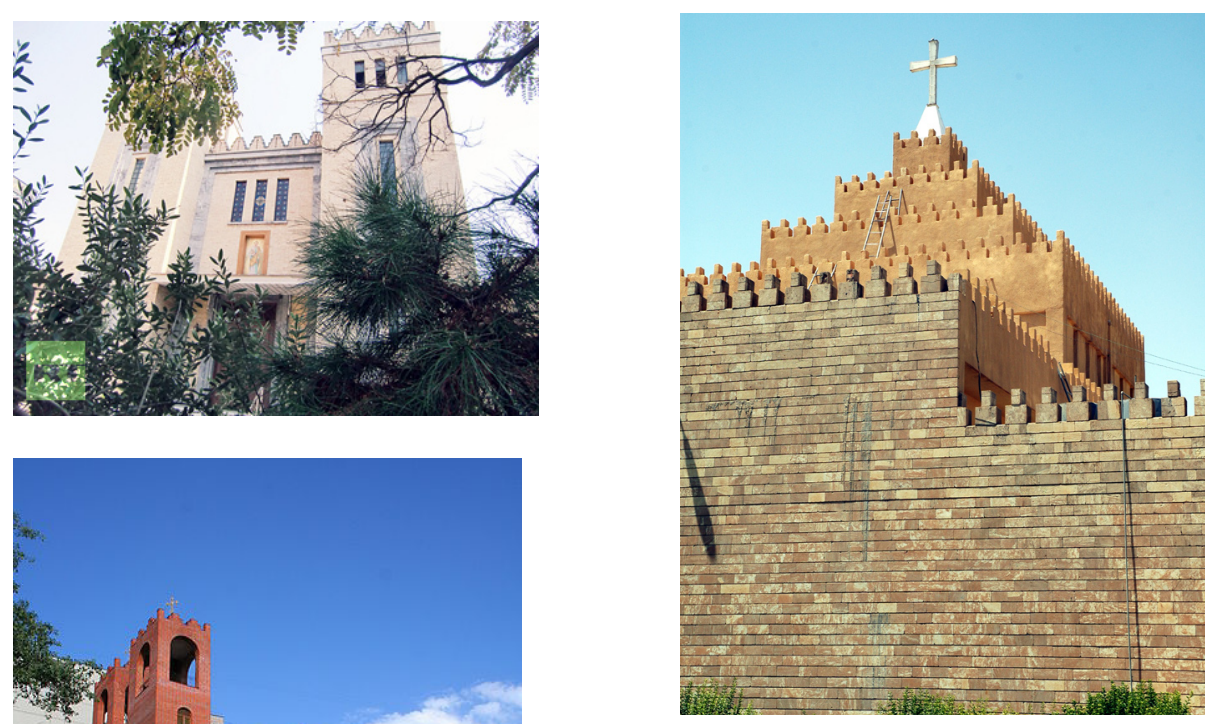

Il. 35
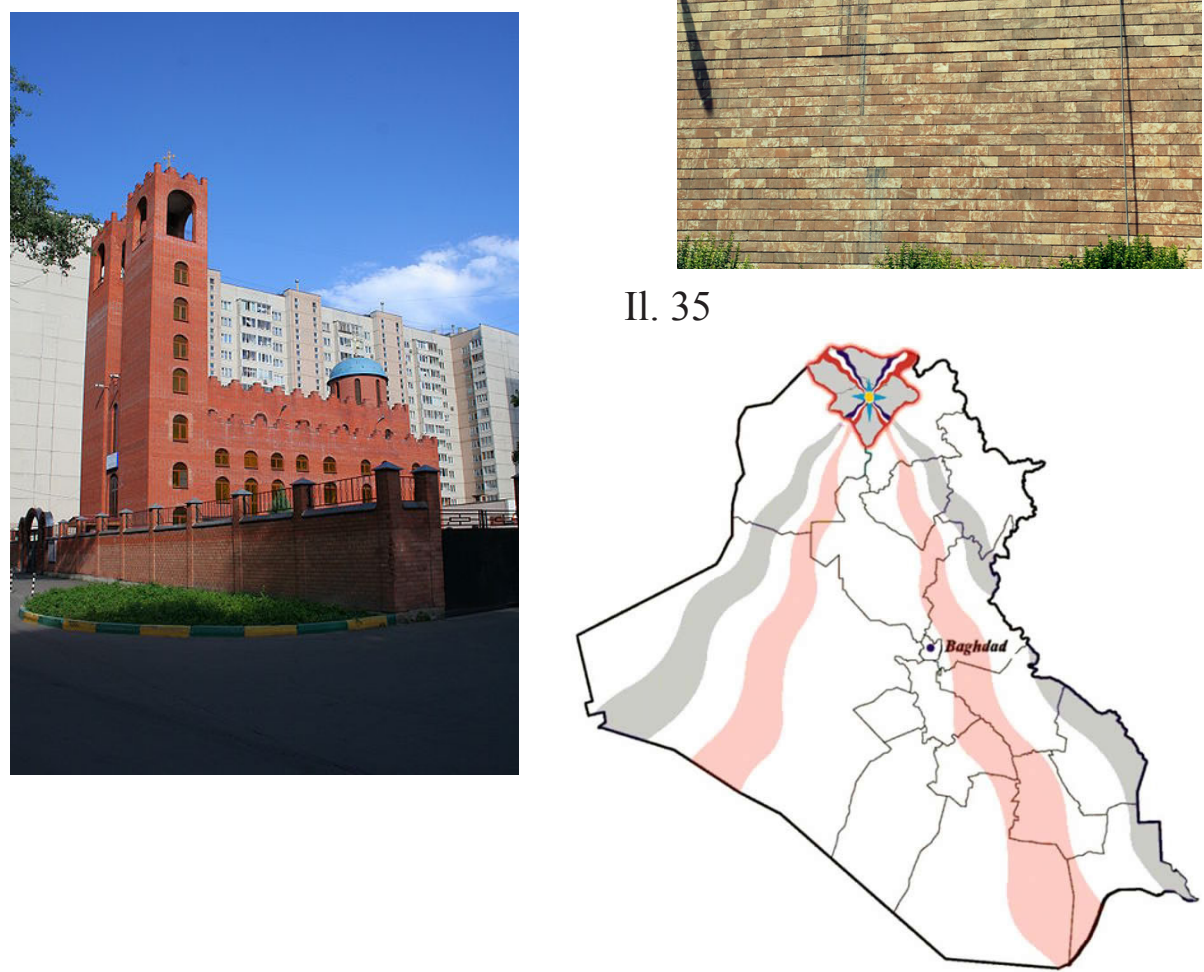

Il. 36 